Monika Ankele, Benoît Majerus (eds.)

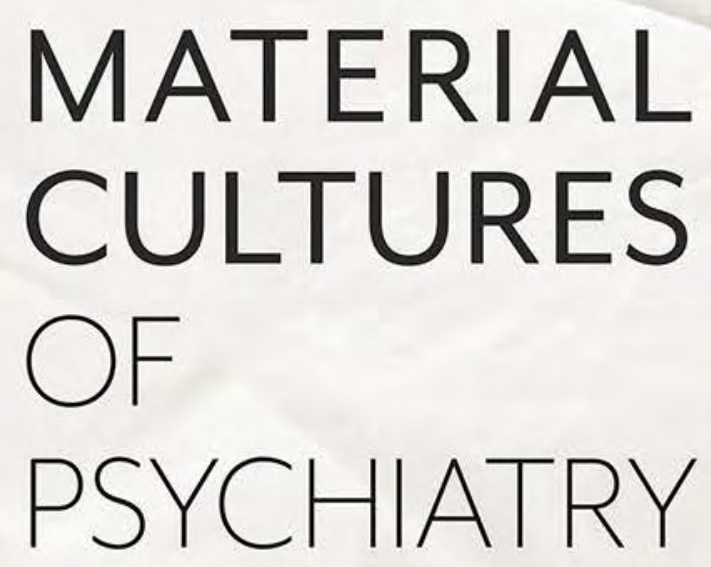

[transcript] Histoire 
Material Cultures of Psychiatry 
Monika Ankele is a historian. She is a scientific researcher at the Institute for History and Ethics of Medicine at the University Medical Center Hamburg-Eppendorf and curator at the Medical History Museum Hamburg.

Benoit Majerus is a historian. He is professor of European History at the Centre for Contemporary and Digital History at the University Luxembourg. 
Monika Ankele, Benoît Majerus (eds.)

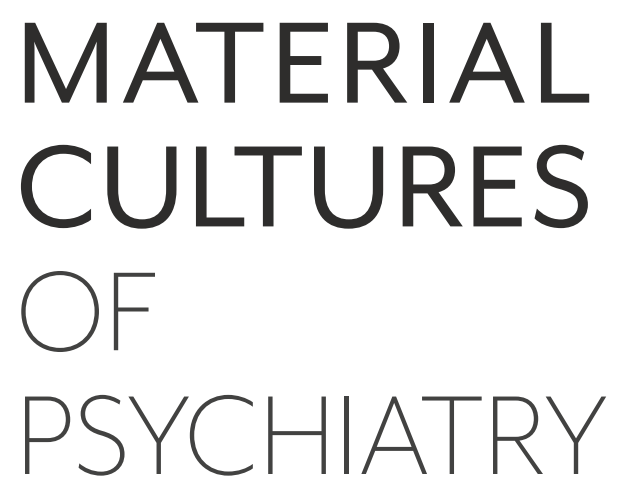





\section{CONTENT}

Christine Rehders

AT Aktion \#I246a

8

Viviane Stopp

Pat. No. 25682

30

Monika Ankele, Benoît Majerus

Material Cultures of Psychiatry

IO

\section{Scenography and Space}

\section{Mascha Deneke}

Oil on Canvas:

An Isolation Cell Constructed

by the k.k. Hofoperntheater

for the Asylum

42

\section{Kai Sammet}

Silent "Night of Madness"?

Light, Voice, Sounds, and Space in the Illenau Asylum in Baden between I842 and I9Io

44

\section{Anatole Le Bras}

"Le cabanon du fou": Uses of the Shed As a Confinement Device for the Insane in French Rural Households in the igth Century

\section{Linnea Kuglitsch}

"Amongst the Most Important

of the Agencies":

Materializing "Nature"

at the American

Lunatic Asylum

96

\section{Lisa Landsteiner \\ Have a Seat!: \\ Approaching the \\ Object of the Chair \\ at the Site of Psychiatry \\ II6}




\section{Transforming Practices}

\author{
Raja Goltz \\ Have a Seat \\ I38
}

\section{Monika Ankele}

The Fabric of Seclusion: Textiles

As Media of (Spatial) Interaction in Isolation Cells of Mental Hospitals I40

\section{Katrin Luchsinger}

Theories of the "Savage":

The Material Varek (Seagrass)

As a Bearer of Meaning

in Psychiatry around 1900

I58

\section{Lydia Oertelt}

Untitled

I84

\section{Louise Hide}

The Uses and Misuses of

Television in Long-Stay Psychiatric and "Mental Handicap" Wards, I950s-I980s

I86

\section{Max Gawlich}

Buttons and Stimuli: The Material Basis of Electroconvulsive Therapy As a Place of Historical Change

\section{Agents of Healing}

\author{
Daniela Hoge \\ Materiality \\ 226
}
Novina Göhlsdorf
"The Magical Device":
Temple Grandin's Hug Machine 228

\section{Stefan Wulf}

The Piano in the Asylum and the Insanity of the Composer: Two Variations on a Theme (with Interlude) 256

\section{Michelle Williams Gamaker} The Effectiveness of Symbols: Psychogeographic Explorations of the Body 282 
IV. Bodies, Senses, and the Self

Anne Wilk

Loss of Identity

298

\section{Teaching Projects}

Céline Kaiser

Artistic Research on

Things in/of Psychiatry:

An Interdisciplinary

Teaching Project

380

\section{Anna Urbach}

Cover, Rip Up, Unwrap:

Scenes with Material

from the Mental Asylum.

A Documentary Theater

Based on Medical Records

386
Marianna Scarfone

Lives in Storage: Clothes and

Other Personal Effects As a Way of Recovering Patients' Histories in a Psychiatric Hospital

300

Sari Kuuva, Kirsi Heimonen

A Corridor That Moves:

Corporeal Encounters with

Materiality in a Mental Hospital

334

Maia Isabelle Woolner

Psychographics

and the Materials

of Time Measurement in

Modern French Psychiatry

354 
Aktion \#I246a

Christine Rehders 


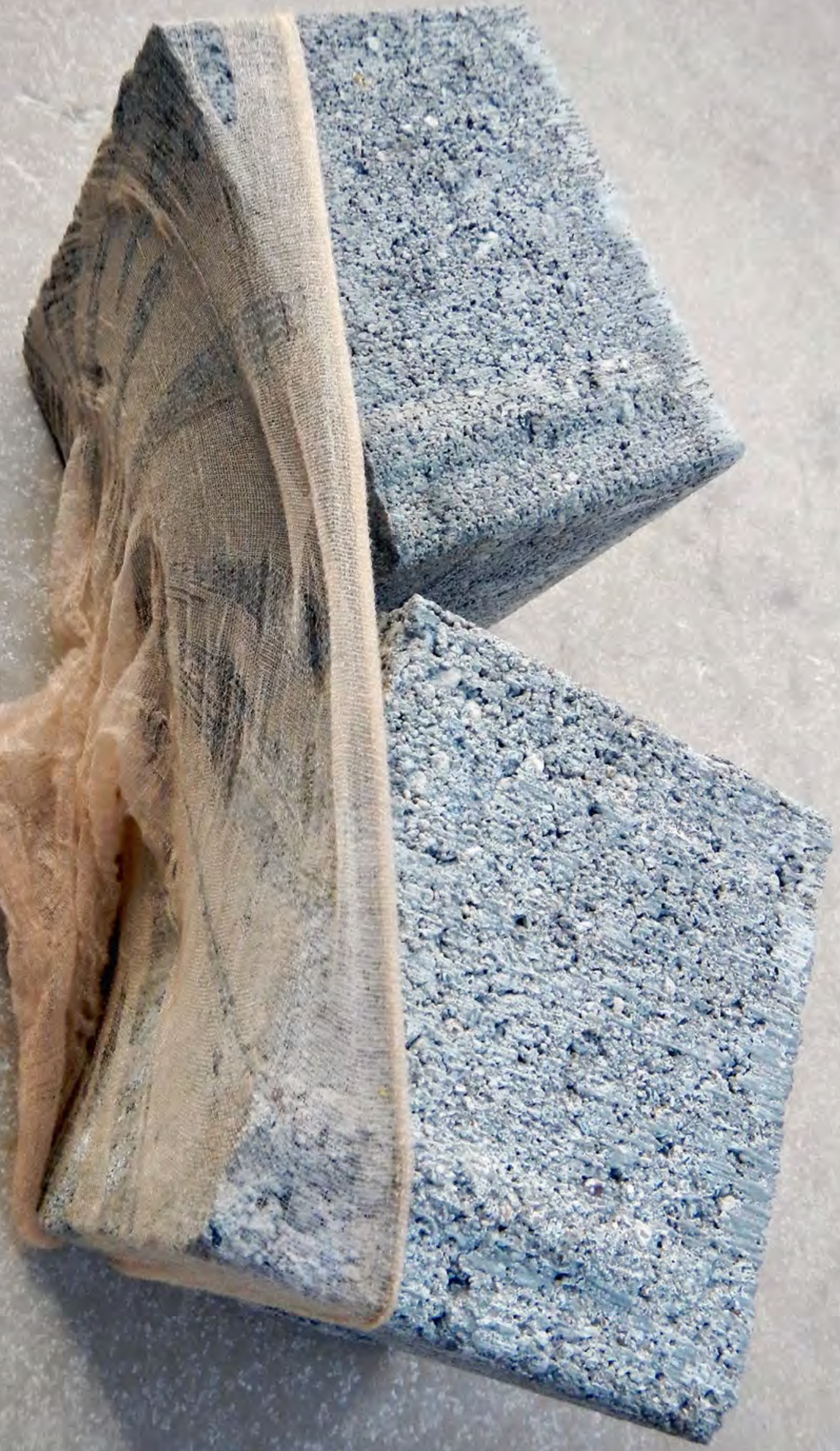




\title{
Material Cultures of Psychiatry
}

\author{
Monika Ankele and Benoît Majerus
}

Flowers and Space

When a historic building housing the Massachusetts Mental Health Center in Boston (founded in 1912) was to be demolished in 2003, artist Anna Schuleit conceived a project that memorializes the place, its history, and its people. Schuleit decided for a walk-in installation and placed a total of 28 , ooo potted flowers on the four floors of the abandoned building. She put flowers in the former treatment rooms, offices, staircases, and corridors. Even the hospital's swimming pool was turned into a sea of flowers. In their overwhelming numbers, the flowers, tender and powerful at the same time, overgrew the floors. They made it impossible to pass through hallways or rooms. The spareness and baldness of the building, the hardness and coolness of its walls were contrasted with the softness and vibrancy of the blossoms that flooded the building with their liveliness and colorfulness. They soaked the built space in radiant colors - purple, orange, green, pink, and white - and one can imagine how they spread their scent across the floors, how they enfolded the building with their presence, being what they are: flowers. The installation heavily affected the building's atmosphere, how it was perceived by the visitors, and how it enabled them to reflect on the building's history and the thousands of patients that spent a lifetime in this place.

Brought into a hospital, flowers are taking on a different meaning. We bring them to the sick to give comfort, to refer to life through the beauty of nature. Flowers symbolize life. Maybe that is the reason why the protagonist of Sylvia Plath's poem "Tulips," as she is being treated in the hospital, fears them. "I didn't want any flowers, I only wanted / To lie with my hands turned up and be utterly empty," she wrote (2016 [196I]: 28). For Schuleit, her project Bloom referred to the other side of what flowers can mean to the sick, to their "healing symbolism ... when they are bedridden and confined to hospital settings" (Jobson 2012). Especially in mental hospitals, patients rarely received flowers, as Schuleit had observed as a visiting artist in a psychiatric center. The installation can therefore be described as a "multitude of greetings on every floor" (ibid.). 
We chose Schuleit's art project Bloom as an opener to introduce the reader to the subject of the book and at the same time inspire him or her about what material cultures in institutionalized settings can mean, sensitizing to its manifold dimensions, which are also inscribed in something as common as flowers. Brought to a psychiatric building, the flowers "do" something with the space and its people, they have not only a symbolic meaning, but a realness. As in Bloom, they interact with people's movements and affect their actions, influence the way they experience space and themselves, stimulate the senses, bear possibilities. They are linked to certain cultural ideas, and - as Plath's poem shows - can have different meanings to different people. Schuleit's project played with the tensions between a psychiatric materiality and an a-priori non-psychiatric object, illustrating that flowers, like all things, are ambiguous.

What things do to psychiatry and what psychiatry does to things is the subject of this book. Indeed, objects have long been and still are shaping our ideas about psychiatric institutions and their history. In many cases, it is exceptional objects such as caged beds or binding belts that we often associate with the history of psychiatry, rather than everyday cultural objects such as flowers. These objects are often used as a synonym for psychiatry and the way psychiatric patients were treated. Straitjackets, for example, impressively embody the power of the institution and possess a strong symbolic meaning. But what do we really know about the "social life" (cf. Appadurai 1986; Majerus 20II) of these as well as less outstanding objects in the daily life of psychiatric institutions and, more generally, about material cultures in psychiatry? What perspectives on psychiatry, its settings, and actors does an approach based on material cultures open up? What practices, relationships, and interactions does it reveal? What ideas of mental illness, its treatment, and the attitudes toward the mentally ill become manifest? And what analytic potential does a material culture approach to the history of psychiatry hold? What does it bring into view, and what findings can it lead to? These questions are discussed in this introduction and are explored in more detail in the essays of this volume.

\section{Writing the History of Psychiatry Today}

With the beginning of the 2Ist century, the historiography of psychiatry has changed and opened up to new sources, methods, and theories. From the I96os onward, the social sciences and humanities have gradually become interested in psychiatry. 
Their approach was often critical of narratives produced by psychiatrists, but these tensions proved to be productive: The history of psychiatry was and is a field with heated debates, an abundant number of monographs, and its own scientific journal since 1990 with an editorial board composed of physicians and historians.

After a focus on the social history of the discipline and its cultural hegemony to define insanity in the I970s and I980s, historians began to broaden their view in the late I990s, integrating new actors, especially patients (Bacopoulos-Viau/Fauvel 20I6), and gradually illustrating how the discipline and its institutions co-constructed race, age, gender, and class (Leckie 20I9; Taylor 20I7; Rose et al. 20I6; Studer 20I6; Hide 20I4; Ankele 2009; Nolte 2003; Jackson 2005).

In the last fifteen years, several shifts can be observed. First of all, the historiography of psychiatry partially shifted its focus away from the "classical age" from the I830s until the beginning of World War One and started to address not only the first half (Schmuhl/Roelcke 20I3), but also the second half of the 2oth century (Hess/ Majerus 20II; Meier et al. 2007). At the same time, the definition of what the history of psychiatry meant became more fluid as psychiatry was no longer only "performed" inside the walls of the asylum (Schmiedebach 20I6; Hess/Schmiedebach 20I2). It entered schools, became a tool to resolve marital problems, and was used to care for victims of terrorism (Crocq/Bouchard 20I8; Boussion 20I6; Weinstein 2013). The classic distinction underlined by Michel Foucault between reason and madness became more fragile: mental disorders and no longer mental illness became the new paradigm as illustrated by the (contested) triumph of the Diagnostic and Statistical Manual of Mental Disorders (first edition in 1952, fifth edition in 2013). Furthermore, the historiography of psychiatry was opening up to new questions. Science and technology studies (STS) proved to be a stimulating way to renew the contextualization of therapies, be it psychosurgery (Meier 2015; Braslow 1997), electroshock therapy (Gawlich 20I8), or neuroleptics (Henckes 20I6; Balz 20IO).

Using notions of "comparative history," "entangled history," or "transnational history" made it possible to transcend the national frontiers in which the history of psychiatry is still often encapsulated (Müller 20I7; Digby et al. 20IO; Ernst/Müller 20IO; Gijswijt-Hofstra et al. 2005). And finally, the history of nursing also became more and more researched as a part of the history of psychiatry that has been neglected for far too long (Borsay/Dale 20I5; Hähner-Rombach/Nolte 20I5; Boschma 2003).

Questions of the material turn have also been taken up, albeit slowly, by the academic historiography of psychiatry. Even if not explicitly, studies since the 2000 s on the asylum's architecture and landscape offered references to the material turn 
by taking the materiality of the institution as their starting point and showing that "psychiatric hospitals were potent forces in the treatment of mental illness" (Yanni 2007: 7; Topp 2017; Hickman 2009; Topp et al. 2007). Historical archaeology and the archaeology of institutions have made an important contribution to the research by focusing on the material conditions of institutional life (Hamlett 2015; Beisaw/Gibb 2009; Piddock 2007). Not only built space was studied, but sensory phenomena such as sound and sight and their material effects have also been explored, pointing to the relationship between material culture and sensory perception (Kearin 2019, 2020; Fennelly 20I4; MacKinnon 2003).

In the last decades, historiography engaged more systematically with the opportunities and challenges of this turn. While the materiality of the walls remains central, other aspects are also taken into account such as paper technologies (Hess 2018; Borck/Schäfer 20I5) or medical and control devices such as pills (Majerus 2017), keys (Wernli 20I9), the sickbed (Ankele 20I9), the bathtub (Ankele 2020), and the electroconvulsive therapy machine (Boschma 20I9). Another topic being researched is the question of the impact of material culture on the development of scientific knowledge in the field of the "mind sciences" (Guenther/Hess 20I6) or in the formation of Sigmund Freud's psychoanalysis (Müller 2019).

\section{Witnessing the Material Cultures of Psychiatry}

Apart from the influence that the material turn has had on the historiography of psychiatry, two other fields in particular have addressed the importance of materiality in the history of psychiatry: museums and abandoned asylum projects.

\section{Museums}

Museums of psychiatry were unsurprisingly the first to attach great importance to historical objects that attest to the material culture of institutional life. 'Though museums have sometimes be criticized for a fetishistic approach to objects by de-contextualizing them, they not only saved them from disappearing by collecting, conserving and tagging them with metadata, but also told the history of psychiatry around materiality (cf. Coleborne/MacKinnon 20II; Coleborne 200I). As Bart Marius, artistic director at the Museum Dr. Guislain in Ghent, Belgium, 
puts it: "[T]he museum might contain objects that have been robbed of their (vital) functions, but stories cling on these objects: living stories" (Marius 2019: I4). In museums, historical objects are used as tools for telling these stories, whereby they operate with one and the same object for different exhibition subjects and thus demonstrate that one object holds a multitude of stories that unfold and come alive through its physicality (ibid.: I6). With their collections and exhibitions, museums visualize the many possible perspectives that are inscribed in the objects, the complex networks in which they are integrated, the relations that they evolve, the ambiguities and contradictions that they hold, and, last but not least, how microand macro-history condense in one single object.

In addition to treatment devices and everyday objects, some of the museums also collect artworks or self-testimonies from patients like drawings, three-dimensional objects, or handwritten notes as compiled by many psychiatrists at the turn of the I9th to the 2oth century. Some psychiatrists even founded their own collections (cf. Luchsinger 20I6). ${ }^{2}$ These documents and the materials that were used by patients, such as packaging paper, seaweed, blankets, bread, and many others (cf. Fahrni 2008), attest to the material cultures of the psychiatric institution and refer to the life in it. Moreover, many of these collections open up an approach to the history of psychiatry from a patient's perspective: they give insights into how patients experienced being institutionalized and how they used and appropriated the material culture of the institution for their own needs, to communicate or to reassure themselves (cf. Von Beyme/Hohnholz 20I8; Ankele 2009).

\section{Abandoned Asylums}

A second important strand that relates to the material culture of psychiatry is the fascination with abandoned asylums especially in the United States but also in Italy (cf. Burger 2017). These two countries had very large institutions and experienced a massive closing down of asylums from the I970s on. It is part of a larger phenomenon often subsumed under the terms of "dark tourism" or "urban exploring," where people visit old asylums, take photos of these buildings in decay, and discover abandoned medical notes, treatment devices, or patients' luggage. In some places, this interest in abandoned asylums led to the conservation of objects as well as to historical research on the institution (cf. Manicomio di Volterra; Northhampton State Hospital). Impressive monographs focusing on abandoned asylums have been published (Payne 2009; Penney et al. 2009), stimulating exhi- 
bitions have been put together (cf. The Willard Suitcases by Jon Crispin; Lost Cases, Recovered Lives: Suitcases from a State Hospital Attic, New York State Museum at Albany, 2004), and site-specific installations created (cf. Anna Schuleit, Habeas Corpus, 2000, and Bloom, 2003). In contrast to exhibitions in museums that usually tell their stories with single objects, abandoned asylum projects deal with the whole environment of the institution and provide a sensual experience of these places and their material culture. They cling onto the "sensual orientation" (Howes 2006: I6I) in material culture studies and strongly refer to the field of historical archaeology (cf. Piddock 20I7).

\section{Relating the History of Psychiatry to Material Cultures}

In recent years, the anti-psychiatric attitude of the humanities has sometimes been seen as a hinderance, on the one hand because it makes discussions with psychiatrists and caregivers more difficult, and on the other because it rarely does justice to the historical complexity in its gross simplification. An approach to the history of psychiatry via its material culture makes it possible to tie in with the critical genealogy of the history of psychiatry of the I970s and at the same time goes beyond a Manichean narrative that reduces psychiatry to a tool of social domination and control.

In closed facilities like psychiatric hospitals, the material could operate (and often operated) as a tool of power, control, regulation, and discipline, sometimes accompanied by the argument of providing protection against self-inflicted or third-party injuries. Focusing on the material culture of an institution (treatment rooms, objects of daily use, light, sound, etc.) can reveal the ways in which power structures were not only exercised by humans, but how they materialized and stabilized through the material culture of the place, how they were embedded in the physicality of the place.

Patients of closed facilities usually experienced this place through a reduced world of things. Power was exercised over them through the things they were exposed to, but also through the things they were deprived of. Here the material world reveals the asymmetries of power that structure the experience of institutionalization. On the other hand, a material culture perspective transgresses a simplistic approach that makes patients appear passive and mute and not as acting subjects: after all, the focus on objects in relation to corresponding practices not only makes power 
asymmetries visible, but also reveals moments of self-empowerment and subjectification. Beyond that, it brings people into focus to whom the history of psychiatry has paid little or no attention for a long time. And these are not only patients, caregivers, and doctors, but also economists, craftsmen, architects, gardeners, chemists, and even bed manufacturers. They all form a dense network and are connected via individual objects. Such an approach also contradicts the "fundamental separation" between inmates and personnel, which sociologist Erving Goffman (I973 [I96I]: I8) cited in his famous book Asylums as a central element of total institutions, ${ }^{3}$ or, at least, reveals a different perspective on their relationship.

After all, objects pass through many hands and are always sites of interaction, which condense and materialize in the object. They are - like a letter leaving the institution - transboundary. Things move - often in contrast to the inmates of a closed facility - between different places and actors who, so to speak, encounter each other in the object, who intervene in it, and give it a meaning.

A history of things first and foremost extends a historiography in which physical objects often appear in the background, as the decoration of a human-centered history. In the case of this book, a material culture approach shows the important role that objects play in what psychiatry brings forth as a social and political place. As Derix et al. write, a thing-historical perspective is likely to "productively unsettle seemingly unalterable certainties about ... social orders" (20I6, no page number). The present volume aims to contribute to this productive uncertainty in the field of the history of psychiatry.

\section{When We Are Talking About "Material Cultures"}

It is "ambiguous and only vaguely defined," Hans Peter Hahn writes about the term "material culture" (20I4a: 9), and in the Handbuch Materielle Kultur the term is described as "contradictory" (Hahn et al. 20I4: 3), because among other things it assumes that there is geistige Kultur independent of a material culture, and so the term tempts us to hold on to this dichotomy that does not exist.

Nevertheless, we have chosen to use the term "material culture(s)" in the title of the book, and in the following we want to clarify which aspects of the term and its meaning are relevant to the present volume, although the various contributions provide many more references. 
The term "material culture" is used in this volume to cover both everything physical that affects the space, its actors, and their actions, as well as the non-physical that reveals material dimensions. Thus, in addition to that which is physically present, the term as we use it also includes phenomena such as air, light, color, smell, and sound, which are just as "highly relevant" to "human practice" because they "appear as an active counterpart" (Kalthoff et al. 2016: 12): they configure perceptions and inform actions. ${ }^{4}$

The objects around which the contributions in this volume are centered and from which they unfold their analysis are not always clearly identified as objects of psychiatric practice, treatment, or care, but also include common things and ordinary materials, which at one moment may remain in an "inert state" and at another moment may attract considerable attention (Hahn 2015:38).

Through the institutional framework, objects in psychiatry undergo a transformation, both in terms of their symbolic meaning and their physicality/materiality and function. Objects designed by engineers and doctors (objet pensé) change in the course of their production, whether through technical or material limitations (objet fabriqué). In a next step, the objects are used by very different groups (objet agi), whereby the use does not always correspond to the original intention of their developers or those who implement or provide the objects (cf. Majerus 20II). When objects cross the outside-inside-border and become part of a (more or less) closed facility, they may not always change their shape, but they often change what they stand for: not only a bed undergoes a transformation in psychiatry, but also flowers, a mirror, or a blanket.

The essays in this volume focus less on the analysis of a concrete object and its materiality than on the question of how objects are embedded in specific, often contradictory or competing contexts of action, use, and meaning and the relations they develop to other people, things, and spaces. Objects are conceived and analyzed as interfaces of practices, as meeting areas of different actors, as physical manifestations of discourses. Following an approach that conceives culture as practice, as a "doing culture" (Hörning/Reuter 2004), the concept of material cultures is directed at practices in the sense of doings with things. Thus, with the concept of "material arrangement," sociologist Theodore Schatzki (2010) emphasizes the interactions between interconnected material entities and social practices. By taking the practices evoked by things into account, the manifold contexts in which things are embedded and the relations they establish become visible. As sociologist John Law (2010: 173-I74) points out, "to understand mattering of the material, you need to 
go and look at practices, and to see how they do whatever reals that those practices are doing, relationally ('Reals' because different realities are being enacted in different practices)." Also, the actor-network theory (ANT), to which many research projects in the field of material culture studies refer, focuses on practices in the analysis of things. Its approach emphasizes the agency of things as non-human actors (Latour I99I).

Starting from this praxeologically inspired concept of material culture, we use the term in the plural: we speak of material cultures because things are polyvalent and ambiguous. One and the same object can not only generate different perceptions and offer different meanings, but can also be embedded in different contexts of use, as the contributions to this volume show. The plural use of the term is therefore intended above all to sensitize to those practices in dealing with objects that undermine their intended sense of use, contradict it, or simply ignore it. At the same time, by analyzing the practices associated with the objects, the objects reveal their "stubbornness" [Eigensinn] (cf. Hahn 20I4) and their relative indeterminacy. The latter is particularly evident in restrictive facilities such as psychiatric hospitals, which are characterized by a reduced world of objects. Thus, as historian Jane Hamlett (2015) shows, inmates of closed institutions generate "material subcultures" and adapt objects, materials, and spaces according to their needs (cf. Ankele 2009). These "material subcultures" can be assigned to the field of "secondary adaptation," which Erving Goffman (I973 [I96I]) describes as a characteristic of "total institutions" such as psychiatric hospitals. Through secondary adaptation, inmates do not directly question the institution, but try to circumvent what the institution considers them to do and therefore who they should be. After all, objects also subjectify those who deal with them (cf. Reckwitz 2008; Ankele 2019).

\section{Outline of the Book}

This volume offers a new perspective on the history of psychiatry by bringing together different scientific and artistic approaches that deal with manifold aspects of the material world of the Western psychiatric space (Germany, France, Finland, United Kingdom, Switzerland, the United States, and Canada) from the I 9 th to the 2Ist century. The essays have been organized in four parts: Scenography and Space; Transforming Practices; Agents of Healing; and Bodies, Senses, and the Self. 
Two additional essays focus on teaching projects that were carried out with medical students and students of art therapy and will be further explained in the last chapter of the introduction.

\section{SCENOGRAPHY AND SPACE}

"The spatial and the material have often been treated separately, but to understand the operation of the material environment we need to look closely at its spatial aspect," writes Jane Hamlett in her book At Home in the Institution (2015: 8). Space is a central element through which the material culture of a place unfolds. This is particularly relevant for the psychiatric space, in which power and control structures are embedded, which configure the relations between patients, doctors, and caregivers, and which frame the possibilities to act. At the same time, it is a variety of spaces and scenographies that psychiatry has developed and which have been adapted and changed in the course of history according to the contemporary ideas of treatment and care as well as the economic possibilities.

The first section, entitled "Scenography and Space," therefore focuses on the psychiatric space and discusses scenographic aspects of its material arrangement (cf. Kaiser 2019; Ankele/Ledebur/Kaiser 2019). The section opens with a work by stage designer Mascha Deneke, who created a true-to-scale replica using the example of a canvas-lined isolation cell from I883. By transferring the descriptive text into a three-dimensional model, this powerful and limiting space can be experienced visually. In his essay, medical historian Kai Sammet examines the spatial-material dimensions of immaterial phenomena such as light and sound using the example of the German Illenau asylum near Baden. His article focuses both on the physicality of light and voice and on their metaphorical and cultural-historical meanings, which he brings into resonance for the analysis of the psychiatric space. The historian Anatole Le Bras focuses on a material artifact used for confining the mentally ill in various settings outside the asylum: the shed (cabanon in French). A scandalous object for alienists, the sheds tell us much about the material culture of insanity in domestic spaces. The spatial arrangement and material setting of sheds reveal "lay" attitudes toward mentally ill people. Archaeologist and historian Linnea Kuglitsch takes a whale vertebra excavated on the site of the Eastern Lunatic Asylum in Virginia and a sand dollar found at the dump of the Western Washington Hospital 
as the starting point for her essay. For Kuglitsch, these two fossils not only refer to the therapeutic concepts that, like I9th-century moral management, postulated the curative power of nature, but they also testify practices of patients who used nature as a source of material culture, "rather than a series of scenes and settings that could channel exercises and recreations that would benefit patients' state of mind" (page III). The extent to which therapeutic interventions are dependent on specific spatial and material arrangements that unfold via a concrete object is shown by psychologist Lisa Landsteiner in her contribution using the example of the chair in psychiatry. The chair assigns the actors involved in a therapy their place in the room and thus brings them into a specific relation with one another. Without chairs, a therapeutic treatment session would have to be redesigned, or it would not be possible to conduct it in the customary manner, as Landsteiner's interviews from a psychiatric clinic in Switzerland show.

\section{TRANSFORMING PRACTICES}

A praxeologically oriented analysis of material culture refers to the connection between objects and practices. Every object is a call to action, an affordance (cf. Gibson 1977), and harbors a multitude of possibilities that are realized in its appropriation and use. At the same time, things also elude attempts, as Herbert Kalthoff et al. write in the introduction to their anthology Materialität, "to unify them by using them" (2016: 24). The manifold, ambiguous, and often contradictory practices that an object evokes and the way in which it is able to transform practices and patterns of action are examined in the section "Transforming Practices." It opens with an artwork by art therapy student Raja Goltz, who crocheted a chair from strips of bedsheets. Through the textile material she used for it, the chair can no longer fulfill the function ascribed to it - namely to hold a seated body - and new practices of interaction, of dialogue between the user and the object are tested and found. In her contribution, historian Monika Ankele draws attention to the practice of seclusion and focuses on the interior of the rooms that were intended for carrying out the treatment. She asks what significance textile materials like firmly quilted blankets and bed sheets could have had in this context as a means of interaction for both the institution and the patient. The art historian Katrin Luchsinger focuses in her essay on a material that has so far gone unnoticed in the history of both art and 
psychiatry, although it is a material that has been present in psychiatric institutions in a variety of ways: seaweed. Based on objects that the patient Lisette H. made from this material in a Swiss asylum around 1900, Luchsinger unfolds several aspects of their use and the meaning attributed to them in the institutional context. At the same time, the works of Lisette H. impressively demonstrate the scope of (albeit limited) possibilities that the material could open up for patients if they had the practical knowledge to make use of it. With her amulets made of bread and water (a reference to corresponding objects made by historical patients), art therapy student Lydia Oertelt refers to the lack of material which patients in mental asylums were confronted with and the inventiveness that they necessarily developed in dealing with the materials that were at hand. In her contribution, historian Louise Hide explores how the introduction of television sets in long-stay psychiatric and "mental handicap" wards changed the daily routines of caregivers and patients and reshaped the relationship between them. The development of the technical device for carrying out electroconvulsive therapy is the focus of the essay by historian Max Gawlich. Using the introduction of this new form of shock therapy, he questions the relationship between the technological object, the body to be treated, and the therapeutic practice, and explains how the apparatus was used to create a new material culture in psychiatry, which was accompanied by new treatment practices as well as a changed spatial situation.

\section{AGENTS OF HEALING}

The section "Agents of Healing" focuses on human-thing relationships and the question of how objects could or should have possible healing effects on their users. The section opens with a photograph that shows the bed (blanket and pillow) of art therapy student Daniela Hoge in a sterile environment. With her installation she raises the question of the difference between one's own familiar bed at home and the sterile bed in a hospital in terms of recovery. The hug machine designed by Temple Grandin, which enables people diagnosed with autism to experience touch and at the same time learn to tolerate it, is the focus of the contribution by cultural scientist Novina Göhlsdorf. She analyzes the hug machine in Bruno Latour's sense as a "human-nonhuman association" and at the same time points out the shortcomings of Latour's approach, in that the hug machine takes on far more 
tasks in the interplay with its users than that of delegation, of "standing in" (page 244) for someone. At the same time, the machine developed by Grandin can be brought into line with traditional concepts of autism, which claim a close relationship between autism and the material object world. The piano in psychiatry is the starting point for the essay by historian Stefan Wulf. He uses the composers Robert Schumann and Paul Abraham as examples, who were both under psychiatric treatment, albeit at different times and places, and both of whom had the possibility of playing the piano during their institutionalization. Wulf illustrates the therapeutic function that piano playing had and how it offered the two composers the possibility of retaining part of their identity in the institution. The artist Michelle Williams Gamaker does not take a concrete object and its effects on the human body as her starting point, but rather poses the question of the extent to which immaterial phenomena such as a song can also show physical effects on the body and its state of being, and in this sense can also be considered objects of healing.

\section{BODIES, SENSES, AND THE SELF}

The section "Bodies, Senses, and the Self" contributes to the sensual and bodily dimensions of material culture. It is the experiencing subject that is the focus of this section. As Nicolas Saunders states, material objects have the ability "to act as a bridge between mental and physical worlds" (Saunders 2002: I8I, quoted in Howes 2006: I6I). The section opens with a poem by art therapy student Anne Wilk that raises the question of how objects construct selfhood. Her poem refers to the fact that patients usually had to hand in their clothes and personal belongings when entering an asylum. Patients' clothes and personal belongings are also the focus of the contribution by historian Marianna Scarfone. An abandoned patients' storage room at the Perray-Vaucluse psychiatric hospital in the Paris area is the starting point of her essay. This room was used to store the patients' suitcases and personal effects, which provide a glimpse into individual lives. While written self-testimonies and medical records have so far been used for a patient-oriented approach, Scarfone follows this approach on the basis of material belongings. Through the material world of former patients, she encounters their personal lives. Scarfone also reflects on her emotional encounters when entering the storage room, opening suitcases, and unfolding personal notes that may have never been read before. 
Dancer and researcher Kirsi Heimonen and art historian and cognitive scientist Sari Kuuva reenact written memories of patients who were institutionalized in Finnish asylums between the I930s and 20I0s. Their attention is drawn to how the physical environment and materiality of the place and its objects are remembered by the patients. Using the corridor, a patient's room, and a window sill as examples, they illustrate the tension between a somehow "invisible" materiality that fundamentally structures the experience of hospitals, the notions of enclosure and freedom they simultaneously produce. The historian Maia Woolner shows how alienists tried to control insanity not only through the walls of the asylums but also by framing it in time. Stopwatches, clocks, and other timekeeping devices were arranged to transform the single patient as well as his or her bodily reactions, senses, and emotions into diagrams, charts, and numbers. Borrowing devices and recording techniques from other (medical) disciplines, psychiatrists hoped to better understand mental illness.

\section{TEACHING PROJECTS}

The last section presents two teaching projects carried out by Céline Kaiser, Monika Ankele, and Anna Urbach. Both projects chose different approaches relating to the fields of artistic research to address the topic of material cultures of psychiatry, articulating central questions and opening resonant spaces, as will be explained in more detail in the next section.

\section{Background to the Book and Acknowledgments}

This volume brings together a selection of papers that were presented at the transdisciplinary conference "Material Cultures of Psychiatry." The conference was held in cooperation with the University of Luxembourg from May 2 to 4, 2018, at the Institute for History and Ethics of Medicine at the University Medical Center Hamburg-Eppendorf and the Medical History Museum in Hamburg and was financed by the German Research Foundation and the University of Luxembourg. Researchers from different scientific fields as well as performance artists and artist 
researchers were invited to use material culture to open up new perspectives and deepen our understanding of the history of psychiatry. The conference followed the idea of artistic research as a practice-based method of knowledge production that highlights the epistemic value of artistic methods. Artistic and scientific contributions were meant to complement and enhance each other. We thank our graphic designer Juma Hauser, who was able to translate this approach in the design of the book, which is characterized by the balanced relationship between text and images, and between more artistic and more scientific approaches to the subject of the book.

During the conference, self-taught artist Christine Rehders showed a selection of her artworks in the historical autopsy hall of the Medical History Museum. The objects that she creates are characterized by removing very basic materials (including concrete, nylon, wire, and paper) from their initial context and combining them with materials that show opposite qualities (hard and soft, elastic and stiff, light and heavy). These new objects that emerge question the properties of the single material and its ability to transgress (see page 8 ). The historical autopsy hall also became the stage for artist Kirstin Burkhardt and her performers, who offered the participants in the conference an extraordinary spatial experience through the sound of their voices and sensitized them to the material dimensions of a non-material phenomenon such as sound. Kirsi Heimonen and Sari Kuuva questioned the relationship between memory and the psychiatric space and combined classical lecture techniques with visual images and movements of the body. And performance artist Michelle Williams Gamaker, together with students from the Hochschule für bildende Künste Hamburg, prepared her contribution on a psycho-geographic exploration of the body as a performance lecture in the small autopsy hall of the museum. All these freer formats based on artistic research methods accompanied the more traditional scientific lectures.

The subject of the conference also provided the impetus for two teaching projects, whose results were presented during the conference: Céline Kaiser and Monika Ankele organized a seminar at the University of Applied Arts in Ottersberg on material cultures of psychiatry, in which students of art therapy developed artistic interventions in response to the topic. The interventions were presented during the conference (see Céline Kaiser's essay), and some of them are included in the book. Together with students of the medical faculty of the Otto-von-Guericke University Magdeburg, the physician and medical historian Anna Urbach and the theater pedagogue Kerstin Reichelt developed a documentary play on the basis of medical records from around I900 that focused on material practices of patients (see Anna Urbach's essay). 
The play was performed during the conference. Its script is published in the book.

We would like to thank Juma Hauser for the carefully planned graphic design of the book, Anthony DePasquale for the translation of the German texts by Max Gawlich, Céline Kaiser, Katrin Luchsinger, Kai Sammet, Anna Urbach, and Stefan Wulf, as well as for the editing, Ulrike Nichols for the translation of the German text by Monika Ankele, and all the contributors for their willingness to revise their papers and make them available for publication. Furthermore, we would like to thank the German Research Foundation ${ }^{5}$ and the the Luxembourg Centre for Contemporary and Digital History $\left(\mathrm{C}^{2} \mathrm{DH}\right)$, which made the financing of the book possible.

\section{Notes}

1

See, for example, the Museum Dr. Guislain in Ghent, Belgium; the Bethlem Museum of the Mind in London, England; the Psychiatrie-Museum in Bern, Switzerland; the Mu-Seele in Göppingen, Germany; the Württembergisches Psychiatriemuseum in Zwiefalten, Germany; the Psychiatriemuseum in Haina, Germany; the Museo di Storia della Psichiatria in Reggio Emilia, Italy; and the Museum Ovartaci in Aarhus, Denmark. In their book on museums of psychiatry in Europe, Rolf Brüggemann and Gisela Schmid-Krebs list more than 60 museums (2007: 15).

\section{2}

See, for example, Sammlung Prinzhorn in Heidelberg, Germany (cf. Von Beyme/Hohnholz 2018); the Collection de l'Art Brut in Lausanne, Switzerland; Het Dolhuys in Haarlem, Netherlands; the Museum Ovartaci in Aarhus, Denmark; the Psychiatrie-Museum in Bern, Switzerland.
3

Even though the concept of the "total institution" has been critically questioned and new approaches have been developed (cf. Tanner 2005), reference is still made to Goffman's concept in works on the history of psychiatry (see also some of the contributions in this volume) as it still offers some important points of view and reflection.

4

Hans P. Hahn (2012) argues for a more integrated approach to material culture by including perception as an important strand of material culture that is overseen by a semiotic approach.

5

The book is part of the research project "Bed and bath: Objects and spaces of therapeutic acting in psychiatry of the 19th and 20th century. An outline of a material history of psychiatry" (SCHM 1311/11-1) at the Institute for the History and Ethics of Medicine at the University Medical Center Hamburg-Eppendorf and was funded by the German Research Foundation from 2015 to 2019 


\section{Bibliography}

Ankele, Monika (2020): "Material Configurations of Nursing and their Ethical Implications: The Prolonged Bath Treatment in Psychiatry." In: European Journal for Nursing History and Ethics 2, pp. 101-123, DOI10.25974/enhe2020-10en, accessed on July 7, 2020.

Ankele, Monika (2019): "Horizontal Scenographies: The Sickbed as a Setting for Psychiatric Subjectivation." In: Lars, Friedrich/Harrasser, Karin/ Kaiser, Céline (eds.): Scenographies of the Subject, Wiesbaden: Springer Verlag, pp. 43-58.

Ankele, Monika (2009): Alltag und Aneignung in Psychiatrien um 19oo: Selbstzeugnisse von Frauen aus der Sammlung Prinzhorn, Vienna/ Cologne/Weimar: Böhlau.

Ankele, Monika/Ledebur, Sophie/Kaiser, Céline (eds.) (2019): Aufführen - Aufzeichnen - Anordnen: Wissenspraktiken in Psychiatrie und Psychotherapie, Wiesbaden: Springer.

Appadurai, Arjun (1986): The Social Life of Things: Commodities in Cultural Perspective, Cambridge et al.: Cambridge University Press.

Atzl, Isabel/Artner, Lucia (2019): "Material Care Studies." In: European Journal for Nursing History and Ethics 1, pp. 1-16, DOI 10.25974/enhe 2019-3de, accessed on April 3, 2020.

Bacopoulos-Viau, Alexandra/Fauvel, Aude (2016): "The Patient's Turn: Roy Porter and Psychiatry's Tales, Thirty Years on." In: Medical History 60/1, pp. 1-18.

Balz, Viola (2010): Zwischen Wirkung und Erfahrung - eine Geschichte der Psychopharmaka. Neuroleptika in der Bundesrepublik Deutschland, 1950-1980, Bielefeld: Transcript.

Beisaw, April M./Gibb, James G. (eds.) (2009): The Archaeology of Institutional Life, Tuscaloosa: Alabama University Press.

Borck, Cornelius/Schäfer, Armin (2015): Das psychiatrische Aufschreibesystem: Notieren, Ordnen, Schreiben in der Psychiatrie, Paderborn: Fink.
Borsay, Anne/Dale, Pamela (eds.) (2015): Mental Health Nursing: The Working Lives of Paid Carers in the Nineteenth and Twentieth Centuries, Manchester: Manchester University Press.

Boschma, Geertje (2003): The Rise of Mental Health Nursing: A History of Psychiatric Care in Dutch Asylums, I890-1920, Amsterdam:

Amsterdam University Press

Boschma, Geertje (2019): "Electroconvulsive Therapy (ECT) and Nursing Practice in the Netherlands, 1940-2010." In: European Journal for Nursing History and Ethics 1, pp. 17-39, DOI 10.25974/ enhe2019-7en, accessed on April 3, 2020.

Boussion, Samuel (2016), "Le premier congrès international de Psychiatrie infantile (Paris, 1937), ou le baptême d'une spécialité ambitieuse." In: Revue d'histoire de l'enfance "irrégulière." Le Temps de l'histoire 18, pp. 57-80.

Braslow, Joel (1997): Mental Ills and Bodily Cures: Psychiatric Treatment in the First Half of the Twentieth Century, Berkeley/Los Angeles/London: California University Press.

Brüggemann, Rolf/Schmid-Krebs, Gisela (2007): Verortungen der Seele - Locating the Soul. Psychiatrie-Museen in Europa - Museums of Psychiatry in Europe, Frankfurt am Main: Mabuse Verlag. Burger, Christoph (2017): Manicomio, n.p.: Books on Demand.

Coleborne, Catharine/MacKinnon, Dolly (eds.) (2011): Exhibiting Madness in Museums: Remembering Psychiatry through Collections and Display, New York/Oxon: Routledge.

Coleborne, Catharine (2001): "Exhibiting 'Madness': Material Culture and the Asylum." In: Health and History 3/2, pp. 104-107.

Crocq, Louis/Bouchard, Jean-Pierre (2018): "Histoire de la psychotraumatologie: 'Les dramatiques attentats terroristes de 2015 et 2016 ont eu des répercussions considérables sur les psychismes'." In: Annales médico-psychologiques 176/3, pp. 305309.

Derix, Simone/Gammerl, Benno/Reinecke, Christiane/Verheyen, Nina (2016): "Der Wert der Dinge. Zur Wirtschafts- und Sozialgeschichte der Materialitäten." In: Zeithistorische Forschungen 3, pp. $387-$ 
403. https://zeithistorische-forschungen.de/3-2016 /5389? language=de, accessed on April 3, 2020. Digby, Anne/Ernst, Waltraud/Mukharji, Projit B. (eds.) (2010): Crossing Colonial Historiographies: Histories of Colonial and Indigenous Medicines in Transnational Perspectives, Newcastle upon Tyne: Cambridge Scholars Publishing. Ernst, Waltraud/Müller, Thomas (eds.) (2010): Transnational Psychiatries: Social and Cultural Histories of Psychiatry in Comparative Perspective, c. 1800-2000, Stuttgart: Franz Steiner.

Fahrni, Jacqueline (2008): "Propellerknopf und Seegrashut: Materialien und Materialbeschaffung in psychiatrischen Kliniken um 1900." In: Luchsinger, Katrin (ed.): Pläne. Werke aus psychiatrischen Kliniken in der Schweiz, I850-1920, Zurich: Chronos, pp. 85-94.

Fennelly, Katherine (2014): "Out of sound, out of mind: noise control in early nineteenth-century lunatic asylums in England and Ireland." In: World Archaeology 46/3, pp. 416-430.

Gawlich, Max (2018): Eine Maschine, die wirkt: Die Elektrokrampftherapie und ihr Apparat, 1938-1950, Paderborn: Schöningh.

Gibson, James J. (1977): "The theory of affordances." In: Shaw, Robert/Bransford, John (eds.): Perceiving, Acting and Knowing: Toward an Ecological Psychology, Hillsdale, New Jersey: Lawrence Erlbaum, pp. 67-82.

Gijswijt-Hofstra, Marijke/Oosterhuis, Harry/ Vijselaar, Joost/Freeman, Hugh (eds.) (2005): Psychiatric Cultures Compared: Psychiatry and Mental Health Care in the Twentieth Century: Comparisons and Approaches, Amsterdam: Amsterdam University Press.

Goffman, Erving (1973 [1961]): Asyle: Über die soziale Situation psychiatrischer Patienten und anderer Insassen, Frankfurt am Main: Suhrkamp. Guenther, Katja/Hess, Volker (2016): "Soul Catchers: The Material Culture of the Mind Sciences." In: Medical History 60/3, pp. 301-307.

Hähner-Rombach, Sylvelyn/Nolte, Karen (eds.) (2017): Patients and Social Practice of Psychiatric Nursing in the I9th and 2oth Century, Stuttgart: Franz Steiner.
Hahn, Hans Peter (2015): "Die geringen Dinge des Alltags: Kritische Anmerkungen zu einigen aktuellen Trends der Material Culture Studies." In: Braun, Klaus/Dietrich, Claus-Marco/Treiber, Angela (eds.): Materialisierung von Kultur. Diskurse - Dinge Praktiken, Würzburg: Königshausen \& Neumann, pp. 28-42.

Hahn, Hans Peter (2014a): Materielle Kultur. Eine Einführung, Berlin: Reimer.

Hahn, Hans Peter (2014): "Widerständigkeit und Eigensinn des Materiellen: Alternative Modelle der Wahrnehmung der dinglichen Welt." In: Bielfeldt, Ruth (ed.): Ding und Mensch in der Antike: Gegenwart und Vergegenwärtigung: Interdisziplinäres Symposion, Heidelberg: Winter, pp. 67-88.

Hahn, Hans Peter (2012): "Words and things: reflections on people's interaction with the material world." In: Maran, Joseph/Stockhammer, Philipp W. (eds.): Materiality and Social Practice: Transformative Capacities of Intercultural Encounters, Oxford: Oxbow, pp. 4-12.

Hamlett, Jane (2015): Home in the Institution: Material Life in Asylums, Lodging Houses and Schools in Victorian and Edwardian England, Houndmills: Palgrave Macmillan.

Henckes, Nicolas (2016): "Magic Bullet in the Head? Psychiatric Revolutions and Their Aftermath." In: Greene, Jeremy A./Condrau, Flurin/Watkins, Elizabeth S. (eds.): Therapeutic Revolutions: Pharmaceuticals and Social Change in the Twentieth Century, Chicago: University of Chicago Press, pp. 65-96.

Hess, Volker (2018): "Bookkeeping madness: Archives and filing between court and ward." In: Rethinking History 22/3, pp. 302-325.

Hess, Volker/Majerus, Benoit (2011): "Writing the history of psychiatry in the 20th century." In: History of Psychiatry 22/2, pp. 139-145.

Hess, Volker/Schmiedebach, Heinz-Peter (eds.) (2012): Am Rande des Wahnsinns. Schwellenräume einer urbanen Moderne, Vienna/Cologne/Weimar: Böhlau.

Hickman, Clare (2009): "Cheerful prospects and tranquil restoration: the visual experience of landscape as part of the therapeutic regime of the British 
asylum, 1800-60." In: History of Psychiatry 20/4, pp. 425-441.

Hide, Louise (2014): Gender and Class in English Asylums, 1890-1914, London: Palgrave Macmillan. Hörning, Karl/Reuter, Julia (eds.) (2004): Doing Culture: Neue Positionen zum Verhältnis von Kultur und sozialer Praxis, Bielefeld: Transcript.

Howes, David (2006): "Scent, Sound and Synaesthesia: Intersectionality and Material Culture Theory." In: Tilley, Chris/Keane, Webb/Kuechler, Susanne/Rowlands, Mike/Spyer, Patricia (eds.): Handbook of Material Culture, London/Thousand Oaks/New Delhi: Sage Publications, pp. 161-172.

Jackson, Lynette A. (2005): Surfacing Up - Psychiatry and Social Order in Colonial Zimbabwe, 1908-1968, Ithaca, New York: Cornell University Press.

Jobson, Christopher (2012): "Bloom: 28.000 Potted Flowers Installed at the Massachusetts Mental Health Center." In: Colossal, https://www.thisiscolossal.com/2012/03/bloom-28000-potted-flowers-installed-at-the-massachusetts-mental-healthcenter/, March 12, 2012, accessed on April 20, 2020.

Kalthoff, Herbert/Cress, Torsten/Röhl, Tobias (2016): "Einleitung: Materialität in Kultur und Gesellschaft." In: Kalthoff, Herbert/Cress, Torsten/Röhl, Tobias (eds.): Materialität. Herausforderungen für die Sozial- und Kulturwissenschaften, Paderborn: Wilhelm Fink, pp. $11-41$.

Kaiser, Céline (2019): Szenen des Subjekts. Eine Kulturmediengeschichte szenischer Therapieformen seit dem I8. Jahrhundert, Bielefeld: Transcript. Kearin, Madeline Bourque (2020): "'As syllable from sound': the sonic dimensions of confinement at the State Hospital for the Insane at Worcester, Massachusetts." In: History of Psychiatry 31/1, pp. 67-82. Kearin, Madeline Bourque (2019): "'A State of Conscious and Permanent Visibility': Sight As an Instrument of Cure and Control at the Worcester State Hospital for the Insane, 1833-1900." In: The New England Quarterly 92/3, pp. 431-476.

Latour, Bruno (1991): "Inscrire dans la nature des choses ou la clef berlinoise." In: Alliage 6, pp. 4-16.
Law, John/Mol, Annemarie (1995): "Notes on Materiality and Sociality." In: Sociological Review 43, pp. 274-294.

Leckie, Jacqueline (2019): Colonizing Madness: Asylum and Community in Fiji, Honululu: University of Hawaili Press.

Luchsinger, Katrin (2016): Die Vergessenskurve: Werke aus psychiatrischen Kliniken in der Schweiz um 190o, Eine kulturanalytische Studie, Zurich: Chronos.

MacKinnon, Dolly (2003): "Hearing madness': The soundscape of the asylum." In: Coleborne, Catherine/MacKinnon, Dolly (eds.): 'Madness' in Australia: Histories, heritage and the asylum, St. Lucia QLD Australia: The University of Queensland Press, pp. 73-82.

Marius, Bart (2019): "Unhinged: A User's Guide." In: Allegaert, Patrick/De Cleene, Arnout/Lamot, Yoon Hee/Marius, Bart/Scull, Andrew/Van Bouchaute, Sarah: Unhinged. On Jitterbugs, Melancholics and Mad-Doctors, Bruges: Hannibal Publishing, pp. 13-19.

Majerus, Benoît (2017): "The Straitjacket, the Bed, and the Pill. Material Culture and Madness." In: Eghigian, Greg (ed.): The Routledge History of Madness and Mental Health, London: Routledge, pp. 263-276.

Majerus, Benoît (2011): "La baignoire, le lit et la porte. La vie sociale des objets de la psychiatrie." In: Genèses 82/1, pp. 95-119.

Meier, Marietta (2015): Spannungsherde: Psychochirurgie nach dem Zweiten Weltkrieg, Göttingen: Wallstein.

Meier, Marietta/Bernet, Brigitta/Dubach, Roswitha/ Germann, Urs (2007): Zwang zur Ordnung: Psychiatrie im Kanton Zürich, 1870-1970, Zurich: Chronos Verlag.

Müller, Lothar (2019): Freuds Dinge: Der Diwan, die Apollokerzen und die Seele im technischen Zeitalter, Berlin: Die Andere Bibliothek.

Müller, Thomas (ed.) (2017): Zentrum und Peripherie in der Geschichte der Psychiatrie: regionale, nationale und internationale Perspektiven, Stuttgart: Franz Steiner.

Nolte, Karen (2003): Gelebte Hysterie. Erfahrung, 
Eigensinn und psychiatrische Diskurse im Anstaltsalltag um 1900, Frankfurt am Main: Campus. Payne, Christopher (2009): Asylum: Inside the World of State Mental Hospitals, Cambridge: MIT Press.

Penney, Darby/Stastny, Peter (2009): The Lives They Left Behind: Suitcases from a State Hospital Attic, New York: Bellevue Literary Press.

Piddock, Susan (2007): A Space of Their Own: The Archaeology of Nineteenth Century Lunatic Asylums in Britain, South Australia and Tasmania, New York: Springer.

Plath, Sylvia (2016 [1961]): "Tulips/Tulpen." In: Plath, Sylvia: Ariel: Gedichte, englisch und deutsch, Frankfurt am Main: Suhrkamp, pp. 26-33.

Reckwitz, Andreas (2008): Subjekt, Bielefeld: Transcript.

Samida, Stefanie/Eggert, Manfred K. H./Hahn, Hans Peter (2014): "Einleitung: Materielle Kultur in den Kultur- und Sozialwissenchaften." In: Samida, Stefanie/Eggert, Manfred K. H./Hahn, Hans Peter (eds.): Handbuch materielle Kultur: Bedeutungen - Konzepte - Disziplinen, Stuttgart/Weimar: J. B. Metzler, pp. 1-12.

Schatzki, Theodore (2010): "Materiality and Social Life." In: Nature and Culture 5/2, pp. 123-149. Schmiedebach, Heinz-Peter (ed.) (2016): Entgrenzungen des Wahnsinns: Psychopathie und Psychopathologisierungen um 1900, De Gruyter: Oldenbourg.

Schmuhl, Hans-Walter/Roelcke, Volker (eds.) (2013): "Heroische Therapien": die deutsche Psychiatrie im internationalen Vergleich, 19I8-1945, Göttingen: Wallstein.

Studer, Nina Salouâ (2016): The Hidden Patients: North African Women in French Colonial Psychiatry, Cologne/Weimar/Vienna: Böhlau.

Rose, Wolfgang/Fuchs, Petra/Beddies, Thomas (eds.) (2016): Diagnose "Psychopathie": Die urbane Moderne und das schwierige Kind, Vienna/ Cologne/Weimar: Böhlau.

Tanner, Jakob (2005): “Der 'fremde Blick': Möglichkeiten und Grenzen der historischen Beschreibung einer psychiatrischen Anstalt." In: Rössler, Wulf/ Hoff, Paul (eds.): Psychiatrie zwischen Autonomie und Zwang, Berlin/Heidelberg: Springer, pp. 4566.

Taylor, Steven J. (2017): Child Insanity in England, 1845-1907, London: Palgrave Macmillan.

Topp, Leslie (2017): Freedom and the Cage: Modern Architecture and Psychiatry in Central Europe, I890-I9I4, University Park, Pennsylvania: Pennsylvania State University Press

Topp, Leslie/Moran, James E./Andrews, Jonathan (eds.) (2007): Madness, Architecture, and the Built Environment: Psychiatric Spaces in Historical Context, New York/London: Routledge.

Von Beyme, Ingrid/Hohnholz, Sabine (2018) Vergissmeinnicht - Psychiatriepatienten und Anstaltsleben um 190o: Aus Werken der Sammlung Prinzhorn, Wiesbaden: Springer.

Weinstein, Deborah (2013): The Pathological Family: Postwar America and the Rise of Family Therapy, Ithaca: Cornell University Press.

Wernli, Martina (2019): "The Fake Three-Sided Key: Patient-Fabricated Duplicate Keys in Psychiatry around 1900." In: European Journal for Nursing History and Ethics 1, pp. 67-86, DOl10.25974/enhe 2019-5en, accessed on April 5, 2020.

Yanni, Carla (2007): The Architecture of Madness: Insane Asylums in the United States, Minneapolis/London: University of Minnesota Press.

\section{Websites}

Manicomio di Volterra,

https://manicomiodivolterra.it, accessed on April 20, 2020.

Northhampton State Hospital, https://northamptonstatehospital.org, accessed on April 20, 2020.

The Willard Suitcases, Jon Crispin, https://www.willardsuitcases.com, accessed on April 20, 2020.

The Lives They Left Behind: Suitcases from a State Hospital Attic, http://www.suitcaseexhibit.org, accessed on April 20, 2020. 


\section{Pat. No. 25682}

Viviane Stopp

The idea for my work came from the project Willard Suitcases by Jon Crispin.

In a former psychiatric hospital in New York, hundreds of numbered suitcases with personal belongings of patients were stored. Crispin photographed the suitcases and their contents. His photographs inspired me to create my drawings, which not only show personal objects, but also spatial situations in psychiatry and specific objects that represent the history/histories of this place. 


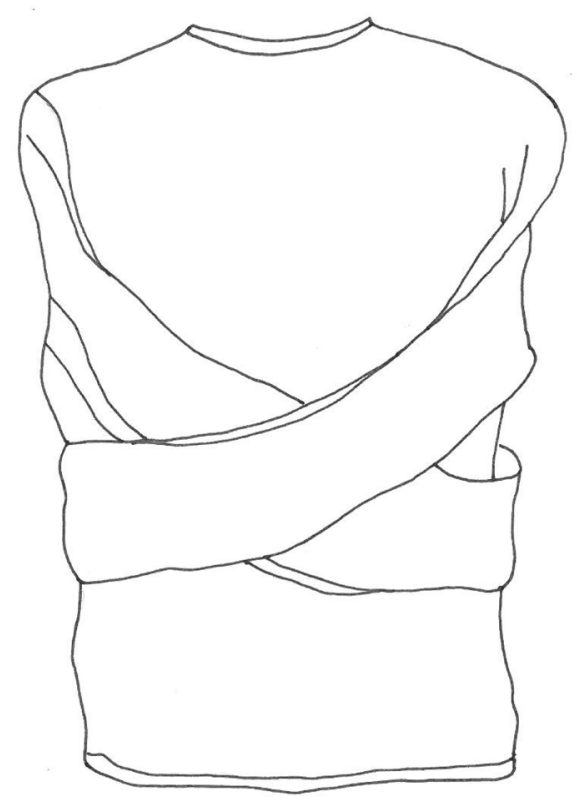




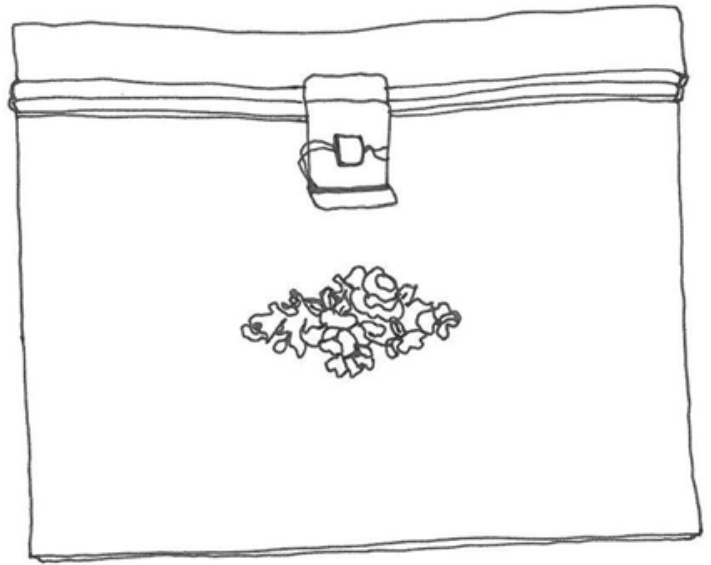


Pat. No. 25682

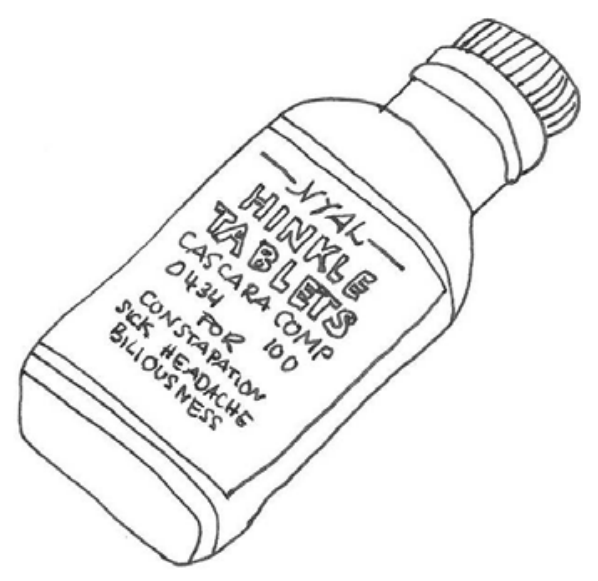




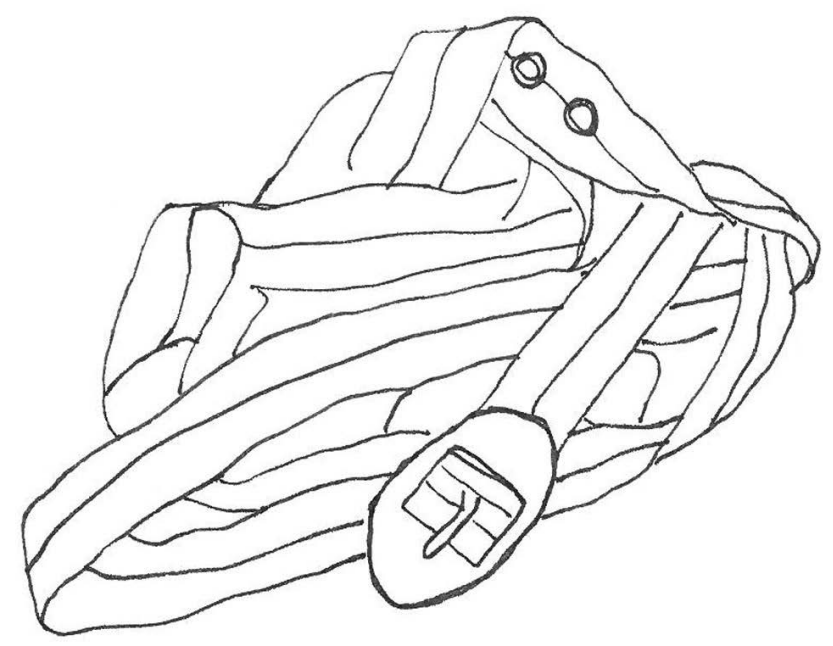


Pat. No. 25682

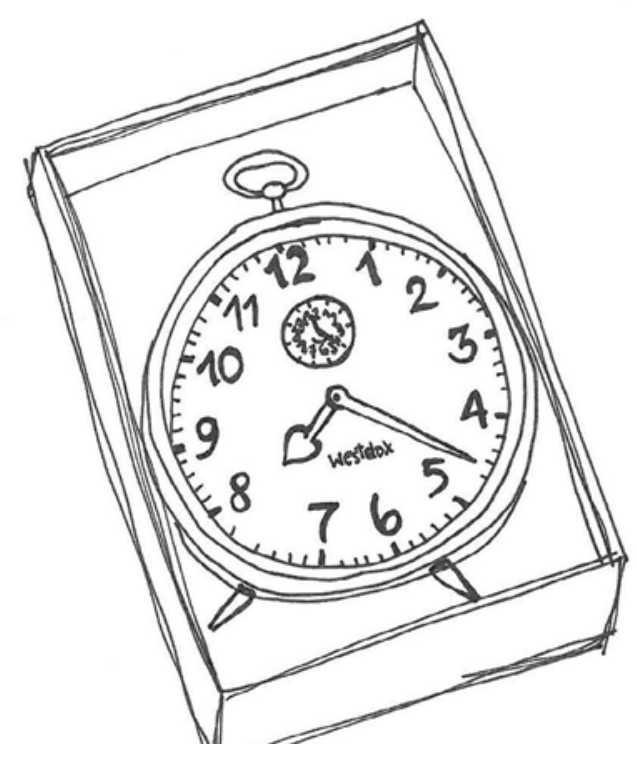




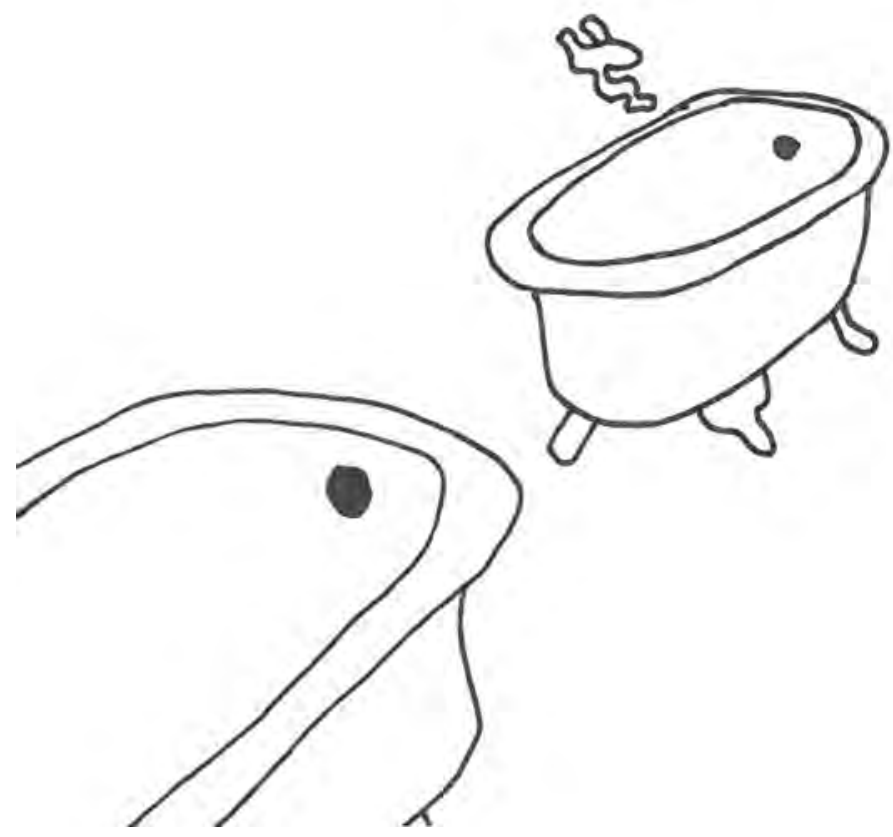


Pat. No. 25682

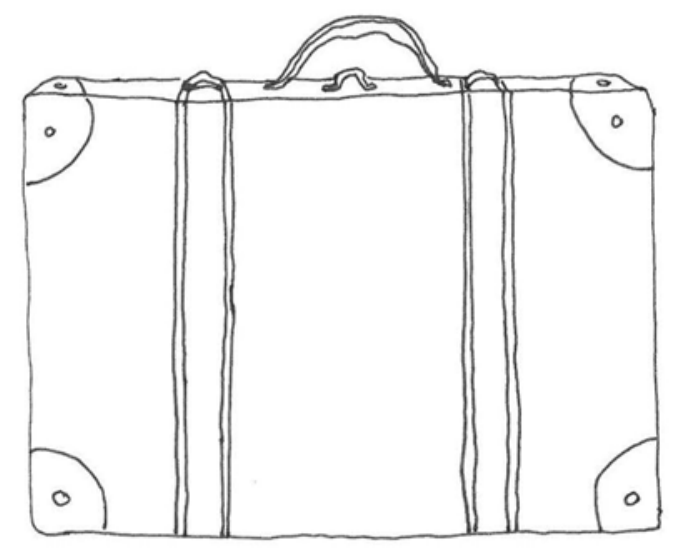


Stopp

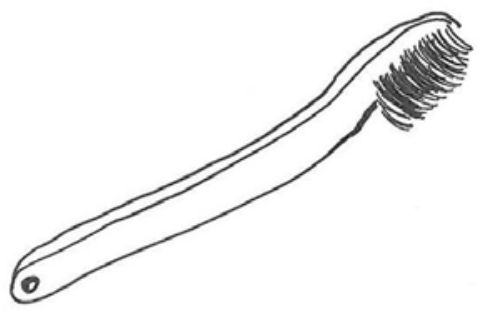

38 
Pat. No. 25682

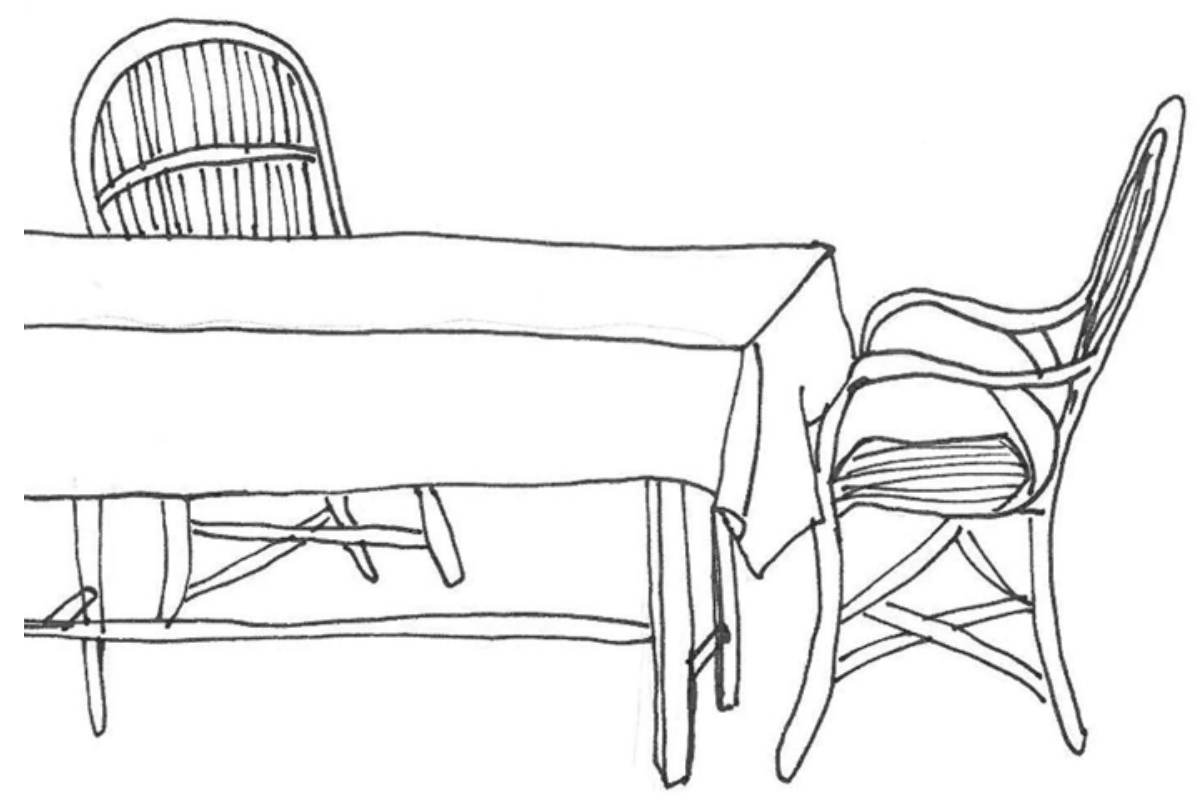



I

SCENOGRAPHY AND SPACE 


\title{
Oil on Canvas: An Isolation Cell Constructed by the k.k. Hofoperntheater for the Asylum
}

\author{
Mascha Deneke
}

\begin{abstract}
The question of how to accommodate disturbed patients given to self-destructive behavior, without using restrictive means, long ago led to the equipment of mental asylums with so-called padded cells. Thus, in many asylums there are cells with padded frames on their walls up to a certain height. These frames are constructed with the aim of protecting the patients from injury during attempts to hit their heads, hands, feet, or other parts of their body on the cell walls. Since the ordinary padded cells have various disadvantages, it was my intention to construct a cell in which these disadvantages are eliminated or at least minimized. ${ }^{\mathrm{I}}$

(Schlager 1883: 321, transl. by M. Deneke)
\end{abstract}

In this text from 1883 , the Austrian psychiatrist Ludwig Schlager describes in detail the "canvas cell" [Leinwandszelle], which he invented and had constructed by the k.k. Hofoperntheater in Vienna. Conceived as a textile room that is installed into the actual cell almost like a stage set in a theater, it is meant to protect the patient from self-injury as well as to counteract the disadvantages of the padded cell. In contrast to a stone wall, the surface of the canvas is smooth, and it is able to absorb movements without losing its shape. Based on Schlager's descriptions, the stage designer Mascha Deneke built an accurate I:25 scale model of this cell, which facilitates a specific form of spatial perception. 


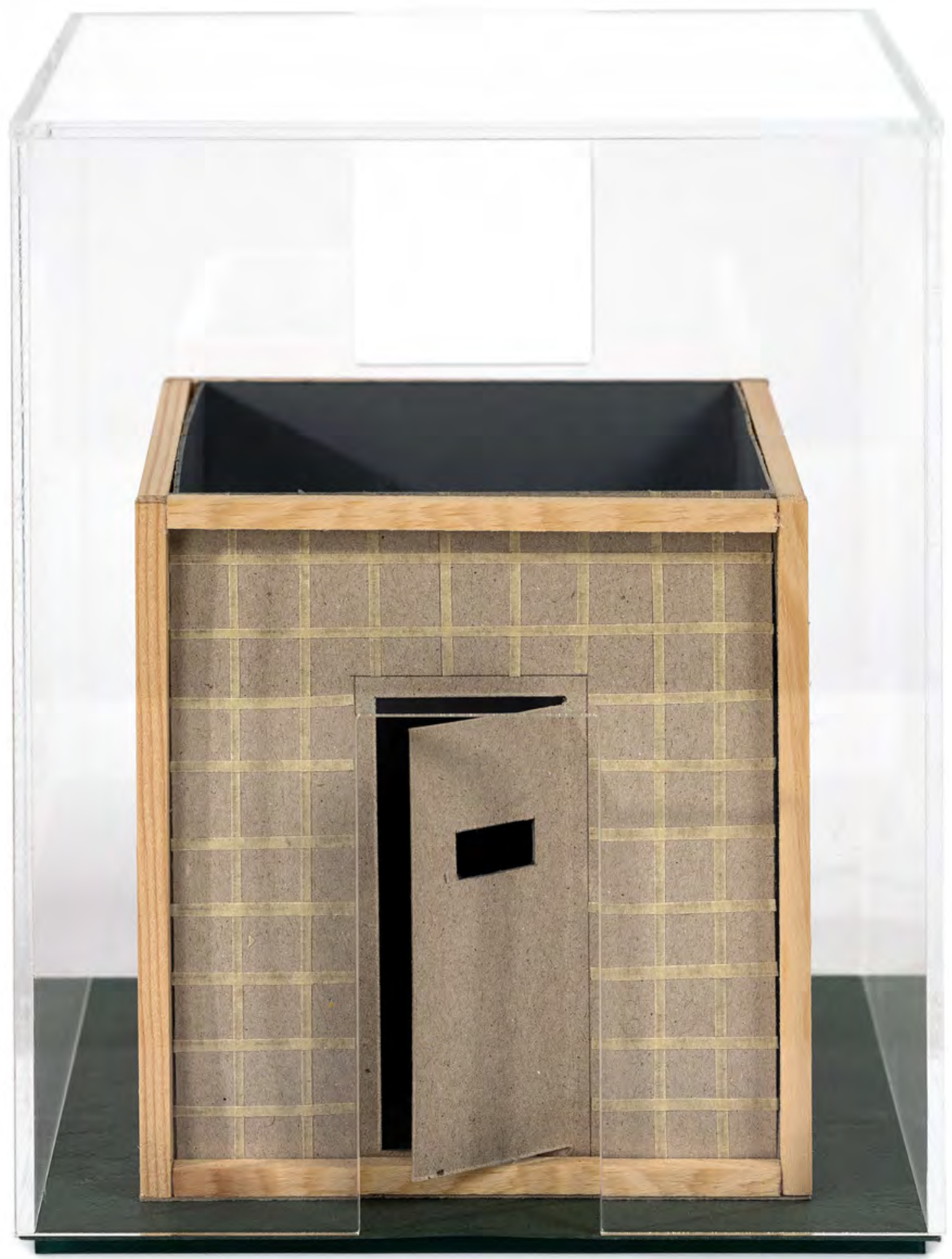




\section{Silent "Night of Madness"? \\ Light, Voice, Sounds, and Space \\ in the Illenau Asylum in Baden \\ between I842 and I9IO}

Kai Sammet

The Illenau asylum in Baden was built between 1837 and 1842 according to plans by Christian Friedrich Wilhelm Roller (I802-I878) near the town of Achern on the edge of the northern Black Forest. It was the first institution specifically designed for the mentally ill in the Grand Duchy of Baden and was meant to accommodate around 300 patients. Prior to its construction, Roller wrote a kind of pamphlet for the authorities in I83I in which he explained his views. Die Irrenanstalt nach allen ihren Beziehungen is a compendium of psychiatric care around 1830 in which Roller frequently refers to theories and views of leading psychiatric theorists.

In the following I will cover only a few aspects related to light, noises, and space at the Illenau. ${ }^{\text {I }}$ Further studies would then have to compare different institutions and writings.

First, we can ask the question: How bright was it at night at the Illenau? Outside? Inside? Was it a silent "night of madness" (Roller I83I: VII-VIII)? Outside it was probably mostly dark. But what does that mean? What lightscape can we imagine? This cannot be said with certainty. But photographs allow us to make conjectures. 


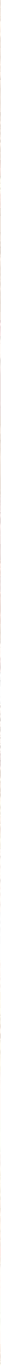

This is the avenue from Achern, ten minutes by foot from the Illenau, which was surrounded by countryside. Here no street lights are visible. At night this avenue was probably unlit, and the entrance to the asylum was dark. The Illenau was probably surrounded by darkness at night. The avenue leads to the main entrance. Oil lamps are visible to the left and right of the pillars at the entrance. ${ }^{2}$ Closer examination shows these to be the only light sources. On the left are arcades, which can be seen in more detail in figure 3.

These arcades are not brightly lit, nor is the building where the officials lived. We can assume (with all due caution - the pictures are from 1876 , and photos from the early days have likely not survived) (fig. 2) that the Illenau was surrounded by darkness and at night there were only a few sources of light. 

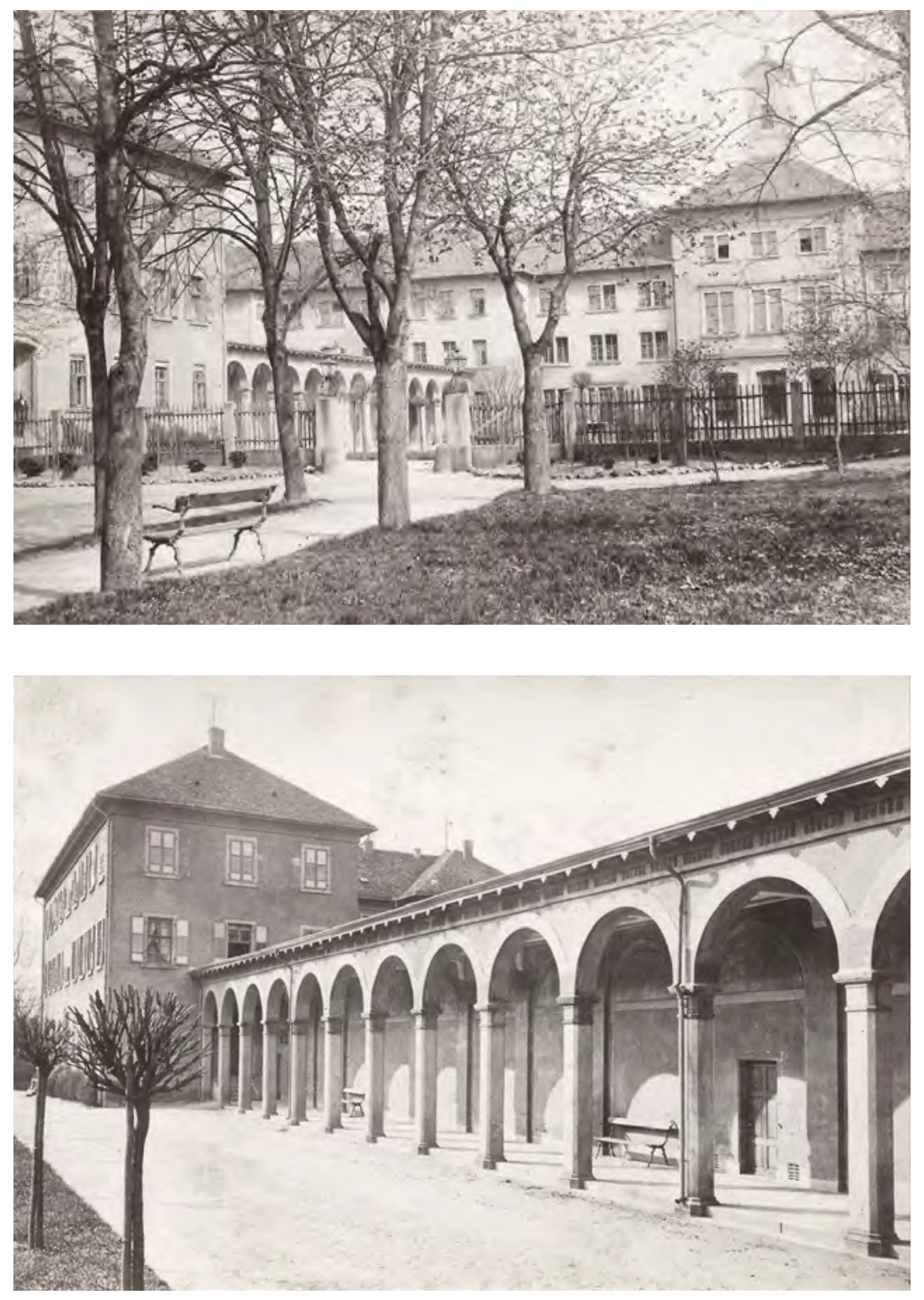

Fig. 2: Main entrance, GLA Karlsruhe 69 Baden,

collection $1995 \mathrm{FI}$ no. 78, 14, image I

Fig. 3: Arcades, GLA Karlsruhe 69 Baden,

collection $1995 \mathrm{FI}$ no. 78, 18, image 1 
And inside? What artificial light sources existed in the rooms? It was not until I892 that electric light was introduced (Schüle I9I0: 7). Previously there were oil lamps and later kerosene lamps. In the sequence of artificial light sources from candles to oil lamps, kerosene, gas, and electricity (Schivelbusch 2004), gas was never used at the Illenau. Roller was of the opinion that the danger of fire was too great (Roller I83I: I49). How bright the light sources were is unclear. A candle has an intensity of one candela. Other light sources have many multiples of one candela, but because the intensity of premodern lighting often depended on the quality of the fuel, it is impossible to make precise statements. It is difficult to estimate how bright certain oil lamps were. It is also unclear how many light sources there were in a room, where they were, and whether the lighting was moveable or fixed to the wall. Here, too, a photo of the "ladies' salon" from I876 offers a clue (fig. 4). No light sources are visible on the walls. A lamp is placed on top of a chest of drawers. It does not seem to be attached to it. Was it brought to the little table in the middle of the room in the evening - a soft, cone-shaped light for chatting and sewing?

What other indications are there? Corridors were to be illuminated all night, and dormitories were to be lit with a faint "shimmer" (ibid.: I49). Due to the risk of fire, the patients were not allowed to have light. In that case, perhaps there would have been light in the corridors, but the patients would have lain in the dark all night in the dormitory, briefly illuminated by the night watches on their rounds? And what can we imagine "faint shimmer" to mean? What effect did this have?

The perception of light as bright, faint, or glaring is historically contingent (Schivelbusch 2004). According to recent spatial sociological theory, spaces exist only as they are read and perceived. Spaces are relational. Atmospheres are important in order to understand them (Löw 200I). What kind of light atmosphere was there at the Illenau, and how did the patients, doctors, and staff perceive it? This, too, is difficult to precisely discern. But there is another indication of how part of the lightscape at the Illenau could have been. The doctor Oscar Mahir, who traveled through Belgium, France, the United Kingdom, and Germany in the early I840 to see mental asylums, complained in I846 that the lighting at the Illenau was "too dim, which has an adverse effect on the mood of the patients" (Mahir I846: I78).

Altogether, it can be supposed that night at the Illenau was a preindustrial, rural night. Dark night around the asylum, enclosed in itself, its isolation; in the rooms light cones rather than a broadly scattered light. In the dormitories is darkness, in the corridors the lighting is difficult to discern, but it is likely dim. Is that all that can be said about light at the Illenau? No, but the following also remains fragmentary. 


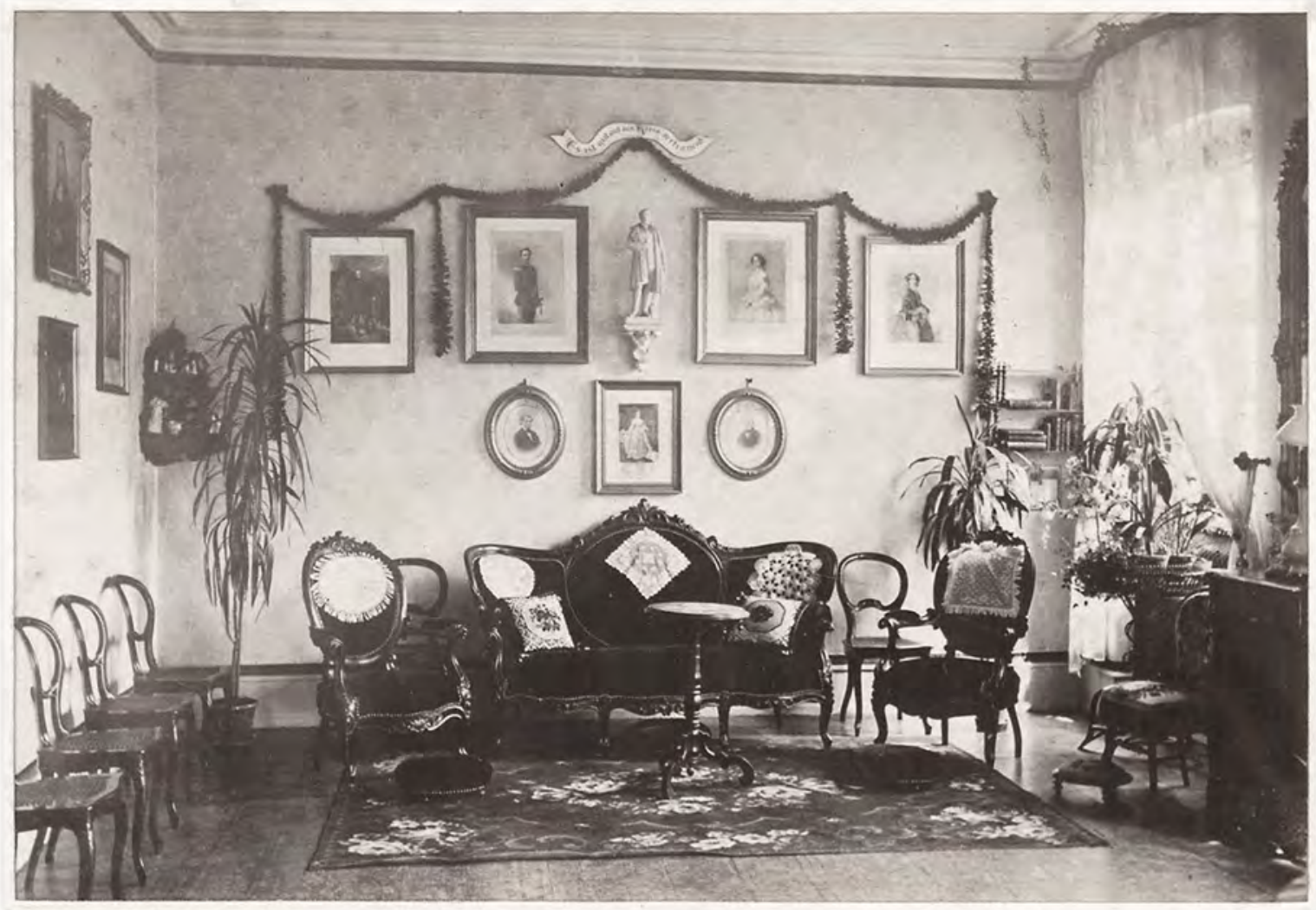

Light is not among the under-theorized concepts, neither in science nor in philosophy, religion, superstition, or art history. Almost every aspect has been covered in literature. There are nuanced differences between terms such as light metaphor, light metaphysics, light symbolism: ontologically, theologically, epistemologically, mystically, in terms of natural philosophy (cf. Beierwaltes/Bormann 1980; Beierwaltes 1980). I will limit myself to just a few aspects and will discuss them only selectively. I am mainly interested in light as a medium of connection and communication. What follows are some anecdotes and excerpts. 


\section{From Freud to Roller to Bresson: Anecdotes and Fragments}

The first anecdote is from Freud (1942: 126). A three-year-old boy asks from a dark room: "Aunt, talk to me; I am afraid because it is so dark." The aunt, in the room next door: "What good will that do you? You can't see me." The boy: "It doesn't matter. When someone speaks, it gets light."

The next four passages are from Roller's book Die Irrenanstalt nach allen ihren Beziehungen (I83I) and from a publication about the Illenau from I865. These discuss (I) the patients' clothes: "every patient" received two sets of summer and winter clothing, "avoiding any sense of a uniform by using different materials, colors, and cuts" (Roller I83I: I26). They also discuss (2) walking areas. Dense bushes were taboo. Better choices were "lawns decorated with flowers and shaded by avenues of linden trees or acacias" (ibid.: II4). In $\$ 89$ of the house rules from 1865 , it is emphasized (3) that the institution must always be kept tidy, and "especially" the corridors must "not be blocked" (Direction I865: II8). Then it describes (4) the therapeutic effect of the mental asylum. The patients are confused; "law and order, which is no longer dictated by his own reason, must be impressed from the outside, ... become the property of the patients as if reflected according to optical laws" (Roller I831: I6I-I62).

The following three passages are from Notes on the Cinematographer by the filmmaker Robert Bresson. They discuss the eye and/or gaze. Bresson speaks of the "ejaculatory power of the eye," then goes on to say: "Two people who look into each other's eyes do not see their eyes but their gazes." And finally: "Putting together a film means connecting people to each other and to things through gazes" (Bresson 2007: 22).

What connects these passages? Although in different ways, they all deal with light. Better: different connotations of light are evoked.

What is light? And what does it have to do with "materialities"? In the "material turn" in historiography (I) artifacts, things that are made, and/or naturally existing, non-living objects are the focus of attention (Derix et al. 2016). (2) Then it is asked how human (knowledge) practice is incorporated in them. (3) It is asked if/how objects are assigned a kind of actor status ("actant" [Latour 2007]) within practices. It also deals with "immaterial" properties of material, objects, their semantics and knowledge technologies. Almost no other "material" embodies this entanglement of the material and the immaterial better than light.

In reflections on the structure and space of mental asylums, light and the illumination of patient rooms, corridors, and functional rooms play an important role. 
For instance, windows (transparent media for light) and their size and construction have been discussed in depth (cf. e.g. Roller I83I: 99-IO2). But this is not just meant in a concretely material sense. Light has long been metaphorically linked to knowledge, divinity, reason, while darkness stands for chaos, unreason, insanity.

Concepts of light and brightness are also etymologically associated with saying, with revealing in speech. Light and speech are closely connected. Freud's threeyear-old shows this. Interestingly, around 1800 the voice ${ }^{3}$ of the psychiatric physician played an important role in views on therapy for the mentally ill. Darkness, on the other hand, stands for silence as the metaphor for unreason. But while the absence of speech is negatively connoted, another form of noiselessness, silence, is seen positively as a possible therapeutic practice (for example, in a dark room).

Etymologically, light is also related to spatial concepts, which results in complex links between illumination as a material phenomenon and, for example, the illumination of spaces.

In the above passages, light now appears metaphorically, sometimes physically and materially; sometimes it is about what actions light makes possible - seeing and looking - and sometimes it is about architectural lighting.

\section{What Do These Passages Mean?}

Let us first turn to Freud's anecdote about the three-year-old boy. Alone in the dark, it is the same: It is the original model of devastating abandonment in humans as animals that form bonds (Strauß 20I4; Lengning/Lüpschen 20I2). The three-yearold is without bonding, isolated, separated from the people he has bonded with: isolation, communication vs. non-communication, the gaze, supervision, observation, silence, voice. These are, as already indicated, central phenomena in the theory of the mental asylum. In Freud's three-year-old the most important sense organ is denied bonding. Consider how children's eyes communicate with their mothers in unfamiliar situations, how they reassure themselves with a glance (whether the smiling stranger in the bus is trustworthy or not). The boy does not see his aunt. There is no light from her, since no gaze comes from her. Bresson: "Two people who look into each other's eyes do not see their eyes but their gazes." If he saw her, he would not be alone. Then he would have confidence. What does he do? He establishes a bond with the aunt through the voice. He brings her to him through 
talking, so to speak; he makes her present. Now her body is there, even though he is not there. The aunt believes that only seeing will help, only face-to-face contact will take away his fear - he will not gain the light, the sight of her presence. The boy knows better. Speaking turns on the light.

Now I will turn to Roller's discussion of clothing. The house rules call for colors. Colors are the wavelengths of the spectrum that are visible to our eye. This is the physical and material side. But why should there be colors in the asylum? There were discussions about whether or not patients should wear uniform-like clothing (Roller I83I: 126). Roller advocated for individuality. Colors in general (see the flowers) offer a friendly sight. What is a "friendly sight"? Apparently, something that connects the eye and the object in a certain way - friendliness. This connection between the eye and the object can already be found in Plato's analogy of the sun, which ties together the sun, eye/seeing, visibility of objects, and light. The sun-like eye can see because there is light; light connects the eye and objects and truth. On the one hand, then, the gaze is an emanation of light; light makes it possible to see; thus it produces seeing.

Now, however, seeing something is always determined by the one who sees this object: each individual sees things differently. Thus, the gaze of the one who is looking also has a "producing" aspect. This is Bresson's "ejaculative" power. Taking this "phallic" metaphor seriously means not only throwing out, but, in connection with the sexual connotation, engendering. A gaze engenders a connection between the eye and what is seen - and in this regard an object can be "friendly" (for why this is so, see below). To understand the next passage from Roller's book, which deals with the walking areas, we must look at pictures.

We are looking at the Illenau, in the foreground two building ensembles, separated by an avenue (fig. 5). These are farm buildings (stables, among other things). In the background the asylum itself. In front of the left building complex of the asylum are walking areas. We can see the plants. Nowhere do they run wild. It is a cultivated landscape created by human beings. The type of planting and thus the composition of the space is even clearer in figure 6 .

We are looking at the church and the interior of the asylum (we already saw this; on the left are the arcades again: cf. fig. 2 and fig. 3). Inside and outside, this landscape has been constructed. Inside is the well, around it bushes and trees; everything is loosely distributed. On the one hand, this is Enlightenment: creating anew according to human principles (Porter I99I; Reed 20I2). On the other hand, it is also the theory of the Earl of Shaftesbury (I67I-I7I3) of nature as a moral power. According to 


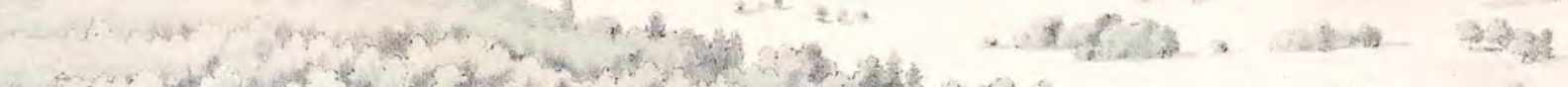

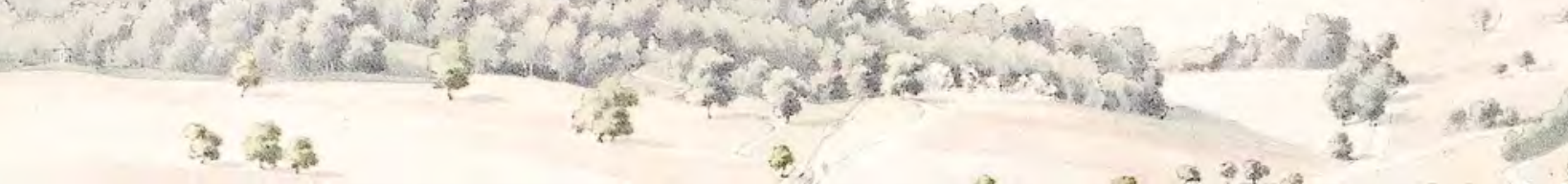

W.

$3 x^{3}+3+2+3$

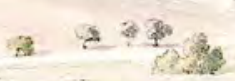

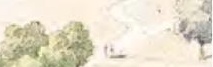

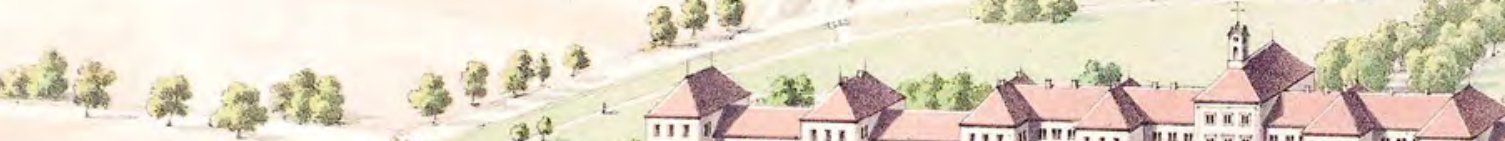

क Q

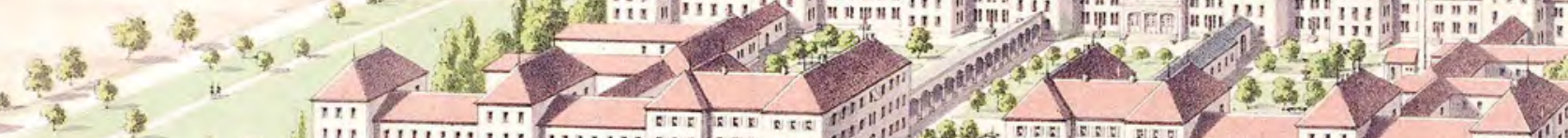
Q

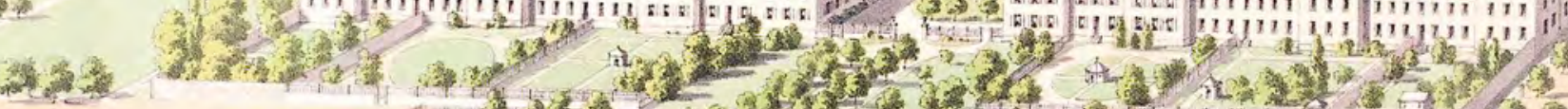
3.

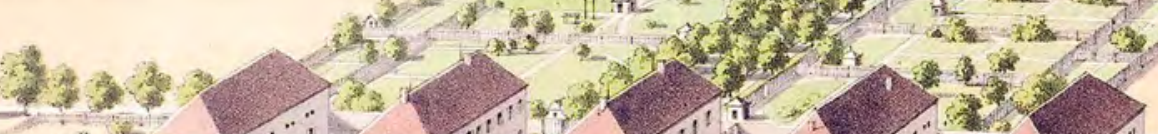

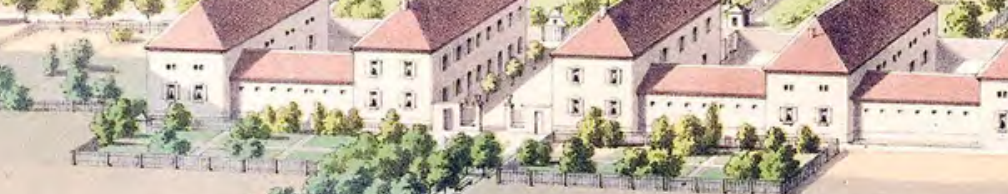

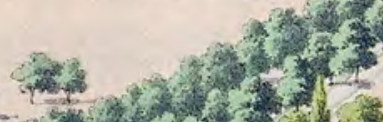

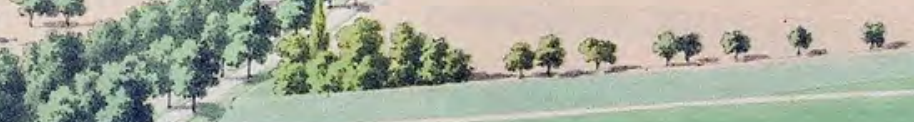


this theory, nature reflects the harmony of the cosmos; it is good, and so it is a moral power. It looks friendly; the sight of it is friendly. As beauty, it awakens morality in people (Klein 2003: 15-18). And what kind of cultural space is built there? With this approach to planting there is a play between light absorption by bushes and trees and the passage of light, and thus the gaze. Here a space made of shade, light, color, and the gaze has been built.

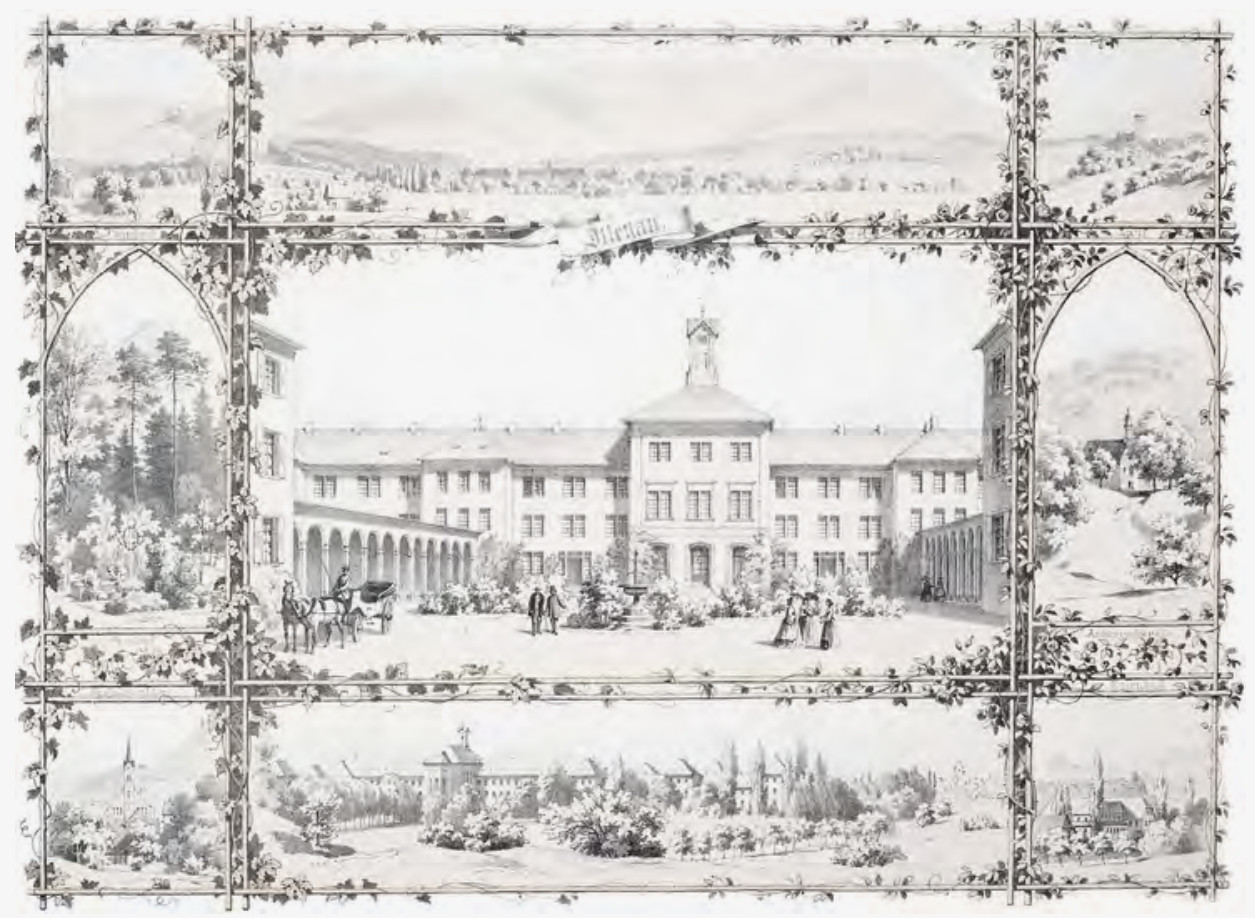


The light is not stopped by dense bushes like it is by a wall. This is important. Although Roller says the asylum needs an enclosure, meaning it must be separated and isolated in space as a separate space, he does not want a high wall as a means against escape attempts, because that would give the institution an "unfriendly, prison-like appearance" (I83I: II5). But how should escape attempts be prevented? Roller: "mainly through the living supervision" (ibid.). So again through the gaze, seeing through the medium of light. But Roller is also against dense bushes, because they make supervision more difficult. The patients must be visible - this requires not only light, but a lighting created by the construction of the space. Light then allows observation. Natural light is thus tamed on the one hand; on the other hand, it radiates, but it is also scattered, for example by leaves on a tree. In order not to seem too claustrophobic, living supervision is needed to walk around and observe. This must be accommodated by the construction of the asylum. It must be constructed so that "anything angular is avoided" (ibid.: 93). Light does not bend around corners. What is meant by this can be found in the third example: Corridors must not be blocked.

We are looking down the corridor of the women's section (fig. 7). Although there are many rubber plants here, the passageway itself is free. The visual axis is clear. Lighting through architecture. The light wanders through the straight corridor. This is why the passageway must not be blocked.

Finally, I come to the last passage from Roller's book mentioned above: The patient is confused; "law and order, which is no longer dictated by his own reason, must be impressed from the outside, ... become the property of the patients as if reflected according to optical laws" (ibid.: I6I-I62). This is a strange metaphor. But it shows again how closely reason/optics/light are linked together. The patient is confused, "thoughts and desires" (ibid.) ceaselessly wander around in his mind. Nothing is ordered; everything is somehow random. The element of the coincidental and ceaseless means a disregard for reason - and this, in turn, is identified with blindness in Plato's analogy of the sun (Plato I97I: 506c). The patient is able to see again when law and order cast light like in a mirror and from this mirror ("reflected") the rays of reason are cast into the mentally ill person and then law and order become the "property" of the patient. It is dark in the "night of insanity." The natural light of reason which is otherwise radiant in us is extinguished; now it is lit again by law and order. 


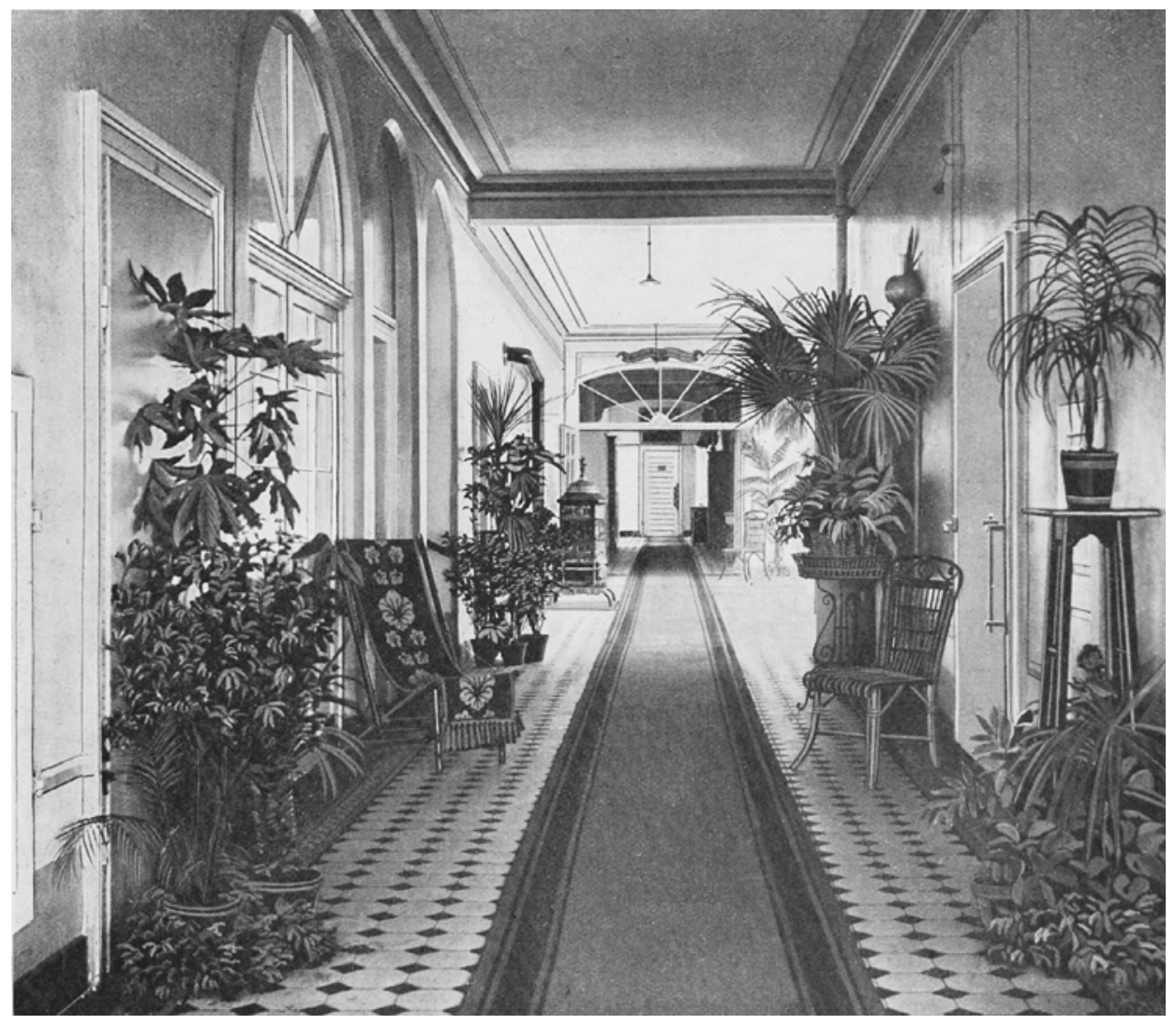

Light As Surveillance

Roller postulated: Only a newly built institution would fulfill the purposes of healing and care. Therefore, for the Illenau, the first asylum in Baden, existing building complexes (for example, a former monastery) would not be adapted. This, in turn, is a concept from the Enlightenment. The new must not be built into the old; the new must be created anew from the ground up. Only in a "suitable place" can "house rules and supervision" be carried out (Roller I83I: 18). Again, supervision and observation require a spatial order, which implies an order of light. We saw it in the bushes, in the corridor. Lighting through buildings or plants serves surveillance. 
Is this simply panoptism through architecture? Is light only a medium of surveillance and discipline? Surely, supervision is central to the asylum. There are many passages in Roller's book that not only give the impression of being about ensuring surveillance and discipline through constant visibility. For instance, Roller is against single rooms because "no supervision takes place" (ibid.: I06). Larger rooms make supervision easier. An attendant can sleep in them so that the patients are under (virtual) surveillance all night long (ibid.: I06-IO7). The patients are to eat together in the designated halls, where "complete supervision is possible. The doctor can easily supervise all the patients at this hour" (ibid.: I66-I67). Roller sees little value in the proposal to divide an institution into several small buildings, a pavilion system, since this would make "inner supervision difficult" (ibid.). In connected buildings, moreover, "internal communication" is easier (ibid.: 94). Does that mean (as is so often said) that "the asylum" is nothing but a disciplinary institution, here too and explicitly a "total institution" because the surveillance is "total" (Goffman 196I)? That would be an exaggeration. Furthermore, in Germany there was only one institution designed according to the architectural model of Jeremy Bentham: Erlangen, with a surveillance tower in the middle. This is partially evident in Roller's approach: nothing angular, the free corridor. However, it seems that the architecture was meant to promote a kind of mobile, flexible panoptism: "living supervision." And:

The supervision in the mental asylum must be general, must extend over everything and encompass the whole: the police, the farm buildings, as well as the symptoms of the disease; it is a joint duty, must be exercised from the first director to the last servant, so that everyone is watched by the one above him. Then it must be constant, must not be interrupted by any incident or time of day. It must continue through the night. (Roller I83I: I7I)

All this sounds like flexible panoptism with the main purpose of control. Foucault posits: "He who is subject to visibility and knows it takes over the coercive means of power and plays them against himself; he internalizes the power relationship ... ; he becomes the principle of his own submission" (Foucault 1992: 260). This is certainly intentional in (disciplinary) institutions. But Foucault offers no argument why this should be so. The vague concept of internalization obscures it. Why should people not be able to distance themselves from the gazes of others? Moreover, perhaps something other than control is meant by this. One can 
also interpret gaze/visibility differently: Freud's three-year-old does not want to be supervised; he wants to be protected. Roller wants a coherent structure because "internal communication" (emphasis mine; Roller I83I: 94) is possible in it, meaning connection. If the attendant sleeps in the hall, then he is present, maintains a connection. It remains undecided whether light is a disciplinary technology or a medium of communication. It is both at the same time.

\section{Other Aspects of Light}

There are other aspects that could support a different interpretation of the mental asylum as a mere disciplinary institution. Let us look at the natural light on Saturday, 2 September 1865 , for example. It is 5 a.m. in Achern. The day is dawning. It is time for the night attendants, "keepers of the sleeping, protectors of the houses, invisible observers and silent judges," 4 in 1865 two of them male and two female, at the Illenau, to wake the daytime attendants. Did anything particular happen at night? Perhaps someone died: "The dead are brought to the morgue in the silence of the night" (ibid.: 169). Perhaps someone became wild; mania expresses itself especially at night. Perhaps the doctor, who is supposed to do night rounds, was not present. If his body of reason is not there, the silence gives birth to monsters. The doctors must be present in the institution at all times; they must live in the institution. After all: "At every hour of the day and night they must be able to look after things and remain in constant contact with the institution." In this context, Roller quotes the French psychiatrist Jean Étienne Dominique Esquirol: "One has no real insight into insanity if one has not frequently observed the mentally ill during the night" (ibid.: 32I-322).5

And: Night and death are the same; the dead are not dead, they descend upon the living. Light dispels fear and chaos; the gaze of the physically present doctor dispels the darkness of mania. This is not supervision. It is magical and psychological thinking at the same time. The doctor is the embodiment of reason. If he is there, then there is light.

After the attendants, a bell wakes the patients, all at the same time. In the winter it is still dark. The bell is a central regulating noise in the institution. It separates day from night. Thus it is a light switch: with its sound, the sick come out of the isolation of their solipsistic, insane nights, out of their silent night of madness, into 
the community and thus communication and connection with everyone. Later the work begins - preferably in the field and in the garden, outdoors (ibid.: I87). In the winter, wood is chopped, some work in workshops, some even in the dark cellar, where often artificial light is necessary.

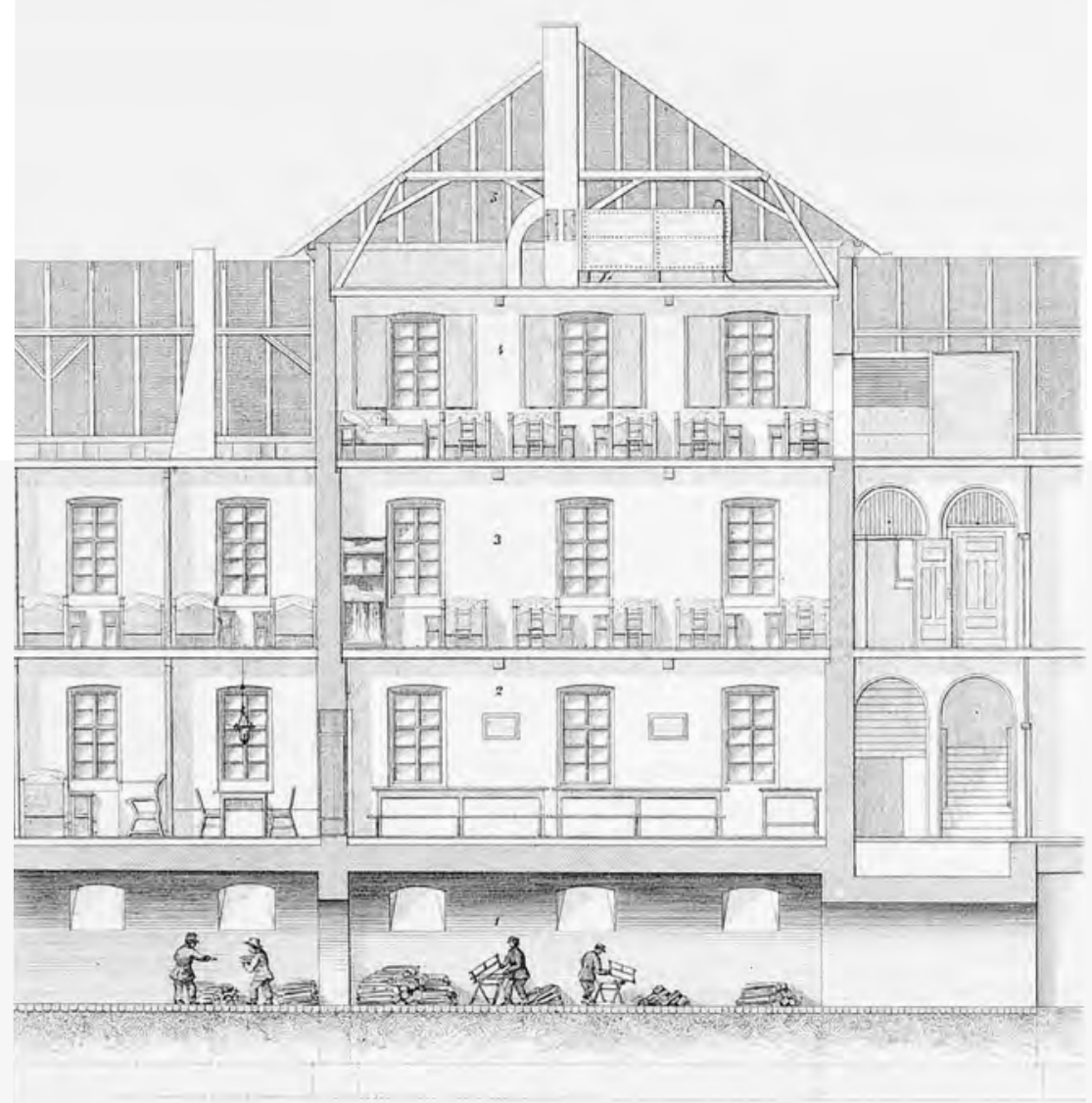

Fig. 8: Chopping wood in the cellar (from: Direction 1865)

> Fig. 9: Geographical orientation of the Illenau (from: Direction 1865) 
It seems trivial that the lighting conditions for individual patients were different depending on the season, day/night, weather conditions, indoors/outdoors. But if light were only a medium of panoptism, then the asylum would be like a high-security prison: glaring light 24 hours a day and/or constant exposure to the gaze. This is not the case; it is not just about control. At 9 p.m. the bell sounds: bedtime. With this last sound, the light is switched off, so to speak, and the patients wander back to the isolation of their sleep - in dark rooms.

Let us start the day again. The day is dawning. What is illuminated by the sun? In the morning the sun strikes the back parts of the institution at an angle, and in the evening the front parts. In I83I Roller preferred the main facade to be facing south (ibid.: 64). Here it is different. From Achern the road makes a curve and then straightens out; this is not a north-south orientation.

That may have been a pragmatic decision; several areas in Baden were visited before the construction. Or it is not so important. It is not just about the angle at

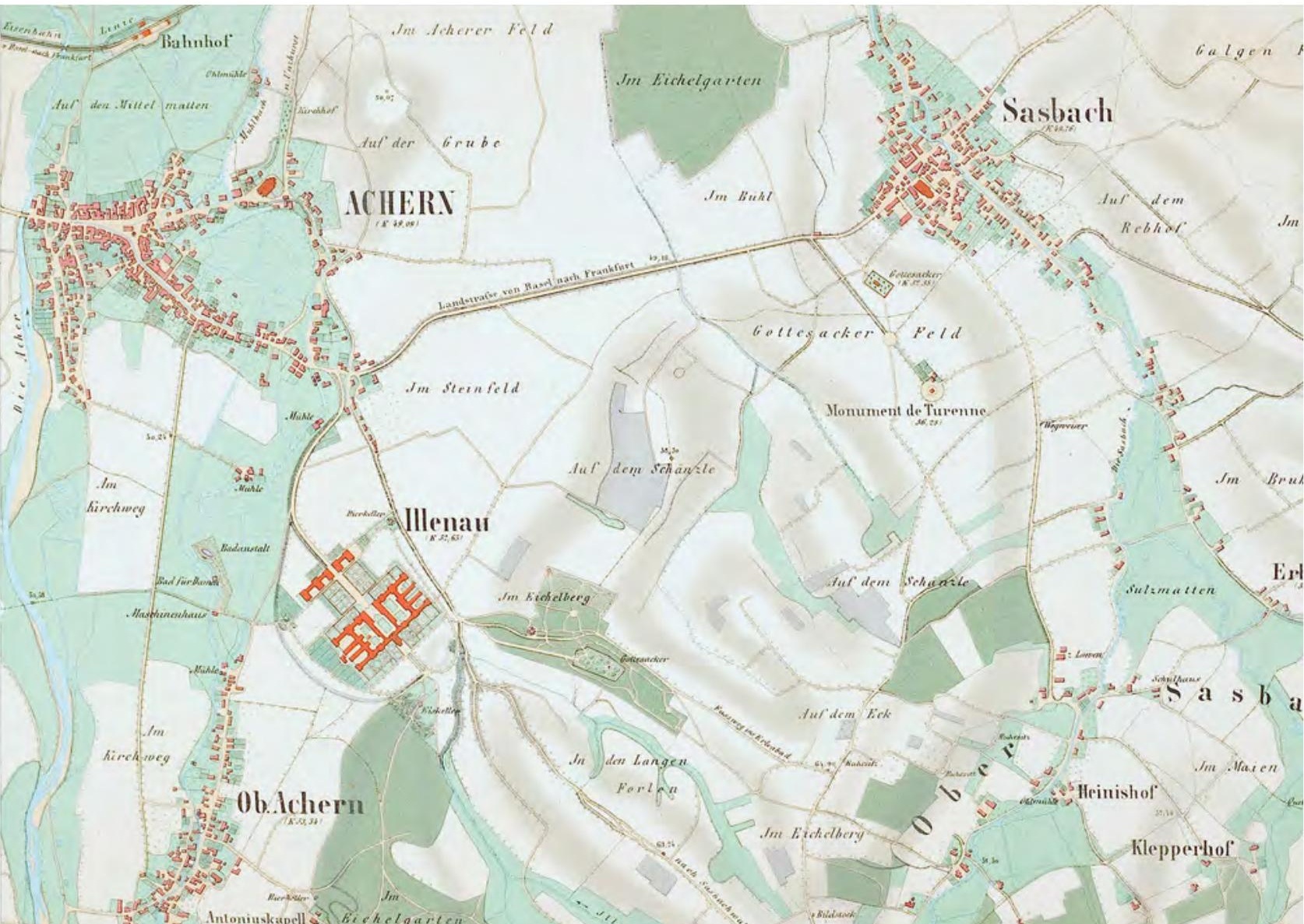




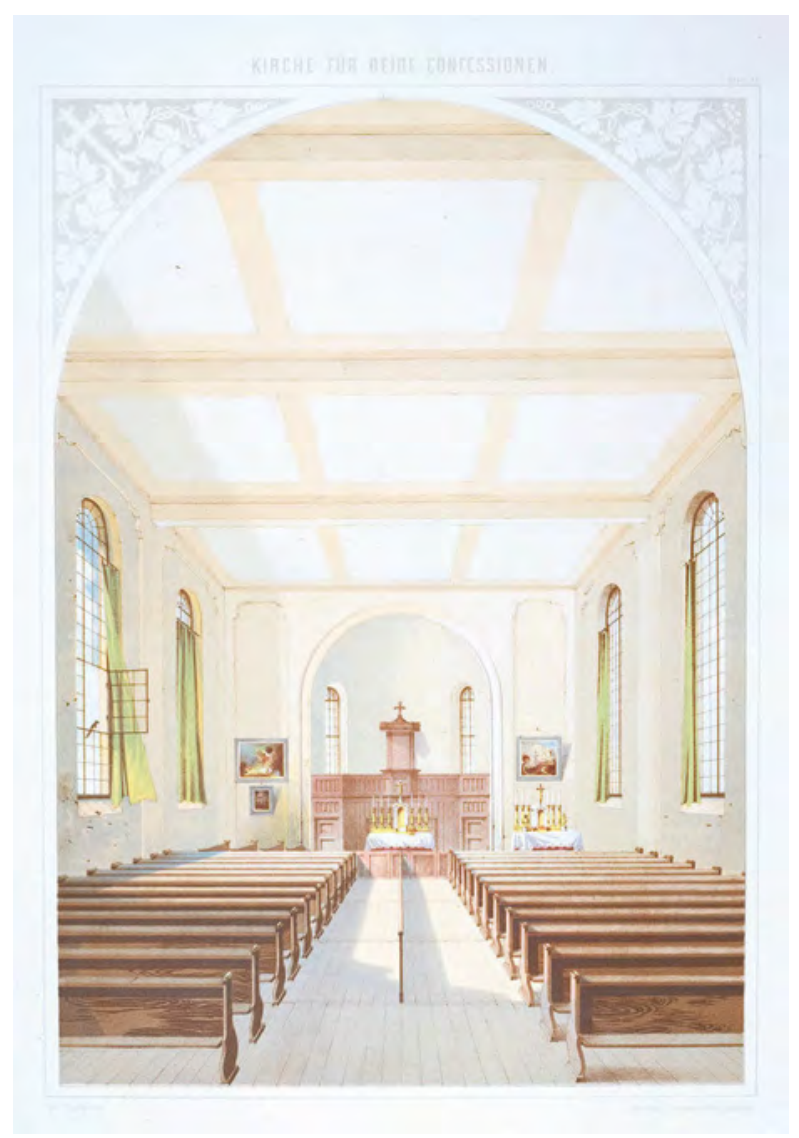

old, silence was social death. If the bell in the morning in the Illenau turned on the light in a sense, then now, "during the church service, solemn silence must reign in the whole institution" (Direction I865: 103). Only in silence is a connection to God established. Silence allows one to collect oneself (Jungwirth 1935/6; Kemmer 1986; Mensching/Hertzsch 1961; Wohlfart/Kreuzer 1992). And what is God's role here? He turns on the light. He is the light. And insanity is loss of "reason," the light that shines in us. This light has purposes: 
Reason was given to man, that he should be free from the compulsion of the laws of nature, that he should learn wisdom, recognize a god, be like him, that he should share in the bliss of immortal spirits. And he rejoices in this reason. He needs it to become ever better, more perfect and blessed. He proudly rises above the other creatures, but he does not forget that he may lose this divine gift, if only here in this time, and then sink lower than an animal can ever sink. (Roller I83I: VII)

Reason elevates us above nature, connects us with God. This materializes in the visual axis and church windows and presence in the room. Is this not also an optical reflection of order in the mentally ill via space? Spatial order makes light order. Light is not a medium of surveillance but of communication. It connects things and people with each other through gazes.

Again, how does the light fall on the institution in the morning? In figure II we see letters, the individual departments, the structure of the relatively connected sanatorium $^{6}$ : to the left, in the west, Pflegeanstalt (the section for long-term care); to the right, in the east, Heilanstalt (the section for treatable conditions). Men's department above, to the north, and women's department to the south. As for the natural light, neither part is given preference. The sun shines on the curable and incurable, on men and women. In the morning, the sun shines on the short-term care wing, and in the evening on the long-term care wing. The gender and the hopelessness of the disease are not reflected in architecture and light. Class differences also play no role in sunlight. The departments of the better-off are located in the middle facing the church. This makes no difference for the incidence of natural light.

Are there differences in lighting according to gender, class, or prognosis inside? Rooms were furnished differently according to the level of care (social class). For instance, in third class there was a bed, a chair, and a bedside table; in second class, straw chairs and blinds; in first class, patients could sit in an armchair, while retirees could relax on a sofa instead of an armchair; carpets were laid out in front of their beds (Direction I865: 22). (Did the carpets have a "friendly" color?)

Clearly, however, construction and light were based on the state of illness and behavior. In the case of the curable, three classes are distinguished according to social class: calm patients from the "upper classes," calm patients from the "second class, townspeople from the middle class," and calm patients from the "third class, farmers" (Roller I83I: 83). In manic, aggressive patients, "no difference in class is 
made. The manic baron, as long as he is manic, can be quite well located next to the manic farmer" (ibid.). Raving madness erases differences in class.

In the incurable, things were more complicated. Here class differences were in part ignored, and in part upheld. There was only one section for calm patients from the second and third classes: farmers and townspeople (from the middle class) were treated equally. A separate department was kept for the first class, because "not all incurables" are "imbecilic," meaning so deranged that they would no longer perceive the difference in class (ibid.). They still lived in rooms for the upper classes, where the furniture, colors, color play, and lighting conditions were maintained for them.

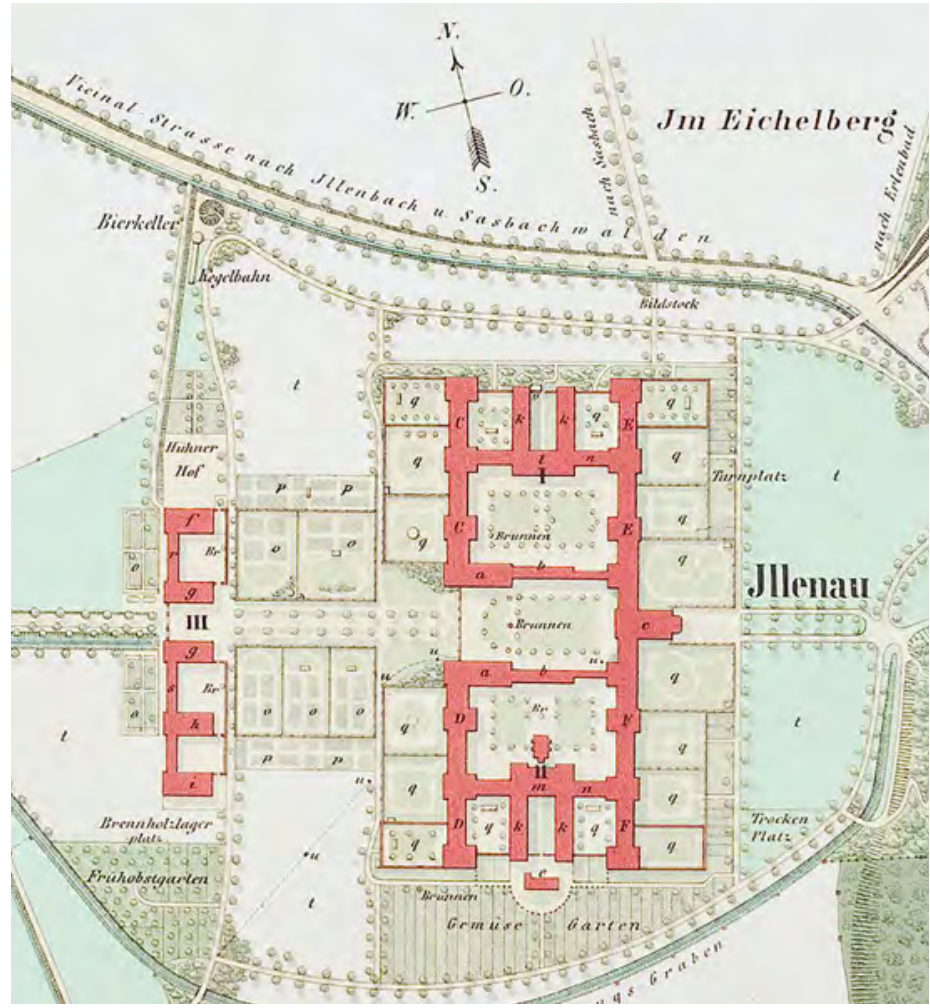




\section{Lellen.}

Langenschnit eines Zellengebaudes und des Luftheitzungsofens

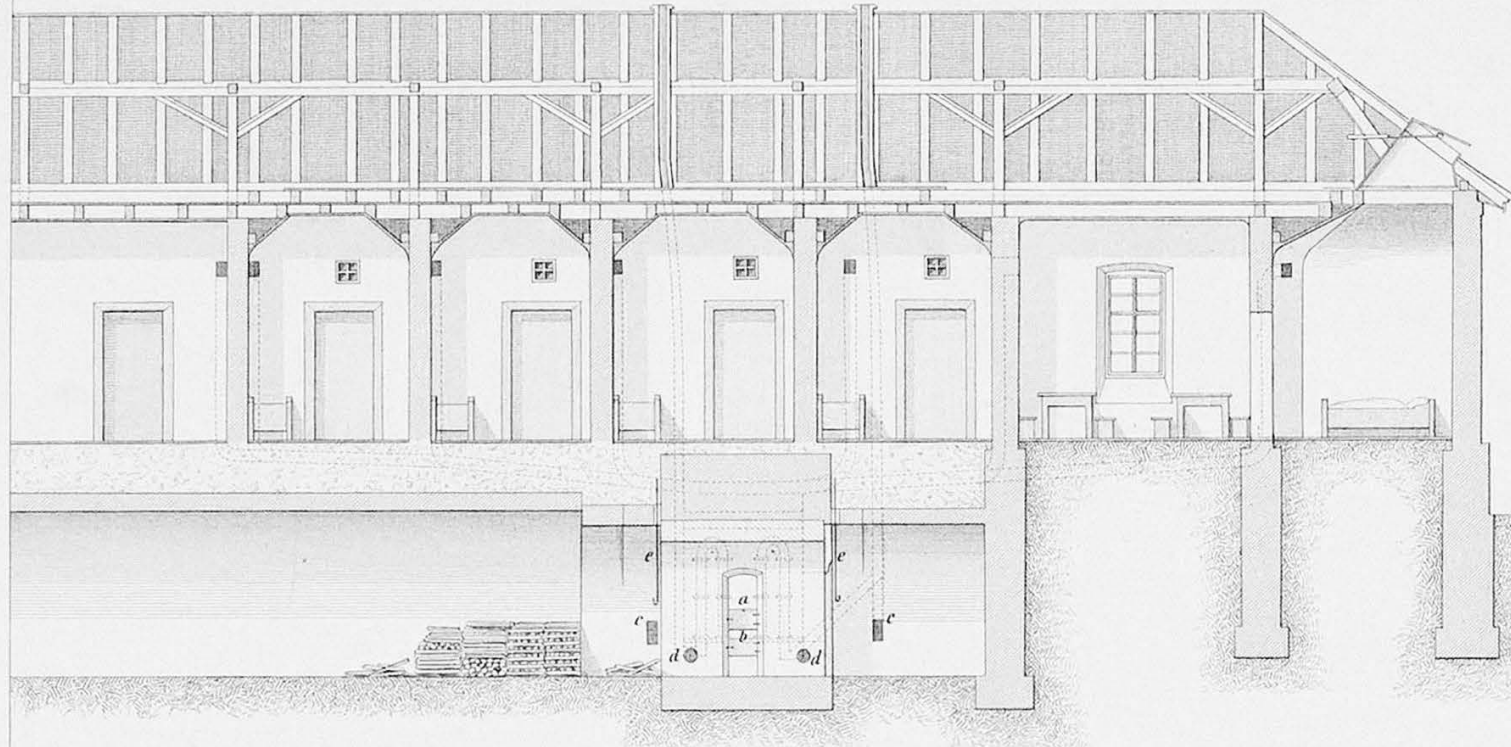

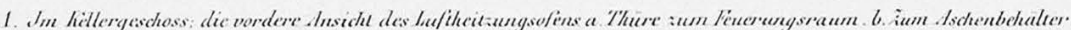

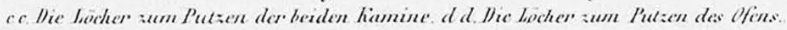

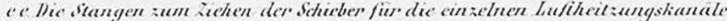

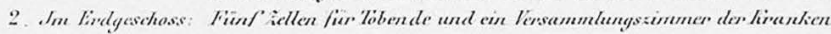

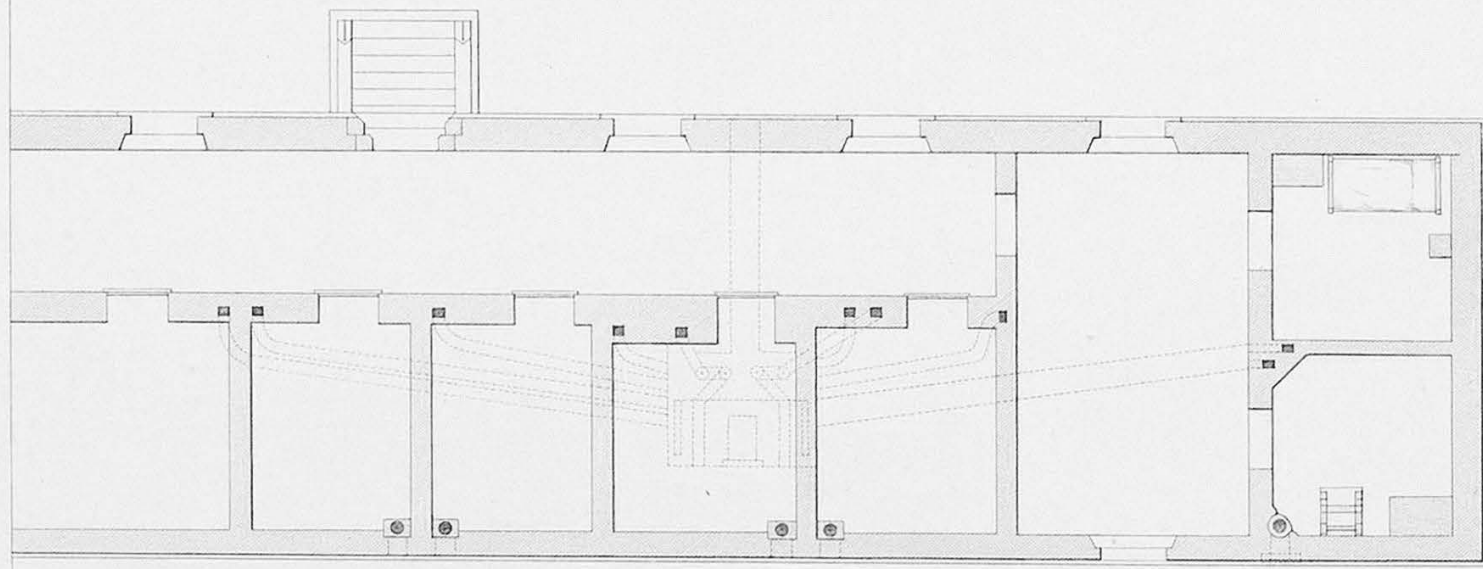

Fig. 12: Department for manic patients (from: Direction 1865)

> Fig. 13: Cell for manic patients (from: Direction 1865) 


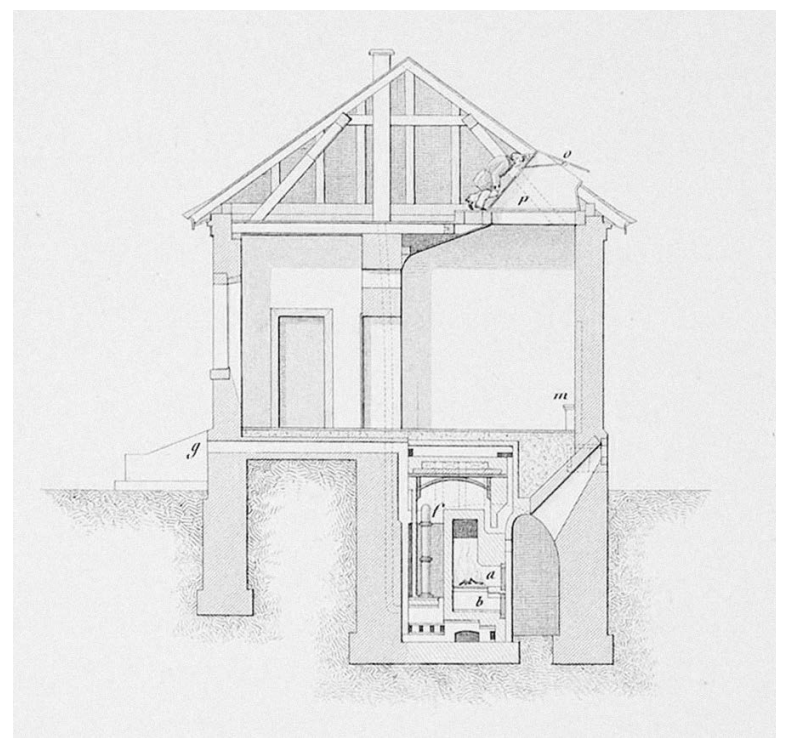

Let us examine the letters $\mathrm{K}$ in figure II - these are the areas for manic patients. They are spatially and visually constricted: the department for manic patients is one story tall (ibid.: 97), while the other departments are two stories tall. The cells receive little light. Their construction makes them even darker.

Consider figure I2 and I3: At the top left are five cells for manic patients, with high windows. The light can be mechanically regulated. The cells are dark; all light can be blocked out. Here no light flows; it is stopped, it is taken away or granted. Darkness is punishment and therapy (is it meant to create fear?). At the same time: "A prolonged detention" - meaning isolation - is a "sensitive punishment. It becomes even more so when the light is simultaneously taken away" (ibid.: 229-230). But it is not just about punishment, because "with darkness one also turns to silence" (ibid.). Silent darkness equals silence equals punishment equals peace equals pacifying. Manic patients alone in the dark - isn't that awful (see Freud's three-year-old)? 
Isolation, Light, and Communication

Isolation has positive connotations in the asylum. Patients must be isolated in an asylum; their ties to their family must be broken (ibid.: 3). Why? As will be shown, here light and communication/ties are brought together. After all, isolation is justified with reference to the place where the ties are broken, the family, and, secondly, with reference to the place where the isolation takes place: the asylum and in some cases in the asylum itself. Isolation in all three spatial dimensions was meant to prepare the patient for bonding and communication, and thus healing.

Mental illness means misunderstanding something in communication at home; mental illness is a communication disorder (ibid.: 4) as a bonding disorder: "What one says" to the patients "they understand in the wrong way or not at all and become impatient. Signs of the greatest tenderness they take for insults, or they seem to them like unsolvable riddles. The patients' mistrust grows, they become gloomy and fearful," and now the "most tender son, who found his greatest happiness close to his parents, in carrying out childhood duties, ... escapes from the family home" (ibid.). This is not meant as a cognitive disorder; it is the disorder of and fundamental damage to the patient's sociability: he becomes suspicious, breaks off communication and bonding. The words he exchanges with his family members no longer spread any truth in him. Dialogue as the basis of bonding and relationship is disturbed.

As mentioned, not only light and truth are closely related, but also speaking and light and truth (Bremer 1974). Etymologically, the connection between light and saying/revealing is deeply rooted in Indo-European languages. Saying is to make appear what has not yet appeared (Bechtel I879: I3I). In Greek, "shine and speak were originally one" (Curtius 1879). Why is saying the same as making appear? Because saying is "always a letting know" (Bremer 1974: 194); but knowing is based on seeing in Indo-European languages; thus, saying becomes "making to see and showing" (ibid.).

At home there is conversation. In the family, understanding, bonding through speech takes place. But the mentally ill person misunderstands. He is not illuminated, it does not become light, it becomes dark. He has to go to the asylum. There he is isolated. First he is bathed, then "he receives a refreshment and for a time is left to think about his new situation." Then: "During the initial period the patients remain in the rooms specially reserved for new arrivals," since the patient should not "immediately be brought into the varied company" of the other patients, and he must 
"be observed": "A device made for this purpose, but only invisible to the patients" - an observation window, a spyhole - would make sense here (Roller I83I: 273).

He is isolated in a room, is observed. This is the gaze of surveillance. But here, too, silence takes effect. He is left to himself, and so he is confronted with silence: "The first effect of isolation is that the new objects produce new impressions" (ibid.: 3). He is isolated - he receives the new impressions through optical laws through sight. The silence leads him to stop in his madness; the patient is meant to be able to collect himself, since now silence reigns, so that new impressions can penetrate into him. But voices have to appear again, so that the light of reason reappears in him. This is why, as was previously mentioned, the doctor's voice is so important in therapy. When he speaks, it becomes light. But also when he looks. It is advantageous if the doctor can impress by "his voice, his gaze" (ibid.: 317). Surely this gaze is also meant to banish madness, instill fear, tame the animal nature (through the light of reason):

[T] he first object of a physician, when he enters the cell, or chamber, of his deranged patient, should be, to catch his EYE, and look him out of countenance. The dread of the eye was early imposed upon every beast of the field. The tyger, the mad bull, and the enraged dog, all fly from it: now a man deprived of his reason partakes so much of the nature of those animals, that he is for the most part easily terrified, or composed, by the eye of a man who possesses his reason. (Rush I8I2: I75)

Originally, Roller said that the chief physician must be constantly present in the asylum, in constant contact with the patients (I83I: 32I). This proved impractical, since the Illenau was too large for the director to visit each and every patient on a daily basis, but he was meant to visit the four main departments (curable men, curable women, incurable men, incurable women), each of which was led by one doctor, at least "several times a week" (Direction I865: I2). He received the necessary information in the daily conferences. Communication and connection took place in conversations, in conferences. The department physicians were meant to be in close contact with the patients. ${ }^{7}$ Attendants were always present. They were responsible for the operative vocal business and maintained a bond with the patients. The higher-ranking attendants communicated with their superiors and were charged with "working on the individual patients" (ibid.: 30). Speaking can replace seeing. 
But there are also dangerous sights. The ailing do not belong in mental asylums; their sight is "not pleasing" - meaning not "inspiring trust" - to the mentally ill (Roller I83I: 8). Friendly sights create trust, like the colors of the clothes - connection through seeing. An unpleasant sight creates mistrust, and mistrust, in turn, as we saw in the example of the family, causes a communication disorder. But these visual axes are not only between people. Communication works through the institution itself: the interior and the exterior of the institution must be "calculated" for "inspiring trust," creating a bond, since trust is the "sacram anchoram of all psychic influence" (ibid.: I04).

Light creates a bond; it makes communication possible - but not all communication is allowed. For example, Roller is against teaching students in the asylum; relatives do not want to expose their sick "family members to the gazes of students," which would be embarrassing for them (ibid.: 37 ). It is about concealment/secrets, and so there are "improper" gazes. Outsiders are not allowed into the asylum: "The sanctuary for misfortune is desecrated by the gaze of curious onlookers" (ibid.). But is this just about shame? No. The gaze itself which falls on the patients, can be of different qualities: "women, children, and all non-scientifically educated men ... must be simply forbidden to enter the asylum" (ibid.: I73-I74) due to their lack of reason. "Improper" gazes must also be considered in the construction of the institution: It must not be on a mountain slope, where outsiders could look in from above (ibid.: 63).

But light cannot always be controlled. Roller is uncertain in his discussion of windows. Windows are a problem: they are transparent. Light can suddenly, uncontrollably penetrate into the interior - unless it is controlled as in the areas for manic patients. But there are techniques to control the light. What were the windows like from the inside? Were they like in figure 4 , the salon for ladies? The natural light is kept out somewhat; the curtains gently veil the outside.

And what about the corridor of the women's department in I9IO in figure 7 ? I already mentioned the straight light axis, but the incidence of natural light remains unclear in this picture. What was the relationship between windows and light at the Illenau? There is some information on this: "On each floor there can only be one row of rooms, all of which open to the corridor" (ibid.: I08). This had reasons related to lighting: otherwise it would be too dark in the corridor. 


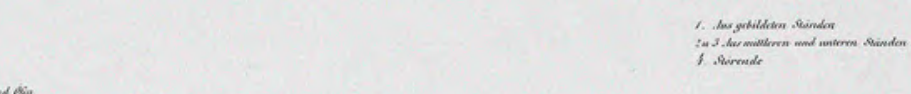

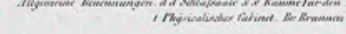
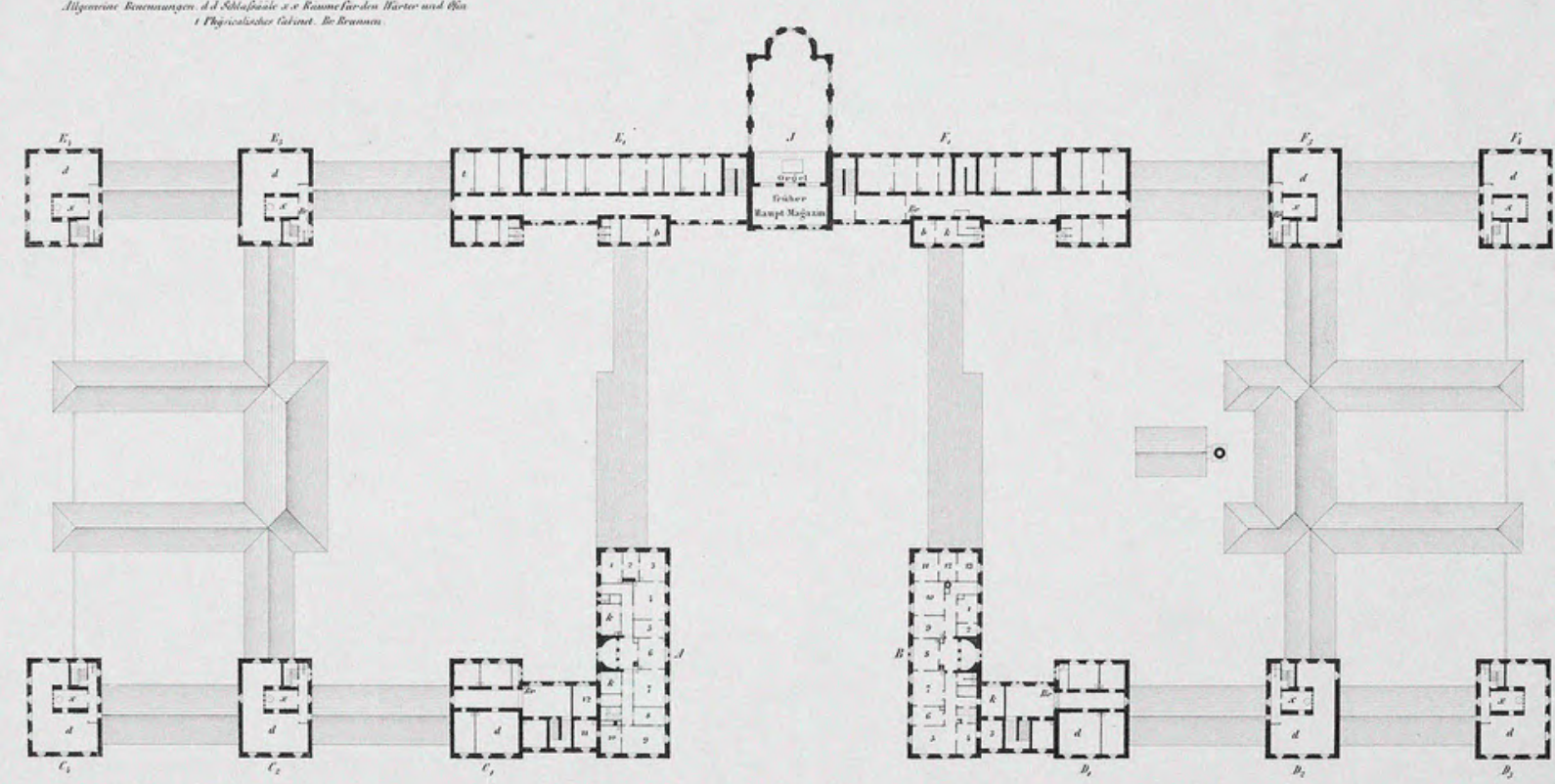

Figure I4 and I5 are views of the first floor of the men's side. In the detail view, the doors are not exactly parallel to the windows. There is no simple line of sight. Then we see the corridor. The aforementioned visual axis is broken at right angles. The rooms are at right angles to the main axis. But didn't Roller call for anything "angular" to be avoided? More precisely one must say: straight lines and right angles are allowed, but no other angles.

The patients should not be completely transparent. Living supervision must help, as the statute of 1852 specified: "The supervision must be complete; the patient must be observed in every place and at every hour, but in such a way that he is not too constrained and embittered" (quoted from Burkhardt 2003: 20I). 


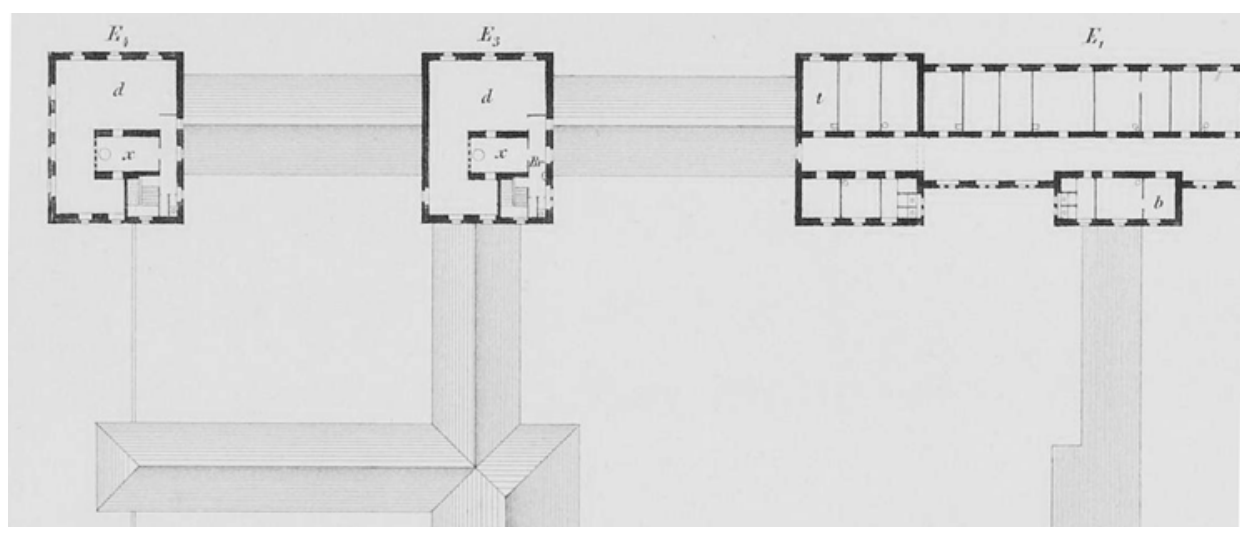

Summary and Conclusion

There are many things that I have only briefly touched on. A more detailed analysis would have to discuss architecture, metaphor, and intellectual history in a much more nuanced manner. However, some key concepts can be cited: (I) Light is a medium of communication; it connects people and things. (2) The construction of the asylum constructs lighting conditions through visual axes, outdoors through a specific arrangement of bushes, light, and space, among other things. The construction cannot address everything. Living supervision is important. (3) Sound and voice and silence have complex meanings in connection with light and dark. Sometimes it has to be quiet so that light or its night side, the dark, can take effect. But hearing and sound can replace seeing. (4) Constant physical presence would be important for communication and bonding. This is not possible. Talking in the asylum replaces the presence of the body. When someone speaks, it becomes light: we learned this from the statement by Freud's three-year-old boy. And now for the third excerpt from Bresson: If you replace "film" with "asylum" and add voice/ sound, then it reads: "Creating a mental asylum means connecting people to each other and to things through the gaze and the voice" (cf. Bresson 2007: 22). Then, one hopes, there is light in the dark auditorium or in the deranged mind. 


\section{Notes}

1

I can only rudimentarily discuss the history of the Illenau as a whole. Accounts of the Illenau and care for the mentally ill in Baden with different focuses include: Faulstich (1993); Beck (1983); Gehrke (1986); Kramer (1997); Löłsch (1996, 2000); Schneider (1981).

\section{2}

According to information from the director of the Achern city archive, Andrea Rumpf, on March 15, 2018.

\section{3}

I cannot dwell on the complex phenomenon of the "soundscape" of the asylum in full detail. But see for further information Kearin (2020); Fennelly (2014); MacKinnon (2003).

\section{4}

For instance, in the fifth century, the Roman prefect Cassiodorus described the functions of the night watches, quoted from Fischer (2015: 69).

\section{5}

Roller quoted in the original; the translation is my own: "on n'a pas une véritable instruction sur l'alimentation mental, si l'on n'a souvent observé les aliénés pendant la nuit."

\section{6}

A "relatively connected sanatorium" referred to a concept that was meant to supplant the previously propagated spatial separation of such institutions in the second phase of German psychiatry around 1830, see Damerow (1840).

\section{7}

The fact that even the department doctors were barely present for patients is illustrated by a case from the year 1875 in which a patient complains that the department doctor spends barely fifteen minutes in the department because he is too busy (Burkhardt 2003: 208).

\section{Bibliography}

Bechtel, Friedrich (1879): Über die Bezeichnungen der sinnlichen Wahrnehmungen in den indogermanischen Sprachen, Weimar: Böhlau.

Beck, Clemens (1983): Die Heil- und Pflegeanstalt Illenau unter C.F.W. Roller, dissertation med., Freiburg im Breisgau.

Beierwaltes, Walter (1980): "Lichtmetaphysik." In: Ritter, Joachim/Gründer, Kalfried (eds.): Historisches Wörterbuch der Philosophie, vol. 5, Darmstadt: Wissenschaftliche Buchgesellschaft, col. 289.

Beierwaltes, Walter/Bormann, C., von, (1980): "Licht." In: Ritter, Joachim/Gründer, Karlfried (eds.): Historisches Wörterbuch der Philosophie, vol. 5, Darmstadt: Wissenschaftliche Buchgesellschaft, col. 282-289.

Bremer, Dieter (1974): "Licht als universales Darstellungsmedium." In: Archiv für Begriffsgeschichte 18, pp. 185-206.

Bresson, Robert (2007 [1971]): Noten zum Kinematographen (edited by Robert Fischer), Berlin: Alexander Verlag.

Burkhardt, Marga Maria (2003): Krank im Kopf: Patienten-Geschichten der Heil- und Pflegeanstalt Illenau I842-I889, dissertation med., Freiburg im Breisgau.

Curtius, Georg (1879): Grundzüge der griechischen Etymologie, Leipzig: Teubner.

Damerow, Heinrich Philipp August (1840): Ueber die relative Verbindung der Irren-Heil- und Pflege-Anstalten in historisch-kritischer, so wie in moralischer, wissenschaftlicher und administrativer Beziehung: Eine staatsarzneiwissenschaftliche Abhandlung, Leipzig: Wigand.

Direction der Großherzoglichen Heil- und Pflegeanstalt Illenau (1865) (ed.): Illenau: Geschichte, Bau, inneres Leben, Hausordnung, Bauaufwand und finanzielle Zustände der Anstalt, Karlsruhe: A. Bielefelds Hofbuchhandlung.

Derix, Simone/Gammerl, Benno/Reinecke, Christiane/Verheyen, Nina (2016): "Der Wert der Dinge: Zur Wirtschafts- und Sozialgeschichte der Materialitäten." In: Zeithistorische Forschungen 13, pp. 387-403. 
Faulstich, Heinz (1993): Von der Irrenfürsorge zur "Euthanasie". Geschichte der badischen Psychiatrie bis 1945, Freiburg im Breisgau: Lambertus.

Fennelly, Katherine (2014): "Out of sound, out of mind: noise control in early nineteenth-century lunatic asylums in England and Ireland." In: World Archaeology 43, pp. 416-430.

Fischer, Ernst Peter (2015): Durch die Nacht: Eine Naturgeschichte der Dunkelheit, Munich: Siedler. Foucault, Michel (1992 [1975]): Überwachen und Strafen: Die Geburt des Gefängnisses, 10th edition, Frankfurt am Main: Suhrkamp.

Freud, Sigmund (1942): Gesammelte Werke, vol. 5, London: Imago Publishing Co.

Gehrke, Wolfgang (1986): Die Reformanstalt Illenau und ihre Bedeutung für die badische Irrenfürsorge in der Ära Roller: eine psychiatriehistorische Studie anhand der Illenauer Krankengeschichten I826-I877, dissertation med., Freiburg im Breisgau.

Goffman, Erving (1961): Asylums: Essays on the social situation of mental patients and other inmates, New York: Anchor Books.

Jungwirth, H. (1935/6): "Schweigen." In: Bächtold-Stäubli, Hanns (ed.): Handwörterbuch des deutschen Aberglaubens, vol. 7, Berlin/Leipzig: De Gruyter, col. 1460-1470.

Kearin, Madeline Bourque (2020): "'As syllable from sound': the sonic dimensions of confinement at the State Hospital for the Insane at Worcester, Massachusetts." In: History of Psychiatry 31/1, pp. 67-82. Kemmer, A (1986): "Schweigen." In: Höfer, Josef/ Rahner, Karl (eds.): Lexikon für Theologie und Kirche, vol. 9, Freiburg im Breisgau: Herder, col. 540-541.

Klein, Andrea (2003): "Jede Kommunikation ist wie Kunst”: Die Sprache des Gartens, Würzburg: Königshausen \& Neumann.

Kramer, Cheryce (1997): The Psychiatry of Gemueth in a Biedermeier Asylum, dissertation, University of Chicago.

Latour, Bruno (2007 [2005]): Eine neue Soziologie für eine neue Gesellschaft: Einführung in die Akteur-Netzwerk-Theorie, Frankfurt am Main: Suhrkamp.
Lengning, Anke/Lüpschen, Nadine (2012): Bindung Munich/Basel: Ernst Reinhardt Verlag.

Lötsch, Gerhard (1996): Christian Roller und Ernst Fink: Die Anfänge von Illenau, Achern: Acheron Verlag.

Lötsch, Gerhard (2000): Von der Menschenwürde zum Lebensunwert: Die Geschichte der Illenau von I842 bis I94O, Kappelrodeck: Achertäler Verlag.

Löw, Martina (2001): Raumsoziologie, Frankfurt am Main: Suhrkamp.

Mackinnon, Dolly (2003): "Hearing madness': The soundscape of the asylum." In: Coleborne, Catharine/MacKinnon, Dolly (eds.): 'Madness' in Australia: Histories, heritage and the asylum, St. Lucia QLD Australia: The University of Queensland Press, pp. 73-82.

Mahir, Oscar (1846): Ueber Irren-Heilanstalten, Pflege und Behandlung der Geisteskranken nach den Principien der bewährtesten Irren-Aerzte Belgiens, Englands, Frankreichs und Deutschlands, Stuttgart/Tübingen: J.G. Cotta.

Mensching, Gustav/Hertzsch, Erich (1961): "Schweigen." In: Religion in Geschichte und Gegenwart, vol. 5, 3rd edition, Tübingen:J.C.B. Mohr, col. 1605-1606. Plato (1971): "Politeia." In: Eigler, Gunther (ed.): Plato. Werke in acht Bänden, vol. 4, Darmstadt: Wissenschaftliche Buchgesellschaft.

Porter, Roy (1991): Kleine Geschichte der Aufklärung, Berlin: Wagenbach.

Reed, Terence James (2012): Mehr Licht in Deutschland: Eine kleine Geschichte der Aufklärung, Munich: C.H. Beck.

Roller, Christian Friedrich Wilhelm (1831): Die Irrenanstalt nach allen ihren Beziehungen, Karlsruhe: Müllersche Hofbuchhandlung.

Rush, Benjamin (1812): Medical Inquiries and Observations upon the Diseases of the Mind, Philadelphia: Kimber \& Richardson.

Schivelbusch, Wolfgang (2004): Lichtblicke: Zur Geschichte der künstlichen Helligkeit im 19. Jahrhundert, Frankfurt am Main: Fischer.

Schneider, Hugo (1981): "Die ehemalige Heil- und Pflegeanstalt IIlenau." In: Die Ortenau 61, pp. 191-231. 
Schüle, Heinrich (1910): "Die Landesanstalt Illenau." In: Bresler, Johannes (ed.): Deutsche Heil- und Pflegeanstalten in Wort und Bild, vol. 1, Halle (Saale): Marhold, pp. 1-9.

Strauß, Bernhard (2014): Bindung, Gießen: Psychosozial-Verlag.

Wohlfart, Günter/Kreuzer, Johann (1992): "Schweigen, Stille." In: Ritter, Joachim/Gründer, Karlfried (eds.): Historisches Wörterbuch der Philosophie, vol. 8, Darmstadt: Wissenschaftliche Buchgesellschaft, col. 1483-1494.

All quotations originally in German were translated by Anthony DePasquale. 


\section{"Le cabanon du fou": \\ Uses of the Shed As a Confinement Device \\ for the Insane in French Rural Households \\ in the I9th Century}

Anatole Le Bras

Last April 25, police officers passing in Mons-Boubers learned that, for approximately two years, Delphine Roussel, aged 33, had not left the house of her father, and that the latter, when asked about her, always answered that she was sick and staying in bed.

The law enforcement officials, whose suspicions were aroused, asked to see Delphine Roussel. They saw that the poor creature was confined in a robust shed, built in the corner of a room with closed shutters. In this very small recess, closed with a wooden door and an enormous lock, Delphine Roussel, pale and thin, was crouching on rotten straw, exhaling a disgusting smell.

She had no clothes but an old petticoat; excrement had accumulated in a corner.... An opening in one of the walls of her cell barely let enough air in, and was used to convey her some food.

Delphine Roussel explained that she had been confined for two years in this recess, where she never saw daylight and spent the winter without fire and with no other clothes than the petticoat she was covered with.' 
This sensational story, reported by the newspaper Le Petit Journal in the summer of I879, may sound exceptional, but actually resembles dozens of other similar cases of scandals of illegal sequestrations of mentally ill persons by their families. Working on these affairs, I was struck by the omnipresence of cabanons, or "sheds" (most of the time made of wood boards), mirroring contemporary practices of confinement in rural Indonesia, known as pasung ${ }^{2}$, which sometimes involved the building of a wood cabin for keeping the mentally ill.

Mental institutions never have had a total monopoly on the confinement of the insane. And yet, household sequestrations of mentally ill persons are a phenomenon that attracted little attention from historians. Charlotte Brontë's (I816-I855) "madwoman in the attic" 3 is well known, but it is difficult to know whether this literary figure corresponded to real social practices or not. A couple of cases of sequestrations are mentioned in the archives of the English Commissioners in Lunacy studied by Akihito Suzuki (2006: 166). David Wright, in his study of familial care of "idiot" 4 children in Victorian England, showed how "houses themselves became informal 'asylums', outside which the child was not supposed to go unattended" (1998: 188). However, these examples are piecemeal and neither sufficient to provide a detailed study of sequestration practices, nor to expose their motives. Therefore, a more systematic study requires finding new material. "Getting out of the asylum" (Wright 1997) and using judiciary archives will enable us to put families and communities, rather than doctors, at the center of the study. ${ }^{5}$

The study of the material culture of psychiatry offered stimulating insights about asylum life and social relations between doctors and patients (Majerus 20II), but less is known about objects used by families to take care of or manage their mentally ill kin. This paper uses a singular approach, focusing on a material item situated on the edges of psychiatry, and which became an object of psychiatric discourse only to be denounced. The shed was not an emblematic object of psychiatry, as the straitjacket could be. Quite the contrary, it served as an anti-model for French alienists. Studying the shed thus amounts to writing a decentered history of I9th-century psychiatry.

This article rests on a corpus of 47 cases of illegal sequestration, collected from the Gazette des tribunaux, a jurisprudence and legislation newspaper, Le Petit Journal, a newspaper with a nationwide audience and a print run of over a million copies in the I890s, and prominent psychiatry journals such as the Annales médico-psychologiques. ${ }^{6}$ While the analysis is mainly based on trial reports found in the newspapers, ${ }^{7}$ it also relies on several case files from the criminal court archives of three departments. ${ }^{8}$ 
According to article 475 of the Penal Code, ${ }^{9}$ the sequestration of a "lunatic" was not criminally reprehensible in itself and could be punished only if it had been accompanied by abuse or neglect. Hence the bias of our study: the practices of sequestration that can be studied through the prism of judiciary archives are only the most extreme. However, this article will try to show that these cases are nonetheless revelatory of norms of behavior and attitudes towards the mentally ill considered acceptable - or not - by the community and by the judicial authority. The number of acquittals was not negligible, especially if the accused managed to convince the jury that they had been compelled to confine the mentally ill person because of his or her violence, thus showing a certain degree of acceptance of the practice of sequestration. All of this suggests that even if the cases studied are just the tip of the iceberg, they tell us a lot about what is below.

In at least 16 of these 47 cases, the sequestration occurred in sheds. These could be placed inside the house, in annex buildings, or outside. The judiciary procedure entailed a wealth of details about the material conditions of confinement. During the trial of Granier (I866), a facsimile of the shed where the young Adeline had been confined for ten years was even exhibited to the jury. ${ }^{\text {Io }}$ The report of the trial explained that a doll was placed in the model house to help the jury understand the painful position Adeline was forced to adopt during her sequestration. The materiality of sheds was at the center of the legal authorities' attention and psychiatric discourse. For the historian, it is also highly revealing about family strategies for coping with the mental illness of their kin, and about the place of the lunatic in his or her family and community.

\section{The Shed:}

\section{An Object of Scandal and an Antimodel for 19th-Century Psychiatry}

The second half of the I9th century was, in France as in most European countries, the golden age of the asylum. Nonetheless, in three different and apparently unrelated settings, sheds came to the attention of alienists because they were still used to confine the mentally ill. In all these cases, they were condemned by psychiatric professionals as a symbol of the archaic nature of practices still prevailing outside modern asylums. 


\section{Hospital, Colonial, and Household Settings: A Multifaceted Device of Confinement}

In Ancien Régime and early-I9th-century hospitals and nursing homes, special "lodges" were used to confine raging lunatics (Petit 1980). They were made obsolete by the law of $1838^{\text {II }}$ that made asylums the only legitimate places of confinement for the insane. However, it turned out that hospital sheds were still in use in hospitals all over the country as late as in the i88os. They were used to accommodate lunatics whenever one of them was admitted - which happened frequently because article 24 of the law of 1838 provided for the possibility to temporarily send lunatics to hospitals or nursing homes before they were sent to the asylum. Their stay was supposed to be limited to I5 days, but this rule was not enforced, and lunatics could stay for several months in many hospitals.

In the late I880s, the alienist Désiré-Magloire Bourneville went on a tour of French hospitals to inquire about lunatics' living conditions and published several articles exposing their situation (Bourneville I889). He noted that most hospitals did not have proper isolation rooms for the insane. Most of them were placed in sheds. These were generally located outside the main buildings and could be near the pigsty (Lunéville), the stable (Arbois), or in the farmyard of the hospital (Bar-sur-Aube). They were devoid of any furniture, lacked heating, and the windows had no panes. Given their peripheral location, the lunatics placed in these sheds were not watched over, which led to many suicides. As Gabriel Monod, director of the Public Assistance, concluded: "It seems that old abuses, the most regrettable of ancient misguided ways, proscribed from asylums, continue to flourish in hospitals" (Monod I889: 3II).

The same could be said of new imperial spaces. In the early 2oth century, while psychiatrists' attention turned more and more to the colonies, it appeared that there, too, sheds were largely in use. French psychiatrists tried to document this reality of pre-colonial treatment of the insane, thus constructing a representation of indigenous means of treatment and care as archaic and barbaric. The following drawing (fig. I) of a shed used to confine the mentally ill in Siam and Laos was presented at the Congress of Tunis in I9I2.

The doctors Solomon Lwoff and Paul Sérieux (I9II) also published photographs of tools of containment used in the sheds of Fez hospital, such as iron necklaces and shackles. Their stated goal was to convince the authorities to set up a modern system of psychiatric care in the colonies in order to put an end to such practices.

The same motive pushed the alienists to express their concerns about the use of sheds by French families - especially in the countryside. Starting in the I840s, a 


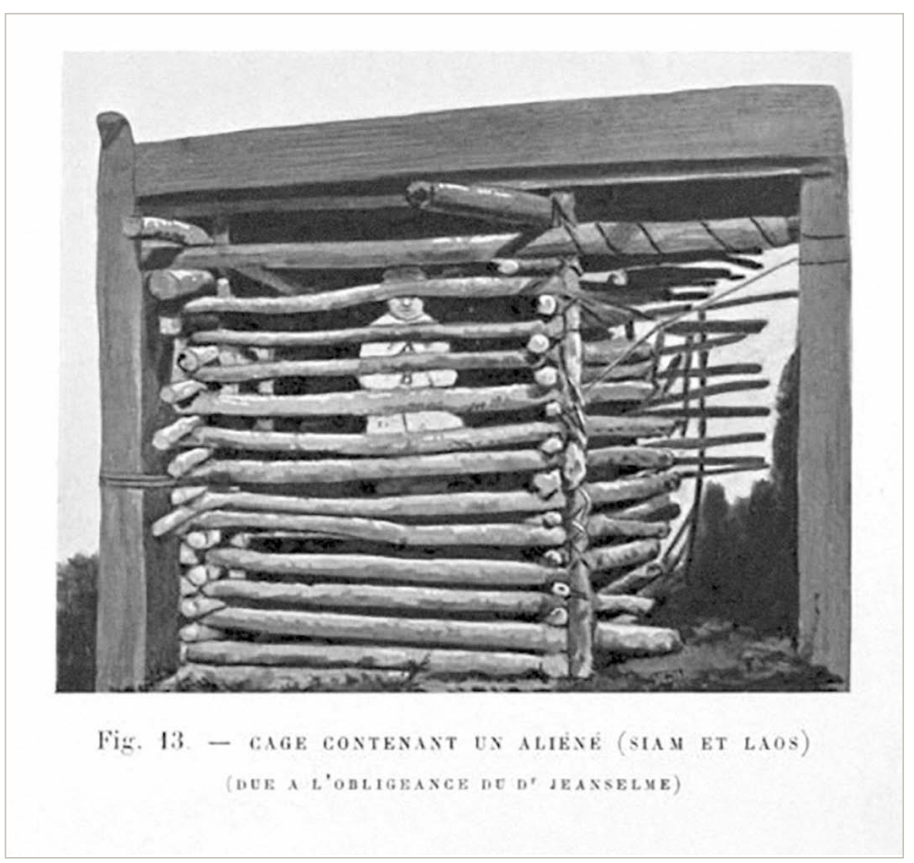

number of articles in psychiatric journals commented on cases of the sequestration of lunatics by their own families. These publications generally coincided with two types of events: a new sequestration scandal that spurred a series of reactions or debates, or parliamentary debates about the revision of the I838 law. After he witnessed a case of sequestration in Toulouse, the alienist Victor Parant ${ }^{12}$ (I884) published the first systematic study on the topic of household sequestrations. Gabriel Izard (1903), a colonial army doctor, published his study on the same topic not long after the scandal of the "séquestrée de Poitiers," in 190I. ${ }^{13}$

These concerns about the situation of lunatics kept at home must be replaced in the context of a longstanding effort by alienists to encourage and facilitate placements in asylums - at the expense of families if necessary. Now that they had succeeded in setting up a national system of care and to have their professional competency recognized, alienists were willing to expand their control over new domains, such as colonies, hospitals, and households. 


\section{An "Archaism" That Questioned the Flaws of the French Psychiatric Legislation}

For French alienists, the shed was not just an inappropriate way to confine the mentally ill. It also revealed the mentality of the rural population. The doctors analyzed sequestrations through the lens of an urban elite, who was socially very distant from rural classes.

According to them, the main explanation of sequestrations was peasants' greed. Their so-called selfishness, egoism, and avarice were endlessly commented on. The insane were kept at home because rural people were willing to avoid contributing to the cost of asylum care. But bad treatment inflicted upon the mentally ill also reflected the peasants' archaic mindset. Commenting on a case of sequestration, the medical superintendent of the Quimper public asylum (Brittany) admitted that means of appropriate treatment were not easily accessible in the countryside. But he also added that "prejudices are still excessive toward the mentally ill" (Baume 1874: 418). The practice of sequestration was part of a set of old beliefs. After having received a young "idiot," who had been locked in a shed for a month in his village of the rural Pyreneans, the superintendent of the Pau Public Asylum interpreted his sequestration as a result of the fear that mental alienation inspired to peasants, who tended to confuse insanity with demonic possession (Girma/Vernet 1894). The negligence and indifference of neighbors and local authorities was also often criticized. All strata of the rural society were deemed collectively responsible for inhumane treatment of the mentally ill. The sequestrations were also used strategically in the public discourse of the psychiatric profession. It enabled them to reverse the accusation of wrongful confinement launched by hostile "anti-alienist" campaigns ${ }^{14}$ : "It is among private individuals, and in the families, not in the asylums, that arbitrary sequestrations, negligence, abuses are to be feared," exclaimed Achille Foville ${ }^{15}$ (1870: 407).

These cases nonetheless led the psychiatrists to question the existing legislation and system of psychiatric care. First, they deplored the fact that the I838 law remained totally silent regarding the mentally ill outside of asylums, contrary to the English or Scottish legislation, which were often cited as models. ${ }^{16}$ They also agreed that the committal of "idiots," epileptics, and more generally all lunatics deemed inoffensive should be facilitated.

Second, psychiatrists called into question the common law and the penal code of I8Io. Indeed, all these scandals revealed that sequestrating a mentally ill person was not illegal in itself. Article $475, \$ 7$ of the French penal code punishing those who let an insane person, "a raving lunatic," or "a ferocious animal" who was supposed to 
be in their custody roam freely, created an exception to article 34I, which punished unlawful sequestration. "In other words," Victor Parant (I884: 8) commented, "the law allows the families to sequestrate in their household those of their members who are affected by mental alienation. This right is not submitted to any restriction." As a consequence, many French psychiatrists advocated the creation of a special institution, on the model of the British Commissioners in Lunacy, dedicated to controlling the treatment of the mentally ill kept in their households.

The attitude of the legislator and of public authorities was nonetheless ambiguous. Concerns were raised as to whether such a system of surveillance would lead to an infringement over the intimacy of families. The legislator was not really willing to attack the "rights of the families," and the various projects of reform of the I 838 law that were debated at the Chamber of Deputies throughout the igth century were very cautious on the topic of surveillance of lunatics outside the asylum - apart from the reform supported by the socialist member of parliament Édouard Vaillant (I840I9I5) in I894, which was largely dismissed by the Chamber (Hubert I902: I54-I57). ${ }^{17}$

The shed, as a tool of confinement, can thus be understood as an expression of

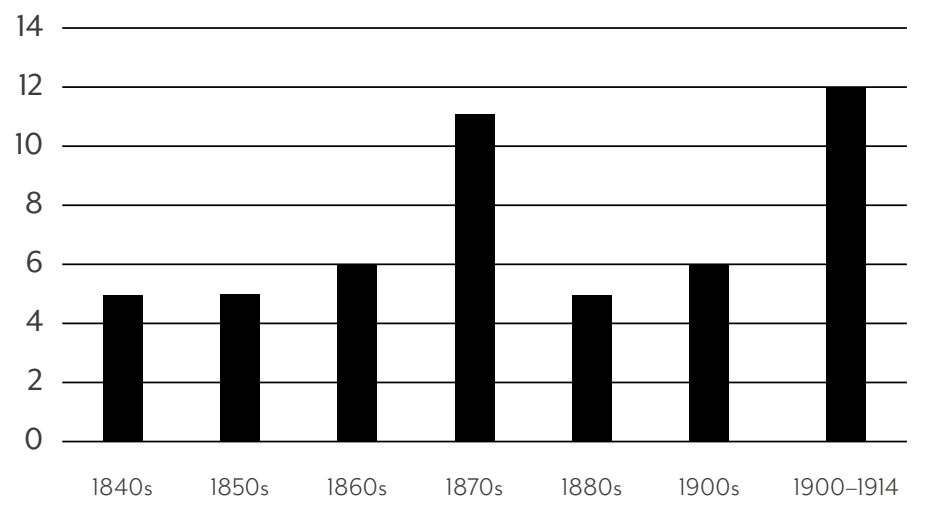


the sovereignty of the family over its members. ${ }^{18}$ Despite denunciatory discourses, the number of cases of illegal sequestrations did not seem to decrease in the second half of the century.

These figures are obviously not exhaustive, and they tell us more about media coverage than about the real number of sequestrations (the high figures of the last decade can be attributed to the repercussions of the "séquestrée de Poitiers" in I90I); yet the trend was clearly not toward a decline or disappearance of scandals.

The persistence of sequestrations and the periodic resurgence of the shed indicate that understanding it only as an archaism is not sufficient. It is necessary to analyze it as an object that shaped the relations between the lunatics and their families.

\section{Confining the Insane at Home: A Study of Material Practices of Confinement in 19th-Century French Families}

The most well-known of sequestration cases (that of Poitiers in I90I) was used by novelist André Gide (1930) to denounce the oppressive atmosphere of bourgeois families. However, sequestrations happened most of the time in rural areas and farmers' families.

Gender clearly played a role in the decision to confine. The number of sequestrated women in our corpus of cases (32) is almost two times the number of men (I7). ${ }^{19}$ The most common forms of mental alienation are, not surprisingly, idiocy, imbecility, and others forms of mental deficiency. However, a detailed study of the reports shows that this state of idiocy could be a consequence rather than a cause of the sequestration. Many of the sequestrated were not affected by congenital diseases, but by various types of mania, dementia, hysteria, etcetera, which appeared in their adulthood. Some of the victims were old people afflicted by senile dementia, but usually the confinement began while the mentally ill were still under 30 years old..$^{20}$

A brief overview of the identity of those deemed responsible for the sequestration shows that confining an insane person was mostly a prerogative of the closest kin. The parents were involved in more than half the cases. Confining the insane was a way for the close relatives to keep them under their control. It was also a manifestation of parental and male authority ( 42 men involved versus 28 women). The sequestration was usually a long-term strategy: in more than half the cases considered, the sequestration lasted for more than a year. 


\section{The Shed As a Last Resort for Managing the Insane}

One of the main motives for sequestration was the fear of public shame. "He was bringing shame on us!" exclaimed the father of Albin Le Gouallec. ${ }^{21}$ When a member of the family started acting like an insane person in public, the honor and reputation of the lineage were at stake. Revealing the mental illness of the member of the household entailed the risk of tarnishing the reputation of the whole lineage and threatened matrimonial projects. A lunatic was also seen by other family members as a risk for property - be it that of the family or that of neighbors. While free, Albin Le Gouallec was accused by his father (and by several village dwellers) to have broken a pane at the village chapel and to have damaged his fathers' fields. ${ }^{22}$ Later, after Albin had been locked in the stable, the mayor asked his father to unchain his son. He replied that he would consent to do it only if the mayor accepted to take full responsibility for the acts that his son might commit, and to pay for all damages he may cause to the property of village dwellers. Nobody being ready to take that risk, it seems that the mayor agreed tacitly to the prolongation of Albin's sequestration.

The recourse to household sequestration must also be understood as the failure or rejection of other options that appeared too costly or too difficult for the family. During his trial, the father of Delphine Roussel explained that he could not find anybody willing to be hired as a guardian for his daughter. The mayor of Mons-Boubert had advised him to do his best to keep her by himself, because the Roussel family was not indigent and therefore would not obtain a free committal to the local asylum. In this case as in many others, the main obstacle to the committal of the lunatic appears to have been the cost of such a measure for the family and for the municipality. ${ }^{23}$

As Akihito Suzuki (2006: II7) observed, "the existence of a lunatic in a family destabilized the boundary between the public and private spheres and invited forceful intervention from the outside world." The shed was a response to this threat. It was a way to reaffirm the boundary between the private and the public, to maintain the family's autonomy vis-à-vis outside authorities. However, the barriers inside which families tried to keep the insane were under constant threat, because of the reactions of the insane person himself but also because of the intrusions of neighbors and local authorities. In I873, Delphine Roussel's father built a shed inside the house, with a louvered door. In the beginning, his daughter only slept there and was free to move during the day, except when her parents were working on their distant fields. She was also permitted to go to mass every Sunday. But from I877 onwards, her confinement became permanent. One day in July I878, she managed 
to get out and broke the clock and some vases. The risk of material damage caused by the lunatic was often decisive in the decision to sequestrate. Delphine's father replaced the louvered door of the shed with a more solid door without openwork.

It is thus necessary to place the shed in a range of more or less tight control and surveillance means. Married in I827, Ismérie Danchelle, from the Ardennes department ${ }^{24}$, apparently suffered from puerperal mania following her second child delivery. Unable to take care of her because of his professional occupation, her husband entrusted her to her parents, in exchange for a monthly pension. The parents agreed to take care of her, but after having called a doctor once, they refused to pay for any more medical care. Ismérie's health deteriorated quickly, and she began acting in an unconventional way: she ran after men in the streets, went outside naked, etcetera. Her parents first locked her up in a room. After she broke the window panes several times, they added wooden bars at the windows. But she somehow managed to break them and escape. Finally, they built the shed in which they would confine Ismérie for eight years.

Building a shed was generally the result of similar series of improvisations and adaptations to an unpredictable behavior and/or a decreasing degree of tolerance. The study of the shed's material features confirms that its primary function was to keep the insane person from doing harm at a minimal cost. When it was possible, the shed was made of a preexisting structure. In that respect, it is worth noting a specificity of the region of Brittany: the use of the closed bed [lit clos]. Generally I.6 to I.7 meters long, out of fashion in the east but still used in the more traditional west of Brittany, known as Basse-Bretagne, this piece of furniture was used at the same time as a bed, a cupboard and bench. It was opened only on one side and could usually be hermetically closed by a door or a shutter. Several sequestration cases, but also some patients' case histories in the archives of the Quimper public asylum ${ }^{25}$ show that closed beds were frequently used as a device of confinement for the insane, as in the Cadiou case.

Two closed beds were juxtaposed in the main room of the Cadiou house, in order to create a confined space from which it was impossible to escape on both sides (fig. 2). A heavy wooden door was added on the third side, and the window on the wall was obstructed. The young Anne-Marie stayed there for more than four years. Her case illustrates the adaptation of existing house furniture to new purposes, a process through which an ordinary piece of furniture could acquire a new role and meaning as object of management of the mentally ill. Here the closed bed seems to have been a particularly practical tool of confinement because of its robustness 


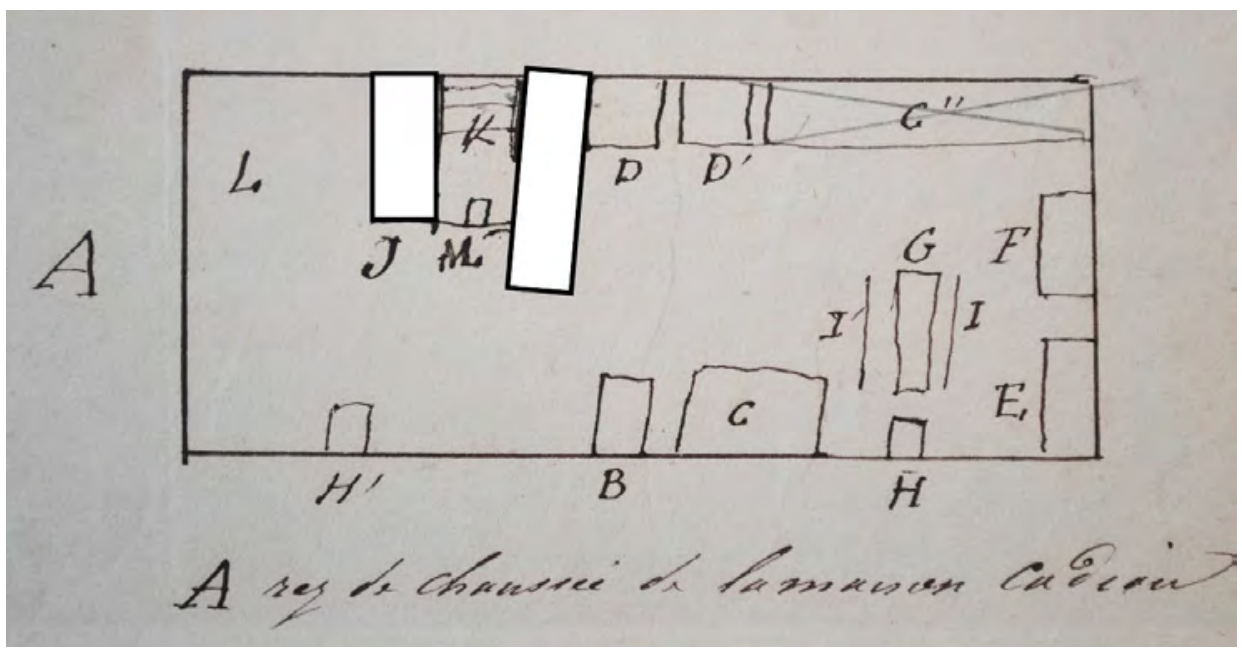

and because it could easily be locked from the outside. The same applies to specific units of the farmhouse that could become a shed of confinement. This was the case in Jaunay's case ${ }^{26}$ in 1903. Jaunay was a 23-year-old, who became very agitated. Because the administrative procedure to commit her to the public asylum was very time-consuming, her parents lost their patience and decided to lock her up in the rabbit hutch - which was not even cleaned before accommodating her.

In other instances, however, the shed was built for the purpose of confinement, after other material forms of management had failed. The police officers were impressed by the solidity of the shed built by Delphine Roussel's father, made of brick and wood, so that his daughter could never escape again. The family members were sometimes helped by artisans of the village in this task. In the case of Le Gouallec, the father was assisted by the blacksmith of the village and by another farmer of the surroundings. ${ }^{27}$ This participation of other members of the community in the setting up of the device of confinement shows that the sequestration could be socially accepted. In the case of Roussel, by contrast, the mason and the carpenter that helped Delphine's father were not informed of the purpose of the strange hut they were asked to build in the corner of a room. 


\section{Mistreatment and Abuse}

The main objective of the shed was not only to confine the insane person and to prevent him or her from wandering in public, but also to drastically restrict his or her freedom of movement. It was often combined with other devices of containment: for example, Albin Le Gouallec was chained to the main beam of the stable for approximately three years. The chain weighed two kilograms, and at first it was not even long enough to allow his foot to touch the ground, so that he had to lie on the ground with one foot up. During the investigation, the key was nowhere to be found - a sign that Albin's containment was meant to be permanent and probably for the rest of his life. Besides being confined in a pig hut, Madeleine Pigniot was tied up with ropes. ${ }^{28}$ This desire to restrict freedom of movement can also be seen in the extremely small size of confinement spaces. In a case commented on by Victor Parant (I884:3-7), two sheds were built in a room for a young raving lunatic and his father. Both of them could nonetheless access a small cage situated in the yard of the house, where they had a little more freedom of movement. In many instances, the sequestrated were totally deprived of any light and air. During the trial of Jahan, the doctor Vaugiraud, called as a witness, underlined "that the shed contained just nine cubic meters of air, and what air? A stale air, coming from the stable where the manure was piled up." ${ }^{29}$

In the Cassany case,,$^{30}$ an "idiot" woman was confined in a piece of furniture just I.2 meters long and 78 centimeters wide. Lucien Bodeau could not stand in his shed, which was just I.4 meters high. ${ }^{\text {I }}$ Terrible conditions of hygiene ensued. Delphine Roussel was never allowed to go out, even for satisfying basic material needs: a layer of ten centimeters of excrement covered the soil of her shed when the police found her.

These extreme material conditions had spectacular effects on the bodies of the sequestered. The absence of freedom of movement could lead to a progressive loss of mobility functions for the persons confined, who also tended to keep their knees close to their shoulders, as a derisory protection against the cold. This situation was documented by a photograph published in I894 (fig. 3).

The doctors who presented Laporte's case at the La Rochelle congress of mental medicine in I893 explained that he had been found completely naked, unable to speak or walk, in a wooden shed of just one square meter, in his small village of Saligos, in the Pyrenees. The picture was taken not long after his arrival at the local public asylum. 
Most of the sequestered were found in an even worse state, emaciated, with long hair, beard, and nails, scars on the body, etcetera. The alienists who commented on sequestration scandals did not miss an opportunity to underscore the negative consequences of family confinement for the physical and mental health of the mad. They contrasted the mistreatment inflicted by the family with the modern standards of care and material comfort prevailing in asylums. Bad treatment was indeed frequent - as mentioned earlier, the accused were not so much tried for the sequestration as for the mistreatment and abuse that accompanied it.

Could these extremely harsh living conditions be a covert way to accelerate the coming of death? The answer was sometimes yes. In certain scandals, the will of the family to come into possession of the inheritance of the mentally ill person was a suspected motive for the sequestration. In the case of Le Gouallec, the father was even said to have promised the quick death of his son to his new son-in-law, who hoped to inherit the family farm. But most of the time, the way the mentally ill person was fed contradicts the idea that sequestrating was a roundabout way of killing. The persons confined were usually deprived of freedom, air, light, heat, but rarely of food. Sheds usually had a single opening: a small hatch through which their meals were delivered.

The abuse that went along with sequestrations seemed to rather result from a slow process of progressive degradation, growing indifference, and neglect, which is exactly the process that fascinated André Gide in the case of "la séquestrée de Poitiers": without any malevolent intention at first, the Monnier family was slowly driven to a barbaric behavior. ${ }^{32}$ However, bad treatment resulted from extreme situations of material deprivation. Ismérie Danchelle's mother told the jury how she had always tried to alleviate the plight of her daughter. But when the young woman ripped up all the clothes she was given, she was finally left naked. ${ }^{33}$ Albin Le Gouallec was fed with a broken piece of cauldron because his parents did not want him to break their plates. After Blancher Monnier smashed her chamber pots, she was deprived of them and had to relieve herself in her own bed. Most of the sequestered, however, did not sleep in a bed: all pieces of furniture were removed from their shed or room. They slept at best on a pallet, or on piles of straw. Bad treatment could also result from an incapacity to adequately cope with the manifestations of 
mental illness: when the sequestered were noisy or violent, some family members could imagine no other way to silence them than to beat them.

A series of recurrent material elements raises the question of the perceived animality of the mentally ill: the forced nudity, the impossibility of standing up, the similarity of sheds with cages, the fact that they were sometimes kept in spaces usually reserved for animals. Albin Le Gouallec lived for approximately three years in a stable shared with two heifers and a pig. He even sympathized with the latter, which sometimes slept at his side. ${ }^{34}$ Historian Annick Le Douget (20I4: I44) compares the situation of the mentally handicapped kept at home in rural families of the Finistère with that of animals that were also living very close to humans and could share the same room. During their trials, the defendants sometimes echoed popular prejudices about the supposed endurance and insensitivity of the mentally ill. When Larose's mother was told that her daughter's feet had frozen, she exclaimed: "The insane don't freeze!" 35

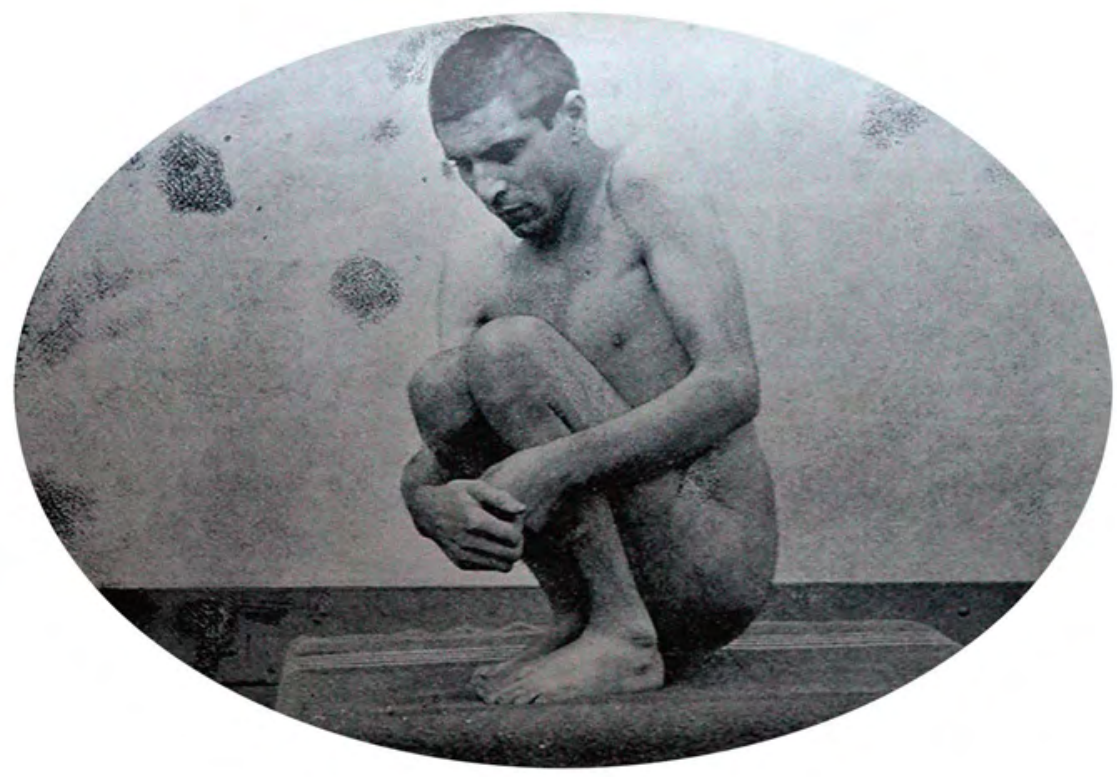


A Spatial Setting That Reveals the Place of the Insane in the Family and Community

The idea of a possible assimilation of the mentally ill and farm animals is partly corroborated by the study of the spatial settings of sequestrations. A more precise look at where the sheds were located reveals the status of confined persons in their families and village communities.

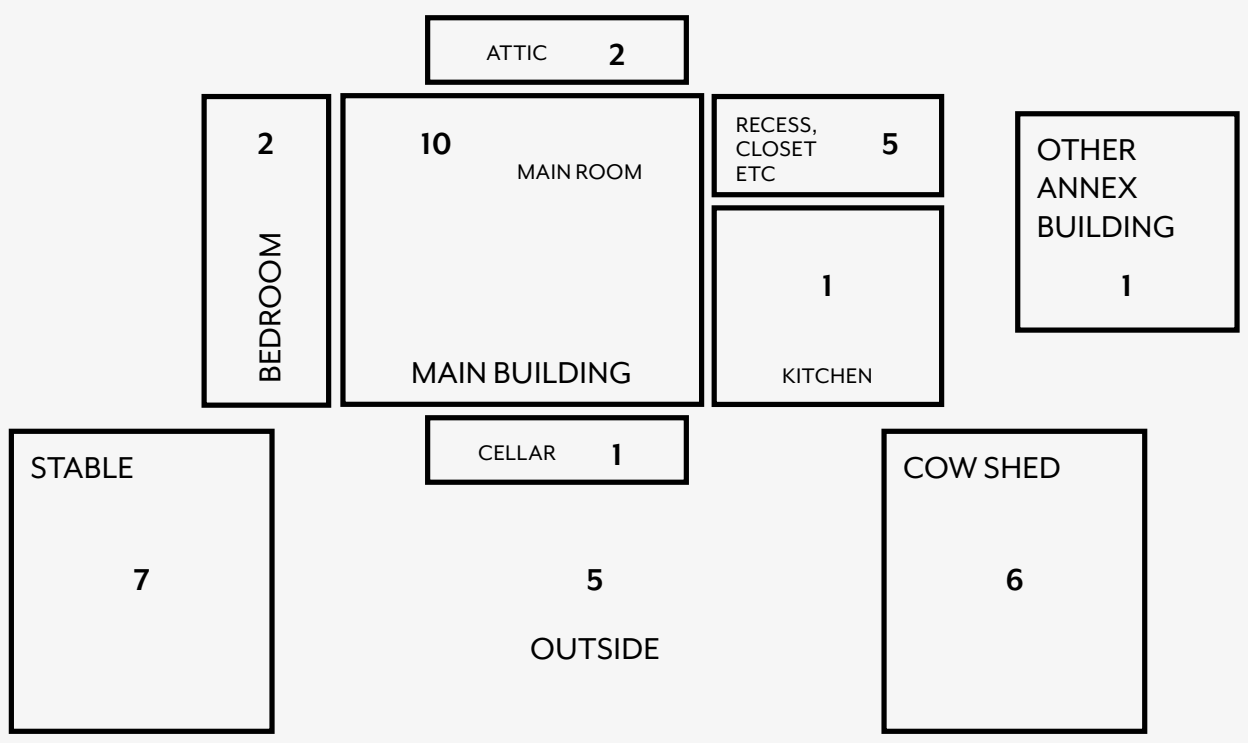


This distribution of confinement places thus offers a mixed picture (fig. 4). Approximately half the sequestrations occurred in annex buildings such as stables and cowsheds. Sometimes the shed was even located outside, in spite of the cold.

But the other half occurred in the main building, and even in the main room, showing that keeping the insane away was not perceived as necessary, and that families got used to coexisting with them. The case of Cadiou, mentioned earlier, perfectly illustrates this (fig. 2). The location of the shed where Delphine Roussel was confined (fig. 5) is also interesting: whereas plenty of other buildings could have been used, notably the cowshed (in the bottom left corner of the picture) or the stable (on the right side), Delphine's parents decided to build the shed (cabanon) in the main living area, in the room next to the kitchen.

This proximity implied regular contacts, interactions, and conversations. During the trial, the criminal charges noted with astonishment that during the previous winter the Roussel parents had gathered the family and had a celebratory meal just a few meters away from the shed where the daughter was still locked. This setting, which involved proximity and exclusion at the same time, resulted in what can be called a situation of relegated proximity.

This isolation of the mentally ill could be an attempt to hide him or her from the view of the neighbors. Magistrates and investigators usually described the incriminated families as "solitary," and their dwelling places as "isolated farmhouses." This suggests that in central villages with contiguous dwellings, not to mention urban settings, there might have been higher pressures on the families to take the initiative to commit the mentally ill to institutions. In Roussel's case, several witnesses explained to the police that whenever they paid a visit to the family, they were allowed to enter the yard, but never the main building, where Delphine was confined. Families were willing to delineate a private sphere around the mentally ill and defend it against intrusions.

Total secrecy was impossible, though. Information was constantly circulating. However distant the farms were from one another, members of rural communities were constantly watching and thereby monitoring each other's behavior. In many trials, the depositions of witnesses clearly showed that the very fact of the sequestration was rarely ignored by the neighbors, even if they generally claimed that they thought the person confined was well treated. The families sought discretion rather than secrecy. Once again, the Le Gouallec case offers a fascinating example of how the sequestration of the insane, without being concealed from the community, was nonetheless excluded from the sphere of discussion. A former friend of 


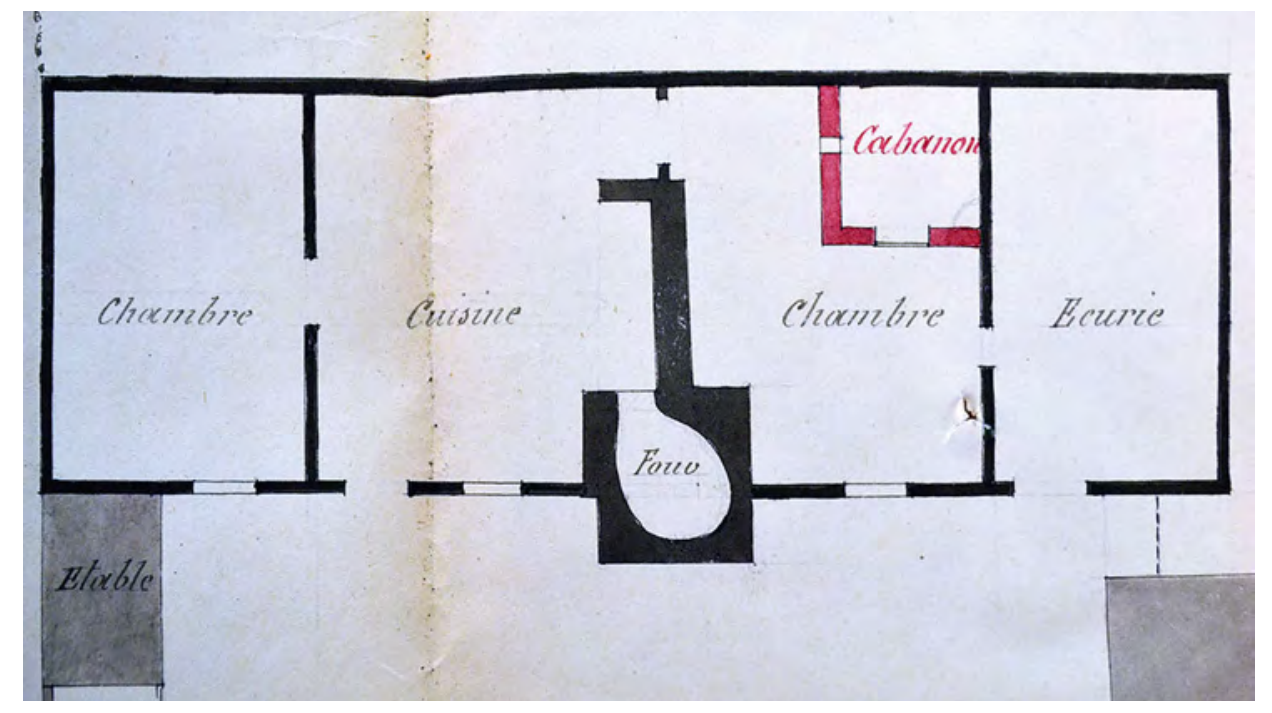

Albin related one of his conversations with the father: "I asked to see Albin but he wouldn't let me, I told him that if he didn't let me see him I would speak badly of her daughter who is about to get married; on my insistence he finally opened the door, which was locked, and let me in alone with Albin." ${ }^{36}$ Thus, relatives or neighbors could be allowed to see Albin in the stable - but only if they insisted. Although confined, Albin was integrated into the rites of collective life. A witness explained that twice a year, after the assembly of the village community at the Flowers Chapel, relatives and friends of the Le Gouallec family would go for lunch at their farm. After the meal, everybody paid a visit to Albin, who was dressed in a white shirt and had been given some fresh straw for the occasion. Le Gallo, a day laborer from the same village, also testified: "They did not really talk about it and did not appreciate Albin being visited, so I abstained from doing it; however, after the pilgrimage to the Flowers Chapel, the prohibition being lifted, I yielded to curiosity and I did like the others; I saw Albin lying in the stable." ${ }^{37}$ Although family members knew they could not completely hide the sequestration, they struggled to evade public discussion and to reaffirm their authority over the insane - not without accepting some compromises. 


\section{Conclusion}

During the second half of the I9th century, psychiatrists made the shed a symbol of the archaic attitudes of the colonized peoples as well as the French peasants in their struggle to defend the asylum as the only desirable solution. But behind the denunciatory discourses, sequestration scandals reveal a much more ambiguous attitude of legal authorities towards the family's sovereignty over their mentally ill kin, upon which the doctors and legislators were not willing to infringe. The shed was not just an archaism, a remnant of old practices doomed to disappear. It reveals the reluctance of families and local authorities to have recourse to mental institutions, even until the early 20 th century.

This study thus sheds light on a regime of "domestic psychiatry" that is quite distinct from, and maybe less idealized than the one described by Akihito Suzuki (2006). The coexistence with the sequestered lunatics was based on a regime of relegated proximity. While maintained in the family and community, the insane person was at the same time materially and symbolically put aside. The material world of the management of the mentally ill in the domestic sphere was made of adaptations ofs everyday furniture (such as closed beds, stables, etcetera), but also of structures specifically conceived for confinement, such as the shed. Most of these objects highlight the difficulties that rural families encountered when trying to cope with the mental illness of their kin. The ropes and chains that restrained the lunatics as well as the sheds and hutches that shut them away are all indications of how much families were distraught and disconcerted by the presence of mental illness in their midst, and how they improvised as they could to minimize its material, financial, as well as reputational costs. But sequestration cases probably bring out only a small part of the wide variety of tools and artifacts that were used to deal with lunatics at home, and further studies are needed to illuminate more completely the materiality of domestic care in the I 9 th century. 


\section{Notes}

1

"Le 25 avril dernier la gendarmerie de SaintValéry, de passage à Mons-Boubers, apprit que, depuis deux ans environ, la nommée Delphine Roussel, âgée de trente-trois ans, ... n'avait point quitté la maison de son père, et que ce dernier, aux questions qui lui étaient adressées, répondait toujours qu'elle était malade et gardait le lit. Les agents de l'autorité, dont les soupçons s'étaient éveillés, demandèrent à voir Delphine Roussel. Ils purent alors constater que cette malheureuse était enfermée dans un solide cabanon, construit dans le coin d'une chambre dont les volets, étaient hermétiquement clos. Dans ce réduit aux dimensions exiguës, fermé par une porte de bois plein, garnie d'un énorme verrou, Delphine Roussel, pâle et amaigrie, était accroupie sur de la paille pourrie exhalant une odeur infecte. Elle n'avait pour tout vêtement qu'un vieux jupon; des excréments étaient accumulés dans un coin ... Une ouverture pratiquée dans l'une des cloisons de ce cachot laissait à peine pénétrer l'air nécessaire à la recluse et servait à lui passer des aliments. Delphine Roussel raconta que depuis deux ans elle était confinée dans ce réduit, où elle ne voyait jamais le jour et où elle passait l'hiver sans feu et sans autre vêtement pour se garantir du froid que le jupon qui la couvrait." "La recluse de Mons-Boubers." In: Le Petitfournal, July 21, 1879, p. 3, transl. by Anatole Le Bras.

\section{2}

Breaking the Chains, documentary directed by Erminia Colucci, 2014.

\section{3}

In Charlotte Brontë's novel Jane Eyre (1847), Bertha Mason is kept secretly locked in the attic by her husband Mr. Rochester.

\section{4}

The terms "idiocy" and "imbecility" were commonly used by alienists to refer to forms of mental retardation.

\section{5}

In the past decades, a wealth of historical studies has shed a new light on the relations of families to psychiatric institutions in the 19th century, see Coleborne (2010). For France, see Prestwich (2003) and Le Bras (2016). But the domestic care of lunatics is still under-documented and studied, with the notable exception of studies using judiciary archives, see Suzuki (2006) and Nootens (2007).

\section{6}

The Gazette des tribunaux was founded in 1825 , Le Petit Journal in 1863. The Annales médicopsychologiques, founded in 1843, was the main review of French alienists, gathering all tendencies and sensibilities. A certain degree of sensationalism was of course involved in the coverage of these cases. This corpus of cases should therefore not be deemed representative of the average situation of lunatics kept at home. But I will try to show the heuristic utility of these "borderline cases."

7

These reports are often very detailed, and usually reproduce verbatim the criminal charges.

\section{8}

At the Department archives of Finistère (region of Brittany), Morbihan (ibid.), and Somme (region of Hauts-de-France).

\section{9}

See below.

10

"Séquestration d'une fille par ses parents. Horribles détails." In: Le Petit Journal, February 27, 1866, p. 3.

11

The law of June 30, 1838 imposed the presence of an asylum in each department and regulated the modes of admission to the asylum. Confinement was now a medical and administrative act, and no longer a judicial one. The full text of the law (in French) is available online at http://psychiatrie.histoire.free.fr/index.htm (Législation -> Internements -> La Loi du 30 juin 1838). 
12

Victor Parant (1848-1924) was the director of the Braqueville public asylum, near Toulouse. A regular contributor of the Société médico-psychologique, he was also an influential member of the Société de Saint-Luc, an organization of catholic doctors.

\section{3}

This case made headlines in 1901, after the police discovered a woman, named Blanche Monnier, who had been confined for more than 25 years in a bourgeois house in Poitiers (prefecture of the Vienne department). The trial led to the acquittal of her brother.

\section{4}

About the "anti-alienist" movement in France in the 19th century, see Fauvel (2005).

\section{5}

Achille Foville (1831-1887), son of Achille Louis de Foville, himself a well-known alienist, was the director of the Quatre-Mares public asylum, near Rouen.

\section{6}

As early as 1828 in England, the County Asylums Act allowed the Lord Chancellor to visit any private house where an insane person was detained. Following the 1890 Lunacy Act, some non-pauper lunatics placed in private houses (but not those treated by their close family) could also be placed under the supervision and protection of the Chancellery. But the true model of French alienists was the 1857 Scottish Lunacy Act, which established a mandatory declaration to the authorities when the lunatic had to be contained or when the mental illness lasted more than a year. The Commissioners in Lunacy could also visit any private house whenever bad treatment was suspected.

\section{7}

Vaillant's proposal was to make home treatment subject to a judicial authorization.

\section{8}

On the topic of family life in 19th-century France, see Perrot (2015).
19

The total number (49) is greater than the number of cases (47) because there were two cases of double sequestrations.

\section{0}

25 sequestrated people were below 30 when the confinement began; ten were between 30 and 50; and five above 50 (the information could not be found for the remaining nine).

\section{1}

Deposition of Royau, Case file of Le Gouallec, 2U2/561, Morbihan Department archives, Vannes France.

\section{2}

Deposition of Victor Le Gouallec, case file of Le Gouallec, 2U2/561, Morbihan Department archives, Vannes, France.

\section{3}

If the family had recourse to a "voluntary placement," it had to pay for the entire cost of the stay; if a "placement d'office" was requested by the prefect, the department paid for most of the costs, but the municipality and the family were also expected to contribute at a variable rate, depending on their level of income.

\section{4}

"Une folle. Séquestration. Mort." In: La Gazette des tribunaux, August 16-17, 1841, pp. 1080-1081.

\section{5}

The doctors of Quimper public asylum sometimes noted that patients had been locked in a closed bed before being sent to the asylum, see Le Bras (2016).

\section{6}

"Jeune fille séquestrée." In: Le Petit Journal, July 10, 1903, p. 5.

\section{7}

Criminal charges, case file of Le Gouallec, 2U2/561, Morbihan Department archives, Vannes, France.

28

"Séquestration d'une jeune fille par son père 
et sa mère." In: La Gazette des tribunaux,

December 19, 1873, p. 1240.

\section{9}

"Séquestration." In: La Gazette des tribunaux, September 14, 1877, p. 892.

30

"Séquestration d'une mère par son fils." In: La Gazette des tribunaux, June 26, 1874, p. 608.

31

"Séquestration." In: La Gazette des tribunaux, November 2, 1890, p. 1049.

\section{2}

The publication of the case file was the second volume in a new collection by Gallimard called "Nejugez pas!" ["Don't judge!"], published in 1930.

\section{3}

"Une folle. Séquestration. Mort." In: La Gazette des tribunaux, August 16-17, 1841, pp. 1080-1081.

\section{4}

Interrogation of Albin Le Gouallec, case file of Le Gouallec, 2U2/561, Morbihan Department archives, Vannes, France.

\section{5}

"Séquestration d'une fille, par son père et sa mère. Deux ans de martyre. Horribles détails." In: Le Petit Journal, June 10, 1865, p. 3.

\section{6}

"Je lui dis que ... s'il ne me laissait pas voir Albin [je] dirai du mal [de sa fille], à force d'insister, il m'a conduit à l'écurie, il a ouvert la porte qui était fermée à clef et il m’a laissé seul avec Albin." Deposition of François Kergouët, case file of Le Gouallec, 2 U2/561, Morbihan Department archives, Vannes, France. Transl. by Anatole Le Bras.

\section{7}

"On en parlait peu dans la maison et on n'aimait pas que l'on allât le visiter, je m'en suis abstenu; cependant à l'époque du pardon des fleurs, l'interdiction paraissant levée, j'ai cédé à la curiosité et jai fait comme les autres, j’ai vu Albin couché dans une écurie ..." Deposition of Le Gallo, case file of Le Gouallec, 2 U2/561, Morbihan

Department archives, Vannes, France.

Transl. by Anatole Le Bras.

\section{Bibliography}

Baume, Irénée-Célestin (1874): "Affaire Albin Le Gouallec. Séquestration dans une écurie avec emploi d'une chaîne. Rapport médico-légal." In: Annales médico-psycholoqiques 11-12, pp. 411-420.

Bourneville, Désiré-Magloire (1889): "De l'assistance des aliénés dans les hôpitaux-hospices de province." In: Le Progrès medical 2/9, pp. 31-33.

Coleborne, Catharine (2010): Madness in the Family. Insanity and Institutions in the Australasian Colonial World, I860-I9I4, New York: Palgrave Macmillan.

Colucci, Erminia (2014): "Breaking the Chains." Movie-Ment, http://movie-ment.org/breakingthe chains, accessed March 26, 2020.

Fauvel, Aude (2005): Témoins aliénés et "Bastilles modernes": une histoire politique, sociale et culturelle des asiles en France (I8OO-I9I4), dissertation, Paris: École des hautes études en sciences sociales. Foville, Achille (1870): "De la législation spéciale aux aliénés et des améliorations qu'il serait possible d'apporter à la loi du 30 juin 1838." In: Annales d'hygiène publique et de médecine légale 2/33, pp. 381-420. Gide, André (1930): La Séquestrée de Poitiers, Paris: Gallimard.

Girma/Vernet (1894): "Un cas de séquestration d'un aliéné par ses parents." In: Annual Congress of Mental Medicine, La Rochelle, 1-6 August 1893, pp. 720-723.

Hubert, René (1902): Protection légale des aliénés en France, Paris: Arthur Rousseau éditeur. 
Izard, Gabriel (1903): Séquestration des aliénés dans la famille, Bordeaux: J. Durand.

Le Bras, Anatole (2016): "L'asile d'aliénés et le désordre des familles." In: Revue d'histoire du XIXe siècle 53, pp. 171-187.

Le Douget, Annick (2014): Violence au village. La société rurale finistérienne face à la justice, I8I5I9I4, Rennes: Presses Universitaires de Rennes.

Lwoff, Solomon/Sérieux, Paul (1911): "Sur quelques moyens de contrainte appliqués aux aliénés au Maroc." In: Bulletin de la Société clinique de médecine mentale, pp. 168-174.

Majerus, Benoît (2011), "La baignoire, le lit et la porte. La vie sociale des objets de la psychiatrie." In: Genèses 82, pp. 95-119.

Monod, Henri (1889): "'Les cellules d'observation des aliénés dans les hospices.' Congress of Mental Medicine, 9 August 1889." In: Archives de neurologie 18, pp. 304-313.

Nootens, Thierry (2007): Fous, prodigues et ivrognes. Familles et déviance à Montréal au XIXe siècle, Montreal/Kingston/London/lthaca: McGill-Queen's University Press.

Parant, Victor (1884): De la séquestration des aliénés dans leur famille, Paris: Rougier.

Perrot, Michelle (2015): La vie de famille au XIXe siècle, Paris: Seuil.

Petit, Jacques-Guy (1980): "Folie, langage, pouvoirs en Maine-et-Loire (1800-1841)." In: Revue

d'histoire moderne et contemporaine 27, pp. 529 $-564$.

Prestwich, Patricia (2003): "Family Strategies and Medical Power: Voluntary committal in a Parisian Asylum, 1876-1914." In: Porter, Roy/Wright, David (eds.): The Confinement of the Insane: International Perspectives, I80o-1965, Cambridge: Cambridge University Press, pp. 79-99. Reboul, Henri/Régis, Emmanuel (1912): L'assistance des aliénés aux colonies, Paris: Masson. Suzuki, Akihito (2006): Madness at Home. The Psychiatrist, the Patient, and the Family in England, I820-I860, Berkeley: University of California Press.

Wright, David (1997): "Getting Out of the Asylum. Understanding the Confinement of the Insane in the Nineteenth-Century." In: Social History of Medicine 10, pp. 137-155.

Wright, David (1998): "Familial Care of 'Idiot' Children in Victorian England." In: Horden, Peregrine/Smith, Richard (eds.): The Locus of Care. Families, Communities, Institutions and the Provision of Welfare since Antiquity, London: Routledge, pp. 176-197.

\section{Newspapers}

"Une folle. Séquestration. Mort." In: La Gazette des tribunaux, August 16-17, 1841, pp. 1080-1081.

"Séquestration d'une fille, par son père et sa mère. Deux ans de martyre. Horribles détails." In: Le Petit Journal, June 10, 1865, p. 3.

"Séquestration d'une fille par ses parents. Horribles détails." In: Le Petit Journal, February 27, 1866, p. 3.

"Séquestration d'une jeune fille par son père et sa mère." In: La Gazette des tribunaux, December 19, 1873, p. 1240.

"Séquestration d'une mère par son fils." In: La Gazette des tribunaux, June 26, 1874, p. 608.

"Séquestration." In: La Gazette des tribunaux, September 14, 1877, p. 892

"La recluse de Mons-Boubers." In: Le Petit Journal, July 21, 1879, p. 3.

"Jeune fille séquestrée." In: Le Petit Journal, July 10, 1903, p. 5.

The author thanks Marion Henry, Monika Ankele, Benoît Majerus, and Anthony DePasquale for their remarks and proofreading. 


\section{"Amongst the Most Important of the Agencies": \\ Materializing "Nature" at \\ the American Lunatic Asylum}

Linnea Kuglitsch

In the summer of 1859, a letter arrived at the Eastern Lunatic Asylum in Williamsburg, Virginia. The sender - Mr. James Majetts, who lived in a small town located in Southampton County, about 50 miles south of the asylum - had written Dr. John M. Galt, superintendent of the institution in need of professional advice (Majetts 1859). Over the previous months, a series of troubling changes in personality and habit had befallen his 27-year-old son. Alongside an increasingly abusive temper and "an irreverent attitude towards the bible," Majetts (1859: 4) reported that his son, Walter, had declared his ability to "tame any animal, wild or otherwise ... if he can come in sight of [it] ... [and] by beckoning [or] talking to it ... [and] make it follow him or do anything he may ask it." These concerns had peaked as Walter began trying to catch and tame water moccasins, a species of venomous snake native to the region, as well gathering their eggs to bring them home to hatch. 


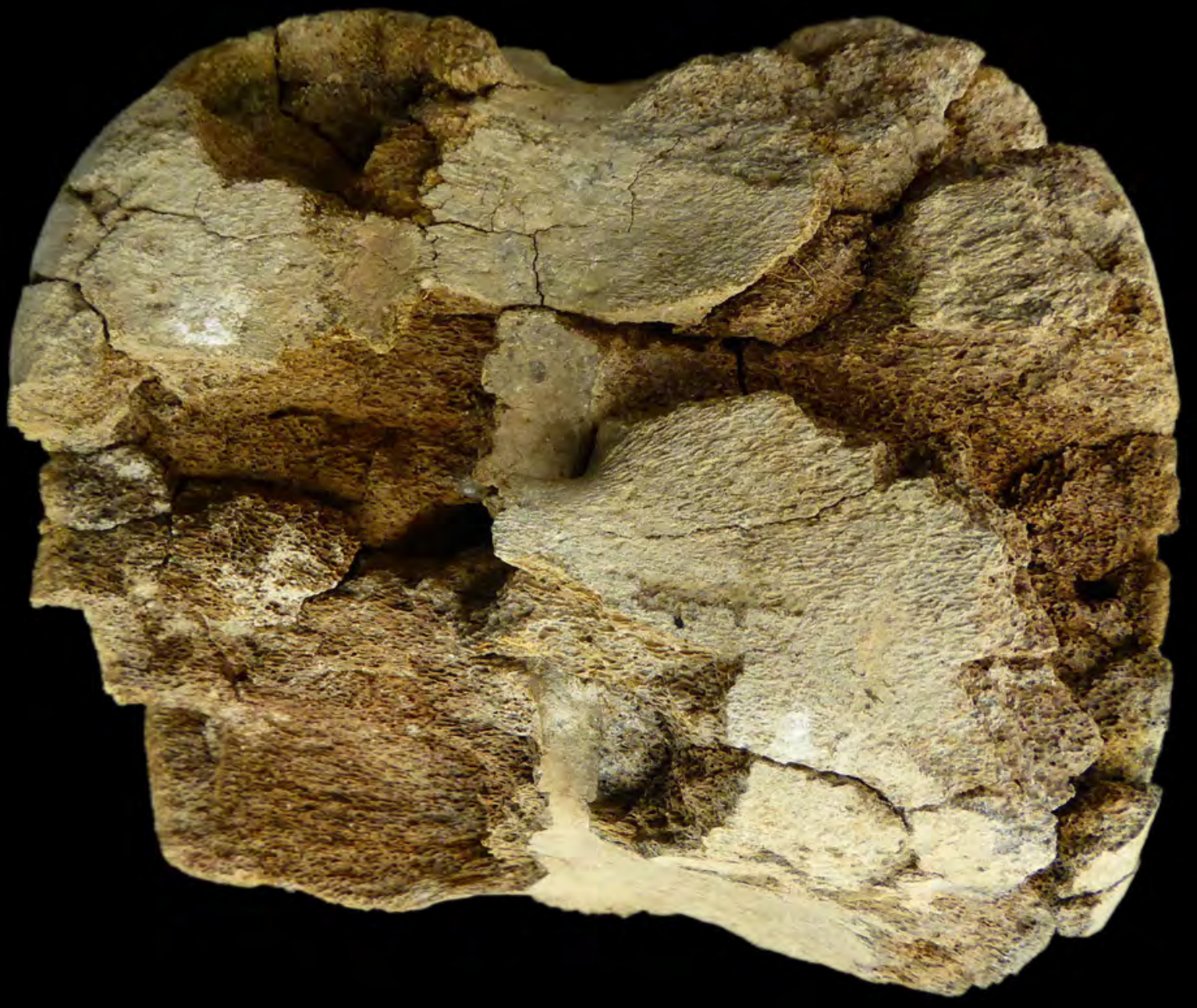


Whether this young man found a place in the Eastern Lunatic Asylum is unclear. His father's detailed account of his behavior, however, highlights the underexplored intersection of mental illness, the natural world, and curative measures in the history of psychiatry. Historians in this field have written at length about how socio-medical discourses about 'nature' and the 'natural world' informed the treatment of mental illness in the I9th and early 2oth centuries. These analyses draw on official documents like medical diaries and annual reports - records that reflect the desires and motivations of the institutional authorities who wrote and compiled them, but which neglect the perspectives of the patients they treated. While historians like Claire Hickman (2013) acknowledge that the 'natural' spaces at these institutions - that is, the lawns, gardens, fields, and other outdoor spaces integrated into the curative regime - sometimes evoked unexpected or undesirable responses among the patients who engaged with them, the maps and reports that inform these interpretations offer little insight into how patients themselves experienced or related to these landscapes. To achieve a more complete understanding of how nature and institutional life converged in the past thus requires a novel methodological approach.

This chapter explores how treatment practices centered around the natural world shaped patient life in two of American asylums: the Eastern Lunatic Asylum, which operated in Williamsburg, Virginia from I773 until I885, and the Western Washington Hospital for the Insane, which opened in Steilacoom, Washington in I87I (Dain I971; Hollander 1982). While these institutions differed in their geographic and cultural contexts, both operated according to the curative framework known as moral treatment or management. No single definition of or formula for moral management existed.

Instead, the practice encompassed a cluster of different therapeutic activities that were selected for their capacity to re-impose normalcy and regularity over the moral, emotional, and intellectual dimensions of the patient. Advocates of moral management called for patients' removal to the asylum estate, where the orderly environment and regulated routine of institutional life - combined with respectful, humane treatment and an assortment of recreational, occupational, and religious activities - was calculated to restore patients' ability to moderate their own thoughts and actions (Brigham I847). Moral management practice is commonly understood to decline among institutions on the eastern coast of the United States by the final quarter of the I9th century; however, it lingered on in the western territories (Wickham 2016). Thus, as late as 1908, Dr. John Semple - superintendent at 
Eastern Washington Hospital for the Insane, an institution founded in Washington in I89I as a counterpart to the Western Washington Hospital - explicitly linked the treatment of insanity to the moral treatment framework (Semple I908).

Moral treatment was entangled in the material and emotional landscapes of institutional life, both indoors and out. "Employment, amusement, diversions of various kinds," as superintendent at Eastern Washington Hospital for the Insane John Semple (I908: 5I) wrote, gave structure to the institutional life and operated as a mechanism for "teaching self-control and respect for the rights of others, inducing interest in books, music, flowers, open air exercises, regular methods of living, and [strengthening] all the agencies which tend to lead the mind in normal channels of thought" (ibid.). As Semple's description implies, the natural world constituted an indispensable resource in the quest to restore the insane to reason. As medical educator and practitioner Robley Dunglison declared several decades earlier, "exercise and amusement out of doors are amongst the most important of the agencies adopted in the treatment of insanity" (I836:37I). Outdoor activities, like agricultural work, picnics, sports, and walks, were understood to strengthen the body and exercise the mind, helping patients rebuild the willpower and self-control that moral collapse and organic disease had stripped away. Even patients unable to benefit from direct engagement with the carefully designed and curated grounds of the asylum estate were believed to benefit from visual exposure to pleasant, natural scenery, which diverted their attention from unhealthy, brooding thoughts (cf. ibid.).

Yet, as Majetts's letter to Dr. Galt reveals, the worrisome thoughts and troubling behaviors that medical and lay authorities interpreted as proof of mental disorder did not disappear at the asylum's threshold; they materialized outdoors, too. This chapter uses archaeological artifacts and documentary records to examine the dissonance between rhetoric and practice at two American institutions. Exploring the inherent contradictions of moral management practice, this chapter examines the tensions that arose around the 'natural world' of the institution. Different inhabitants of these establishments defined and used the grounds and gardens in different ways, creating an undercurrent of tension. While the superintendent and the attendants understood the natural world to be a tool of treatment, its value in this respect depended on their ability to control - and to some extents, limit - how patients engaged with these natural surroundings. Furthermore, the natural resources available to an institution did not always match the idealized descriptions put forth in historical advice literature. In such cases, the curative connection between patients and the natural world had to be fostered in inventive and unorthodox ways. 
This chapter opens with a brief introduction to historical archaeology, thereby positioning its approaches and contributions amongst extant scholarship investigating the grounds, gardens, and natural world of the asylum. It then introduces two archaeological artifacts: a fossilized whale vertebra and a sand dollar. Together, these artifacts illustrate dissonance between rhetorical ideals of moral management framework and the practical realities of operating an institution, shedding light onto the inhabitants of these historic sites and illuminating their relationship to the lawns, grounds, and gardens that surrounded them.

\section{Historical Archaeology and the Asylum}

Historical archaeology draws on both documentary and archaeological data to explore human culture and experiences in the past. Archaeological approaches use cultural remains, typically recovered through archaeological excavation and referred to as artifacts, to examine these topics. In practice, excavation involves the systematic stripping away of distinct stratigraphic layers, or contexts, which correlate to distinct historical periods, events, or processes. A context may correlate to a single, dramatic event, like the collapse of a building during a fire, or a long-term process like the steady filling of a household privy. The removal of each stratigraphic layer and its contents, however, amounts to the destruction of a site, so each context must be carefully documented and recorded in a manner that preserves these contextual relationships. In this manner, the archaeological process creates a simulacrum of the site, allowing researchers to continue exploring its history after excavations have been concluded. The artifacts enfolded in these contexts, meanwhile, enhance this history further, by highlighting the human activities that occurred when each stratigraphic layer was deposited. ${ }^{\mathrm{I}}$

This chapter draws on the materials, methodologies, and perspectives of historical archaeology to reexamine the relationship between the institution and the individual. It directs this through a lens that is familiar to at least a handful of historians of psychiatry and the asylum: that of its grounds and gardens. Many historians have considered these institutions and their surroundings as components of a larger therapeutic landscape - that is, as a location that was understood or engineered to facilitate physical, spiritual, mental, and emotional healing (Gesler 2005). Chris Philo's (2004) geographical examination of madness in England, for example, 
provides a survey of the development of facilities dedicated to the care and cure of the insane from the medieval to the Victorian era. This wide brushstroke brings the important role played by the natural world into focus - a theme that has been examined by several other scholars. In Therapeutic Landscapes, landscape historian Clare Hickman (2013) offers an overview of hospital gardens and their uses in several British institutions since I80o. This work, which illustrates how their design merged medical concepts with established garden types and forms, borrows from Sarah Rutherford (2005), whose scholarship highlights the development of institutional grounds as a specialty among garden designers. Stephanie Eastoe's (20I6) examination of the estate of the Caterham Imbecile Asylum - a I9th-century British institution for the chronic and incurable insane - medical authorities typically selected an institutional site and designed and apportioned its grounds to accommodate a number of requirements, from sanitary management to its curative effects.

The visual experience of the asylum grounds and gardens has also been examined. Institutions such as Brislington House tried to embed elements of picturesque scenery into their estates, suggesting that even passively absorbing scenery around the estate was understood to have a beneficial impact on the moral health of the patient (Hickman 2005, 2009). Steven Cherry and Roger Munting (2005) attend more closely to recreational regime that these landscapes supported. In their survey of late Victorian and early-2oth-century asylums in Britain, they examine how the institutions surroundings were apportioned, maintained, and used to facilitate patients' recovery through activities like cricket, football, and badminton. These outdoor activities operated as both a means of cure and as a mechanism for relieving the overcrowding that patients and staff endured as the residential populations of these establishments expanded in the mid-nineteenth century.

Scholars from a wide range of backgrounds thus agree that the grounds of the asylum played an important role in institutional life - yet, this vein of scholarship remains subject to the limitations that characterize many historical analyses. Roy Porter's (1985) foundational article, The Patient's View, charged historians of medicine with factoring patients' perspectives and experiences into the stories they tell. In recent years, the asylum patient has received significantly more scholarly attention. Still, historians of medicine have not followed through on this shift in perspective wholesale (Condrau 2007). This difficulty can be traced to methodological concerns about the character of the records that survive in the archives, documents disproportionately represent the perspectives of institutional officials. The biases, motivations, and incidental ignorance of the people who authored the primary source documents 
that have survived into the present day, combined with sparse preservation and selective curation, culminate in an assemblage of documents that challenges traditional historical research methods. ${ }^{2}$

Historical narratives surrounding the institutional landscape are especially vulnerable to these limitations. Hickman notes that many patients at the nineteenth-century asylums viewed the time they spent in the grounds and gardens as "a mixed experience;" yet, the patient perspective - and the perspectives of the staff tasked with caring for them - are conspicuously absent from the documents that commonly inform this genre of historical research (Hickman 2013: 5). Detailed descriptions needed to understand and picture the grounds typically originate in official reports written by the superintendent. Photographs, maps, and other visual renderings of the grounds were often commissioned by officials to promote the institution to potential patrons, or to underscore the success of the superintendent's innovative landscaping or horticultural programs. These records provide a clear picture of how institutional authorities defined these landscapes and how they wanted patients to interact with the grounds; however, the perspectives of patients and their attendants - and the daily realities that they faced - remain excluded from these documents and the narratives that they feed.

Still, many historians remain optimistic about the prospect of accessing the patient perspective. Brendan Kelly (20I6) insists that while patient voices remain at present largely unknown, they are not unknowable. Kelly recommends further methodological experimentation and interdisciplinary collaboration as a solution to the challenges that these sites and their histories present to historians. The outcomes from interdisciplinary collaboration "necessarily and irrevocably ... entwine bodies, minds, geographies and temporalities in creative, ambivalent and often conflictual ways," producing outputs that communicate complex and sometimes contradictory stories (Callard et al. 2015: 6). In historical archaeology, such dissonances are understood to improve, rather than detract from, the stories we tell about the past. Encountering incongruities between different datasets is a common occurrence in historical archaeology, an inherently interdisciplinary field which has a lot of methodological potential to offer researchers interested in these types of sites.

Archaeology examines the material world in terms of the physical, spatial, and geographical context in which it is encountered to learn about the human experience in the past. Historical archeology integrates archaeological data with documentary research, providing a more rigorous understanding of a site's history: from the processes that formed it to the meanings and relevance of the artifacts recov- 
ered from it. Philosopher of science Alison Wylie (1989) refers to the practice of combining different types of data as cabling. Following Wylie, when the historical and archaeological data are used together in research, they create a joint narrative that is ultimately more robust than one that is spun from a single dataset. Furthermore, any dissonances between the archaeological and archival datasets that do appear can be treated as an opportunity for further research, flagging up an area of inquiry that might have otherwise been overlooked. If reports from the hospital board of trustees, for example, indicate that dining room tables on the wards were set with plain, heavy-duty china, one would expect this type of tableware to occur commonly in an archaeological assemblage associated with that site. However, if excavations yield only porcelain from stylish teawares, researchers must return to the archival record to extrapolate on how and why these unexpected materials entered the archaeological record (Piddock 2007, 2009; Longhurst 2015).

The ability to juxtapose the stories told in documents and the remains of lived experience, or "the written and the wrought," too, is essential to seeing the whole picture of institutional life (D’Agostino 1995). By combining archaeological and documentary data, we are able to create a narrative that balances the evidence of lived practice and historical conditions with the equally important human stories of the past. This balancing act allows the researcher to explore both the mundane (and subsequently unrecorded) aspects of institutional life, and to better understand the lives, attitudes, and actions connected to "those of little note" - that is, the patients - in these histories (Scott 1994). Thus, by threading the physical residue of institutional life and treatment into the narrative, archaeological methods can help de-institutionalize asylum histories (Eghigian 20II).

The following sections introduce two artifacts recovered over the course of archaeological investigation of the aforementioned sites. First, I use archival materials to inform an analysis of a fossilized whale vertebra found on the grounds of Eastern Lunatic Asylum. As detailed examination suggests, this object has a unique curative role to play. My analysis of a second item - a sand dollar, recovered in an institutional dump associated with the Western Washington Hospital for the Insane - takes a more patient-centered approach, examining the unexpected movement of 'natural' materials into the controlled interior spaces of a morally managed institution. Adopting the methods and perspectives of historical archaeology, it becomes clear that the rhetorical ideals of moral management did not always translate into practice - particularly in the context of institutions tasked with balancing moral, sanitary, medical mores with the daily management of hundreds of patients. 


\section{Natural History at the Eastern Lunatic Asylum}

The Eastern Lunatic Asylum (hereafter, the Asylum) was established in Williamsburg, Virginia in I773. Over the first sixty years of its operation, the Asylum functioned as a custodial institution - feeding, clothing, and confining the mentally ill, but offering little in the way of effective treatment. With the popularization of moral management in the United States in the early I9th century, the need to bring the Asylum in line with professional and public values became clear to its Board of Directors. In 1839, the board of directors announced their plans to reform the institution to better accommodate the practices, landscape, and values of the moral management movement. Two years later, Dr. John M. Galt was hired on as the first superintendent of the asylum (Zwelling 1985). Credited with introducing several reforms to this institution - from fitting barren patient rooms with chairs, tables, bedsteads, and bedding, introducing occupations like shoemaking, knitting, and carpentry, to establishing a patient library - Galt's superintendence is generally regarded as the zenith of moral management at the Asylum.

Galt, like his contemporaries, regarded the institutional grounds as a powerful resource for restoring his patients' sanity. "There is no medical authority," Galt (I854: 5I) wrote, "who does not attach great importance to [the] locality [of an asylum], destined as it is to exert a continuous impression on the insane. An asylum is all the better for being provided with beautiful walks, purling streams, flowery parterres, orchards, groves, [and] beautiful views." The grounds of the Asylum never reached the level of sophistication that Galt envisioned, offering little in the way of babbling streams or scenic parterres over the course of his two-decade tenure as superintendent. They did, however, offer a pleasant setting for evening walks, carriage rides, and games of battledore. Both male and female patients made use of the enclosed lawns and gardens; a handful of male patients were even permitted to take trips into the nearby woods to walk, fish, and collect nuts (ibid.).

As the I9th century progressed, however, bringing patients into contact with the natural world through the Asylum grounds became increasingly difficult. This was due in part to the physical situation of this institution. Most mid-century lunatic asylums were established in rural locations, which provided ample opportunities for outdoor entertainment and employment that would draw patients out into the healing influence of the natural world. In comparison, when first established, the Asylum existed on periphery of the city of Williamsburg (Dain I97I: 4). By the time Galt 
became superintendent in I84I, the area surrounding the Asylum had been built up, exacerbating another imperfection of the establishment: lack of land.

The Asylum campus was minute by the standards of the era. An I835 Report to the Virginia House of Delegates described the Asylum as situated on "four acres of land in a pleasant part of the city of Williamsburg, to which is attached about two acres of land" (Garland I835: I). In I843, these holdings increased to about twenty acres with the purchase of a small farm located several miles outside of the city (Dain 197I: 9I). The Association of Medical Superintendents of American Institutions for the Insane (I885: 25) - a medical organization founded in I844, which focused on improving asylum management and patient treatment - recommended that every institution of this kind possess no less than 50 acres of land, with an additional Ioo acres for every 200 patients it served. As a founding member of the Association, Galt was intimately aware that the Asylum's twenty-acre tract was insufficient to ensure its ever-growing patient population be exposed to the healing powers of the natural world.

In I862, Dr. Galt died. His demise marked the decline of moral management practice at the asylum. By the end of the American Civil War in I865, this institution had returned to delivering custodial care. In I885, a fire destroyed the asylum buildings. This disaster, the rapid abandonment of the buildings, and the levelling of their burned-out shells left a substantial material footprint and preserved the archaeological contexts that the disaster created. Archaeological exploration of the asylum was initiated by Ivor Noel Hume in the I970s and continued intermittently throughout the second half of the 2oth century. Hume and his successors produced a wealth of data and artifactual evidence, recovering items ranging from curtain weights and mouth harps to bottles from the dispensary (Myzk I983; Hume I996). Reanalyzing these materials - now curated as a legacy collection at Colonial Williamsburg - in 20I7, one artifact stood out for its peculiarity and its resonance with the natural world. Weighing in at nearly six pounds and measuring just over six inches across, the fossilized whale vertebra recovered from the Asylum's cellar may seem out of place in an assemblage dominated by the mundane and the medical (fig. I). When viewed through the lens of the archival record, however, its significance becomes clear.

Information gleaned from historical documents associated with the asylum provides valuable context for exploring the significance of this particular artifact. Dorothea Dix, prominent advocate for asylum reform in the United States, visited the Eastern Lunatic Asylum on several occasions over the course of Galt's superin- 
tendence. The correspondence between Miss Dix and the superintendent's sister, Sarah Marie Galt, demonstrates the significance of this unusual artifact. After her brother died, Sarah Galt continued to exchange letters with Dix. In several of these, Sarah Galt (I863: 3) refers to the "almost-museum of rare shells [and] curiosities" that her brother kept in the cottage they shared on the Asylum's grounds. These "natural anomalies from foreign lands," she explained, were used as a part of the therapeutic regime during Galt's tenure; combined with Galt's "ever-agreeable innervation and explanation[s]" of their significance, this collection of objects - including the archaeologically-recovered fossilized vertebra - was used to withdraw patients "from their insane delusions" (ibid.).

While the Asylum lacked the physical resources needed to heal its patients through direct exposure to the natural world, Galt's small collection of curios helped pull patients from their moral decline. Engaging patients with artifacts reminiscent of the principles of natural history thus brought them into contact with the natural world in a novel way, acting as a mechanism for 'making do' with the Asylum's limited acreage and crowded surroundings. The rational discussions and friendly visitations that they facilitated, Sarah recounts, operated "with great success in soothing the agitated feelings \& rousing the torpid intellect" (Galt I869: I).

\section{Natural Artifacts at the Western Washington Hospital for the Insane}

In contrast to the Asylum, the Western Washington Hospital for the Insane (hereafter referred to as the Hospital) boasted a substantial estate of upwards of 400 acres throughout the late igth and early 2oth centuries. Opened in the remains of Fort Steilacoom as the Lunatic Asylum of Washington Territory, the institution capitalized on its natural surroundings from the very beginning. From the mid-I870s, patients enjoyed the use of this institution's "magnificent park;" they played baseball and football, attended dances, swam, and went walking, berry picking, fishing, and riding under its "grand and lofty shade-trees" (Hospital for the Insane I877: I). In I 887 the site was formally dedicated to the hospital. This event was marked by the construction of a new, purpose-built structure to replace the worn-down garrison buildings as well as the creation of new opportunities for outdoor employment. Male patients were put to work landscaping the grounds, maintaining the buildings, and caring for the gardens, orchards, and livestock. Female patients worked 
in the greenhouses, harvested small fruits and vegetables, and gathered seeds and wildflowers from the groves and prairies around them (Waughop I887: 20; Goldsmith/Reed I9I2: 25). By the early 20th century, outdoor activities were a well-established part of the Hospital's daily routine.

In 20I6, construction activities to install a fence on the old campus of the Hospital disturbed a dense layer of historic artifacts buried about a meter under the surface of the ground. Salvage excavations recovered a dumpsite associated with the hospital dating to around the turn of the 2oth century. In one of the earliest deposits, the fragmentary remains of Dendraster excentricus - a species of sea urchin known as a sand dollar - were recovered (Jovilette et al. 20I6). While Dendraster is native to the pacific northwest, its presence in an institutional dumpsite nearly a mile inland from its natural habitat makes it worthy of further consideration. Similarly, unlike the other bones, shells, and botanical remains present in the hospital assemblage, sand dollars are not edible. Their cultural value relates to their whimsical appearance, instead (Allman/Rubio 20I3).

The lace-like pattern on the anterior side of the animal - combined with the ease of locating and recovering them from the shoreline when washed ashore after rough weather - made these items attractive to the region's growing population of natural history collectors (Whittemore I885: 192; Merrill 1989). Specimens of Dendraster and other species of sand dollar were so popular, in fact, that they could be purchased through advertisements in specialist magazines like The Oölogist (I889) and The Museum (1895). The specimen recovered from the Hospital dump, however, does not seem to have been acquired through this avenue. The goods sold through these magazines were delivered by mail, meaning suppliers had to dry, bleach, and otherwise preserve their goods to prevent them from decaying in transit. The Hospital sand dollar, however, does not appear to have been treated in this way. Considered alongside the archival record, these material details suggest another narrative: one in which a patient visiting the nearby shoreline noticed the interesting little sand dollar, collected it, and carried it back to the Hospital, where an attendant or other institutional employee ultimately intercepted and disposed of it.

Situated on the prairie overlooking an inlet of the Puget Sound known as Chambers Bay, the Hospital was located about a mile east of the nearest shoreline. A natural depression in the landscape - known among staff and inmates of the institution as the gulch - cut through the steep bluffs that separated the Hospital from the shore and provided a convenient thoroughfare. Hospital patients and staff made frequent trips to the shoreline: as early as I88I, for example, an attendant and 
several patients were expected to hike along the gulch to the streetcar line that ran along the Bay to collect and deposit the Hospital's mail (Cooley 1964: 23). Returning from their outdoor excursions, patients regularly tried to smuggle any interesting or useful objects they encountered during their outdoor excursions onto the wards. Attempts to carry items ranging from scraps of rope to whole evergreen boughs were met with varying success, and many were intercepted by shrewd and observant attendants (Waughop I894: II). Small objects were the most difficult for hospital staff to notice and confiscate; in one case, a male patient managed to smuggle "a very harmless looking piece of sheep's rib ... picked up in one of his daily walks" to his room (ibid.:II-I2). Measuring just under eight centimeters wide and no thicker than a centimeter, the sand dollar was similarly unobtrusive - perfectly-sized to carry back indoors after a walk, tucked into a pocket or beneath an item of clothing.

\section{Constructing, Deconstructing, and Materializing 'Nature' at the Lunatic Asylum}

Examined through the lens of the documentary record, artifacts discussed above highlight a fundamental tension between the perceptions and practices surrounding nature's curative influence. Returning to the point made by Semple, inducing patients' interest in elements of the natural world, from flowers to open-air exercises and regular methods of living, could produce improvements in patients' moral and physical health (Semple I908: 5I). As researchers like Hickman (2005) and Rutherford $(2003,2005)$ suggest, this perspective was typical of the rhetoric surrounding moral management. The natural world played an important role in the curative regime of the morally managed institution. Its buildings were carefully designed and sited, and its grounds engineered, apportioned, and maintained to maximize the curative benefits of the natural world. Yet, the relationship between the institution and the natural world was more complex, as becomes clear upon transposing the archaeological remains that correlate to the activities and practices that surrounded the institutional experience of the 'natural world' over these documentary accounts. Despite their shared reliance on moral management, the Asylum and the Hospital related to their grounds - and thus the 'natural world' - differently.

Dr. John Galt's small collection of natural curiosities at the institution was kept with the intention of applying them with therapeutic effect. While viewing and discussing these objects allowed asylum authorities to guide patients towards rational 
channels of thought and practice proper decorum, they also provided a valuable way of "occupying the mind to the exclusion of false notions and morbid feelings" (Galt I852: 28). This approach was not unusual. An I847 article written by Amariah Brigham, psychiatrist and editor of the Journal of American Insanity, encouraged incorporating the study of the natural sciences into the asylum regime. The "regular and rational employment of the mind" provided by this study, Brigham (I847: I2) argued, was particularly suitable as a curative mechanism for its ability to engage patients' attention and foster the "improvement of [their] mental and moral powers." A supply of "books, maps, apparatus illustrative of different sciences, and ... collections in natural history" would be required for these discussions, including examples to explain principles relating to chemistry, mineralogy, and conchology (ibid.).

At the Asylum, this collection may have offered a unique way to bring the out of doors indoors, as a therapeutic mechanism. The role was especially valuable at this institution precisely because it lacked grounds that were sufficiently large or developed enough to ensure that all patients had access to the curative benefits of nature. Archaeological and archival evidence suggests that Galt explicitly employed the fossilized whale vertebra recovered from the Asylum site as a mechanism of the moral management cure, and the substantial size of the object makes it unlikely that it was casually encountered on the grounds. Rather, this piece of natural history exemplifies the use of nature in moral management practice - as well as a somewhat makeshift solution to institutional shortcomings. Contrastingly, it seems increasingly likely that the remains of the sand dollar recovered from the Hospital dump were collected by a patient from the nearby beach. Meanwhile, the circumstances of its disposal in the dumpsite suggests that artifact was viewed as an inappropriate or undesirable addition to the institutional landscape. In this way, the sand dollar articulates a point of conflict between these meanings and constructions of nature as a therapeutic resource, and how the patients in their care related to it.

Rather than existing passively in a landscape intended for moving through, viewing, and interacting with institutionally-approved ways, patients also approached their 'curative' natural surroundings as a material resource. Many professionals acknowledged this tendency and worked to balance out this co-option without discouraging patients from their interests. Prominent British psychiatrist Charles Mercier suggested an approach that integrated patients' desire to engage with the natural world with the benefits of maintaining such curiosities. In his treatise, Lunatic Asylums, Their Organisation and Management, Mercier (I894: I9I) encouraged superintendents to retain interesting items that patients collected during their outdoor 
recreations. The asylum estate could yield an array of natural curiosities, he noted, from 'ancient' flint implements to birds' nests. "If preserved ... suitably described and labelled with the name of the contributors," Mercier observed, these objects could "afford gratification to [the patients who collected them] and arouse the emulation of others" (ibid.). By reframing patient activities in this way, potentially dangerous habits could thus be made to fit the needs and purposes of the institution.

Mercier's suggestion for mediating the juxtaposing ways in which patients and practitioners might relate to the natural world, however, does not appear to have been commonplace practice. Nellie Bly, author of Ten Days in a Madhouse - a published version of her exposé The Women's Lunatic Asylum on Blackwell Island, which she infiltrated as a reporter on behalf of the New York World in 1887 - identified a similar tension between institutional management and individualized patient treatment that was articulated through interactions with the natural world:

[Patients] are not allowed on the grass - it is only to look at. I saw some patients eagerly and caressingly lift a nut or a colored leaf that had fallen on the path. But they were not allowed to keep them. The nurses would always compel them to throw their little bit of God's comfort away. (Bly I887: 130)

Restrictions like these existed in tension with the curative ideals of moral management - at least, insofar as they were articulated in the literature. While the grounds were curative, boundaries had to be drawn between the interior and the grounds to ensure patients' and staff members' safety. A patient subculture of secreting articles into the hospital from the grounds created significant challenges to institutional efforts to maintain control over the material world on the wards. Meanwhile, 'natural' objects like the sand dollar may have been barred from the wards over sanitary concerns. As superintendent of the Pennsylvania Hospital for the Insane and co-founder of the Association for Medical Superintendents of American Institutions for the Insane Thomas Kirkbride (I854: 2I) advised, a well-built and run lunatic asylum harbored "[no] spot for foul air, or ... deposit of filth." Organic matter was subject to decay. To Kirkbride and his successors, 'filth' of this kind would have presented a threat to the physical health and emotional well-being of patients and their caretakers. This perception of danger, then, also motived the removal of natural or organic materials from the interior spaces of the institution. An untreated sand dollar picked off the shoreline would begin to decay and, invariably, start to smell. This unpleasant sensory marker would not only betray its presence on the 
ward but impel its disposal. If this object was intercepted and confiscated before entering the institution, its disposal is similarly telling. While amassing collections of bird nests and shells was discussed as bearing significance in the therapeutic process, preserving the sand dollar properly required time and resources that the institution was unwilling or unable to dedicate to its preservation. Thus, while the natural surroundings of the asylum were understood by its advocates to serve as a curative resource, patients could co-opt these landscapes - engaging with them as if they were a source of material culture, rather than a series of scenes and settings that could channel exercises and recreations that would benefit patients' state of mind. As both case studies highlight, then, the resources available to institutional authorities were often insufficient to ensure that the realities of the moral management cure matched up to its rhetorical ideals.

\section{Conclusions}

While the Eastern Lunatic Asylum and the Western Washington Hospital for the Insane operated in very different contexts, both institutions framed the treatment that they delivered in terms of the rhetoric of moral management. By integrating archaeological and historical research it becomes clear that patient and institutional realities often diverged from idealized natural encounters described in much of the formal literature. Dr. John Galt, Superintendent at the Asylum, curated a small collection of natural wonders to redirect patients' attention and give them an opportunity to practice rational thought and conversation. While there is no evidence that this unusual collection was a direct response to its insufficient estate and limited natural resources of the Asylum, its assemblage of natural history materials supplemented its curative role - relocating some of curative encounters from the sparse Asylum grounds and into the institution itself. Contrastingly, the Hospital possessed an estate that aligned more closely in terms of size and character; patients were able to participate in various occupations, chores, and recreations on its grounds. However, as the archaeological record attests, patients did not always view or interact with the natural world in the capacities that institutional authorities envisioned. The Hospital's patients were expected to take interest in viewing and moving through the grounds that surrounded them, and to benefit from the exercise and other outdoor activities it afforded them. However, this curative prac- 
tice was complicated by an institutional subculture of collecting objects that patients brought back onto the wards.

As Nancy Tomes (I984: vii) observes, life inside the I9th-century lunatic asylum was ultimately shaped by "all-too-human blend of medicine, morality and expediency." The financial and material limitations of the grounds and gardens of these institutions, combined with health and safety concerns, restricted the ideal forms of moral management practice espoused in a wealth of treatises, proceedings, and annual reports. Thus, by bringing conflicts between ideal and practice into focus, the human element of these complex institutional histories can be revealed.

The rhetoric of the moral management movement positions the natural world as a central curative force in asylum treatment. Asylum authorities believed that bringing patients into contact with the 'right' kind of natural landscapes in the 'correct' ways would channel patients' bodies and minds back towards physical and mental health. Scholars in several disciplines, from garden history to geography, have scrutinized the historical therapeutic role of the gardens, lawns, and sports fields that made up these institutional estates; however, the ongoing reliance on documentary sources alone means that the narratives produced are drawn largely from a singular, institutional perspective. The addition of novel, interdisciplinary perspectives adds nuance and depth to these historical landscapes, highlighting the tensions between ideal and practice. Historical archaeology, which brings together archival and archaeological data, makes the dissonances between the rhetorical ideals and the lived realities of asylum life increasingly clear. It is this dissonance between rhetoric and practice that re-humanizes the historic asylum. 


\section{Notes}

1

For further reading on archaeological approaches, methods, and theory, see Deetz (1977): Hall/Silliman (2006); Hicks/Beaudry (2006).

\section{2}

For further discussion of these challenges, see Condrau (2007); Swartz (2008); McCarthy et al. (2017).

\section{Sources}

Anonymous (1877): "Hospital for the Insane: Special Correspondence of the Standard, 4 July." Washington State Archives, Institutions Department, Western State Hospital, 1871-1979. Box 94.

Cooley, C. (1964): "The Western State Hospital, Fort Steilacoom, Washington, History 18711950." Washington State Archives, Institutions Department, Western State Hospital, 1871-1979. Box 126.

Galt, J. M. (1845): "The Annual Report of the Physician and Superintendent of the Eastern Asylum, in the city of Williamsburg, Virginia, for 1844." Richmond: Shepherd and Colin. Library of Virginia, Eastern State Hospital Collection. Box 74, Folder 8.

Galt, J. M. (1852): "The Annual Report of the Physician and Superintendent of the Eastern Asylum, in the city of Williamsburg, Virginia, for 1851." Library of Virginia, Eastern State Hospital Collection. Box 75, Folder 5.
Galt, J. M. (1854): "The Annual Report of the Physician and Superintendent of the Eastern Asylum, in the city of Williamsburg, Virginia, for 1853-4." Richmond: Ritchies \& Dunnavant. Library of Virginia, Eastern State Hospital Collection. Box 75, Folder 7.

Galt, S. M. (1863): "Dearest Miss Dix, You told me when you visited me in the summer..." Swem Library, College of William and Mary. Williamsburg, VA. Galt Family Papers I: Medical Papers. Box 3, Folder 34

Galt, S. M. (1869): "My Dear Miss Dix, One of the viscitudes experienced by my unhappy country..." Swem Library, College of William and Mary. Williamsburg, VA. Galt Family Papers I: Medical Papers. Box 3, Folder 34

Majetts, J. (1859): "To the superintendent of Either Lunatic Asylum, Va." Swem Library, College of William and Mary. Williamsburg, VA. John Minson Galt Papers II: Medical Papers. Box 78, Folder 165.

Myzk, W. R. (1983): "Draft Final Report Public Hospital Excavation October 1981-January 1983." Office of Excavation and Conservation, Department of Archaeology, Colonial Williamsburg Foundation.

Semple, J. (1908): "Eastern Washington Hospital for the Insane, Medical Lake: Superintendent's Report." In: Fourth Bienniel Report of the State Board of Control for the Term Beginning October 1, 1906 and Ending September 20, 1908. Olympia, Washington: C.W. Gorman, Public Printer. Washington State Archives, Institutions Department, Western State Hospital, 1871-1979. Box 1. Waughop, J. W. (1887): "Report of the Superintendent." Olympia, Washington: C.B. Bagley, Public Printer. Washington State Archives, Institutions Department, Western State Hospital, 1871-1979. Box 9.

Waughop, J. W. (1894): "Report of the Superintendent, Hospital for the Insane, 1893-4." Olympia, Washington: O.C. White, State Printer. Washington State Archives, Institutions Department, Western State Hospital, 1871-1979. Box 1. 


\section{Bibliography}

Allman, Skye/Rubio, Sina (2013): Dendraster excentricus, Animal Diversity Web, http://animaldiversity.org/accounts/Dendraster_excentricus, accessed January 8, 2018.

Association of Medical Superintendents of American Institutions for the Insane (1885): History of the Association of Medical Superintendents of American Institutions for the Insane, from I844 to I884, Inclusive, edited by J. Curwen, Warren, Pennsylvania: E. Cowan \& Co. printers, https://hdl. handle.net/2027/chi.41668591, accessed August 4, 2017.

Bly, Nelly (1887): Ten Days in a Mad-House, New York: Munro.

Brigham, Amariah (1847): "The moral treatment of insanity." In: American Journal of Psychiatry 4/1, pp. 1-15.

Callard, Felicity/Fitzgerald, Des/Woods, Angela (2015): "Interdisciplinary collaboration in action: Tracking the signal, tracing the noise." In: Palgrave Communications 1, pp. 1-7.

Cherry, Steven/Munting, Roger (2005): “Exercise is the Thing'? Sport and the Asylum c. 1850-1950." In: The International Journal of the History of Sport 22/1, pp. 42-58.

Condrau, Flurin (2007): "The patient's view meets the clinical gaze." In: Social History of Medicine 20/3, pp. 525-540.

D'Agostino, M. E. (ed.) (1995): The Written and the Wrought: Complementary Sources in Historical Anthropology: Essays in Honor of James Deetz, Berkeley: Kroeber Anthropological Society. Dain, Norman (1971): Disordered Minds: The First Century of Eastern State Hospital in Williamsburg, Virginia, I766-I866, Williamsburg: Colonial Williamsburg Foundation.

Deetz, James (1977): In Small Things Forgotten: The Archaeology of Everyday Life in Early America, New York: Anchor Books.

Dunglison, Robley (1836): General therapeutics, or Principles of medical practice: with tables of the chief remedial agents and their preparations and of the different poisons and their antidotes Philadelphia: Carey, Lea, and Blanchard.

Eastoe, Stef (2016): "'Relieving gloomy and objectless lives.' The landscape of Caterham Imbecile Asylum." In: Landscape Research 41/6, pp. 652-663.

Eghigian, Greg (2011): "Deinstitutionalizing the history of contemporary psychiatry." In: History of Psychiatry 22/2, pp. 201-214

Garland, D. (ed.) (1835): "[Doc No. 36] Report of the Committee Appointed to Examine the State and Condition of the Lunatic Hospital at Williamsburg." In: Journal of the House of Delegates of Virginia, pp. 1-9.

Gesler, Wilbert (2005): "Therapeutic landscapes: an evolving theme." In: Health \& Place 11/4, pp. 295-297.

Goldsmith, M./Reed, A. (1912): Report of Conditions in the State Institutions of Washington Together with Recommendations for Needed Changes in Administration and Legislation, Olympia: E.L. Boardman, Public Printer.

Hall, Martin/Silliman, Stephen W. (2006): Historical Archaeology, Malden: Blackwell.

Hickman, Clare (2005): "The Picturesque at Brislington House, Bristol: The Role of Landscape in Relation to the Treatment of Mental Illness in the Early Nineteenth-Century Asylum." In: Garden History 33/1, pp. 47-60.

Hickman, Clare (2009): "Cheerful prospects and tranquil restoration: the visual experience of landscape as part of the therapeutic regime of the British asylum, 1800-60." In: History of Psychiatry 20/4, pp. 425-41.

Hickman, Clare (2013): Therapeutic Landscapes: A History of English Hospital Gardens since I80o Manchester: Manchester University Press.

Hicks, Dan/Beaudry, Mary (eds.) (2006): The Cambridge Companion to Historical Archaeology, Cambridge: Cambridge University Press.

Hollander, Russell (1982): "Life at the Washington Asylum for the Insane, 1871-1880." In: Historian 44/2, pp. 229-241.

Hume, Ivor Noel (1996): In Search of This \& That: Tales from an Archaeologist's Quest, Williamsburg: Colonial Williamsburg Foundation. 
Jovilette, Stephanie et al. (2016): Archaeological Monitoring for the Western State Hospital Fenceline Installation Project and Testing of a Late-Nineteenth-Century Institutional Trash Deposit, Site 45PII05, Fort Steilacoom Historic District, Pierce County, Washington, Washington: Statistical Research Inc.

Kelly, Brendan D. (2016): "Searching for the patient's voice in the lrish asylums." In: Medical Humanities 42/2, pp. 1-5.

Kirkbride, Thomas Story (1854): On the Construction, Organization, and General Arrangements of Hospitals for the Insane, New York: Arno Press.

Lattin, Frank H. (1889): The Oölogist: For the Student of Birds, Their Nests and Eggs, Albion, N.Y.: Frank H. Lattin.

Longhurst, Peta (2015): "Institutional non-correspondence: Materiality and ideology in the mental institutions of New South Wales." In: Post-Medieval Archaeology 49/2, pp. 220-237.

McCarthy, Angela et al. (2017): "Lives in the Asylum Record, 1864 to 1910: Utilising Large Data Collection for Histories of Psychiatry and Mental Health." In: Medical History 61/3, pp. 358-379. Mercier, Charles A. (1894): Lunatic Asylums: Their Organisation and Management, London: Griffin.

Merrill, L. Lynn (1989): The Romance of Victorian Natural History, Oxford: Oxford University Press.

Philo, Chris (2004): A Geographical History of Institutional Provision for the Insane from Medieval Times to the I860's in England and Wales, Lewiston: Edwin Mellen Press.

Piddock, Susan (2007): A Space of Their Own: The Archaeology of Nineteenth Century Lunatic Asylums in Britain, South Australia and Tasmania, New York: Springer.

Piddock, Susan (2009): "John Conolly's 'Ideal' asylum and provisions for the insane in nineteenth century South Australia and Tasmania." In: Beisaw, April M./Gibb, James G. (eds.): The Archaeology of Institutional Life, New York: Springer, pp. 187-205.
Porter, Roy (1985): "The Patient's View: Doing Medical History from below." In: Theory and Society 14/2, pp. 175-198.

Rutherford, Sarah (2003): The Landscapes of Public Lunatic Asylums in England, I808-19I4, PhD thesis, Leicester: De Montfort University, https://www.dora.dmu.ac.uk/handle/2086/4783, accessed December 1, 2019

Rutherford, Sarah (2005): "Landscapers for the Mind: English Asylum Designers, 1845-1914." In: Garden History 33/1 pp. 61-86.

Scott, Elizabeth M. (1994): Those of Little Note: Gender, Race, and Class in Historical Archaeology, Tuzcon: University of Arizona Press.

Swartz, Sally (2008): "Colonial lunatic asylum archives: Challenges to historiography." In: Kronos 34/1, pp. 285-302.

Tomes, Nancy (1984); A Generous Confidence: Thomas Story Kirkbride and the Art of AsylumKeeping, 1840-I883, Cambridge: Cambridge University Press.

Webb, W. F. (1895): The Museum: A Journal Devoted to Research in Natural Science, Albion, New York: W.F. Webb. Hathi Trust Digital Library. Weimerskirch, Philip. J. (1965): "Benjamin Rush and John Minson Galt, II: Pioneers of Bibliotherapy in America." In: Bulletin of the Medical Library Association 54/4, pp. 510-526.

Whittemore, M. E. (1885): "Sand Dollars and Sea Eggs.” In: Vick's Monthly Magazine 8, pp. 192.

Wickham, Blaine (2016): Into the Void: A Crossborder Comparison of the Mental Asylum on the American and Canadian Frontier, dissertation, University of Saskatchewan: Saskatoon, https:// harvest.usask.ca/handle/10388/7648, accessed August 20, 2020.

Wylie, Alison (1989): "Archaeological Cables and Tacking: The Implications of Practice for Bernstein's 'Options Beyond Objectivism and Relativism.' In: Philosophy of the Social Sciences 19/1, pp. 1-18. Zwelling, Shomer S. (1985): Quest for a Cure: The Public Hospital in Williamsburg, I773-I885, Williamsburg: Colonial Williamsburg Foundation. 


\section{Have a Seat!:}

\section{Approaching the Object of the Chair at the Site of Psychiatry}

Lisa Landsteiner

Cultural studies in recent years has been dealing in greater depth with questions relating to the material production and composition of psychiatric space, taking up a thread of analysis that was laid out by psychiatrists like Jean Étienne Esquirol (I772-I840), Wilhelm Griesinger (I8I7-I868), and Johann Christian Reil (I759-I8I3) (Ankele 20I8; Majerus 20I7; Hess/Majerus 20II; Hicks/Beaudry 20I0). As Monika Ankele (2018a) points out, psychiatric science always had to take into account the effects of the materiality and spatial quality of the psychiatric institution, since treatment never takes place under laboratory conditions. Reflections of these epistemological preconditions initiated the development of theory work concerned with institutional architecture, including scenography and material culture in the psychiatric space (Kaiser 2019; Topp 20I7; Moran/Topp/Andrews 2007; Yanni 2007; Gittins 1998). In the sense of Michel Foucault's (I990) description of space as "heterotopia," psychiatry brings together several spaces in one place. These are, of course, socio-psychological spaces like safe spaces, trauma zones, emotional valves, and treatment limits, but also an extensive arrangement of physical spaces, for example entrances, treatment rooms, waiting rooms, meeting rooms, hallways, kitchens, studios, and offices. Differing in terms of use and accessibility, these rooms share one particular commonality that caught my research interest: they are all filled with chairs.

The beginning of my approach to the object of the chair in the psychiatric space marks a coincidental moment when I walked down the hallway on my way back to my desk during my internship at a Swiss acute day clinic. It was already after clos- 
ing time and nobody seemed to be around, when I passed a group room next to my office. Without intention, unexpectedly, I stopped and came to a standstill. It was a brief moment of irritation, and its essence was that I knew the room was empty, but still suspected that a group therapy was taking place. I entered the room to make sure of the situation. Nobody was present. All I saw was a circular arrangement of chairs, which - similar to an empty stage - suggested the situation of something taking place. It was the constellation of the chairs which led me to suspect a particular kind of presence despite the absence of a group. This particular spatial experience was the beginning of my interest in the scenographic weight of the chair object, its meaning to the people that move in psychiatric spaces, and its influence on the perception of it.

In the context of this contribution, I will discuss which positions, relations, and performative practices are central to the phenomenon of sitting in psychiatry. First, I will briefly outline some aspects that have shaped the long-lasting cultural and historical dimensions significant to the use and relevance of the chair object. Based on the findings of a qualitative study I conducted in a Swiss psychiatric acute day clinic (Landsteiner 20I7), I will show how patients and staff perceive the chair at the site of psychiatry and how their movements, communication, and perceptions are structured by the practice of sitting - also in (experimental) demarcation to other postures like lying or standing tested and discussed by patients and staff. Finally, I will deal with scenographic aspects when I address the importance of sitting as a positioning strategy in psychiatry.

\section{Cultural Studies and Cultural History Aspects of the Practice of Sitting}

Psychiatry today, in its spatial and social constellation, is strongly characterized by sitting objects and practices. During therapy, people usually sit at an angle of 45 degrees to one another, waiting on one of the linearly threaded chairs in the waiting room, documenting at the desk, eating, sitting together in group activities or in the circle of chairs. Cultural-scientific analysis of the object of the chair provides us with insight into the forms of human everyday life and the underlying constitutions of meaning and instrumentalizations (Dodel 1997; Eickhoff 1993, 1994, 20II; Eickhoff/Sting I994; Schmidt I97Ia, I97Ib). The object of the chair holds a range of possibilities for the expression of power, individuality or creativity. Significant 
examples of this are the arrangement of chairs in parliament, the fixed reserved place at the family table, the allocation of chairs to university professors, chair design as a form of applied arts, the arrangement of seats in public transport, or the often hesitant act of taking a seat at the presiding chair in a restaurant.

According to cultural historian Hajo Eickhoff (1993: I44), the posture of sitting is a basic posture of today's work and everyday activities. In Western societies there seems to be a tendency to "have a seat," to remain seated - especially when it comes to processes of mental creation which require a high degree of physical immobilization and calming of inner emotions. Elaborating this argumentation, Eickhoff quotes the ergonomist Heinz Gelbrich, who concluded in 1928: No work should be done standing if it can be done just as well sitting (ibid.: 144). The first people who sat on chairs were enthroned rulers (ibid.: 77). For them, the throne in the form of the practice of cultivated etiquette and the demonstration of courtly decency

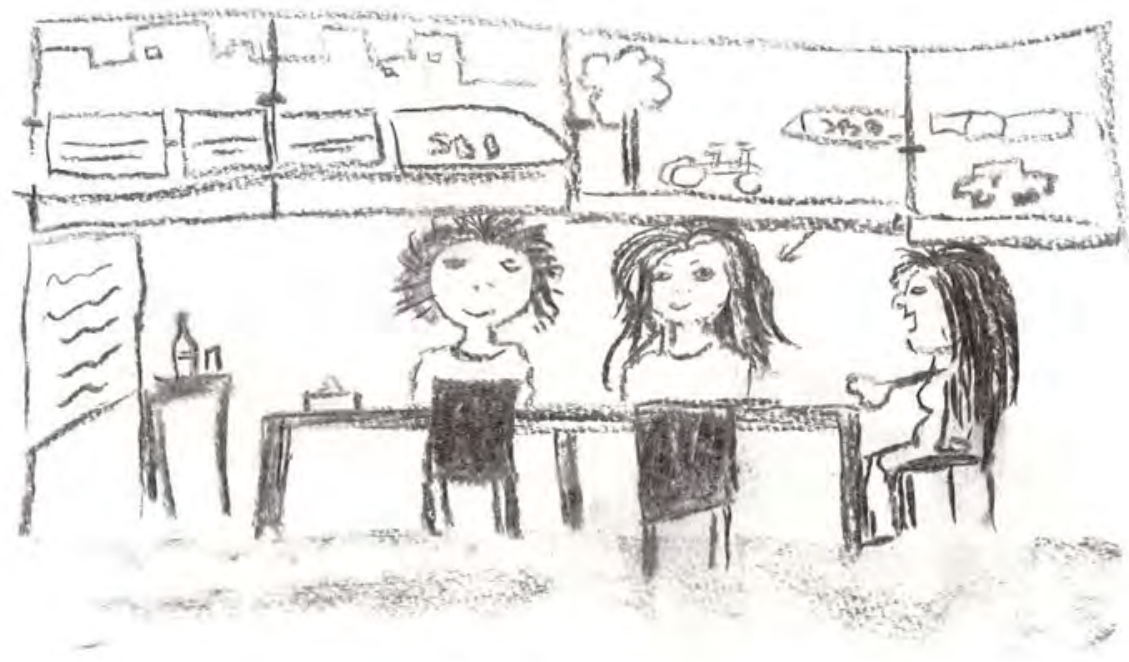


played an important role in education and everyday life. Enthroning must be practiced. In former times, individual members of the communities deserved neither the privilege nor the torment of sitting. They were free to move, but exposed and subjected to those who were not.

Sitting in a chair in everyday life is a European invention (ibid.: 40). European bourgeoisie transformed the consecrated royal and heavenly throne into a profane object - the everyday chair. Initially merely an object of the upper middle class, all social classes fought for centuries to gain the right to sit (Schmidt I97Ib). These fights found a striking political and economic turning point in the course of the French Revolution and the increasing purchasing power of the masses in the wake of Industrial Revolution. As a consequence, the seating privilege for secular rulers and clergy over the middle-class lost its validity.

In the rising discipline of ergonomics during the late igth century, the mastery of a correct posture of sitting was elaborated as a mechanism for inner formation (Eickhoff 1993: 158). Here, Marcel Mauss's (1979: 70) notes on the human gait as the product of a culturally influenced education in movement also seem to have an essential relevance in the case of sitting: Similar to the upright gait that must be learned by the growing human being, it is indispensable to learn how to maintain an upright, "correct" sitting position and to guarantee this by means of appropriately designed seating that supports this posture. Sitting can thus be regarded as a cultural achievement to the extent that it enables people to suppress and postpone spontaneous inner expressions (e.g. hunger, thirst, sex drive) in order to devote oneself to longer-term, mentally demanding activities. Under the effects of breathing reduction and muscle tension, one of the first things children learn during their socialization is how to sit. Early in the morning, pupils sit longer than they stand, run, walk, and lie down, and those who leave school after years are used to the posture of sitting (Eickhoff I993: 22I).

Against this background, it is not surprising that the famous French psychiatrist Jean Étienne Esquirol notes that the inability or unwillingness to sit properly is a characteristic feature of "idiotism" " "Never was she made to sit on a chair, she slept, her body rolled up, always on the ground" (Esquirol I827: 507).

In the early I9th century, a special type of chair was used in psychiatric institutions: the so-called "tranquilizer" chair [Zwangsstuhl], originally invented by the American psychiatrist Benjamin Rush (I745-I8I3), in which agitated patients were fixed in a seated position for up to 48 hours. The enforced sitting was intended to have a calming effect on the patient (Siefert 1983). 


\section{Your Chair, My Place, Our Setting: The Object of the Chair and the Practice of Sitting in Psychiatry}

In my qualitative study (Landsteiner 2017), for which I applied the research style of Grounded Theory (Glaser/Strauss 2008), I asked staff (doctors, nurses, psychologists, social workers, and movement therapists) what effects the paradoxical situation of a sudden disappearance of all chairs from the psychiatric interior could have and what conclusions they would deduce for the significance of sitting at the psychiatric site. I repeated this reflexive gesture within the framework of a performative group discussion, but in doing so I put the hypothetical situation used for the experts in reality: a group of four patients entered a room in which there were too few chairs for all of us. I waited for the reaction of the patients. Afterwards, I asked them about their reflections on sitting practices during psychiatric treatment and everyday routines in psychiatry.

In both constellations, the indispensability of the object stood out in its absence. The first verbal reaction to the entrance situation of the group discussion took place when the patients were entering the room. CC, one of the patients, made the ascertaining statement:

CC: The chairs are missing here. ${ }^{2}$

After a short time of looking around, two participants went to fetch stackable chairs from an adjoining room for the whole group and for me as well. Subsequently, the group formed a circle of chairs.

In the course of the interviews, the perception of sitting as a matter of implicitness can also be demonstrated on the part of the staff members. When they are confronted with the question of the effects of a sudden absence of all chairs, it is noticeable that the focus is primarily on the restoration of the social order, which is obtained in a way by the sitting arrangement. In the interviews, the main point is that if all the chairs are missing, therapeutic routine is interrupted. It was common to all the staff members interviewed that they wanted to restore the material foundation for psychiatric treatment. In some interviews, ideas were expressed to save the situation by supplementing the chairs with quasi-objects such as rolled up gymnastics mats as stools, tables as chairs, or walls to lean on. In the hypothetical situation, it was the members of the staff who would assume the role of those re- 
sponsible for restoring the order: they had to become active in order to reorganize the chairs as the basis for therapeutic work and at the same time create an alternative framework for the patients. In addition, staff members mentioned that the lack of chairs could also have far-reaching effects on the relationship with the patients, the daily routine and therapeutic goals as a whole. As an illustration, here are some responses given by staff in the examined Swiss psychiatric clinic: SA, a social worker, responds to the question of the effects of a sudden absence of chairs:

SA: Oh. (.) First of all there would be quite a bit of unrest (.) I have the feeling (.) everyone would be looking and saying that is not possible, you can't do that? (7) Because to work there without chairs is a little difficult (5) yes, I think there would be a little revolution (.)@(.)@you can't ask them [note: the patients] here and not offer them a place to sit.

LA, a psychiatrist, estimates the hypothetical absence of chairs in the clinic as an exceptional situation outside of everyday practice. To deal with it, she suggests following reactions to the hypothetical situation:

LA: We would investigate why they were stolen (.) the patients will surely be afraid that someone has entered the clinic (I) and removed the chairs (.) without others knowing about it.

LL [note: Lisa Landsteiner, interviewer]: How do you think such a hospital routine would run without chairs?

LA: This will not be a normal everyday life, so I strongly assume that there should be a discussion with the patients (2) if I, so I refer this to our everyday routine $/ / \mathrm{mhm} / /$ if I now (I) out of therapeutic considerations, you know? or experimental, but in clinic routine (I) I would have an emergency meeting with the patients (.) where (.) so emergency not//@(.)@// but simply (.) depending on what the need is from the patients, I would also approach patients and and and offer answers to the (.) certain questions will probably exist and to be able to simply perform. I also assume that this also could be no no (I) not a big topic for the patients (.) if that is so, then this conversation, then I would like to discuss it with them. How that is for them. Yes.

In his assessment, the psychoanalyst RO describes the effects that would result for his therapeutic work if all chairs had disappeared. In his opinion, therapy would not work in the absence of chairs: 
RO: This is a nightmare, isn't it? (.) for an analyst. his space is (.) is suddenly no longer what it needs to be (.) what will he do, right? (.) it would be a huge nervousness or would break out in the question what do I do now? (.) well, you can say ok, look, this is something (I) like (2) it's not (I) uh:m like it's not planned, we have to move (.) sorry, so we have to move (.) I have to sort the things out with the chairs, right? (2) when can you come again?, right? (.) and you would make a new appointment (.) That would be the best case, wouldn't it? where you could "contain"? that you can just focus on the patient (.) who has his needs (.) yes

LL: That means no therapy without chairs?

RO: Mhm. Mhm (.) no, impossible.
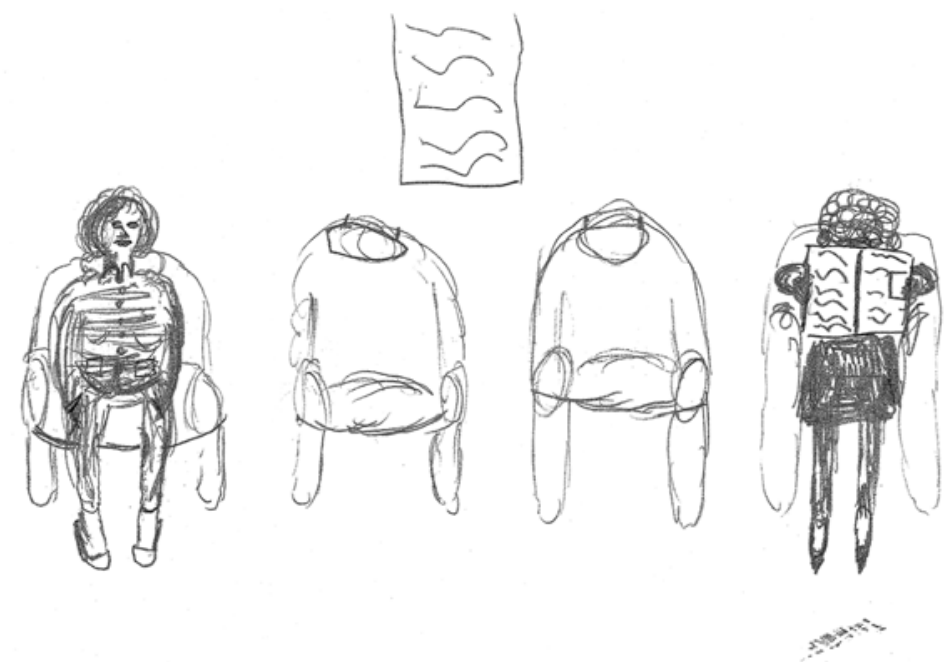


\section{Psychiatries As Sitting Societies}

The scenography in psychiatric space is strongly influenced by the presence of an immanent and frequent practice of sitting (Landsteiner 20I7). In the Swiss acute day clinic which I examined, there were I5I chairs, i.e. three chairs available for each person at the same time. When I asked patients to draw themselves in a typical situation in the acute day clinic, in most cases the picture showed themselves in a seated posture (see fig. I). For therapeutic reasons, but also influenced by deeply rooted, implicitly inscribed cultural aspects, people moving in psychiatric space form "sitting societies." They vary in their temporal existence and size and take on different forms. These are: sitting in a circle of chairs, sitting at a table, sitting at a desk, sitting opposite each other (frontally or at a slightly open angle), sitting next to each other, and sitting alone. The forms of movement in the psychiatric space are essentially differentiated into medical-therapeutic, nursing and administration staff, patients, and visitors. Some differences occur between patients and staff. For example, only staff members spend part of their time in the psychiatric space at the desks of their offices writing documentation and reports, doing internal and external communication, and preparing group and individual therapy.

Sitting societies, which almost exclusively include patients, are those that are predominantly formed in the context of waiting. Reading the newspaper, using their phones, having conversations with fellow patients, and drinking coffee, patients spend a lot of time in waiting areas and waiting rooms that have been specifically created for this activity. Figure 2 shows a waiting scene chosen as a motif for the depiction of a typical situation in the acute day clinic.

The forms of sitting societies can be dissolved - albeit predominantly by the staff members - or merge smoothly into one another, e.g. getting up from the desk in order to sit together in the kitchen and drink coffee before the start of the introductory round, or patients rising from the circular arrangement of chairs in group therapy in order to talk one on one with the therapists in their offices.

A special form of sitting societies at the place of psychiatric institutions are socalled non-sitting societies. These rarely occur and are formed within the sitting culture inherent in psychiatry. In the interviews, patients as well as staff members referred to non-sitting when actively distancing themselves from the sitting posture. They are formed, mostly consciously, with the aim of "not sitting all day and bringing movement into everyday life" (Landsteiner 20I7: I09). 


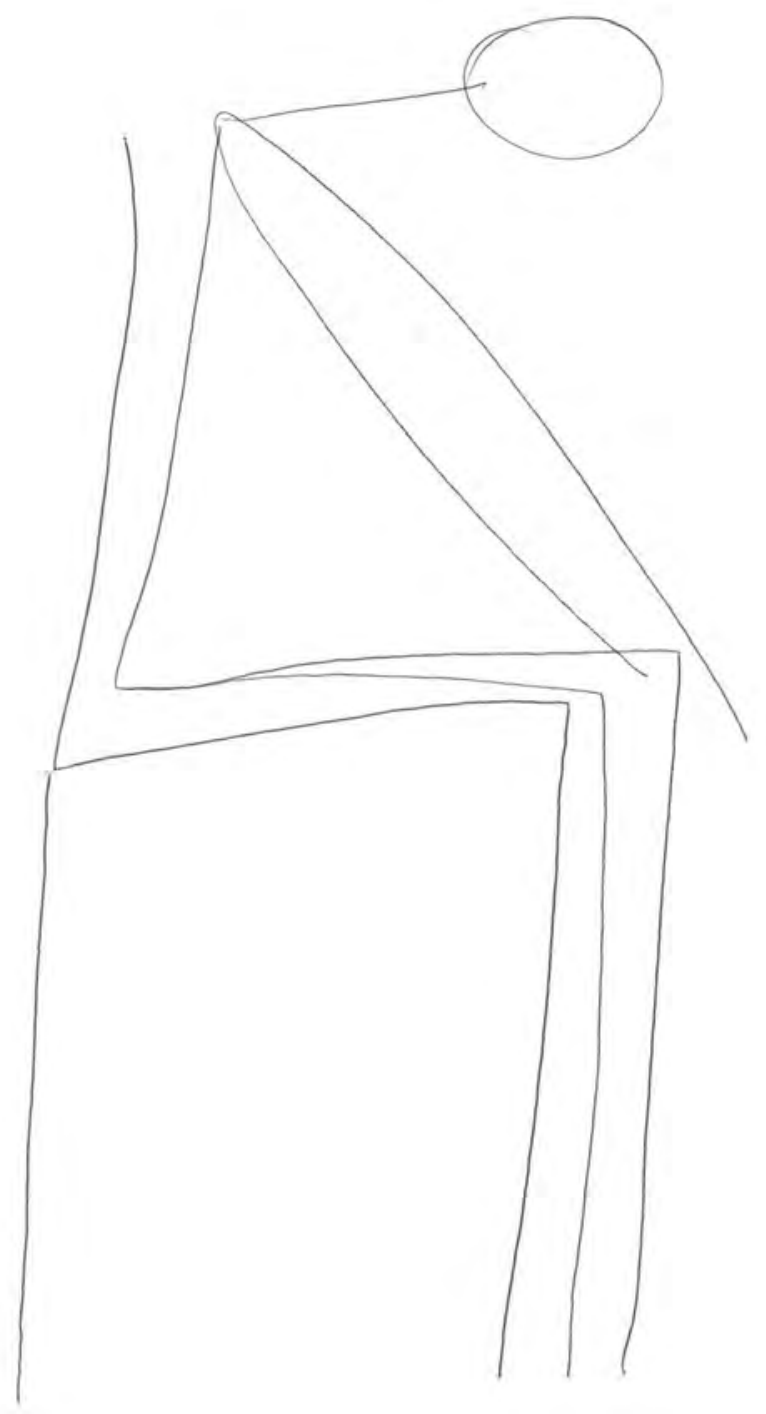

Fig. 3: "Untitled" [Ohne Titel]

(drawing by patient TM, Landsteiner 2017: fig. 14) 


\section{Sitting As a Hybrid Formation with the Object of the Chair}

At the psychiatric site, the chair appears as a transparent object. In contrast to monumental objects, such as the automatic coffee machine in the patient's kitchen or the table tennis table in the acute day clinic, the chair's meaning and relevance for the everyday life of patients, doctors, therapists, and other clinical personnel in the day clinic remains invisible.

In its use, the chair becomes an integral part of human body work and posture when sitting and being seated. Due to the robustness of the material, the person can be supported completely; the sitting person's legs are almost completely relieved and have room to maneuver, making the chair a tool and "device," so to speak. The specific thing about the human-chair connection is a transformation of the human action radius. If we take a closer look at the connection between a sitting person and a chair, the constitution of meaning of the human back in particular becomes especially relevant. The chair carries the weight of the seated person, protects her or him from behind through the backrest, enables him or her to fall back, to sink into it, to lean on it, to be supported and to help bear the apparently unbearable on it.

The patient TM draws a typical situation in the acute day clinic in less than 60 seconds (fig. 3). TM does not want to give his work a title; it speaks for itself, he says. There is nothing in particular that he experiences as "typical" in the acute day clinic. However, in the conception of what he depicted, he thought of the first days in the clinic when he was not feeling well, "sitting around" all day.

The interpretation of the drawing shows that the center of the picture lies exactly between the depicted seat and the contoured thighs of the self-depicted person. The person seems to float, but at the same time he supports himself with his arms on his thighs.

In the picture, another aspect of the chair-human connection is depicted: When TM was predominantly "sitting around" when he was not feeling well, the chair was a supporting instrument for him. However, it could not support him fully in order to feel better - here, TM's chair reached its hybrid material limits. The depicted void between stool and TM presents more a test of tearing apart than a hybrid fusion. Facing physical as well as psychological demands, TM schematically needs to use his hands to maintain the supporting sitting posture.

On the one hand, chairs can be - or appear - homogeneous in their design and form, while on the other hand they can be considered outstanding in their perception as personal objects (e.g. "my chair", "our seats"): 
BR: Can you remember, that just comes to mind, VV's seat? I think, you weren't there yet (.) VV would always come into the room, in which the morning round takes place, and she always sat on the very first chair, so right at the front, always. And if "her chair" was occupied, she reclaimed her seat, so she really always sat there (.) of course, because of that, her seat was kept for her, even when she had left the clinic (.) it was simply her seat @(.)@)

The first chair in the room is a hybrid object, shaped by the patient VV even after being discharged from the clinic. The connection between $\mathrm{VV}$ and her seat is expressed in the action rituals of her fellow patients who are still in the clinic in such a way that having a seat in her chair evokes memories and concrete behavior patterns in the other patients and staff, which they associate with VV. The perception of the chair object and its arrangement coincide and materialize for a certain time in VV's chair. The demanding of the seat and the establishment of the pattern of action that the place was always kept free for VV can be called personalization. In this case, the chair is linked to a material quality, a surplus, a re-/presentational, emotional, normative, ritual added value (Breuer 2013).

\section{Have a Seat, Lie Down, Move Forward! A Comparative Note on Postures}

As it has emerged in the analysis of the interviews and group discussions with patients and staff, there are indications that, in contrast to lying or standing, the sitting posture is related to the present in terms of time. Thus, the position of lying is associated with the re-experience of the past or standing or walking with a focus on the future. Sitting seems to occupy an intermediate position in the demarcation between standing and lying: due to the poles of positive engagement with the present, it mediates between the past and the future, while lying carries the danger of falling too far into and sticking to the past, and standing carries the risk of moving forward too quickly. Although in the course of the interviews with staff and the group discussion a tendency is emerging that the concept of sitting at the site of psychiatry might take shape in its definition by means of a delimiting distinction from lying and standing, it has to be conceded that the following findings are preliminary and should be subject to detailed review in the future. Chairs offer fixed frames, define minimum distances, and are per se a medium of communication: 
on the one hand, they bring people's bodies into the posture of the seated person; on the other hand, they bring them into a certain spatial relation to each other. Thus, the chair appears stable in its composition, but it also can become a support. At first it seems as if it is mainly patients who attribute great importance to the protective dimension of the chair. Among other things, the chair provides support and is like a shield for them when they are no longer able to hold themselves physically or mentally. On the other hand, it is also practitioners who attach great importance to the protective component of the chair-human connection within the framework of the interviews. This is how the movement therapist CI describes this protective function of the chair, who has set up only a few seats in her movement space:

CI: Yes, oh yes, we are also talking about protection, I think the chair has a lot to do with protection (3) if you feel like sitting down, you hear that when people come in to my room, but I don't have any chairs@(.)@ and then they come in, and mostly they sit somewhere in the niche (.) or on the bench, I just have a small bench.

If there are no or hardly any chairs, CI describes that patients tend to create a supplement to the hybrid chair-human prosthesis. The niche replaces the essential features of the chair: the slight elevation of the wall serves as a seat; the wall itself serves as a backrest offering support and protection.

If chairs were missing as the basis for therapeutic work, standing - according to the psychiatrist AA - would be connected to the task of taking over the supporting and protective function of the chair for the patients:

AA: (clears throat) (4) it all depends on (2) of course I could bring it in more movement (.) I've never thought about how this would all be done standing up, I think there are moments of (.) exhaustion, where also feelings lead to the fact that then you just (.) so to speak (.) would like to sit down or fall into a chair or would like to be supported somehow and (I) I would be worried that I would have to take over something, what the chair does, that would be my fear, that if I would always do psychotherapy while standing, I would have to hold somebody, so to speak, and (.) that the chair also somehow relieves me of something. I would be a little worried about that.

The psychologist TA confirms these impressions when she also states that with sitting a moment of being present arises: 
TA: It is like one takes his or her time and because of that takes a seat (.) like this: now we sit. there is space for each other in the here and now.

Movement therapist CI also describes associations with thoughts of fleeing when she dedicates her assessment to the posture of standing in the psychiatric context.

CI: Actually, standing is also a little (I) when you stand it is more possible to escape. that you get away faster (.) yes, you can turn your back (.) so when you walk, you continue and follow your own thoughts and when sitting on the chair I find that, well, you also sit opposite each other and also rather open up. It's less possible to escape your thoughts. it does not mean that you always listen while sitting, but turning away is simply more difficult.

CI also emphasizes the aspect of the danger of re-experiencing traumatic experiences. When working with patients suffering from trauma it would therefore be advantageous to work with them in the physical posture of sitting, which as such refers more to the present.

CI: Yes (.) lying down is also natural, because if you don't know people so well and for example when people have a trauma (.) lying down (.) is quite difficult, so I think because the traumatic experience might reappear easier when lying down (.) or you might be more vulnerable. now in my relaxation groups patients lie down a lot (.) on the floor (.) but e:h, patients with trauma, I usually let them sit on the bench (.) and just make them lean against something or so. Yes.

On the basis of his observations, the nurse $\mathrm{MO}$ compares the experience of sitting as a comfortable "resting position" with the postures of standing, walking, and lying:

MO: When sitting it is possible to rest, it is a resting position, in contrast to standing or walking (I) and it has the advantage of comfort (.) you get up again faster than if you lie on the floor or in bed @(.)@ (.) and you can (.) rather stay in the here and now: (.) and it's the same eye level when you sit

Patients explore the use of different postures in the group discussion. In the concrete situation, ST, CC, BR and RS were asked to jointly explore what it is like to stand in a circle instead of sitting in a circle of chairs. 
ST: Yes (3) so I think it feels funny.

BR: Yes, it feels weird. It's like (.) you're walking, a little, a little (.) you have the feeling that the therapy session is finished now and you're moving on with the next one, so, already out, so it’s like this ((goes two steps towards the door))@(.)@

This is also shown by a remark made by the patient RS during the group discussion. Standing has something escape-like about it, whereupon her interlocutor BR underlines the importance of taking a seat together on chairs: by sitting the person is more "present."

RS: Yes, but you're much more protected (.) on the chairs, so I wouldn't tell a psychiatrist my life story while standing (I) just because (2) I don't have any other protection, besides (.) honestly, then I could go right away, if I'm standing around with him. ST: Well, you don't have a position in the room either.

BR: That's right, and you're more present as well, so you can get more involved with the chairs.

According to Claudia Guderian (2004), sitting on the chair prevents these concerns, in which concentrated, controlled thinking and talking affect the adult sense of reality and reasonable discussion. Following Sigmund Freud (I856-I939), Nixon (2005: 50) states that a function of the setting of couch and chair typical for psychoanalysis is that analysts and their patients are kept separate in order to prevent them from getting tangled up visually or reflexively. In psychoanalysis, the lying position on the couch, which loosens the muscles, reduces energy consumption, and promotes immersion in early memories and regression, is predominantly chosen to give room to free association.

In the context of systemic therapy, special attention is paid to the use of the chair in the therapeutic setting, especially when it comes to therapy with outpatients. For inpatients it has to be mentioned that the object of the bed plays a long and important role in the history of psychiatry (Ankele 20I8; Majerus 20I7). In psychiatry, the chair is used and arranged in various forms of systemic constellation work. Chair techniques such as the "empty chair," which originated in psychodrama, coined by Jacob Levy Moreno (I889-I974), are particularly worth mentioning (I965: 2I3; quoted after Staemmler I995: 3I-32). Therefore, chairs are used to experience and understand inner conflicts or contradictions or conflictual social dynamics and to find a better way to deal with them. For this purpose each part of the patient or the 
social system is represented on a chair of its own. With the "hot chair," Fritz Perls (I893-1970) developed a technique for group therapy that allows the therapist and patients to perform individual therapy in a group setting (Perls 1974: 80). Therefore, one group member is assigned a special place on the hot chair and the focus of the group is on his or her exposed immediate and often unconscious thoughts, fantasies, emotions, and physical gestures and attitudes.

\section{Sitting As a Positioning Strategy}

As the sitting posture represents the characteristic setting of patients and therapeutic staff, the chair is a defined terrain in the psychiatric space. The setting - a term of special importance in the context of psychiatry - can be understood as the constellation of spatial (room size), material (furnishings, objects), temporal (duration), and inclusion factors (role, relationship) that is adapted to the context of action (therapeutic, private, professional, etc.). When sitting, each person occupies a seat which isolates her or him from the others and prefigures boundaries between people: The chair ensilages the seated person, whereby the space of the chair becomes a microcosm for the individual (Eickhoff 1993: I73). At the same time, the chair makes the boundaries explicit through its spatial arrangement.

By sitting down, not only the body sits down, but also other forms of experience may be addressed and expressed. Furthermore, the posture of sitting does not allow one to fully stay in position. It rather requires - initially on a purely physical level - adapting muscle movements, modifications in the positioning of body parts, the shifting of weight, etc., in order to retain oneself in the position, meaning to stay seated. The assumption of an unmoving body posture however seems to be paradoxical: although culturally trained seating postures appear anything but moving, the body is constantly in motion, e.g. with blood supply, transmission of stimuli, breathing, etc. Concerning the multiple non-static characteristics of the sitting posture, the psychoanalyst RO explains:

RO: Exactly where you just brought it up, right? or? Posture is really interesting (.) to distinguish, I think, it is more ambiguous, or? and, of course I meant the (psycho)analytical setting. Regarding the psychological relationship between analyst and patient, but (.) also regarding that they sit, physical, opposite each other. 
At the site of psychiatry, people adopt more than just physical postures, but position themselves in many different dimensions. Taking a seat and the offering of a chair also happens in the midst of power relations inscribed in the psychiatric space itself. In their positioning, patients and staff members therefore not only affect, but also always are affected when they experience various therapeutic settings. In the following example, the patient BR shares the following experiences in the group discussion:

BR: So what I would like very much would be, if a therapist or psychiatrist would ask a patient (.) in which setting would you like us to talk? And that they work on different possibilities, that the patient (.) that I feel comfortable in that position. and not just: there, chair, do this, sit down, so that there really are several (.)) that there is the possibility for patients to choose (.) If a patient feels comfortable, then he or she also are more open about their issues (.), and then he or she won't shut him- or herself in, is it really difficult (.) so you have to feel comfortable.

ST: Yes, me too, you know, he just sat in the opposite and I felt totally stupid (.) so I (.)

BR: Like a job interview actually

ST: Yes. And he also asked me so many things and (.) yes.

In the vast majority of cases it is the therapists who determine certain aspects of the setting by adjusting something beforehand, starting with the therapy plan and also including the material quality of the psychiatric space: here, the spatial pre-arrangement dominates on the side of the therapeutic staff, the potential of power, of seating the patient here, there or somewhere else resonates quietly with it. This is a point of reference that directs a critical gaze to the mechanisms of power expressed in sitting or in the choice of seating position and arrangement of chairs.

In the interview, psychiatrist AA advocates a de-hierarchized encounter with patients. She rejects an asymmetry of the seating constellation - as it would be expressed for example in different heights of the chairs - and adapts its spatial position to the people who enter her treatment room as patients.

AA: And I do this for example in my room, when the room was cleaned (.) for a while, the room care staff always set my seat height higher, this one here ((points to the desk chair)). and that means I always came in and then (.) when a patient 
visited, then I sat like this ((shows a height of about $80 \mathrm{~cm}$ above the floor)) and I always put the height down immediately (.) so that I am at the same level. Patients sometimes notice it, then they also tell me that they were with therapists who sat there on his or her chair and looked at them closely from above sitting in his or her 'fat armchair' and (.) that comes very quickly actually, that patients complain so much about these seating constellations or (.) sometimes they also say that we sit too far away (.) sometimes.

The psychoanalyst RO describes this tightrope walk of power structures in the encounter of therapist and patient. In his perspective, seating orders can never completely produce an anti-hierarchical or experiential quality:

RO: Yes yes (.) yes yes what is of course quite obvious, that is of course the thought (.) that the chairs don't have to be the same model (.) I think it has to be the same two chairs (.) but now of course the next question comes, because where I sit it's a little different than where you sit, you can see the window, I can see the door and so it comes again and again that it is different@(.)@ it's never quite the same (.) it's never quite the same. and you, as the therapist, you have to prepare the space (.) Are you really preparing the seat, the place, metaphorically speaking, where you have the feeling as a patient that you can think reasonably, fearlessly about exactly that stuff with someone? (.) and fearless means that he or she is not too scared where he or she sits and (.) and whether someone should have the door in his or her back now is really (.) I think yes (.) that could be unpleasant (.) for others, and of course for others who are more constricted in the corner and so on, but (.) I am not (I) so each setting (.) constructs something, too, isn't it? it's not just the relationship that creates something (.) it's not just the fact that someone goes to see the other (2) but the person that is seen has set something up before, chairs and the setting in a broader sense. 


\section{Summary}

Sitting proves to be an essential positioning strategy at the site of psychiatry. The chair is a space-structuring instrument that creates order. This important aspect already becomes manifest when patients enter the clinic. Psychiatric treatment does not begin with the discussion of the treatment contract, medical history, or diagnosis, but rather with a gesture of presence: entering the building, shaking hands and having a seat opposite of each other. In this way, sitting at the site of psychiatry is an important strategy right from the beginning of the treatment.

Psychiatry encompasses a large number of sitting societies whose foundation is the chair. Much of therapeutic progress is directly related to the practice of sitting. In hybrid interaction, the chair functions as a vessel, a protective boundary for the sitting person. The chair functions as a media for communication and the creation of meaningful relationships in which therapeutic progress and regression take place. The success of a treatment seems to consist in positioning oneself relatively from each other in order to establish a trusting relationship that gives security to both patients and staff members. The chair crystallizes as a medium of positioning. Its supporting function not only offers protection and can be an expression of individual style, but sitting on it also creates a basis of communication which is inherent in and a prerequisite for the many forms of therapeutic work. 


\section{Notes}

1

Esquirol refers here to the description of idiocy (in the German translation: Blödsinnige), which he describes using the example of observations of the behavior of a female patient.

2

Since I conducted my interviews in German, I translated the original parts for this article into English. The interviews were transcribed with the TiQ (Talk in Qualitative Social Research) system. Here is a brief overview of the most important symbols: (.) Pause up to one second, (2) Number of seconds of a pause in speech, MississippiTermination of a word, oh=noo combined pronunciation,combi::nedelongation, @no@ laughing, e.g."no”spoken,@(.)@short laugh, @(3)@three seconds laughter, //mhm// audible, overlapping signal.

\section{Bibliography}

Ankele, Monika (2018): "Sich aufführen: Rauminterventionen und Wissenspraktiken in der Psychiatrie um 1900." In: Ankele, Monika/Ledebur, Sophie/ Kaiser, Céline (eds.): Aufführen - Aufzeichnen Anordnen. Wissenspraktiken in Psychiatrie und Psychotherapie, Wiesbaden: Springer, pp. 71-89. Ankele, Monika (2018a): "Horizontale Szenographien: Das Krankenbett als Schauplatz psychiatrischer Subjektivation." In: Friedrich, Lars/Harrasser, Karin/Kaiser, Céline (eds.): Szenographien des Subjekts, Wiesbaden: Springer, pp. 49-64. Attali, Jaques (2008): Die Welt von morgen: Eine kleine Geschichte der Zukunft, Berlin: Parthas.

Breuer, Franz (2013): "Hybride Objekte verbinden Personen und Generationen: Weitergabe - Gedenken - Transzendenz." In: Journal für Psychologie 2/ 21, 34 pages, http://www.journal-fuer-psychologie. de/index.php/jfp/article/view/267, accessed April 30, 2018.

Brückner, Burkhart (2010): Die Geschichte der Psychiatrie, Cologne: Psychiatrie Verlag.

Dodel, Franz (1997): Das Sitzen der Wüstenväter: Eine Untersuchung anhand der Apophtegmata Patrum, Freiburg im Breisgau: Universitätsverlag. Eickhoff, Hajo (2011): "Thronen als Denken und Meditieren." In: Hackenschmidt, Sebastian/Engelhorn, Klaus (eds.): Möbel als Medien: Beiträge zu einer Kulturgeschichte der Dinge, Bielefeld: Transcript, pp. 33-46.

Eickhoff, Hajo (1994): "Die Sedativierung im Sitzen: Eine Strategie der Perfektion." In: Kamper, Dietmar/Wulf, Christoph (eds.): Anthropologie nach dem Tode des Menschen, Frankfurt am Main: Suhrkamp, pp. 216-231.

Eickhoff, Hajo/Sting, Stephan (1994): "Fortschritt als festsitzende Mobilität." In: Kamper, Dietmar/ Wulf, Christoph (eds.): Anthropologie nach dem Tode des Menschen, Frankfurt am Main: Suhrkamp, pp. 245-249.

Eickhoff, Hajo (1993): Himmelsthron und Schaukelstuhl: Die Geschichte des Sitzens, Vienna: Carl Hanser. 
Esquirol, Jean Étienne (1827): Esquirol's allgemeine und specielle Pathologie und Therapie der Seelenstörungen, edited by Karl Christian Hille, Leipzig: C.H.F. Hartmann.

Foucault, Michel (1990): "Andere Räume." In: Barck, Karlheinz (ed.): Aisthesis: Wahrnehmung heute oder Perspektiven einer anderen Ästhetik, Leipzig: Reclam, pp. 34-46.

Gittins, Diana (1998): Madness in Its Place: Narratives of Severalls Hospital, 1913-1997, London: Psychology Press.

Glaser, Barney G./Strauss, Anselm (2008): Grounded Theory. Strategien qualitativer Forschung, Bern: Huber.

Guderian, Claudia (2004): Die Couch in der Psychoanalyse: Geschichte und Gegenwart von Setting und Raum, Stuttgart: Kohlhammer.

Hess, Volker/Majerus, Benoît (2011): "Writing the History of Psychiatry in the 20th Century." In: History of Psychiatry 22/2, pp. 139-45.

Hicks, Dan/Beaudry, Mary C. (2010): "Introduction: Material Culture Studies: A Reactionary View." In: Hicks, Dan/Beaudry, Mary C. (eds.): The Oxford Handbook of Material Culture Studies, Oxford: Oxford University Press, pp. 1-21.

Kaiser, Céline (2019): Szenen des Subjekts: Eine Kulturmediengeschichte szenischer Therapieformen seit dem I8. Jahrhundert, Bielefeld: Transcript. Landsteiner, Lisa (2017): Platz nehmen: Zur Psychologie des Sitzens am Ort der Psychiatrie, Bielefeld: Transcript.

Majerus, Benoît (2017): "Material Objects in Twentieth Century History of Psychiatry." In: BMGN Low Countries Historical Review 132/1, pp. 149169.

Mauss, Marcel (1979): Sociology and Psychology: Essays, London/Boston: Routledge and K. Paul. Moran, James E./Topp, Leslie/Andrews, Jonathan (2011): Madness, Architecture and the Built Environment: Psychiatric Spaces in Historical Context, London: Routledge.

Nixon, Mignon (2005): "On the Couch." In: October (MIT Press Journals) 113, pp. 39-76.

Perls, Fritz (1974): Gestalt-Therapie in Aktion, Stuttgart: Klett-Cotta.
Schmidt, Leopold (1971a): "Bank und Stuhl und Thron." In: Antaios 1/12, pp. 85-103.

Schmidt, Leopold (1971b): "Stuhl und Sessel: Zur Geschichte des europäischen Sitzmöbels." In: Studia Ethnographica et Folkloristica in Honorem Béla Gunda 10, pp. 349-359.

Siefert, Helmut (1983): "Der Zwangsstuhl. Ein Beispiel für den Umgang mit Geisteskranken im 19. Jahrhundert in Haina." In: Heinemeyer, Walter/ Pünder, Tilmann (eds.): 450 Jahre Psychiatrie in Hessen, Veröffentlichungen der Historischen Kommission für Hessen 47, Marburg: Elwert, pp. 309-320.

Staemmler, Frank-M. (1995): Der leere Stuhl: ein Beitrag zur Technik der Gestalttherapie, Munich: Pfeiffer.

Topp, Leslie (2017): Freedom and the Cage: Modern Architecture and Psychiatry in Central Europe, I890-19I4, University Park, Pennsylvania: Pennsylvania State University Press.

Virilio, Paul (1978): Fahren, fahren, fahren, Berlin: Merve.

Yanni, Carla (2007): The Architecture of Madness: Insane Asylums in the United States, Minneapolis: University of Minnesota Press.

All quotations originally in German were translated by the author. 

II

TRANSFORMING PRACTICES 


\section{Have a Seat}

Raja Goltz

The main actors of my performance Have a Seat are the performer, the chair as an object, and the fabric as a material. Through the performer's various attempts to appropriate the chair crocheted from bed sheets, to reshape it and use it in a new way, the boundaries between object and subject, human actor and non-human actor become increasingly blurred. Who is holding whom? 


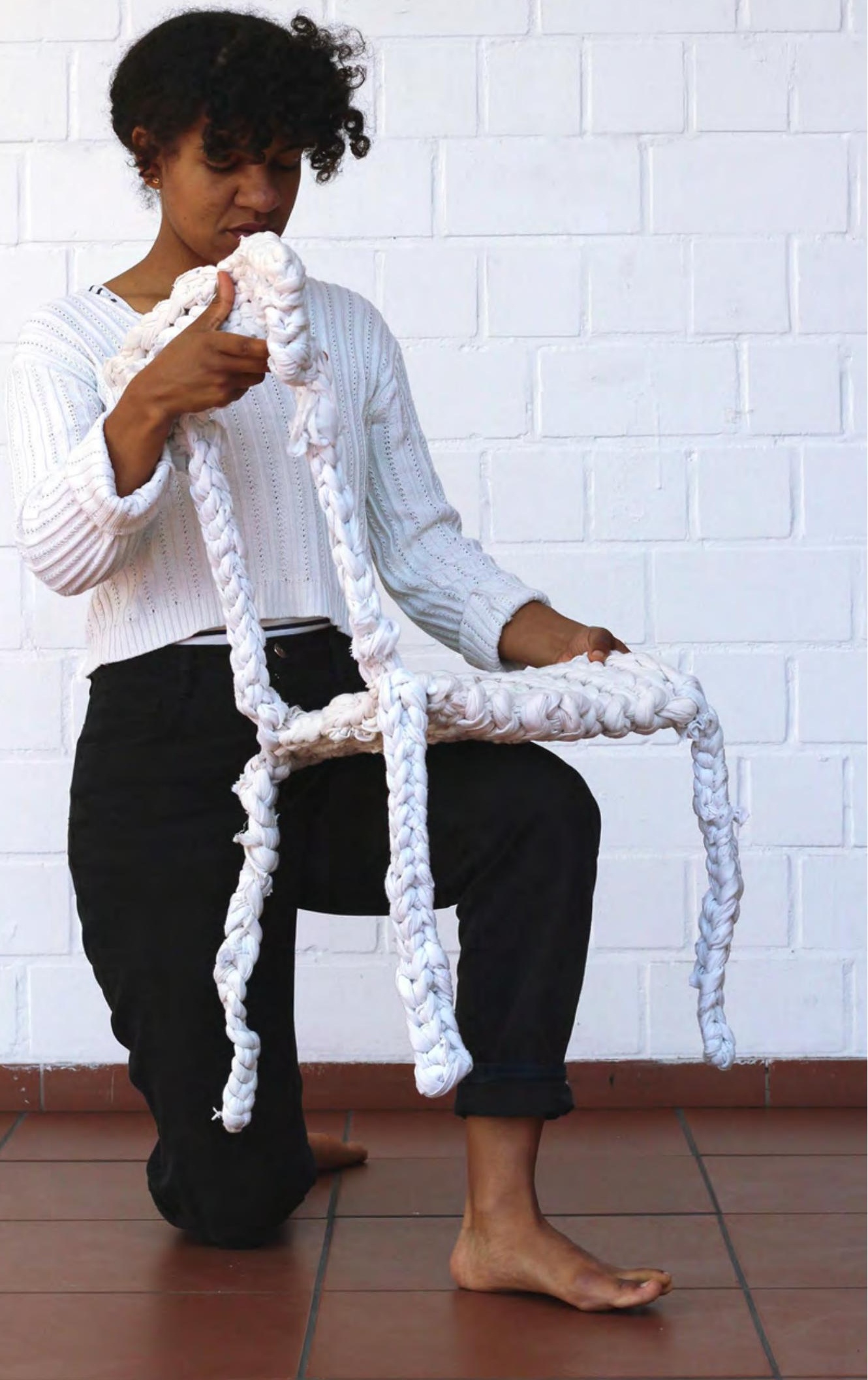




\section{The Fabric of Seclusion: \\ Textiles As Media of (Spatial) Interaction \\ in Isolation Cells of Mental Hospitals}

Monika Ankele

\section{Picking Up the Thread}

In the "Atlas and Introduction into Psychiatry" [Atlas und Grundriss der Psychiatrie], published by the psychiatrist Wilhelm Weygandt (1870-1939) in 1902, we find an image of the interior of an isolation cell whose unusual decoration demands attention. Between the bare walls of the cell, there is a fragile web made of threads that connect the adjacent walls (fig. I). Weygandt calls this web, that stands in stark contrast to the architecture of the room, a "hammock." He explains that it was made by a patient who had removed the threads from his bed sheet. The patient had used bread to glue the individual threads to the wall and decorated them with bits of cloth, paper, pieces of bread etc. (cf. 1902: 380). He used the materials that had been left in his cell and created something that can be described as an architectural (Latin for the "art of construction") intervention that was determined by the possibilities and qualities of the fabric he used. In this regard, the intervention posed the largest possible contrast to the built space of the cell: while this was characterized by its massiveness, durability, and rigidity, the architecture the patient created with individual threads from his bed linen felt rather weightless, temporary, and unstable. Two different material cultures that were interconnected met here as the built room on the one hand and as the decorated room on the other hand: the material culture of the institution met the material (sub-)culture ${ }^{\mathrm{I}}$ the patient had created by taking a thread from his bed linen during his isolation and finding a new purpose for that thread. 


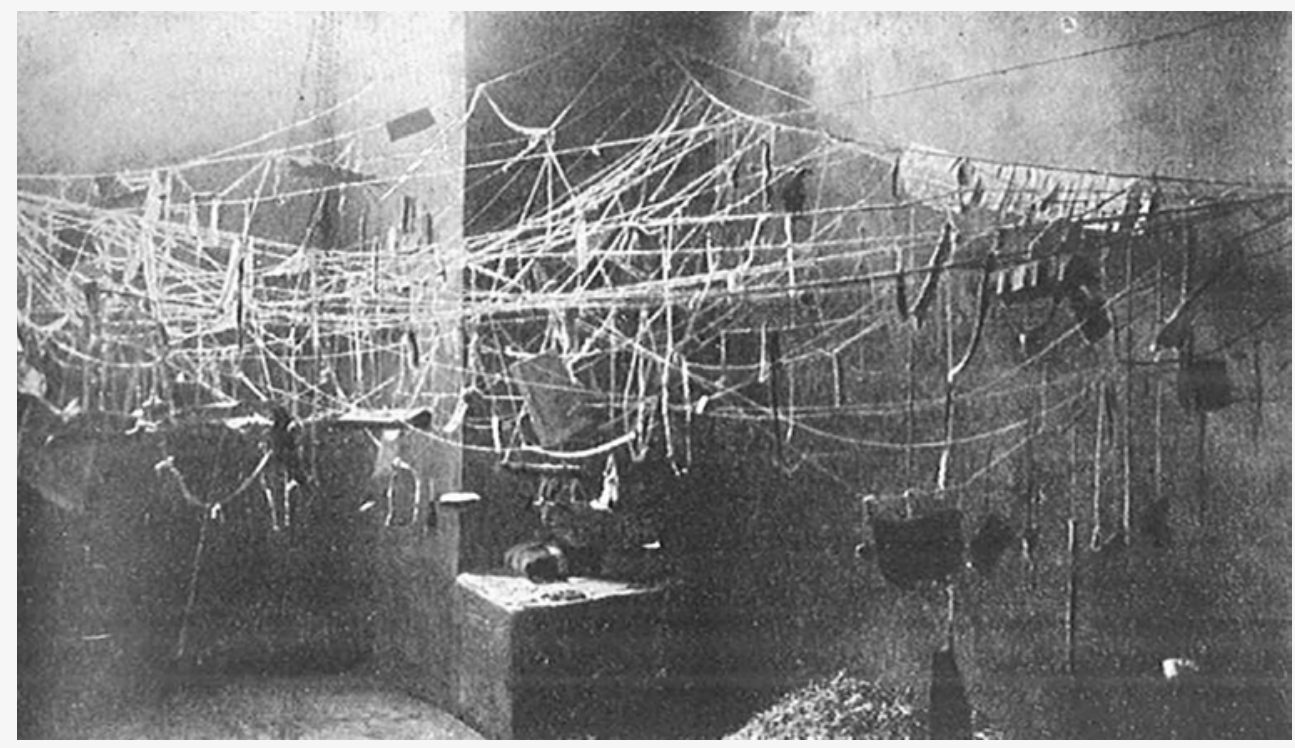

This article leads us into these closed rooms that served to separate patients. It focuses on those moments when the inhabitants tried - with the aid of merely a thread, a bed linen, a blanket - to suspend the given spatial structure, to have an impact on the unequal power relation that were inscribed in this place, or simply to create a new spatial situation. Historical examples like the one that Weygandt used in his book illustrate a seemingly heightened significance of textiles in these socalled "single rooms" or "isolation cells." They also raise awareness for the options of action or affordances ${ }^{2}$ inherent in textiles that were not only based on their specific material qualities, but were also framed by the context of usage in the institutions. In an edition titled "Ephemeral Architectures" of the journal "Arch+," the editors compared textiles with light, climate, and sound, i.e. immaterial goods that contribute to shaping space (Kuhnert/Oswalt I99I: 25). In contrast to erected spaces that represent as it were the "hardware," textiles form the "software" (cf. ibid.) of a space. Yet, this software is equally crucial for the experience and perception of the space and, most importantly, for the possibilities of its utilization. Drawing on this concept, I will investigate the interactions between patients and their space that were provoked 
by the confined rooms in mental hospitals and evoked by the materials and objects provided (or lacking) to the patients. What opportunities could textiles such as bed linen or the thread of a piece of cloth provide them? What kind of spatial situation could these potentially soft and adaptable materials introduce into the brickwalled space of the cell? To find answers to these questions I will first analyze the material culture of those spaces that were intended to seclude patients. How were these rooms furnished and decorated? How did the material culture of these rooms correlate with the symptoms that the patients showed before and during their isolation? How did the institutions initiate its interaction with the patients through its choice of specific materials and objects? I will then focus on two historical examples from mental hospitals that put the perspective on the patients' actions and their appropriation of textile materials in confined rooms. Finally, I link these examples to the concept of "textile architecture" that the cultural studies scholar Heidi Helmhold (2012) developed. My article focuses on German psychiatry at the shift from the igth to the 2oth century.

\section{The Practice of Seclusion}

"Isolating" patients consisted of moving them into single rooms to seclude them from their fellow patients for a certain amount of time. Starting in England, isolation gained more attention from the I840s in the context of the non-restraint movement and eventually succeeded as an alternative to mechanical restrictions such as the straitjacket and restraint chair (cf. Topp 20I8). However, from that time onwards the practice was accompanied by critiques that became stronger in the German speaking countries towards the end of the I9th century. The question "[S]hall we isolate?" (Wattenberg I896) resulted in heated discussions. The main issue was whether isolating patients in closed-off rooms was still an up-to-date practice or whether it could be replaced with a bed treatment or a prolonged bath therapy. In many places, isolation cells were dismantled to give space to new treatment methods with communal wards and bathrooms (cf. Ankele 2019 and 2020). While this reconstruction fundamentally changed the architectural structure of the institutions, it was also a symbolic act that should signal the beginning of a more "humane" treatment of mental patients. Simultaneously, other institutions expanded the number of isolation cells and isolation wards (cf. Kreuser I894: 2IO; 
Beyer 2009), either because of the lack of therapeutic options and staff issues, due to overcrowding, or quite simply out of conviction. Despite the debates, even after I900 the practice of isolation was still fairly common. ${ }^{3}$ However, the concept of isolation demanded corrections and adaptations if it was to be more than a "makeshift" situation (Kraepelin 1903: 320) and had to be transformed into a "therapeutic isolation" in the sense of a medically indicated measure (Ziehen I908: 316; cf. Gross 1912: 139; Heilbronner I897). Hence, the reasons leading to the isolation of a patient were supposed to be determined more rigidly. The "temporary removal of a disruptive patient" (Weygandt 1902: 140) did not count as a therapeutically justified isolation. Furthermore, any isolation was meant to be temporary and last no longer than absolutely necessary. Isolations that were continued over a longer period of time resulted in negative effects on the patient. Terms like "degeneration" and "state of neglect" (Verwahrlosung, cf. Paetz I893: 89) were used in this context. The pejorative term "cell" was supposed to be replaced with more neutral terminology such as "single room" (Einzelraum, Dornblüth 1904: 224; Einzelzimmer, Gross I9I2: 138) and the name for the treatment was to be changed into "single room treatment" (Heilbronner I897). Physicians such as Heilbronner (I897: 739) and Scholz (I894: 697) favored the use of a bed treatment even for those patients who were isolated. They wanted these patients also to experience the therapeutic effect of bed rest because, just like isolation, the bed rest prescribed in a communal ward aimed at reducing outer stimuli caused by either humans or objects, and thus allow the patient to calm down. Psychiatrists like Adolf Gross (I9I2) differentiated between "isolation" as a security measure and "separation" as a therapeutic intervention. To separate a patient, he or she was moved to a single room that was adjacent to the communal ward or the hallway. A glass door or a window for observation served to help the nurse to continue monitoring the patient. In contrast, when a patient was isolated, he or she was put into a room far away from the other patients and was not monitored. Justifications for such a move were constant loud and noisy behavior, or if their behavior posed a danger to the other patients. Similarly, Wilhelm Weygandt differentiated various forms of isolation and described in his textbook the separation in a room with an open door ("optical isolation"), the separation in a closed single room ("acoustic isolation"), and the isolation in a padded cell (cf. I902: I4O-I4I). However, the latter were not very common in the German speaking countries. For instance, the directors of the Zwiefalten institution expressed their opposition to setting up such a cell in 1896 because the padding would interfere with the adaptability of the cell and restrict its usability. 


\section{The Physiognomy of the Cell}

Adaptability was an important quality of those rooms that were designated to separate patients and that were crucial to enable an isolation at all. Their adaptability was a prerequisite for being able to respond to the symptoms of the patients who were to be isolated depending on the individual situation. The equipment of these rooms had to be mobile so that furniture, objects, and materials could be removed or added according to specific requirements and needs. Simultaneously, the richer or poorer furnishing of the room served also to communicate to the patient his or her improvement or deterioration of health. While there were also single rooms in which beds and chamber pots were screwed into the floor, the cells without fixed furnishings were more practical to handle. The outer border of these rooms was an absolute fixture with indestructible walls, reinforced doors, windowpanes with tempered glass, shutters made of sheet iron, and solid locks, yet the inside of the rooms was flexible and could always be newly arranged and redefined: beds standing on the floor versus bedsteads, straw versus seagrass, straw sack versus leather mattress, woolen blankets versus "solid blankets" [feste Decken]. These items formed the mobile furniture of the isolation rooms that could already be changed through small interventions. In 1927 one could read in the supplement of the "Hamburger Anzeiger" about the furnishing of a single room at the Langenhorn state asylum: "When it is necessary, the bedstead can be replaced with a straw sack and patients who rip apart the bedlinen receive especially solid blankets." ${ }^{4}$ Through these interventions into the material culture of the room, i.e., its "physiognomy" that, as Hans Glückel (I906: 26) put it, "reflected the ethical level of care of the insane," also changed. Simultaneously, with the change of materials - straw sack instead of a bed, solid blankets instead of ordinary bed linen - the patients' behavior was sanctioned. For that, not many words were needed. The objects, their physical properties, and their cultural connotation spoke for themselves. They had 
an effect on the patient and his or her actions. Yet they also spoke for the institution and the attitude that it showed towards the patient. Because, whether an institution respected the dignity of their patients or whether it violated it, became also apparent in its objects of daily use and its furnishing, as the psychiatrist Albrecht Paetz declared (cf. I893: 74). This also applied to the practice of isolation. If the separation of a patient was to be valued as a form of therapeutic treatment, the respective rooms, their interior and, most importantly, the materials used had to be modified. ${ }^{5}$

\section{The Fabric of Seclusion}

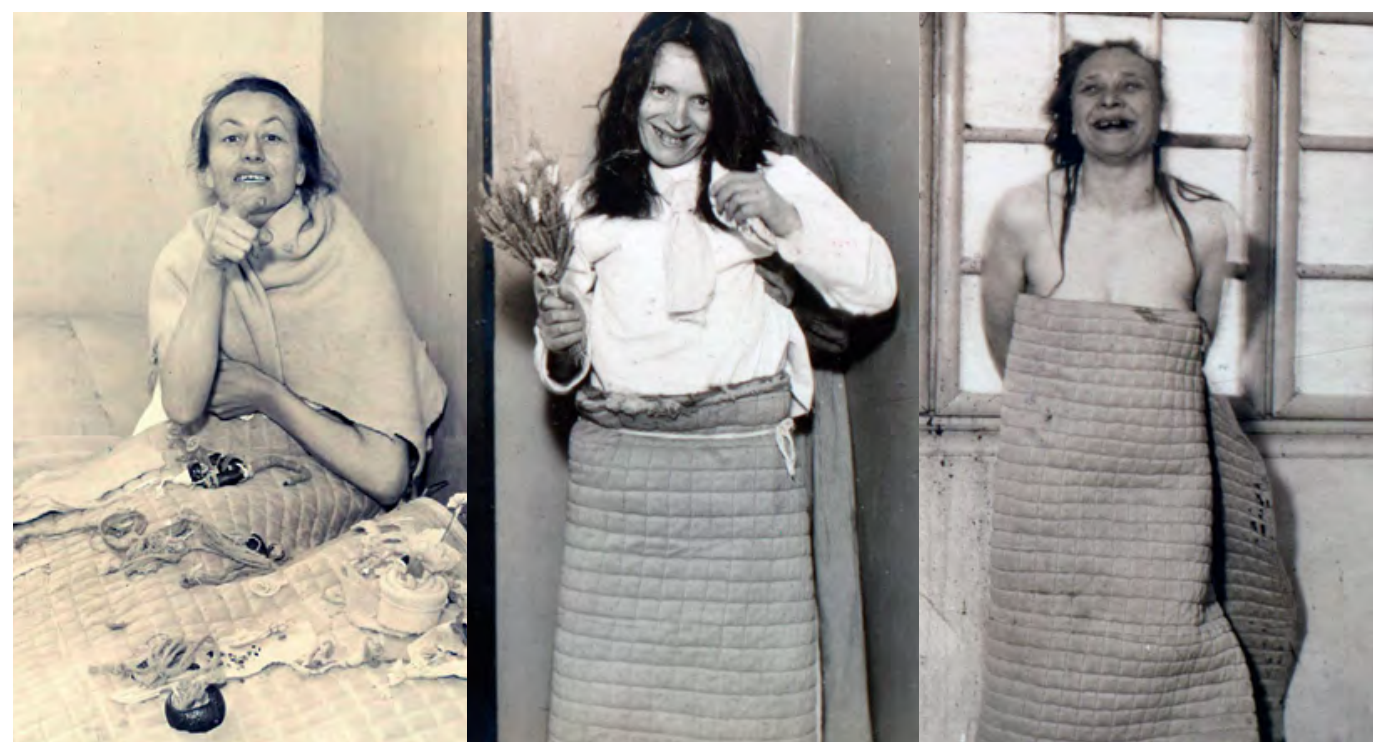

In January I896, the Royal Medical College in Stuttgart requested information from the Württemberg mental asylums in Zwiefalten, Weissenau, Schussenried, Pullingen, and Göppingen on the "use of seagrass in the cells for unclean and disturbed patients." ${ }^{6}$ Seagrass could be both washed and reused and was also relatively cost-effective ${ }^{7}$ in comparison to other materials that is why it was used for isolating 
mainly so-called disturbed and unclean patients. For this purpose, all the other objects and materials were removed from the isolation cell and seagrass was put into the room for "a bed." 8 The directors of the institutions emphasized in their letters that seagrass was only used in exceptional cases and only after everything else had been previously tried with the patients. ${ }^{9}$ Mainly the ripping of linen and clothing that posed a significant cost factor for the institutions often resulted in an isolation with seagrass. As soon as the doctors noticed an improvement of the patients in question, the seagrass was removed from the cell and the patients received - on a trial basis as it was phrased - "proper bed linen" and "proper clothing." "I If the patients ripped them again, the textiles were removed again and replaced with seagrass.

Towards the end of the Igth century a new object was introduced that served both as an alternative to seagrass and to ordinary bed linen and clothes: the so-called solid blanket. (fig.2) To create these blankets, the duvets were quilted and tufted into canvas [Segeltuch], ${ }^{\mathrm{II}}$ a very tightly woven fabric (cf. Heiden I904: 469), and could have had a leather trim on the edges. ${ }^{12}$ The Zwiefalten asylum reported that, "[s]ince the purchase of canvas linen ... was authorized and completed for destructive patients," the use of seagrass could be reduced to only a few patients. ${ }^{13}$ Similarly, the asylum in Pullingen noted that it had been able to replace seagrass with "solid, tufted blankets" in a number of cases. ${ }^{14}$ Compared to seagrass, canvas had the advantage that it was a textile material and thus evoked different connotations than seagrass. The director in Schussenried called the isolation with seagrass as a "type of nursing that ... went against ones feelings." ${ }^{15}$ After visiting the asylum in Winnenthal in November I895 a medical officer of health noted that the seagrass left a scent that reminded him "more of a shed than of a living room" and in a particular cell even "of a scent like stables." ${ }^{16}$ And the psychiatrist Friedrich Scholz (cf. I894: 700) associated a prolonged isolation with seagrass with an "animalization" of the patients. Moreover, canvas was very difficult to tear in comparison to other fabrics. The psychiatrist Otto Snell (1897: 65) described it as "highly resistant" and "hard." This is why the fabric was also used for straitjackets (cf. Kraepelin I903: 424) ${ }^{17}$ and solid clothes, ${ }^{18}$ but also for covers for the prolonged baths (cf. ibid.). Because of its durability canvas was particularly suitable for those patients who ripped to pieces every piece of cloth or clothing they received whilst in isolation. It was also regarded as relatively safe in comparison to "dangerous bedlinen:" ${ }^{19}$ While one could quickly turn an ordinary bed sheet into a rope,$^{20}$ canvas was resistant against such attempts. A solid blanket was far less adaptable, versatile, and changeable than an ordinary bed sheet. The solid blanket kept its shape. You could possibly wrap it around the body (cf. fig. 2), 
but the blanket would not bend to its contours and keep its distance - unlike a wool or linen blanket. The hands could do little against a solid blanket - even though it would not always resist when the impact was particularly strong. Although the solid blanket was made of textiles, it differed from a bed sheet or a blanket in its feel, its physical properties, and thus in providing possibilities of appropriation. The psychiatrist Otto Dornblüth (I860-1922) was critical because of the lack of care [Fürsorge] the solid blankets implied. He advocated that the patients should "rather rip a few blankets and duvet covers than to deprive the sick of the feeling of care" (1904: 225). Instead, every effort was supposed to be made to "adapt the patient to a better bed and a better furnished room" (ibid.). If a patient received his "proper bed linen" back, he or she were implicitly told that the staff had noticed a decline of the symptoms and that the prospect of a possible end of the isolation had come closer as well. Simultaneously, the white sheet that were given to the patients could (and should) make an impact on their behavior. For instance, Heilbronner (I897: 730) claimed that he had repeatedly seen that "in particular in a single room, patients threw and pulled around parts of the mattress, pillows, and duvets without covers and cases but that they were gentle to and used the bed when it was covered with white linen." But not only nurses and doctors, also patients interacted with the materials, their physical properties, and cultural connotations, as I will now show through two examples.

\section{Marie Lieb (1844-1916)}

After Marie Lieb had to be admitted to the University Psychiatric Hospital Heidelberg for a second time in April I894 with the diagnosis "mania," she was alternately treated with bed rest, prolonged baths, hyoscine injections, and isolation. On I5 October I894, after she had been isolated in a single room for two weeks, a doctor noticed the peculiar decoration of the floor in her cell and left a corresponding note in her file: ${ }^{2 \mathrm{I}} \mathrm{With}$ pieces of linen that Lieb had ripped apart she created "meaningful names and signs on the floor of her cell. Some individual pieces she created with huge skill and patience. She highly cherishes her work and only destroys it after a few days." ${ }^{22}$ During the following years, Lieb was repeatedly put in isolation and again and again, she intervened into the built space of the cell with the materials that had been left there. Inevitably, textiles such as linen (but also woolen 

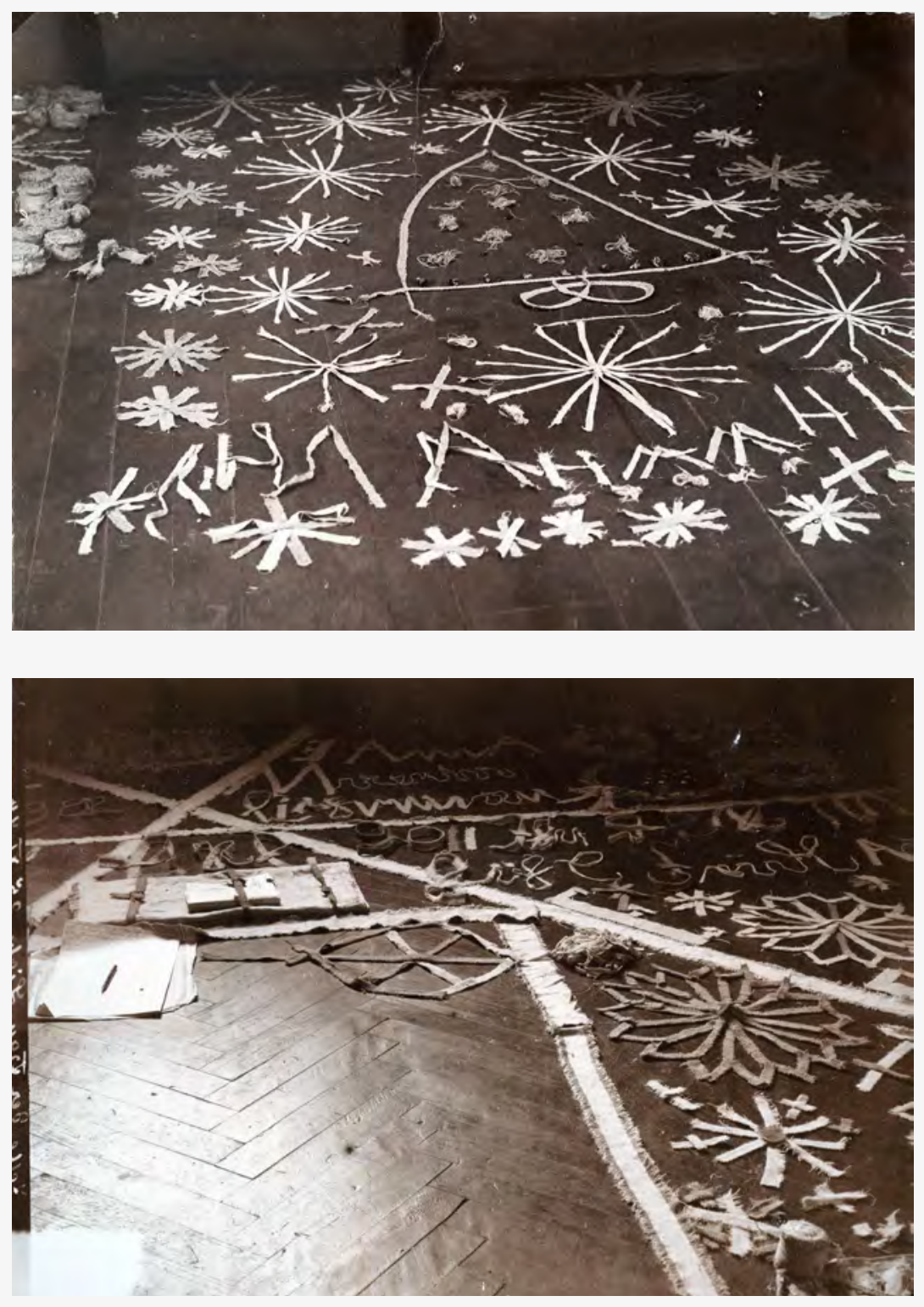

Fig. 3: Cell floor in the University Psychiatric Hospital

Heidelberg, decorated by Marie Lieb,

(c) Collection Prinzhorn, Heidelberg University

Hospital, Inventory-No. 1771/1

Fig. 4: Ibid., (c) Collection Prinzhorn, Heidelberg

University Hospital, Inventory-No. 1772 
blankets and clothes) gained a prominent role, not only because they were often the only material available in the cell, but also because of their physical qualities and affordances. This becomes evident through notes in the patient file and also in photographs of two cell floors that Lieb had decorated (fig. 3 and 4). Thus, the two photographs show the strips of fabric that Lieb had torn evenly from her bed linen and rolled up into many small bales, before arranging them into space-filling patterns on the floor of the cell. She also loosened individual threads from the bed linen and integrated them into the "textile architecture" she had designed, unfolding it into the space fixed by others. Lieb's architecture contrasted, filled, and softened the bleak and hard space of the cell through and with the physical qualities of the textiles. With her intervention, she created an in-between that mediated between her physical body and the building structure. According to Heidi Helmhold (20I2), this mediation is a central quality of "textile architectures." It enables an "unclarification" of the factuality of a room and creates "interspatial resonances" (ibid.: II).

The entries in Marie Lieb's patient chart also report that she received "solid stuff," 23 but there is nowhere a note that her intervention into the room, i.e. the repeated ripping of sheets and clothes, resulted in a "naked isolation" (Weygandt I902: I4I) or an isolation with seagrass. Maybe the patient was supposed to keep a material that she could change and shape with her bare hands and that she could form. In I896, the Zwiefalten asylum argued against a transfer of patients into empty padded cells because these "would be very uncomfortable for patients who - in their addiction for mobility - want something to keep their hands busy." ${ }^{24}$

\section{Katharina Detzel (1872-1941)}

Nurses and doctors at the mental asylum in Klingenmünster made a strange discovery when they opened the door to the isolation cell of the patient Katharina Detzel on the morning of I4 April I9I4: Attached to the wire mesh of a lamp, a life-size doll was dangling (fig. 5). ${ }^{25}$ Detzel had made this figure over night from the few materials that she had been given in the cell. She used a fabric that the patient chart described as canvas to form the shape of a man with glasses and a beard that she stuffed with the seagrass from her mattress. Detzel's goal was to use this doll to be transferred out of the isolation cell into the monitored ward with her fellow patients. She explained to the doctors that the "guys" who had been in her cell at 
night and done "this thing" would soon return and hang her up in this room. ${ }^{26}$ Detzel used the few means provided to her to create a spatial scenography illustrating and visualizing the threatening aspects of the cell thus revealing the possible dangers the room offered to its inhabitant. With the hanging doll, she identified the room as a life-threatening space where - even though she was unsupervised and unprotected - she was not necessarily alone. Detzel used the situation of the room and its material culture to confront and thus to interact with the doctors, hoping to impact their actions and decisions. However, the doctors did not react the way she had hoped. Instead of moving Detzel to the monitored ward, she stayed in the cell though with a significant change: a "naked isolation" was ordered and the mattress, canvas blanket, and clothes were removed from the cell. Now, the naked body encountered the brick room without any barrier. The only material that was left with Detzel in the cell was chaff. With the changes of the material culture of the cell and the removal of all objects the doctors punished Detzel for her actions. They wanted to prevent the threat of a suicide (that they did believe would not occur), but without having to give in to the patient's desire to be transferred.

\section{"Tries to use the blanket to shove on the walls of the cell" ${ }^{27}$}

Threads, fabrics, or blankets formed the material that the patients used to thwart the structure of the confined room, mediated between themselves and the room, or changed the spatial situation. In the encounter with brick walls, the opposite qualities of textiles become apparent. Textiles follow their own rules, are malleable, compliant, adaptable, and undefined. They invite you to take them into your hands, wrap them around your body, hide beneath them, tie knots, fold or bind them, smell them, leave traces in them, and rip them. They enable you to fit them into a room and to create new spatial structures and architectures. Inherent to textiles are possibilities for and hopes of the users that are all the more significant the more threatening the rooms are that the users inhabit. "Tries to use the blanket to shove on the walls of the cell." 


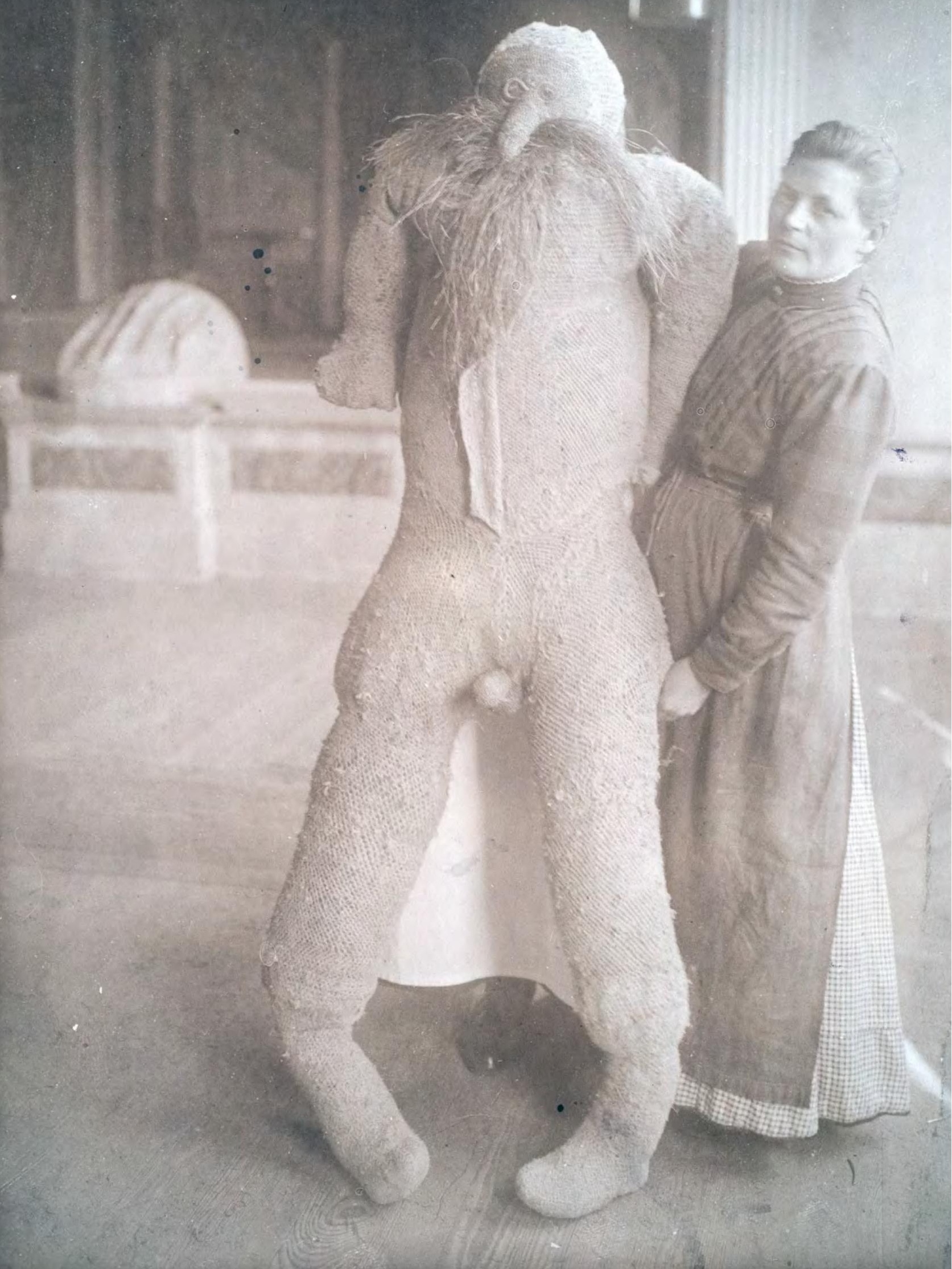


Heidi Helmhold (2012) coined the term "textile architecture" for these kinds of interventions into a built space. She calls them "vernacular" because the inhabitants of rooms act with them in their everyday life and react depending on the situation to particular demands or (spatial) needs (cf. ibid.: 19). In contrast to built architectures that are based on academic knowledge and that are massive, representative and aimed for longevity, textile architectures are "soft" and "responsive," draw on knowledge from experiences, are temporary, and correspond with the body and its affects (cf. ibid.). They rise from a (physical) need of humans to "soften" the built space and - like pillows, curtains, carpets, bed linen - they are used as media to negotiate between the room and the physical body. They target simultaneously both the physicality of the space and the physicality of the body. The use of textiles in a spatial context is an expression "that we are searching for opportunities that are kind to the body so that we can live between hard walls and motionless barriers and interact with them" (ibid.: I8). Properties such as malleability, pliability, and adaptability qualify textile materials to be used as media to interact and to shape temporary spaces within the constructed architecture, as the historical examples from psychiatric institutions show. Since textiles are omnipresent in our daily lives, be it as clothes, carpets, blankets etc., and since they "belong to the familiar handling experiences of every person" (ibid.: 97), their withdrawal causes feelings of hurt and vulnerability (ibid.: 98). Without textile architecture, Helmhold argues, we would not live in rooms but be detained in them (ibid.: 9). Punitive institutions such as prisons but also psychiatric institutions according to Helmhold (ibid.: 97-99) use them to create an impact on their inmates. For psychiatric institutions around 1900 we can confirm these findings even though the circumstances that led to the respective interventions could be complex and multi-faceted. In the psychiatric hospitals, accommodation in a single room was characterized by the expropriation of not only personal, but (nearly) all items. For the patient it was the end of a long line of material deprivations and expropriations that had begun with the admission at the institution and continued with treatments such as bed rest and prolonged bath before finally culminating in the "naked isolation." In the context of these losses, textiles such as bed linen, a blanket, or a piece of cloth gained a special meaning since they were often the only materials that the patient could keep (also in his or her cell) and that they could form and shape and use to mediate between the institutionalized space and their own spatial and physical needs. Beyond that, it was also a culturally connoted material that resonated with the outside of the cell. 


\section{Notes}

1

In her book Jane Hamlett (2015) coined the term of a material subculture that inmates of institutions created.

\section{2}

The psychologist James]. Gibson coined the term "affordance" in the sense of an "option for action" that an object, a material etc. offers. In archaeology, affordance means the utilization options of an object that emerge from its physical qualities. "Materials afford certain potentials: thus plastic allows new shapes, reinforced concrete allows larger buildings, the Eiffel Tower would not have been possible in wood" (Hodder 2012: 49, cited after Meier et al. 2015: 66).

\section{3}

Kreuser (1894) conducted a survey on the practice of isolation in which 50 institutions in Germany and Switzerland took part. This suggests that the majority of the institutions had isolation rooms.

\section{4}

State Archives Hamburg (StAHH), 352-8/7, Sig. 166. Kankeleit (1927): "Die Staatskrankenanstalt Langenhorn." In: Hamburger Anzeiger 32 (Illustrierte Wochenbeilage), newspaper clipping, n. pag.

\section{5}

Leslie Topp (2018) illustrates that in the England of the 1840s, the discussions about isolation resulted in a modification of the cells. She refers to John Conolly (1794-1866), but restricts her analysis to the architecture of the building structure. 
6

State Archive Freiburg (StAF), E 163, Bü 110:

"Medizinalkollegium Heilanstalten: Maßnahmen gegen unreinliche, unruhigie und gewalttätige Geisteskranke, 1891-1925."

\section{7}

See the contribution of Luchsinger to this volume.

\section{8}

Report by the state asylum Weissenau from Januar 17, 1896, StAF, E 163, Bü 110.

9

Ibid.

\section{0}

Cf. report from the asylum Zwiefalten from January 29, 1896, StAF, E 163, Bü 110.

\section{1}

Cf. the description in the inventory of the interior furnishing of a prospective psychiatric institution in Heidelberg [Aufstellung über die Innen-Einrichtung einer prospektierten Psychiatrischen Irrenklinik in Heidelberg] (1876), General State Archive Karlsruhe (GLA), Sig. 235, No. 30356.

\section{2}

Cf. report by the asylum Pullingen from January 28,1896 , and the report by the asylum Göppingen from January 27, 1896, StAF, E 163, Bü 110.

\section{3}

Report by the asylum Zwiefalten from January 29, 1896, StAF, E 163, Bü 110.

\section{4}

Report by the asylum Pullingen from January 28, 1896, StAF, E 163, Bü 110.

\section{5}

Report by the asylum Schussenried from January 16, 1896, StAF, E 163, Bü 110.

\section{6}

Report by the asylum Winnenthal from January 6, 1896, StAF, E 163, Bü 110.
17

"The straitjacket is a jacket made of canvas that is closed at the front and can be laced at the back, with long sleeves without openings, allowing the arms to be held in place across the chest" (Kraepelin 1903: 424).

\section{8}

Schussenried reported the decline of the usage of seagrass since the introduction of clothing made of tear-proof canvas. Report by the asylum Schussenried from January 16, 1896, StAF, E 163, Bü 110.

19

Report by the asylum Zwiefalten from January 29, 1896, StAF, E 163, Bü 110.

\section{0}

"Attempted a suicide at lunch time by setting up a straw sack and artfully attaching a strip of bedlinen that [s/he] had ripped off before" (Raecke 1901: 158).

\section{1}

In the state asylum Langenhorn doctors noted on the August 8, 1929: "Pat[ient] was repeatedly agitated. ... Three days before she had used wool that she had picked out of the mattress to artfully assemble a head with legs like a painting on the cell floor." A corresponding sketch accompanies this entry. StAHH 352-8/7 (Abl. 1995/2), Sig. 18077.

22

University Archive Heidelberg (UAH) L-III (Frauen), Sig. 94/95 (patient file Marie Lieb), entry from October 15, 1894. On Lieb cf. Röske (2010); Michely (2004); Ankele (2009). Lieb's installation is also the subject of artistic explorations like in Charlotte McGowan-Griffin's short film "Folie Circulaire" (2019). Lieb's cell floor decoration was reconstructed for the exhibition "Inextricabilia: Magical Mesh" (Maison Rouge, Paris 2017). The photographs of her cell floor were shown in the exhibition "When the Curtain Never Comes Down" (American Folk Art Museum, New York 2015). 
23

Ibid., entries from June 10, 1894, October 1, 1894, April 20, 1895.

24

Report by the asylum Zwiefalten from January 29, 1896, StAF, E 163, Bü 110.

25

See Kreuser (1894: 226) on the lightning in isolation cells: "More than 2/3 of the institutions have installed their own source of light in a special wall cut-out often above the door that is protected from the interior through wire mesh or thick glass." On Detzel see Röske (2010); Michely (2004).

26

Kreisirrenanstalt Klingenmünster, patient file Katharina Detzel, copy of the file in the Collection Prinzhorn, Heidelberg University Hospital, original file in the Pfalzklinik Landeck Nr. 2554.

\section{7}

StAHH, 352-8/7 (Abl. 1995/2), Sig. 2750, entry from November 22, 1908 (patient file Friedrichsberg).

\section{Bibliography}

Ankele, Monika (2020): "Material Configurations of Nursing and their Ethical Implications. The Prolonged Bath Treatment in Psychiatry." In: European Journal for Nursing History and Ethics 2/1, pp. 101-123.

Ankele, Monika (2019): "Horizontal Scenographies. The Sickbed as a Setting for Psychiatric Subjectivation." In: Lars, Friedrich/Harrasser, Karin/Kaiser, Céline (eds.): Scenographies of the Subject, Wiesbaden: Springer Verlag, pp. 43-58.

Ankele, Monika (2009): Alltag und Aneignung in Psychiatrien um 190o. Selbstzeugnisse von Frauen aus der Sammlung Prinzhorn, Vienna/Cologne/ Weimar: Böhlau.

Beyer, Christoph (2009): Von der Kreis-Irrenanstalt zum Pfalzklinikum. Eine Geschichte der Psychiatrie in Klingenmünster, Kaiserslautern: Institut für Geschichte und Volkskunde.

Dornblüth, Otto (1904): Kompendium der Psychiatrie für Studierende und Ärzte, Leipzig: Veit und Comp. Gückel, Hans (1906): Zur Geschichte der Isolierung von Geisteskranken, dissertation, Erlangen.

Gross, Adolf (1912): "Allgemeine Therapie der Psychosen." In: Aschaffenburg, Gustav (ed.): Handbuch der Psychiatrie, Allgemeiner Teil, vol. 4, Leipzig/ Vienna: Franz Deuticke, pp. 49-208.

Hamlett, Jane (2015): At Home in the Institution. Material Life in Asylums, Logding Houses and Schools in Victorian and Edwardian England, New York/London: Palgrave Macmillan.

Heiden, Max (ed.) (1904): Handwörterbuch der Textilkunde aller Zeiten und Völker, Stuttgart: Ferdinand Enke.

Heilbronner, Karl (1897): "Bettbehandlung und Einzelzimmerbehandlung." In: Allgemeine Zeitschrift für Psychiatrie 53, pp. 718-739.

Helmhold, Heidi (2012): Affektpolitik und Raum. Zu einer Architektur des Textilen, Cologne: Walther König.

Kuhnert, Nikolaus/Oswalt, Philipp (1991): "Ephemere Architektur." In: Arch+ IO7 (Textile Architektur), pp. 24-25. 
Kraepelin, Emil (1903): Psychiatrie. Ein Lehrbuch für Studierende und Ärzte, vol. 1., Leipzig: Johann Ambrosius Barth.

Kreuser, Heinrich (1894): "Üeber die nothwendige Anzahl und die zweckmässigste Anlage und Einrichtung der Zellen an den öffentlichen Heilund Pflegeanstalten." In: Allgemeine Zeitschrift für Psychiatrie 50, pp. 208-233.

Meier, Thomas/Ott, Michael R./Sauer, Rebecca (eds.) (2015): Materiale Textkulturen: Konzepte - Materialien - Praktiken, Berlin: De Gruyter. Michely, Viola (2004): "Marie Lieb." In: BrandClaussen, Bettina/Michely, Viola (eds.): Irre ist weiblich. Künstlerische Interventionen von Frauen in der Psychiatrie um 1900, Heidelberg: Das Wunderhorn, p. 162.

Michely, Viola (2004): "Katharina Detzel." In: Brand-Claussen, Bettina/Michely, Viola (eds.): Irre ist weiblich. Künstlerische Interventionen von Frauen in der Psychiatrie um 1900, Heidelberg: Das Wunderhorn, p. 178.

Paetz, Albrecht (1893): Die Kolonisierung der Geisteskranken in Verbindung mit dem OffenThür-System, ihre historische Entwicklung und die Art ihrer Ausführung auf Rittergut AltScherbitz, Berlin: Springer Verlag.

Raecke, Julius (1901): "Beitrag zur Kenntniss des hysterischen Dämmerzustandes." In: Allgemeine Zeitschrift für Psychiatrie 58, pp. 115-163.

Röske, Thomas (2010): "Krankheitssymptome oder kritisches Aufbegehren? Stick-, Näh- und Häkelwerke aus der Psychiatrie." In: Weddigen, Tristan (ed.): Metatextile, Emsdetten: Dietrich Reimer Verlag, pp. 51-61.

Scholz, Friedrich (1894): "Die nächste Aufgabe der Irrenpflege." In: Allgemeine Zeitschrift für Psychiatrie 50, pp. 699-704.

Snell, Otto (1897): Grundzüge für Studirende und Aerzte, Berlin: Georg Reimer.

Topp, Leslie (2018): "Single Rooms, Seclusion and the Non-Restraint Movement in British Asylums, 1838-1844." In: Social History of Medicine 31/4, pp. 754-773.

Wattenberg, [NA] (1896): "Sollen wir isolieren?" In: Allgemeine Zeitschrift für Psychiatrie 58, pp. 928-959.
Weygandt, Wilhelm (1902): Atlas und Grundriss der Psychiatrie, Munich: Lehmann's.

Ziehen, Theodor (1908): Psychiatrie für Ärzte und Studierende, Leipzig: Hirzel.

\section{Website}

Cook, Peter (Archigram): Instant City, 1968-1970, https://www.frac-centre.fr/_en/art-and-architecture - collection/rub/rub-317.html?authID=44\&ensembleID=113, accessed on June 25, 2020 .

This article is a result of the research project "Bed and bath: Objects and spaces of therapeutic acting in psychiatry of the 19th and 20th century. An outline of a material history of psychiatry" (SCHM 1311/11-1) at the Institute for the History and Ethics of Medicine at the University Medical Center Hamburg-Eppendorf. It was conducted by the author and funded by the German Research Foundation from 2015 to 2019.

All quotations originally in German were translated by Ulrike Nichols. 



\section{Theories of the "Savage": \\ The Material Varek (Seagrass) \\ As a Bearer of Meaning in Psychiatry around 1900}

Katrin Luchsinger

On November 24, 1913, the patient Lisette H. (1857-1924) made a women's hat out of seagrass in the Rheinau psychiatric hospital in the canton of Zurich, where she

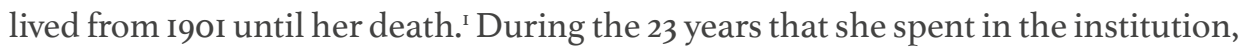
Lisette $\mathrm{H}$. made several objects out of this material, seven of which have survived (an eighth object is made of cotton waste). ${ }^{2}$ Seagrass was known as Varek and was used to stuff mattresses. In particular, the so-called "floor beds" in the isolation cells of psychiatric institutions were filled with Varek. ${ }^{3}$ At the Rheinau psychiatric hospital, Varek was used since 1897 because, unlike straw and horsehair, which were both also used, it was washable. ${ }^{4}$ Since the grass curls up as it dries, it had to be gently fluffed after being washed. Horsehair, which is not washed but only shaken out, is then fluffed in the same way, as shown in figure I. 


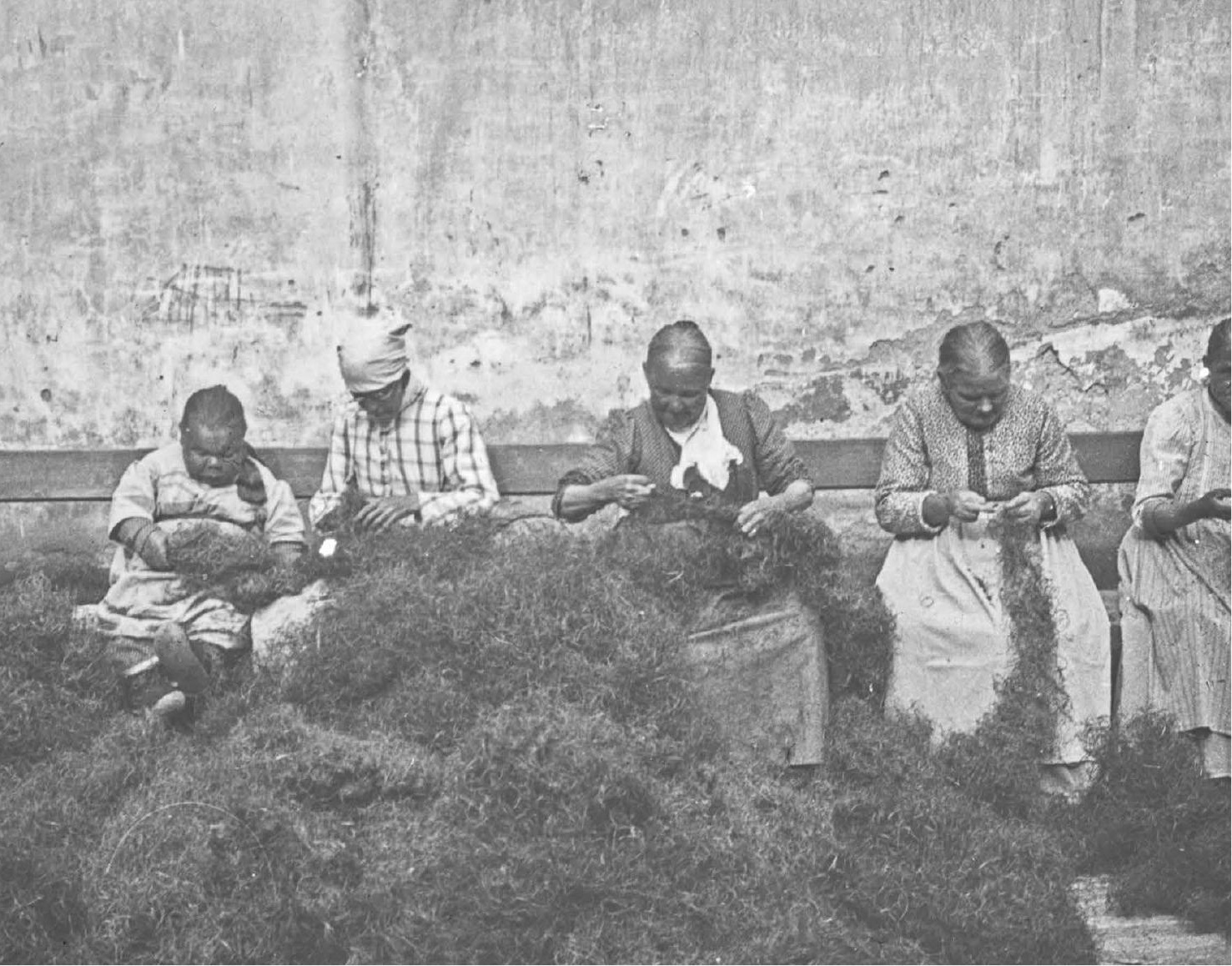

Seagrass (Zostera) grows in the sea near the coast at a depth of up to I5 meters. Narrow bands unfurl from the round stalks and can grow up to one meter long. They are common along the coasts of the Northern Hemisphere, Ireland, England, Scandinavia, and on the coasts of the North Sea and the Baltic Sea. In the winter, the dead seagrass is left behind in heaps on the beaches. In Denmark it was once used to cover roofs, and around 1900 it was exported as a material for filling mattresses, because it does not rot like straw when it becomes wet. At bathing beaches seagrass was and continues to be collected in the spring to keep the beach clean, after which it is either disposed of or converted into biogas. Some companies sell it as insulation material. Pillows with seagrass filling are available, and summer hats are woven out of it. The dried blades of grass (only the flat parts, not the stalks) are about two to eight millimeters wide, curly, and (due to the processing) only about 20 centimeters long, often shorter. The material smells earthy. Currently manufacturers recommend washing the filling from time to time in a washing machine. The grass curls up and then has to be spread out to dry and gently fluffed before being put back in the casing. 
In psychiatric hospitals around I900, "fluffing Varek" is mentioned as one of the jobs that was assigned to the patients (this job was reserved for women) in the "disturbed" wards for the most seriously ill, the least self-sufficient patients, or women who refused to comply with the nurses' or doctors' instructions, as will be discussed below. The material is very common and is not often mentioned in psychiatric writings. However, some photos show horsehair being gently fluffed, and seagrass must have been treated in a similar way. In these pictures, the horsehair lies in piles on the ground, from which one can conclude that, in accordance with its purpose, it was available in large quantities. In contrast, only limited amounts of wool or yarn were given to patients, which is why some female patients, and occasionally also male patients, used seagrass for other purposes, such as needlework, shoes, or jewelry, just as many other materials were used for new, sometimes artistic purposes for want of more suitable materials (Fahrni 2008). ${ }^{5}$

This study focuses on the use and importance of seagrass in Swiss psychiatry in the 2oth century. The seven works made of seagrass - a purse, a women's hat, two pairs of fine stockings, and a decorative doily ${ }^{6}$ - which survived from Lisette $\mathrm{H}$. will be a special focus of attention because their uniquely high quality demonstrates Lisette H.'s unbelievable skill in handicrafts. According to entries in her medical record, Lisette H. also made many other handicrafts from the material, which have been lost. ${ }^{7}$ Thematically the group of her works that survived concentrates on one major concern: the handbag, women's hat, baby's jacket, stockings, and decorative doily can stand for the housewife's work and belongings. Lisette $H$. was such a housewife before entering the psychiatric hospital. Based on these works by Lisette H., I will examine where and in what context patients came into contact with the material and what significance it had in the context of living and treatment at mental hospitals. Based on photos that depict the various uses of seagrass, the purpose for taking the photo and the context in which it might have been published will be investigated. Furthermore, I will consider the question of what purposes, besides stuffing mattresses, patients used Varek for due to a lack of more adequate materials. Medical record entries and photos documenting and commenting on such uses represent a kind of rudimentary "reception history" of the objects in the institution. ${ }^{8}$ The fact that objects made of seagrass were mentioned and commented on at all in patient files and textbooks is due to the fact that the discrepancy between the material and the object in its usual, familiar form was so great that it challenged the psychiatrist to interpret it in the context of mental illness. In order to be able to better reconstruct the conditions for the creation of her work, Lisette H.'s medical record will be used as an example for the argumentation in the following section. 


\section{Biographical References, Life in the Asylum, and Descriptions of Works}

Only two documents offer information about her biography, treatment, and the living and working conditions at the Rheinau psychiatric hospital: Lisette H.'s medical history and the "Registration of the patient Lisette H.-K., born on December I9, I857, for the Rheinau psychiatric hospital" from September 4, I90I. This document was written by the psychiatrist Eugen Bleuler (I857-I939), director of the Burghölzli university psychiatric clinic in Zurich from I898 to 1929. This institution was well known even outside of Switzerland. In I90 Bleuler decided to transfer the patient from Burghölzli, where she had been staying for eight years, since April 2I, I893, to the Rheinau psychiatric hospital for the incurably mentally ill. ${ }^{9}$ Bleuler begins his report: "The patient has a great hereditary burden," despite the fact that the following enumeration of relatives who supposedly had a hereditary disease by no means suggests as much. Lisette H.'s father was healthy, and her mother was supposedly melancholic. However, she did not die of this condition, but of tuberculosis. An uncle, Bleuler explains, "drowned in old age after he had no means of subsistence." It can be concluded that poverty and disease were present in Lisette H.'s family. In his registration letter, Eugen Bleuler emphasized or constructed the hereditary nature of her disease possibly with a view to her transfer from the university clinic to the psychiatric hospital, which was deemed to be unavoidable when the medical board pronounced the judgment of "incurability." A hereditary disease represented the strongest argument for this. At the age of 26, Lisette K. married the master weaver Heinrich H. She gave birth to five children, one of which was stillborn, and one of which died of meningitis as an infant. The other children were healthy.

"Patient used to be healthy, intelligent ... ; the marriage was happy, without worries," Bleuler writes in his report. Lisette H. worked as a housewife. In March I893 there was a "fire nearby," which might have been the trigger for a state of deep confusion. Bleuler now notes, in contradiction to his statement above, that she "did not really work before." Lisette H. was sent to the Catholic Mönchhof hospital in Kilchberg near Zurich, where she stayed for about a month. ${ }^{\text {Io }}$ From there she was transferred to the Burghölzli psychiatric clinic in Zurich on April 2I, I893. She "had to be kept in disturbed wards" in a cell, bath, or observation room and at times had to wear "gloves," the psychiatrist writes. The prolonged bath, the observation room, and the (fingerless) gloves can be described as compulsory measures (Meier et al. 2007: 3I-43), which in the case of Lisette $H$. were motivated by the fact that she could not adjust to the procedures in the wards and did harm to herself. ${ }^{\text {II }}$ 
For instance, she tore her clothes, which is why she had to wear "cell clothes," ${ }^{12}$ and ripped out her hair; she was anxious and agitated. "Now she is working on fluffing wool and horsehair, and often adorns herself with garlands of such material," Bleuler concludes his registration letter. On October 28, I90I, she arrived at the Rheinau psychiatric hospital with a "mass transport" (Gehry I932: I6) from Burghölzli, and she was taken to the newly opened facilities called "Neu-Rheinau." 's She died of tuberculosis there at the age of 67. Until 1906 there is a short entry in her medical history about every six weeks. Lisette H. was always assigned to "disturbed" wards, which were designated with the letter L at Neu-Rheinau: LI to L3. ${ }^{\text {I4 }}$ This suggests that she was unable to adjust to daily work with less monotonous (but more tiring) jobs than simply "fluffing Varek" or knitting, as was usual in the other wards. Since she "could not tolerate treatment in bed in the observation room" together with seven other patients, she was often in the "cell" and during the day "with the others." ${ }^{5}$ She knitted and "sits quietly at the table and fluffs Varek." ${ }^{16}$ On May 22, 1902, she "knitted a stocking out of split and knotted Varek, well-proportioned in form, using only a match" (fig. 2). ${ }^{17}$

The two stockings pictured here were in an envelope with the inscription "Varek stocking by Mrs. H. knitted with match. 3.5.1902." ${ }^{18}$ The stocking mentioned in the medical record is probably one of the two stockings shown here. These, as well as the remark "knitted with a match," raise many questions. They are knee-length socks, 40 and 34 centimeters long. The foot corresponds approximately to the shoe size 35. One of the stockings has a crocheted edging made of cotton thread. Both are knitted with plain stitches (not crocheted), for which five needles (or, to at least fulfil the principle of knitting, two needles) would be necessary. However, these two stockings are round, knitted without a seam. The mention of "a" match remains inexplicable. As was mentioned, Lisette H. split the seagrass lengthwise into pieces one to two millimeters wide, and in some cases even thread-like bands, each of which was only about 20 centimeters long. Some protruding ends of threads can be seen. The leg section of the stocking has different colors, with lighter and darker stripes, corresponding to the natural material (fig. 3). The instep clearly shows that the stitches were gathered and the heel was knitted. In the front Lisette H. shaped 


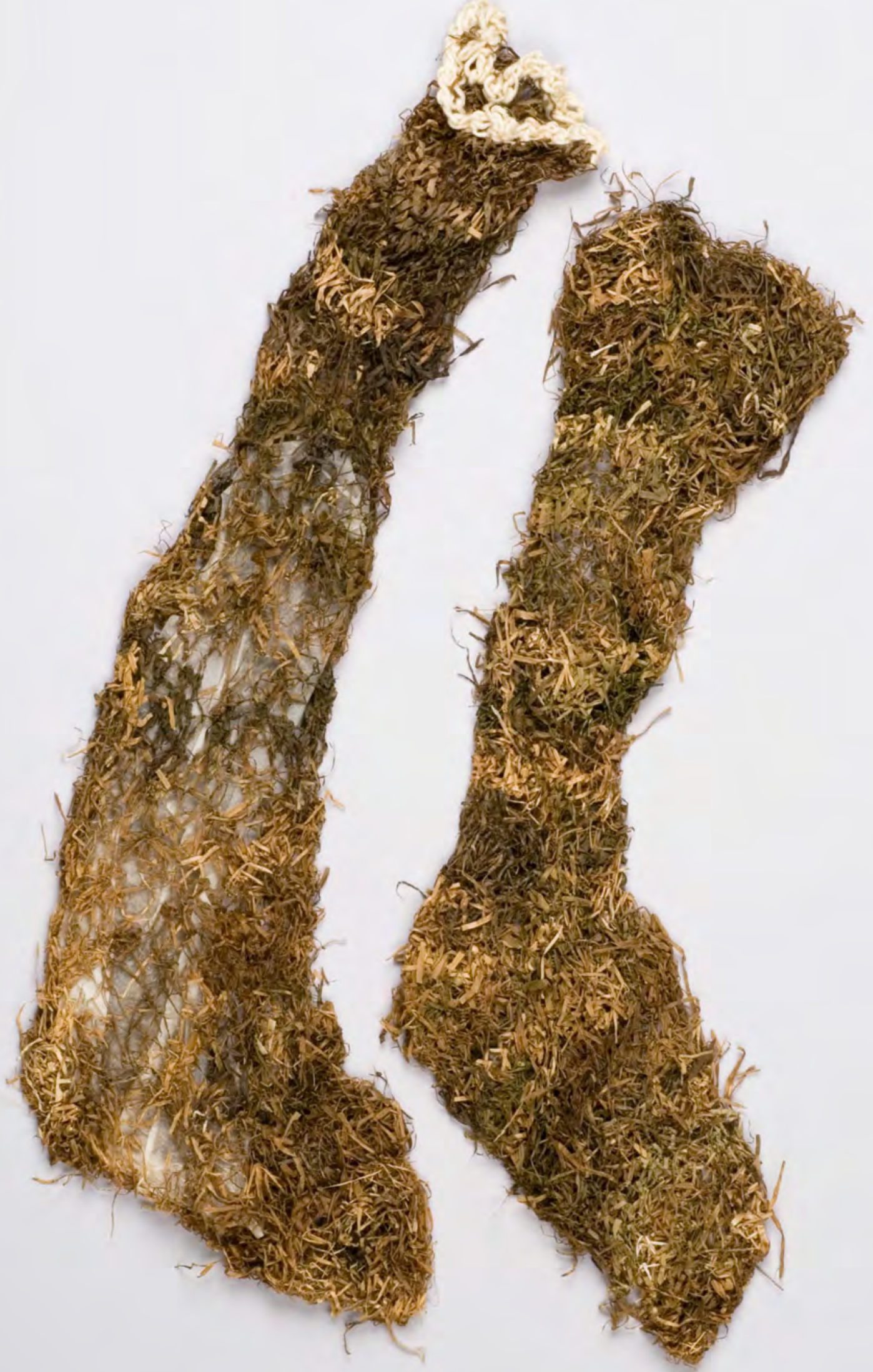



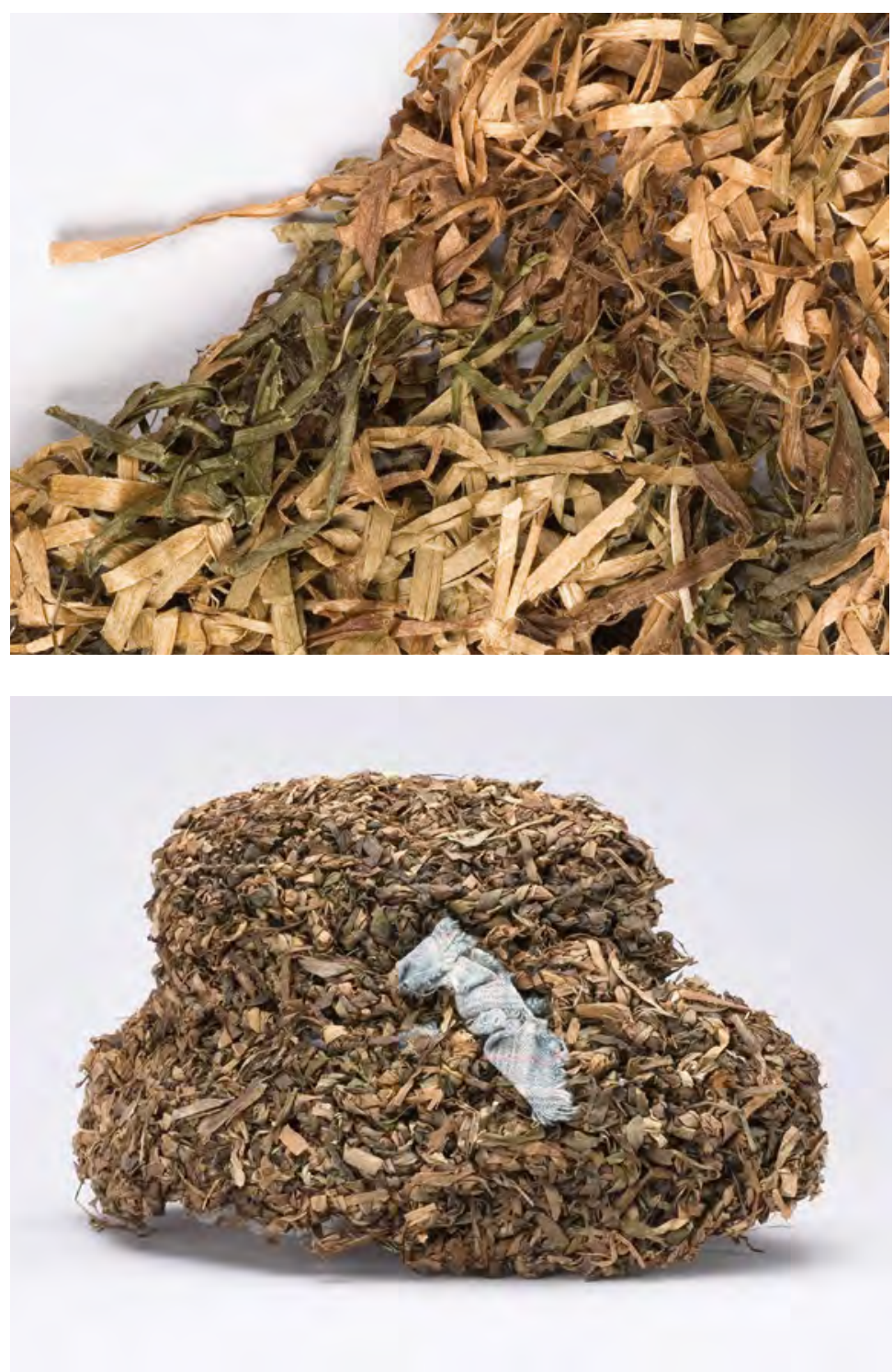

Fig. 3: Detail from left stocking with edging cotton edge (in fig. 2): stripes in various colors of split Varek, knitted round

Fig. 4: Lisette H., women's hat, crocheted out of braided Varek, dated November 24, 1913 
the stocking into a point. Especially the slightly longer stocking with its cotton edging is extremely thin and transparent, so it becomes clear that Lisette H. intended to knit "fine" stockings, not thick wool stockings. How she was able to make the fragile texture out of stitches is inexplicable, and it is hard to imagine how Lisette H. knitted tapers or saved stitches for the heel (which forms the right angle to the foot) and transferred them to another needle (especially if one must assume that she did not have access to conventional knitting needles). She must have had extraordinary skill, experience, and a great deal of patience. The stockings are almost weightless, dry, and brittle. On September 6, 1904 the file reads: "Crochets children's dress during quiet time." She carefully crocheted such a garment, the size of a newborn's shirt, out of cotton waste and decorated the collar with a torn-off strip of brown-and-gold brocade about five millimeters wide.

In 1904 Lisette H. fell ill with pneumonia, and in 1906 she was seriously ill for several months. In that year it is noted that she "no longer makes little things" and "does not work." After 1907, the entries become sparse. For seven years there was not a single entry in her file. In 1915, I9I8, and I9I9 the only entries simply read: "Status idem," "Nothing new," and "Unchanged." After the long interruption in 1906, in 1907 Lisette $H$. began weaving ribbons out of Varek longer than the short single blades of grass, which resulted in a much more stable weave: "Endlessly wove threads out of Varek," the medical record reads. ${ }^{19}$ Despite the slightly disparaging remark about her "endless" weaving, a few years later, a hat that Lisette H. produced made a certain impression on the author of the entries. On November 24, 1913 (as was already mentioned) the file reads: "made a pretty hat out of Varek" (fig. 4). ${ }^{20}$

The new technique of braiding, crocheting, or knitting braids out of the short pieces of Varek allowed Lisette H. to make more robust and larger objects and to precisely shape them. From a technical point of view, if the hat were not so small (including the brim, it is only 26 centimeters long and 17 centimeters wide), it would be wearable. Although Lisette H. certainly did not have a hat block, her hat is exceptionally well formed. The top of it is flattened in the shape of an ellipse (one of the Varek braids runs over the top) and then bulges downward. The brim sticks outward and bulges slightly again, so that the hat, if it were worn, would somewhat shade the wearer's forehead. Both are connected with a hat ribbon, for which $\mathrm{Li}$ sette H. used a torn-off strip of a blue-and-white mattress fabric that she pulled through the Varek braids and tied in a nice bow. The loving care that Lisette $\mathrm{H}$. showed contrasts starkly with the meagre materials that were available to her. A handbag that she made in the same technique has also survived (fig. 5, 6). 


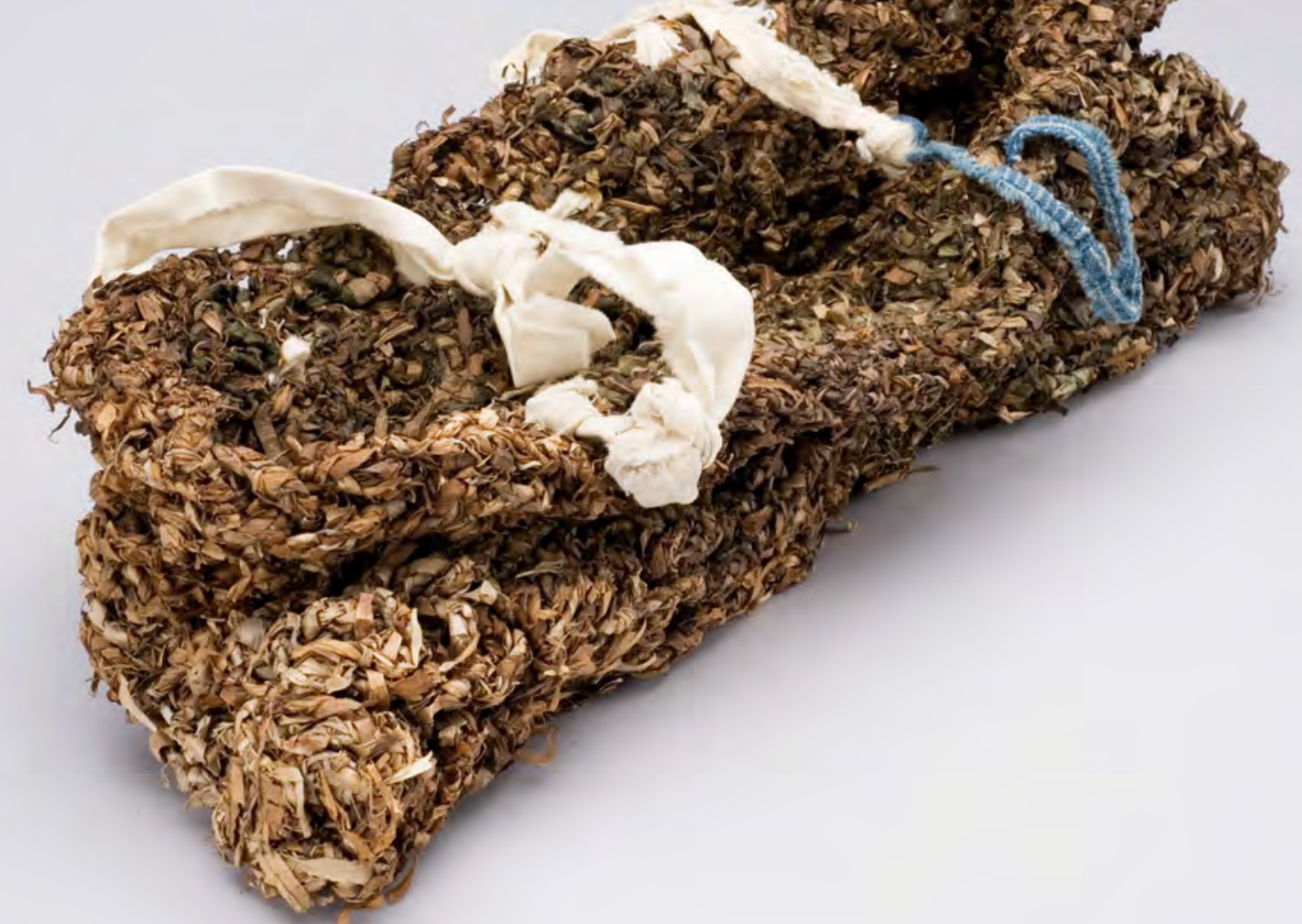

The handbag is 35 centimeters wide and 16 centimeters tall. The base is a five-anda-half-centimeter-wide, 35-centimeter-long rectangle, which is securely connected to the side walls. The technique in which Lisette H. made the handbag is difficult to discern, since the braids lie flat along the sides. The upper edge seems to be chained off; perhaps she used a mix of techniques here. Her self-perception was apparently different from others' perception of her, as evidenced by the Varek bracelets that she made for herself and wore. ${ }^{21}$ Although the attendants and doctors were sometimes impressed by her technical abilities their comments were largely skeptical. On the one hand, this may be due to the fact that Lisette H.'s health deteriorated from 1906 onward. Her use of the strangely inadequate material of seagrass also probably contributed to the skepticism. It was thus reminiscent of so-called "savages" and it was inscribed into the discourse of primitivism due to such associations. 
I will try to demonstrate that the attribution of the material to "primitive" qualities was one of the reasons why it was apparently impossible for Lisette H.'s psychiatrists to appreciate the unbelievable skill that Lisette $H$. showed and the grieving expressed in her choice of motifs. Her living environment, which was restricted to the observation room, the bathtub, the cell, the dayroom, and the cell yard after I893, shrank again after 1920 in her final years, and finally consisted of her bed, the space under her blanket (see also Ankele 2009b: I35-I37; 2009a: I45-I50). The only entry from I920 states: "Always has her Varek bag full of threads, stones, and the like, and plays with them." ${ }^{22}$ When she could no longer leave her bed in I924, she played with these things under the covers, tore the linens, and "makes garlands out of the pieces, puts feathers in her hair." ${ }^{23}$ In her bed and under her blanket, Lisette $\mathrm{H}$. kept a place of retreat in which the psychiatric hospital, a "total institution," in the words of the sociologist Erving Goffman, did not intervene. Goffman calls this strategy "underliving in the asylum" (Goffman I973[I96I]: 202), with which he describes actions of patients which were not allowed but were tolerated, and so were not directly subversive and made it subjectively easier for them to survive in the asylum.

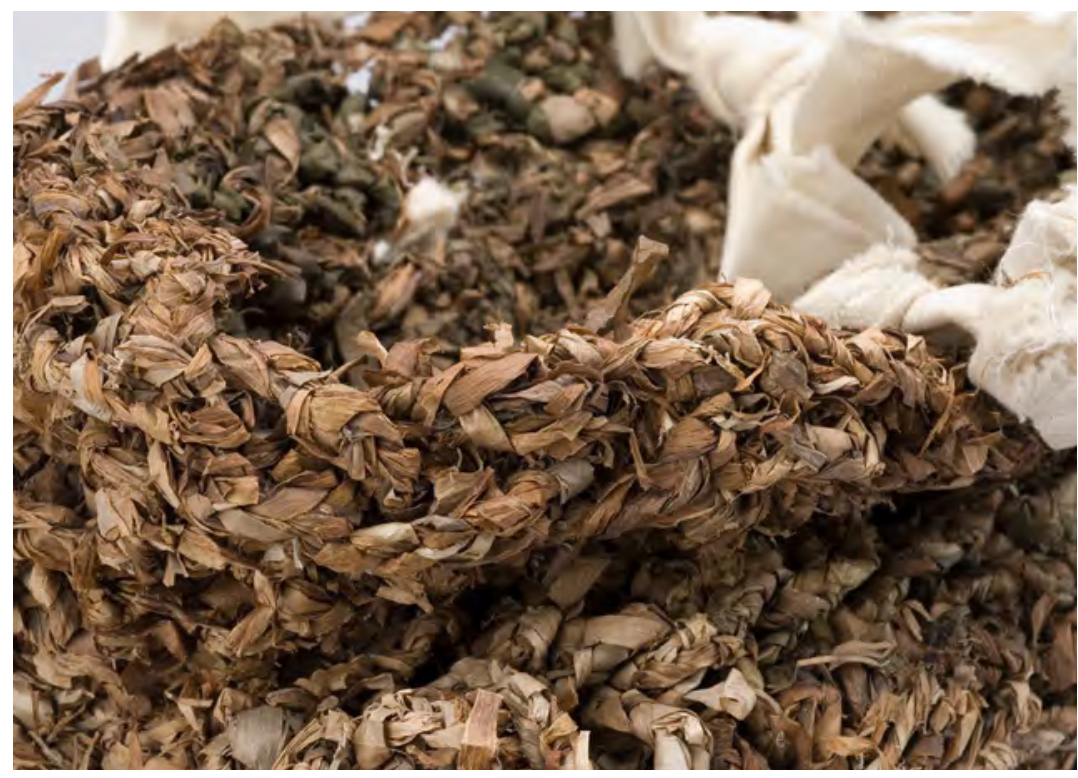




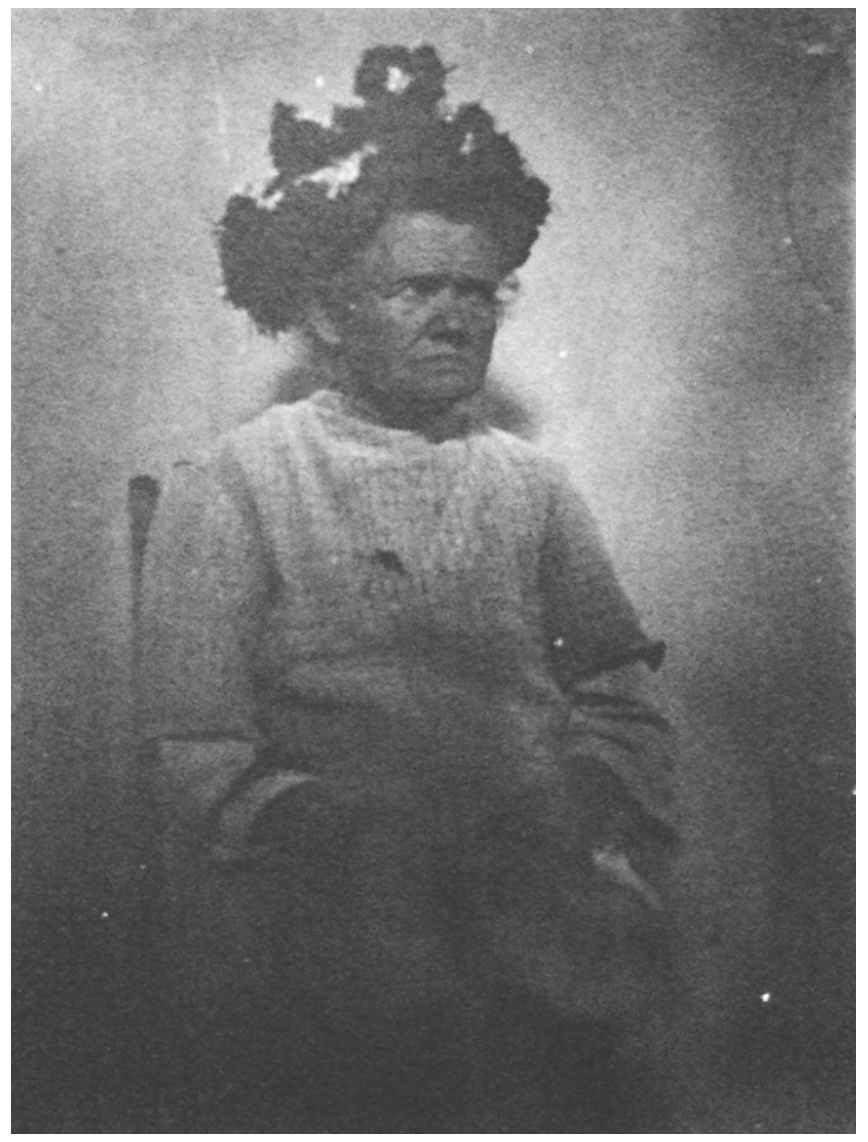

Fig. 7: Lisette H., dated 1914 


\section{"Foreign" and "Savage" Things in Photographs from the Asylum}

A photograph from I9I4 shows Lisette H. sitting on a chair dressed in a hospital gown. She is wearing a headdress made of a garland and braids, both presumably made of Varek. ${ }^{24}$ A ribbon appears to be woven into the garland and she wears bracelets of Varek (fig. 7). ${ }^{25}$

As the cultural studies scholar Susanne Regener calls it, the picture is a "photograph against the subject's will" (20I0: 95-II6, IOI). Regener uses this expression to examine the large number of photographs of patients taken between I900 and I9I4 in psychiatric institutions. Like conventional portraits, they depict an individual person in full or in close-ups. In contrast to commissioned photographs, however, the picture is not taken in agreement with and for the benefit of the subjects. There is a lack of communication, and the picture was "captured" (ibid.: 96). Photography is "the materialization of a particular medical gaze," which "attests to violence and claims to power over the individual" (ibid.). Based on the example of seven photo albums from the German Heil- und Pflegeanstalt Weilmünster, Regener examines what might also apply to Lisette H.: the fact that the photographed patients often came from lower social classes and had no experience with how to present themselves favorably in a photograph. The hospital bed or the chair on which they were photographed sitting becomes a stage on which, often also for educational purposes for prospective psychiatrists, their mental illness was supposedly presented. In the portrait the patient is completely "medicalized ... both as a social person and as a human type" (ibid.: 95). ${ }^{26}$

In the aforementioned photograph, Lisette $H$. is sitting on a wooden chair in front of a wall. She looks watchfully or even mistrustfully into the upper right corner, where perhaps an attendant is standing, and ignores the camera. She presents herself in a costume that contrasts starkly with her simple hospital apron. With the chair in front of the bare wall, the setting is more reminiscent of a police portrait than of a conventional portrait and contrasts sharply with her impressive clothing, which she surely understood as significant.

Another comparable "materialization" of a specific scientific gaze at the beginning of the 2oth century is the innumerable anthropological photographs depicting representatives of the indigenous population of colonies in clothing that was incomprehensible to European audiences, since it was unexplained. Such anthropological pictures attracted a great deal of interest from a broad audience, includ- 
ing psychiatrists. After all, in psychiatry in the first decades of the 2oth century, cultural-historical questions, prompted by psychoanalysis - especially in the milieu of the Burghölzli clinic in Zurich - played an important role. Cultural-historical statements, for instance artworks from the Middle ages, from ancient Egypt or just as well from the colonies were seen as being related to early stages of development and related to the regressions caused by the onset of mental illness. Aided by the use of the medium of photography, the older concept of the criminal anthropologist Cesare Lombroso (I835-1909) of a "step backward" to earlier stages of development was entangled with anthropological explanatory models. ${ }^{27}$ An undated glass slide in the Museum of Psychiatry in Bern, which presumably also served to train psychiatrists and is found among many images from the psychiatric institution, supports this assumption: It shows an unclothed, dark-skinned woman with scar embellishments on her stomach, whose at first glance incongruous appearance in the psychiatric context must be read as a cultural-historical reference. ${ }^{28}$ A group of photographs of tattooed patients from the same collection could serve as an indication of an interest in the importance of bodily adornments. ${ }^{29}$ The Bern psychiatrist Walter Morgenthaler (I882-I965), who was very interested in artworks created by patients, wondered in his monograph about his patient Adolf Wölfli (I864-I930), who is considered one of the outstanding Swiss artists, whether, due to his illness, the artist arrived at even "more original artistic elements" (Morgenthaler I985 [I92I]: 89-90) than some avant-garde artists. Terms such as "archaic" and "primitive," as well as "ugly" and "savage" were trendsetting for the avant-garde that defied bourgeois norms as examined by the art historian Klaus Herding using the example of Picasso's 1907 work Les Demoiselles d'Avignon (Herding I992: 4I, note 58). They also gained a new connotation - if not positive, at least worthy of interest - among psychiatrists with an interest in cultural history. Some patients seem to have embraced the field of associations around the notion of the "savage" as a space for imagination, as in the photograph of a self-assured patient from the Waldau hospital posing in animalistic savagery, dressed (or dressed up?) in a Varek sash and skirt that recalled the bast skirts that were known from photographs of traditional Polynesian clothing, and adorned with feathers (fig. 8). ${ }^{30}$

His attendant clutches the square key to the scratched wooden door to an empty room whose floor seems to be piled high with the same material, and bravely and 


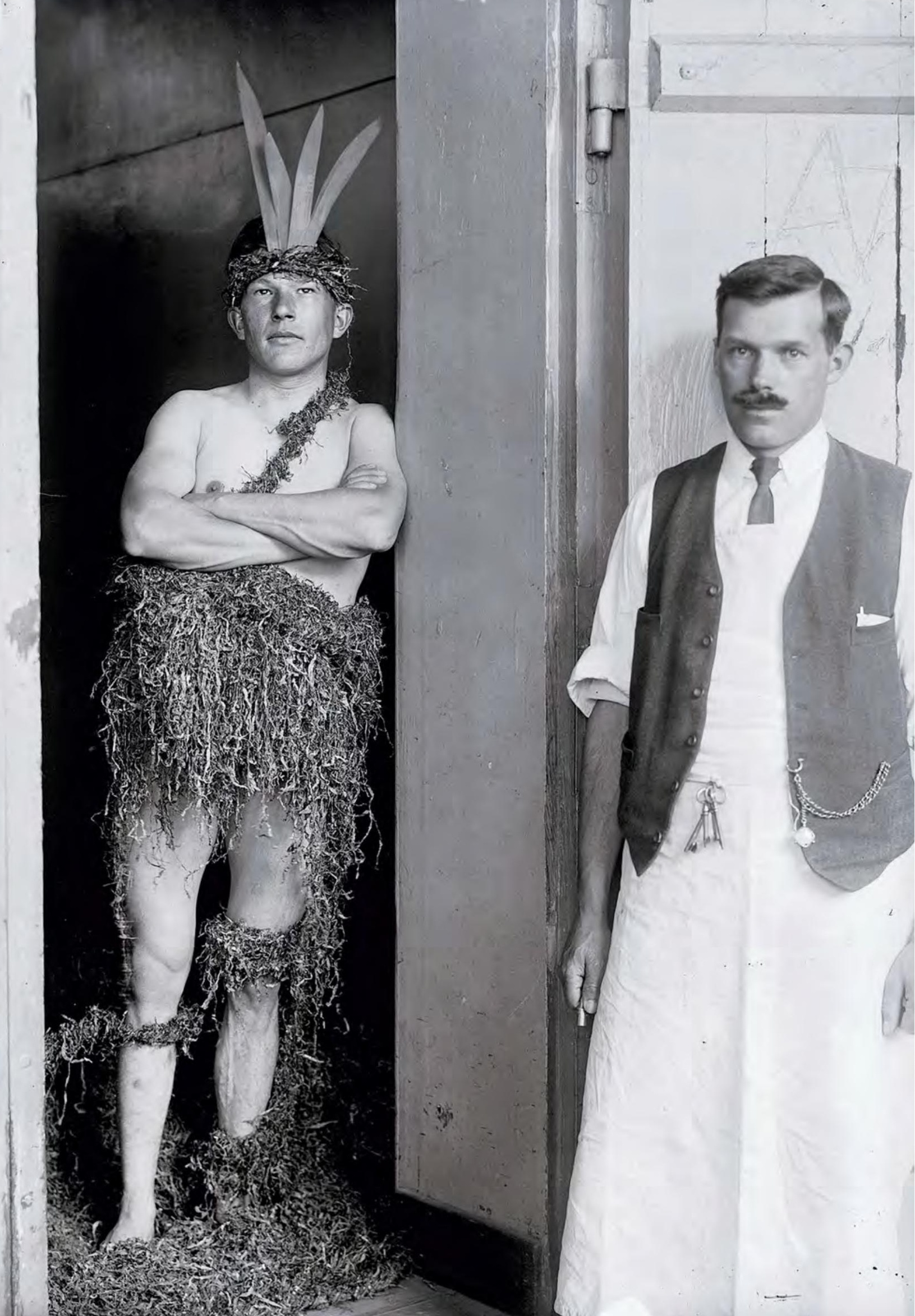


proudly presents this exotic figure, a situation reminiscent of photos of early human zoos. The material Varek, which was found in large piles after being washed, and which could be laboriously fashioned into handicrafts, though these never looked as if they had been made of spun yarn, fit into this context of the primitive and the savage.

However, Lisette H. could not benefit from this renewed interest in herself and her works for three reasons. As a woman, she was much less likely to do independent creative work than a man (Morgenthaler I9I8: 255-308); ${ }^{31}$ handicrafts were rarely considered objects of interest (Ankele 2009a: I62); ${ }^{32}$ and thirdly, Lisette $\mathrm{H}$. spent her years at the Rheinau psychiatric hospital in the wards for "half-calm" or "disturbed" women, which were described as the most hopeless places in the institution. The place where a material is found and used for creative work seems to be central to the emergence of complex works as well as their preservation and reception, which means that a doctor commented on the work and set it aside. In the following section I will discuss the importance of the ward, the place where Lisette H. spent her years in the psychiatric hospital, and the importance of the structure of the day, meaning the treatment, which consisted of making the patients work ("work therapy"), and I will examine what significance was accorded to the material Varek in this context.

\section{The Ward and Treatment}

Since its beginnings in I80o, psychiatry has divided its institutions into wards: for men and women (mostly in separate wings of the building or in their own pavilions) and for so-called calm, half-calm, and disturbed patients. Three classes of care required additional wards (Meier et al. 2007: 56-63).

Each had a yard designed according to the ward's needs: there were "cell yards" for the "disturbed" and "half-calm" wards, which were surrounded by walls or fences; residents of the calm wards had access to a garden or park and sometimes were allowed to go out on their own (Gehry 1932: 15). The division into wards was designed to prevent men and women from meeting, and agitated or aggressive patients from disturbing, threatening, or bothering calmer patients. Wards were meant to create peace and order, but they also allowed for oversight and control (Walser 1970: 4-8). ${ }^{33}$ The early psychiatric facilities built in collaboration between 
psychiatrists and architects were meant to have a therapeutic effect as carefully planned milieus. ${ }^{34}$ In Switzerland the early institutions at Préfargier (1848), Waldau (1855), Burghölzli (1870), and others were usually built in a symmetrical X or $\mathrm{U}$ shape (in some cases with annexes). For example, the calm wards of all three classes were housed in the south-facing central building of the Burghölzli clinic (Meier et al. 2007: 56). The first class was on the second floor, the second was on the third floor, and the third was on the first floor. The middle of the central building on the second floor also housed the apartment of the director and his family. The north-facing side wings with their annexes housed the "half-calm" patients, and farthest away from the director were the one-story "disturbed" wards and cell wards. The spatial arrangement of the wards shows that the bourgeois social order was reflected in this system of accommodation and in how it was handled (ibid.: 56 ). For instance, "calm" patients (those who were able to do structured and relatively complex work at the asylum) lived in brighter, sunnier, and quieter rooms than the "disturbed" patients (who, due to their condition, were unable to do 'useful' work). First-class-patients, who paid a multiple of the general rate, had the most privileged living conditions. At around 1900, institutions were often built in the pavilion style. The annexes to the Rheinau hospital had been built in I9oI, when Lisette H. arrived there, consisting of four large two-story pavilions for about Ioo people each (four wards), two for men and two for women (fig. 9).

Each ward housed around 25 people, and there were several observation rooms, a day room, and cells (Gehry I932: 20-2I). The aerial photograph from 1930 shows the house of the senior physician and his family with an office, pharmacy, and treatment room facing the Rhine. Behind it on the north side (left) are three pavilions for "calm," "half-calm," and "disturbed" women, and to the right the same arrangement for men. In I9OI II7 patients lived in the original pavilions. By 1902 there were already around 400 (ibid.: 36). In I9I4 two pavilions were built for an additional 250 patients (in the foreground of the picture), and the kitchen area was constructed (ibid.: 20). The hospital between Alt-Rheinau and Neu-Rheinau now had a total of IO77 patients, making it one of the largest in Switzerland. Like many rural asylums, Rheinau was self-sufficient, which meant that attendants, patients, and specialists had to work in the vegetable gardens and fields as well as the kitchen, laundry rooms, and tailoring workshop (Blum 2010: 23-30). It had only one class of care. Nevertheless, there was a system of privileges, which resulted in a hierarchy. ${ }^{35}$ In the "calm work wards," patients had limited freedoms and few possessions: "The 'well behaved' had all sorts of belongings with them, perhaps a picture on the wall, 
a bedside table," writes the psychiatrist Karl Gehry, senior physician of the Rheinau psychiatric hospital (1932: 22). Rewards were also given, allowances were paid, extra food was offered, and permission to come and go freely was granted for strenuous or difficult jobs. However, these were only given out in the calm wards, because in the "disturbed" wards only monotonous and simple tasks were required or permitted.

Furthermore, patients were not only assigned to the wards according to their condition, but the transfer to another ward was frequently used as a disciplinary measure and as such part of the treatment: patients were also sent to a "disturbed" ward as punishment. Insight into this practice can be gained from the autobiography of the patient Anna Z. (I867-I938), who lived at the Neu-Rheinau hospital at the same time as Lisette H. (Luchsinger 20I3 ([19I6]). The report that she had written is an impressive demonstration of how large the differences between the wards were, how narrow the freedom of self-determination was in a "disturbed" ward, and how feared these wards were among more privileged patients. They considered the women who had to live there dirty, lazy, and uncontrollable, which contradicted a bourgeois female catalog of virtues, according to which a girl had to be clean, hard-working, and strive for good manners.

\section{The Entanglement of Work and Therapy}

The Rheinau psychiatric hospital was one of the largest farms in Switzerland and so there was plenty of work to be done. Nevertheless, in I886, when the young psychiatrist Eugen Bleuler took over as director of the Rheinau psychiatric hospital at the age of 29, many patients did not work. Bleuler saw this circumstance as responsible for many patients' poor condition. He had the men in one ward split wood and sent patients along with the guards to the fields and subsequently saw great improvements in their condition (Bleuer I898a: n. pag.). He called his ideas on the productive employment of patients work therapy, which was also meant to make it possible for the severely ill to socialize better, in specific activities or for a 


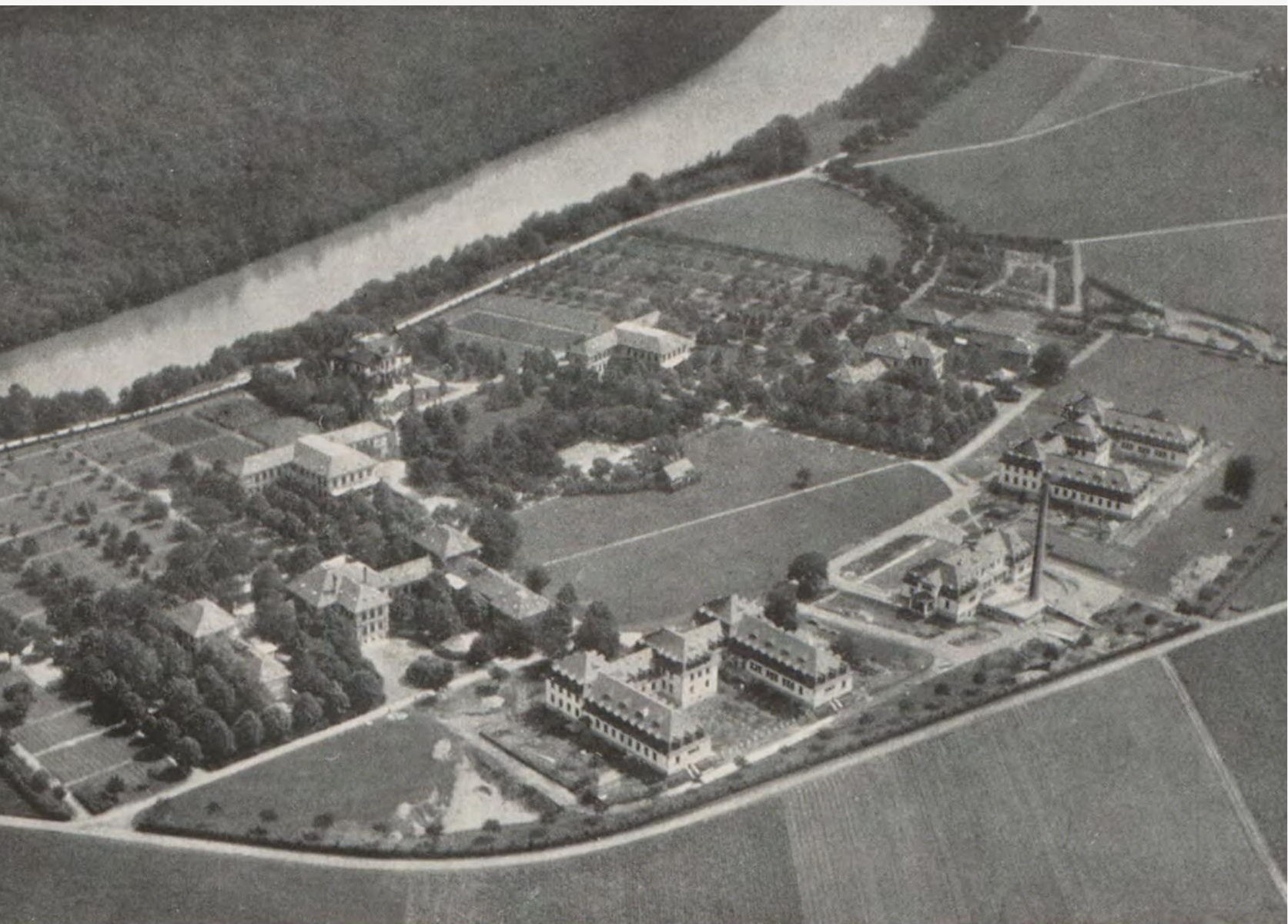

certain amount of time (Bleuer I898b). ${ }^{36}$ This could help them recover to some extent, Bleuler argued. Bleuler coined the term "social healing" (Bernet 2013: 195-206), a partial cure that was hoped to lead to a greater number of discharges. This early form of work therapy was adopted with more or less enthusiasm in almost all psychiatric institutions in Switzerland. In the Rheinau hospital there was much to do. When the first patients arrived at Neu-Rheinau in I90I, "every square meter of garden land ... had to be dug up over and over, passed through sieves, and cleared of stones.... This enormous task was just right for us, since we had all kinds of work for patients, which never ran out" (Gehry 1932: 24). For patients who could not even perform such tasks, Gehry introduced the concept of "occupation," which included both handicrafts and artworks: 


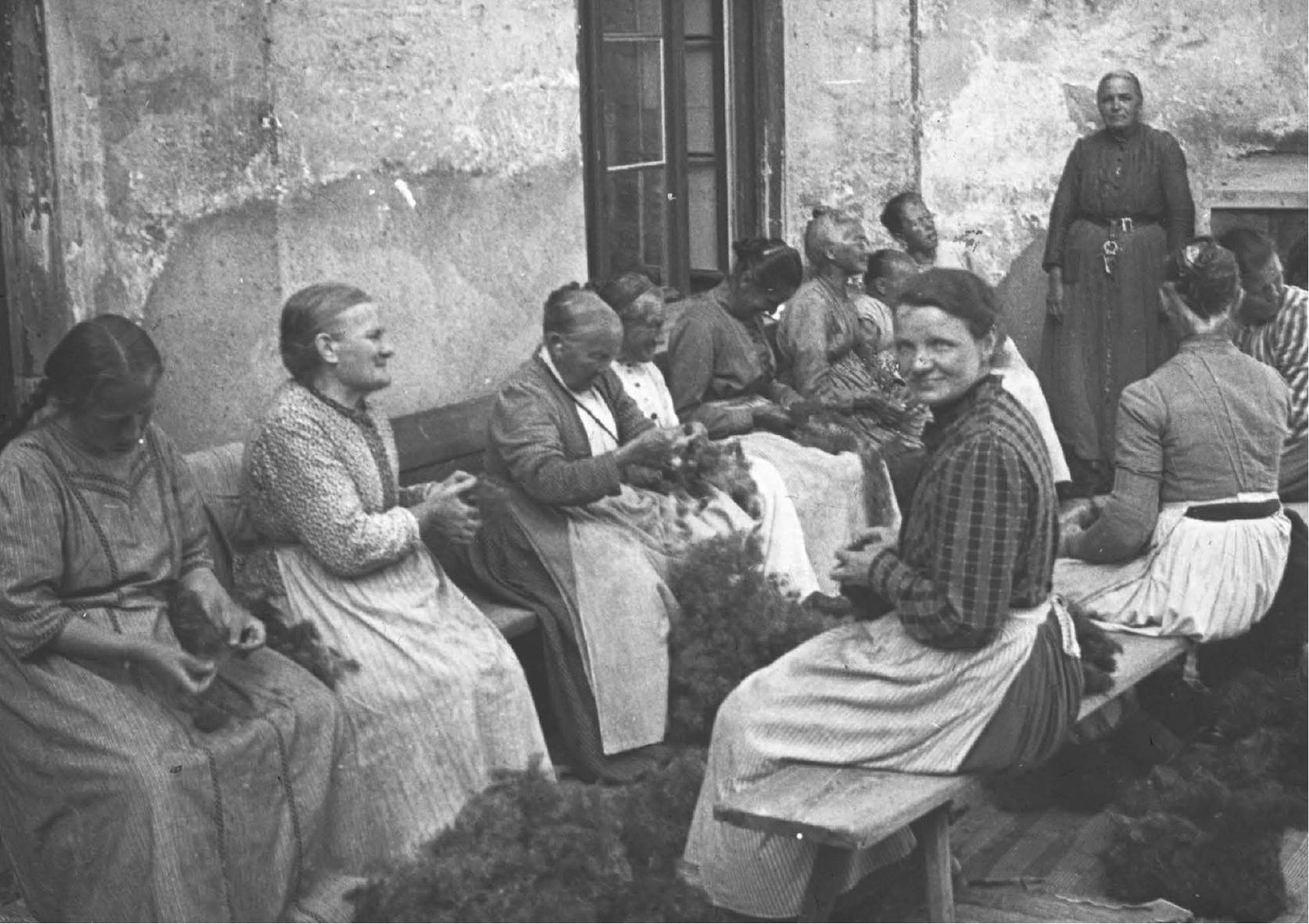

Almost all the women are given knitting or sewing tools, even if to them it is more like a toy than a tool for work; at least they believe that they are doing something, even if their successes do not go so far that we can record them on the work inspection. If a patient initially does not want to work, but draws, ... knits, ... we have nothing against that; however, one day these activities will lead to more useful work. (Ibid.: 47)

Lisette H. stayed either in the day room, in her cell, or in the courtyard surrounded by a picket fence, covered in part with gravel, where she fluffed Varek or horsehair. The material Varek, which was mainly found here, was densely "inscribed," so to speak, with the connotations and judgements on this place and these activities. 
In his popular monograph on the Rheinau psychiatric hospital, Karl Gehry includes a picture of the process of "horsehair fluffing" (which here can stand in for "Varek fluffing") in Alt-Rheinau (fig. Io).

The photo shows eleven patients, their feet sinking into bales of horsehair, which they fluff under the watch of the strict supervisor in the background with a keychain on her belt. Gehry devotes a chapter of his richly illustrated monograph to "treatment." In his commentary on the series of photographs (it shows women preparing vegetables, men weaving straw mats, four handicrafts that illustrate the concept of "occupation," and three photos of agricultural work), he says that work is not compulsory, but that patients should not be left to themselves. Even if they only believed that they were achieving something, their work should be tolerated because it could lead to the "drive to do something more useful" (ibid.: 47, image ibid., no. 3).

Figure Io shows two rows of patients. Walls and two attendants block off the narrow space on three sides. The second attendant, who sits closest to the foreground in a clean apron on the bench, looks into the camera with a friendly face and horsehair in her hands, pointing to the potential usefulness of the activity, like her older colleague. However, many of the patients are looking amusedly to the right, where something entertaining seems to be happening.

Women like these, the psychiatrist suggests based on the photograph, are the most severely impaired, still "beginners" in work therapy. At some point something useful could result from their efforts. The piles of horsehair photogenically represent the disorder against which psychiatric treatment competes in a friendly and patient manner.

Spinning Straw into Gold:

The Range of Meanings Revealed by Lisette H.'s Handicrafts

With the eight works that have survived, Lisette $H$. opens up a different range of meanings from the perspective of an art historian than that intended by the psychiatrists. Her choice of motifs was decidedly limited. Each of her objects is carefully and lovingly designed with an attention to detail. Her works require an unusual, almost unimaginable degree of craftsmanship and patience. These are skills that Lisette $H$. acquired as a housewife and not only had not lost, but perfected with the unwieldy material. The contrast to the aforementioned psychiatric attributions 
(confusion, disorder, and uselessness) could not be greater. It becomes clear from her works that the material itself does not produce any meaning, but is open to any attribution.

Although, based on the entries in her medical record, only a few of Lisette H.'s works were preserved, without exception these revolve thematically around the tasks on the one hand, and on the other hand the appearance or status of a housewife and mother. Especially the fact that she wore a handbag, hat, and fine stockings distinguished the bourgeois woman outside of her home. By limiting her motifs, Lisette H. says little about her biography or her personal experiences, and instead addresses the social role of housewives and mothers. It cannot be ruled out (a letter included in the file suggests as much) that at times Lisette H. denied that she lived as a patient in the asylum. However, this does not explain the efforts that she made to overcome the greatest technical difficulties and, over the years, to make stockings, hats, bags, jewelry, and jackets for infants out of a material that barely allows these things to be worn. However, this makes sense, because Lisette $\mathrm{H}$. left behind everything that these objects represent and no longer had any use for them. By turning to Varek as a knitting material that was actually not suitable for her purposes, she created things that represented something that meant a great deal to her, but that she had lost. The incongruity of the objects is not due to the fact that she used the "wrong" material for jewelry, garments, etcetera, but that she continued to use this material, and with the help of this incongruity evoked both her role as a housewife and mother and the loss of this role. Her skill makes her objects easily recognizable and almost usable. By continuing to do what she was used to doing at the asylum, but under living and working conditions that made the success of her work impossible, Lisette $H$. created a context of meaning. She gave her grief over the loss of her former duties a form that showed it to be continued, and thus incurable. The material speaks through the constellations that she created. She presented a difficult, even unsolvable situation to an imaginary public and answered it emotionally. A transdisciplinary notion of art which is interested in the relationship to "foreign" things, as the art historian Carl Einstein conceived as early as I9I4, or the designs for an expanded conception of art that Bauhaus artists with experience in textiles pursued could even at her time have been interested in Lisette H.'s works if they had had the opportunity to see them. ${ }^{37}$ All the more a current notion of art that is open to investigating as complex conditions as an asylum, conditions that question all attributions of authorship, of creation, and of the access to the public can focus on researching an oeuvre like hers. 


\section{Notes}

1

State Archives of the Canton of Zurich (in the following StAZH), patient file, Rheinau psychiatric hospital, Z 542, KG no. 2644, no page, entry from November 24, 1913: "Recently made a pretty hat out of Varek."

\section{2}

The eight objects made by Lisette H. are now at the State Archives of the Canton of Zurich (StAZH, inventory numbers Z 542.15 to Z 542.22).

\section{3}

These beds were sacks filled with Varek or straw without springs, or ordinary mattresses without a bedframe. Cantini and Pedroletti even mention cellfloors covered with Varek (2000: 77-79).

\section{4}

In the annual report ( Jahresbericht, in the following JB) from 1897, it was noted that a a spin-dryer for seagrass [Varektröchne] was purchased. Pflegeanstalt Rheinau, 1897 annual report, no page.

\section{5}

Cardboard boxes, chewed cardboard, envelopes, berries, grass, paper, chewed bread, marrowbones, silver paper, and other things were used for jewelry, garlands, sashes, weapons, and many other things. On a cardboard revolver from the Morgenthaler Collection (inv. no. 66) see Wernli (2018: 60-71). The Morgenthaler Collection at the Psychiatrie-Museum Bern includes a braided shoe made of Varek (inv. no. 73). Eugen Bleuler (1916) photographed a patient with a Varek sash (fig. 35) as well as a patient wearing a crown of rowan berries (fig. 42), and Angus Ma Phee (1916-1996), a patient at the Craig Dunan clinic in Scotland from 1950 to 1996, knitted clothing out of braided grass. Most of his objects are now part of the Scottish Collection of Art Extraordinary in Pittenweem, Scotland, and some are in the Collection de l'Art Brut in Lausanne, see Laing (2011: 91-102).

\section{6}

An infant jacket made of cotton waste by Lisette $H$. is also preserved (StAZH Z 542.21).

\section{7}

Entries in Lisette H.'s patient file which refer to handicrafts with Varek: March 25, 1902: "Crochets with Varek using a match." May 22, 1902: "Knits a well-proportioned stocking out of split and tied Varek using only a match." May 8 , 1904: "Asks for knitting supplies." June 13, 1906: "Hasn't created little things anymore in a long time." August 23, 1907: "Braids threads of Varek endlessly." June 22, 1907: "Makes rings out of Varek." September 22, 1911: "Often makes various things out of Varek such as hats, stockings, etc.; ties the Varek threads together, out of which she laboriously forms a mesh." November 24, 1913: "Recently made a pretty hat out of Varek." August 1, 1920: "Always has her Varek bag full of threads, stones, and the like, plays with it."

\section{8}

Since objects made of Varek are extremely fragile, there is no history of the reception of objects made of Varek outside the asylum from the time of their creation.

\section{9}

StAZH, Z 542, KG no. 2644, no page; registration by Eugen Bleuler: supplement.

\section{0}

The private foundation of Johann and Maria Hedinger was renamed the Privat-Heil- und Pflegeanstalt Kilchberg in 1888, now the Sanatorium Kilchberg, cf. https://www.sanatorium-kilchberg. ch/ueber-uns/geschichte-tradition-refugium/.

11

The "gloves" were fingerless linen gloves that were put on patients who threatened to injure themselves (Meier et al. 2007: 31)

12

StAZH, Bleuler, see note 7. "Cell clothes" were made of supposedly unrippable, rough, light gray, or striped linen fabric. 
13

Karl Gehry (1881-1962) was the physician at Rheinau. In 1908 he became senior physician, and from 1909 to 1931 he was responsible for Neu-Rheinau in this capacity. From 1931 to 1943 he was director of the Rheinau psychiatric hospital. Gehry writes that on October 23, 1901 "a number of patients from the most overcrowded wards from the old building [moved] to Neu-Rheinau. Soon others from Burghölzli followed." This must refer to the "mass transport" on October 28. Around the new buildings there was still rubble from the construction (Schoop-Russbült 1988: 11). The patient file includes both dates, October 23 and 28, 1901, StAZH, Z 542, KG 2644.

\section{4}

Construction on the annexes to the Alt-Rheinau psychiatric hospital, called Neu-Rheinau, began in 1901. They were expanded in 1907 and 1931.

They consisted of four and later six pavilions for 80 to 120 patients with wards K ("calm, capable of working"), L ("disturbed"), and M ("in need of care"). One pavilion had four wards with 25 patients each. Each had observation rooms (eight beds), a common room, and cells. "Disturbed" wards were surrounded by a wooden fence. In 1901, 117 patients lived in the new buildings. In 1907 there were 500. In 1914, 1077 patients lived at both hospitals, slightly more women than men (cf. Gehry 1932: 15-20).

15

StAZH, Z 542, KG 2644, no page, entry from November 15, 1901.

16

Ibid., entry from January 16, 1902.

17

Ibid., entry from May 22, 1902.

18

At the Rheinau psychiatric hospital, in 2001, when part of the institution was closed down, there were 825 works by patients left that had been collected, ranging from the time of the clinic's founding in 1876 into the 1960s.
This "Rheinau Collection" was inventoried in 2008 as part of a research project of the Zurich University of the Arts under the direction of the author and funded by the Swiss National Science Foundation, and is now in the State Archives of the Canton of Zurich. See Luchsinger/Blum/ Fahrni/Dessort Baur/Rufer (2018).

19

StAZH, Z 542, KG 2644, no page, entry from June 22, 1907. Entry from September 22, 1911: "Often makes various things out of Varek such as hats, stockings, etc." Ibid.: "Knots the Varek threads together, out of which she laboriously forms a mesh."

20

Since the entries in the patient files are not signed, it cannot be said who wrote the individual entries. On individual assistant physicians, see Schoop-Russbült (1988), various notes.

21

StAZH, Z 542, KG 2644, no page, entry from August 23, 1907: "Makes rings out of Varek for herself."

22

StAZH, Z 542, KG 2644, no page, entry from August 1, 1920.

23

StAZH, Z 542, KG 2644, no page, entry from August 24, 1924.

24

The photo is included in the patient file, StAZH, Z 542, KG 2644, no page.

25

StAZH, Z 542, KG 2644, no page, entry from August 23, 1907: "Makes rings out of Varek."

26

Regener quotes the sociologist Robert Castel (1979: 11).

\section{7}

Cesare Lombroso described such "regressions" in 1860 as "atavism." His hypothesis was widely accepted by psychiatrists. Lombroso saw a 
relationship between what in cultural history was assumed to be "early" and a "regression" as a result of hereditary mental illness to ontologically and even phylogenetically "earlier" stages. Lombroso (1887; 1906: 325-330), here in: Luchsinger (2016: 89-104).

\section{8}

This glass slide is the only one in this kind of ethnological photograph from Africa in a collection of 800 slides, most of which depict situations at the Swiss Waldau cantonal mental hospital. Some of the pictures are private travel photos. Psychiatrie-Museum Bern, glass slide collection, Sig. K04-098. On the collection at the Psychiatrie-Museum Bern, see Altorfer (2008).

\section{9}

Psychiatrie-Museum Bern, undated, Sig. K08-092, K05-036.

\section{0}

Psychiatrie-Museum Bern, undated, sig. K11-037.

\section{1}

"Much more significant and consistent with the findings from the children's drawings is the strong preponderance of the male sex over the female (59 men and 18 women)," writes Walter Morgenthaler in his postdoctoral thesis (1918: 257), for which he reviewed 8000 patient files from the Waldau hospital from between 1855 and 1918. See also Luchsinger (2016: 283-286).

\section{2}

In the collection of around 2600 works by patients, which he accumulated between 1918 and 1930, Morgenthaler gave all the works inventory numbers except the handicrafts. See Luchsinger/ Blum/Fahrni/Dessort Baur/Rufer (2018) as in note 20: Inventar der dreidimensionalen Objekte der Sammlung Morgenthaler, 310 objects, 183 of which are handicrafts, https://blog.zhdk.ch/ bewahrenbesondererkulturgueter/3-6-bernwaldau/. Ankele (2009a: 162-165) points to the fact that particularly in the case of pieces of clothing deviations were subject to sharp observation and strict judgement.
33

On the significance of the wards, see also Ankele (2009a: 83-86).

\section{4}

On the hospital buildings up to 1930, for instance those in western Switzerland: Fussinger/Tevaerai (1997); Luchsinger (2016: 150-155). For the Burghölzli university psychiatric clinic, see Meier et al. (2007: 56-62).

\section{5}

The privileges were modest: additional food for dinner, lemonade, a small allowance, toothpaste (cf. Luchsinger 2016: 175).

\section{6}

Beginning in 1924, the elaborated concept of work therapy ("active treatment of patients") according to Hermann Simon, director of the Heil- und Pflegeanstalt Gütersloh, became prevalent throughout Europe. Simon presented it in 1924 at the annual conference of the Deutscher Verein für Psychiatrie. It was also enthusiastically adopted in Switzerland. On the interwoven discourses around work and therapy in the interwar years, see Germann (2007: 195-233); on the concept of "social healing," see also Bernet (2013: 195-206); the most successful person to engage in theory and practice with the conditions that work as a means of therapy had to fulfill was Moritz Tramer (1927/1928, 1927: 187-213; 1928: 122-144), director of the Rosegg hospital in Solothurn. On the relationship between the concept of work therapy and artistic creation, see Luchsinger (2016: 171-180).

\section{7}

See for example Einstein (1994 [1914]: 234), preface in exhibition catalog. Here Einstein criticized the fact that "Distance and prejudices ... impede any aesthetic assessment [of African art, addition by KL], indeed prevent it altogether, because such an assessment requires proximity." His critique also concerns evolutionary hypotheses and "a false conception of primitiveness" (ibid.). On women at the Bauhaus, see Müller (2019). 


\section{Image References}

Fig. 1: City Archive Schaffhausen, Friedrich Ris estate, 91/91A/91B, || 59

Fig. 2: left $40 \times 10.5 \mathrm{~cm}$, right $34 \times 9 \mathrm{~cm}, \mathrm{StAZH}$, Collection Rheinau, inv. no. R 1443.2, Z 542.16 (left), inv. no. R 1443.3, Z 542.17 (right)

Fig. 3: Photo Zurich University of the Arts (ZHdK), FP Conservation of Special Cultural Assets I, StAZH, Collection Rheinau, inv. no. R 1443.2, Z 542.16 (left)

Fig. 4: 13×26×17 cm, StAZH, Collection Rheinau, inv. no. R 1443.1, Z 542.15

Fig. $5: 16 \times 35 \times 5.5 \mathrm{~cm}$, undated, StAZH, Collection Rheinau, inv. no. R 1443.6, Z 542.20

Fig. 6: 16×35×5.5 cm, undated, photo ZHdK, FP Conservation of Special Cultural Assets I, StAZH, Collection Rheinau, inv. no. R 1443.6, Z 542.20

Fig. 7: up to 2004 supplement to KG Z 472.1526, KG 2644, StAZH, now lost

Fig. 8: Photographer unknown, patient and attendant, undated, Museum of Psychiatry Bern, K11-037

Fig. 9: Gehry, Karl (1932): Pflegeanstalt Rheinau, Kt. Zürich, Anhang Kloster Rheinau von Hermann Fietz, Zurich: Verlag Eckhardt und Pesch, p. 21.

Fig. 10: City Archive Schaffhausen, Friedrich Ris estate, 91/91A/91B, 058, from: Gehry, Karl (1932): Pflegeanstalt Rheinau, Kt. Zürich, Anhang Kloster Rheinau von Hermann Fietz, Zurich: Verlag Eckhardt und Pesch, p. 42, bottom illustration.

The following kindly gave their permission to use the illustrations:

Fig. 1, 10: City Archive Schaffhausen,

Friedrich Ris estate

Fig. 2-7: StAZH, photo: ZHdK

Fig. 8: Museum of Psychiatry Bern

\section{Bibliography}

Altorfer, Andreas (2008): In der Anstalt: Das Leben in der Psychiatrischen Klinik anfangs 20. Jahrhundert, exhibition catalog, Psychiatrie-Museum Bern, September 22, 2007-August 23, 2008, Bern: Ed. Solo.

Ankele, Monika (2009a): Alltag und Aneignung in Psychiatrien um 190o: Selbstzeugnisse von Frauen aus der Sammlung Prinzhorn, Vienna/ Cologne/Weimar: Böhlau.

Ankele, Monika (2009b): "Das Krankenbett: Raumaneignungen von Frauen in Psychiatrien um 1900." In: Schweizerische Ärztezeitung/Bulletin des médecins suisses/Bolletino die medici svizzeri 90/49, pp. 1935-1937.

Blum, Iris (2010): "Im täglichen Gang der Anstalt": Das Praxisfeld Arbeit in der Pflegeanstalt Rheinau in den Jahren 1870-1930." In: Luchsinger, Katrin/ Blum, Iris/Fahrni, Jacqueline/Jagfeld, Monika (eds.): Rosenstrumpf und dornencknie: Werke aus der Psychiatrischen Pflegeanstalt Rheinau I867I930, Zurich: Chronos, pp. 23-30.

Bernet, Brigitta (2013): Schizophrenie. Entstehung und Entwicklung eines psychiatrischen Krankheitsbilds um I9oo, Zurich: Chronos.

Bleuler, Eugen (1898 a): Jahresbericht der Pflegeanstalt Rheinau pro I897, Rheinau, unpublished. Bleuler, Eugen (1898 b): Die allgemeine Behandlung der Geisteskrankheiten: erweiterte Antrittsvorlesung an der Universität Zürich, Zurich: Rascher. Bleuler, Eugen (1916): Lehrbuch der Psychiatrie, Berlin: Julius Springer.

Cantini, Claude/Pedroletti, Jérôme avec la collaboration de Geneviève Heller (2000): Histoires infirmières. Hôpital psychiatrique de Cery sur Lausanne, 1940-1990, Lausanne: Editions d'en bas.

Castel, Robert (1979): Die psychiatrische Ordnung: Das goldene Zeitalter des Irrenwesens, Frankfurt am Main: Suhrkamp.

Einstein, Carl (1914): "Negerplastik," preface in the exhibition catalog Neue Sezession, Sechste Ausstellung, Neue Galerie, Berlin, April-Mai 1914, here in: Haarmann, Hermann/Siebenhaar, Klaus (eds.) 
(1998): Carl Einstein, Werke, vol. 1, Berlin: Fannei \& Waltz, pp. 234-252.

Fahrni, Jacqueline (2008): "Propellerknopf und Seegrashut: Materialien und Materialbeschaffung in psychiatrischen Kliniken um 1900." In: Luchsinger, Katrin (ed.): Pläne: Werke aus psychiatrischen Kliniken in der Schweiz um I9oo, Zurich: Chronos, pp. 85-93.

Fussinger, Catherine/Tevaerai, Deodaat (1998): Lieux de folie - monuments de raison. Architecture et psychiatrie en Suisse romande, I8301930, Lausanne: Presses Polytechniques et Universitaires Romandes.

Gehry, Karl (1932): Pflegeanstalt Rheinau, Kt. Zürich. Anhang Kloster Rheinau, von Hermann Fiertz, Zurich: Eckhardt \& Pesch.

Germann, Urs (2007): "Arbeit als Medizin: Die 'aktivere Krankenbehandlung' 1930-1960." In: Meier, Marietta/Bernet, Brigitta/Dubach, Roswitha/Germann, Urs: Zwang zur Ordnung: Psychiatrie im Kanton Zürich, I870-1970, Zurich: Chronos, pp. 195-233.

Goffman, Erving (1973 [1961]): Asyle: Über die soziale Situation psychiatrischer Patienten und anderer Insassen, Frankfurt am Main: Suhrkamp. Herding, Klaus (1992): Pablo Picasso: Les Demoiselles d'Avignon: Die Herausforderung der Avantgarde, "Kunststücke" series, Frankfurt am Main: Fischer.

Meier, Marietta/Bernet, Brigitta/Dubach, Roswitha/Germann, Urs (2007): Zwang zur Ordnung: Psychiatrie im Kanton Zürich, I870-1970. Zurich: Chronos.

Laing, Joyce (2011): “Angus Ma Phee." In: Peiry, Lucienne (ed.): Fascicule de l'Art Brut 23, Lausanne: CAB, pp. 91-102.

Lombroso, Cesare (1887): Genie und Irrsinn in ihrer Beziehung zum Gesetz, zur Kritik und zur Geschichte, Leipzig: Reclam.

Lombroso, Cesare (1906), "Il mio museo." In: Archivio di psichiatria, antropologia criminale e scienze penali II, aXXXIII, no. 13, April 1, pp. 325-330.

Luchsinger, Katrin (ed.) (2013 [1916]): Anna Z., Schneiderin: "Lebensbeschreibung einer (Unglücklichen!) sowie die Schilderung der Erlebnisse wäh- rend zehn Jahren im Irrenhaus," Zurich: Chronos. Luchsinger, Katrin (2016): Die Vergessenskurve: Werke aus psychiatrischen Kliniken in der Schweiz um I9oo: Eine kulturanalytische Studie, Zurich: Chronos.

Luchsinger, Katrin/Blum, Iris/Fahrni, Jacqueline/ Dessort Baur, Isabelle/Rufer, Anita (eds.) (2018): Bewahren besonderer Kulturgüter I, https://blog. zhdk.ch/bewahrenbesondererkulturgueter, accessed August 17, 2019.

Morgenthaler, Walter (1918): "Übergänge zwischen Zeichnen und Schreiben bei Geisteskranken."

In: Schweizer Archiv für Neurologie und Psychiatrie 3/2, pp. 255-308.

Morgenthaler, Walter (1985 [1921]): Ein Geisteskranker als Künstler: Wölfli, Vienna/Berlin: Medusa.

Müller, Ulrike (2019): Bauhausfrauen: Meisterinnen in Kunst, Handwerk und Design, Munich: Elisabeth Sandmann.

Regener, Susanne (2010): Visuelle Gewalt: Menschenbilder aus der Psychiatrie des 20. Jahrhunderts, Bielefeld: Transcript.

Sanatorium Kilchberg, https://www.sanatoriumkilchberg.ch/ueber-uns/geschichte-tradition-refugium, accessed June 23, 2019

Schoop-Russbült, Birgit (1988): Psychiatrischer Alltag in der Autobiographie von Karl Gehry (I88I1962), dissertation, Zurich: Juris

Tramer, Moritz (1927/1928): "Arbeitstherapie." In: Schweizerisches Archiv für Neurologie und Psychiatrie 21 (1927), pp. 187-213, (1928), pp. 122-144. Walser, Hans (1970): Hundert Jahre Klinik Rheinau 1867-1967: Wissenschaftliche Psychiatrie und praktische Irrenpflege in der Schweiz am Beispiel einer grossen Heil- und Pflegeanstalt, published by the Schweizerische Gesellschaft für Geschichte der Medizin- und Naturwissenschaften, Aarau: Sauerländer.

Wernli, Martina (2018): "Schlüsselgeschichten: Walter Morgenthalers Sammlung nachgemachter Schlüssel." In: Luchsinger, Katrin/Hirsch, Helen/ Röske, Thomas (eds.): Extraordinaire! Unbekannte Werke aus psychiatrischen Einrichtungen in der Schweiz um 1900, exhibition catalog, Zurich: Scheidegger \& Spiess, pp. 60-71. 


\section{Untitled}

Lydia Oertelt 


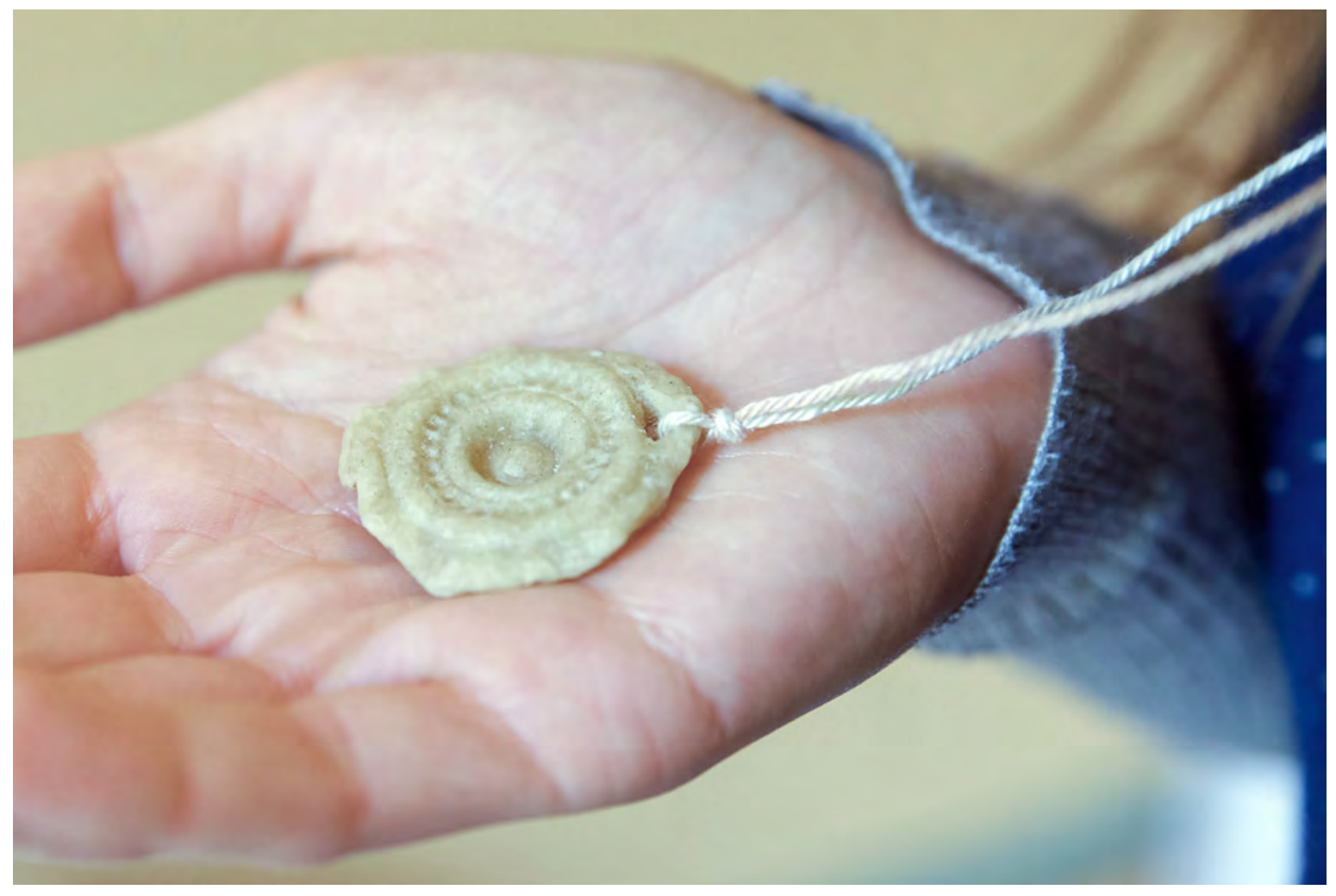




\section{The Uses and Misuses of Television \\ in Long-Stay Psychiatric \\ and "Mental Handicap" Wards, \\ I950s-I980s}

Louise Hide

In June 1949, the Fulham Chronicle newspaper (24 June 1949:7) reported the success of an experiment that had taken place in a ward at the Western Hospital in South West London for patients with infectious diseases. The article explained how "[i]n pyjamas and dressing gowns patients ... saw the Ascot Races simply by leaving their beds, walking down the ward and looking at the two-hour telecast from the course." Accompanying the short article was a photograph of nurses and patients crowding around the television set as a Mr. Wilfred Abery from the Beaufort Electrical and Radio Service pointed out "the highlights of Ascot racing on the television screen."

Television was catching on fast. Within a few years, it transformed the social and cultural life of Britain, bringing people together to witness and experience major public and sporting events from the comfort of their own living rooms or, as in the above case, hospital wards. In 1953, the coronation of Queen Elizabeth II was telecast to the largest national audience ever (Thumim 2002: II), boosting the sale of television licenses to over I million (Moran 20I4: 73). By I96I, 75 percent of British households owned a television set, which increased to 9I percent in 197I (Marwick 2003: 9I). According to John Hartley, television played a vital part in a new "ideology of domesticity" and the long-term transition of built spaces from "dwellings" to "homes" (1999: 105-I06). In America, almost two-thirds of homes had installed a set by 1955 , rising to nearly 90 percent by 1960 (Spigel 1992: I). Indeed, its rapid rise in popularity provoked alarm. From the 1950s, numerous studies were conducted into 
as part of a narrative of domesticity and progress," which in the case of portable televisions altered viewing habits from more social events that promoted family bonding to an activity of "personal indulgence" (20II: 372-373).

Television was also finding its way into different institutional settings, including psychiatric and "mental handicap" wards², many of which already had a "wireless" or radio. Black-and-white television sets began to appear on wards during the I950s (Sherrett 1958), while color televisions grew in popularity from the late I960s (Moran 20I4: I62). Both were expensive and often donated to wards by former patients and charities, or by families or friends of patients (Graffy I983). In her study of the role of television in American public spaces such as shopping malls and airport lounges, Anna McCarthy examines the relationship between television and temporality by exploring its role in "the act of waiting" in hospital waiting rooms. She has observed that "often associated with wasting time, watching television is a way of passing time suddenly legitimized when it takes place in waiting environments" (200I: 199). Yet, hospital waiting rooms and public spaces more generally were built for more transient populations and embedded into large infrastructures with a different mix of interests.

Despite the growing ubiquity of televisions in hospital wards in the UK and America from the I950s, little in-depth research appears to have been conducted by historians on the relationality between the new technology, the long-term ward space, and its occupants. In this essay, I draw mainly on studies that were conducted in the post-war period by social scientists and social psychiatrists primarily in Britain, but also in America and Canada, into the effects of the ward environment on patients. While long-stay psychiatric and mental handicap wards were occupied by people with different mental and physical abilities and needs, often at different stages of their lives, I want to demonstrate how the mutable ontology of the television set could affect the lived experiences of vulnerable patients who, unlike those in the Western Hospital, had little agency. How, I ask, did the television as an object in and of itself gain agency and influence the rhythms, routines and social relationships within different spatial and temporal contexts? How, in the words of Janet Thumim, did it become "part of everyday life, part of mundane experience in ways that fundamentally alter previously crucial structuring boundaries such as those between past and present, here and there, self and other/s" (Thumim 2002: 3)? Contrasting the ways in which the activity of television watching was constituted by perceptions of patients' cognitive, intellectual, sensory, and physical abilities in different ward spaces reveals much about attitudes and practices of the time. 


\section{From Space to Place}

The closest historical study to address the impact of television on residents in a large semi-bounded community is a fascinating account by historian Christina von Hodenberg (20I6) on how television changed communal relations in a small and remote rural farming village in West Germany. Drawing on a rich archive of sources gathered by "gloomy" ethnographers over three decades from the I950s, von Hodenberg describes how traditional community life changed as village residents purchased their own television sets and withdrew from communal spaces and activities in order to watch at home. The daily routine of village life changed. An early-to-bed, early-to-rise rhythm was disrupted as villagers sat up late, glued to their screens. In the summer, those who had previously sat outside their houses to chat with neighbors preferred to stay at home to watch television. People became better informed of current events and less dependent on the counsel of the church and village authorities.

I am not suggesting that a small village in West Germany is comparable to a large mental institution. But there were some resonances given that both communities were porous yet bounded, and isolated from larger urban areas. Von Hodenberg argues that while television had a huge impact on the reconfiguration of family life and small communities, dissolving urban/rural boundaries and accelerating the "modernization, secularization, nationalization and politicization" of rural societies, the old patriarchal system prevailed (2016: 842, 865). The television played a similar role in large institutions by dissipating the borders of the public/private spheres that kept patients separate from the world outside, while changing social relations and the meanings of space inside, reinforcing and re-constituting different networks of power.

The study drawn on by von Hodenberg was one of many conducted from the I950s by a new generation of social scientists. Some subjected large mental hospitals in Britain and the US to particular scrutiny in an endeavor to understand the effects on people of living and working in overcrowded, broken-down, and understaffed institutions (Stanton and Schwartz I954; Caudill I958; Goffman I96I). ${ }^{3}$ That asylums and hospitals were detrimental to patients' physical and mental health had been known for decades, but it was not until this post-war period that the institution began to be framed as pathological in its own right. Terms such as "institutionalization" began to gain currency (Martin 1955). In Britain, Russell Barton, the social psychiatrist and medical superintendent of Severalls Psychiatric Hospital in Essex, used the term 
"institutional neurosis" and published a book in 1959 in which he enumerated a number of factors which, in his opinion, gave rise to such a condition. ${ }^{4}$ One was the "ward atmosphere," which in the third edition from 1976 included "noise" such as "clatter of ward activity, jangling of keys, television sets playing, doors slamming, telephones ringing, noise of electric cleaners, patients shouting and sounds coming from without" (Barton 1976: 19). From the mid-I960s, television documentaries and newspaper exposés began to reveal in horrifying detail how many of society's most vulnerable people - often older people and people with severe learning disabilities - were "cared for" in grossly inhumane conditions. Such revelations ramped up the volume of the call to close the big institutions and to relocate patients back to their families or to smaller residential homes in the community.

This process did not begin in earnest until the I980s. Meanwhile, tens of thousands of people were still living on long-term wards, which were "home" for many. The domestic character of these wards can be traced back to the mid-Igth century when homely effects were intended to have a "civilizing" influence on patients' behavior (Hamlett 20I5). The ward was a place of containment where patients were categorized and managed according to the levels of "care" they were believed to need. It was also a quasi-clinical space, run in Britain by the National Health Service (NHS) from 1948. Doctors, nurses, and other clinicians might have been trained in psychiatry - not everyone was - but much of their work related to the physical care of patients. Older people were believed to be suffering from irreversible conditions such as "senile dementia" that could not be treated (Hilton 20I6). It was assumed that little could be done for those with severe and/or multiple learning disabilities, although people with milder disabilities might expect to leave the institution once a suitable home for them in the community had been found. Long-stay wards were, therefore, both public and private spaces. Clinical, domestic, institutional, and in some respects carceral, they were hybrid environments that were ambiguous by nature. When television sets arrived, they not only added to the domestic atmosphere by reflecting the family home outside but gave wards a visible boost of modern technology. They played a therapeutic role by amusing and occupying as well as educating and informing more able and well patients.

Yet, as Jane Hamlett has noted, not everyone saw the hospital ward as "home" (2015: 7). Space becomes place when, according to Tim Cresswell, "humans invest meaning in a portion of space and then become attached to it in some way" (2015: I6). This could have been the whole ward environment, or just a corner of a room which might be given a specific meaning by an object. Benoît Majerus has demon- 
strated how material culture gains agency by showing how a bed "changes its function when transposed from a standard room to an asylum" (20I7: 272). Once a space had been designated for the television, chairs would be arranged around it in a semi-circle or in cinema-style rows that were lined up in front of it (see fig. I). Inserting the television as both a medium and an object into a ward space changed it to a place which had myriad meanings for different people at different moments in time, particularly when certain programs were being shown. The significance of the television space would not have been the same for older patients who were "parked" in front of a screen for the better part of the day as it was for the patients in the Western Hospital who eagerly crowded around the set to watch the Ascot races in full knowledge that they could walk away when the last horse crossed the finishing line.

"Consciousness constructs a relation between the self and the world," writes Cresswell. Drawing on Edward Relph, he explains how humans can only exist "in place," so "place determines our experience" (2015:38). Yet, landscape or "the world out there," Barbara Bender notes, "refuse[s] to be disciplined" as it invokes "both time and place, past and present, being always in process and in tension." The ontological status of human and non-human actors and objects constantly shifted within the subject/object dyad constituting and reconstituting relations (Bender 2006: 304). This, I suggest, made for a highly unstable ward environment with no single or secure meaning for its residents, particularly for those with diminished agency and ability to create a secure sense of "being" within it.

In her work on cancer narratives, Victoria Bates explores how the senses construct a phenomenological experience of place which is tied to notions of recovery and illness, noting how "the same sensory environment can be a different place over the course of an illness" (2019: IO). There was little expectation of recovery on long-stay wards. On "geriatric" wards for older people, the prognosis for many patients was rarely more hopeful than gradual deterioration and death. The Nursing Times reported in 1966 "that a very great number of elderly people sit waiting for death in mental hospitals, where they have no business to be" (cited by Robb 1967: Io). Attitudes were different on mental handicap wards where, depending on the perceived and actual severity of their disability, both children and adults of different ages might expect to spend the rest of their lives in an institution, or to leave the hospital and live in the community.

Many hospitals began to implement rehabilitation programs to prepare as many people as possible for life in the community. Resources were tight. Progress was slow. Ward doors started to be unlocked to allow patients to move freely around the 
hospital and to mix with each other unchaperoned. New methods were introduced that transformed some wards which had previously been run along quasi militaristic lines into therapeutic communities involving more meaningful interactions between the nursing staff and patients. Although reservations were sometimes expressed around installing televisions on wards, broadly it was seen as a good thing. In I969, Dr. J. Gibson from St. Lawrence’s Hospital for people with mental handicaps described the implementation of the latest reforms: wards had been opened; the sexes were allowed to mix; food, clothing, and heating had improved. ${ }^{5}$ Furthermore, television sets had been introduced onto the wards, which he claimed "brought the patient more sharply into appreciation of the outside world and has entertained and educated him" (Gibson 1969: 592). In the I980s, David Hughes and his team conducted an ethnographic study of a single ward called Ward Twenty, which had been established to provide young people with learning disabilities in Scotland with a less institutional and more "family" style of life. They reported that the television was usually on all day, with Hughes commenting that "what patients come to know about such areas as relations between the sexes, and many aspects of everyday family life, almost certainly derives in large part from what they see on the small screen" (Hughes et al. 1987:39I). For those who were getting ready to leave institutional care, television could potentially have helped to prepare them for life outside, even though the "world" patients viewed was carefully constructed and mediated by two broadcasters competing for audiences' attention: the BBC, which was funded by license fees and considered informative, educative and paternalistic; and ITV, which dished up a menu of light entertainment, old films, and soaps that were paid for through advertising (Donnelly 2005: 77-79). Television did, therefore, play a role in the deinstitutionalization process. Often described as a "window on the world," ${ }^{6}$ it dissolved some of the notional boundaries between the hospital and the world outside, between the private and the public spheres.

The real therapeutic benefits of television were believed to be gained not through the direct interaction between a patient and the TV screen but through a triadic relationship between patient, television, and staff involving activities and interactions based on programs they had watched together. At Severalls Hospital, patients were allowed a limited amount of television watching. On Sundays, they could watch from 5 to 7 p.m. Then, after visiting and supper time between 7 and 8 p.m., patients who needed "supervision" were put to bed, while others were permitted to watch television until io p.m., which was to be followed by a brief discussion of the programs viewed. For Barton, it didn't matter what they discussed; it was "participation 
in the discussion that counts" (I976: 42-44). Engagement between patients, staff, and the television took "watching TV" into the territory of occupational therapy which nurses, rather than qualified occupational therapists, provided in some mental handicap hospitals (Jones I975: 27-28). In the early I960s at Holywell Hospital in Northern Ireland, the ward staff devised a series of activities and music evenings that were based on television game shows and popular programs such as "Twenty Questions," "Juke Box Jury," and “Top of the Pops.” Both staff and patients participated in these games, all competing with each other (Prior/McClelland 2013: 405).

Attitudes towards staff engagement with television were ambivalent, even when it was for the patients' benefit. A major concern in both general and psychiatric hospitals in America and Britain was that it would distract nurses from their work (Fuqua 2003: 242). Many institutions operated a strong task-centered, rather than patient-centered, culture where nurses focused on keeping the ward looking clean and tidy but had little meaningful interaction with patients. When not actively occupied, they might prefer to remain in the nurses' station or office. Sociologist Pauline Morris carried out a major survey of almost half the hospitals for the "subnormal" in England and Wales during the i96os. She remarked that in one institution, even when a shift was well staffed, nurses stood "around talking to each other" rather than interacting with "fifty older children wandering around aimlessly or sitting making noises" (2006 [1969]: I70). Television could entice staff out of their office. The American psychologist D. L. Rosenhan (1973) noted how nurses would occasionally emerge from "the cage" - a glass station that allowed them to observe patients - to give medication, speak to a patient etc., and to watch television in the dayroom, even though they tended to keep to themselves. During an inquiry into abuse at South Ockendon Hospital in East London, one nurse asserted in the early I970s that she had been most distressed by the patients' "clothing and appearance," and how they were "forsaken-looking." She stated that "the staff were looking at television, and the patients needed attention" (Committee of Inquiry 1974: 92).

In some hospitals, especially those which were short-staffed, television was a convenient way of trying to keep patients occupied with as little effort as possible. In the hospitals she visited, Morris observed that "[a]lmost all wards were equipped with items which entertained the patients with the minimum of supervision, i.e. television and radio" (2006 [1969]: 9I). Following a visit to a mental handicap hospital, she noted that there was nothing to suggest that "television and radio programmes or reading matter were chosen with the cognizance of the abilities, needs and interests of the patients" (ibid.: 226). These items were purchased by charities 
such as the League of Friends, which, Morris argued, could have spent their money better by providing comfortable chairs, which wards were in desperate need of. Indeed, Morris reported that over 89 percent of patients were in wards with a television, radio, and record player, compared to 70 percent of patients who were in wards providing toys, games, or books (ibid.: 9I), which generally required more interaction by staff. However, given that television was a regular feature of domestic spaces by the late I960s, the absence of a ward set may have given the impression of depriving residents of a valued source of entertainment and enjoyment.

Other hospitals did attempt to engage more fully with the potential therapeutic effects of television. In their study of three anonymized mental hospitals in England and Wales conducted in the late I950s, sociologists Kathleen Jones and Roy Sidebotham reported that long-stay wards in one mental hospital employed special "television nurses" - described as "married women who work part-time" - on the female side. Their role was to attend to the patients during "television hours" in order to free the regular staff to attend to other tasks (I962: 59). This practice mirrors those recorded by Joy V. Fuqua (2003), who examines how television was integrated into general hospital nursing practice in America in the post-war period, when TV hostesses were employed to meet patients' viewing needs and to ensure that nurses were not distracted from their work.

Well aware of the adverse effects of watching too much television and the temptation of using it to keep patients quiet, some hospitals went to considerable lengths to discourage too much viewing. Jones and Sidebotham reported how one hospital placed television sets in dining rooms where chairs were hard in order to encourage patients to find other "more profitable forms of activity" and not just to "keep patients quiet" (1962: 87). At Severalls Hospital, Russell Barton devised a timetable of activities that offered patients more stimulating and sociable activities. He was not alone in believing that activity could reduce "aggression, tearing, picking, hoarding, masturbation and other undesirable behavior." While he believed that "television was useful to fill in some evenings," he argued that "it is better to do something than to watch something" (I976: 42, 44, my emphasis).

Concerns in wider society that too much television watching would replace more valuable social activities were reflected in hospitals. Pauline Morris (2006 [1969]: I85) explained how dances (often single-sex) became less popular with patients after televisions were introduced on the wards. They did, however, tend to be more popular with male patients. Morris suggested that this may have been because men were less bothered about their appearance and easier for the nursing staff to get 
ready. While the men were at the dance, the women might be watching television, reflecting national trends which claimed that children and older people watched the most television, and that it was more popular among women than men (Marwick 2003: 206). However, if there were no other forms of activity available, Morris (2006 [1969]: 170) reported that on the male wards in one mental handicap hospital patients tended to play billiards or watch television, while on the female wards a few women might sew, knit or do jigsaws. Both sexes watched television depending on the wider context in which it was available.

\section{The Meaning of "Watching"}

In 1972, Noel Wharton published a study of two "crib" wards in a state institution for the "mentally retarded" in Ohio. Patients were described as having "limited or non-ambulation capacity" which meant spending most or all of their time in a crib. Staff on the female ward, he reported, would spend the most time with patients between dinner time and bed time "usually watching television" together (I972: I27, I3I). In this section, I examine the meaning of "watching" television. Was it an activity? Did it, as Barton questioned, imply doing something? Did it need the interaction of staff to legitimize it as such? What did it signify for patients who were unable to engage with it in a meaningful way? A 1974 Canadian study into the patterns of activity and uses of space on three wards in a large mental hospital classified watching television as "[m]ixed active behavior" alongside listening to the radio, eating, or housekeeping with others (Willer et al. 1974: 458). This ambiguous classification allowed the act of watching television to be imbued with a multitude of meanings depending on the temporal and spatial context as well as the subjectivity of the individuals who were "doing" the watching, or not. I have discussed above how three-way interactions between television, patients, and staff could be therapeutic. In this section I turn to the very large number of patients, many with severe cognitive and sensory impairments, for whom television reinforced the harmful effects of the institution.

In the early 1960s, researchers John Cumming and Elaine Cumming reported how the huge dayrooms in the "chronic wards" of Weyburn Hospital in Saskatchewan were "lined around the edges with chairs - like an enormous waiting room" (I962: IOI). They noticed how patients tended not to sit in these rooms, but on floors of the hallways watching the attendants and doctors go by, commenting that patients 
would always seek out places "where interaction is highest." This suggests that watching the coming and going of staff on the ward was a meaningful activity for patients who preferred to observe a world to which they felt some connection, however mundane and routine. This, then, raises the question of how patients who were unable to choose where they would spend their day or evening experienced being "parked" or coerced to sit in front of the television with little say in the matter.

Over the weekend in Ward Twenty, when not much was going on and fewer staff members were on duty, the television and radio or record player tended to be on all day because nurses were not obliged to organize any activities. Staff remarked on how the children were "watching TV," giving the impression that they were doing something, even though there was little interaction between the television set and the children. Few appeared to be engaged with the programs (Hughes: 406, footnote 7). Morris noted that in one hospital where the television was on constantly in the day rooms "one patient ... preferred to escape the cathode tube image by sitting alone in an ill-lit lavatory, quite absorbed in reading seed catalogues!" (2006 [1969]: 232).

For those who were unable to remove themselves from the set, its effects reached beyond engendering poor posture and inactive bodies, or of rendering minds numb and passive (Black: 2005). For many, it caused deep psychological and emotional stress. First, as we see in figure I, patients may have been placed in chairs facing the television screen but with their backs to the ward, psychologically dislocating them from ward life and disrupting their sense of feeling anchored and secure in their environment. Second, many people were mentally unwell and/or experienced severe and profound cognitive impairments which would have limited the degree to which they could engage with and follow television programs, if at all. This was exacerbated by the pernicious practice of routinely removing spectacles and hearing aids on some British geriatric wards, making it harder to see and hear the television (Robb I967: xiii). Third, the sound emitted from televisions and radios was known to be stressful. One seriously ill woman in a general hospital reported in I959 how she suffered "absolute torture" due to the constant noise of the television, which other patients did not want to switch off (Observer 1959: 5). A recent study into the environment of a home for people living with dementia in Canada suggests that "excessive ambient noise" such as that made by staff, other residents, and television or radio agitated patients, negatively affecting social interactions in special care units (Campo/Chaudhury 20II). As Bates notes, sound becomes intrusive noise, especially when one is anxious and has no control over it (20I9: I8). In many general hospitals, patients were given headphones so that the television did not 
disturb other patients (Liverpool Echo 1960: 9; Coventry Evening Telegraph 1976: 5). Even though this gesture was mooted for long-stay mental hospital wards from the I950s (Warwick and Warwickshire Advertiser I95I: I2), I have yet to see a report of headphones being used in this context.

To contain noise, some hospitals designated special television rooms that were away from the main ward area. This did reduce stressful background din on the ward, but it could also isolate some patients even further. In the male crib ward in Ohio, some patients would be "gotten up" before being taken in wheelchairs to the dayroom where they were placed in front of the television and left there for some hours. They rarely spoke to each other "unless to comment on something that happened on the television or in the hall outside" and became isolated because the room was separated from the rest of the ward. They were returned to the same room for a couple of hours after dinner in the evening, when staff might "duck in and out ... briefly interacting with patients" (Wharton I972: I3I-I32). The presence of the television in this room did, therefore, legitimize the practice of placing patients inside this container within a container where their presence would almost certainly have been questioned had the television not been there.

\section{Technology of Control}

One evening, when a new seating arrangement was implemented on Ward Twenty, children were reported to have been "placed in unusually neat rows with the seats facing the T.V." Those who normally sat on the floor in order to see and hear the set better were instructed to sit on the chairs, even though some of them were short-sighted and not able to see the television because their glasses were kept at school (Hughes et al. 1987: 388). This notion of the television as an agent of control is reflected in accounts from other institutions. One doctor at a hospital for "mentally defective" children in Somerset, England claimed in 1955 that the children's behavior improved during the hours leading up to the television being switched on, so that they might "not be stopped from attending on account of misbehavior" (De M. Rudolf I955: 59).

The television's role as a technology of control was woven into practices on adult wards as well. In an environment in which patients were so often infantilized, watching television at night conferred on them a certain adult status denoting 
that they were mature enough to watch programs which could include violent and sexualized content. At night, television spaces became adult spaces. In one private hospital in Boston, patients were granted "television privileges," which meant they could stay up late in return for good behavior (Segal 1962: 262). One psychiatric social worker with a father in one of the big London psychiatric hospitals explained how she visited him one evening and found that he was already in bed by 7 p.m. He claimed that because he was not on a ward with a television set, he and all the patients were "settled down early" (Robb 1967: 6I-62). In other words, patients were "managed" and "kept quiet" in the evenings, either by being put to bed (often with a sedative) or by being allowed to watch television, if they had earned the privilege. Being allowed to stay up late and watch television became a reward for good behavior. Patients who had this privilege withdrawn could consider themselves punished (Jones et al. I975: 25, II2). Patients not only had to earn the right to stay up late and watch television; they had to earn the right to be treated as an adult. It was through the agency of the television set that this was made possible.

\section{Conclusion}

Since the mid-Igth century, wards for the long-term care of people who were mentally unwell or with intellectual disabilities were in many respects hybrid domestic and quasi medical spaces of containment. In this essay, I have argued that these characteristics continued well into the 20 th century and imbued the objects and people inside them with multiple and mutable meanings. Consequently, the implementation of objects such as the television set could be misused and even abused, which created an unstable and insecure environment particularly for the most vulnerable patients able to exercise minimal agency.

Some patients enjoyed watching television. As a medium, it could have therapeutic value that could help to forge stronger bonds between staff and patients, and dissolve boundaries between the institution and the wider world, sometimes playing an important role in preparing patients to move out of the hospital and live in the community. Quickly absorbed into the spatial and temporal landscape of the ward, it soon became embedded in networks of power and invested with agency that changed and shaped rhythms, routines, behaviors, and even identities. But television could also legitimize practices which excluded some of the most vulnerable 
patients from ward spaces and increased the stress felt by those who were left in front of it for hours on end, thus maintaining the appearance that they were doing something.

The television set was and continues to be a powerful technology in and of itself. When used discriminately and thoughtfully, it could add to the quality of life of long-stay patients; when used indiscriminately, it could be pathological and reinforce the harmful effects of institutional living.

\section{Notes}

With thanks to Monika Ankele, Joanna Bourke, Jane Hamlett, Simon Jarrett, and Benoît Majerus for their useful and insightful comments.

1

John P. Murray (1980) included a bibliography of 3,000 citations relating to the effects of television on children between 1955 and 1980 .

\section{2}

I use the terminology of the period and inverted commas for first mention only.

\section{3}

In 1954, the number of people packed into mental institutions in England and Wales exceeded an unprecedented 151,000 (Jones 1993: 161); 46 percent were estimated to have lived in the institution for over ten years (Turner et al. 2015: 605).
4

In Britain, these included the News of the World 1967 report on Ely Hospital in Cardiff and a 1968 World in Action documentary on the appalling conditions in Ward Fl3 at Powick Hospital in Worcestershire.

5

Despite so-called "improvements," the 1981 documentary The Silent Minority revealed the shocking conditions in which people were still living at two hospitals, one of which was St. Lawrence's.

6

The current affairs program Panorama used the subtitle "Television's window on the world," http:// news.bbc.co.uk/panorama/hi/front_page/newsid _7753000/7753038.stm, accessed July 11, 2019. 


\section{Bibliography}

Barton, Russell (1976): Institutional Neurosis, 3rd edition, Bristol: John Wright \& Sons.

Bates, Victoria (2019): "Sensing Space and Making Place: The Hospital and Therapeutic Landscapes in Two Cancer Narratives." In: Medical Humanities 45, pp. 10-20.

BBC: "Panorama: A History," 10 December 2008 http://news.bbc.co.uk/panorama/hi/front_page/ newsid_7753000/7753038.stm, accessed July 11, 2019.

Bender, Barbara (2006): "Place and Landscape." In: Tilley, Christopher/Keane, Webb/Küchler, Susanne/Rowlands, Michael/Spyer, Patricia (eds.): Handbook of Material Culture, London: Sage, pp. 303-314.

Black, Lawrence (2005): "Whose Finger on the Button? British Television and the Politics of Cultural Control." In: Historical Journal of Film, Radio and Television 25/4, pp. 547-575.

Campo, Michael/Chaudhury, Habib (2011): "Informal Social Interaction among Residents with Dementia in Special Care Units: Exploring the Role of the Physical and Social Environments." In: Dementia 11/3, pp. 401-423.

Caudill, William (1958): The Psychiatric Ward as a Small Hospital, Cambridge: Harvard University Press.

Chambers, Deborah (2011): "The Material Form of the Television Set." In: Media History 17/4, pp. 359-375.

Committee of Inquiry (1974): Report of the Committee of Inquiry into South Ockendon Hospital, HCl24, London: HMSO.

Corner, John (1991): Popular Television in Britain: Studies in Cultural History, London: BFI Publishing.

Cresswell, Tim (2015): Place. An Introduction, 2nd ed., Chichester: Wiley Blackwell.

Cumming, John/Cumming, Elaine (1964 [1962]): Ego and Milieu: Theory and Practice of Environmental Therapy, London: Tavistock Publications.
De M. Rudolf, G (1955): "The Effect of Children's Television on Behaviour." In: Mental Health 14/50, pp. 55-60.

Donnelly, Mark (2005): Sixties Britain: Culture, Society and Politics, Harlow: Pearson Education. Fuqua, Joy V. (2003): "You Take Care of the Patients, We'll Take Care of Their TV': Attending to Hospital Television." In: Television E New Media 4/3, pp. 231-256.

Gibson, J. (1969): "Subnormal Hospitals." In: The British Medical Journal 3/5670, p. 592.

Goffman, Erving (1991 [1961]): Asylums. Essays on the Social Situation of Mental Patients and Other Inmates, London: Penguin Books.

Graffy, Jonathan (1983): "Ward Meetings: A Forum for Patients' Concerns." In: British Medical Journal 286/6362, pp. 371-372.

Hamlett, Jane (2015): At Home in the Institution. Material Life in Asylums, Lodging Houses and Schools in Victorian and Edwardian England, Basingstoke: Palgrave Macmillan.

Hartley, John (1999): The Uses of Television, London: Routledge.

Hilton, Claire (2016): "Psychogeriatrics in England in the 1950s: Greater Knowledge with Little Impact on Provision of Services." In: History of Psychiatry 27/1, pp. 3-20.

Hughes, David/May, David/Harding, Susan (1987): "Growing up on Ward Twenty: The Everyday Life of Teenagers in a Mental Handicap Hospital." In: Sociology of Health \& Illness 9/4, pp. 378-409.

Jones, Kathleen/Sidebotham, Roy (1962): Mental Hospitals at Work, London: Routledge and Kegan Paul.

Jones, Kathleen/Brown, John/Cunningham, W. J. /Roberts, Julian/Williams, Peter (1975): Opening the Door: A Study of New Policies for the Mentally Handicapped, London: Routledge and Kegan Paul. Jones, Kathleen (1993): Asylums and After: A Revised History of the Mental Health Services from the Early I8th Century to the I990s, London: Athlone Press.

Majerus, Benoît (2017): "The Straitjacket, the Bed and the Pill: Material Culture and Madness." 
In: Eghigian, Greg (ed.): The Routledge History of Madness and Mental Health, London/New York: Routledge, pp. 263-276.

Martin, Denis V. (1955): "Institutionalisation." In: The Lancet, 3 December, p. 1188.

Marwick, Arthur (2003): British Society since I945, 4th edition, London: Penguin.

McCarthy, Anna (2001): Ambient Television: Visual Culture and Public Space, Durham: Duke University Press.

Moran, Joe (2014 [2013]): Armchair Nation. An Intimate History of Britain in Front of the TV, London: Profile Books.

Morris, Pauline (2006 [1969]): Put Away: Institutions for the Mentally Retarded, London: Aldine Transaction.

Murray, John P. (1980): Television and Youth. 25 Years of Research and Controversy, Boys Town, Nebr:: Boys Town Center of the Study of Youth Development.

Oswell, David (2002): Television, Childhood, and the Home: A History of the Making of the Child Television Audience in Britain, Oxford: Oxford University Press.

Prior, Pauline/McClelland, Gillian (2013): "Through the Lens of the Hospital Magazine: Downshire and Holywell Psychiatric Hospitals in the 1960s and 1970s." In: History of Psychiatry 24/4, pp. 399-414. Robb, Barbara on behalf of AEGIS (1967): Sans Everything. A Case to Answer, London: Nelson. Rosenhan, David L. (1973): "On Being Sane in Insane Places." In: Science 179/4070, pp. 250-258.

Segal, Bernard E. (1962): "Nurses and Patients: Time, Place, and Distance." In: Social Problems 9/3, pp. 257-64

Sherret, David (1958): "Impact of New Methods of Treatment in A Provincial Mental Hospital." In: British Medical Journal 1/5077, pp. 994-996.

Spigel, Lynn (1992): Make Room for TV. Television and the Family Ideal in Postwar America, Chicago: University of Chicago Press.

Stanton, Alfred H./Schwartz, Morris S. (1954): The Mental Hospital. A Study of Institutional Participation in Psychiatric Illness and Treatment, London: Tavistock Publications.
Thomson, Mathew (2013): Lost Freedom: The Landscape of the Child and the British Post-War Settlement, Oxford: Oxford University Press.

Thumim, Janet (ed.) (2002): Small Screens, Big Ideas: Television in the I950s, London: I B Tauris. Turner, John/Hayward, Rhodri/Angel, Katherine/ Fulford, Bill/Hall, John/Millard, Chris/Thomson, Mathew (2015): "The History of Mental Health Services in Modern England: Practitioner Memories and the Direction of Future Research." In: Medical History 59/4, pp. 599-624.

Von Hodenberg, Christina (2016): "Square-Eyed Farmers and Gloomy Ethnographers: The Advent of Television in the West German Village." In: Journal of Contemporary History 51/4, pp. 839-65. Wharton, Noel (1972): "A Study of the Social Functioning of Institutionalized Mentally Retarded 'Crib' Patients." In: Sociological Focus 5/4, pp. 120-141.

Willer, Barry/Stasiak, Eugene/Pinfold, Peter/Rogers, Marjorie (1974): "Activity Patterns and the Use of Space by Patients and Staff on the Psychiatric Ward." In: Canadian Psychiatric Association Journal 19/5, pp. 457-462.

Wood, Helen (2015): "Television - The Housewife's Choice? The 1949 Mass Observation Television Directive, Reluctance and Revision." In: Media History 21/3, pp. 342-359.

\section{Newspapers}

NA, (1949): "Television in Hospital Ward." In: Fulham Chronicle, 24 June, p. 7.

NA (1951): "Televisions in Hospitals. Earphones for Patients." In: Warwick and Warwickshire Advertiser, 5 January, p. 12.

NA (1959): "'Absolute Torture' of Television in Hospital Ward." In: The Observer, 4 December, p. 5

NA, (1960): "Silent Television for Patients." In: Liverpool Echo and Evening Express, 26 May, p. 9. NA (1976): "Vision On, Sound Optional, in the Wards." In: Coventry Evening Telegraph, 3 June, p. 4. 


\section{Buttons and Stimuli: \\ The Material Basis of Electroconvulsive Therapy \\ As a Place of Historical Change}

Max Gawlich

While the "pill" is emblematic of the pharmacological turn in psychiatry, in addition to lobotomy, electroconvulsive therapy (ECT) is considered iconic for somatotherapy and shock therapies in the mid-twentieth century. However, it not only represents a particular complex of ideas about forms of psychiatric treatment, but, due to the concrete technological object, was an essential element of the therapeutic act and psychiatric practice. The central features of electroconvulsive therapy were a technical device, the unusually strong electrical stimulus, and patients who experienced an epileptic seizure while unconscious. ${ }^{.}$The first machines for electrically induced convulsive therapy were developed and presented in 1938 and 1939 in Italy and Japan. Lucio Bini (1908-1964), Ugo Cerletti (1877-1963), and their colleagues in Rome, as well as the Japanese psychiatrists G. Yasukoti and H. Mukasa in Fukuoka pursued electro-technical strategies to replace pharmacological substances such as Metrazol as triggers for seizures. ${ }^{2}$ Shortly before and at the beginning of the Second World War, this information was disseminated especially by refugees and emigrants. For example, the Krakow neurologist and psychiatrist Zenon Drohocki (1903-1978) had publications and blueprints among his documents during his attempt to escape to Switzerland via France (Borck 2005: 258). The Berlin doctor Lothar Kalinowsky (I899-1992) - who was first an employee of Cerletti in Rome and later emigrated to the United Kingdom and the United States - also campaigned for the Italian device during his escape (Peters 1992: 36I-362). In the I940s numerous psychiatrists had their first contact with electroconvulsive therapy and its device. However, the economic and political conditions of the Second World War often prevented or impeded a deep engagement with the new therapy as well as the continuation of international exchange, so that it was only in the late I940s that it became an established or mature form of therapy. Yet the I940s were the time when the ECT device took 
shape in the respective national contexts and fundamental technological decisions were made. Thus, based on the development of the device, a period can be defined within which electroconvulsive therapy arrived at its form. This example can be used to pose the question of how the relationship was shaped between a therapeutic practice and a technological object. In what form did the development of treatment and that of enabling technology define each other? How did established therapeutic processes influence the design of the devices? How were local conditions - material and conceptual - integrated into the construction of the new device?

The development of ECT as a technological object will be considered with examples from the history of its development in Switzerland and Germany. The case studies come from the company Siemens-Reiniger Werke ${ }^{3}$ in Erlangen, Germany, as well as from the psychiatric clinic Münsingen, Switzerland, and from the mental hospital [Heil- und Pflegeanstalt (HPA)] Eglfing-Haar near Munich. ${ }^{4}$ In the following, the main interest in the relationship between therapeutic practice and technological factors will be further defined. Then I will clarify the conceptual basis of the investigation and further outline the historiographic research on the topic.

The starting point is the basic assumption that the introduction of ECT changed the concrete practice of convulsive therapy. In the historical example this relates to the following aspects: How was the pharmaco-therapeutic unit of measurement of the dose altered through the use of electricity and adapted along with the technical design? Furthermore, I will follow the interaction between clinical practice and technological development, meaning the co-evolution of psychiatric therapy and the technological object. I am neither assuming that the technical apparatus was a functional and symbolic expression of the ideological or epistemic system of psychiatry, nor that the therapy was unilaterally determined by the artifact. Also, the relationships between therapeutic knowledge, action, and technical artifact are historically contingent. As Benoit Majerus has shown, the history of material culture offers a way of understanding this and can allow insights into the relationships and connections between things and their human and non-human environment as well as the everyday experience of doctors, patients, and caregivers (Majerus 20I7b: 272-273).

The topic of therapeutic technology and material culture has receinicved some attention in recent psychiatric historiography. The research followed broader developments in historical studies, where at the latest since the turn of the millennium material questions have been an increasing focus (Ludwig 20II: 6-7). In this field, a new materialism was proclaimed in a gesture of distinction. In contrast to or in expansion of a cultural history that mainly studies texts and images, now the focus 
was on things, bodies, and practices (Daston 2004: I7; Sarasin I999: 439; Stoff I999: I45-I46). Andreas Ludwig (20II: 7-8) and Simone Derix et al. (20I6) offer an overview of these recent developments. In the history of science and medicine, research has been conducted on note-taking systems, materials, and substances (Rheinberger 2002; Stoff 2012; Hess/Mendelsohn 2013), and the history of psychiatry has also begun to explore the field (Topp et al. 2007; Majerus 20I7a; Peter 2013). Psychiatric therapy in general, and electroconvulsive therapy in particular, have rarely been studied in terms of their practice or material culture. Conventional perspectives from medical history, economic history, and the history of ideas have dominated. In addition to the disciplinary development, in historical research on therapies the negotiation of success and effectiveness between doctors, patients, and relatives was considered a core problem (Braslow 1997; Pressman 1998; Schmuhl/Roelcke 2013). The fruitfulness of research perspectives that examine the practical and bodily dimensions of therapeutic work in psychiatry has been demonstrated in studies of the performance of insulin coma therapy as well as in studies about "tensions" and their "dissolution" in lobotomies, among others (Doroshow 2006; Meier 20I5). Older works on medical history also provide points of reference, which, following the social history of technology in the I990s, examined technical devices in medicine in the I9th and 2oth centuries and, in addition to diagnostic instruments, also considered therapeutic devices in some cases (Blume I992; Howell I995; Stanton 1999).

The following chapter wants to supplement the previous works on the psychiatric history of the therapy with a focus on the question of how technological design changed the usage in concrete situations, meaning the therapeutic use of ECT devices by doctors and nurses on patients in psychiatric institutions.

Despite intensive engagement with somatic therapies, including the works of Joel Braslow and Jack Pressman, the historiographic discourse seems to remain polarized to the extent that affirmatively teleological or negative attitudes generally permeate the publications. By contrast, historiography in the 1990 in particular emphasized the historical contingency of knowledge and norms in psychiatric therapy and demonstrated how the effectiveness and success of certain therapeutic measures were the subject of discursive and social negotiations. Electroconvulsive therapy is still considered the cornerstone of a new biological neuro-psychiatry in recent works (Shorter/Healy 20I3: 3-5; Rzesnitzek/Lang 20I7: 67-68) and is rarely embedded in its historical context, in which psychoanalysis, cybernetics, and Nazism played important roles. In particular, examining the perspective on its material culture will allow these simplistic historiographical narratives on ECT to be expanded 
and contrasted, since this involves considering the conceptual indeterminacy and potential diversity at the beginning of the development process in the I940s.

In the following, I will conceptualize and operationalize this material dimension. Three points are central to this discussion: first, electroconvulsive therapy took place as a practice involving both people and things (Hirschauer 2004: 88-89). Second, it took place through and on historical bodies and machines. And third, the actual practice increased the contemporary knowledge about the body, the psyche, and machines (Haasis/Riesk 2015: 29-30). An example from an early publication by the Swiss psychiatrist Max Müller (I894-I980) on electroconvulsive therapy can illustrate this:

Whether the seizure follows immediately or only after a latency is, as already suspected by Bingel and Meggendorfer, according to our investigations, directly associated with the current or duration used. The above-mentioned authors therefore rightly assume that increased dosages cause the latency to completely disappear. The question is only whether this is desirable; for us, the lack of latency, as already mentioned, is instead an indication of an overdose and of a subsequent overwhelming and not harmless seizure.

(Müller I94I: 2II-2I2)

As the quote by Max Müller shows, the proper use of the electroconvulsive therapy device as a historical norm of practice was dependent on a specific historical knowledge and by no means defined, but controversial within the discipline. But the "right" usage - that is, setting an adequate amount of current, while using as little as possible - was also determined by the space, the technical design of the device, the physical condition of the patients, the actions suggested by the switch design, and habits with other seizure-inducing substances. However, here this comprehensive perspective is limited to the question of how the technical design changed the material culture of the therapy. In order to pursue this focus, in particular I have examined the reflections of the French technical philosopher Gilbert Simondon (1924-1989) on the technological object and its development (I958 [2012]). Conceptualizations of the historical development of technical-human relations, such as the actor-network theory (ANT) developed in particular by Bruno Latour, and social-constructivist works have presented significant and fundamental insights into the social genesis of technology (König 2009: 49-52; Schulzer-Schaeffer 2008; Heßler 20I2: I42-I44). However, most of these works were remarkably uninterested in the technical and 
functional design of the devices, their circuit, and ultimately their concrete material form, and instead focused on the needs and appropriations of users and their social consequences. Similar to cybernetic approaches, the devices were black-boxed as actors and their social position was examined in interconnections and social developments (Schmidgen 20I2: I22-I23). Georges Simondon set himself apart from both cybernetic designs and Martin Heidegger's philosophy of technology. His notion of a fundamental purpose-boundness and his interpretation of the technical as a subjugation of people and nature to technical rationality were replaced with a symmetrical and historicizing perspective by Simondon. ${ }^{5}$ He positioned human beings "among the machines" in order to act meaningfully together with them. Ultimately, these technical objects only existed with human beings, but they went through an independent development that revealed their essence (Simondon 20I2: IO-II). In this way, Simondon criticized first the assumed finality of the seemingly functionally fixed technical object, and secondly, he made possible an investigation of genetically unfolding variance inherent in the technical object as a process (Hörl 2OII: I9-20). In his imagination, this evolution tended toward an increasing integration [concrétion] of discrete - logically and materially separate - parts of the technical object. ${ }^{6}$ The genetic examination of this concretion of the circuitry, technology, and the form of the technical object is a methodological starting point for historical research and deals with the technical artifact as a subject of cultural-historical inquiry (Simondon 20I2: I9-2I). I will take up this approach in the following and follow it in the examination of the technical development of electroconvulsive therapy.

\section{The Dose in Electroconvulsive Therapy}

The examination in this first step will take place based on the technical attempts to determine the dose, which historically was an indeterminate unit of therapeutic practice. Thus, the changes in psychiatric therapy can be understood based on and through an altered understanding of the dose. In March 1939, physicians in the cantonal clinic in Münsingen received information about electrically induced seizure therapy for the first time, which had been developed over the previous few years in Rome. Lothar Kalinowsky had informed the head of the Swiss institution, Max Müller, about a finished device and its major advantages (Müller I982: 244-249). However, only in September of the same year did Müller succeed in testing the new 
device in a clinic in Milan. ${ }^{7}$ Despite this, he had already ordered a device from the Italian company Arcioni in the summer of 1939 and eagerly awaited it, as illustrated by letters to the Swiss psychiatrist Oscar Forel (I89I-I982) (Müller 1939a). What did he want to do with it? Convulsive therapy as a psychiatric practice was received throughout Europe beginning in the mid-I930s. Especially the cardiac drug Metrazol was injected in large doses $(3$ to $5 \mathrm{cc}$ ) in patients who suffered a grand mal seizure after a short period, usually accompanied by anxiety and unpleasant feelings (McCrae 2006: 7I-72). The seizure, also called an epileptic seizure, was typically done on a wooden treatment table on which the patients were laid before treatment. First, the now unconscious patient thrust their arms and legs upward and writhed convulsively. Frequently doctors tied down the patients or nurses tried to hold their bodies still. Subsequently, the seizure slowly dissipated, accompanied by convulsions. The strong kinetic forces exerted by the patients' muscles during a seizure often led to dislocations, vertebral fractures, or even fractures of the long bones of the upper limbs. After a while, the patients regained consciousness. The medical history of 52-year-old Rosina M., who had been hospitalized in Münsingen since June 1939, is a remarkable source for the transition from pharmacologically to electrically induced convulsive therapy in the second half of the year (Kantonale Heil- und Pflegeanstalt Münsingen 9997, 1939). Rosina M. initially received some treatments with "sleep therapy" as well as with Metrazol convulsive therapy to alleviate her depressive feelings and suicidal thoughts. After an exhausting and complicated series of Metrazol, in November 1939 the psychiatrists decided to try ECT on Rosina. This step is very clearly noted in the patient file. While the rest of the page in her medical history is filled with typewritten descriptions of the failing attempt at Metrazol convulsive therapy, the following note appears in pencil at the bottom:

I30 V $(0,3) \mid 300$

(KHPA Münsingen 9997, 1939: I2)

But what does this mean? At this time, the psychiatrists in Münsingen used the device made by the Italian company Arcioni, as developed by Cerletti and Bini. A belt with electrodes at the height of the temple was put on the patient resting on a stretcher. The doctor set the voltage, strength, and duration of the electric stimulus on the quite large and heavy device on a trolley. Then they triggered the stimulus, and for a brief moment the current flowed. After a latency of 5 to 20 seconds, the 
patient had a seizure. This Italian device, as well as the prototype from Siemens, included two circuits (Müller I939b: I). The first circuit with low voltages around I volt was used to measure the electrical resistance of the patient's skull. Based on Ohm's law, a direct proportionality between electrical resistance, voltage, and current was initially assumed. In the first considerations on using electroconvulsive therapy, the voltage and current entailed the highest potential for risk and were applied in as low doses as possible, which is why the electrical resistance of the patient's skull was an important variable for the Italian builders and the psychiatrists who performed the therapy. ${ }^{8}$ The second so-called treatment circuit offered the ability to regulate the duration, voltage, and current of the circuit. ${ }^{9}$ The note is thus a description of the electrical impulse used for Rosina M.'s treatment: 130 volts at 300 milliamps for 0.3 seconds were the settings for the treatment dose of electric current. But the question arises of what this information meant for electroconvulsive therapy. For contemporary psychiatrists, this information was also hardly self-explanatory, because electrical stimuli differ significantly in their characteristics from pharmacological substances, with which doctors had previously gained experience. From this position of a lack of knowledge, the psychiatrists initially devoted themselves enthusiastically and meticulously to the measurement and calculation of the stimulus before the actual treatment. With the measuring circuit, the electrical resistance of the patient's skull was measured at I volt in order to have a basis for calculating the electrical stimulus. On this basis, the physician was to attempt to get as close as possible to the therapeutic dose for the individual patient, which meant gradually bringing the human and a machine into alignment (Ewald/Haddenbrock I942: 64I).

Initially this approach was the norm for all first-generation devices developed by companies such as Arcioni in Italy, Purtschert in Switzerland, Edison Swan in the United Kingdom, and Siemens in Germany in 1939 and 1940. ${ }^{\text {Io }}$ The detailed measurement combined with a calculation of the dose and the individual setting of the device gave the physician performing the treatment a performative feeling of control and a specific therapy tailored to the individual patient (Doroshow 2006: 220-22I). At the same time, the physicians and engineers soon became aware that measuring with low voltages was very prone to error due to the characteristics of the skin. Measuring the electrical resistance of the patient's skull at I volt often resulted in high values because the skin had its own resistance at these low voltages, a property that was lost at higher voltages (Pätzold I94I: 277-278). The measured and sometimes greatly fluctuating values therefore had no equivalent in the treatment circuit at Ioo volts and regularly resulted in excessively high calculations for the electrical stimuli. ${ }^{\text {II }}$ 
The companies and numerous psychiatrists nevertheless continued to make the measurements until the late I940s, since they considered the attentiveness to the device and the patient an important verification routine for the safety of the procedure. Anton von Braunmühl (I9OI-1957), psychiatrist and director of the so-called insulin ward at the Eglfing-Haar clinic near Munich, by contrast, chose a different path. He explained that he usually works with a relatively strong electrical stimulus (350 $\mathrm{mA}$ for I second) that reliably triggers epileptic seizures without putting the patient at risk, in his view (Von Braunmühl I942: I52-I54). It was precisely von Braunmühl's strong electrical stimuli, which triggered epileptiform seizures with only a short latency or no latency at all, that were the cause of Max Müller's above mentioned critique of the correct use of electroconvulsive therapy. The engineers at Siemens-Reiniger Werke, who worked with physicians at the university clinic Erlangen as well as with Anton von Braunmühl in I939 and 1940, also attempted to eliminate the factor of uncertainty in the measurement of resistance (Pätzold/Koersche/Olbrich 1940: 5-6). The theoretical and technical transformation went hand in hand with the work of the Siemens engineers around Johannes Pätzold (19071980). The starting point was the practical observation during the therapy that at high voltages of Ioo volts the electrical resistance had a lower value and barely fluctuated (ibid.: 2-3). By adding further high-impedance resistors to the treatment circuit (cf. fig. I), possible variations in resistance in the patient's skull became entirely insignificant.

By eliminating the measurement as an initial step in electroconvulsive therapy, the usage of the device was changed. Physicians could assume that the devices and patients were in alignment and immediately set the values of the electrical stimulus. This changed the conceptualization of the stimulus on the part of the engineers, whose focus was no longer on the complex relationship between current intensity and voltage as a function of the electrical resistance of the skull. They adopted a thinking about electrical energy based on pharmacological substances and "conceptualized" the electrical stimulus subsequently as an amount of electricity per unit of time (SRW Erlangen I940: I). Thus, through experimenting and developing, between the device, doctors, and engineers the reproducible triggering, the necessary time, and ultimately the seizure itself developed as the operative unit of electroconvulsive therapy. For von Braunmühl, the strategy of the fixed standard dose was strengthened and further simplified by this technical development. Thus, he came to describe the seizure as a dose and no longer annotated individual sessions with data on the electrical stimulus, but with details on the seizure (fig. 2). 
This means that in this phase of development, the Siemens electroconvulsive therapy device took on a form that was based on a fundamentally different function. While at first the emphasis was on the measurement and calculation of the correct electrical stimulus, the device was now developmentally optimized and its use was designed for the production of seizures - a process that was also ultimately reflected in the choice of "Konvulsator" (Latin: convulsio) as a brand name. The previously described measures of testing and measuring had been central to Max Müller and the Italian devices. They had forced a special attention to the arrangement of the device, the patient, and the doctor and were bound to a special medical and technical expertise, but they lost their plausibility in the new setting and were obsolete. The doctor's ability in dealing with the device and the patient was replaced with technical reliability and allowed for a certain carelessness in dealing with the new device. This circumstance made it possible to increasingly turn to the operationalization of the seizure as a therapeutic tool. At Eglfing-Haar, this development took place in a specific institutional and personnel context and resulted in a form of work that required very little time and personnel resources. The insulin ward of the Eglfing-Haar clinic suffered a dire shortage of personnel since the mobilization at the start of the war, as a large proportion of the male nurses had been conscripted. ${ }^{12}$ Von Braunmühl has described the situation in his ward: there together with two nurses he treated 60 patients with ECT in one morning, which required the use of an efficient regime. The Siemens device allowed him to treat all patients in the same way, without the need for specific measurements or adjustments, and no complications were expected. On this basis, psychiatrists began to organize electroconvulsive therapy like an assembly line. The treatment ward was operationalized as a place where all patients underwent a uniform convulsive therapy session. The tailoring to the individual patient took place with a treatment scheme that specified the sequence of treatment days according to the diagnosis or the reason for treatment (Von Braunmühl I947: I82). The following treatment certificate (fig. 3) from the patient file of Rosalie H. accompanied the treatment as a paper documentation system and attests to the administrative and technical rationalization that characterized electroconvulsive therapy at Eglfing-Haar. The patients were brought to the ward according to the chosen treatment regimen and the individual seizure was simply checked off. 


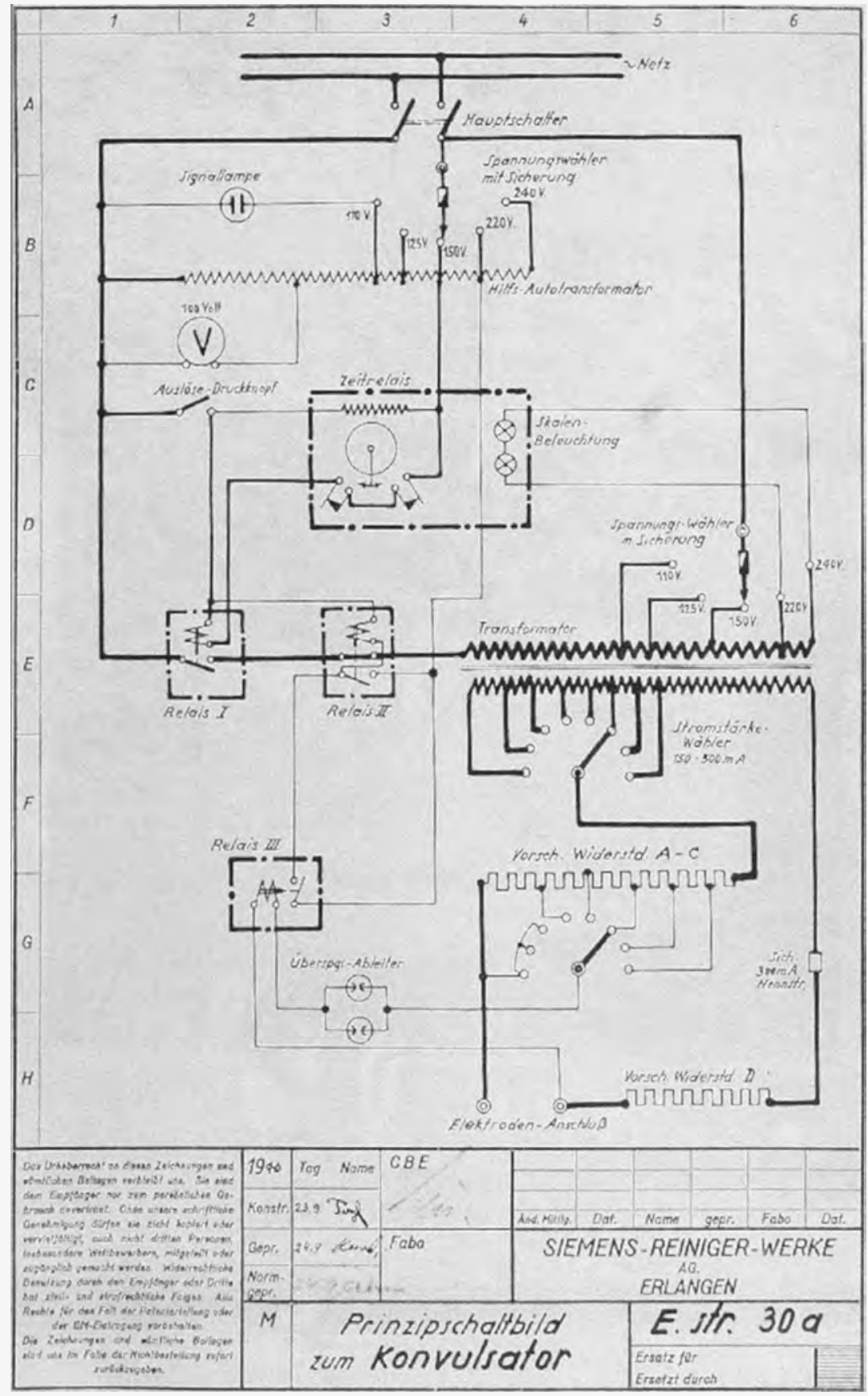




\section{Name:}

Geb.:

Station:

Scherna I.

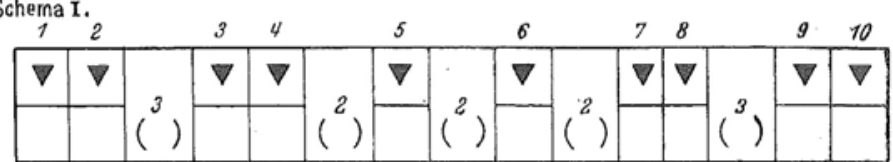

Schema II.

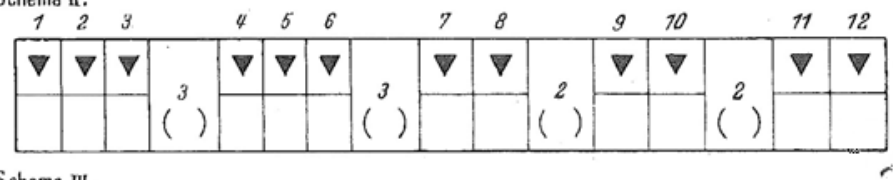

Schema ㅍ.

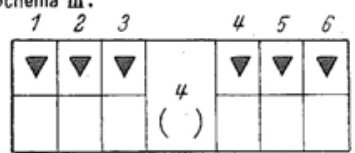

$$
\begin{aligned}
& \text { Behandiung } \\
& \text { vom mitt } \\
& \text { Zahl der Heilkrämpfe: }
\end{aligned}
$$

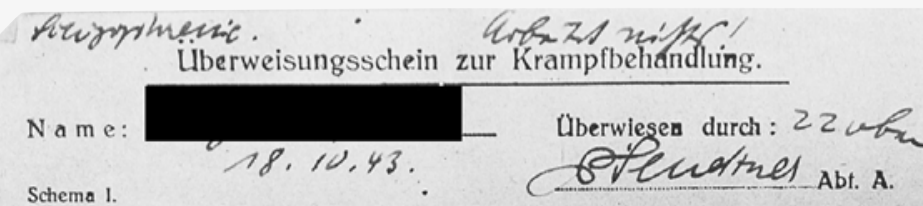

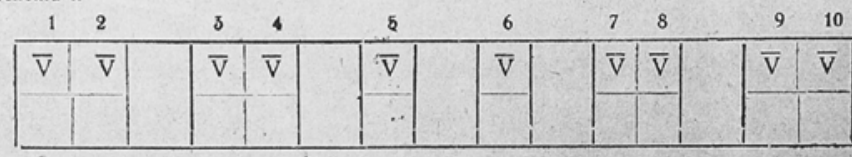

Schema II.

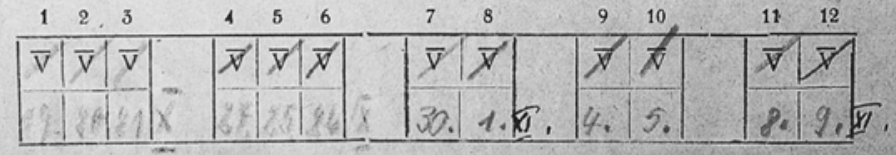

Schema III.
\begin{tabular}{c|c|c|c|c|c|c|}
1 & 2 & 3 & 4 & 5 \\
\hline $\bar{V}$ & $\bar{V}$ & $\bar{V}$ & & $\bar{V}$ & $\bar{V}$ & $\bar{V}$
\end{tabular}
Krampfbehandlung
vom $19, \bar{x}, \quad$, mit $9, \bar{x}, 43$
Zahi der Krampre: 12 Slevelro

Fig. 2: Treatment scheme for convulsive

treatment (Von Braunmühl 1947: 183)

Fig. 3: Treatment certificate for Rosalie H.,

October 1943 (HPA E-H 7662, 1941) 
In the postwar period, this strategy of rationalization was taken one step further by running power lines through the walls of the treatment ward. For example, the treatment electrodes could be plugged into power sockets above the head end of the beds and the doctor performing the treatment could do so without any major preparatory measures. The room itself provided the psychiatrist with the necessary electrical stimuli and became the carrier of the therapeutic affordance of the seizure (Von Braunmühl I947: I60-I6I). While previously the adjusting of settings, indeed the technology of the electroconvulsive therapy device, were moved out of view and into the interior of the device, now the entire technical device moved below the surface of the treatment room. The dose formed a key point, because it now differed completely from pharmacological convulsive therapy insofar that no longer the stimulus, but the treatment session itself was referred to as a dose. This circumstance marked the transition from pharmacologically to electrically induced convulsive therapy particularly clearly. In the same step, it was clinically understood that it was neither the electric current nor substances such as Metrazol, but the seizure that constituted the core element of the therapy. It was only here that it became possible to organize the therapeutic practice in such a way that instead of the individual treatment session being designed, the individual session formed the element of a therapeutic sequence.

\section{Pushbutton Psychiatry}

I first followed the change in practice with a specific aspect of the therapy. In the following I would like to look at the use of the treatment from an additional perspective by means of "pressing buttons" and thus investigate how agency was created and negotiated on the material level in electroconvulsive therapy. At Eglfing-Haar, the triggering of the seizure took place in an increasingly standardized and uniform manner. The pressure on the button to trigger the stimulus on the machine, and later directly on the treatment electrodes, was a relatively small movement, but triggered a chain of events: first the electrical impulse, then the epileptic seizure, the healing process, etcetera. This cascade of effects and consequences contrasts starkly with the minor act of pressing a button. In view of the exceptional potency inherent in the pushing of a button, the term "pushbutton psychiatry" (Kneeland/ Warren 2008) seems to directly correspond to the situation. The German psychia- 


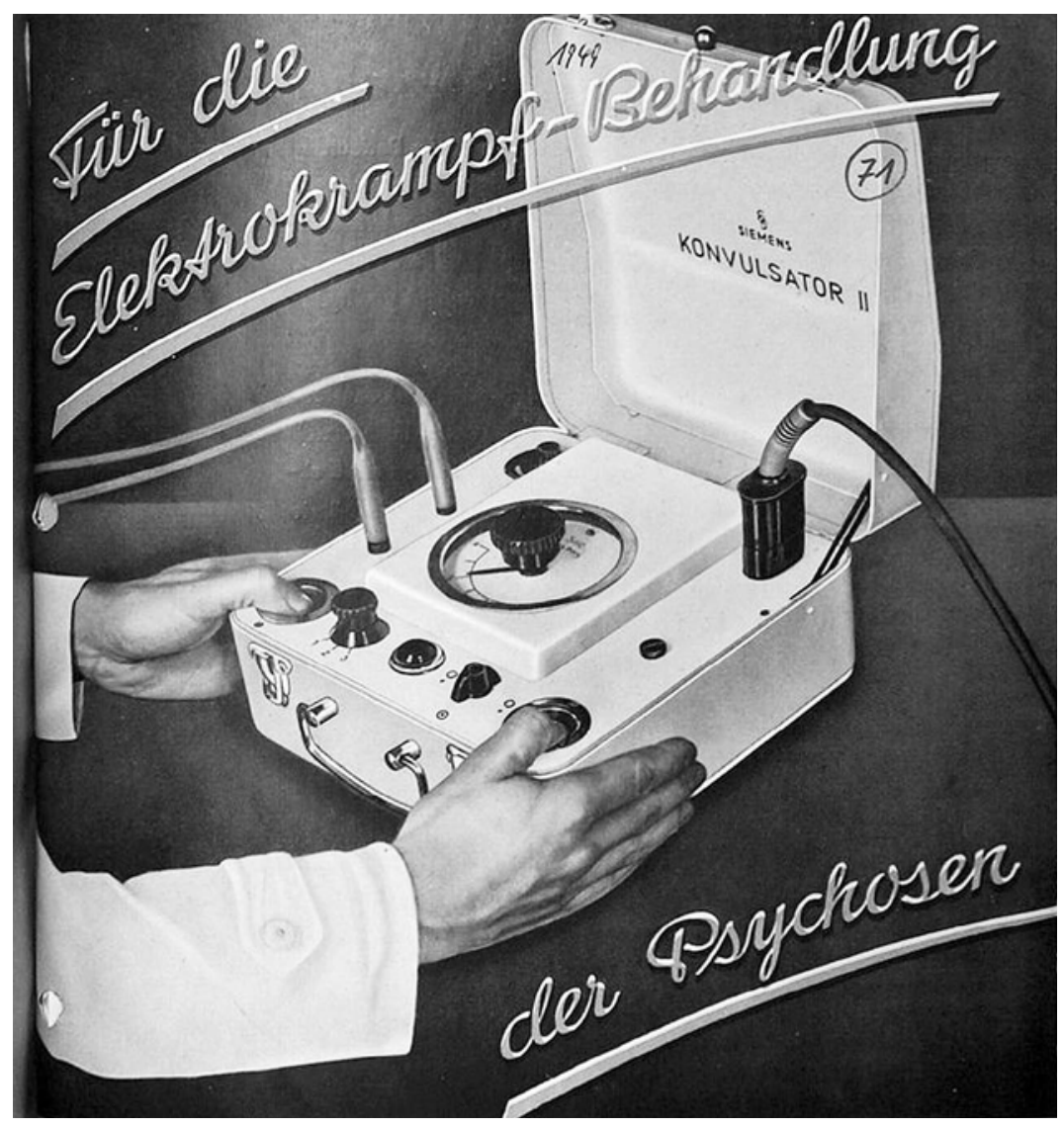


trist and medical historian Werner Leibbrand also viewed this material consolidation of therapeutic practice critically in 1947 :

When people today speak of "progress," they mean ... the summation of some kind of complicated energetic or mechanical processes in a simple gesture - one presses a button and this or that happens. (I947: I48-I49)

Another dimension evoked by the concept of pushbutton psychiatry is that of the uniform, disciplined, and disinterested treatment regimen, which therapeutically "shocked away" disorders as well as affective failures (Braslow I997: 9). While these two dimensions can be analytically separated, they are held together in practice by the pushbutton, whose potential to trigger the seizure was at the center of the negotiations over who should actually press the button.

As I have already described, the first electroconvulsive therapy devices were equipped with numerous switches, buttons, and gauges, an arsenal that was increasingly reduced at Siemens until the "small device" of the Konvulsator II was introduced for "mobile clinical use." The K II, weighing six instead of I7 kilograms, was much more portable and was meant to facilitate its use in pavilion-style institutions and to allow for outpatient treatments. ${ }^{13}$ The device had a reduced surface consisting of a central display/setting for the length of stimulation, a three-step setting for the stimulation strength, and an on/off switch (fig. 4). One striking aspect was the two widely spaced trigger buttons, which contradicted the general trend toward simplification and reduction. These were arranged in a sequential circuit and had to be pushed simultaneously to trigger the electrical stimulus. ${ }^{14}$ Numerous psychiatrists who tried out the new device expressed their impression that its usage was made unnecessarily difficult. For example, the psychiatrist Friedrich Schmieder (I9II-I988) wrote to Johannes Pätzold that this construction restricted his work because it was impossible to operate the device with one hand (Schmieder I943: I). However, this was exactly what the engineers had in mind, as Pätzold's marginal notes in Friedrich Schmieder's letter show. They wanted to make the use of the buttons so difficult that the device would not be accidentally triggered, in order to protect both the physicians and the patients, because in their view the simplified device entailed a greater risk. This shift of a social regulation into the technical form is clearly reminiscent of the examples that Bruno Latour used for his analyses of non-human agency. Among other things, based on the so-called Berlin key, he described how users of doors in apartment buildings were forced to lock the doors 
due to the special shape of the key, since the key could only be pulled out of the door after the door was locked. In Latour's description, the key could thus replace the social control by the building attendant (Latour 1996:37-40). Like the Berlin key, the electroconvulsive therapy machine demanded certain actions of humans and forced them to use both hands to trigger the electrical stimulus. With the two buttons of the device, negotiations were conducted in the sense of the actor-network theory over who bore the risk of the treatment and what concessions to the doctor's agency seemed reasonable. This interpretation is close to the view of the doctors, who depressed the annoying second button with tape so that the device could once again be used with one hand. This allowed them to practice their accustomed procedures, and they did not allow their autonomy to be questioned by engineers or devices. Here therapeutic agency was an intention embodied by physicians which took on a certain form through interventions in the device.

However, I would like to return to the fundamental question and, in view of the "pressing of buttons," ask how electroconvulsive therapy changed the material culture of psychiatric therapy. The starting points are Metrazol convulsive therapy or insulin coma therapy, both of which were determined by the injection of pharmacological substances. If we consider electroconvulsive therapy analogous to those historically parallel practices of injecting, it becomes clear how the device and the user brought about the new form of treatment in the joint act. The physicians - no longer with syringes, but with electrodes in their hands - learned to act as participants in this new electrical practice with and through the devices. Contrary to a description of device and machine as actors in the network, here the joint activity, in which both are involved as participants, is given the central importance, because only in joint practice did the agency granted to the actor come about and take on its form. Anton von Braunmühl's works offer a remarkable concrete example of these ideas (Von Braunmühl I943: 2). After he had fixed one of the two triggering buttons in place, he went on to press the second button repeatedly. He attempted to use the rapid repetition of weaker stimuli to "shake" the patient into the seizure (Olbrich I943: 2). Regardless of the technical and physiological evaluation of the procedure, it was the experience of the pushbutton with its immediate mediation of the electrical stimulus to the patient's body which created the knowledge and the ability to imagine and try out this form of treatment. ${ }^{15}$ Thus, it was not only a negotiation of agency between human and non-human actors, but in common practice a "distributed agency [that] was no longer attributable to the unit of one actor" and took on a specific form (Hörl 2OII: 2I). 
Using the example of electroconvulsive therapy, I have examined how the introduction of a technical device in the middle of the 2oth century changed the material culture of psychiatric therapy. The differentiation from pharmacological procedures of shock therapies was the starting point for initial developments and remained a frame of reference for psychiatrists in Europe for a long time. By determining the "right dose" and "pressing the button," it was reconstructed how knowledge about the therapy emerged as a product of the application and the practical use of the new technology, thereby innovating as well as updating existing knowledge. By following existing experience with pharmacological substances and technically regulating the specific, surprisingly complicated electrical relationships between the physician, the device, and the patient - that is to say, making them unproblematic - the focus of the dose shifted from the electrical stimulus to the seizure. A second analytical focus was on the increasingly device-oriented and ultimately spatial affordance of seizures. Here it was possible to understand how actions became available by bringing people and machines together as technical systems. The resulting discomfort in clinical daily life was formulated by Werner Leibbrand in the above-mentioned place: "For many doctors, this therapy is indeed unpleasant ... ; it is the fault of the first step - the stone once thrown (pushbutton!) cannot be called back!" (1947: 154).

The condensed therapeutic agency that arose from the relationship between the device and the doctor became clear in the consequences of a banal push of a button. The push of a button mediated and was a meeting place where the possibility of the technical arrangement was realized in a concrete therapeutic action. The path to this point was the combination of the two developments, the push-button and the availability of electroconvulsive therapy embedded into the room. 


\section{Notes}

\section{1}

Electroconvulsive therapy used a strong current in comparison to electro-medical applications established in neurological medicine at the time (cf. Steinberg 2014: 878).

\section{2}

After the publication of Metrazol convulsive therapy by Ladislaus Meduna in 1935, the search for alternative substances or techniques for triggering seizures began: in 1930, convulsive therapies were only one among numerous procedures that put the patient's body in a state of emergency (fever, coma, seizure) in order to alleviate or cure mental disorders. For further details, see Joel Braslow's work on shock therapies in California (1997) or the overview of their use in the German Reich by Hans-Walter Schmuhl and Volker Roelcke (2013).

\section{3}

The Siemens-Reiniger Werke was founded in 1932 as part of Siemens \& Halske AG and, as part of the company, was responsible for the development of electro-medical technologies and their sales.

\section{4}

The institutions differed significantly in their number of beds, but generally served the region and devoted themselves in a publicly exposed manner to the shock therapies. For historical information, see Laehr (1937: 29, 153); for historiography see especially Richarz (1987); Germann (2013).

\section{5}

This very condensed presentation of the work of Heidegger (2000: 12-13) and the ANT serves to further define Simondon's theory and does not claim to offer a complete portrayal of the positions. Among others, Erich Hörl has done detailed work on Heidegger and Simondon (2008), as has Ingo Schulzer-Schaeffer (2008) on technical terms in Latour's work.
6

In Simondon's words, it is the increasing concretion of discrete parts, exemplified by the cylinder head, in which cooling fins combine previously separate functions of stiffness and cooling (2012: 23-24).

\section{7}

For this purpose he was invited by Guiseppe Corberi to Milan (Müller 1939b: 1; Müller 1982: 244-249). He had a close relationship with Corberi as well as Kalinowsky since the "Schizophrenia Conference" in 1937 in Münsingen. It was here that an informal group of doctors came together whom Cornelius Borck convincingly described as the "Internationale of Shock Therapy" (2013: 138-139).

\section{8}

Early publications dealt with the question of whether the duration or the current strength is the decisive unit in determining the "strength" of the electrical stimulus, with most authors varying only slightly in terms of voltage and using about 100 volts (cf. Müller 1941: 206-211).

\section{9}

These technical data were compiled in particular from the documents, schematics, and manuals for the Italian device in the archive of the SiemensReiniger Werke in Erlangen (SRW Erlangen 1939). On the state of the records, see also Gawlich (2018: 30-39)

10

I have discussed the differences between generations in the development of electroconvulsive therapy devices in more detail elsewhere, including detailed information on the individual devices and producers (cf. Gawlich 2018: 158).

11

An academic feud between the Italian inventors and their German competitors, including the Siemens-Reiniger Werke, developed out of this source of error, which was motivated not least by their aim to file for their own patent and thus economic interests (cf. Pätzold 1941; Gawlich 2018: 164-166). 
12

This shortcoming was exacerbated by the fact that Eglfing-Haar was a relatively large institution with 2500 beds and that many patients were referred to the insulin ward (Stockdreher 1999: 328). Despite the difficult personnel situation at the beginning of the war, Eglfing-Haar had taken numerous patients from institutions that were closed. Added to this was the logistical role that the institution had in the context of the centrally controlled murder of patients. Patients were transferred to Eglfing-Haar before being sent via collective transports to killing centers or being murdered in the second decentralized phase of "euthanasia" in Eglfing-Haar itself (Süß 2003: 324-325; Tiedemann 2014: 37).

\section{3}

The trigger for the development was in particular the economic situation during the war, which made the acquisition of the expensive and

\section{Sources}

Heil- und Pflegeanstalt Egling-Haar. 1941.

Rosalie H. Patient file E-H 7662.

Archive, Bezirk Oberbayern.

Kantonale Heil- und Pflegeanstalt Münsingen. 1939. Rosina M. Patient file 9997.

Archive, Psychiatriezentrum Münsingen.

Müller, Max (1939a): An Forel, O. 23.10.1939.

Letter, typescript, carbon copy, FA Müller II-9

Burgerbibliothek Bern.

Müller, Max (1939b): An Wilmanns, K.

03.11.1939. Letter, typescript, carbon copy,

FA Müller II-11 Burgerbibliothek Bern.

Olbrich, Hermann (1943): Betr. Besuch bei Medizinalrat Dr. v. Braunmühl, Eglfing Haar, June 21 and 22, 1943. File note. Siemens Med-Archiv.

Pätzold, Johannes/Koersche, NA/Olbrich, Hermann (1940): Bericht des E-Laboratoriums, resource-intensive predecessor model impossible for many clinics (cf. Pätzold/Koersche/Olbrich May 23, 1942).

14

Precisely this circumstance of the translation of social relations into technical conditions is at the center of the early ANT works by Latour (cf. 1991: 109-110).

\section{5}

Von Braunmühl theorized the procedure as a summation of subliminal stimuli, which through repetition built up a potential that triggered the epileptic seizure after a certain time. The engineers threw up their hands in the face of his severe technical abuse and misunderstanding and urged him to refrain from further attempts until they had built him a technical device that could handle the periodic interruptions of the electrical stimulus (cf. Olbrich 1943).

über die Entwicklung des Gerätes "Konvulsator" für Elektrokrampfbehandlung. File note.

Siemens Med-Archiv.

Pätzold, Johannes/Koersche, NA/Olbrich, Hermann (1942): Bericht über die Entwicklung eines vereinfachten, tragbaren Gerätes für die Elektrokrampfbehandlung. File note.

Siemens Med-Archiv.

Schmieder, Friedrich (1943): To Pätzold,

06.07.1943. Letter, typescript.

Siemens Med-Archiv.

SRW Erlangen (1939): Übersetzung "Officine Eletrotecniche Italiane Ing V. Arcioni. Anweisungen für den Gebrauch des Elektroschock-Apparates." Abschrift/Kä. Siemens Med-Archiv.

SRW Erlangen (1940): An Medizinalrat Dr. V. Braunmühl 21.05.1940. Letter, typescript, carbon copy. Siemens Med-Archiv.

Von Braunmühl, Anton (1943): An Pätzold 03.06.1943. Letter, typescript.

Siemens Med-Archiv. 


\section{Bibliography}

Blume, Stuart S. (1992): Insight and Industry: On the Dynamics of Technological Change in Medicine, Cambridge, Mass: MIT Press.

Borck, Cornelius (2005): Hirnströme: Eine Kulturgeschichte der Elektroenzephalographie, Göttingen: Wallstein Verlag.

Borck, Cornelius (2013): "Die Internationale der invasiven Therapien und die Diskussion in Deutschland." In: Schmuhl, Hans-Walter/Roelcke, Volker (eds.): "Heroische Therapien": Die deutsche Psychiatrie im internationalen Vergleich, 1918-1945. Göttingen: De Gruyter, pp. 131-148.

Braslow, Joel T (1997): Mental Ills and Bodily Cures. Psychiatric Treatment in the First Half of the Twentieth Century, Berkeley: University of California Press.

Daston, Lorraine (2004): "Speechless: Introduction." In: Daston, Lorraine (ed.): Things That Talk: Object Lessons from Art and Science, New York: Duke University Press, pp. 7-24.

Derix, Simone/Gammerl, Benno/Reinecke, Christiane/Verheyen, Nina (2016): "Der Wert der Dinge: Zur Wirtschafts- und Sozialgeschichte der Materialitäten." In: Zeithistorische Forschungen 13/3, pp. 387-403

Doroshow, Deborah B. (2006): "Performing a Cure for Schizophrenia: Insulin Coma Therapy on the Wards." In: Journal of the History of Medicine and Allied Sciences 62/2, pp. 213-243

Ewald, Gottfried/Haddenbrock, Siegfried (1942): "Die Elektrokrampftherapie: Ihre Grundlagen und ihre Erfolge. Ein Beitrag zur Pathogenese der Psychosen." In: Zeitschrift für die gesamte Neurologie und Psychiatrie 174/1, pp. 635-669.

Fumarola, Gioacchino (1939): "Eine neue Methode der Krampfbehandlung in der Psychiatrie: der Elektroshock." In: Psychiatrisch-Neurologische Wochenschrift 41/8, pp. 87-88.

Gawlich, Max (2018): Eine Maschine, die wirkt: Die Elektrokrampftherapie und ihr Apparat 1938I950, Paderborn: Schöningh.
Germann, Urs (2013): "Ein Insulinzentrum auf dem Land: Die Einführung der Insulinbehandlung und der therapeutische Aufbruch in der Schweizer Psychiatrie der Zwischenkriegszeit." In: Schmuhl, Hans-Walter/Roelcke, Volker (eds.): "Heroische Therapien": Die deutsche Psychiatrie im internationalen Vergleich, 19I8-I945, Göttingen: De Gruyter, pp. 149-167.

Haasis, Lucas/Riesk, Constantin(2015): "Historische Praxeologie. Zur Einführung." In: Haasis, Lucas (ed.): Historische Praxeologie: Dimensionen vergangenen Handelns, Paderborn: Schöningh, pp. 7-55. Heidegger, Martin (2000): "Die Frage nach der Technik." In: Herrmann, Friedrich-Wilhelm, von (ed.): Gesamtausgabe: I. Abteilung: Veröffentlichte Schriften 19I0-1976, Frankfurt am Main: Vittorio Klostermann, pp. 5-36

Hess, Volker/Mendelsohn, J. A. (2013): "Paper Technology und Wissensgeschichte." In: Zeitschrift für Geschichte der Wissenschaften, Technik und Medizin 21/1, pp. 1-10.

Heßler, Martina (2012): Kulturgeschichte der Technik, Frankfurt am Main/New York: Campus. Hirschauer, Stefan (2004): "Praktiken und ihre Körper: Über materielle Partizipanden des Tuns." In: Hörning, Karl H./Reuter, Julia (eds.): Doing Culture: Neue Positionen zum Verhältnis von Kultur und sozialer Praxis, Bielefeld: Transcript, pp. 73-91.

Hörl, Erich (2008): "Die offene Maschine: Heidegger, Günther und Simondon über die technologische Bedingung." In: Modern Language Notes 123/3, pp. 632-655.

Hörl, Erich (2011): "Die technologische Bedingung: Zur Einführung." In: Hörl, Erich (ed.): Die technologische Bedingung: Beiträge zur Beschreibung der technischen Welt, Berlin: Suhrkamp, pp. 7-53. Howell, Joel D. (1995): Technology in the Hospital: Transforming Patient Care in the Early Twentieth Century, Baltimore: John Hopkins University Press. Kneeland, Timothy W./Warren, Carol (2008): Pushbutton psychiatry: A cultural history of electroshock in America, Walnut Creek, CA: Praeger. König, Wolfgang (2009): Technikgeschichte: Eine Einführung in ihre Konzepte und Forschungsergebnisse, Stuttgart: Franz Steiner Verlag. 
Latour, Bruno (1991): "Technology Is Society Made Durable." In: Law, John (ed.): A Sociology of Monsters: Essays on Power, Technology and Domination, London: Routledge, pp. 103-131. Latour, Bruno (1996): Der Berliner Schlüssel: Erkundungen eines Liebhabers der Wissenschaften, Berlin: Akademie Verlag.

Laehr, Hans/llberg, Georg (1937): Die Anstalten für Geisteskranke, Nervenkranke, Schwachsinnige, Epileptische, Trunksüchtige usw. in Deutschland, Österreich und der Schweiz: Einschließlich der psychiatrischen und neurologischen wissenschaftlichen Institute, Berlin: Walter de Gruyter.

Leibbrand, Werner (1947): "Heilung' durch den Schock." In: Die Wandlung 2/2, pp. 148-156.

Leibbrand, Werner (1941): "Die Elektrokrampfbehandlung (Cerletti)." In: Fortschritte der Neurologie - Psychiatrie 13/6, pp. 203-227.

Ludwig, Andreas (2011): "Materielle Kultur." In: Docupedia-Zeitgeschichte, https://docupedia.de/ zg/Materielle_Kultur?oldid=84634, accessed on March 30, 2016.

Majerus, Benoît (2017a): "Material Objects in Twentieth Century History of Psychiatry." In: Low Countries Historical Review 132/1, pp. 149-169. Majerus, Benoît (2017b): "The Straitjacket, the Bed, and the Pill: Material Culture and Madness." In: Eghigian, Greg (ed.): The Routledge History of Madness and Mental Health, London: Routledge, pp. 263-276

McCrae, Niall (2006): “'A Violent Thunderstorm': Cardiazol Treatment in British Mental Hospitals." In: History of Psychiatry 17/1, pp. 67-90.

Meier, Marietta (2015): Spannungsherde: Psychochirurgie nach dem Zweiten Weltkrieg, Göttingen: Wallstein Verlag.

Müller, Max (1982): Erinnerungen: Erlebte Psychiatriegeschichte 1920-1960, Berlin: Springer.

Pätzold, Johannes (1941): "Bemerkungen zum Aufsatz von Prof. Dr. U. Cerletti und Dr. L. Bini, Rom. Über einige Prinzipien der Anordnung des ersten Elektroschockapparates." In: PsychiatrischNeurologische Wochenschrift 43, pp. 287-290.

Peter, Sebastian, von (2013): "Agency, Materiality and Mental Illness." In: Social Theory \& Health 11/4, pp. 317-26.

Peters, Uwe H. (1992): "Die Einführung der Schockbehandlungen und die psychiatrische Emigration." In: Fortschritte der Neurologie Psychiatrie 60/09, pp. 356-365

Pressman, Jack D. (1998): Last Resort: Psychosurgery and the Limits of Medicine, Cambridge: Cambridge University Press.

Rheinberger, Hans-Jörg (2002): Experimentalsysteme und epistemische Dinge: Eine Geschichte der Proteinsynthese im Reagenzglas, Göttingen: Wallstein Verlag.

Richarz, Bernhard (1987): Heilen, pflegen, töten: Zur Alltagsgeschichte einer Heil- und Pflegeanstalt bis zum Ende des Nationalsozialismus Göttingen: Vandenhoeck \& Ruprecht.

Rzesnitzek, Lara/Lang, Sascha (2017): “"Electroshock Therapy' in the Third Reich." In: Medical History 61/1, pp. 66-88.

Sarasin, Philipp (1999): "Mapping the Body: Körpergeschichte Zwischen Konstruktivismus, Politik und 'Erfahrung.". In: Historische Anthropologie 3, pp. 437-451.

Schmidgen, Henning (2012): "Das Konzert der Maschinen: Simondons politisches Programm." In: ZMK - Zeitschrift für Medien- und Kulturforschung 2, pp. 117-134.

Schmuhl, Hans-Walter/Roelcke, Volker (eds.)

(2013): "Heroische Therapien": Die deutsche Psychiatrie im internationalen Vergleich 1918 I945, Göttingen: Wallstein Verlag.

Schulzer-Schaeffer, Ingo (2008): "Technik in heterogener Assoziation: Vier Konzeptionen der gesellschaftlichen Wirksamkeit von Technik im Werk Latours." In: Kneer, Georg/Schroer, Markus/ Schüttpelz, Erhard (eds.): Bruno Latours Kollektive: Kontroversen zur Entgrenzung des Sozialen, Frankfurt am Main: Suhrkamp, pp. 108-154. Shorter, Edward/Healy, David (2013): Shock Therapy: A History of Electroconvulsive Treatment in Mental Illness, New Brunswick, NJ: Rutgers University Press.

Simondon, Gilbert (2012): Die Existenzweise technischer Objekte, Berlin: Diaphanes. 
Stanton, Jennifer (1999): "Making Sense of Technologies in Medicine." In: Social History of Medicine 12/3, pp. 437-448.

Steinberg, Holger (2014): "'Auch die Electricität leistet keine Wunder!': Die vergessenen Beiträge deutscher Psychiater um 1880 zur Therapie von Depressionen und Psychosen." In: Nervenarzt 85/ 7, pp. 872-886.

Stockdreher, Petra (1999): "Heil- und Pflegeanstalt Eglfing-Haar." In: Cranach, Michael, von/ Siemen, Hans-Ludwig (eds.): Psychiatrie im Nationalsozialismus: Die bayerischen Heil- und Pflegeanstalten zwischen 1933 und 1945, Munich: Oldenbourg.

Stoff, Heiko (1999): "Diskurse und Erfahrungen: Ein Rückblick auf die Körpergeschichte der neunziger Jahre." In: 1999 14/2, pp. 142-160.

Stoff, Heiko (2012): Wirkstoffe: Eine Wissenschaftsgeschichte der Hormone, Vitamine und Enzyme, 1920-1970, Stuttgart: Franz Steiner Verlag. Süß, Winfried (2003): Der 'Volkskörper' im Krieg: Gesundheitspolitik, Gesundheitsverhältnisse und Krankenmord im nationalsozialistischen Deutschland 1939-I945, Munich: Oldenbourg.

Topp, Leslie E./Moran, James E./Andrews, Jonathan (eds.) (2007): Madness, Architecture and the Built Environment: Psychiatric Spaces in Historical Context, London: Routledge.

Von Braunmühl, Anton (1942): "Aus der Praxis der Krampftherapie." In: Allgemeine Zeitschrift für Psychiatrie 120, pp. 146-157.

Von Braunmühl, Anton (1947): Insulinschock und Heilkrampf in der Psychiatrie, Stuttgart: Wissenschaftliche Verlagsgesellschaft.

Von Tiedemann, Sybille (2014): "Dezentrale, Euthanasie' in der Heil- und Pflegeanstalt Eglfing-Haar: Eine Untersuchung der Münchner Todesfälle 19391945." In: Hohendorf, Gerrit/Raueiser, Stefan/Von Cranach, Michael/Von Tiedemann, Sybille (eds.): Die 'Euthanasie'-Opfer zwischen Stigmatisierung und Anerkennung: Forschungs- und Ausstellungsprojekte zu den Verbrechen an psychisch Kranken und die Frage der Namensnennung der Münchner 'Euthanasie'-Opfer, Kontur-Verlag: Münster, pp. 34-51.
Yasukoti, G./Mukasa, H. (1939): "Elektroschocktherapie der Schizophrenie: [Siemens Med Archiv, Elektroschock 1940 - Februar 1941, Literatur]." In: Fukuoka Acta Medica 32/8, pp. 1-2. 


III

AGENTS OF HEALING 


\title{
Materiality
}

\section{Daniel Hoge}

\begin{abstract}
Before I go to bed, I shake my blanket. This causes a breeze. A breeze that brings with it this familiar smell - this smell of childhood, memories, and my life. The feathers that had just gathered at the foot end have been shaken upwards and are now mostly at the top of the blanket - like a cloud. I slip under my blanket, into the soft, warm nest and enjoy the moment of arriving, of feeling close to myself. The certainty that this must be the most beautiful place in the world brings a smile to my face. I snuggle up comfortably, cuddle up, warmth spreads.

What happens to this feeling of well-being when arriving in a psychiatric ward, at the latest when I get onto the disinfected bed?
\end{abstract}

The installation juxtaposes the structure and smell of the home bed linen with the smell and bed linen of the hospital and plays with polarities such as sterility and intimacy, functionality and individuality, lightness and stiffness. 


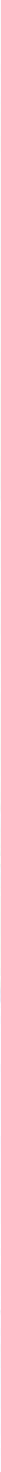




\section{"The Magical Device": \\ Temple Grandin's Hug Machine}

Novina Göhlsdorf

In August of 1947, when Temple Grandin was born in Boston, her mother perceived her as "a normal, healthy newborn" and a "quiet, 'good' baby girl" (Grandin/Scariano 1996: 23). According to Grandin, the mother felt a change after her daughter was six months old: "I was no longer cuddly and ... stiffened up when she held me. When I was a few months older, Mother tried to gather me into her arms, and I clawed at her like a trapped animal" (ibid.). Grandin describes the resistance to her mother's hugs as the first indication of her "disorder" (ibid.: 9). The impossibility of hugging her is also one of the starting points of Grandin's narrative of her life, which is depicted as thoroughly shaped by autism. In her account, her reactions and relations to embraces appear as a nucleus for most of her personal evolution. They are, often painfully, intricate. For she longed to be hugged but could not bear the tactile stimulation, because she was physically overwhelmed by it. As a teenager, she invented a machine that gave her much-needed hugs of a sort she could endure and eventually enjoy. She continually transformed the device and made it her mundane companion: her hug machine.

Grandin's hug machine - a leitmotif in her story - is the topic of this article. I will first show how its emergence was strongly interlaced with her development as she reports it - her own versatile emergence, which too is the title of her autobiography. Secondly, I will examine the machine's materiality, and the functions and effects 
Grandin attributes to it. Largely, she delineates it as a tool for handling challenges associated with her autism, mitigating her sensory difficulties, structuring her mental world, and teaching her to connect to others. However, her representations of the apparatus do not fully account for its instrumental features that supposedly make her function better, despite her condition. Thus, thirdly, I will explore the device as an actant in its own rights. Here, Grandin and the machine will not be analyzed as a bounded and one-sided constellation of a subject in charge and an object in use, but rather as an open and dynamic assemblage formed by two acting and interacting parties. Instead of depleting symptomatic expressions of a supposed "disorder," this association of a human and a machine generates experiences and affects beyond the categories of psychiatric pathology and treatment. Based on this perspective, I will, fourthly, address the question of how the synergies between Grandin and her machine might entail a sociality and relationality that is genuinely more than human. Finally, in view of recent statements by people with autism, I will contemplate this sociality and relationality as a potential autistic way of being in touch.

\section{The Emergence of Temple Grandin}

At the age of two, Grandin became a medical case. She compiles a list of features she did or, mostly, did not exhibit at that time: "no speech, poor eye contact, tantrums, appearance of deafness, no interest in people, and constant staring off into space" (2006: 33). As it turned out that she was not deaf, a neurologist deemed her "brain-damaged" (ibid.). A couple of years later, she was "labeled autistic" (Grandin/Scariano 1996: II). In her writings, Grandin retrospectively corroborates this label by picturing herself as a child showing typical signs of so-called "classic autism," like the traits and non-traits registered above. Contemporarily however, in the late 1940s and around 1950, autism as a distinct nosologic category was still in its earliest infancy, too. It was not yet a simply given and widely known diagnostic denomination, nor did there exist any subdivision like "classic." Against recommendations to put her in an institution, Grandin's mother created an individualized educational program for her at home. Grandin eventually began to speak and went to kindergarten, school, and college. She finished a Ph.D. and is today a renowned animal scientist and an internationally acknowledged designer of livestock systems (cf. Jacobson 2012). 
In 1986, the by then 39-year-old Grandin published the earliest broadly received autobiography by an author with autism. ${ }^{2}$ Emergence is a memoir of her life up to this point. It is a success story. The book in itself figures as the very manifestation of Grandin's achievements: the ultimate "emergence" of someone who was characterized by an inability to express herself intelligibly and was expected to forever remain immersed in her own private universe.

Moreover, every page of the text underpins Grandin's role as the first public expert on autism with autism. ${ }^{3}$ As a specialist on her own case, she shapes and proclaims a particular idea of autism. In opposition to a long-prevailing concept of it being a psychogenic disorder, a child's response to the psychic trauma of cold parenting, ${ }^{4}$ she defines autism as a developmental condition that derives from neurological irregularities bringing forth a "defect in the systems which process incoming sensory information" (Grandin/Scariano I996: 9). This defect "causes the child to over-react to some stimuli and under-react to others" (ibid.). For Grandin, all presumably generic symptoms of autism, including the notoriously invoked closed "world of one's own" (cf. Göhlsdorf 20I9a), are effectuated by misguided and therefore overwhelming or imperceptible input from the senses: "The autistic child often withdraws from her environment and the people in it to block out an onslaught of incoming stimulation" (Grandin/Scariano I996: 9).

"The autistic child" Temple Grandin once was herself is portrayed as either oblivious to external stimulation or, above all, as highly vulnerable to it, especially to touch. Touch regularly provoked "nerve attacks" (ibid.: 75) in her. In the book, hugs recur like floods of stimuli. Hugs from a large relative caused anxiety in Grandin: "I was totally engulfed and I panicked. It was like being suffocated by a mountain of marshmallows. I withdrew because her abundant affection overwhelmed my nervous system" (ibid.: 29-30). Due to what Grandin speaks of as her autism-related "tactile defensiveness" (ibid.: 36, I36), she was not able to shake someone's hand until into her twenties. ${ }^{5}$ She wanted to be touched, yearned for a specific combination of physical warmth and pressure. However, she could not stand the perceptual overload. "It was a conflict situation. In order to get over the tactile defensiveness, I needed tactile stimulation but I withdrew" (ibid.: 38). She tried to find relief by wrapping her body in blankets or weighting herself down with pillows. 
Still a young girl, she started to fantasize about an apparatus providing the right type of stimulation - in other words, a machine that gave her the hugs she wished for, "available at any time to soothe" (ibid.: 36) her and under her own control (ibid.: 58). This "magical device" (ibid.: 90), to cite Grandin, is metaphorically and literally at the center of her book. ${ }^{6}$ What at first was a secret reverie (ibid.: IOo) eventually became her most important project.

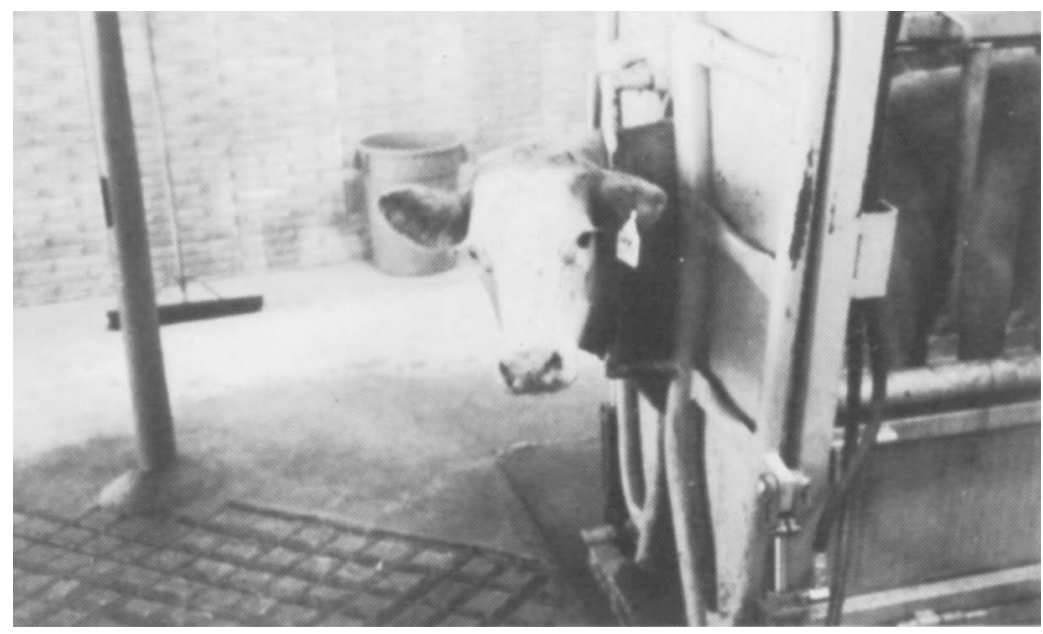

At the age of fifteen, she visited her aunt's farm where she discovered the "squeeze chute," a steel and wood device used for calming down cows before they were branded or vaccinated. The animal was driven into the chute, its head positioned into a gate. By pulling a rope, the side panels were closed and pressed against the flanks of the cow. Grandin noticed how this appeased the nervous animals. She had her aunt operate the cattle chute with herself, Grandin, inside, to find out if it had the same palliating effect on her, who was regularly suffering from anxiety and the aforementioned "nerve attacks." It did mollify her (cf. 1996: 93-95). She pictures her first moment in the cattle chute as a turning point in her life. Her childhood dream seemed viable: a magical device giving her hugs on demand, and of a kind she could tolerate. 


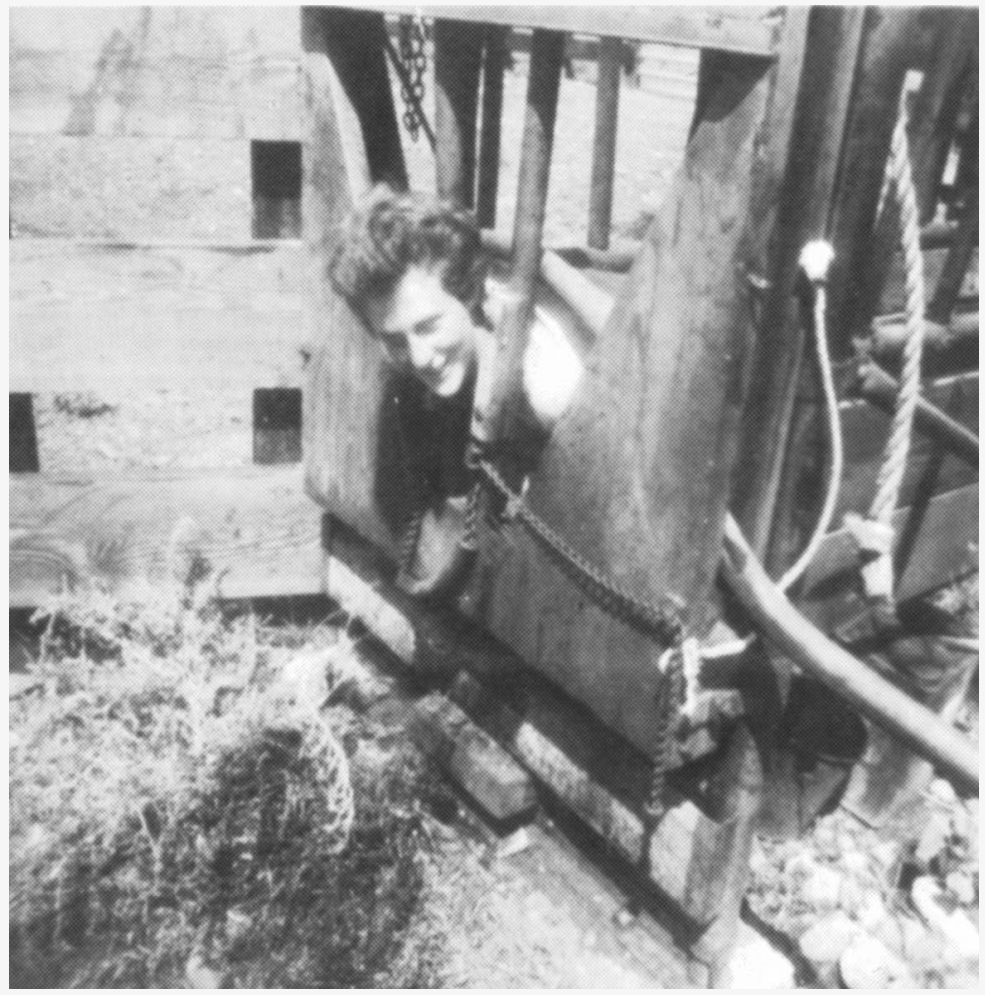

Fig. 2: Grandin in cattle chute

(Grandin/Scariano 1996: 95), (c) Arena Press 
The cattle chute became a model for what Grandin alternately calls her squeeze chute, squeeze machine, or hug machine. A teacher helped her construct a wooden apparatus replicating the chute on her aunt's farm. The teacher and her aunt were the only ones who approved of Grandin's machine (ibid.: 99). Psychiatric experts around her interpreted it psychoanalytically, attributing it to perverse sexual fantasies, for example (ibid.: I08). More importantly, her mother, presented as her main guardian, supporter and confidante throughout the book, was also against it. The strong opposition to the apparatus provoked feelings of guilt and inner conflicts in Grandin (ibid.).

When in college, she started to scientifically rebut the symbolic charge of the squeeze machine and verify its effectiveness, aiming to legitimize her usage of it. She investigated the contemporaneous research on sensory interaction and built a foam-padded prototype - PACES (Pressure Apparatus Controlled Environment Sensory) - a "Cadillac" (ibid.) compared to the first version. She asked test subjects to enter it and collected empirical data, showing that sixty-two per cent of the "normal [i.e., non-autistic] college students" (ibid.: IIO) appreciated being held by the machine and reported relaxation. Gradually, Grandin's affinity for the apparatus was accepted by those close to her. She also implies that these experiments were the beginning of her career as a scientist, with squeezing machines, sensory input, and livestock being recurring topics in her work (cf., e.g., ibid.: 130). She studied animal sciences, wrote her master's thesis on the design of cattle chutes, and later developed methods for slaughtering cattle. Today she ranks as a pioneer in the area of animal handling.

Grandin's narrative of herself builds on the machine. It is a dominant protagonist in her autobiography, staged as the pivotal condition of all of her accomplishments. It continued to be a significant motif in her writing. Be it in texts on autism, visual thinking, cattle behavior, or her empathy toward animals, the object - the squeeze machine - is frequently a prominent subject (cf. Grandin 2006; Grandin/Johnson 2006, 2010).

\section{The Hug Machine As an Instrument and Tool}

The setup of the hug machine was inspired by agricultural and industrial engineering. Determined by her respective resources and needs, Grandin adapted its construction and design over time. In spite of the various changes, the general, purely mechanical functionalities stayed the same, and no advanced or digital technology 
was ever involved in the machine's configuration. The prototype modeled after the cattle chute on Grandin's aunt's farm was a simple device made of rough scrap wood. Like the chute, the earliest variant had to be operated by another person. Grandin soon modified it and was able to "lock" and "release" (Grandin/Scariano I996: I0o) herself independently.

Two side boards are hinged at the bottom to form a V-shape. The user enters it and is embedded in it, lying down prone in the V-shaped space, lifted up from the floor. By moving a hand gear, the boards close in around her. Similar to the chute for farm animals, the first versions of the machine merely transmitted pressure, yielding a tranquilizing result due to the sheer compression. The later prototypes became more and more comfortable and they exerted less force, since Grandin's desire for "very intense pressure, almost to the point of pain" (Grandin 2006: 60) had decreased. Padding the side boards with foam rubber and fake fur added softness and a more complex quality to the squeeze. She also equipped the machine with a head rest and an upholstered element to sustain the neck (Grandin/Scariano 1996: I2O; Grandin 2006: 60). Thus, her body was supported from head to toe and fully embraced.

Although the basic arrangement - the V-shaped boards encircling a user in a horizontal position - was maintained throughout the prototypes, Grandin enhanced the pushing mechanism, for instance with a lever-operated pneumatic valve, aiming to apply a deep touch along both flanks of the body. Moreover, this had the result that the pressure was even and could be most subtly amplified and attenuated (Grandin/Scariano I996: I30-I3I). ${ }^{7}$

The hug machine affects Grandin on at least three levels: physical, mental, and interpersonal. It is sometimes difficult, in fact, to distinguish those levels in her text, and many of her statements suggest that their very distinction impedes a proper understanding of the apparatus's work. It is nevertheless of heuristic value to differentiate them at first. The primary effect Grandin describes is a bodily one, initiating all other impacts. The apparatus emits sensory stimuli and, depending on the prototype, the touch is harder or gentler. Besides stimulating her, the device fastens her. The touch and the fixation calm her down, but only given that the pressure is 

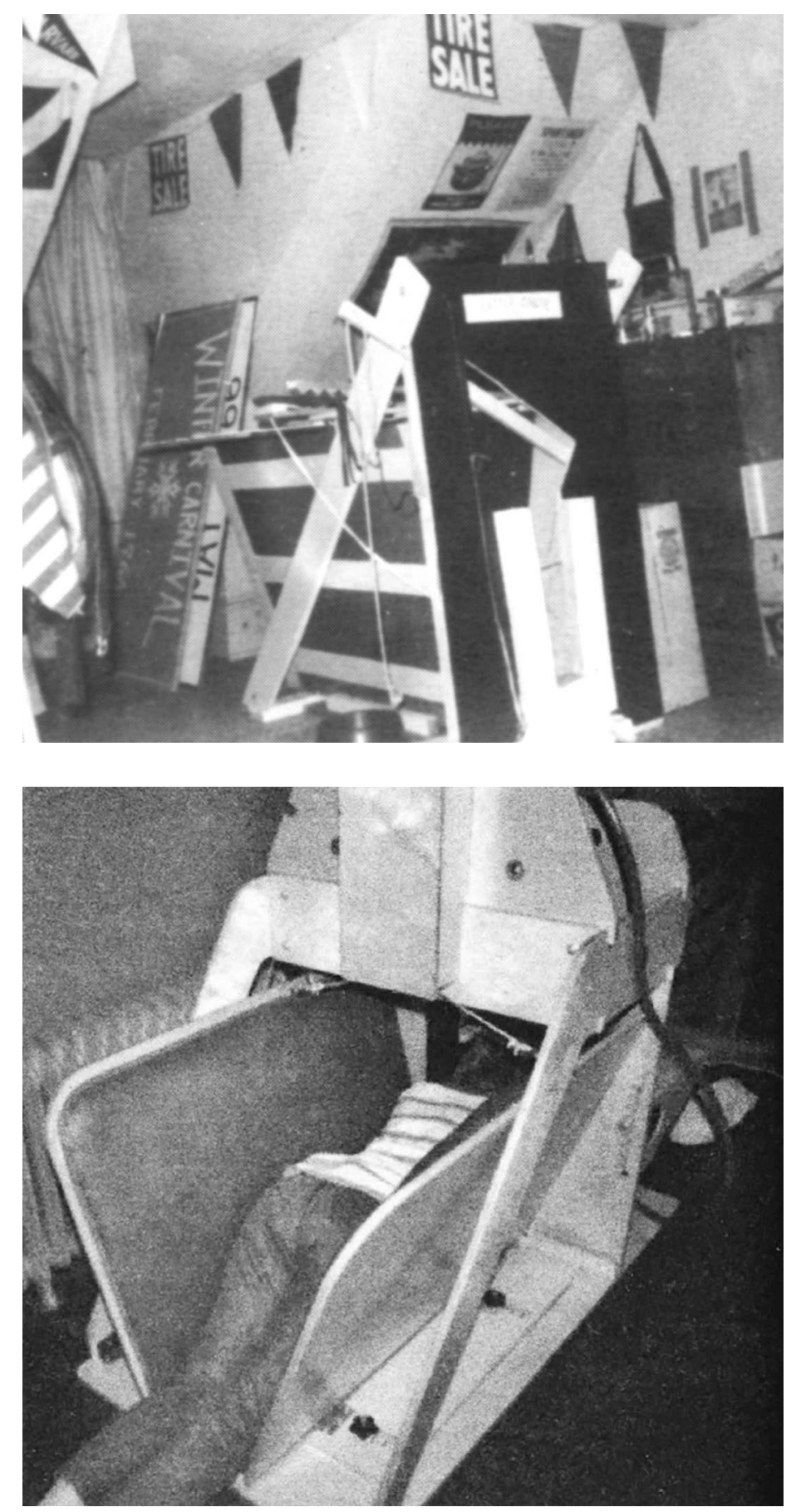
firm enough to surpass a particular threshold. Within this threshold, the touch is intolerable due to its lightness and makes her react with adamant resistance. Even when a sufficiently high pressure is achieved, she still needs to come to terms with "being confined" (ibid.: IIo).

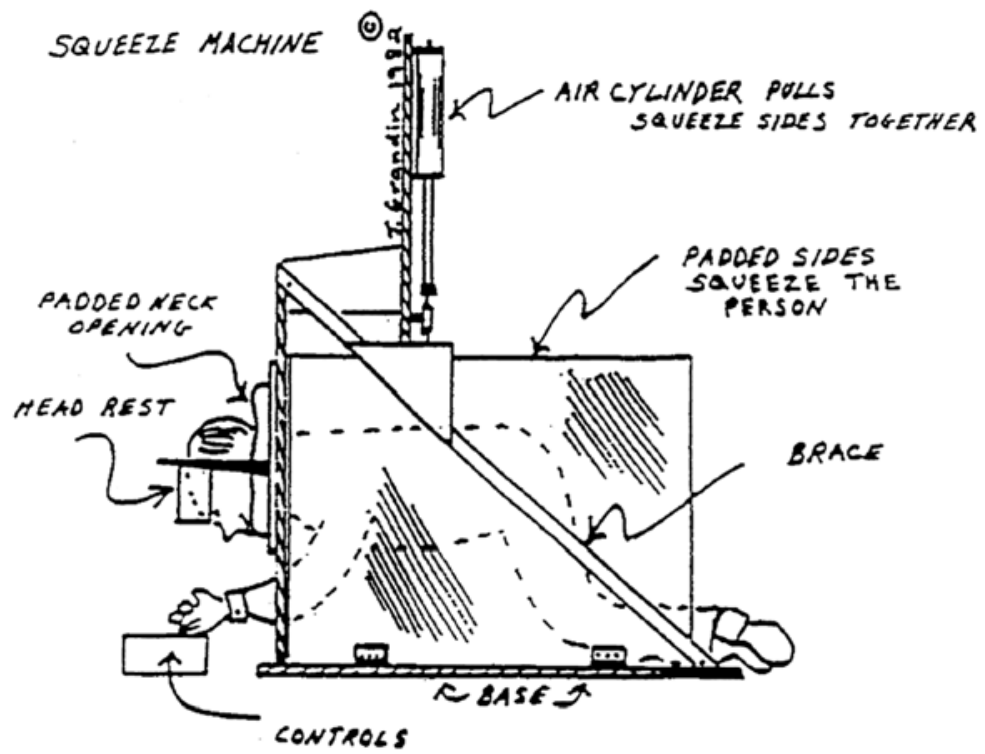


At the moment she first entered the cattle chute at her aunt's farm, she already realized that relief took effect solely after successfully restricting herself and overcoming the urge to withdraw:

I had to walk in calmly and quietly and not scream and struggle when the lever that would close a metal yoke around my neck was pushed down ... I had a panicky urge to jump out before the steel bars entrapped me. But I controlled myself and did not bang against the sides. (Ibid.: IO2)

She had to yield to the touch she would usually escape from, had it been elicited directly by humans. Only then she felt pleasantly stimulated and relaxed at the same time. After frequently applying the machine to herself as a disciplinary force, Grandin became increasingly capable of defeating the compulsion to fight the constraint (ibid.: IIO, I2O).

She utilized it as a training tool for self-control, which, in this case, is just as much a loss of control, or even more: a controlled loss of control, since she was the one steering the movement of the side boards. This, in turn, helped her gradually reduce her "tactile defensiveness": "I was finally beginning to be able to endure brief physical contacts like a pat on the shoulder or a handshake“ (ibid.: I09). She grants the machine healing, or rather, repairing faculties, as it supposedly fixes the "damaged nervous system" (ibid.: III) she traces back to autism. According to her, the apparatus can "cause new neural circuits to form" (ibid.) that she holds to be missing or broken in autistic people's brains. The less Grandin felt overpowered by the machine, the more she could deploy it as a source of comfort and regalement. Thus, she employed it as a motivating reward: "[S]ince I wouldn't allow myself the relaxation/stimulation of the chute until my homework was completed, the squeeze chute served as an incentive" (ibid.: IOo).

In Grandin's account, her corporal perceptions provoked by the device are accompanied by specific mental processes. Like the ability to manage her bodily reactions to tactile stimuli, her capacity to handle outbursts grew, for example: "I learned to control my aggression" (ibid.: I2O). She also faced affective and emotional ${ }^{8}$ states of new or unknown sorts, again due to a dialectic of forced submission and opened-up sensation. "I was learning how to feel," (ibid.: I08) she writes. "It was as if an accordion folding door had been shoved back revealing my emotions" (ibid.: IOo). This confrontation was an initially distressing one for her. In qualifying the machine as a device that taught her "to feel," she hints at a genuine deficiency within herself, implicitly 
confirming psychological assumptions about autism she otherwise condemns (ibid.: 57). ${ }^{9}$ The apparatus offered an ambience in which she could mentally experience what had before been imperceptible to her. In it, she was able to "accept affection" (ibid.: 120) and practiced grasping inner motions or representing them (ibid.: IOo).

The hug machine is a powerful medium of affects and emotions, inducing or amplifying them, raising her awareness of them and rendering their reflection possible. Here, Grandin trained herself in processing not only perceptual information but affective or emotional input and output as well. Her depictions ascribe psychotherapeutic functions to the apparatus. It unfolds an inward space and allows for its non-judgmental introspection. It might even recall a traditional psychoanalytic setup - a reversed couch - fostering what correspondingly would be framed as regression. Of course, instead of a talking cure, it facilitates a tactile one, and in place of stirring transferences between patient and therapist, it guarantees complete seclusion from human interaction, enabling very distinct transferences. In any case, however, it inspires Grandin to establish a connection with a self that simultaneously is developing in this very process. The machine is thus a technology that enhances technologies of the self, ${ }^{\text {o }}$ generating, shaping, and regulating a subject in its relation to itself.

Interestingly, Grandin refers to "feelings" or "affection" mainly as manifestations of interpersonal bonds. She had "thoughts about love" (ibid.) while in the machine. Only there could she truly realize that others cared about her or vice versa. "[I]t provided a warm, soft, comfortable environment which helped me receive and give affection" (ibid.: 133). Experiencing, differentiating and acknowledging her own mental states made her more aware of those of other people. It afforded her feelings for related parties (ibid.: I2I). She indicates that, within an enclosed setting ensuring retreat, solitude, and physical distance from others, she sensed attachment to them that had not been accessible to her before. Some passages suggest that her readiness to be emotionally touched coincides with and is indistinguishable from her capacity to permit her body to be held (ibid.: IOO). Grandin mentions contemporary theories of autism that associate it with a supposed deficit in empathy (ibid.). Drawing on primate research and her own biography, she wonders if this results from an absence of hugs in early life:

Feeling the soothing pressure from the squeeze machine slowly enabled me to start to have feelings of empathy. I wrote in my diary: 'Children have to be taught to be gentle. Since I missed out on this, I have to learn it now. The squeeze chute gives the feeling of being held, cuddled and gently cradled in Mother's arms ...' 
... I speculate that the regular use of the squeeze machine may help change some of the abnormal biochemistry which was caused by the lack of comforting tactile stimulation during my early childhood. Maybe the lack of empathy in many autistic adults is caused by their avoidance of hugging and affection when they were children. (Ibid.: I09) ${ }^{\mathrm{II}}$

Grandin conceives of the hug-providing and affection-triggering machine as an empathy training device that helps her catch up on lessons she could not learn as a child (ibid.: I08-I09). She credits it with altering her relationships to others and reducing what is to date delineated as a key symptom of autism spectrum disorders: "social communication impairments" (American Psychiatric Association 2013): "I was making great strides in communicating with people. I attributed this "breakthrough' in getting along better with people to my ... squeeze machine" (Grandin/ Scariano 1996: 108).

Encompassing the physical, mental, and interpersonal level, the squeeze machine constitutes a testing scenario and learning environment for Grandin. She often praises it as a potent self-help instrument that aids with challenges she believes to be caused by autism. Thus, it evokes three conflicting therapeutic contexts: firstly, much like many psychoanalytic or psychodynamic methods, it prompts emotive processes and their observation. Secondly, it changes perceptions and conduct similar to behavioral techniques exerting physical stimuli. And thirdly, it addresses neuro-cognitive, i.e. biological, systems by means of sensory input. Altogether, it instigates self-modification (ibid.: IOo). In Grandin's view, it helped normalize and integrate her into a neurotypically determined society (Almanza 20I6: I63), into "the world of love and human understanding" (Grandin/Scariano 1996: 36).

However, by focusing on these therapeutic functions and effects of the object, one might overlook how it opens up other worlds overall. For, more implicitly, Grandin also points to a differently productive and not merely instrumental dimension of the apparatus. From this perspective, one does not perceive her as a subject using it primarily as a tool that fulfills training or remedial purposes. Rather, one sees the whole setting - the mechanized hug between Grandin and her "magical device" as an assemblage generating states that do not solely compensate or alleviate deficits. What if we disregarded it as a device facilitating the entrance into spheres that are populated by humans who are - ideally - self-aware, properly delimited, and suffused with identifiable emotions? What if we examined it, instead, as an actant in its own right? And what is it, then, to be hugged by a machine? 


\section{Assembling Grandin and the Hug Machine}

Often, Grandin presents the apparatus as an object substituting for humans by granting her embraces she was not otherwise able to receive. It hence appears as a proxy or makeshift, its inanimateness a defect that has to be accepted. But when one considers all aspects of the machine mentioned by Grandin, one has to also ascribe a peculiar and innate quality to its very nonhumanness, an important surplus deriving precisely from it being a lifeless entity. This status can neither be apprehended as mere limitation nor as an intermediate step on the road to "true" interpersonal encounters. It constitutes an important feature in itself.

In separating it from other people, the hug machine makes physical contact always available. Its mechanics allow for the exact determination of the degree of pressure one exposes oneself to, and due to its construction, the touch is particularly intense, intimate, and extensive. It envelops almost all parts of the body, giving an all-embracing hug that no fellow human could offer. Whereas another person could only provide local and small-scale touches, the machine completely surrounds Grandin. Regardless of the theories and research results that she uses to explain its impacts, the device emerged from physical experiences, from trying out a chute designed for cattle and recognizing its sensory effects. Its development initially proceeded without any discourse but rather through bodily practices and the way they affected her. It primarily creates experiences that subvert any framework of social communication. They are determined neither by mutual expectations nor by the exchange of meanings or symbols. They account for communication only in the most genuine sense: as commerce, an exchange of forces, of hugs that consist in pure sensation with specific properties, depending, for example, on its firmness or temperature.

In spite of the inner struggle it provoked in the first moments, once Grandin was capable of opening herself to the stimulation, it relaxed her and gave her pleasure. This was her main impetus to build the squeeze chute and to hold on to it, despite the widespread disapproval and her own immediate resistance to its stimuli. Apart from deploying the machine as a means to diminish the symptoms of her condition, she also and increasingly resorted to it for sensual relief and indulgence: for self-stimulation. Self-stimulation has long been pathologized ${ }^{12}$ and made a target of intervention within the psy disciplines. Lately, however, it has been acknowledged as a valuable "self-regulatory mechanism" (Kapp et al. 20I9: I), notably for people 
exhibiting sensory processing difficulties. Within autism communities, it is being more often referred to as "stimming" and endorsed as an engine that is equally relieving, joyful, and empowering. For autistic literary scholar Melanie Yergeau, it "is desirous and self-exploratory and self-fulfilling" (2018: 202). In the course of her analyses, Yergeau emphasizes that "stims harbor ... possibility - the possibility of self-soothing, or self-regulating, or releasing" (ibid.: 204). Thus, the machine can itself be regarded as self-technology, but only by giving a new meaning to the word here. As opposed to shaping a self that can more smoothly fit into a fabric composed of interacting people, it enables one to meet one's needs and wishes self-sufficiently, without conceding one's aloneness. Self-sufficiency and aloneness have been held to be key manifestations of autism since its earliest description as a discrete syndrome, ${ }^{\mathrm{I} 3}$ and its treatment was typically aimed at attenuating them. In lieu thereof, the squeeze machine complies with an urge for reclusiveness.

Grandin's ambivalence toward the apparatus also derived from her own reservations about turning to a bare object with her desire for embraces and attributing such power to it. This was all the more so since this object was patterned on a chute often crudely applied to animals (cf. Grandin/Scariano I996: I22-I23, I26). Then again, the very interplay with the machine circumvents the categorical discriminations that her concerns are based on, since it suspends any clear distinction or constellation of subject and object. The subject position remains in abeyance here - is it Grandin steering the apparatus, or the apparatus affecting her? Certainly, it makes her equally potent and vulnerable. ${ }^{14}$ This becomes most obvious considering Grandin's already discussed controlled loss of control while in the machine. In one passage, she brings up a crucial detail about the points of transition between mastery and impotence, addressing an effectively ungovernable factor: As soon as the pressure gets too overwhelming for her, she can unlock herself, but before the release motion sets in, she has to tolerate a moment of being immobilized, without any room for maneuver (Grandin 2006: 76). In this short but critical instant, the squeeze machine can be recognized most clearly as a party that acts.

Even when it operates less autonomously, though, the machine is an actant - in the sense this term was given by philosopher and sociologist Bruno Latour, who distinguishes nonhuman "actants" from human "actors" (I999: I80). ${ }^{15}$ Latour promotes a new notion of "the social" based on the omnipresent collectives or "associations of humans and nonhumans" (2004: 83). He advocates abolishing a conception of the social founded firstly on a dichotomy of subjects and objects, and secondly on agency belonging exclusively to subjects supposedly pursuing intentions (ibid.: 246). 
Instead, he explicates acting in an inclusive sense, not taking it for "a property of humans but of an association of actants" (Latour 1999: I82, original emphasis). ${ }^{16}$ In his understanding, acting is not defined by purpose but is solely tied to changes in the other involved party, hence always already taking place within collectives (Latour 2004: 75). Acting things are thus more than ancillary objects: "In addition to 'determining' and serving as a 'backdrop for human action'," they "might authorize, allow, afford, encourage, permit, suggest, influence, block, render possible, forbid, and so on" (Latour 2005: 72). Building on this, he outlines a social composed of versatile and intermittent networks that emerge from the reciprocal interactions between diverse parties (ibid.: 65), resulting in "variable ontologies" (Latour I993: 85).

The conjunction of Grandin and her hug machine can be interpreted as a human-nonhuman association in the way Latour delineates it, in particular due to his underlying idea of an actor or actant: "any thing that does modify a state of affairs by making a difference" (Latour 2005: 7I). Seen in this light, Grandin and her machine both act, because they modify each other. By "habits ... rather than essences" (Latour 2004: 86, original emphasis), they constantly engender bilateral variations. These transformations occur during every single use of the machine.

Despite its angular and non-organic design, the hug machine offers an environment that corresponds to an inverted human body, fitted to fully contain Grandin. Thus, it invites being engaged with in a specific manner. When she enters the machine, its elements support her whole figure and sustain her entire weight, provoking at once a change of her position, perspective, and self-perception. Its leverage encourages a certain form of being manipulated, in Latour's words, a "programme of action" (2000: I8), enabling certain activities, disabling others. So already by accessing the machine, proposals and forces between the two participants are being "swapped." ${ }^{17}$ Subsequent to prompting the clasp of the side boards, the device squeezes Grandin's body, influencing her physiological and mental condition and thereby the state in which she then continues to direct the mechanism. After this initial movement, at the latest, Grandin's position as the first yet "unmoved mover" becomes volatile. Especially due to the possibility to induce, at least temporarily, her own passivity, agency here is intricately divided between human and machine. Both contribute to diverse "[c]irculations, sequences, transfers, translations, displacements, crystallisations" (ibid.: IO). The association or assemblage of Grandin and her machine renders these phenomena mentioned by Latour as concrete as possible, since both of their kinetic energies are continuously being shifted. The configuration is driven by ongoing transmissions and processes of mutual affordance and allowance. 
Grandin and the machine alter each other in the long term as well. As shown before, the use of the apparatus changes her on multiple levels. Also proceeding from her development in this way, she reconstructs, adjusts, and supplements its mechanics, breeding further complexities and subtleties in its mode of operation. She and the device are each increasingly stabilized as actor and actant, respectively, with more multifaceted dispositions and alternatives to perform. Not only are Grandin's options for feeling and behaving expanded with the help of the machine, and not only does she eventually obtain the status of a "high-profile figure" (Murray 2008: 32); the device, too, becomes progressively nuanced and ultimately less individualized and idiosyncratic. First modeled after an appliance for cattle and strongly resembling it, it took shape as the handiwork of an amateur and a unique specimen for Grandin's own personal use, which was repeatedly rebuilt. Finally, it served as a prototype for an industrially manufactured and commercially distributed item advertised for people with autism. ${ }^{18}$ This might imply that it finally turned into a mere therapeutic tool. Presumably, however, any person's association with a hug machine generates synergies that do not simply reduce impairments but produce experiences impalpable in registers of pathology and therapy. Even as a disseminated commodity, it creates mechanical hugs incorporating two-way modifications and intimacy apart from health care treatment programs.

It is my claim that, in this respect, this human-nonhuman collective exceeds many of Grandin's explanations of the machine's functions. I argue that it equally surpasses the above mentioned Latourian framework. Grandin's alliance with the machine can admittedly be comprehended as a distinct human-nonhuman association, also identified by Latour as "person-machine interface" (2000: II). Moreover, it might vividly manifest a hybrid of a human and a "technical object" as depicted by him: "[o]ne generally finds oneself in the realm ... of what is called the 'body corporate' or the 'artificial person'” (I999: I92). The artifacts that Latour chooses as examples, however, display an instrumentality that subverts his own argument. Be it a handgun or a speed bump (cf. ibid.: I76-I80, I86-I87), they are typically of practical or, in any case, purposive value. They make humans reach - howsoever ferocious - goals in manners that curiously threaten to re-erect the very subject-object dichotomy that Latour wants to dispose of. Due to its non-instrumental and non-targeted traits, the Grandin-machine interface - or rather, the Grandin-machine assemblage - may be a better illustration of a Latourian conception of a new type of social. This assemblage essentially questions the duty of "delegation," which he equivocally attributes to nonhuman actants. According to 
him, "[a]n object stands in for an actor" (ibid.: 189). A speed bump then works as a "sleeping policeman"' (ibid.: 186). This contradicts his compelling designation of nonhuman actants as "mediators," as opposed to "intermediaries": Whereas intermediaries are surrogates which merely relay messages that can also be formulated elsewhere, mediators have a profound influence on these messages; they can shape or sabotage them. They are "endowed with the capacity to translate what they transport, to redefine it, redeploy it, and also to betray it" (Latour 1993: 8I). Unlike the cases Latour cites, Grandin's squeeze machine perfectly exemplifies these mediators. It does not deputize or symbolize interpersonal occurrences. It is not an intermediary, carrying out acts of human communication in nonhuman guise, like a speed bump does. Instead, it makes relations - of a not purely human kind. In other words, even though Grandin sketches it at times as a "delegate" for people hugging her, the special qualities of its embrace transcend such assignment. The hug machine might be a thing that is liberated from "standing in." Perhaps this is where the magic of the magical device lies?

\section{Towards a More-Than-Human Sociality}

Grandin's representations of the machine and, first and foremost, her practices around it, re-shaped the knowledge about autism and the discourse on it, its research and therapy. ${ }^{19}$ They were used to trace the condition back to special ways of sensory processing, to overpowering or insufficient stimulations. ${ }^{20}$ Maria Almanza ascribes "embodied knowledge" (2016: I73) to the machine: "Grandin's account of her sensory experience is intimately linked to the squeeze machine." It "gives testimony to Grandin's unique sensory life" (ibid.: I66).

Furthermore, the Grandin-machine assemblage inherently revaluates criteria that have traditionally been regarded as core symptoms and deficits defining autism. I have already pointed out that the assemblage permits and enables "aloneness," long classified as the main deviation exhibited by autistics. It also accommodates an affinity for objects that was originally treated as a pathological sign of autism, too. In his first studies on "autistic disturbances of affective contact," child psychiatrist Leo Kanner not only identified aloneness and insistence on sameness as characteristics of the children he soon diagnosed with "early infantile autism" (1943: 249; 1944). He also emphasized that his young patients treated people "as if 
they were objects" (Kanner 1944: 212), meaning with indifference. At the same time, they would strangely connect with real objects like artifacts or toys, handling them "with care and even affection" (1944: 2I2). This assumption implies that their attachments to items resembled the ones children without "infantile autism" typically had toward people - and it reinforces a longstanding hierarchy of subjects and objects, rigidly distinguishing the sorts of relationships one should naturally have to each of them. For Kanner, his patients' "good relation to objects" (1943: 246, original emphasis) thus manifested their deviance. He also associated it with what he designated as autism's main symptom. Objects are preferred over people, because they "never threaten to interfere with the child's aloneness" (ibid.). By devoting himself to objects, the autist "has a gratifying sense of undisputed power and control," as Kanner concluded (I944: 216).

Grandin's conjunction with the squeeze machine is an intimate bondage with a lifeless device, more intimate than the devotion to objects that Kanner once scandalized. In the beginning, she too is unsettled about this, since it was criticized, most importantly, by her mother. Grandin cites a letter from her stating that "[o]bjects cannot speak to you or hug you. Objects are only something made out of imagination and energy and raw materials" (I996: I05; original emphasis). However, Grandin's persistent habit of using the machine profoundly questions this presumption: It lets the machine communicate with her and embrace her. It appreciates the force that stems from the "imagination, energy and raw materials," of which the object - or more precisely, the thing - is made. Likewise, and as I have demonstrated, Kanner's idea regarding the autist's "undisputed power and control" over artifacts is scrutinized by the power and control of Grandin's apparatus. I have also shown that her alliance with the machine confounds any clear order of subjects and objects.

Her maintaining a close relation to a machine evokes as much as it reassesses another stereotypical notion of autism. To date, it has been linked with a problematic kind of mechanization: Either the parenting of autistic children, the rapport people with autism have with others, their conduct, or even just autistics themselves have frequently been portrayed as mechanical or technical, as an impoverished or downright subhuman existence (cf., e.g., Asperger I944: 93, III; Kanner 1945: 25; I949: 422; Bettelheim 1959, 1967). ${ }^{21}$ In her narrative of her life and especially in writing about the squeeze machine, Grandin, by contrast, positively marks her attraction to mechanical gadgets and technology as a gift (Grandin/Scariano I996: 38). What has for many decades been understood as aberrance, she turns into a potential and passion. Besides, in her entanglement with the apparatus, "mechanical" does not 
metaphorically refer to a behavior deprived of interpersonal "warmth," but it is a fitting term for the very functionality at hand: an effective mechanization of touch.

The Grandin-machine assemblage brings about, or in Latourian vocabulary, "articulates" (Latour 2004: 86; I999: I87), a specific kind of contact. It is physical, mental, and social - i.e., happening among actants. But it is always based on tactile encounters and thus matches the genuine connotation of the word contact. Hugging here is no more and no less than a sensory experience between oneself and one's surroundings. It has no currency in the business of interhuman exchange, no representational duties. There are reasons to interpret this type of contact as an autistic being in touch.

This is not meant to impose yet another definition of autism from an allistic, i.e. non-autistic, viewpoint. ${ }^{22}$ Firstly, however, this approach is feasible, according to Grandin's own understanding of the condition. Since she conceives of autism as an augmented responsivity to sensations, the equally magnified and regulated sensory occurrences within the machine can indeed be grasped in terms of a particular relationality to one's environment. This relationality is non-discursive, non-intentional, and beyond hermeneutic logics of symbols or denotations. Instead, it is driven by dynamics of immersion, penetrability, and perceptual intensities. It is "an invention that allows for the autist's creative relation to other people, objects, and animals" (Almanza 2016: I69).

Secondly, the "embodied knowledge" of Grandin's machine and this very relationality resonate with recent utterances made by other people with autism. They deny being disconnected from the outside world or non-communicative, instead emphasizing how strongly they interact - given that interaction is fathomed differently. Autism advocate Mel Baggs, for instance, did not use verbal language. She reported, however, being in continuous dialogue with the spaces around her, including things and materials like water, which, for Baggs, clearly had agency. ${ }^{23}$ Her communication with them was non-symbolic.

$[\mathrm{M}] \mathrm{y}$ language is not about designing words or even visual symbols for people to interpret. It is about being in a constant conversation with every aspect of my environment. Reacting physically to all parts of my surroundings. ... Far from being purposeless, the way that I move is an ongoing response to what is around me. (Baggs 2007) ${ }^{24}$

Philosopher Erin Manning contends that for Mel Baggs " $[\mathrm{t}]$ here is nothing but relation" (2012: IO, original emphasis). Manning speculates that autists are the sole adults able to perceive this comprehensive relationality - "affective attunement" (ibid.: II) - 
with our ambience, since most humans purportedly lose it while growing up. Those "affective attunements" vary significantly from the "affective contact" Kanner posits between people. ${ }^{25}$ Manning refers to an idea of affect held to be an "event" that "concerns the movements of the body" and "is not subjective in the sense of belonging to a subject to which the body belongs" (Massumi 2015: I05). ${ }^{26}$ Furthermore, it is not bound to volition (cf. Manning 20I6: 19-20).

For Melanie Yergeau, "involuntarity" is a crucial element of an autistic rhetoric that she asserts. She also calls it a "sensorimotor rhetoric" (20I8: 56). For her, it flips rhetorical traditions grounded on intentionality or symbolism. In autistic rhetoric, intention might emanate from body parts and meaning from "[p]erceptual signification" (ibid.: 55) rather than from any structure of representation. It is a rhetoric that "tics, ... stims" and "averts eye contact" (ibid.: 3I). Grandin's hug machine can be viewed as a manifestation of such rhetorics. It articulates stims; it also affords a concurrency and dispersion of agency and non-agency in both involved parties that are at the center of Yergeau's conception of an autistic rhetoric. This rhetoric - as does the Grandin-machine assemblage - rejects criteria of purpose, causation, or finality. It features processuality and non-discursiveness. Moreover, an "irreducible relationality" appertains to it which is "forged with and between things, fields, spaces, air particles, moments, motions" (ibid.: 72). Here Yergeau seems to aptly capture the above-mentioned relationality entailed by Grandin's machine. Such "irreducible relationality," similarly outlined by Baggs and Manning, goes along with what Yergeau describes as a distinctive sociality in autistic rhetorics. It is "without a you or a me" (ibid.: 34, original emphasis), and "more than human" (ibid.: 7I).

The Grandin-machine assemblage indeed generates and expresses a sociality that does not prioritize any human affiliation but fosters one with a thing that eventually becomes Grandin's steady and intimate companion. ${ }^{27}$ More indirectly, it also connects her to animals. Its first scheme was born after she had put herself figuratively and then literally into a cow's position. It emerged from the kinship with animals which she accredits to herself and many autistic people, a kinship she claims to repeatedly perceive when in the machine. As an animal scientist and professional designer of livestock facilities, she developed chutes for cattle, based on her experiential insight from the use of her device. In turn, her observations of chutes at feedlots helped her technically improve her own apparatus.

Grandin also devised a large part of the slaughterhouses in the US, enforcing supposedly humane standards by applying her knowledge of the soothing impact of tactile pressure. She relates how she once constructed a cattle chute for kosher 
slaughter. She herself directed the mechanism to calm a cow before and while it was being killed: "[T]he parts of the apparatus that held the animal felt as if they were an continuation of my own body, similar to the phantom limb effect" (Grandin 2006: 25). This chute constitutes a mediator. It allows Grandin to hug an ani$\mathrm{mal}^{28}$ or the animal, the chute, and Grandin to form an animal-nonhuman-human association. ${ }^{29}$ According to Gary Wolfe, this scene attests to "trans-species affinity" (Wolfe 2010: 120). Grandin here "crosses not only the lines of species difference, but also of the organic and inorganic, the biological and mechanical" (ibid.: II7). Wolfe considers her "disability" the very qualifier for the ability to traverse those divides. ${ }^{30}$ So does Grandin herself. In Animals in Translation, she writes: "Autism is a kind of way station on the road from animals to humans, which puts autistic people like me in a perfect position to translate 'animal talk' into English" (Grandin/Johnson 2006: 6-7). For her self-image, her familiarity with animals has been as crucial as her familiarity with mechanical things. To Grandin, autism is where species meet. ${ }^{31}$ In any case, the assemblages made possible by Grandin's hug machine or her aforementioned cattle chute transcend the typical regime of species which distinguishes between humans, animals and objects. These assemblages indeed enable "variable ontologies" (Latour 1993: 85) - but again, in a more radical and consistent manner than Latour envisions. They enhance wider-reaching affiliations and impel morethan-human affective ecologies.

Many recent remarks by those who are experts on autism through experience lastingly reframe ideas about it. Instead of considering it a disorder defined by deficiencies, they value it as a legitimate and rich way of being. Instead of locating it within a barred and walled domain, they view it as a key that opens extensive worlds. Temple Grandin was the first public autistic specialist on autism. During the past 30 years, her presence and her statements have been crucial and influential for debates on the condition. Numerous texts of hers, however, contribute to its ongoing pathologizing. They uphold the ideal of integrating people with autism into neurotypical cultures, assigning those cultures normalcy and normativity.

One could, however, arguably conceive of her hug machine as an autism advocate avant la lettre. This would make another act of the machine discernible: In its association with Grandin it brings forth an autistic being in touch. It thereby modifies assumptions about what it means to be autistic and about what it means to be in touch. The magical device can make us rethink the human, and it might truly reassemble the social. 


\section{Notes}

1

This might explain the divergent information Grandin gives on her diagnostic history (cf. 1996: 11; 2006: 33). In this regard and concerning Grandin's supposed early signs of autism, her account also deviates from her mother's (cf. Cutler 2004: 6-7, 25, 30).

\section{2}

A year before, in 1985, David Eastham's book Understand: Fifty Memowriter Poems was released, which is, according to Melanie Yergeau, "[a]rguably the first published autie-biography" (2018: 21). However, it largely went unnoticed.

\section{3}

This is based on a curious juxtaposition: Large parts of her book contain general, matter-offact paragraphs using selected evidence from science, which are only loosely connected to the descriptions of her personal experiences.

\section{4}

In seminal writings on infantile autism, it was presented as an outcome of a non-loving attitude of parents, especially mothers, towards their offspring (cf., e.g., Kanner 1949). Because of the alleged traumatizing lack of emotional warmth and care, the autistic child would retreat into her barred-off universe, rejecting dynamics of interpersonal relations altogether. See Bettelheim (1967) and footnote 11 of this article.

\section{5}

She believes this threshold of "tactile defensiveness" affects many autistic people (cf., e.g., Grandin/Scariano 1996: 36-37).

\section{6}

A chapter titled "The Magical Device" is dedicated to the machine and positioned in the very middle of her book. However, the apparatus is mentioned in nearly every chapter.

\section{7}

For the machine's technical details see, e.g., Grandin/Scariano (1996: 182-184).

\section{8}

For a lucid differentiation of a "processual, bodily affect" and a "subjective, representable emotion," see Bösel (2018: 19).

\section{9}

Inadequate or plainly absent emotion in autistic patients has been a ubiquitous topic in the psy disciplines, especially in psychoanalytically inclined studies (cf., e.g., Kanner 1943; Bettelheim 1959, 1967)

10

See Foucault (1988) and Rose (1996).

11

The diary entry by the younger Grandin cited in this paragraph imparts a singular significance to the motherly hug, while the older Grandin, consistent with most of her statements about hugs, describes them as a bodily stimulation defined by technical parameters, yielding measurable physical effects. In some sequences of her book, however, her ambiguous notions of "hugging" become apparent. She explains her longing for being touched through a want of embraces, namely from a nanny who had rejected the concept of physical tenderness. Grandin ascribes symbolic quality to hugs as expressions of "affection" - another term she uses equivocally: "Since the governess ... never hugged or touched my sister or me, I craved tender touching. I ached to be loved - hugged" (Grandin/Scariano 1996: 36). This curiously preserves an all too familiar idea of autism, linking it to the fault of a tender and warm familial milieu (cf. Kanner 1944, 1949; Bettelheim 1959, 1967). Grandin replaces the emotionally negligent mother - a recurring figure in the discursive history of autism - with the governess, thus indirectly reanimating the "cold mother," without blaming her own mother. 
12

For the history of the pathologizing of self-stimulation and its association with masturbation, see Yergeau (2018: 201-202). The early criticism of Grandin's hug machine can also be explained by a not yet established discourse on self-stimulation. Much less did there exist a positive understanding of it.

\section{3}

See most prominently the seminal work Kanner (1943).

\section{4}

I will address the discrimination between human and animal and its subversion by Grandin's use of the machine in the next chapter.

\section{5}

This is mostly a nominal distinction, however, since human and nonhuman parties, for Latour, act in similar ways.

\section{6}

In this phrase, he applies "actants" as a word for both human and nonhuman parties.

\section{7}

Here I am referring to Latour's mention of "swapping properties among inert, animal, symbolic, concrete, and human materials" (1999: 190).

\section{8}

See Therafin Corporation, http://www.therafin. com/squeezemachine.htm, accessed July 5, 2019

\section{9}

Especially after the publication of Emergence in 1986, the machine influenced scientific studies on autism and methods of treatment; its clinical value was progressively acknowledged (cf., e.g., Krauss 1987). Even before the release of her autobiography, Grandin also began to author and co-author articles in the area of autism research (cf. Grandin 1984; 1992; Edelson et al. 1999). Applying deep pressure has been increasingly approved of as treatment for autistic patients (cf. Bestbier/Williams 2017). Accordingly, the use of squeezing devices inspired by Grandin's apparatus has become a suggested means (cf. Duvall 2017).

\section{0}

The most recent definition of autism in the Diagnostic and Statistical Manual of Mental Disorders (DSM) lists "hyper- or hyporeactivity to sensory input" (American Psychiatric Association 2013) as a symptom relevant for its diagnoses.

For recent "[s] ensorimotor approaches" (Yergeau 2018: 195) to autism see, e.g., Tavassoli et al. (2019); Neil et al. (2016); Donnellan et al. (2013); Savarese (2013); Green et al. (2012); Pellicano/ Burr (2012); Mottron et al. (2006); Jones et al. (2003); O’Neill/Jones (1997).

\section{1}

This notion is still strongly tangible in psychologist Simon Baron-Cohen's influential ascription of a genetically inherited "technical mind" to people with autism (cf. Baron-Cohen 2012). For the ever-present discursive linkage of autists with apparatuses, preferably robots, in science and popular culture see Göhlsdorf (2019a: 292f; 2019b). Amit Pinchevski and John Durham Peters also stress the continuous interleaving of autism and the technical world (cf. 2016: 2514).

\section{2}

Rather, I consider it one potential autistic way of being in touch, that is prevalent and a matter of wider discussion among people with autism. Still, for an allistic author, there is a precariously fine line between, on the one hand, reflecting autism founded on statements and practices of those identifying themselves as autistic and, on the other hand, putting the label "autism" onto a phenomenon one does not experience oneself, thus repeating a violent gesture that has dominated autism's history.

\section{3}

Pinchevski and Peters therefore locate Baggs "on the cutting edge of new materialism, thing theories, and what Walter Benjamin (1973) called "empathy with inorganic things'" (Pinchevski/ 
Peters 2016: 2520). For them, Baggs and other autistics "may be the pioneers of object-oriented ontologies" (ibid.). Baggs, who died in April 2020, was non-binary and preferred to be referred to by the pronouns "sie" and "hir."

\section{4}

This text forms part of a YouTube video authored and produced by Baggs. The words are uttered by a computerized voice and legible in subtitles from minute 3:32 through 4:05. https://www. youtube.com/watch?v=JnylMIh/2jc

\section{5}

Manning, however, borrows this term from Daniel Stern, who focused on "affect attunement" between mothers and their not yet verbal children (cf. Stern 1998: 138-161).

\section{6}

See also Bernd Bösel's account on the "eventology" (2018: 19-20) of affect, building on Brian Massumi's theory.

\section{7}

Although I deem Oliver Sacks's much-noticed portrait of Temple Grandin, including her hug machine, highly problematic, he offers a credible description of how the device accompanies her in everyday life (cf. Sacks 1995: 262-265).

\section{8}

This setting recalls the chute that Grandin's aunt operated with Grandin inside of it, allowing the aunt to give her niece a hug that could not be realized without the chute.

\section{9}

This particular cattle chute also serves as a prosthesis for Grandin. Grandin's hug machine has been analyzed as a "prosthetic extension of the self" (Almanza 2016: 162, original emphasis) as well. However, Almanza's depiction of the machine as "a prosthetic, non-linguistic means for Grandin to communicate her needs to others" (ibid.: 196) is questionable, because it again subordinates the apparatus to primarily interpersonal processes.
30

For Wolfe, Grandin's self-apprehension within a "register of the technical and mechanical" (2010: 131) and as someone who shares ways of visual and tactile perception with animals alludes to an idea of an "ahuman" (ibid.: 112) inspiring a productive convergence of post-human thought and disability studies. By "[l] earning from Temple Grandin" (ibid.: 127), Wolfe declines to base affinity across species on "subjectivity as agency" (ibid.: 138, original emphasis) but, instead, on "vulnerability and passivity" or - in Derrida's words - on "'non-power at the heart of power" (ibid.: 141). Even though Wolfe does not make such a reference, his conception of "non-power" can also be applied to the non-agency, or rather semi-agency, that is effectuated by the hug machine.

\section{1}

It would be fruitful to also examine Grandin's hug machine with the help of Donna Haraway's work on, e.g., the interspecies "subject- and object-shaping dance of encounters" (2008: 4). It is not possible within the scope of this article. For good reasons, however, the Grandin-hug machine assemblage can be understood as a cyborg in the way illustrated by Haraway, too. Furthermore, it would be productive to draw on her thoughts on the autonomy of machines and boundary confusions (cf. Haraway 2016). 


\section{Bibliography}

Almanza, Maria (2016): “Temple Grandin's Squeeze Machine as Prosthesis." In: Journal of Modern Literature 39/4, pp. 162-175

American Psychiatric Association (2013): Diagnostic and Statistical Manual of Mental Disorders (5th ed.), Washington DC, https://doi.org/10.1176/ appi.books.9780890425596 (F84.0), accessed August 19, 2019

Asperger, Hans (1944): "Die 'Autistischen Psychopathen' im Kindesalter." In: Archiv für Psychiatrie und Nervenkrankheiten 117, pp. 76-136. Baggs, Mel (2007): In My Language, https:// www.youtube.com/watch?v=JnylMlhl2jc, accessed August 19, 2019.

Baron-Cohen, Simon (2012): "Autism and the Technical Mind." In: Scientific American 307/5, pp. 72-75.

Bestbier, Lana/Williams, Tim I. (2017): "The Immediate Effects of Deep Pressure on Young People with Autism and Severe Intellectual Difficulties: Demonstrating Individual Differences." In: Hindawi. Occupational Therapy International, https://doi.org/10.1155/2017/7534972, accessed August 19, 2019.

Bettelheim, Bruno (1959): "Joey: A 'Mechanical Boy.". In: Scientific American 200/3, pp. 116-127. Bettelheim, Bruno (1967): The Empty Fortress: Infantile Autism and the Birth of Self, New York: The Free Press.

Bösel, Bernd (2018): "Affect Disposition(ing): A Genealogical Approach to the Organization and Regulation of Emotions." In: Media and Communication 6/3, pp. 15-21.

Cutler, Eustacia (2004): A Thorn in My Pocket: Temple Grandin's Mother Tells the Family Story, Arlington TX: Future Horizons.

Donellan, Anne M./Hill, David A./Leary, Martha R. (2013): "Rethinking autism: implications of sensory and movement differences for understanding and support." In: Frontiers in Integrative Neuroscience 6/124, n. pag., https://doi.org/10.3389/fn int.2012.00124, accessed August 19, 2019.
Duvall, Julia Claire (2017): Bear Hug: The Design and Development of an Active Deep Touch Pressure Garment for Sensory Processing Disorder, master's thesis, University of Minnesota, https:// conservancy.umn.edu/handle/11299/191299, accessed August 19, 2019.

Eastham, David E. (1985): Understand: fifty memowriter poems, ed. by Anne Grice, Ottawa: Oliver Pate.

Edelson, S. M./Edelson, M. G./Kerr, D. C./Grandin, T. (1999): "Behavioural Physiological Effects of Deep Pressure on Children with Autism: A Pilot Study Evaluating the Efficacy of Grandin's Hug Machine." In: The American Journal of Occupational Therapy 53/2, pp. 145-152.

Foucault, Michel (1988): "Technologies of the Self." In: Luther H., Martin/Gutman, Huck/Hutton, Patrick H. (eds.): Technologies of the Self. A Seminar with Michel Foucault, London: Tavistock, pp. 16-49.

Göhlsdorf, Novina (2019a): "Autismus: Diagnose der Gegenwart." In: Kinder- und JugendlichenPsychotherapie. Zeitschrift für Psychoanalyse und Tiefenpsychologie 50/182, pp. 277-303.

Göhlsdorf, Novina (2019b): "Der seelenlose Cyborg. Wenn Philosophen hassen." In: Frankfurter Allgemeine Sonntagszeitung, August 11, p. 34

https://www.faz.net/aktuell/feuilleton/debatten/wiephilosoph-michel-onfray-greta-thunberg-pathologisiert-16325690.html, accessed August 19, 2019

Grandin, Temple (1984): "My Experiences as an Autistic Child and Review of Selected Literature." In: Journal of Orthomolecular Psychiatry 13/3, pp. 144-174

Grandin, Temple (1992): "Calming Effects of Deep Touch Pressure in Patients with Autistic Disorder, College Students, and Animals." In: Journal of Child and Adolescent Psychopharmacology 2/1, pp. 63-72

Grandin, Temple (2006 [1995]): Thinking in Pictures and Other Reports from My Life with Autism, London: Bloomsbury.

Grandin, Temple/Johnson, Catherine (2006 [2005]): Animals in Translation: The Woman Who Thinks Like a Cow, London: Bloomsbury. 
Grandin, Temple/Johnson, Catherine (2010): Animals Make Us Humans: Creating the Best Life for Animals, New York: Harcourt.

Grandin, Temple/Scariano, Margaret M. (1996 [1986]): Emergence. Labeled Autistic, New York: Grand Central.

Green, Shulamite A./Ben-Sasson, Ayelet/Soto, Timothy W./Carter, Alice S. (2012): "Anxiety and Sensory Over-Responsivity in Toddlers with Autism Spectrum Disorders: Bidirectional Effects Across Time." In: Journal of Autism and Developmental Disorders 42/6, pp. 1112-1119.

Haraway, Donna (2016): "A Cyborg Manifesto: Science, Technology, and Socialist-Feminism." In: Haraway, Donna: Manifestly Haraway, Minneapolis/ London: University of Minnesota Press, pp. 3-90. Haraway, Donna (2008): When Species Meet, Minneapolis/London: University of Minnesota Press. Jacobson, Pearl (2012): "Profiles in Science for Science Librarians: Temple Grandin." In: Science E Technology Libraries 31/4, pp. 343-360.

Jones, Robert S. P./Quigney, Ciara/Huws, Jaci C. (2003): "First-hand accounts of sensory perceptual experiences in autism: a qualitative analysis." In: Journal of Intellectual \& Developmental Disability 28/2, pp. 112-121.

Kanner, Leo (1943): "Autistic Disturbances of Affective Contact." In: Nervous Child 2, pp. 217-250. Kanner, Leo (1944): "Early Infantile Autism." In: Journal of Pediatrics 25, pp. 211-217.

Kanner, Leo (1945): "Child Rearing by the Book." In: The American Mercury 60/253, pp. 23-28.

Kanner, Leo (1949): "Problems of Nosology and Psychodynamics of Early Infantile Autism." In: American Journal of Orthopsychiatry 19/3, pp. 416-426. Kapp, Steven K./Steward, Robyn/Crane, Laura/Elliott, Daisy/Elphick, Chris/Pellicano, Elizabeth/Russell, Ginny (2019): “'People Should Be Allowed to Do What They Like': Autistic Adults' Views and Experiences of Stimming." In: Autism, February 28, https:// doi.org/10.1177/1362361319829628, accessed August 19, 2019.

Krauss, Kevin (1987): “The Effects of Deep Pressure Touch on Anxiety." In: The American Journal of Occupational Therapy 41/6, pp. 366-373.
Latour, Bruno (1993): We Have Never Been Modern, transl. by Catherine Porter, Hertfordshire: Harvester Wheatsheaf.

Latour, Bruno (1999): Pandora's Hope. Essays on the Reality of Science Studies, Cambridge MA/ London: Harvard University Press.

Latour, Bruno (2000): "The Berlin Key or How to Do Words with Things." In: Graves-Brown, Paul (ed.): Matter, Materiality and Modern Culture, New York: Routledge, pp. 10-21.

Latour, Bruno (2004): Politics of Nature. How to Bring the Sciences into Democracy, transl. by Catherine Porter, Cambridge, MA/London: Harvard University Press.

Latour, Bruno (2005): Reassembling the Social: An Introduction to Actor-Network-Theory, Oxford: Oxford University Press.

Manning, Erin (2012): Always More Than One: Individuation's Dance, Durham/London: Duke University Press.

Manning, Erin (2016): The minor gesture, Durham/ London: Duke University Press.

Massumi, Brian (2015): The Power at the End of the Economy, Durham: Duke University Press.

Mottron, Laurent/Dawson, Michelle/Soulières, Isabelle/Hubert, Benedicte/Burack, Jake (2006): "Enhanced Perceptual Functioning in Autism:

An Update and Eight Principles of Autistic Perception." In: Journal of Autism and Developmental Disorder 36/1, pp. 27-43.

Murray, Stuart (2008): Representing Autism: Culture, Narrative, Fascination, Liverpool: Liverpool University Press.

Neil, Louise/Olsson, Nora Choque/Pellicano, Elizabeth (2016): "The Relationship between Intolerance of Uncertainty, Sensory Sensitivities, and Anxiety in Autistic and Typically Developing Children." In: Journal of Autism and Developmental Disorder 46/6, pp. 1962-1973.

O’Neill, Meena/Jones, Robert S. P. (1997): "Sensory-Perceptual Abnormalities in Autism: A Case for More Research." In: Journal of Autism and Developmental Disorder 27/3, pp. 283-293.

Pellicano, Elizabeth/Burr, David (2012): "When the world becomes 'too real': A Bayesian explanation 
of autistic perception." In: Trends in Cognitive Sciences 16/10, pp. 504-510.

Pinchevski, Amit/Peters, John Durham (2016) "Autism and new media: Disability between technology and society." In: new media \& society 18/ 11, pp. 2507-2523

Rose, Nikolas (1996): Inventing Our Selves. Psychology, Power, and Personhood, Cambridge: Cambridge University Press.

Sacks, Oliver (1995): An Anthropologist on Mars.

Seven Paradoxical Tales, New York: Vintage Books.

Savarese, Ralph J. (2013): "Moving the field: the sensorimotor perspective on autism (Commentary on 'Rethinking autism: implications of sensory and motor differences,' an article by Anne Donnellan, David Hill, and Martha Leary)." In: Frontiers in Integrative Neuroscience 7/6, n. pag., https://doi.org/10.3389/fnint.2013.00006, accessed August 19, 2019

Stern, Daniel N. (1998 [1985]): The Interpersonal World of an Infant: A View from Psychoanalysis and Developmental Psychology, London: Karnac Books.

Tavassoli, Teresa/Brandes-Aitken, Anne/Chu, Robyn/Porter, Lisa/Schoen, Sarah/Miller, Lucy Jane/Gerdes, Molly Rae/Owen, Julia/Mukherjee, Pratik/Marco, Elysa J. (2019): "Sensory over-responsivity: parent report, direct assessment measures, and neural architecture." In: Molecular Autism 10/4, https://doi.org/10.1186/s13229-0190255-7, accessed August 19, 2019.

Wolfe, Gary (2010): What is Posthumanism? Minneapolis: University of Minnesota Press.

Yergeau, Melanie (2018): Authoring autism: On rhetoric and neurological queerness, Durham/ London: Duke University Press. 



\section{The Piano in the Asylum and \\ the Insanity of the Composer: \\ Two Variations on a Theme \\ (with Interlude)}

Stefan Wulf

The subject of this essay is the piano (or grand piano) as an object in the psychiatric institution. The theme needs to be set within parameters and specified. What is referred to here is not the pianos once found in large numbers in psychiatric wards, where each instrument was accessible to a large number of patients (cf. Bly 2009: 50-5I, 53-54, 8I, 84-85; Wulf 20I7: I7-I8, 39-40). Rather, the focus is on a quite special constellation. Viewed in conjunction with the time spent in asylums by two famous composers, the piano emerges as a tangible object that elicits a specific dynamic both inside and outside the institution. The composers in question are two very different exponents of their craft, namely Robert Schumann (I8IO-I856) and Paul Abraham (1892-1960). The two men's cases and piano playing at the psychiatric hospital will be presented in greater detail. In particular, the essay will investigate the effect the composer's piano had within this psychiatric context, how it was perceived outside the institution's walls, what qualities were ascribed to the instrument (and by which groups), and what expectations and interpretations were brought to bear on the object. 


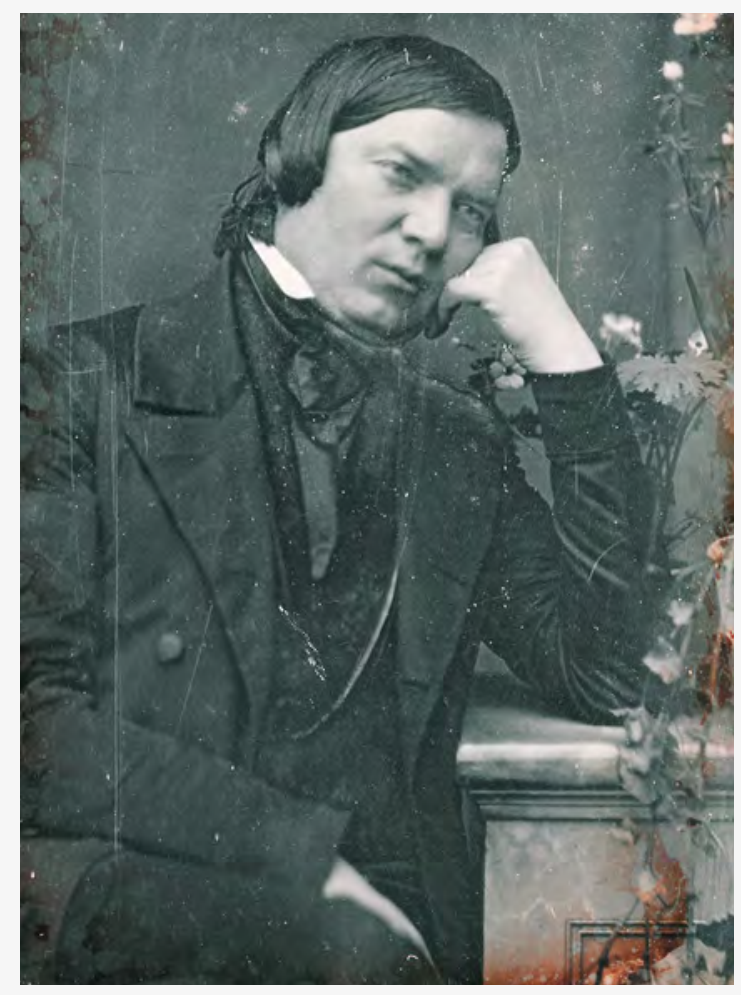




\section{The Composer's Piano in the Psychiatric Institution Robert Schumann in Endenich}

Robert Schumann was one of the foremost composers of the 19th century, as well as a conductor and music critic (cf. Tadday 2006). He was a key figure in German Romanticism. Having started primarily as a composer of piano music, Schumann would also go on to write orchestral works, chamber music, and numerous Lieder - such as Dichterliebe (The Poet's Love, Op. 48), a song cycle composed in 1840 for texts written by Heinrich Heine. He wrote four symphonies, including the Spring Symphony, Op. 38 (184I), and Rhine Symphony, Op. 97 (1850). Another noteworthy work is his Piano Concerto in A Minor, Op. 54, written between I84I and I845. He also composed the opera Genoveva, Op. 8I (I847-1848). Robert Schumann was one of the co-founders of the Neue Zeitschrift für Musik, a music magazine still published today.

In February 1854, Schumann suffered severe psychological problems and became completely mentally unbalanced (cf. Appel 2006: 44-58; Franzen 2006). He complained of "auditory affections." Individual notes, harmonies, even whole orchestras raged in his head. The voices of angels and demons deprived him of sleep. The composer was plagued by self-accusations and notions of sin. He had been mentally unstable for some time. Evidence of psychological anomalies, particularly reactive depressive episodes, can be found in the historical sources from as early as the I830s. Schumann suffered his first severe mental crisis in I844. However, his condition at the start of 1854 was particularly bad. On February 27 , the composer threw himself into the Rhine from the Oberkassel Bridge in Düsseldorf. His life was saved.

A few days later, on March 4, I854 - on the advice of his friend, the physician Dr. Richard Hasenclever (I813-1876) - Schumann admitted himself voluntarily to the clinic in Endenich run by the psychiatrist Dr. Franz Richarz (I8I2-I887). Richarz had established the facility as the "Institution for the Treatment and Care of the Emotionally Disturbed and the Insane" [Anstalt für Behandlung und Pflege von Gemütskranken und Irren] in 1844. The site was a former country house with extensive grounds, located outside the gates of Bonn. The clinic was relatively small. Records for January I, I858 show an occupancy rate of 3I patients (Peters 2006: 450454). The admissions book in Endenich records Schumann's diagnosis as "melancholy with insanity." A supplementary diagnosis of "paralysis" was later added in pencil. Richarz surmised that the patient was suffering from an organic brain disease, which he would later describe as "partial paralysis" (Appel 2006: I8-I9, 439). 
In the years after Schumann's death - specifically, in I858 and I873 - Richarz would contextualize the composer's suffering in terms of "genius and insanity," with the psychiatrist emphasizing the "close intermingling of his artistic nature with his morbidity" and transfiguring Schumann's melancholy into a feature characteristic of great creative minds (ibid.: I9, 429-434, 435-440, quoted here: 440).

Attempts to identify Schumann's medical condition have now been the source of controversy for over a century, precipitated in 1906 by a dispute between the Leipzig psychiatrist Paul Julius Möbius (I853-1907) and his young colleague Hans Walter Gruhle (I880-I958). While Möbius argued the case for dementia praecox, i.e. schizophrenia (Möbius I906: 4I-52), Gruhle believed that Schumann had suffered from manic depression (cyclothymia) and died as a result of progressive paralysis (Gruhle I906). In contrast to Möbius, Gruhle interpreted the symptoms exhibited by Schumann in the latter years of his life as a cerebral, organic process. Even today, this issue continues to attract a broad and contradictory spectrum of interpretations, ranging from progressive paralysis through periodic catatonia to alcoholism (cf. Franzen 2006; Dumke 2006; Franken 2006; Peters 2006, 2009; Otte/Wink 2008: 247-256).

Schumann was a resident at Richarz's Endenich clinic from March 4, I854 until his death on July 29, I856 - a period of nearly two years and five months. His Endenich medical records from September 7, I854 until his death (or, rather, until July 30, I856) have been preserved in their entirety. For the first six months of his stay at Endenich, however, the only medical entries available are for the period April 6 through April 27, I854 (Appel 2006: 9-IO, II, 33-39). A systematic review of Schumann's medical records from Endenich reveals almost 50 (mostly brief) entries relating to Schumann's piano playing at the clinic. The medical records even include a reference to a conversation between the composer and the Bonn piano maker Carl Brambach, who was there to tune the clinic's piano (ibid.: I87). Based on medical records, related correspondence, journal entries by the composer's wife Clara Schumann (I8I9-I896), and contemporary newspaper articles, it is possible to gain a more direct understanding of the piano as a central object for Robert Schumann at the Endenich clinic. ${ }^{\mathrm{I}}$

The first relevant entry in the medical file reads as follows: "Yesterday [he] played piano, was very friendly" (ibid.: I46). ${ }^{2}$ That was on September 24, I854. By then, Schumann had already been at Endenich for over six months. This would suggest that he had not been allowed to play the piano during his initial period at the clinic. On April 2I, I854, his wife Clara wrote to the music writer and publisher Bartholf Senff: 
... he is still not permitted any activity, and save for when he goes on walks, tends to spend his time quietly on the sofa. None of his friends are allowed to visit him yet, since the aim is to avoid anything that could agitate him in the slightest. ${ }^{3}$

(Ibid.: 97)

For a long time, doctors even prohibited contact between Robert and Clara Schumann. Correspondence between husband and wife was (likewise) initiated in September 1854. Owing to the gaps in the surviving medical records, it is not possible to reconstruct at what precise point Schumann was given access to the piano at Endenich. In other available sources, there are no references to a piano during the period in question (March to September 1854).

It can be safely assumed that staff did not make an entry in Schumann's medical notes every time he played the piano. This is confirmed by a letter dated September 28, I854 from Dr. Eberhard Peters (I824-I879), assistant physician at Endenich, to Schumann's wife: "He plays piano for an hour every day and goes for long walks in the surrounding area" (ibid.: I50). ${ }^{4}$ And on December 8, I854 Clara Schumann informed the conductor and composer Johannes Verhulst that her husband played piano "daily" and that she was sending him large quantities of music (ibid.: I82). The concentration and consistency of this musical activity is not, however, conveyed in the daily written entries in the medical record. It would seem that his piano playing was only intermittently noted in the files. The instrument's importance for Robert Schumann during his time at Endenich is, however, illustrated in a short passage from a letter written by the composer to his wife on October I0, I854: "I sometimes wish you could hear me fantasizing at the grand piano; those are my most blissful hours" (ibid.: I55). ${ }^{5}$ The grand piano shaped Schumann's self-perception as someone thoroughly imbued with musical inspiration and granted him a sort of self-affirmation as a musician.

The Endenich medical file contains the following entry for March 3I, I855: "[Patient] played again yesterday at the grand piano until late in the evening" (ibid.: 248). ${ }^{6}$ Mentions of a grand piano [Flügel] are rather few and far between in the historical sources, which almost always refer to a piano [Clavier]. Were there different keyboard instruments at the institution in Endenich? What is there to be said about the instrument to which Schumann appears for a while to have enjoyed regular access? Addressing this question, the musicologist and Schumann expert Bernhard R. Appel mentions "the piano in the lounge of the Endenich clinic" (ibid.: 32). Elsewhere he provides more detailed information: 
Later Schumann is said to have lived in two interconnected rooms on the upstairs floor of the main building. This area was also furnished with a drawing room where there was a piano that Schumann was permitted to play. Located in the neighboring building was a ward for disturbed patients to which Schumann had to be transferred on several occasions. (Ibid.: 498)

During these periods, it seems safe to assume that he would not have enjoyed access to a piano.

In mid-December I854, those close to Robert Schumann felt it was doubtful whether the composer "[would be] able to use the pianoforte" on the upcoming Christmas Eve (ibid.: 185). The instrument in question - Franken refers to a square piano (2006: 443) - may possibly have also been used on special occasions to provide musical entertainment for the other patients at Endenich. The psychiatrist and Schumann scholar Uwe Henrik Peters (2006: 453-454) suggests that the composer did not have access to an instrument of his own. He does, however, refer to a "grand piano" used frequently by Schumann, and which he believes to have been located either in a drawing room or lounge at the Endenich clinic. Here Peters emphasizes that it was not unusual in this period for pianos to be found in psychiatric institutions, and that music was believed not only to have a soothing effect on mental illness but to be endowed with an actively healing power.

Indeed, Johann Christian Reil (I803: 137, 205-208, 246, 345, 362, 498), a founding father of psychiatry, had underlined the importance of music as an element of the psychiatric method of treatment for cases of mental breakdowns as early as I803. In around I850 at the psychiatric hospital in Mariaberg, the piano (alongside the violin) played an educational and therapeutic role with "feeble-minded" children (i.e., diagnosed with "cretinism"; Beobachtungen über den Cretinismus I850: 28). And wherever a Christian lifestyle was considered indispensable for healing "mental pain," [seelische Pein] (cf. Vanja 2008) pianos would doubtless have been used on a frequent basis to accompany hymn singing. The connections between psychiatry and music were manifold. Another such example was the hearing tests conducted on female patients at the Salpêtrière in Paris in the first half of the 19th century, notable for the participation of the composer and pianist Franz Liszt (I8II-I886) (cf. Schwartz 2019: 58-62). It was probably not unusual for there to be keyboard instruments in psychiatric institutions in the 19th century, although they may have been more commonly found in facilities geared towards wealthier patients (cf. MacKenzie 1992: 70, 74, I48, I76-I77). 
While from Schumann's perspective the central object at the clinic was the piano, this was not the case - with regard to his person - for psychiatrists and other members of staff. For them, the most important object relating to the composer's treatment was the clyster [Clystier] - that is, the implement used to administer medical enemas on the bowel via the anus. The clyster (and the consistency of the patient's stools) is referred to with considerably more frequency in Schumann's medical notes than the piano. From a psychiatric perspective, the bowel was practically the main focus of attention. In Schumann's case, the clyster rather than the piano was the actual "object of psychiatry." A crucial factor here was the humeral-pathological approach (in its broadest sense) adopted by staff in treating the patient (cf. Franken 2006: 445; Peters 2006: 474-479).

On April 28, I855, Clara Schumann wrote to the music publisher Bartholf Senff:

Recently there have been several reports in the Kölnische Zeitung about my husband's illness, as though this were still so very bad; my husband, who read this, now writes to me very indignantly on the subject, saying it is actually amusing that he is written about as though he were the most unhappy of artists, when all day he is active, reading and writing, immersing himself on a daily basis at the grand piano, often fantasizing there for long, long periods. ${ }^{7}$ (Appel 2006: 262)

The piano (resp. grand piano) at the Endenich institution here emerges once again as a tangible object, which proved essential to shaping and structuring how Schumann understood and saw himself.

The above letter from Clara Schumann to Senff was sent with a view to enlisting the latter's help in countering negative newspaper reports about her husband (cf. ibid.: 27). The attempt appears to have been successful. A sort of rebuttal appeared in Signale für die Musikalische Welt on May 3, I855. Here readers learned that the dubious newspaper reports were, thankfully, not an accurate representation of the true situation. Schumann, readers were told, was in fact recovering:

... he is active the entire day, writing, reading, playing a lot of piano, including four-handed duets with visiting friends. He corresponds continually with his wife, takes a very keen interest in all events, and doubtless reads with bewilderment reports about himself in the newspapers, which are often as sorely lacking in truthfulness as any hint of sensitivity. ${ }^{8}$ (Ibid.: 269) 
Here the range of activities is described a little more extensively. However, the piano once again appears in view. Yet as a synonym for Schumann's musical and creative activities, it no longer serves simply as an embodiment of the composer's sense of self, but has also become an object of public (and published) opinion about him. While Schumann himself put particular emphasis on his fantasizing at the grand piano, it is the four-handed piano duets that feature most prominently in this account. Not long afterward, on May I2, I855, a corresponding story appeared in the Rheinische Musik-Zeitung (ibid.: 274). In a sense, however, the account was by this stage already outdated. As Schumann's medical records from May 8, I855 note: "Yesterday agitated for the whole day, very loud and animated rambling, also gesticulating vigorously in the garden; afterwards played piano very wildly and chaotically for nearly 2 hours, all the while talking very loudly; ..." (ibid.: 272-273). ${ }^{9}$ The doctors temporarily prohibited him from playing the piano. The view was that he should avoid any kind of agitation. However, it is possible that staff at Endenich were also concerned that the instrument could wind up damaged.

Richarz's Endenich clinic was the scene of multiple historic encounters. On January II, I855, the 2I-year-old Johannes Brahms (I833-I897) came to visit his sick friend Robert Schumann. The following day, Clara gave an account of Brahms's visit to a close friend and confidant:

As Johannes was leaving, he heard him [Schumann, author's note] still playing a novelette downstairs, Robert even told him that he often played all day for entire days at a time, which is also what the doctor said. He has a beautiful instrument Johannes was very pleased with it. ${ }^{\text {Io }}$ (Ibid.: 199-200)

During his visit, Brahms had been requested by the patient to perform his then-unpublished Four Ballades, Op. IO, and Variations on a Theme by Robert Schumann, Op. 9, which had only just appeared in print. According to his wife, Schumann was impressed beyond all measure by Brahms' compositions (ibid.: I99, see also Clara's journal entry from January II, I855).

Brahms wrote about his following visit on February 23, I855 in a letter to Clara: "We then played four-handed! He requested the Caesar Overture. ... It didn't quite hold together, it had been such a long time since he'd last played four-handed"

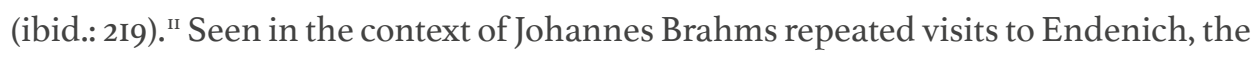
various compositions the two composers performed for one another, and their joint music making at the piano (or grand piano), it becomes clear that this instrument 
is also an object with extraordinary significance for I9th-century music history. Moreover, it is relevant for another quite different reason. Since Schumann suffered from severe speech disorders and at times struggled to make himself even halfway comprehensible, the piano made it possible - particularly with visitors like Brahms - to communicate on another level. It offered a supplementary, nonverbal way to communicate with one another.

Here it is also worth mentioning another artist who paid visits to Endenich. Joseph Joachim (I83I-I907), who would subsequently gain worldwide fame as a leading violin virtuoso, visited Schumann on several occasions in the second half of May I855. Looking back several decades later, he wrote to the Viennese music critic Eduard Hanslick: "In feverish excitement, he leafed through his old compositions, mangling them as he played on the keyboard with shaking hands - heart- and ear-wrenching! The wonderful man must have suffered immeasurably" (ibid.: 286). ${ }^{12}$ Looking back a quarter of a century later, Wilhelm Joseph von Wasielewski (I822-I896), the later biographer of Schumann, recalled the composer playing piano in the summer of I855:

Schumann sat at the piano, which had been put there at his request, and fantasized. We were able to observe him for some time and without being disturbed through an opening in the door. ... His playing was unbearable. It gave the impression that the force from which it arose had been completely crippled, like a machine with a broken mechanism whose attempts to keep working can only proceed by way of involuntary twitches. ${ }^{13}$ (Ibid.: 286)

Schumann's loss of personality was by then already at an advanced stage. For the people close to him, the piano on which he played communicated - more eloquently than anything else - the hopelessness of his condition.

At this point, the composer's piano in Endenich should also be examined in the particular context of Schumann's later work, specifically his compositions written during his time at the institution. For example, he composed a fugue for the piano in January I856. His medical report for January I8 notes: "Yesterday wanted to play some piano, said he wanted to try out his fugue" (ibid.: $35 \mathrm{I}) .{ }^{\mathrm{I}}$ It seems that he was denied this request, as one month later, on February 19, I856, he asked "with utmost urgency if he could at some stage play his fugue on the piano" (ibid.: 360). Other than this fugue, which has not been preserved, the other compositions from his time at Endenich were not musical works in the strictest sense of the term, but rather "works of secondary craftsmanship" (Appel) - in other words, treatments of 
pre-existing musical material, such as the piano accompaniment to Paganini's Violin Caprices, Op. I (cf. ibid.: 3I).

On September 8, I854, readers of the Neue Zeitschrift für Musik learned that the latest news on Schumann's health contained cause for considerable reassurance. He was understood "to be so well recovered that he may once again occupy himself with compositions" (ibid.: I33). Here, news that the mentally ill composer had apparently started writing music again was interpreted as a good sign. However, the relationship between mental health and compositional creativity appears considerably more complex when seen against the backdrop of reception history - something which, from a psychiatric-historical perspective, is entirely relevant. After all, at issue here is the question of, and claims surrounding, "work defects" caused by ill health.

Even during his lifetime, Schumann found himself in the crossfire of competing musical factions, and after his death his detractors invoked the composer's mental illness as an explanation for the alleged deterioration in quality of compositions from his later creative phase (cf. ibid.: 23). In I906, Möbius also stated his view as a psychiatrist that there had been a corresponding decline in the quality of Schumann's compositions (1906: 43). The issue has attracted a broad range of related interpretations and value judgements. In the course of musicological efforts at rehabilitation in the I980s, there was a decided turn against the pathologization and denigration of Schumann's later work (cf. Appel 2006: 23). In his psychoanalytically inspired study "Rückungen - Ver-rückungen" published in I98I, the composer and musicologist Dieter Schnebel observed the events of Schumann's life, the composer's mental state, and the nature of his compositions in terms of a possible causal interrelationship. Nowadays these questions are examined in entirely different contexts - via the framework of disabilities studies, for example (Howe 20I6: 644-646).

\section{Digression: Schumann, Insanity, and the Piano - Destruction in Art}

In 2009 the Australian musician Rowan Vince gave several performances of his project, Schumann and the Art of Piano Destruction (cf. Schmidt 2013: 227-23I). A metal grating divided the audience from the stage. On stage there was an old upright piano and a small grand piano. Propped up against the metal grating were heavy and light hammers, saws, and bolt cutters. Vince first played Robert Schumann's Fantasie in C Major, Op. I7 (1836) on the grand piano. This took about a half hour. 
Shortly afterwards, he began playing a contemporary composition by Tim McKenrie on the upright piano. Almost simultaneously, the composer started to smash the instrument with a hammer. A little later, Vince also joined in the destruction of the piano (cf. Film recording: Performance 2009). Disciplined culture of emotion was here bluntly juxtaposed with uninhibited action.

This performance followed in the tradition of an avant-garde art movement that reached a particular highwater mark in the I960s and I970s (cf. Schmidt 2013). Piano destructions, also called Piano Activities, were an important and iconic branch of so-called Destruction in Art. It was driven by considerable potential for protest, directed against the high culture of "civilized" societies - symbolized by the concert grand or upright piano - though, in essence, also targeting the excesses of destruction and violence committed by this "civilization," such as those that had come to light time and again during military conflicts. Piano Activities can be understood as the reenactment, so to speak, of the insanity of an entire culture that had dedicated itself to destruction. This form of performance art was in certain cases fully intended to evoke insanity and was duly perceived as insanity.

While the historical sources show the mentally ill Schumann in Endenich to be recognizably incapacitated, he still appears to act in a rational, goal-oriented manner in his relationship to the piano. By contrast, in Vince's work - that is, outside the mental facility - goal-oriented rationality is suspended in the artistic act and a stylized form of rage is elevated to an operational principle. Something that in Endenich would have vanished into the "ward for disturbed patients" here appears in the foreground. The piano is not protected from the patient; instead, it is given over to the artist for destruction.

A specific level of destruction is recognizable in Vince's work. Schumann and his Fantasie in C Major can be interpreted as a symbol of sublimation and emotional self-control. The cultural studies scholar Gunnar Schmidt argues that Schumann can be understood in this context as a paradigmatic value, as the "victim of a specific instrumental and expressive rationality." For Schmidt, Schumann is an injured person and a virtuoso of sublimation who represents the affective rational logic of the West's civilizational destiny (ibid.: 227, 229-230). Vince later said of his project: "It is a cathartic experience for the pianist to destroy the instrument that has demanded so many endless hours of practice" (quoted here after Schmidt 2013: 230). In I839, Robert Schumann had commented: "I would often like to crush the piano. It has become too confining for my thoughts" (Jansen 1904: I53). ${ }^{15}$ 


\section{Paul Abraham in Eppendorf}

Measured by the number of performances, Paul Abraham was internationally the most successful composer of operettas in the early I930s (cf. Waller 20I7; ARTE documentary on Abraham). His Victoria and Her Hussar (1930), The Flower of Hawaii (I93I), and Ball at the Savoy (1932) struck a chord with contemporary audiences. His sound was unmistakable. Berlin was at his feet during these years. His name could be seen all over the city on advertising columns and emblazoned in large illuminated letters across the fronts of theaters and movie theaters. Abraham was able to capitalize on an entirely new medium of distribution for his music: the sound movie, which was then making its breakthrough. He had considerable success not only with compositions for the stage but also hit movies, earning a fortune within a very short period of time. However, Nazi terror brought his career to a grinding halt. The political situation meant that the Jewish composer was forced to leave Berlin in early I933. He was active in Budapest until 1939 (and worked in parallel to this in Vienna until I938). He was no longer able to follow on from the successes of his Berlin years. Eventually he escaped via Paris and Cuba to the U.S.A., where he arrived on August 20, 1940.

His subsequent years in New York were shaped by material and health problems. Abraham was eventually admitted to a psychiatric clinic in early 1946, where he was all but forgotten. He suffered from a form of progressive paralysis, a long-term symptom of syphilis (neurolues). A scene retold in a variety of permutations came to symbolize his increasingly forlorn place in the world: Abraham standing in the middle of New York traffic, conducting an imaginary orchestra (Waller 20I7: I64I65). "The Tragic King of Operetta" was the fitting subtitle to Klaus Waller's 2017 biography of Abraham. From 1954, a Paul Abraham Committee campaigned to have the composer brought back to Germany. Negotiations with both U.S. and West German government agencies proved difficult, mainly because the composer was a Hungarian national at a time when Hungary was part of the Communist bloc. It was eventually possible, however, to overcome all these obstacles.

On April 30, 1956, Paul Abraham returned to Germany after more than 23 years. Thanks to the involvement of lawyer Robert J. Meyer (I882-I967), a former president of the Hamburg Higher State Court from Hamburg-Blankenese, Abraham could initially count on a respected figure to act as his official sponsor. As for the various questions relating to performance rights, royalties, and professional fees accrued from the composer's work, having an experienced lawyer on his side was 


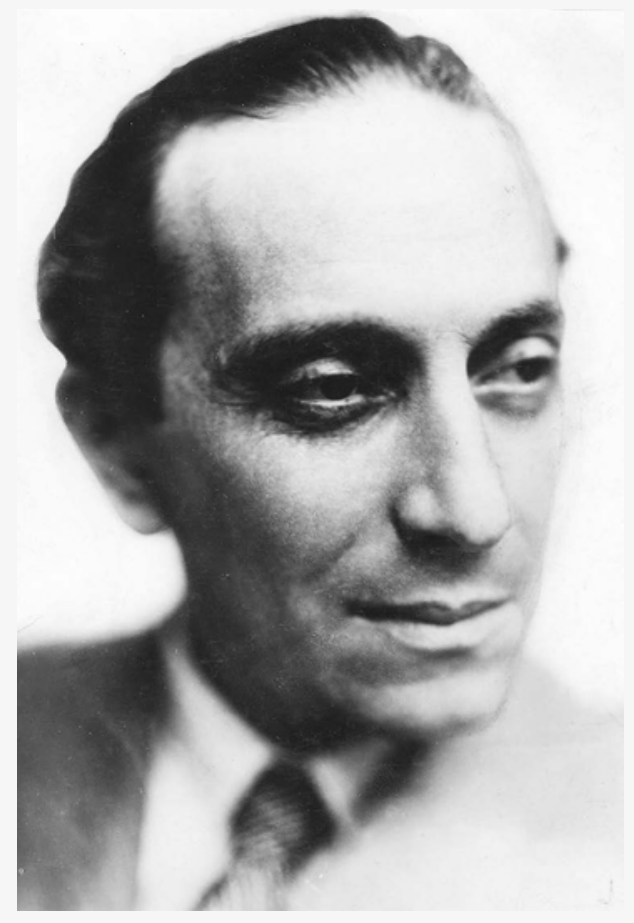

Fig. 2: Paul Abraham, 1931. German Federal Archives, Digital Picture Archive, 183-2010-0316-500

(photographer: not specified) 
certainly an advantage. Meyer made the necessary arrangements for Abraham to be taken directly after his arrival at Frankfurt Airport to the University Hospital in Hamburg-Eppendorf(UKE). From April 30, I956 to September 25, I957, Abraham was a patient at the Eppendorf Psychiatric and Mental Clinic (cf. Spehr et al. 1989). The hospital director was Professor Hans Bürger-Prinz (I897-I976), who had been a prominent psychiatrist during the Nazi period. Six months after he was admitted to the UKE, Abraham remained disoriented with regard to place and time: He believed he was in New York, had big plans there, and could barely be persuaded to speak German.

In New York, Abraham had been taken to the Bellevue Hospital on January 5, 1946. Eleven days later, on January 16, I946, he was transferred to the Creedmoor State Hospital in the New York borough of Queens. Here he underwent a treatment known as malaria fever therapy (cf. Wulf/Schmiedebach 20I4: I2O-I3I; Wulf 20I7; Braslow I996) before then being given several courses of penicillin, the last of which in May 1955 (MF Abr.: Medical Reports Creedmoor State Hosp.). In Hamburg he was given the following diagnosis: "Defective condition after taboparalysis treated with malaria" (MF Abr.: Folder cover and admission forms). More precisely, Abraham's sickness was a combination of a degenerated spinal column (tabes dorsalis) with progressive paralysis associated with neurosyphilis. The period Abraham spent at Creedmoor State Hospital coincides almost exactly with the shift from malaria fever therapy to penicillin, which happened a few years earlier in the United States than in Europe (cf. Cohn 1953: 637; Ehrmann 1957: 65). Compared with Robert Schumann's lifetime, psychiatry had since reached a point where it was able not only to offer an etiological explanation for the paralysis, but also provide a reasonable amount of evidence for the diagnosis, and (most importantly) treat the condition successfully, so long as the appropriate treatment was initiated in good time. This was not the case with Abraham. It was possible to stall the disease's progression. However, the illness had clearly left its mark.

Speaking in a filmed interview in 2008, Johann M. Burchard, who had worked as a psychiatrist at Eppendorf in the I950s, retained a clear memory of Abraham:

His treatment in America was really top notch, first class. He was very much back on his feet when he returned to Europe, only with some minor problems. ... He came to us as a patient who'd completed the treatment, that's to say having been left in a slightly broken condition, but no longer sick. With slight dementia, in other words. ... We medicated him with mild stimulants and, in particular, gave him psychotherapy in its most up-to-date form. He was given a piano. ${ }^{16}$

(ARTE documentary on Abraham: 49:OI-50:25 min.) 
At Creedmoor State Hospital, Abraham had mainly busied himself with sweeping the stairs and washing dishes. "Sometimes he would tinkle away on an out-of-tune piano for the amusement of the attendants" (C/P Abr.: "Paul Abraham no longer recognized his own melodies" [Paul Abraham erkannte seine Melodien nicht wieder] $B I L D$, May 2, 1956). In Hamburg he was given his own instrument. And the patient's piano playing soon lost any incidental character. It developed its own dynamic both inside and outside the clinic.

In their closing medical summary from September 25, 1957, the day Abraham was discharged from the Eppendorf clinic, the attendant physicians gave the following assessment:

The patient's profile is that of a person who has undergone essential cerebral organic changes and is debilitated by advanced dementia. This profile is characterized in particular by a significant reduction in critical faculties and powers of judgment, an insufficient connection to reality, childish behavioral patterns, and affective flattening. ... other than his mental preoccupation with the past, by and large he only retains interest in his meals, in radio and gramophone music, and playing the piano. ${ }^{17}$ (MF Abr.: Bochnik/Krause, Epicrisis, September 25, I957, sheet I, p. 2)

However, since he exhibited no signs of acute illness during his time at Eppendorf, there was no need for any specific course of therapy. Psychiatrists at Eppendorf stated that treatment was duly limited to influencing periodic complaints with medication and general fortifying measures.

This is precisely the context in which to consider the piano provided for Abraham at the Eppendorf psychiatric clinic. Playing the instrument resulted in a noticeable improvement in his mood. When the Hamburg psychiatrist Burchard stated that Abraham had been given "psychotherapy in its most up-to-date form" by virtue of being given a piano at the UKE, it should be noted that the constellation seen here was anything but new. A hundred years previously, Robert Schumann had also been given access to a piano on which, periodically, he was permitted to play and improvise on a daily basis. In Schumann's case, it ultimately remains unclear who made 


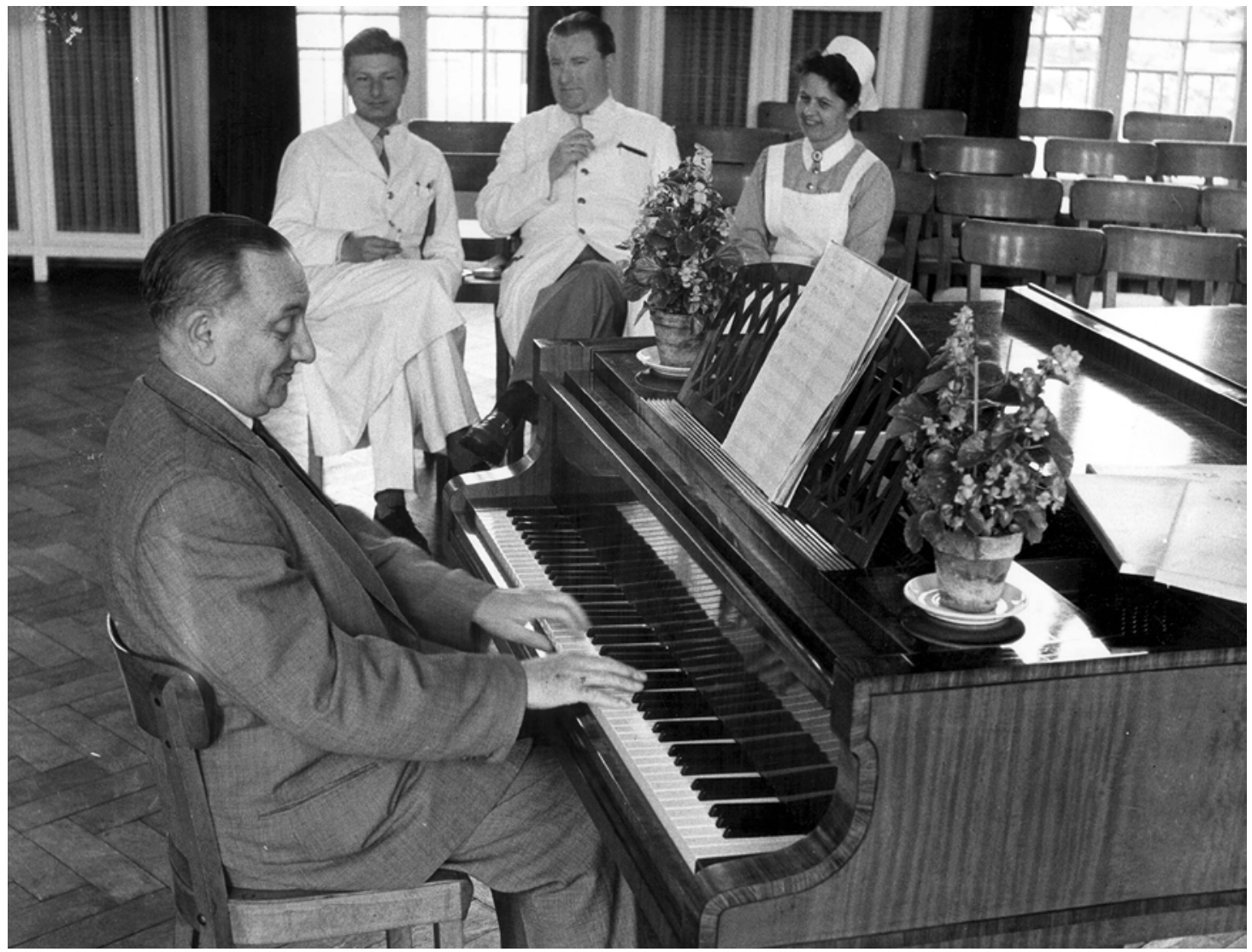


the crucial decision to grant the composer access to a piano, whereas with Abraham, the historical sources show it was a doctor who first initiated this step. An entry from June 2, 1956 in Abraham's medical file notes that the latter's official representative, Robert J. Meyer, had rented a piano at the doctor's request, which had then been delivered to Barrack Io. The entry also mentions that Abraham gave a concert to a small group, with Meyer also in attendance (MF Abr.: Medical entries, 6).

The composer's medical file provides the following account from May 28, I956:

Today we were able to seat the patient at a grand piano in the ceremonial hall of the Jungschwesternhaus [Home for Young Nurses]. He knew precisely why we were there and was already visibly excited on the way over. After we had passed the ceremonial hall's doors and he had caught sight of the grand piano, he walked purposefully towards it, opened the instrument, sat down, and started playing. It is quite clear that Paul Abraham still retains complete mastery of the instrument. ${ }^{18}$ (Ibid.)

The Jungschwesternhaus mentioned here was a building in Eppendorf used for training nurses, originally constructed in around I940 by order of the National Socialist Public Welfare Organization (N.S.V.) (Uhlmann/Weisser I992: I2I). The music performed by Abraham included pieces from his hit operas The Flower of $\mathrm{Ha}$ waii and Victoria and Her Hussar, which the supervising doctor observed he played "from sheet music, flawlessly and with emotion." He also noted:

Patient visibly flourishes at the grand piano. He was in a superb mood and it was only too obvious that playing music has a highly stimulating effect on him. On the way back, he spoke of how he now hoped to play every day, wanted to invite along all the nurses and doctors ... ${ }^{19}$ (MF Abr.: Medical entries, 6)

These medical observations predate the acquisition of a piano for Abraham in Eppendorf and provide ample explanation for why this step was deemed desirable. The patient felt much better with a piano. And that was the aim.

From this point on in Eppendorf, Paul Abraham played on the two instruments mentioned above. On June I8, I956, one of the psychiatrists overseeing his treatment wrote that the composer was very happy whenever he was able to play the grand piano in the Jungschwesternhaus and the piano in Barrack Io. "Recently photographed doing this by a magazine. Patient was entirely in his element" (ibid.: 7 ) ${ }^{20}$ The involvement of press 
and public is here already in evidence. On July 2, 1956, a note in the medical file states that, "full of pride," Abraham had that morning shown his doctor a sheet of music, indicating that he had written a new song. "He could not resist heading straight for the piano to play the piece of music. It is a simple, rather melancholy melody" (ibid.: 9). ${ }^{2 \mathrm{I}}$

An entry in the patient's file from July I8, 1956 notes how the composer would play a small concert to patients in Eppendorf every day from 9 to Io a.m. on the piano in Barrack Io. It seems he was always very keen for as many people as possible to attend. Every day he became impatient in anticipation of this event (ibid.: Io). The entry from December I, 1956 provides a slightly more detailed account of this hospital concert. There had since been a change to the scheduled times. He now played the piano regularly from IO:30 to II:30 a.m. in Barrack IO. Audience sizes varied. Paul Abraham paid considerable attention to the number of attendees. On returning from the performance, he would go straight to the doctor and tell him how many people had attended that day. He would usually appear rather indignant if audience numbers were low (ibid.: I5-I6). Another source notes that Abraham only ever played his own compositions (ibid.: II).

Paul Abraham's entire life at Eppendorf revolved around the piano. As late as spring 1957, he was still giving small concerts in Barrack Io. Consideration was now being given to discharging him. In the meantime, earnings from Abraham's old compositions had once again started to flow abundantly. The search was already on for a suitable house or apartment. Plans for interim accommodation in a sanatorium in the Harz Mountains came to nothing. According to a doctor's note in the patient's file, Abraham's wife had stipulated that a piano would need to be installed in her husband's room, "as playing the piano practically signifies the patient's essential purpose in life." However, this proved impracticable owing to the room's limited size and the disturbance it would create for other guests (ibid.: I8).

Charlotte Abraham was by this point back at her husband's side. The couple had not seen each other since February 1939, and had had no contact with one another for almost as long. She was prepared to take care of her husband in Hamburg - with the assistance of nursing staff - after his discharge from the UKE. On September 25, 1957, the day he was discharged, Abraham at first obstinately refused to leave the hospital and move into his new apartment at IIo Sierichstraße, but then very quickly accepted his new living arrangements. "He immediately sat down at his piano, which had previously been transported from Barrack to to the new apartment, and performed for those present a variety of well-known pieces from his works" (ibid.: 23). ${ }^{22}$ 
Ever since Abraham's arrival at Frankfurt Airport on April 30, 1956, the (tabloid) press regularly featured stories about the composer. This resulted in increasing numbers of people taking an interest in his fortunes. Well-wishers regularly sent mail to him at the psychiatric clinic in Eppendorf. The files from Eppendorf also contain several letters of thanks addressed to Bürger-Prinz and his colleagues $(\mathrm{C} / \mathrm{P}$ Abr.). Newspaper articles and private letters alike transform the piano and grand piano into tangible objects invested with certain hopes and expectations. Abraham's daily piano playing on the two available instruments in Eppendorf was used as evidence that the composer was on the road to recovery - even to a return to writing music. Yet even where people were under no illusions about his mental state, the piano is situated in a similarly causal context: "Paul Abraham plays, but there's no cure," [Paul Abraham spielt, aber keine Heilung] ran one newspaper headline on June 8, I956 (C/P Abr.: Newspaper clipping, June 8, 1956).

While the people around Abraham might not always have been happy about this sort of coverage (cf. MF Abr.: letter from Meyer to Bürger-Prinz, June I4, I956), Meyer and the doctors at Eppendorf were at the same time very much involved in stage managing the composer's public profile and celebrating his "resurrection" as an artist. The piano in Barrack Io and the grand piano at the Eppendorf Jungschwesternhaus were crucial props in this public performance. In press photographs, the protagonist himself appears neatly coiffed, wearing an elegant suit with a white shirt and tie. He even sported a handkerchief in his breast pocket.

On October 4, 1956, an article written by Hans Habe (I9II-I977) was published in the Göttinger Presse under the headline: "Music in the Lunatic Asylum: Leave Paul Abraham Alone!" [Musik im Irrenhaus. Laßt Paul Abraham in Ruhe!] (C/P Abr.). Habe, a Jewish journalist, author, and screenplay writer with U.S. citizenship, was an old friend of Abraham. Here he gave his very personal reaction to the "reports that have for years been regular features, almost permanent columns, about the composer Paul Abraham, who is interned in a mental institution." Habe's bitter criticism was directed toward the "hype of charity." And it was entirely justified:

Since Paul Abraham's homecoming, not a week passes without his poor ruined face being snapped from all directions; without people being told of "fantastic progress" that is nothing of the sort; without the healthy world ogling through the gates into a sick world. ${ }^{23}$ 
The immediate reason for the article was, as Habe put it, a "macabre concert" at the Hamburg clinic. A gypsy band from Budapest had come to Eppendorf, where, dressed in Hungarian costume, they gave a small concert for Abraham. “'Pardon, Madame' [one of Abraham's hits, author's note] resounded through the white halls, and 'on medical advice, the mentally ill composer had to [be] gently dragged away from the grand piano.' It was, as reporters described it, 'a great success." It is also possible to glean from the medical records a psychiatric perspective of the event. The concert held in Abraham's honor had taken place on September 4, 1956 in the hall of the Jungschwesternhaus. It seems all to have been too much for Abraham:

In a state of uninhibited euphoria, the patient began conducting, also sat down at the grand piano, but in his excitement played his melodies incorrectly, had to be led away from the grand piano, appeared greatly fatigued in the ward, was moody, irritable, presumably because his "fun" had been spoiled. Refused to have flowers in his room. ${ }^{24}$ (MF Abr.: Medical entries, II)

The account that appeared in the press reads rather differently:

Then, suddenly, the patient transformed for a few minutes into the old musician: He conducted the orchestra. He rushed over to the grand piano. Nobody could stop him. He took to the keyboard and played 'Pardon, Madame ...'... Thunderous applause as a smiling Abraham left the hall. For a few happy minutes, he had found himself once again in the passionate melodies of his homeland. ${ }^{25}$ (C/P Abr.: "Musician enraptured by the melodies of his homeland" [Melodien der Heimat packten den Musiker] - BILD, September 5, 1956)

Elsewhere it was reported that Abraham had unleashed "veritable storms of enthusiasm with his piano playing, which almost sounded like of old" (C/P Abr.: "Hungary Played for Paul Abraham" - Hamburger Mittag, September 5, 1956). In Habe's view, the guest performance by the red, white, and green gypsy band raised suspicions that "Abraham's compatriots felt it might be cheaper to send the Csárdásfürstin over the border than to settle his accounts." He sharply criticized the "fuss surrounding the concert" at the Eppendorf clinic. "The ageing man, wrecked by inner chaos and external confusion, needs peace; Paul is very sick." 
In his article, Hans Habe described Abraham's piano playing at the Hamburg clinic as "occupational therapy," adding: "Occupational therapy is the scientific term for the alleviation of a diseased condition through familiar employment. While it might not be possible to cure Paul Abraham, he is nonetheless brought relief by listening to and playing music." ${ }^{26}$ Abraham's piano playing at the clinic in Eppendorf can certainly be interpreted in light of this observation. Looking back at his time as one of the psychiatrists indirectly involved with the case, Johann M. Burchard spoke of "psychotherapy in its most up-to-date form." Ultimately, the medical motives behind the decision to give Abraham access to a piano remain relatively vague. In Schumann's case, by contrast, it is not even possible to determine whether this step was even based on a medical initiative. On the contrary, there was more a fear in Endenich that occupation might prove harmful, that it could agitate the patient excessively.

The functions of the piano in the asylum, and the expectations that may have been associated with the instruments at the psychiatric facilities in Hamburg and Endenich, can only be conveyed very equivocally by such terms as "psychotherapy," "occupational therapy," or "work therapy." The composer's piano instead signifies references of a highly personal nature. For artists like Abraham and Schumann, their occupation was a vocation, a pursuit of powerful inner impulses. Not having access to a piano signified for them a state of personal incompleteness, a reduction of their usual means of expression, and - beyond mental problems - a quite distinct disruption to their identity. The piano formed an elementary component of their life. At the psychiatric institution, this instrument durably shaped the men's self-identity and provided self-assurance in a unique way. In Abraham's case, the piano can in a certain respect be interpreted as an extension of the psychiatrist's arm, whose scope for treatment was however limited to restorative measures. The goal was to improve overall health, to uplift the patient's spirits.

The composer's piano structured the daily routine of Schumann and Abraham in the psychiatric institution. It governed where they moved and lingered in the space of the facility and on the grounds of the clinic. It produced certain impulses in the patients. And it created distinct worlds of noise and sound within the clinic and, consequently, particular acoustic impressions for other patients, doctors, and nursing staff. The piano (or grand piano) turned the psychiatric institution into a place 
of artistic interaction and musical performances (concerts), as well as a remarkable setting of both igth- and 2oth-century music history. Thus, the piano in Endenich was the point of reference for Schumann's meetings with Johannes Brahms. With Paul Abraham, it mediated a stage-managed public profile of the composer, and so became the focus of ethically motivated objections. It also revealed a layer of German society's mentality in this period: The Jewish composer was supposed to play and compose again like in the old days - as though nothing had happened. Was this about overcoming an individual sickness or, as it were, a sense of collective guilt?

Outside the psychiatric hospital, the composer's piano, and the respective ways it was used, served as a yardstick - beyond the remit of medical knowledge and doctors' expertise - for both those in immediate proximity and the public more widely to gauge the likelihood of Schumann and Abraham making a return to writing music. The piano in the psychiatric hospital was a surface on which to project corresponding wishes, hopes, expectations, and considerations. Ultimately in Schumann's case, however, it also communicated in stark terms the realization that the composer was beyond saving.

The piano (or grand piano) was fundamental in shaping both patients' periods of residence at the psychiatric institution and, similarly, the respective relationship between inside and outside the clinic. If an "object of psychiatry" is to be understood more narrowly as an item whose effectiveness can essentially be linked to psychiatric concepts, then the composer's piano should be described more as an object in psychiatry, since therapeutic approaches can only reveal an incomplete understanding of its specific meaning. The piano (or grand piano) played respectively by Schumann and Abraham in Endenich and Eppendorf was more than an "object of psychiatry." It can also be considered a remarkable object in both composers' life stories, an extraordinary object of music history, as well as an ambivalent subject of controversial published opinions. 


\section{Notes}

1

Quills, music paper, music manuscripts, and printed music literature also played a role.

Other relevant objects were an atlas, a bible, an

English-language book on chess and other books, as well as a set of dominoes.

\section{2}

"Spielte gestern Clavier, war sehr freundlich."

\section{3}

"[...], noch ist ihm keine Beschäfftigung gestattet, und die Zeit außer, wo er Spaziergänge macht, pflegt er meist der Ruhe auf dem Sofa. Noch keiner seiner Freunde durfte Ihn sehen, denn man will eben Alles vermeiden, was Ihn im geringsten aufregen könnte."

4

"Täglich spielt er 1 Stunde lang Clavier u[nd] macht größere Spazirgänge in die Umgegend."

\section{5}

"Ich wünschte manchmal, daß Du mich am Flügel phantasiren hörest; das sind meine seligsten Stunden."

\section{6}

"Spielte gestern wieder bis spät am Abend auf dem Flügel.”

\section{7}

"In der Kölnischen Zeitung standen vor Kurzem mehrmals Berichte über meines Mannes Krankheit, als ob dieselbe noch so schlimm sey; mein Mann, der es gelesen, schreibt mir nun darüber sehr entrüstet, wie es eigentlich spaßhaft sey,

daß man von ihm schriebe, als sey er der unglücklichste Künstler, während er den ganzen Tag thätig, schreibend und lesend sey, täglich am Flügel sich versenke, oft phantasierend lang, lange."

\section{8}

"[...] er ist den ganzen Tag thätig, schreibend, lesend, spielt sehr viel Clavier, auch vierhändig mit ihn besuchenden Freunden, steht in fortwährender
Correspondenz mit seiner Gattin, nimmt das lebhafteste Interesse an allen Vorgängen, und liest mit Befremden ohne Zweifel in den Zeitungen über sich selbst Berichte, die nicht selten eben so sehr der Wahrheit als jedes Zartgefühls ermangeln."

\section{9}

"Gestern den ganzen Tag aufgeregt, sehr laut und lebhaft faselnd, auch im Garten mit lebhaften Gesticulationen; spielte nachher beinahe 2 Stunden lang auf dem Clavier sehr wild und wirre, dabei sehr laut sprechend; [...]."

\section{0}

"Als Johannes fort ging, hörte er Ihn [Schumann, Anm. S.W.] unten noch eine Novelette spielen, überhaupt erzählte lhm Robert, daß er oft Tage lang den ganzen Tag spiele, was auch der Arzt sagte. Er hat ein schönes Instrument - Johannes war sehr befriedigt davon."

\section{1}

"Wir spielten dann gar vierhändig! Zur CäsarOuvertüre forderte er mich auf. [...] Es ging nicht ordentlich fest zusammen, wie lange hat er auch nicht vierhändig gespielt."

12

"In fieberhafter Erregung blätterte er in seinen älteren Kompositionen, mit zitternden Händen auf der Klaviatur sie verstümmelnd wiedergebend, - herz- und ohrenzerreißend! Der herrliche Mann muß maßlos gelitten haben."

13

"Schumann saß gerade am Clavier, welches man ihm auf seinen Wunsch hatte hinstellen lassen, und phantasirte. Wir konnten ihn lange und ungestört durch eine Oeffnung in der Thür beobachten. [...] Das Spiel war ungenießbar. Es machte den Eindruck, als ob die Kraft, von welcher es ausging, vollständig gelähmt war, gleich einer Maschine, deren Mechanismus zerstört, nur noch in unwillkürlichen Zuckungen fortzuarbeiten versucht." 
14

"Wünschte gestern, etwas Clavier zu spielen, wolle seine Fuge einmal versuchen."

15

"Das Clavier möcht ich oft zerdrücken und es wird mir zu eng zu meinen Gedanken."

16

"Die amerikanische Behandlung war wirklich allererste Sahne, erste Klasse. Er kam vollkommen saniert, aber mit leichten Defekten nach Europa zurück. [...] Er kam also zu uns als ein austherapierter Fall, also ein Restzustand von ein bisschen kaputt, aber nicht mehr krank. Also leicht dement. [...] Er kriegte von uns leichte stimulierende Medikamente und insbesondere bekam er Psychotherapie in der allermodernsten Form. Man gab ihm ein Klavier."

\section{7}

"Der Pat[ient] bietet das Bild eines hirnorganisch wesensgeänderten und hochgradig dementiv abgebauten Menschen. Dieses Bild ist insbesondere geprägt durch eine erhebliche Herabsetzung der Kritik- und Urteilsfähigkeit, durch mangelhafte Beziehungen zur Realität, durch kindliche Verhaltensweisen und durch eine affektive Verflachung. [...]; neben der gedanklichen Beschäftigung mit seiner Vergangenheit interessiert er sich im wesentlichen nur noch für seine Mahlzeiten, für Radio- und Grammophonmusik sowie für das Klavierspiel."

18

"Heute hatten wir die Möglichkeit, den Pat[ienten] im Festsaal des Jungschwesternhauses an einen Flügel zu setzen. Er wusste genau, worum es ging und war bereits auf dem Wege sichtbar erfreut. Nachdem wir die Tür des Saales passiert hatten und er den Flügel erblickt hatte, ging er zielstrebig darauf zu, öffnete das Instrument, setzte sich und begann zu spielen. Es ist ganz offensichtlich, dass Paul Abraham nach wie vor das Instrument in vollendeter Weise beherrscht."
19

"Pat[ient] blühte am Flügel sichtbar auf. Er war blendend gelaunt und es war unverkennbar, dass das Musizieren sehr anregend auf ihn wirkte. Auf dem Rückwege sprach er davon, dass er nun täglich spielen möchte, dazu alle Schwestern und Ärzte einladen wolle [...."

20

"Kürzlich wurden dabei Aufnahmen von einer Illustrierten Zeitung gemacht. Pat[ient] war ganz in seinem Element."

21

"Er ließ es sich nicht nehmen, das Musikstück sogleich auf dem Klavier vorzuspielen. Es handelt sich um eine einfache, etwas melancholische Melodie."

22

"Er setzte sich sogleich an sein Klavier, das bereits vorher von Baracke 10 in die neue Wohnung transportiert worden war und spielte für die Anwesenden verschiedene bekannte Stücke aus seinen Werken."

\section{3}

"Keine Woche seit Paul Abrahams Heimkehr vergeht, ohne daß das arme zerfallene Gesicht von allen Seiten geknipst würde; ohne daß man von ,wunderbaren Fortschritten ' erführe, die keine sind; ohne daß die gesunde Welt durch die Gitter einer kranken Welt glotzte."

\section{4}

"Euphorisch-enthemmt begann Pat[tient] zu dirigieren, setzte sich auch an den Flügel, spielte seine Melodien in der Aufgeregtheit jedoch fehlerhaft, mußte vom Flügel geführt werden, wirkte auf Stat[ion] sehr erschöpft, war mürrisch, gereizt, vermutlich, weil man ihm den ,Spaß' verdorben hatte. Wollte keine Blumen in seinem Zimmer wissen."

25

"Dann wurde plötzlich der Kranke für Minuten der alte Musikant: Er dirigierte das Orchester. 
Er stürzte zum Flügel. Niemand konnte ihn halten. Er griff in die Tasten und spielte, Pardon, Madame .... [...] Tosender Beifall, als Abraham vor sich hinlächelnd den Saal verließ. Er hatte in den heißen Melodien seiner Heimat für glückliche Minuten sich selbst wiedergefunden."

\section{6}

"Heilung durch Beruf nennt die Wissenschaft die Milderung eines krankhaften Zustandes durch gewohnte Beschäftigung. Wenn Paul Abraham auch nicht geheilt werden kann, so bringt ihm gehörte und gespielte Musik doch Milderung."

\section{Sources}

Institute for History and Ethics of Medicine, University Medical Center Hamburg-Eppendorf (UKE) [Institut für Geschichte und Ethik der Medizin, Universitätsklinikum Hamburg-Eppendorf]: Collection of materials relating to Paul Abraham in Eppendorf, 1956/57.

MF Abr. Medical file from the Psychiatric and Mental Clinic at the University Hospital Eppendorf relating to Paul Abraham (no. 2140/56, 25141/59).

C/P Abr. Correspondence and press articles relating to Paul Abraham at the UKE.

\section{Films}

Arte documentary "Bin nur ein Jonny:

Der Operettenkomponist Paul Abraham," János Darvas, WDR 2008,

https://www.youtube.com/watch?v=WxeKWhD kRj8, accessed August 14, 2019.

Film recording of "Schumann and the Art of Piano Destruction - Second Night - 4 Oct 2009," https://www.youtube.com/watch?v=2w j214JFalQ, accessed August 14, 2019.

\section{Bibliography}

Appel, Bernhard R. (ed.) (2006): Robert Schumann in Endenich (I854-I856): Krankenakten, Briefzeugnisse und zeitgenössische Berichte, on behalf of the Academy of Arts, Berlin, and the Robert Schumann Research Centre, Düsseldorf, Mainz et al.: Schott (Schumann Forschungen, vol. 11).

Beobachtungen über den Cretinismus. Eine Zeitschrift, ed. by the doctors of the Mariaberg Psychiatric Hospital (1850), Tübingen: Laupp.

Bly, Nelly (2009): Ten Days in a Mad-House, Rockville, MD: Wildside.

Braslow, Joel T. (1996): "The Influence of a Biological Therapy on Physicians' Narratives and Interrogations: The Case of General Paralysis of the Insane and Malaria Fever Therapy, 1910-1950." In: Bulletin of the History of Medicine 70, pp. 577608.

Cohn, Werner M. (1953): "Observations on 36 Patients with General Paresis treated with Penicillin-Malaria and Penicillin alone." In: Psychiatric Quarterly 27, pp. 637-648.

Dumke, Hans-Otto (2006): "Robert Schumann: Schlussfolgerung nicht zulässig." In: Deutsches Ärzteblatt 103/41, p. A 2700.

Ehrmann, G. (1957): "Penicillin oder klassische Malariabehandlung der Neurosyphilis?" In: Archiv für klinische und experimentelle Dermatologie 205, pp. 65-74.

Franken, Franz Hermann (2006): "Robert Schumann in der Irrenanstalt Endenich. Zum Verlaufsbericht seines behandelnden Arztes Dr. Franz Richarz." In: Appel, Bernhard R. (ed.): Robert Schumann in Endenich (1854-I856): Krankenakten, Briefzeugnisse und zeitgenössische Berichte, on behalf of the Academy of Arts, Berlin, and the Robert Schumann Research Centre, Düsseldorf, Mainz et al.: Schott (Schumann Forschungen, vol. 11), pp. 442-447.

Franzen, Caspar (2006): "Robert Schumann (1810 -1856): 'Qualen fürchterlichster Melancholie'." In: Deutsches Ärzteblatt 103/30, pp. A 2027-2029. Gruhle, Hans Werner (1906): "Brief über Robert 
Schumann's Krankheit an P. J. Möbius." In: Zentralblatt für Nervenheilkunde und Psychiatrie 29/NF17, pp. 805-810.

Howe, Blake et al. (eds.) (2016): The Oxford Handbook of Music and Disability Studies, Oxford et al.: Oxford University.

Jansen, Friedrich Gustav (ed.) (1904): Robert Schumanns Briefe. Neue Folge, 2nd enhanced and improved edition, Leipzig: Breitkopf und Härtel.

MacKenzie, Charlotte (1992): Psychiatry for the Rich: A History of Ticehurst Private Asylum, I792-I9I7, London/New York: Routledge.

Möbius, Paul Julius (1906): Ueber Robert Schumanns Krankheit, Halle (Saale): Marhold.

Otte, Andreas/Wink, Konrad (2008): Kerners Krankheiten großer Musiker. Die Neubearbeitung, 6th edition, Stuttgart/New York: Schattauer. Peters, Uwe Henrik (2006): "Erläuterungen zum Endenicher Krankenbericht Schumanns." In: Appel, Bernhard R. (ed.): Robert Schumann in Endenich (I854-I856): Krankenakten, Briefzeugnisse und zeitgenössische Berichte, on behalf of the Academy of Arts, Berlin, and the Robert Schumann Research Centre, Düsseldorf, Mainz et al.: Schott (Schumann Forschungen, vol. 11), pp. 448-480.

Peters, Uwe Henrik (2009): Robert Schumann. 13 Tage bis Endenich, Cologne: ANA.

Reil, Johann Christian (1803): Rhapsodieen über die Anwendung der psychischen Curmethode auf Geisteszerrüttungen, Halle (Saale): Curt, http:// www.deutschestextarchiv.de/book/view/reil_curmethode_1803?p=6, accessed August 14, 2019.

Schmidt, Gunnar (2013): Klavierzerstörungen in Kunst und Popkultur, Berlin: Reimer.

Schnebel, Dieter (1981): "Rückungen - Ver-rückungen. Psychoanalytische und musikanalytische Betrachtungen zu Schumanns Leben und Werk." In: Metzger, Heinz-Klaus/Riehn, Rainer (eds.): MusikKonzepte. Die Reihe über Komponisten, special volume: Robert Schumann I, Munich: Ed. Text + Kritik, pp. 4-89.

Schwartz, Manuela (2019): "Konzerte für Kranke als medizinische Fallstudien. Hörlabore in rezeptiven Musikexperimenten des 19. Jahrhunderts." In: Ankele, Monika/Ledebur, Sophie/Kaiser, Céline (eds.): Aufführen - Aufzeichnen - Anordnen. Wissenspraktiken in Psychiatrie und Psychotherapie, Wiesbaden: Springer, pp. 43-69.

Spehr, Wolfgang et al. (1989): "Psychiatrische und Nervenklinik. Von der Irrenanstalt zur Universitätsklinik." In: Weisser, Ursula (ed.): Ioo Jahre Universitäts-Krankenhaus Eppendorf, I8891989, Tübingen: Attempto, pp. 303-306

Tadday, Ulrich (ed.) (2006): Schumann-Handbuch, Stuttgart et al.: Metzler/Bärenreiter.

Uhlmann, Gordon/Weisser, Ursula (eds.) (1992) Krankenhausalltag seit den Zeiten der Cholera. Frühe Bilddokumente aus dem UniversitätsKrankenhaus Eppendorf in Hamburg, Hamburg: Kabel.

Vanja, Christina (2008): "Musik im Hospital." In: Grundmann, Kornelia/Sahmland, Irmtraut (eds.) Concertino. Ensemble aus Kultur- und Medizingeschichte. Festschrift zum 65. Geburtstag von Professor Dr. Gerhard Aumüller, Marburg: Philipps-Universität, pp. 244-268.

Waller, Klaus (2017): Paul Abraham. Der tragische König der Operette. Eine Biographie, 2nd revised edition, Norderstedt: BoD

Wulf, Stefan/Schmiedebach, Heinz-Peter (2014): "Wahnsinn und Malaria - Schnittpunkte und Grenzverwischungen zwischen Psychiatrie und Tropenmedizin in Hamburg (1900-1925)." In Gesnerus. Swiss Journal of the History of Medicine and Sciences 71/1, pp. 98-141.

Wulf, Stefan (2017): "Malariablut in der Westentasche. Der Beginn der Malariafieber-Therapie gegen die progressive Paralyse in der Hamburger Staatskrankenanstalt Friedrichsberg (5. Juni 1919)." In: Medizinhistorisches Journal 52, pp. 2-40.

All quotations originally in German were translated by Anthony DePasquale. 


\section{The Effectiveness of Symbols: \\ Psychogeographic Explorations of the Body}

Michelle Williams Gamaker

A performance lecture by Michelle Williams Gamaker

with Violeta Paez-Armando, Rosie Dowd-Smyth, Nina Kuttler, and Hazal Kaygusuz ${ }^{\text {I }}$

In The Effectiveness of Symbols (1972), Claude Lévi-Strauss recounts the experience of a woman undergoing a difficult childbirth. A shaman is called upon to alleviate the "blockage" and she receives a cure by song. The song (an object in itself) represents a voyage through the body's interior geography, in which the shaman encounters fantastic beasts, a way to visualize and personify pain, and thus offer the pregnant woman a way to "see" her pain. This is where the power of objects, the use of theatrical devices and dramatic representation comes in, by highlighting the materiality of the body. This article will explore the idea of healing through theatrical modes, by telling stories and turning the notion of abstract possibilities into concrete action to relate the symbolic and material approaches to effecting "cures."

Michelle Williams Gamaker is dressed head to toe in white thermals. She sits alone on a medical table, with three apples and balls of yarn placed upon it. In front of her is a tiered wooden seating stand - she is in a medical theater packed full of spectators. Hazal Kaygusuz stands further back holding a camera. She takes photos of the scene.

\footnotetext{
Michelle:

In his book "Madness and Civilization" French philosopher and historian Michel Foucault noted that French doctors during the 1700s identified the key role imagination played in effecting cures; he highlights the significance of symbolism in treatments.
} 

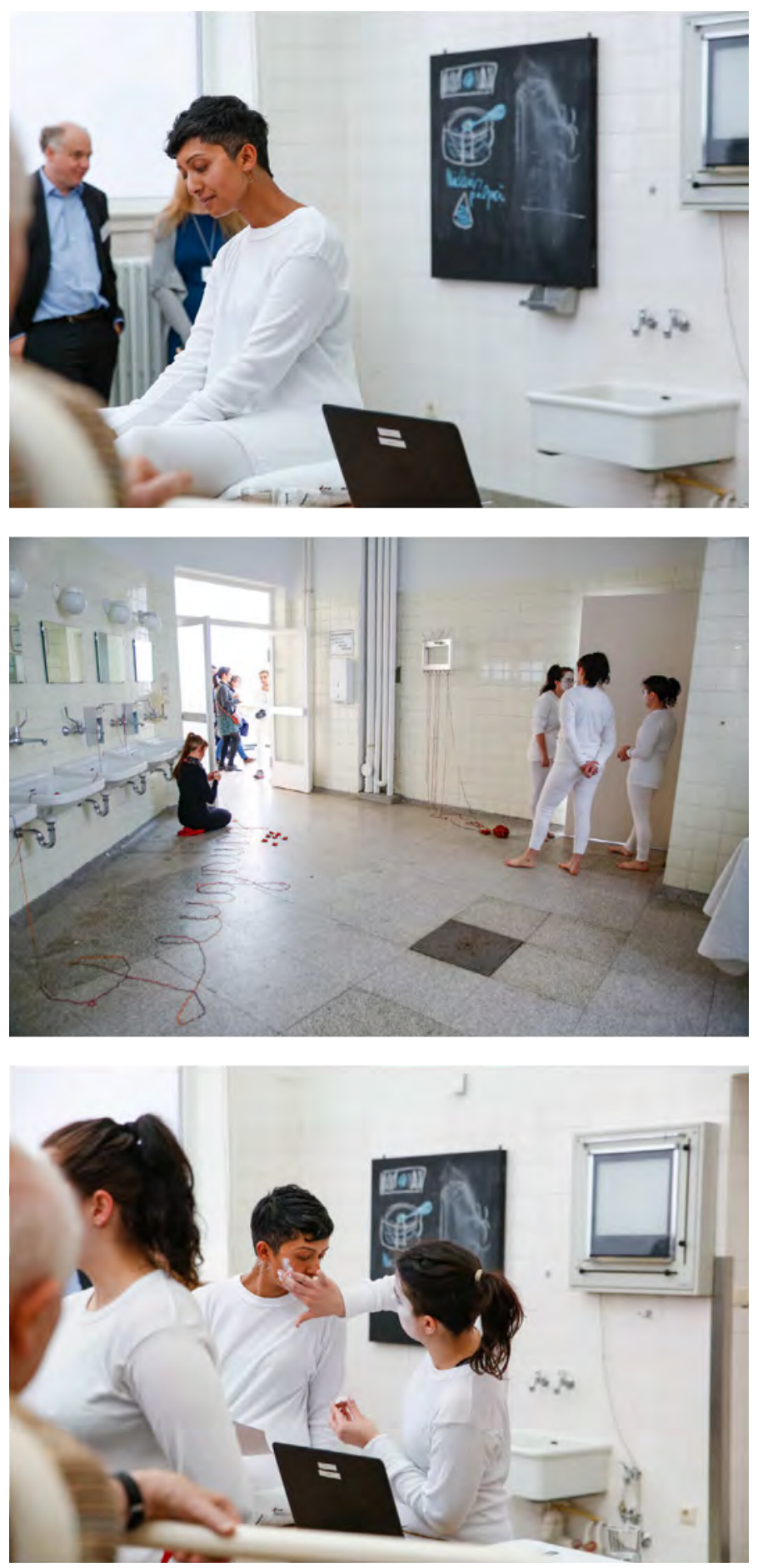
By the late 1700s, however, rather than being widely advocated as a means of cure, "the unity of symbols begins to break down and the techniques lose their total significance" (Foucault 1961 [2001]: 168).

Violeta Paez-Armando, Rosie Dowd-Smyth, and Nina Kuttler enter.

Each wears white thermals and their faces are painted white. They stand in front of Michelle. Each takes an apple from the table and looks directly at the audience. Together the five women look like patients for some nameless institution.

Violeta begins to paint Michelle's face white, while she continues to read:

Foucault writes: "If an illusion can appear as true as perception, perception in turn can become the visible, unchallengeable truth of illusion. Such is the first step to the cure by 'theatrical representation':

to integrate the unreality of the image into perceived truth, without the latter seeming to contradict or even contest the former" (ibid.: 178).

\section{A projector shows the words THEATRICAL REPRESENTATION}

Michelle:

Foucault cites an example that suggests that theatricality can be effective in healing, which can be considered a cure by "theatrical representation."

Foucault describes the case of a man who thought he was dead and thus did not feel the need to eat and in doing so began to die of starvation. Those attending him painted their faces white and dressed themselves in ghostly attire. A table was placed at the foot of the patient's bed and they began to eat and drink, much to the surprise of the patient. When questioned by him they replied that "dead people eat just as much as living ones" (ibid.: 179). The patient was able to integrate this illusion as a fact, and began to eat again. There are also comparable examples of artists operating on the border between art, therapy, and theatrical representation, and this talk will explore Brazilian artist Lygia Clark. 
Violeta, Rosie, and Nina each take a ball of wool. They slowly begin to unravel the yarn, tying one end to Michelle's ankles and the other to members of the audience. They repeat this action while the lecture continues.

\begin{abstract}
Michelle:
Lygia Clark's transformation in the mid-1970s from artist to practitioner of experimental psychotherapy cannot easily be compared with other artists. She began by devising a new role for the art spectator by instigating an active rather than passive subjectivity, passing her agency as artist to the spectator and encouraging them to take control of the creative process.

Upon returning to Brazil from Paris in 1976, Clark established a therapeutic practice in Copacabana. There her clients mainly comprised former art spectators and professional associates undoubtedly familiar with her work, as well as prostitutes working in the area. There were also clients with neuroses and more serious psychotic disorders who attended individual treatments. Following psychoanalytic practice to undergo psychoanalysis as an analysand, Clark underwent analysis with Pierre Fédida (who had been a student of Gilles Deleuze and was influenced by Jacques Lacan's work). Her writing references the work of Melanie Klein, D.W. Winnicott, and Wilfred Bion. Like these analysts, Clark helped her clients return from isolated, non-engaging states to a world in which they could utilize their creative capacity.
\end{abstract}

The trio continues to link Michelle to individuals sitting near the front and those at the back of the tiered seating by tying thread to their wrists.

Michelle:

Clark's Baba Antropofágica, meaning "Cannibalistic Drool" (1973), was an example of what she referred to as "propositions." In "Baba," a figure lies recumbent on the floor with eyes closed. Working with a group called "Corpo Coletivo," the "Collective Body" lean over and encircle their subject and begin pulling continuously from a reel of thread that is concealed in their mouths. As they pull on the thread it falls on the face and body of the figure. 
A red and pink cobweb has formed.

Michelle:

The threads are coated with saliva and in the act of regurgitation it seems to parch the participants mouths. A hot, sticky thread clings like a cobweb that slowly forms a multi-colored crystalline cocoon that smothers and protects the body.

In the transient nature of the material the web appears both strong and frail. After the thread is cast, the group lays their hands over the shrouded figure and begins, randomly, to remove tufts of cotton.

This performance is heavily symbolic: each of these small acts constitutes a metaphor. Art writer Guy Brett discusses "the chain of metaphors" which unravels in "Baba." The cotton thread, as saliva is drawn from the interior of the body, stands for the viscera as a symbol of psychic being. Brett goes on to link the thread to a "lifeline" (2004: 40). The mouth represents a transitional space: interior but also able to expel air and voice into the space outside the body.

Violeta, Rosie, and Nina begin to cough, as if trying to remove something from the back of your throat. They continue connecting yarn to the audience members.

\footnotetext{
This pulling up of the innards brings about a catharsis of the very being of an individual, in which the participant is in an open and seemingly vulnerable position. That vulnerability can be compared to the feeling of a hair at the back of the mouth, an intrusion, a foreign article that is in the wrong place. Here the body reacts in very different ways to thought, its natural instinct is to repel the intrusion, with a spontaneous gagging or coughing action.
}

Violeta begins to paint black lines on Michelle's face, as if her face is covered in fur. Nina and Rosie continue to connect thread to the audience.

Michelle:
In The Effectiveness of Symbols (1972), Claude Lévi-Strauss recounts
the experience of a woman undergoing a difficult childbirth by ex-
ploring a Cuna ${ }^{3}$ song, which details a shaman who is called upon 
The Effectiveness of Symbols
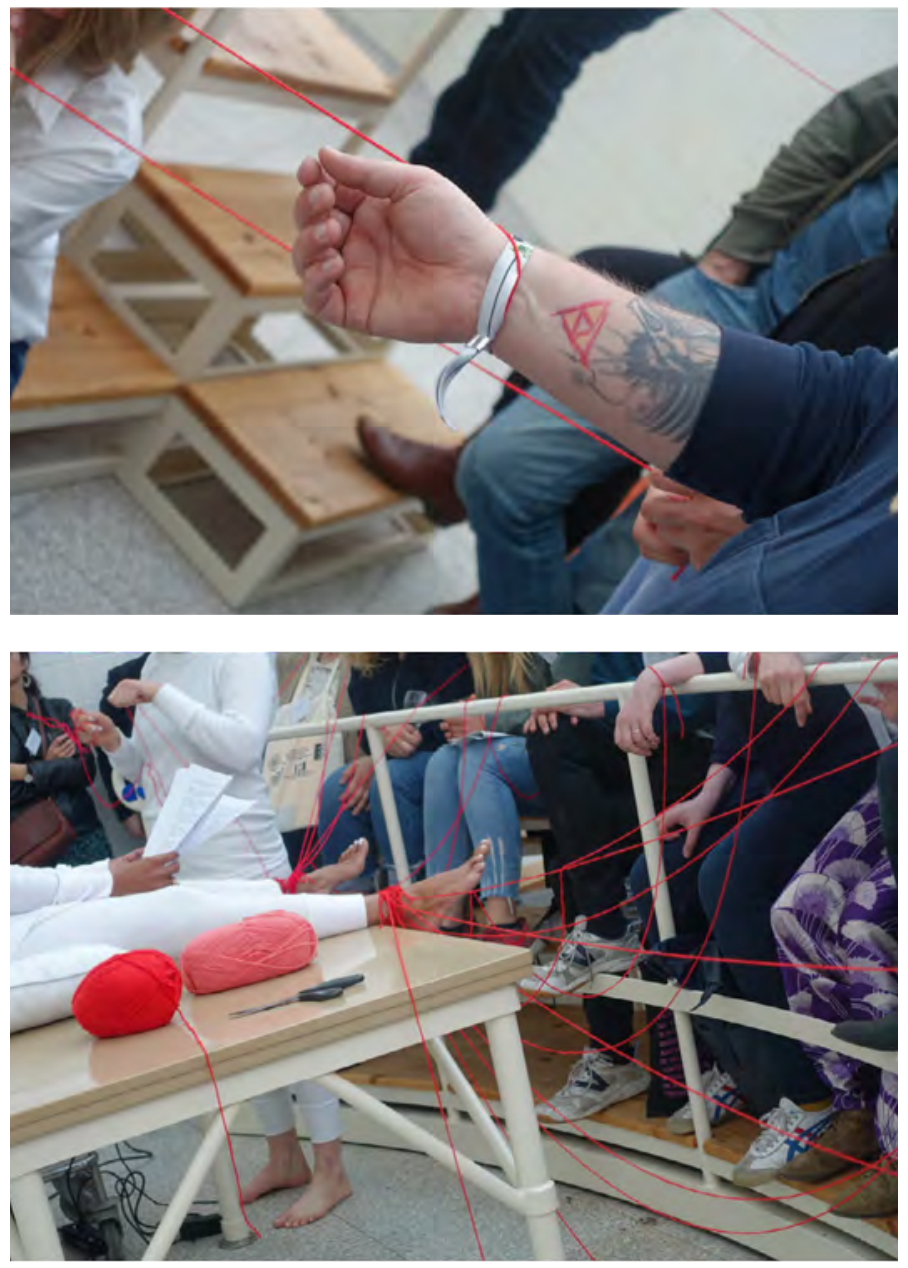
to alleviate the "blockage." The woman in labor receives her cure by song. The song represents a voyage through the body's interior geography, upon which the shaman encounters fantastic beasts that, according to the native informant, "increase the diseases of the laboring woman" (Lévi-Strauss 1972: 195) and populate the ambiguous geographic interpretation of her body.

Lévi-Strauss explains that these creatures, who are actually the product of visualization, personify pain, and in this sense give the pregnant woman a way to see her situation. This is where the power of objects comes in.

The shaman [nelegan] must defeat these animals and "overcome other obstacles, this time material: fibers, loose threads, fastened threads, successive curtains" (ibid.: 196) of multitudinous colors. These fibers must be cut back, and the shaman calls for assistance from the Lords of the wood-boring insects: the wood-boring beetles, longhorn beetles, bark beetles, and weevils, and the metallic flat-headed borers.

And the Lords of the burrowing animals: moles, great gerbil, gopher, groundhog, the hoary marmot to cut at the uterine tissues (ibid.: 196). He notes that these supernatural assistants form part of a coherent system in which the pregnant woman and her community believe. They do not have to question the existence of these mythical protagonists, and Lévi-Strauss observes that the cure consists of "making explicit a situation originally existing on an emotional level and in rendering acceptable to the mind the pains which the body refuses to tolerate" (ibid.: 197).

He locates this as a "relationship between symbol and thing symbolized ... between sign and meaning" (ibid.: 198) suggesting the shaman gives the woman a language to formulate inexpressible psychic states without difficulty. The introduction of a language of signs brings a coherent logic to the mind and body of the woman, which Lévi-Strauss terms a re-organization in her physiological process (ibid.).

It is in this conjunction of functions where objects are outer and become inner, that we can see the analogy between shamanism and the aspects of Clark's practice where art and therapy meet. 
Clark's therapy is similar to the shaman's psycho-geographic exploration of the body in that she articulates through the body as a tool for self-expression that which the patient has no words to describe adequately. She sought to reintegrate the body image with the self, recalling Lévi-Strauss's reorganization of a physiological process. Her Objetos Relacionais [Relational Object], cheap, readily accessible materials are symbolic proxies (like the spirit agents in the Cuna song) that come to personify the subject's pain and anxieties. These shamanistic disciplines allow the patient to clarify and visualize the healing process. Confusion is abated: anxiety and helplessness are given a visualization that allows the patient to comprehend it.

Once given an identity and substance - or, to put it another way, once the abstract nature of the illness has been embodied or objectified - the patient is more able to combat it. It allows the patient to direct his or her self-healing at the source of the disturbance. This extends to the possibility that one need not be ill to experience the beneficial effect of objects.

In The Effectiveness of Symbols, Claude Lévi-Strauss offers an example from a study by Swiss psychoanalyst Marguerite A. Sechehaye, who invented the method that became known as "symbolic realization," for the treatment of schizophrenics from 1947. Her research found that speech, regardless of its rich symbolism, could not go beyond the conscious and that "she could reach buried complexes only through acts" (ibid.: 200).

Lévi-Strauss suggests that the symbolism of these acts is a language the therapist uses, which allows a dialogue "not through the spoken word, but by concrete actions ... to carry their message directly to the unconscious" (ibid.: 200). In considering the physicality of Sechehaye's acts he returns to the idea of manipulation. Whether physical or psychological, he states "the manipulation must be carried out through symbols" (ibid.).

Violeta, Rosie, and Nina continue to cough, as if trying to remove something from the back of their throats.

This time they produce a small piece of wool wrapped like a worm from your mouth. It is covered in saliva. They hand it to individuals in the audience. 
In the essay The Sorcerer and his Magic (1949), Lévi-Strauss wrote on the basis of Franz Boas's observations of the Nambicuara Indians in the savannas of central Brazil and the Kwakiutl Indians of Vancouver, Canada. He gives an account of a man named Quesalid. Unlike the majority of his community, Quesalid did not believe in the powers of sorcery but learned the techniques of the shamans through his inquisitive nature. Initially he set out to expose shamanism for its fraudulent use of trickery but found that he too was equally if not more effective in instigating cures. His key skill (used by the shamanistic schools of the northwest coast of Brazil) was the practice of hiding a worm or a tuft of down inside a corner of the mouth to be produced, covered in blood, at the appropriate moment. Biting the tongue or making his gums bleed achieved this. The object represents a tangible signifier of illness and it is presented to the "patient and the onlookers as the pathological foreign body extracted as a result of his sucking and manipulations" (ibid.: 175).

This technique, utilizing both deception and effective healing, can be compared to Clark's techniques. She referred to her techniques as "gross tricks" that form part of her repertoire of phenomenal tricks to enable the client to understand the abstract nature of their problem. In The Relational Object (1980) Clark describes an instance quite comparable to that of the shaman in Lévi-Strauss's book. It concerns a patient who imagined a stiffened fetus inside his stomach, while neither Clark nor her patient knew what this could mean. She writes:

"He had an enormous belly. I lay upon it, belly upon belly for a long time and I said: "You are going to pass into my belly, you are going to pass into my belly." Then I sucked his belly button a great deal and he went away" (Clark 1983: 2).

Clark employs this somewhat crude, intuitive strategy as a means toward changing the status of a perceived foreign object within the body. Her clinical notes record:

"It was necessary for this gross trick to take place for me to realize that it was his feminine side made explicit as a complement to the masculine side, and stroking his belly affectionately and [with] my hand I said it was going to be integrated, not to be put on the outside, but to integrate it. It was integrated in time" (ibid.: 2). 
Violeta, Rosie, and Nina begin to cut the threads from Michelle.

Michelle:

Rather than attempting to banish the unwanted object of the swelling outside of the psyche (and consequently the body), Clark wanted the object to integrate into the subject's body. This integration implied that her client "dissolved" the foreign object or the concept of its presence into himself. She intervenes by using an approach at once concrete and abstract - concrete in its bodily contact and abstract because no representation is being made. Here, Clark takes the place of her Objetos Relacionais (lying on top of his stomach) and by employing the gross trick of sucking out the psychosomatically induced foreign object (from his stomach). This device, like the shaman's bloody worm, allowed the subject and Clark to grasp the root of the problem. The operative words in the text are "for me to realize," implying that it was through an empathic understanding of the patient that Clark, as a healer, could resolve the disturbance.

In considering the physicality of Sechehaye's acts, Lévi-Strauss returns to the idea of manipulation. Whether physical or psychological, he states "the manipulation must be carried out through symbols" (Lévi-Strauss 1972: 200).

He compares the acts (gestures) of Sechehaye that "reverberate in the unconscious mind of the schizophrenic just as the representations evoked by the shaman bring about modification in the organic functions of the woman in childbirth [the patient]" (ibid.: 200).

Lévi-Strauss discusses the duality of the patient and healer dyad, concluding that the therapist "acts" and the patient "produces the myth," while the shaman produces the myth and the patient performs the actions. These actions manifest themselves inside the body and usually end with good health or, in our example, with the birth of a child. Lévi-Strauss further suggests that "when it [the cure] deals directly with the unhealthy organ, it is too grossly concrete (generally, pure deceit) to be granted intrinsic value" (ibid.: 191).

This implies that poetic narrative and visual imagery are psychological representations that specifically attack the physical manifestations of psychological disturbances by weakening their rigidity. 

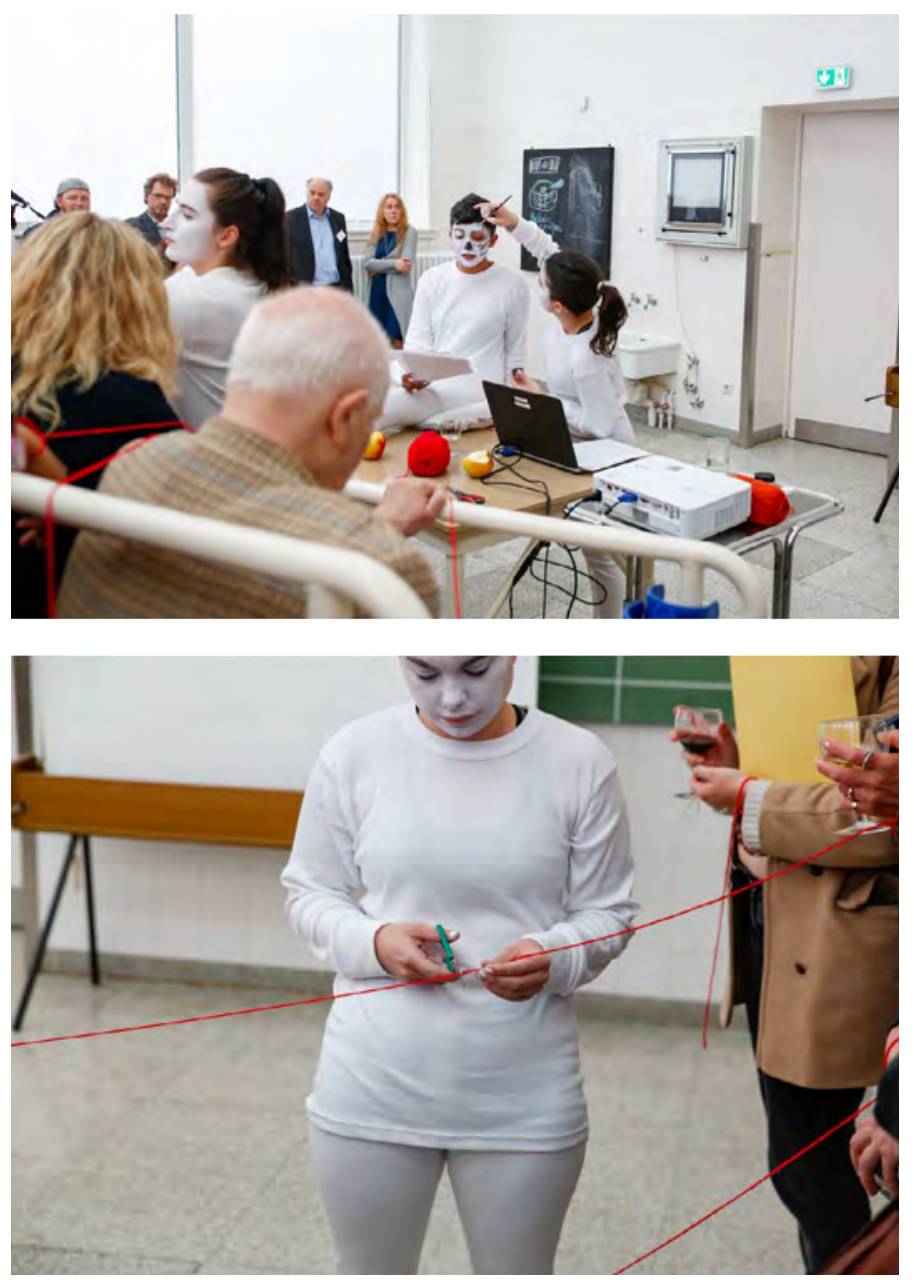
Michelle delves into the crotch of her thermals and produces an apple, which she begins to eat, while continuing to read:

Sechehaye also found that objects held great value in allowing her schizophrenic patients to actualize a fantasy object. In her in-depth study The Poetics of Psychoanalysis: In the Wake of Klein (2005), Mary Jacobus refers to Winnicott's use of Sechehaye's work, in which she produced an object, in this case an apple, at the right moment. Winnicott suggests:

"The important thing was that the patient was able to create an object, and Sechehaye did no more than enable the object to take the apple-shape, so that the girl had created an actual part of the world, an apple" (Jacobus 2005: 115).

Clark, like Sechehaye and the more abstract techniques of shamanism, utilized the potential of objects to enable her clients to access emotional knowledge from their bodies. The Objetos Relacionais, over the course of several sessions, became familiar forms with which her clients could identify.

Through this process of interaction and identification with objects, Clark provided the client with the opportunity to make conclusions about themselves, whether poetic, imagined, or real. These conclusions not only connected her participants to their personal relationships but also enabled them to locate themselves in the world. Clark's contribution to her clients' attempts to develop a creative strategy to draw conclusions about themselves offered an experience as a type of language to help formulate inexpressible psychic states.

By the end of the talk, the threads should all be cut.

This signals the end. 

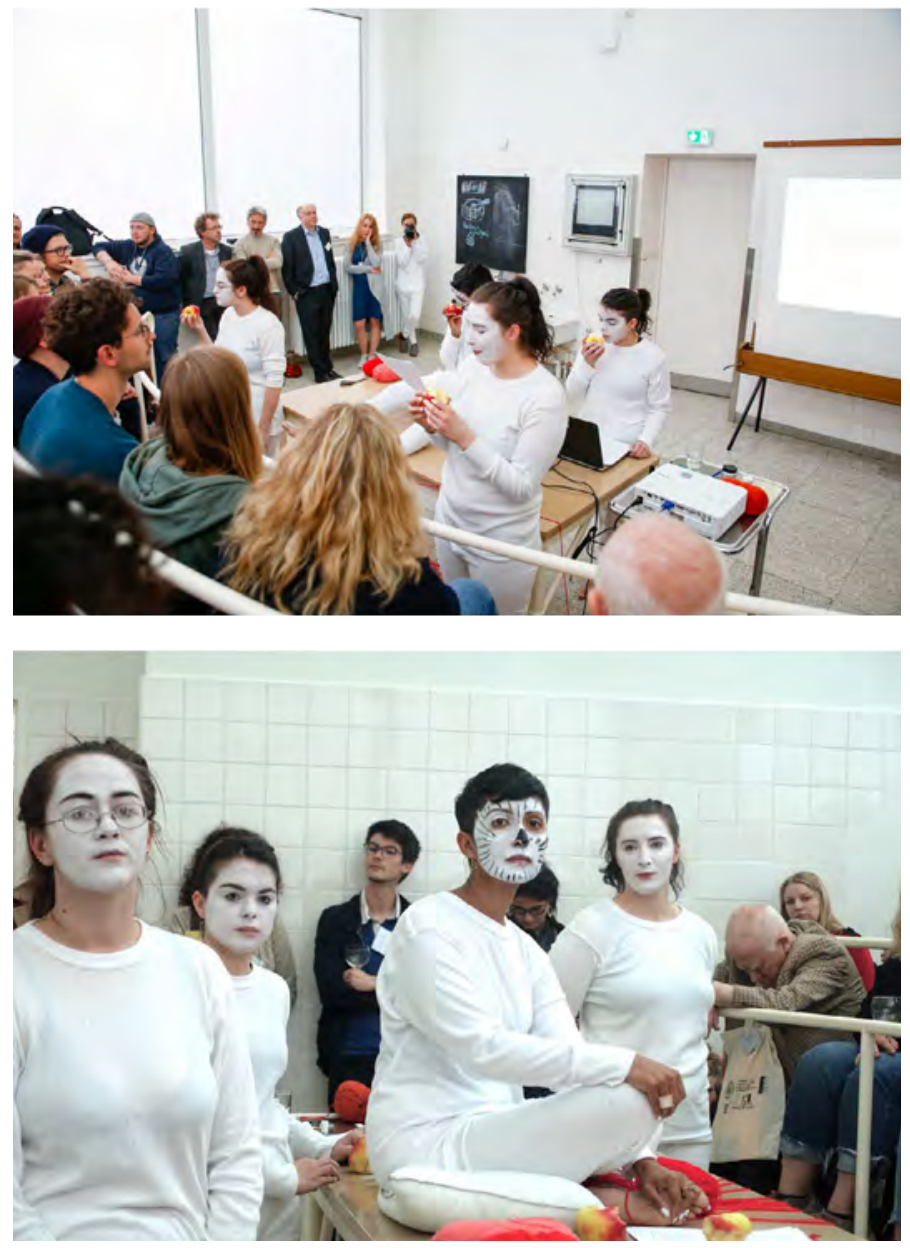


\section{Notes}

\section{1}

Presented at the international conference on

"Material Cultures of Psychiatry" at the Museum for Medical History/Institute for History and Ethics of Medicine at the University Medical Center Hamburg-Eppendorf in cooperation with the Luxembourg Centre for Contemporary and Digital History. The photos of the performance were taken at the conference.

\section{2}

Clark used the term "propositions" broadly to describe individual and collective encounters with materials and objects that she termed "Relational Objects" [Objetos Relacionais]. These were former sculptures that evolved into therapeutic tools in her experimental psychotherapeutic practice.

\section{3}

The Cuna are indigenous people of Panama and Colombia.

\section{Bibliography}

Clark, Lygia (1983): Letter to Guy Brett, Rio de Janeiro, Brazil, October I4, I983, courtesy of the World of Lygia Clark Foundation, Brazil, 2009. Brett, Guy (2004): Carnival of Perception: Selected Writings on Art, London: Institute of International Visual Arts.

Foucault, Michel (2001 [1961]): Madness and Civilization: A History of Insanity in the Age of Reason, transl. from the French by Richard Howard, Abingdon: Routledge.

Jacobus, Mary (2005): The Poetics of Psychoanalysis: In the Wake of Klein, Oxford: Oxford University Press.

Lévi-Strauss, Claude (1972): Structural Anthropology I, transl. from the French by Claire Jacobson and Brooke Grundfest Schoepf, vol. 1, London: Penguin University Books. 



\section{BODIES, SENSES, AND THE SELF}




\section{Loss of Identity}

\section{Anne Wilk}

Things I carry with me.

Practical use. Physical and psychological necessities.

Sentimental bonding to my things.

Bonding. With my possessions.

Banalities. Things that apparently have nothing but material value.

Value. How much of our value do we measure by our possessions?

My possession belongs to me, belongs to me - is: me. A part.

They are me or have I become them?

And if all this is true, who or what am l?

What remains? 

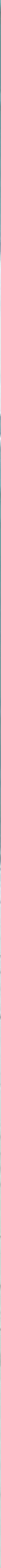


\section{Lives in Storage:}

\section{Clothes and Other Personal Effects}

\section{As a Way of Recovering Patients' Histories \\ in a Psychiatric Hospital}

\section{Marianna Scarfone}

Based on a study of the Perray-Vaucluse psychiatric hospital in the Paris area ${ }^{\mathrm{I}}$, and covering the second half of the 2oth century, this chapter aims to show how certain objects within a mental hospital could serve to animate the everyday lives of patients, or how these same objects could themselves assume a passive existence, marking time as the contents of suitcases and boxes stacked up in an anonymous storeroom. Using the resources found in the hospital's patient storeroom - a space left intact after being abandoned in 2000 - I aim to reconstruct the material functioning of fragments of patients' lives within the asylum: the rituals of dressing and undressing, the availability and circulation of clothes and other personal objects, as well as the interactions between different actors that evolve around this central facility. As Bronwyn Labrum underlines, "dress was as fundamental to these institutions as the architecture, the interior space, the daily regimes, the meals, and the interactions with other patients and with staff" (Labrum 20II: 70). More difficult to reach, but doubtless more stimulating for the historian, I will attempt to uncover the patients' desires and needs as they can be linked to the possession and use of personal objects in contrast to the standardizing logic of institutional life and, linked to this, the ways of operating, i.e. "the practices by means of which users reappropriate the space ... articulated in the details of everyday life" (De Certeau 1988: xvi). I will at the same time go through the reflection of some reformist psychiatrists which marked the second half of the 2oth century: the tendency which privileges the goal of humanization, even in the hospital setting, based on the principle of placing the individual, rather than the institution and its routines, at the center of psychiatric practice. 
By exploiting not only the patients' medical records - now classic sources in the historiography of psychiatric knowledge and practice - but also some of the objects and clothing that belonged to the interned patients, I intend to reconstruct the trajectories of certain individuals whose personal belongings have not moved from the cloakroom. This corpus can provide a new perspective on the patients' daily lives, their intimacy, their relationship with the institution, with their illness, as well as with the outside world, with freedom, and their institutional confinement.

\section{Lives Suspended behind the Storeroom Door: Archaeology of the Contemporary Past, Material History, and the Memorial Approach}

The study I conducted at the Perray-Vaucluse asylum looked at the trajectories of inmates' personal effects, insisting on their anchored physicality and tracing their circulation within the "total institution," 2 always bearing in mind the affective and symbolic value they held for their owners. The storeroom - this centralized asylum facility where personal objects were deposited and made inaccessible to patients was in use from the I950s until 2000, ${ }^{3}$ after which it became a "suspended" space, where nothing has changed since the last person in charge of the service closed the door behind her. ${ }^{4}$ The recent discovery of this forgotten storeroom is an invitation to historians to physically immerse themselves in an uncanny space able to nourish reflections about the epistemic value of material objects in history. The retrieved objects also offer the possibility of reconstructing individual trajectories while connecting them to the history of psychiatric practices.

This field has undergone a profound renewal in last decade, including the study of material cultures, focusing on patient hospital records and paper technologies (Hess 2018), spaces of hospitalization and the ways they were inhabited by different actors (Topp et al. 2007), as well as objects that structured the daily routine in the asylum and their nature (Majerus 20II). Furthermore, the reflection of historians of psychiatry and mental health has already focused on daily life in these institutions, including themes related to personal space within an asylum, the relationship of the individual to the institution, issues of intimacy, regarded through the prism of patients' uniforms and clothing. ${ }^{5}$ The introduction of three-dimensional material as a novel source serves to enrich a multi-factorial approach to the life 
inside the walls of asylums. Material items link us to the patient's intimate life, too often left out of clinical reports, a life transformed and somehow "nourished" by the patient's present reality of hospitalization. They also point beyond the walls of the institution, indicating past habits or a kind of "lost world" of emotions and relationships prior to an episode of internment. These objects can furnish clues about the patient's aspirations for a future life when she or he finally returns to the world outside the asylum. Unfortunately, the reality was too often a present without any hope, as is suggested by this poignant poem written by a patient in 1976 and found in his suitcase, bearing the title "I am a sick person" [Je suis un malade]:

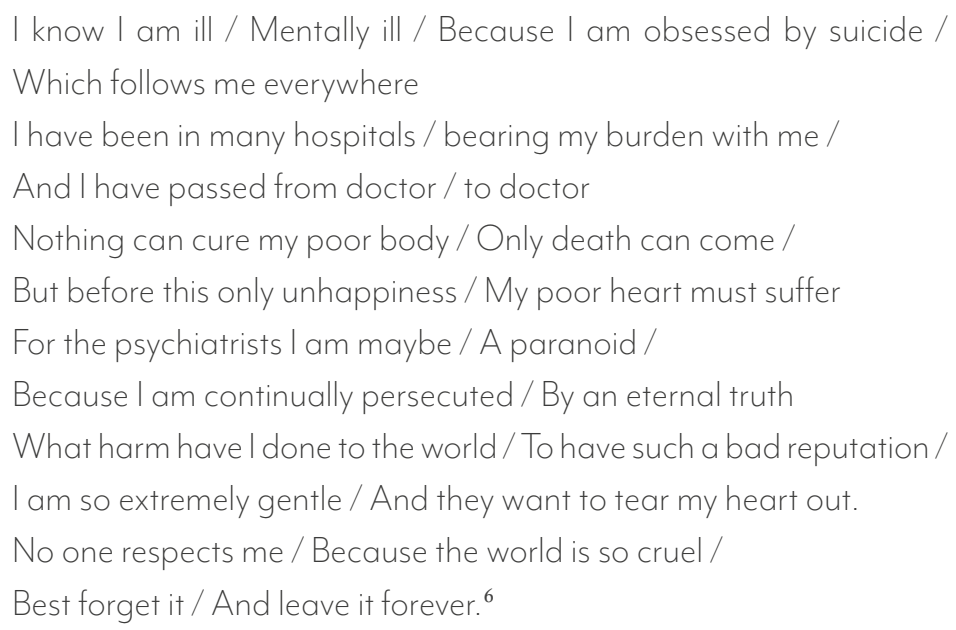

The kind of historical approach that combines biography with social analysis and uses material objects in an almost ethnographic manner has been adopted in other contexts, being pushed even further than I am proposing here. This kind of work has given rise to public exhibitions that displayed the personal effects of interns in an asylum, with an interdisciplinary analysis supplying the relevant context.

Indeed, Vinatier, a psychiatric hospital in Lyon with a strong track record of cultural initiatives, held an exhibition in 2002 around the theme of people's personal effects in a psychiatric institution, entitled "Do you have a soul? Private objects in a psychiatric hospital in the 20th century" [... avez-vous donc une âme? Objets privés et hôpital psychiatrique au XX siècle]. ${ }^{7}$ Here they displayed objects that had been found in the hospital's basement, some of which had been deposited by patients as long ago as I920. The collection consisted of 800 objects in 50 wooden drawers numbered in red paint - individually labelled, stored, and forgotten (Filiod 2003). 
Abandoned in 1995, the patients' storeroom in an attic room of the Willard State Hospital in New York was likewise discovered intact. The person in charge of the users' personal effects at the State Board of Mental Health collaborated with a psychiatrist, a filmmaker, and a photographer in the painstaking reconstruction of the trajectory of these objects and the patients who owned them. They inventoried the contents of 427 suitcases found in the storeroom and managed to retrace the lives of 25 of the patients concerned. They put on an exhibition in 2004 and published a book based on it (Penney/Stastny 2008).

We are only too familiar with straitjackets and binding belts as objects that have helped to shape our ideas of asylums, symbolically asserting their own implicit logic throughout the history (and pre-history) of psychiatry (Majerus 2017). The initiatives in Lyon and New York show how we, whether as historians, cultural mediators, or museum curators, can shift the attention of material interest onto less connoted objects, which might well in the end be of more significance to the individuals who passed through different psychiatric institutions in the 2oth century. One of the characteristics of a "total institution" is that on admission the individual is stripped of both her or his usual, distinctive individual identity, and of the accessories through which she or he habitually maintains this individuality or personality. A process of personal effacement and "mortification" deprives the individual of her or his "identity kit": as Erving Goffman wrote, personal effects like "clothing, combs, needle and thread, cosmetics, towels, soap, shaving sets, bathing facilities are usually taken away or denied him, although some may be kept in inaccessible storage, to be returned if and when he leaves" (Goffman 1961: 20).

It is these kinds of personal effects that I discovered when I found myself opening suitcases; unpacking bundles; reading letters, personal notebooks, and unpublished novels; looking at photographs, identity documents, and drawings; opening toiletry bags; and unpacking perfectly folded clothes and towels in the Perray-Vaucluse storeroom. I found myself looking ever more closely into the lives of others, into the tokens of their memories, their experiences, their everyday lives both within and without the psychiatric hospital.

The archaeology of the contemporary past - a research field informed by a militant political agenda - argues in favor of these kinds of initiatives as well as offering theoretical tools to help the researcher position herself. ${ }^{8}$ The metaphor and the act itself of the archeological "dig," which were central in this approach, reveal much that would otherwise remain invisible, adding to the "uncanny" nature of the objects - both physical and psychical - that were brought to the surface in the process. 
The archeological gesture in a context like this makes the researcher uncomfortable. On the one hand, because of the intimacy entailed by the objects and the vital force that they carry with them, even though they remain inanimate objects, somewhat akin to stuffed animals. On the other hand, because of their sometimes disconcerting banality, since they are everyday objects such as toothbrushes, shoes, lipsticks, books, coats, cigarette packs, but also notebooks, photographs, medallions, etcetera, the researcher is caught in a double movement of emotional immersion and detachment. Of course, the same could be said for any archive, generally a set of paper documents, that serve as the basis for the researcher's acts of reconstruction, interpretation, and abstraction, but the three-dimensional non-verbal archive that can be the storeroom reinforces this double movement.

Entering the psychiatric hospital's storeroom, I found myself in a pre-ordered space. The objects had not only been collected, organized, and archived, but had also been catalogued by the staff who worked in the service. Attempting to exploit this atypical archive meant engaging with this order, trying to understand its logic, and then trying to understand what deeper conceptual order lay behind it. Undoing bundles, opening suitcases, the historian violates the habitual order of this suspended space and penetrates into the intimate lives of those who have left their personal effects behind them. What gives us the right to sift through the personal effects of the inmates of the deceased, or simply of people who have left the place by abandoning, forgetting or refusing their former possessions? Herein lies all the interest of this difficult yet fascinating task: employ these objects to bring those who owned them back to life or at least back to our attention; make those who were the unwilling hosts of the institution speak, through the objects that belonged to them. These anonymous people were, like these objects, locked away in a psychiatric hospital. We know that they left these objects behind, but what else can we know about them? These are the "subalterns" so precious to the philosopher Antonio Gramsci and his intellectual disciples: silenced, locked up, forgotten. Catalogued as disturbed, or maybe just disturbing to the public order, these were people deemed unfit to live out their lives in society. To make these objects talk is to give voice to these forgotten, or rather systematically neglected lives. To give these people a voice is also to reassign their place in history. Thus, the historiographical task before us is an ambitious one: to liberate and retrieve the "subaltern" voice (Spivak I988), to allow it to be heard post mortem, that is to say post vitam. There is another 

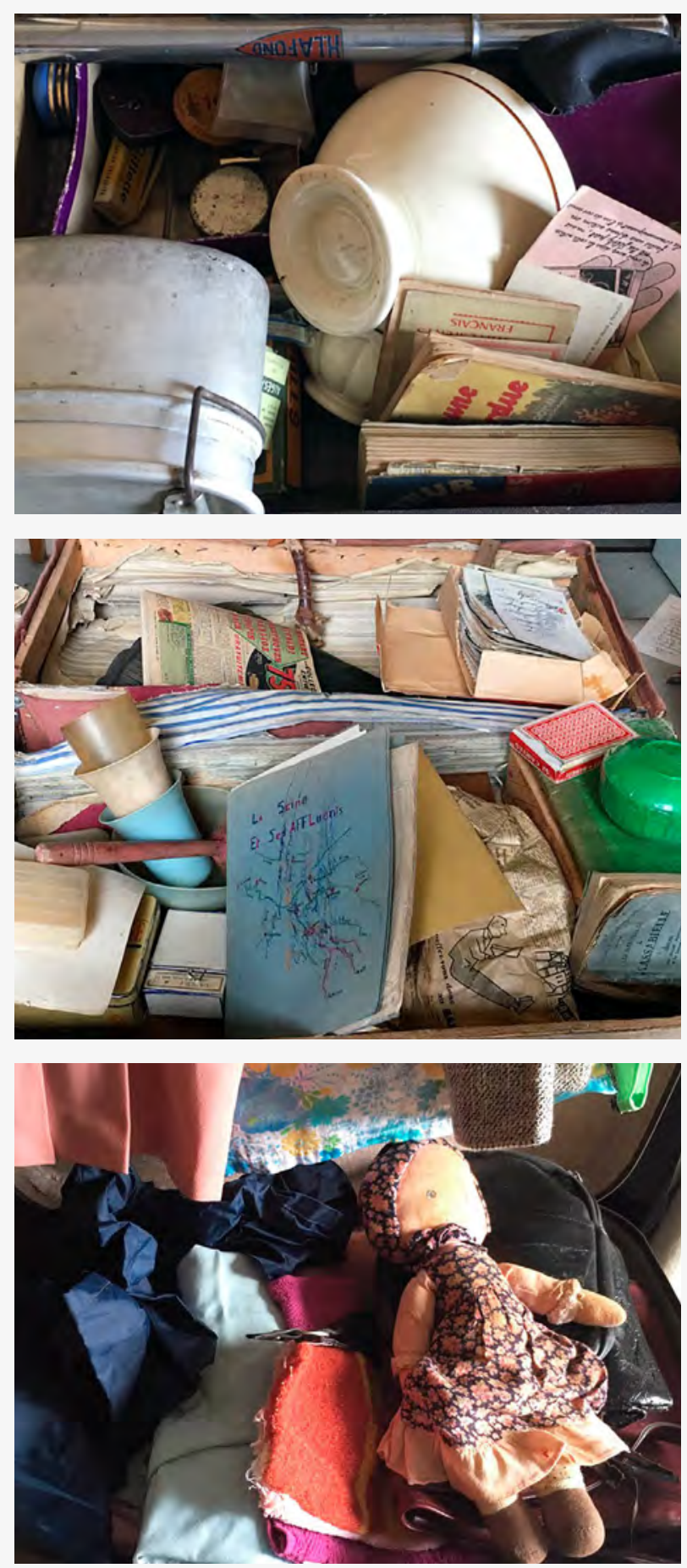
goal here as well: to shed light on everyday life inside the institution, or rather the daily lives of those who lived here. These objects, notably those produced by the inmates themselves, have much to tell us about their relationship with the institution, as well as with the world outside: their families, contemporary culture and public opinion. Once again, this work with and around the inmates' objects is bolstered by another type of source, which makes it possible to contextualize the ensembles from an institutional and clinical point of view, while providing an official cartography of the inmate's trajectory: the medical record, a much more familiar and comfortable object for the historian to handle.
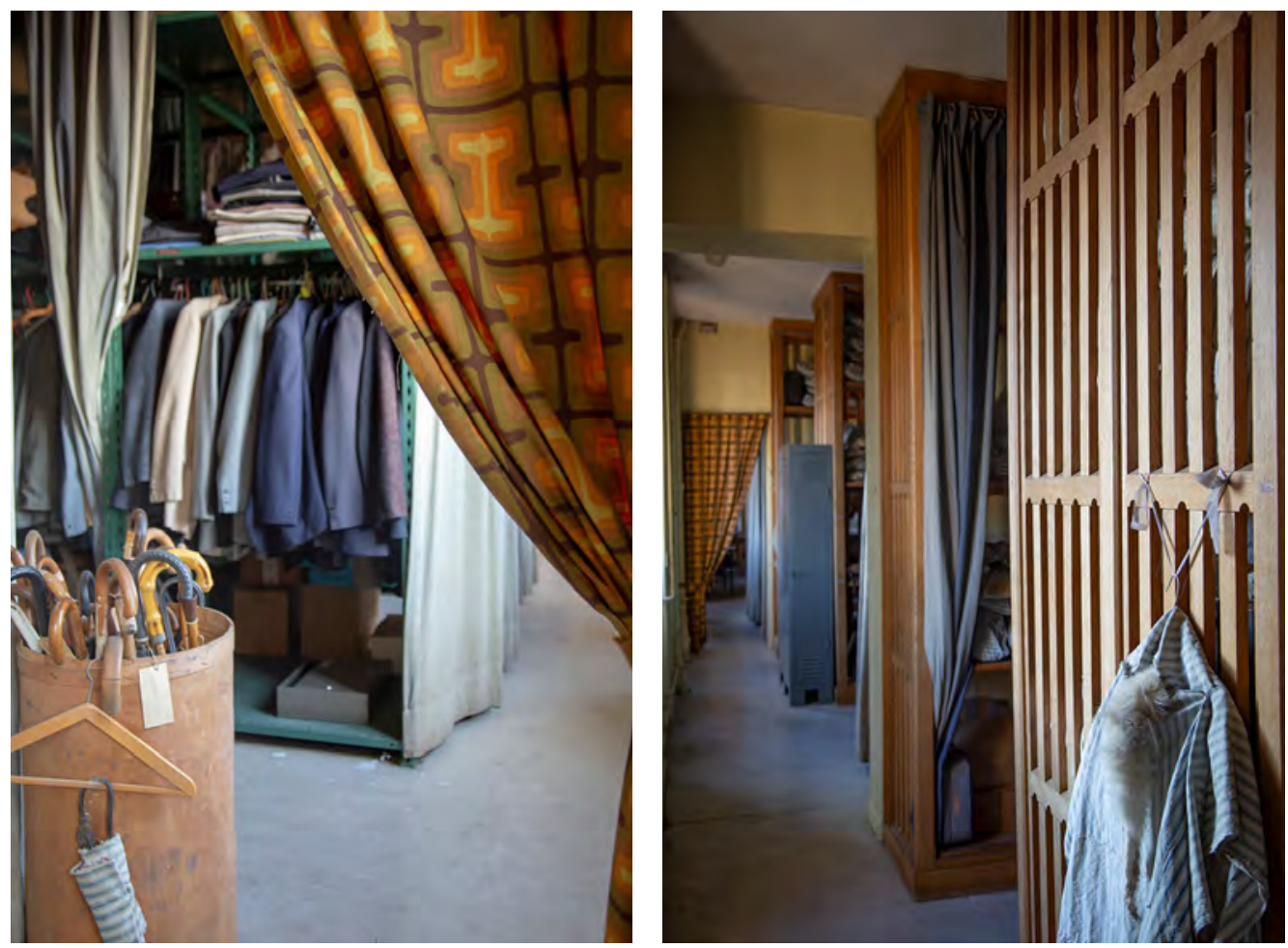
My work in the Perray-Vaucluse storeroom can be assimilated to the actions and activities of the archaeology of the contemporary past in terms not only of the methods employed but also its theoretical underpinnings and its political meaning. It was like a "dig," and the concepts of strata and palimpsest are entirely relevant. The storeroom itself has changed over time, being in continual use over almost half a century: new objects have been deposited, while others have been returned to their owners or their families, and a great deal have simply been destroyed. Many objects have circulated between the storeroom and the different services within the hospital, and with each new arrival the contents changed, provoking numerous reorganizations, allowing the older objects to be replaced with newer ones. The oldest bundles of clothes have been pushed to the back, forming a foundational stratum, which, if I were an archaeologist, I could have described, drawn, and photographed before displacing them and eventually opening them. But I am a historian, and I relied on a historian's approach to an archive in this uncanny setting, penetrating into the lives of these long-forgotten inmates, unpacking their bundles, trying to revive their memories, trying to understand the reality of their daily lives in the hospital and outside.

\section{The Material Functioning of the Storeroom: From a Collective Storage Space to Personal Cupboards}

A 1935 guide to the construction and furnishing of a mental asylum provides the following description of the ideal storeroom:

... its size will vary according to the size of the institution and the way the clothes are going to be organized. It should have a washable floor and walls and everything required for classifying and storing the personal effects. These effects should be catalogued, repaired, disinfected (when necessary), and regularly inspected. A long table is needed for handling and classifying the objects. The "inheritance cloakroom" should be installed in an adjoining room, set up in a similar manner, but equipped with all that is necessary for storing suitcases and trunks.

(Raynier/Lauzier 1935: 96) 
The Perray-Vaucluse storeroom occupied a part of the second floor in the central administration building. On the way in, there is a reception area with a long table and then a swinging door to prevent unauthorized entry. Here shelves are piled with folded material that can be used to make up the bundles. In a cupboard, there are several boxes of labels, some pre-printed, some not, to be stuck onto bundles and suitcases as well as string and pins. Through this room on the left there are eight aisles for storing clothes, objects, and suitcases. The first two aisles make up the "inheritance cloakroom" (clothes left behind by patients who have either died or left the hospital without ever collecting them): not reclaimed by the inmate's family, these belongings could be issued to any new inmates who might need them. The following aisles contain shelves for storing trunks, suitcases, and bundles belonging to those interned in the hospital. Typically, these were stocked here while the person was interned in the hospital, but items could be withdrawn during their stay as long as they had the appropriate authorization from the staff or the written permission of a psychiatrist.

Leaving the sorting room on the right-hand side, we enter the administrator's office, which contained the different registers as well as the blank forms - the key tools for managing the storeroom and ensuring its efficient functioning. These registers represent a familiar and, above all, accessible source for the historian, used to dealing with written materials of this sort. Organized by sex, and then by patient name in alphabetical order, the registers record the patient's identification number, family name and first name, as well as the dates of admission and discharge. There is a column for "observations," where we find notes concerning the patients' institutional "careers" and those of their personal effects. These administrative documents allow us to see the functioning of the storeroom more clearly, notably the way clothes were archived, catalogued, returned, destroyed, or reused. Indeed, in the "observations" section one can read the following comments: "clothing kept by the patient," "kept in the ward," "woolen jacket kept by the patient," "clothing withdrawn by the patient's daughter," "withdrawn by his wife," "clothing handed over to the husband," or "clothing brought by the family two months after internment" for a patient who apparently arrived without any clothes. ${ }^{9}$ 
In the men's registers concerning the 1960s and 1970s, we almost never see the comment "clothes kept by the patient in the ward," while it is relatively frequent for women. In women's services the diversification of clothes is more effective than in men's (Cenac-Thaly 1963: 369), which means that women were more motivated to wear their own clothes - if authorized - instead of the uniforms provided by the institution. This explains why there are fewer suitcases, bundles, and other items belonging to women than to men in the storeroom, with only two aisles dedicated to women, and five to men, notwithstanding an almost equal number of male and female patients in those years.

While each institution had its own rules concerning what personal effects inmates could keep with them, we should not forget that the circulation of objects within psychiatric hospitals was regulated by national legislation in France since I857. ${ }^{10}$ Laying down the ground rules, it constituted the dominant model for at least a century, before a wave of reform passed through the system in the second half of the 2oth century.

In 1952, the journal Esprit, characterized since those years by a strong humanism and alimenting debates concerning issues as laicity, or decolonization, published

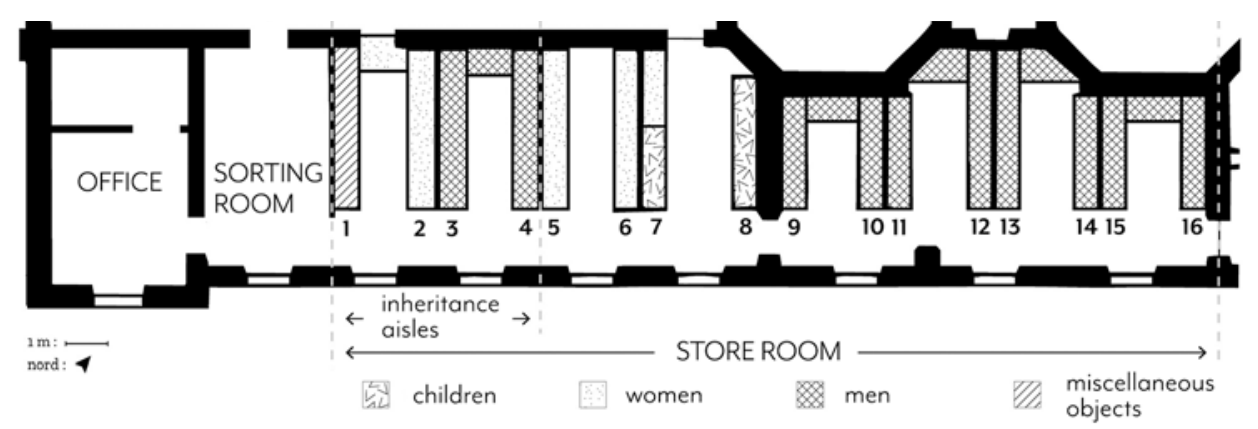

Centre Hospitalier de Perray-Vaucluse,

Bâtiment des services généraux, ze étage

VESTIAIRE DES PATIENTS 
a special issue entitled "The Misery of Psychiatry" [Misère de la psychiatrie]. There, two psychiatrists, Louis Le Guillant and Lucien Bonnafé, pointed out the material and moral catastrophe that being interned could represent for inmates, part of which involved their clothing:

... certain patients - it is true - can rip and soil their clothes. As a result, they have them all taken away upon admission, and they are all dressed in an outfit whose cut, if not dimensions and fabric as well as its worn-out state represent a terrible humiliation for the lucid patients (the vast majority of them) and in particular the women. We have often seen (and God knows how much hospital users are prepared to accept) patients' families moved to tears upon finding their wife or mother wearing a shapeless, worn-out dress, hair unkempt, no makeup, unrecognizable - humiliated! (Le Guillant/Bonnafé ı952: 859-860)

An official circular dated August 2I, 1952 on "The functioning of psychiatric hospitals" [Fonctionnement des hôpitaux psychiatriques] suggests that "for psychological reasons, it might be opportune to allow certain patients to keep their own clothes." II Thus, following the patient's desire, and his or her request to the personnel, and with the agreement of their family and doctor, internees could now be allowed to wear their own clothes "every day, or sometimes just on special occasions, like Sundays, visiting days, outings, etcetera" (ibid.). Another circular from December 5 , I958 on "Making hospitals more human" [Humanisation des hôpitaux] acknowledges that "the rule that forbids hospitalized patients from keeping any jewelry or personal effects is often applied too rigorously." The document goes on to specify that exceptions may be made, in particular for "common objects which often have no other value than that of the memories attached to them." In each establishment, "the administrative commission ... may allow patients who so wish to use their personal linen during hospitalization," and so they should provide "means of storage for patients (individual wardrobes, cupboards)." ${ }^{\text {I2 }}$

It is, therefore, noteworthy that we begin to find the phrase "clothing kept on the ward" in women's registers starting in March 1959, just a few months after the circular was issued. We do not know if this means that from that time onwards each ward was equipped with an individual storage space for each patient, or if a small storeroom or large cupboard was assigned to this function in each ward. ${ }^{13}$ Nevertheless, we have the impression that the patient starts to get closer to her or his personal effects. Isabelle von Bueltzingsloewen has written about a "con- 
quest of cupboards" as a movement that began in France in the second half of the 2oth century (Von Bueltzingsloewen 2003).

This "conquest of cupboards," however, was not a universal movement, as one young Parisian nurse complained as late as 1972. She used to organize voluntary visits to the patients of Perray-Vaucluse and designated herself as the "godmother" of Jean D., also known by the personnel and co-inmates as Jean the accordionist, a patient who had spent his whole life in institutions. In a letter to Jean's ward doctor she wrote:

I am worried about him changing wards so often. He was in the Transit Ward, then Ward I, then Ward 5. I am aware of the reputation that he has made for himself and the "indexing" of which he is the object because of his habits. Of course, I am well aware that the conditions of hospitalization in the asylum are far from those we would like to see. The promiscuity of Ward 5 where Jean has been placed along with the profound morons saddens me. Jean, who still has a lot of activities, does not even have a cupboard there. ${ }^{\mathrm{I}}$

This theme of cupboards was taken up by the psychiatrist Henri Cenac-Thaly in I963 when he presented the results of "A survey of the clothing for the insane" [Une enquête sur la vetûre des malades] in the French journal L'Information psychiatrique. ${ }^{15}$ He raised the problem of storage as one of the obstacles to clothing reform seen as an important step on the way to the personalization of the patient within the institution. The answers to the questionnaire revealed that:

... while storage has found a solution in new establishments and in renovated wards, this is not the case for the old ones, where we can observe the maintenance of asilary costums: deposit in the establishment's storeroom for the mass of personal belongings, accumulation of surplus and administrative effects in suitcases or boxes slid under the beds or quite simply left lying around. At present, the vast majority of hospitals provide patients with individual or collective cupboards, but overall, the percentage of these cupboards is still derisory. Hospitals have also developed ward cloakrooms. These are indeed just an extension of the traditional laundry deposits on the ward, but where not only a reserve of household linen, but also administrative clothes and underwear (the uniforms), Sunday clothes and personal effects are stored. The congestion of the pavilions constitutes a serious obstacle to the development of these cloakrooms. (Cenac-Thaly I963: 373) 


\section{Clothing Issues: Changing Habits in Psychiatric Hospitals}

At the beginning of the I960s, psychiatric hospitals continued to be overcrowded, and the situation of both patients and caregivers alike was often very unsatisfactory. Nevertheless, there was now a desire to reform the institution, and even people within the system started pushing in the direction of more humane treatment for the inmates. The 1958 circular on the "humanization" of hospitals (which did not just concern psychiatric hospitals) had been promulgated and several initiatives had been implemented over the preceding decade, including improvements in both the training and the general status of psychiatric nursing staff. A chance meeting between Germaine Le Guillant from the "training centers for active education" [Centres d'entraînement aux méthodes d'éducation active, CEMEA], and Georges Daumézon at the Fleury-les-Aubrais psychiatric hospital was at the origin of the conception of renewed training courses for psychiatric nurses (Le Guillant 200I). ${ }^{16}$ These courses and traineeships covered different topics: life in the asylum, equipment, relationships with "patients," "users" [usagers] of mental health services. ${ }^{17}$ It is within the framework of this collaboration, "preparing, on behalf of the CEMEA, a conference for the nurses of the psychiatric hospitals of the Seine region on the subject of patients' clothing," that psychiatrist Cenac-Thaly investigated the clothing practices of the patients in psychiatric hospitals across France.

Until then, this subject had not attracted much attention. The investigations of the asylum inspector Julien Raynier had touched on it in the I930s, and so the issue was raised in his reference work L'assistance psychiatrique française. Here, Raynier noted that there was

a diversity of situations as much with respect to their cleanliness as with respect to their general appearance: ... the change of clothes with the approach of winter comes too late, the summer clothes are insufficient, the clothes are ripped, the mending comes undone, they are not clean; even in the wards where patients are relatively careful, the newest clothes are given to patients unable to appreciate this benefit; the use of clogs in the disruptive areas; the absence of socks and straw hats, so absolutely necessary in summer for agricultural work etcetera.... The absence of annexes for the care of clothes and shoes, the insufficient inspection of the contents of the pockets (for knives or other prohibited objects). (Raynier/Beaudoin I950: I4I) 
Thanks to the questionnaires returned to Cenac-Thaly by many of the French psychiatric institutions at the beginning of the $1960 s,{ }^{18}$ he was able to investigate the issue quite systematically. By publishing the results, he wanted "to raise awareness concerning a situation whose misery we are accustomed to ignore" and he did not hesitate to advocate solutions aimed at giving greater freedom to the patients - a trend that was in the air at the time ${ }^{19}$ but which had not yet been addressed through the prism of clothing and personal effects. The importance of these items could now be seen in the context of an institution that, despite its increasingly open door, its outpatient facilities, its occupational therapy, and family visits, remained a total institution.

Cenac-Thaly noted a wide disparity between the different institutions in terms of both the reforms being proposed and those already put into effect, although he found the landscape encouraging, informed by a desire to reform the clothing situation, implying a restructuring of the traditional organization of the psychiatric hospital. Cenac-Thaly's report lists the obstacles confronting the implementation of a new clothing policy and in particular its management by the psychiatric establishments. Routine at all levels, with forms of "collusion from the chronically ill and some highly 'institutionalized' ${ }^{20}$ nurses" is indicated as the first obstacle facing any change in habits. Second, there is the financial argument, although it turns out that the expense incurred by the individualization of clothing would probably be no higher than that of the acquisition of traditional uniforms. Third, the availability of abundant stocks of uniforms and fabric for making more uniforms, the "resorption of which will take many years," also stood in the way of change. In addition, psychiatric hospitals were "bereft of the means for maintenance and storage" (Cenac-Thaly 1963: 368-369). Modernizing the laundry facilities and improving maintenance and storage represented further demands on the already limited resources.

Despite these difficulties, and although he had to admit that the situation varied a great deal from one establishment to another, Cenac-Thaly could still write in 1963 that "an evolution is a certitude, and the traditional uniform is condemned to disappear everywhere, although the renewal of clothing can only be carried out in annual instalments. ... Very few establishments have replaced their traditional uniforms, but the percentage varies greatly depending on the stage attained by the hospital" (ibid.: 369).

Cenac-Thaly describes those who continue to wear the administratively supplied clothing (the traditional uniform of the asylum) in the I960s as being "low-level patients," adding that patients who have been interned for a long time also tend to wear the uniform. The men were much more likely to wear the uniform than the 
women, for whom improvements in clothing seemed to have generally reached a more advanced stage. In an increasing number of French psychiatric hospitals at the time of this inquiry, uniforms were disappearing and dresses of various colors, materials, and cuts were beginning to be introduced. In some women's services, workshops were set up both to produce clothes and to provide a therapeutic activity for the inmates. Thus, at the Pierrefeu mental hospital in Southern France, a director collaborated with a nurse to set up such a workshop in October 1953. They claimed that

while proposing a - partial - solution to the clothing problem, this type of therapeutic activity valorizes the person. This work gives people the possibility of creating something original and allows each person to own their own clothes that are the right size, selected and fabricated by the workshop. Finally, by dressing the other inmates, the patient's activity becomes a vehicle for communication and normal human contact. (Zaborowski i956: 9)

The results of the survey published in L'Information psychiatrique suggest several trends: in $45 \%$ of the establishments, personal clothing is worn only by paying patients and by outpatients. However, exceptions were made to this rule: "patients placed in a locked service under a shared regime may keep their personal clothing if their stay is short or on medical advice. They can also, especially the workers, wear their own clothes on Sundays and on outings." In $35 \%$ of psychiatric hospitals, "personal clothing is left available to entrants, whatever their method of placement," ${ }^{21}$ provided that the patients express a desire for it and that the items are in good condition. In the remaining $20 \%$ of establishments, "the goal is the generalization of personal clothing for all lucid patients, and this goal has sometimes already been achieved" (Cenac-Thaly 1963: 37I). This was the case, for example, at the Lannemezan hospital in the Hauts Pyrenées department, where uniform-style clothes had been phased out in the I950s and were replaced by "fashionable dresses and coats for the women and city suits and overcoats for the men." Here the staff had the "very agreeable surprise of seeing that the inmates dressed very tastefully and took better care of their wardrobe" (Ueberschlag 1956: I5).

We do not know to which of these three groups, empirically determined by Cenac-Thaly based on his survey, we should assign at Perray-Vaucluse asylum since we do not have any precise "photograph" (in the metaphorical sense) of its functioning at that time. Nonetheless, Cenac-Thaly argues that the mental hospitals of 
the Paris region were the stronghold of traditional positions concerning clothing in asylums, with the universal use of uniforms and $\operatorname{clog} s^{22}$, limited circulation and recycling of personal clothing, difficulties with respect to repairs and storage, limited availability of cupboards on the wards, etc.

In Perray-Vaucluse's abandoned storeroom, one can detect evidence of the changing clothing practices both in the registers and in the physical objects themselves, particularly the differences between men and women concerning the use of their own clothes, and the provision of civilian clothing to inmates, probably recovered from former internees. Thanks to these elements - the objects (clothing and other personal effects), the registers and administrative papers, as well as the space of the storeroom itself - we can witness the trends in psychiatric hospitals of the second half of the 2oth century. Following the massive starvation of inmates interned in psychiatric hospitals [hécatombe des fous] that took place in France during World War II (Von Bueltzingsloewen 2007), reformers advocated the humanization of the hospital, covering not only its physical spaces and functioning, but also the relationships between the care-givers and the inmates. Progressive psychiatrists wanted to put the patient at the center of therapeutic practice, reintegrating the subject with his past, his emotions, his attachments, and his roots. People construct their personalities at liberty in the world, weaving together a network of attachments and relationships, before the turmoil that leads them to being interned, and which abruptly deprives them of many of the elements that had constituted their "normal" life.

\section{The Patients' Lives Seen through Their Material Belongings and Their Personal Productions}

One question I asked myself at the outset of this research was, what was locked up in these suitcases? The person's life before internment in the hospital or the life during internment, or both? What do these objects allow us to see? What portion of the inmates' lives can we have access to when we open and look inside their suitcases?

In many cases, there is no doubt that what is contained in the bundle or suitcase relates exclusively to their life before, or even their life on the very day when the future patients were compelled to exchange the clothes they were wearing for the outfits provided by the institution. Indeed, many bundles contain only the clothes the subject was wearing when interned, sometimes including a pair of shoes. Albert B., 
a 34-year-old patient, was admitted on June 30, 1960, and the next day a pair of his underwear was deposited in the storeroom. His underwear was wrapped up in fabric, and the tiny bundle was labelled and placed on the shelves with the others.

But these traces of life prior to internment can also amount to much more: in some suitcases we found photo albums, plate services, toiletries, camping equipment, even war campaign materials. But we need to bear in mind that once their personal belongings had been deposited in the storeroom, the patients no longer had access to them, and so could no longer make any use of them, irrespective of the use they might have had in the past.

This seems to have been the case for the belongings of a French soldier engaged in the First Indochina War and sent back to the fatherland in 1952 for mental troubles. As his clinical notes disclose, "Yvan P. suffers from a schizophrenic syndrome which first revealed itself in Indochina, through bizarre behavior and atypical depressive manifestations. Treated for a confused agitated state using electroshock therapy at the Choquan Psychiatric Center (Vietnam) and aboard the ship Oregon. Currently inactive, indifferent, remains lying down for the entire day, at times performs stereotypical gestures for hours ..., sometimes incoherent." ${ }^{23}$ The list of his personal belongings had been drawn up upon his arrival at the Sainte-Anne Clinic in Paris just before his transfer to Perray-Vaucluse, ${ }^{24}$ and the "small Prussian bleu cardboard suitcase" found in the storeroom contained everything on this initial list.

two books (a French course and an air force instruction booklet), several notebooks, a bowl containing a piece of soap, two penknives, an electric torch, a bottle of perfume, a cigarette lighter, three used tubes of beauty products, a box of soap, a sponge, a comb, four toothbrushes, two pencils, two shaving brushes, a mechanical razor with its case, an identity card, a membership card for the Touring Club de France, four electric batteries, a small diary, five brushes, a spoon, a small nylon bag, papers and photographs of no particular value. ${ }^{25}$

Those contents have not moved from the storeroom since they were first consigned there in January 1952, which means that some patients' belongings could have only a static existence, as they were left in suitcases and boxes unopened since being deposited. 

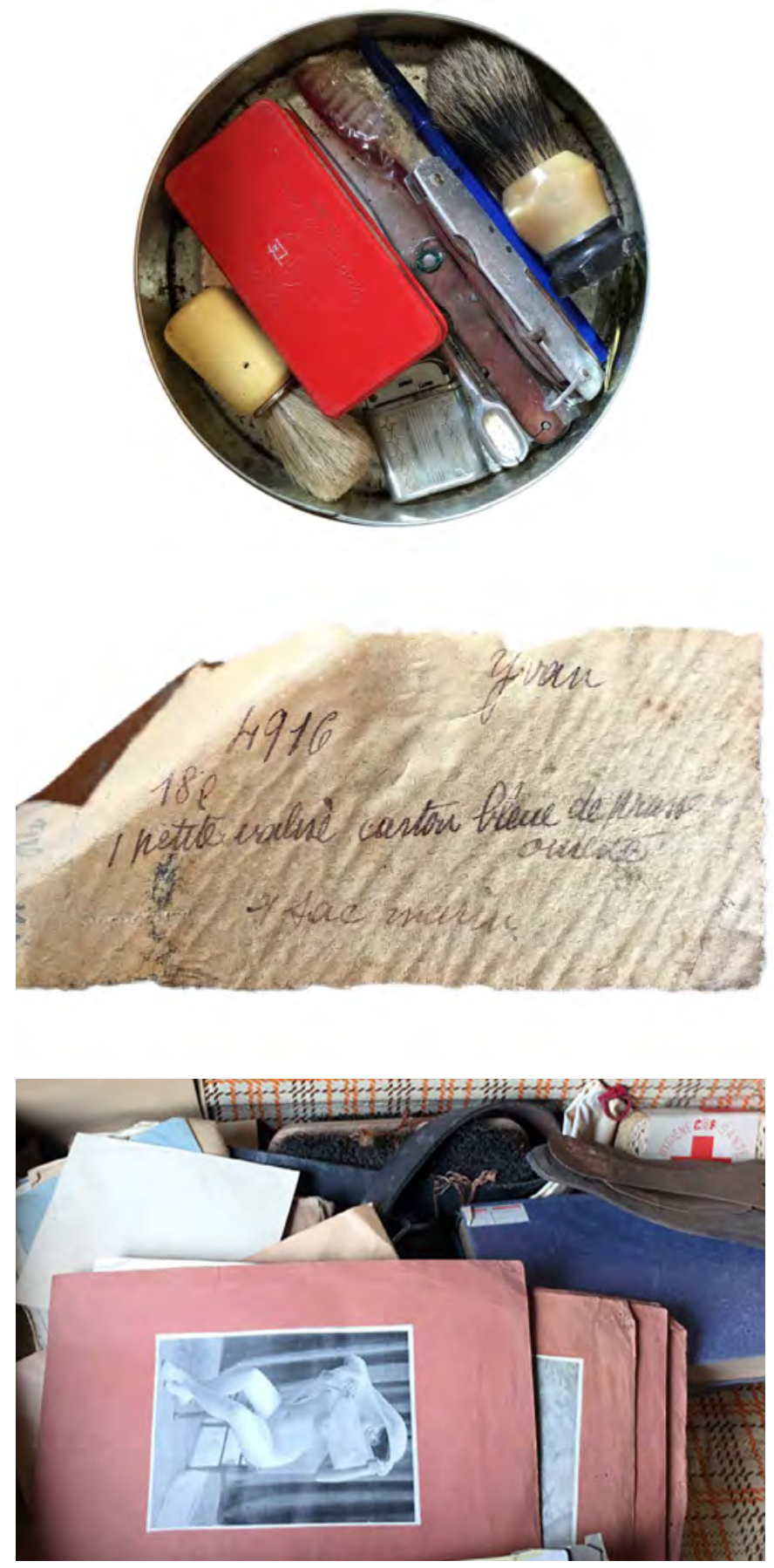
Daniel D. was admitted to Perray-Vaucluse in the mid-I970s, when he deposited a packet containing three penknives, a large knife, a sharpening steel, a fork with two tines, a zester, a sharpener, and an apron. Before being hospitalized and even between his numerous episodes of internment, he had done the washing up in collective kitchens for the SNCF (Société nationale des chemins de fer français) and for a caterer in Garenne-Colombes. One of his release certificates describes him as a "psychopath, hospitalized for alcoholism associated with chronic depression and lack of social insertion." He had also made "numerous suicide attempts by slitting his wrists, following the death of his wife in 1968 and right up until I979." ${ }^{26}$ It was during one of these suicidal phases that he composed the poem quoted earlier in this chapter. In the hospital setting "stopping and abstinence do not pose any real problem, but he relapses once outside:" he did not present "any major problem in terms of transgression apart from his drunken escapades." Following one of these, Doctor M. ordered that he be kept in the ward "in his pyjamas for a week" - the outfit being clearly part of the punishment - and wrote that he refused him "permission to go outside or any authorization to go into the park." As part of his hospitalization, Daniel regularly saw a psychologist, and together they tried to construct professional projects for his reinsertion into the community - what would now be termed recovery - starting with looking for work as a dishwasher. Daniel regularly gave the psychologist samples of his "writing, recipes and stories of everyday life on the ward in the form of a typewritten diary." Unfortunately, this last item was found neither in his suitcase nor in the patient records.

Many of the objects in the storeroom appear to have been used or even produced while the patient was interned in the hospital. Several inmates kept diaries, wrote letters, sketched, and had themselves photographed when relatives came to visit. But one needs to be cautious about assigning these objects to the time spent in Perray-Vaucluse, as they could just as well have come from earlier episodes in other psychiatric hospitals. Nevertheless, these items might well represent a material echo of the patient's "moral career" within the institutional system (Goffman I96I: I30). ${ }^{27}$ These objects sit silently in the storeroom, marking time while the patients' records fill up with outings, escape attempts, releases (provisional or otherwise), treatments, and new internments. 


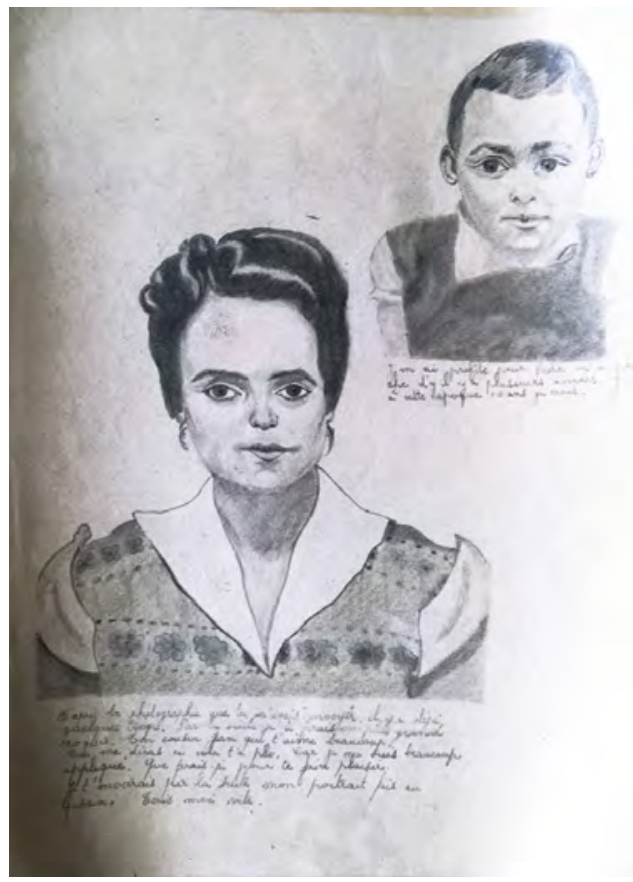

In Damien J.'s folder, we find a collection of postcards immortalizing famous actors from the fifties, a small book of popular jokes, and a collection of postcards with proverbs and images that his girlfriend sent him from another mental hospital, telling him how she hopes to have him back in her arms again soon. There is a box of pencils and charcoals for drawing: Damien copied photographs of famous actors and drew portraits of some of his relatives. There is a portrait of a woman, above which he has written "based on the photograph you sent me some time ago. I will next do a larger sketch. You should tell me if you like it, because I put in a lot of effort. What wouldn't I do to please you? I will send you my portrait in charcoal next. Your cousin Damien who loves you so much." ${ }^{28} \mathrm{He}$ also transcribed the texts of some famous songs of his time in a notebook: Yves Montand's "Ma douce vallée" (1948), George Brassens's "La mauvaise réputation" (1952), "El negro zumbon" from the French version of the movie soundtrack of Anna, an Italian film released in 1952, and many others. We can see how Damien maintains his attachment to the outside world through cultural objects, reproducing images and words, thereby allowing this popular culture composed of music, films, and jokes to resonate with his inner world. 

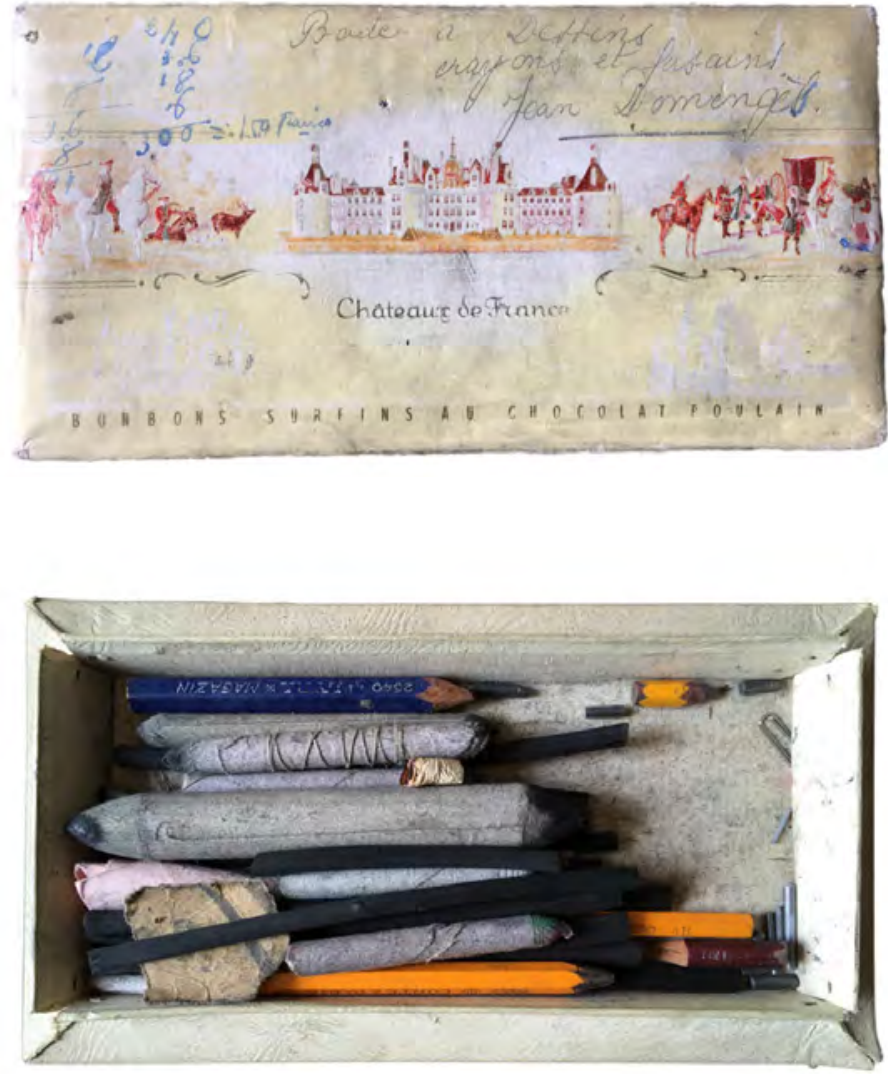
Jean the accordionist - whose "godmother" deplored the absence of a personal cupboard despite his multiple activities at the beginning of the 1970s - spent his whole life in institutions. His clinical file is very thick and his wooden box and suitcase left in the storeroom contain notebooks and diaries, as well as nets, pencils, photos, and clothes that he appears to have mended himself.

Born in 1924, he was interned at the age of $\mathrm{I} 6$ at his father's request. After one year in Perray-Vaucluse, he was transferred to the Châlons sur Marne asylum in I94I, and ten years later was hospitalized for less than two months (from February 7 to March 3I, 1952) at Sainte-Anne Hospital in Paris. On December 19, 195I, he wrote in his notebook: "Mr. Doctor talks to me about having surgery in Paris. Why?"29

On January 8, 1952, "the chief doctor told me again about the operation for the skull," and four days later, "the doctor told me that he had organized something for the operation." On February 7, Jean travelled by train to Sainte-Anne accompanied by two nurses from the Châlons asylum. In his notebook he wrote: "I looked at each station, but I saw no one from my family. ... Arrived at Sainte-Anne after the midday meal. Here I arrive at the men's admission room, after having been deprived of my wooden box and all my stuff." Thus, it appears to have been customary to deprive the patient of his personal effects at each new hospitalization, and Jean seems to be familiar with this practice which accompanies and reinforces the depersonalization or mortification of the self, as described by Goffman, among others. On February 28, 1952, Jean's notebook reads: "Today is a decisive day: lobotomy." According to notes in his clinical file, "after the operation he seemed to behave more calmly, which led to a transfer to Ainay-le-Château" in family care facilities. The certificate filled out by the doctor after his two first weeks in Ainay describes Jean as follows: "a handyman, he adapts well to foster care. Keep it up." ${ }^{30}$ However, his stay in the colony of Ainay-le-Château lasted for only a short time: "After two months of foster care, with very satisfactory behavior, he had a pyromaniac impulse, causing great damage. ... To be definitively reintegrated into a locked service where he will have to be subject to very strict supervision." He returned to Perray-Vaucluse and his notebooks, well-ordered and limited to the essential elements of his life - each month taking up no more than the front and back of a page - offer us traces of Jean's everyday routine. On April 2o, for example, he received a "visit from Mom and Dad bringing me a diatonic accordion; they took my harmonica for repair." ${ }^{31}$ Later, he would exchange the harmonica for a watch with another hospital inmate, in a form of barter that was common among the internees - money being just one among several forms of remuneration for services rendered to ensure the proper functioning 

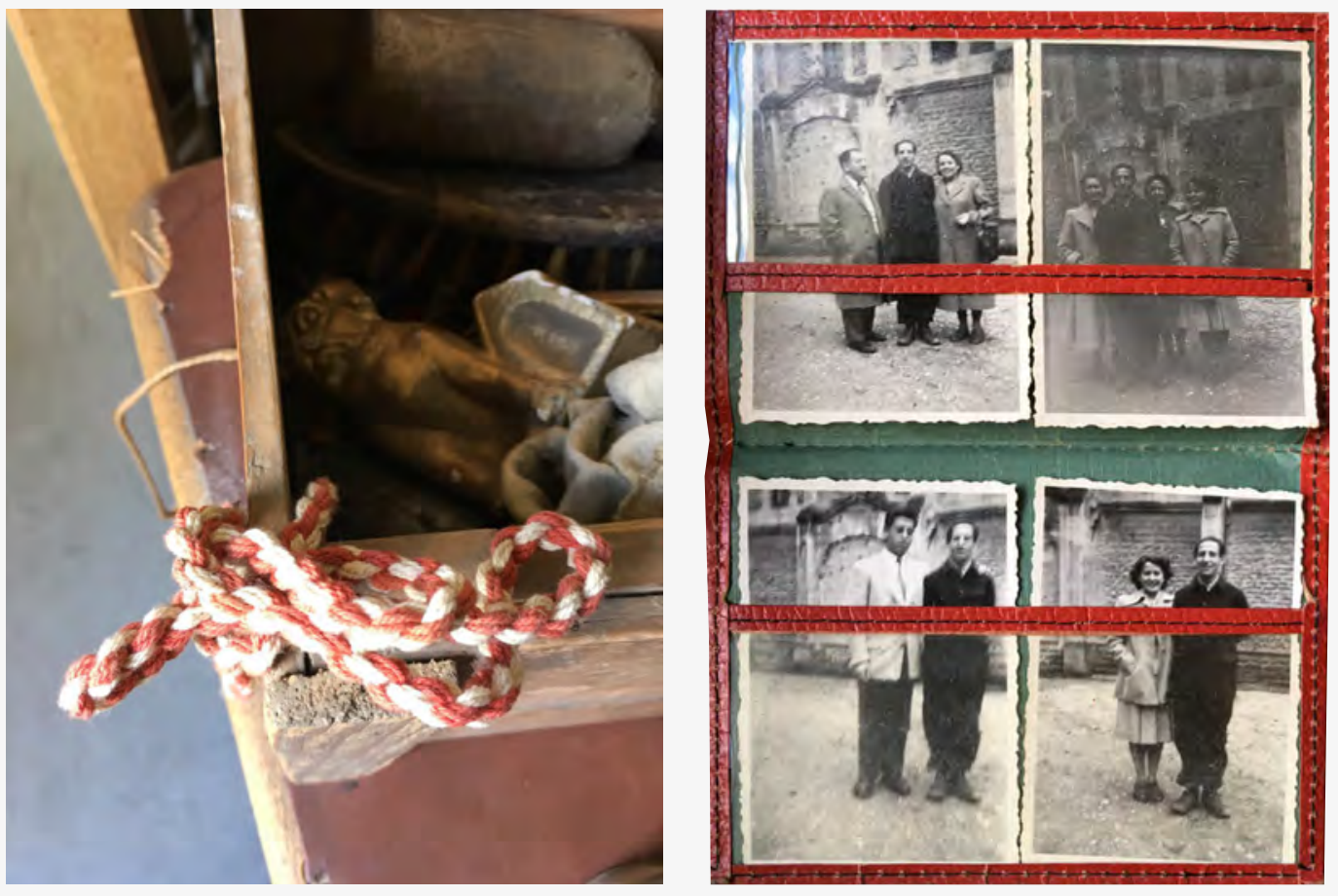

Fig. 6: Nets and other objects, photographs, and a page of the diary found in Jean D.'s box in the PV storeroom 


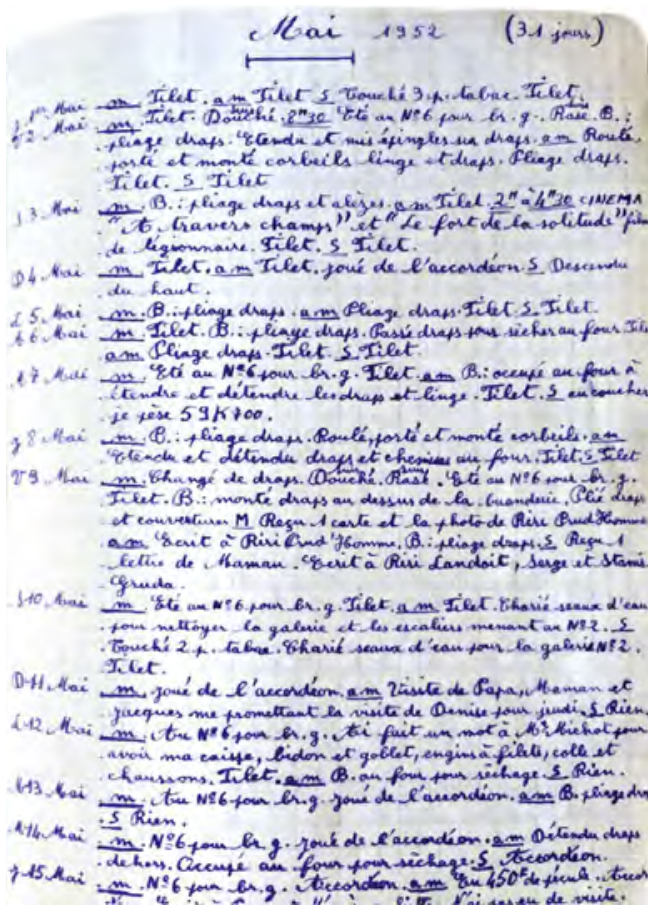

of the hospital system. Jean became inseparable from his accordion: often playing it in the evening, he also played it for the workers doing building on the hospital site, and he played and sang popular tunes of his time as part of theater workshops organized once a month on Ward I. He listened to the radio from time to time as well as playing Monopoly with other inmates, and sometimes played football..$^{32}$

Furthermore, Jean made nets that he would give away or sell, and he mended things around the hospital, helping out where his skills might be needed (on April I5, he "went to the tennis court to fix the net that is irreparable"). When the partner of a fellow inmate brought him "a IOo-gram ball of twisted cotton," Jean offered her a net in return. Remnants of his nets still remain in his wooden box left in the storeroom, and most of the clothes still in his suitcase were darned by himself, some even sporting his family name, which he embroidered on them himself. 
Reading through his diary, we learn that in mid-September Jean was provided with winter clothes and then in mid-June he received summer clothes. From time to time, he received a pair of shoes, or a woolen sweater. Thus, every six months the inmates changed their clothes, and some marginal adjustments or additions could be made. Jean could buy some things from the outside using either the money his parents had sent him or his payments from shaving the other internees or cutting their hair, as we can see in his notes in another diary entitled "little jobs." He browsed through the catalogue of the mail order company Manufrance, and once ordered "a book on making nets, some hemp, and a nail clipper." He also wrote to Paul Beuscher, a musical instrument and music publishing company based in Paris. In return they sent him their brochure, and he bought "a piccolo, a flute, and an album of musical instruments."

On October I4, I953, Jean left the Perray-Vaucluse hospital once again to go to the family care facility of Ainay-le-Château. The day before, "a nurse goes to the storeroom to get the clothes for the transfer. It seems that I am [scheduled] for this one." The patients had been informed a few weeks before of their upcoming departure, but apparently without all the details. Jean meticulously noted down each step in the journey: " 6 a.m.: dressed, I find all my belongings except the watch; 6:30 a.m.: departure by bus; 7:I5 a.m.: arrival at Austerlitz station; 7:30 a.m.: board the train; 8:50 a.m.: train departure; I0:05 a.m.: stop at Les Aubrais Orléans; II:00 a.m.: stop at Vierzon; II:45 a.m.: stop at St. Florent; I2:30 p.m.: we get off at St. Amand Monroud station, two minutes later we get on the coach. I p.m.: arrival at the colony." Likewise he noted down all the elements of the first day at the foster care institution: "6:30 a.m. wake up (not forced); 7:20 a.m.: weighed and measured; try on two new summer outfits as well as new shoes and clogs." His notebooks, a linear and ordered collection of his notes on daily life as an internee, stop two weeks after his arrival in Ainay.

Ten years later, Jean was back in Perray-Vaucluse, and on May 9, 1964, a doctor wrote in his file: "brought back to Perray-Vaucluse ten years ago, there were no more character and behavioral disorders, no more impulses; adapting properly to the atmosphere, doing all kinds of ingenious work, working as a typographer in the hospital printing room, as an organist in the chapel, weaving nets in his spare time, and selling them at a good price, selling a very large number of tickets for the fairs organized at the hospital and in no way behaving as a subject deprived of his senses, as a subject damaged by lobotomy, or as a subject dissociated by a psychotic process." 33

Twenty years later, in I984, his status report reads as follows: "against this background of imbalance and mental debility, Jean's mental state has stabilized rela- 
tively well. His adaptation to the hospital environment is now quite chronic and it is difficult in this context to consider a placement in a different structure." Having passed through the gates into Perray-Vaucluse for the first time in 1940, and after multiple peregrinations in and out of other institutions for the mentally ill, Jean was finally sent to a retirement home in Marly-la-Ville in 1994.

Some of Jean's belongings remained at Perray-Vaucluse: but we can easily see that the contents of one wooden box and a suitcase are little more than a drop in the ocean of his whole life, even if most of it was spent in a total institution. His life was therefore undoubtedly structured by institutional routine, but he also had many other activities, as not only the precious ego-document that his diary represents attests, but also the notes from his doctor and his "godmother." Those activities passed through a materiality which is tangible for us - in the nets found in its wooden box, as well as in the clothes that he darned himself, folded in his suitcase - or just imaginable: Jean playing his accordion on multiple occasions, writing in his diary in bed in the evening, Jean going through the different services with scissors and razor to shave his fellow inmates, browsing the catalogues of some mail order companies to buy objects which might enrich his daily life. The aforementioned are just some of the objects used by Jean to shape his own position in the institution, to inhabit some windows towards "normal life" inside a space thought to be totalitarian. Through those activities and practices, Jean's way of appropriating the space could express itself in a life which escaped the leveling and uniformity that we use to attribute to life in hospital. We must not forget that a life is made up of encounters with both individual subjects - the staff of the institutions as well as fellow inmates - and non-human actors (Latour 2005): inanimate objects capable of interacting while acting on the environment. As Bruno Latour explains, "to be accounted for, objects have to enter into accounts. If no trace is produced, they offer no information to the observer and will have no visible effect on other agents. They remain silent and are no longer actors: they remain, literally, unaccountable" (Latour 2005: 79). The silence of the objects and their unaccountability is something which risks being disconcerting for the historian who finds herself surrounded by those very objects in the suspended space of an abandoned storeroom. But excavating in these places where such objects were once deposited and perhaps have not moved since, forming layers and variably moving strata, the historian feels their anchored materiality, allowing her to retrieve fragments of forgotten lives.

At the end of the last century, this hospital-wide service - once central to the functioning of an institution whose main features were its autarchy and isolation 
- began to operate at an ever diminishing level, until its definitive closure in 2000. At this time, patients could keep their belongings - the ones that were authorized - with them, in modernized wards where every inmate had his own cupboard. The tradition of wearing uniforms, which had applied to both the patients and the staff, was now outdated, and the chronic long-term patients were increasingly being sent out to external ad hoc structures.

A suspended space for the historian who enters it, the storeroom was a liminal space for the inmates, a threshold that they would cross in their admission to the hospital. The passage through this storeroom marked a symbolic separation from what linked these patients to the outside world, to their former "normal" lives. The objects that it still contains today shed light both on the former life of the patient - as tangible traces of a past that was often quite literally abandoned, and largely inaccessible for the time it was locked up in the storeroom - and on the patient's life inside the walls of the mental institution - as non-human actors that animated the patient's routine and everyday practices in all their diversity. 


\section{Notes}

1

Opened in 1869 on the territory of Sainte Geneviève des Bois, in the outskirts of Paris, and equipped with 600 beds, Perray-Vaucluse is the third asylum of the Seine department after Sainte-Anne (founded in 1867) and Ville-Évrard (1868). In 1876 it was equipped with a colony for young mentally ill boys aged eight to 15 . In 2004 the hospital beds were relocated to the 13th arrondissement of Paris, in a facility called Henri Ey hospital. Until 2016, Perray-Vaucluse hospital was in charge of people living in the seventh, eighth, and 17th arrondissements of Paris. It was closed in 2016. Since then, with the Groupement Hospitalier Universitaire Paris Psychiatrie \& Neuroscience (the fusion of the Sainte Anne, Maison Blanche, and Perray-Valucluse mental hospitals), the structures of Maison Blanche and Perray-Vaucluse have now been disused, with their former patients and staff now attached to Sainte Anne, which leads the GHU.

\section{2}

This concept was popularized by the sociologist Erving Goffman in his 1957 paper "On the Characteristics of Total Institutions," then republished in the now classic Asylums (1961). Goffman identifies four features that are common to "total institutions": 1) They remove the barriers that typically separate key spheres of life: home, leisure, work. 2) They imply a "mortification process": inmates' personal characteristics (inner or linked to exterior appearance) are levelled, their autonomy is withdrawn, and their communication with the outside world is limited or prohibited. 3) They function thanks to a privilege system: "a set of prescriptions and proscriptions lay out the main requirements of inmate conduct" (ibid.: 48), combined with rewards and punishments. 4) Inmates set up different forms of adaptation to the life within a total institution, which can also be opportunistically combined: "secondary adjustments, conversion, colonization, and loyalty to the inmate group" (ibid.: 64).

\section{3}

However, I cannot rule out the possibility that another storeroom existed before.

\section{4}

I was able to visit the cloakroom with Marcelle Fillod, the last person who worked there.

\section{5}

Issues of clothing are dealt with in: Hamlet/ Hoskins (2013); Wynter (2010); Baur/Melling (2014); Bazar (2013); Labrum (2011).

\section{6}

"Je sais que je suis un malade / Mais un malade mental / Car je suis obsédé par le suicide / qui ne cesse de me suivre. J'ai fait pas mal d'hôpitaux / en trainant avec moi mon fardeau / Etj'ai passé de docteur / en docteur, Rien ne peut guérir mon pauvre corps / Seul peut-y parvenir la mort / Mais avant d'y parvenir que de malheur / A dû subir mon pauvre cœur. Je suis peut-être pour les psychiatres / Un paranoïaque / Car je suis toujours persécuté / Par une éternelle vérité. Au monde quel mal ai-je fait / Pour être à ce point malfamé / Je suis d'une extrême douceur / Eł l'on veut m'arracher le cœur. Je ne suis de personne respecté / Puisque le monde n'est fait que de méchanceté / Mieux vaut l'oublier / Et à jamais le quitter." The original French version of the poem is in Daniel D.'s personal file, n. 241980, archives of the Groupement public de santé (GPS) de Perray-Vaucluse (henceforth "archives PV"). All the French texts cited in this chapter have been translated by Jonathan Simon.

\section{7}

A historian and an ethnologist contributed to the reconstruction of patients' trajectories and to the reflection on the nature of objects. Patients and staff of the facility also contributed with oral testimonies. 


\section{8}

See for instance: Harrison/Schofield (2010); Buchli/ Lucas (2011); González Ruibal (2018). For a concise and complete summary of the theoretical issues of this field, see González Ruibal (2014). González Ruibal writes that "everyday life is the main concern" of the archaeology of the contemporary past and "it allows us to go deeper and in more detail into other people's lives" (2014: 1685). If the researcher is confronted with the ethical dilemma of the legitimacy of breaking into other people's lives, Buchli/Lucas suggest that "the archaeological method takes us further away, distances us from any attachment to the objects and the material world we encounter. In the same move it makes those objects of archaeological inquiry palatable and sanitized by its distancing effects, enabling us adequately to cope with any distress we might feel in the situation - the distress of invading someone's privacy for example" (2011: 10).

\section{9}

Indeed, many patients arrived from the Saint Anne asylum where they were dispatched "without clothes" [sv: sans vestiaire]. Storeroom registers (six for men and six for women), "before 1959," “1959-1963," “1964-1967,, “1968-1973," "1974-1980," "since 1980," archives PV.

\section{0}

The "Model for Regulations covering Asylums for the Insane" [Modèle de règlement intérieur des asiles d'aliénés], issued in 1857 by the Ministry of the Interior pursuant to the 1838 lunatic asylums act, stated that "the introduction of any edible goods, spirits, sharp instruments, books, newspapers and objects liable to be used in a dangerous or harmful manner into an establishment for insane persons is strictly prohibited, except in cases where the director deems it necessary to authorize it." Modèle de règlement intérieur des asiles d'aliénés du 20 mars 1857, article 181.

\section{1}

Circulaire n. 148, August 21, 1952, Fonctionnement des hôpitaux psychiatriques (Ministère de la Santé
Publique et de la Population, Direction de l'Hygiène sociale, $2^{\text {ème }}$ bureau, DHS 3652/2), https://www.ascodocpsy.org/wp-content/ uploads/textes_officiels/Circulaire_2laout1952_ chapitrel.pdf

\section{2}

Circulaire du 5 décembre 1958 relative à I'humanisation des hôpitaux, Journal Officiel, December 12, 1958, pp. 11184-85, https://www.legifrance.gouv.fr/jo_pdf.do?id=JORFTEXT000000327717\&pageCourante=11185

\section{3}

In his 1935 manual, written some 30 years before these developments, the asylum inspector gave some indications concerning cupboards: "... it would be useful to provide some shelves and clothes rails on which the inmates could store their effects and personal items, although care should be taken to use or provide only designs appropriate for ensuring 'security' and allowing quasi-immediate inspection. There should be no cupboards in the wards or in the patients' rooms, unless it is that rare model of cupboard inserted into the wall that opens on one side in the patient's room and on the other side in the main corridor. Such a setup, coupled with efficient, appropriate locks installed on the interior, permits simple and discrete inspection and the thorough searching of clothes on the special wards. Otherwise, there are mobile wardrobes on wheels that can be pulled along the landing after the patients have gone to bed" (Raynier/Lauzier 1935: 48).

14

This letter was found in Jean D.'s personal file, n. 389883, archives PV.

15

Founded in 1945, and known for its progressive orientation, this journal was a forum for the discussion, development and dissemination of the ideas and practices behind the "sectorization" movement in French psychiatry. 
16

Created to train managers of summer camps, since the 1950s the CEMEA have been committed to the training of psychiatric nurses as a result of this meeting. Germaine Le Henaff (married in 1952 to the psychiatrist Louis Le Guillant) was the former director of a children's home in Villeneuve-St-Denis in the outskirts of Paris, that had taken in Jewish children during the war. She advocated and worked for popular education in the CEMEA, and in the 1950s she became responsible for the organization. Georges Daumézon, director of the Fleury-les-Aubrais psychiatric hospital from 1938 to 1951, and then responsible of the admission service at the Sainte-Anne psychiatric hospital (1952-1967) and the Henri Rousselle facility (1967-1979), is the psychiatrist who introduced the expression "psychothérapie institutionnelle" to identify the new course French psychiatry had taken after World War II (Daumézon/Koechlin 1952).

For more on this movement, see note 19.

\section{7}

They had a regular monthly publication titled Vie sociale et traitements.

\section{8}

65 establishments out of 92 replied.

\section{9}

After World War Il and the death of 45,000 psychiatric patients in French mental hospitals (cf. Von Bueltzingsloewen 2007), some French psychiatrists, most of whom had joined the Resistance, engaged themselves in the désalienation of both the asylum (whose name had changed to "psychiatric hospital" in the interwar reformist period, when the Popular Front was in government) and the psychiatric profession as a means to put the patient at the center of a curative psychiatric practice. This led to the establishing of a series of practical measures as well as a theoretical rethinking of the place of the institution and the role of its inhabitants. The asylum had to become a place of care, and for that reason it had to be cared for. Its internal dynamics had to take on new forms thanks to the fight against the overvaluation of hierarchy, the function of the therapeutic club, the introduction of sociotherapy and psychoanalytic transfer, the rethinking of the uniform, and the rhythms of life. Both caregivers (doctors, nurses, and new emerging figures in the progressive complexification of the mental health system) and patients had to engage in a common radical questioning of ancient practices, without excluding the institution from the picture (as some anti-psychiatrists claimed in the English and Italian contexts since the late 1950s), but investing in it to shape a new psychiatry capable of making the patients feel at the center of any psychiatric praxis (therapeutic but also decisional, personal, and personalized, but also collective) and the ability to be individuals in their own right in a context which wanted to be closer to the outside society. To further develop this point, see among others: Oury (1976); Coffin (2005); Henckes (2007); Veit (2016).

\section{0}

In French, "Asilisé," suggesting a long career history in one particular psychiatric hospital.

\section{1}

The 1838 law on asylums put in place two modes of internment: placement volontaire, following a request from the entourage or the family, and placement d'office, requested by a medical doctor or by the prefect of a department. "Loi sur les aliénés du 30 juin 1838” (1839). In: Collection complète des lois, décrets, ordonnances, règlements, et avis du Conseil d'État, edited by J.B. Duvergier, vol. 38, Paris, A. Guyot et Scribe, pp. 490-521, https://www.ascodocpsy.org/wp-content/uploads/ textes_officiels/Loi_30juin1838.pdf

\section{2}

"The uniforms are disappearing a little everywhere except in the department of the Seine. Yet even this bastion has been challenged by the changes made to summer clothing ... that most of the sick people continue to wear in the winter" (CenacThaly 1963: 368). 
23

Yvan P.'s personal file, n. 316448, archives PV.

24

The admission facility at the Sainte-Anne hospital served as a triage service to dispatch the patients in the different mental hospitals of the Seine department, including Perray-Vaucluse hospital.

25

"List of Yvan P.'s belongings," found inside his suitcase, storeroom PV. The same document appears in Yvan P.'s personal file, n. 316448, archives PV.

\section{6}

Daniel D.'s personal file, n. 241980, archives PV. The following citations are excerpted from different documents contained in Daniel D.'s clinical file.

\section{7}

"The career of the mental patient falls popularly and naturalistically into three main phases: the period prior to entering the hospital, which I shall call the prepatient phase; the period in the hospital, the inpatient phase; the period after discharge from the hospital, should this occur, namely, the ex-patient phase... This simple picture is complicated by the somewhat special experience of roughly a third of ex-patients - namely, readmission to the hospital, this being the recidivist or 're-patient' phase" (Goffman 1961: 130-131).

\section{8}

Handwritten document, Damien J.'s personal file, n. 374112, archives PV.

\section{9}

This quotation and the followings are taken from the patient's hand-written notebook, Jean D.'s personal file, n. 389883, archives PV.

\section{0}

Medical Certificate, Jean D.'s personal file, ibid.

\section{1}

This quotation and the followings are taken from Jean D.'s hand-written notebook found in the Perray-Vaucluse storeroom (ibid.).
32

In his diary, each day of the month was divided into morning, afternoon, and evening, and for each time of day the activity he was doing was meticulously noted, as was the writing activity.

33

Medical Certificate, Jean D.'s personal file, ibid.

\section{Bibliography}

Baur, Nicole/Melling, Joseph (2014): "Dressing and Addressing the Mental Patient: The Uses of Clothing in the Admission, Care and Employment of Residents in English Provincial Mental Hospitals, c. 1860-1960." In: Textile History 45/2, pp. 145-170.

Bazar, Jennifer (2013): Objects of Daily Life: Materiality in North American Institutions for the Insane, PhD thesis, York University.

Buchli, Victor/Gavin, Lucas (eds.) (2001): Archaeologies of the Contemporary Past, London: Routledge.

Cenac-Thaly, Henri (1963): "Une enquête sur la vêture des malades." In: L'Information psychiatrique 6, pp. 367-374.

"Circulaire du 5 décembre 1958 relative à l'humanisation des hôpitaux." In: Journal officiel de la République française 0290, December 12, 1958, pp. 11184-11186.

Coffin, Jean-Christophe (2005): “'Misery' and 'Revolution': The Organization of French Psychiatry, 1910-1980." In: Gijswift-Hofstra, Marijke/ Oosterhuis, Harry/Vijselaar, Joost/Freeman, Hugh (eds.): Psychiatric Cultures Compared. Psychiatry and Mental Health Care in the Twentieth Century: Comparisons and Approaches, Amsterdam University Press, pp. 225-247.

Daumézon, Georges/Koechlin, Philippe (1952): "La psychothérapie institutionnelle française contemporaine." In: Anais portugueses de psiquiatria 9, pp. 272-311. 
De Certeau, Michel (1988 [1980]): The Practice of Everyday Life, Berkeley: University of California Press.

Filiod, Jean-Paul (ed.) (2003): Faire avec l'objet. Signifier, appartenir, rencontrer, Lyon: Chronique Sociale.

Goffman, Erving (1961): Asylums. Essays on the Condition of the Social Situation of Mental Patients and Other Inmates, New York: Anchor Books.

González Ruibal, Alfredo (2014): "Contemporary Past (Archaeology of the)." In: Smith, Claire (ed.): Encyclopedia of Global Archaeology, New York: Springer, pp. 1683-1694.

González Ruibal, Alfredo (2018): An Archaeology of the Contemporary Era, London/New York: Routledge.

Hamlet, Jane/Hoskins, Lesley (2013): "Comfort in Small Things? Clothing, Control and Agency in County Lunatic Asylums in Nineteenth-and Early Twentieth-Century England." In: Journal of Victorian Culture 18/1, pp. 93-114.

Harrison, Rodney/Schofield, John (eds.) (2010): After Modernity. Archaeological Approaches to the Contemporary Past, Oxford: Oxford University Press.

Henckes, Nicolas (2007): Le nouveau monde de la psychiatrie française: les psychiatres, l'état et la réforme des hôpitaux psychiatriques de l'aprèsguerre aux années 1970, PhD thesis, EHESS Paris. Hess, Volker (2018): "A paper machine of clinical research in the early 20th century." In: Isis 109/3, pp. 473-493.

Labrum, Browyn (2011): "Always Distinguishable From Outsiders: Materialising Cultures of Clothing from Psychiatric Institutions." In: Coleborne, Catharine/Mac Kinnon, Dolly (eds.): Exhibiting Madness in Museums: Remembering Psychiatry through Collections and Displays, London: Routledge, pp. 65-83.

Latour, Bruno (2005): Reassembling the Social. An Introduction to Actor-Network-Theory, Oxford: Oxford University Press.

Le Guillant, Germaine (2001 [1980]): "Fleurylès-Aubrais 1948. Les Ceméa s'engagent dans le champ de la santé mentale." In: VST. Vie sociale et traitements 72/4, pp. 50-51.

Le Guillant, Louis/Bonnafé, Lucien (1952): "La condition du malade à l'hôpital psychiatrique." In: Esprit: Misère de la psychiatrie 20/12, pp. 843869.

"Loi sur les aliénés du 30 juin 1838." (1839). In: Duvergier, J. B. (ed.): Collection complète des lois, décrets, ordonnances, règlements, et avis du Conseil d'État, vol. 38, Paris: A. Guyot et Scribe, pp. 490521, https://www.ascodocpsy.org/wp-content/up loads/textes_officiels/Loi_30juin1838.pdf, accessed March 27, 2020.

Majerus, Benoît (2011): "La baignoire, le lit et la porte. La vie sociale des objets de la psychiatrie." In: Genèses 82/1, pp. 95-119.

Majerus, Benoît (2017): "The Straitjacket, the Bed, and the Pill: Material Culture and Madness." In: Eghigian, Greg (ed.): The Routledge History of Madness and Mental Health, London/New York: Routledge, pp. 263-276.

Ministère de la santé publique et de la population (Direction de l'hygiène sociale): Fonctionnement des hôpitaux psychiatriques, Circulaire $n^{\circ} 148$ du 21 août 1952, https://www.ascodocpsy.org/wp-con tent/uploads/textes_officiels/Circulaire_2laout1952 _chapitrel.pdf, accessed March 27, 2020.

Oury, Jean (1976): Psychiatrie et psychothérapie institutionnelle, Paris: Payot.

Penney, Darby/Stastny, Peter (2008): The Lives They Left Behind, New York: Bellevue Literary Press.

Raynier, Julien/Lauzier, Jean (1935): La construction et l'aménagement de l'hôpital psychiatrique et des asiles d'aliénés, Paris: J. Peyronnet.

Raynier, Julien/Beaudoin, Henri (1950): L'Assistance psychiatrique française: assistance, législation, médecine légale, psychiatrie sociale, Paris: E. Le François.

Spivak, Gayatri Chakravorty (1988): "Can the Subaltern Speak?” In: Nelson, Gary/Grossberg, Lawrence (eds.): Marxism and the Interpretation of Culture, London: Macmillan, pp. 271-313.

Topp, Leslie/Moran, James E./Andrews, Jonathan (eds.) (2007): Madness, Architecture and the 
Built Environment: Psychiatric Spaces in Historical Context, London: Routledge.

Ueberschlag, Henri (1956): "Enquête sur la vêture des malades à l'H.P. de Lannemezan." In: Vie sociale et traitements 2/10, pp. 15-16.

Veit, Camille (2016): Voyage à travers l'antipsychiatrie et la santé mentale: des discours organisateurs du sujet à l'épreuve de la folie et de la crise, PhD thesis, Nice University.

Von Bueltzingsloewen, Isabelle (2003): "Le rôle des objets dans la psychothérapie institutionnelle. Une thérapeutique de la consommation?" In: Filiod, JeanPaul (ed.): Faire avec l'objet. Signifier, appartenir, rencontrer, Lyon: Chronique Sociale, pp. 41-52.

Von Bueltzingsloewen, Isabelle (2007): L'hécatombe des fous. La famine dans les hôpitaux psychiatriques français sous l'Occupation, Paris: Aubier.

Wynter, Rebecca (2010): "'Good in all respects': appearance and dress at Staffordshire County Lunatic Asylum, 1818-54." In: History of Psychiatry 22/1, pp. 40-57.

Zaborowski, Michel (1956): "Habillement et thérapeutique." In: Vie sociale et traitements 2/10, pp. 8-9. 



\section{A Corridor That Moves: \\ Corporeal Encounters with Materiality in a Mental Hospital}

Kirsi Heimonen and Sari Kuuva

Prologue

A corridor, the narrow area that leads to or from somewhere, a passageway that is situated in between exits or entrances and that connects rooms, is often a waiting room for appointments, such as for a doctor. It leads to the main space and what that space offers or requires. It can also become a meeting place, a space in which to encounter something new, as its in-betweenness suggests. In addition, a corridor has a unique character of its own.

In our research data, Finnish writers describe their memories of different mental hospitals in Finland from the I930s until the 20IOs. In the mental hospital context, the corridor creates the first impression of the institution: anxiety, uncertainty, or relief are all experienced by patients by walking through it. When one is not allowed to leave, walking or strolling indoors is only possible in the hospital corridors. When one is taken to isolation rooms or treatments via corridors, one has time to prepare oneself - to become more terrified or calmer or to experience any of the feelings in between.

The sound of steps in a corridor informs the hearer about the person in it, about the speed of gait, the material the walker's shoes are made of, and the way in which the walker places each foot on the floor. The form and spatiality of a corridor triggers memories of running, e.g. oneself as a child, through corridors elsewhere.

People move along, pause and wait in corridors. Everything moves, including the corridor, since it contracts in length, even if only very slowly. The notion of change, how people, materialities, and objects are constantly in motion, makes research and writing about this topic challenging. However, the impermanent nature of movement and what can be shared and conveyed through art can be viewed as an opportunity. 
We, an artist-researcher and a researcher on visual art and culture, have produced, in both art and academic contexts, performative events of memories for various audiences. These events have entailed movement, reading written memories aloud, and exhibiting historical and contemporary photographs of exteriors and interiors of mental hospitals. In this article, we discuss the kind of insights and knowledge that emerge when written memories about materialities and material objects are read aloud and accompanied with movement and photographs of mental hospitals. ${ }^{1}$

Like a corridor, this article leads to the threshold of something, while not fully illuminating the rooms that lead off it. However, combining writing with a collaborative research method that focuses on movement and photographs in attuning to memories and their material-affective nature and to the meaning of the materiality of lived experiences of a mental hospital can have a powerful impact. The corridor as a passageway holds generative power - even comparable to a birth canal - and underscores in this article the power of art and alternative research methods.

Interestingly, a kind of "corridor theory," referring to a space of transition, i.e. a philosophical orientation toward experience as the experimental process of becoming, can be found in pragmatism (Bordogna cited by McCormack 20I3: 3I). However, in this approach, including when we are thinking of a corridor as a metaphor for shedding light on this method and the processes it entails, we are not dealing in metaphor alone, since corridors as architectural spaces form the site of the experiences of mental hospital patients and visitors. The feel of the walls and floor of a corridor, the lived experience of its materiality when moving or walking along it, is embedded in the present research method. Corporeal encounters in, at, or along a corridor are crucial, since the human being is entangled, intertwined or inter-enmeshed in more than just the human world - in the present context also with materiality and material objects.

Among other materialities and immaterialities, the corridor becomes one of the things we attach to, a meeting place of memories, physical corridors, photographs, movement, and thoughts. In other words, we are interested here in the material and corporeal dimensions of memories, and how the qualities of memories can be conveyed and shared with an audience in a performative event combining movement, spoken text, and photographs. We unfold our method of performing memories and discuss the material-corporeal dimensions of people's memories of mental hospitals. We focus, in particular, on memories where the relation between the individual and the physical environment of the mental hospital is described and the attention is drawn to the materiality of objects. 
The written memories collected from the present sample of mental hospital patients and visitors are lived, embodied ones, and their transformation into movement, paying attention to the materiality around them, may resonate with an audience even though the knowledge embedded in them is mostly inexpressible. The selection of the memories took place in corporeal reading by Kirsi in which she allowed the material to resonate in her corporeality. In a way, the chosen material haunted her in order to be chosen for further exploration. That act of selection can also be called intuition. The excerpts that drew her attention all have a common feature: the relation with humans and the materiality in mental hospitals.

We cast light on these issues - illuminate the corridor - by beginning with a description of the research material and theoretical background along with thoughts that extend beyond our collaborative research method. We then present three excerpts from written memories, together with photographs, and our independent readings of them. At places, the writing may seem uneven or patchy, since as different researchers our sentences are interwoven from differing perspectives. However, this collaborative effort may result in a kind of synthesis that foregrounds the various possibilities generated by encounters with materiality. The conclusion presents the insights and interpretations gained through this method and discusses ethical questions relating to memories of mental hospitals. Thus, the article contains both an introduction to the method and corporeally oriented interpretations of past experiences.

\section{Researching through Materiality}

Our research data, people's memories and experiences of Finnish mental hospitals, were collected in 2014 and 2015 in collaboration with the archive of the Finnish Literature Association (SKS). The memories comprise about 500 pages of text written by 90 persons - patients, friends, and relatives of patients, and hospital staff and their children. The oldest memory dates from the I930s and the most recent ones date from the 2oros. In our multidisciplinary research project Engraved in the Body: Ways of reading Finnish people's memories from mental hospitals, five researchers are investigating the historical, cultural, bodily, spatial, and affective aspects of memories. $^{2}$ 
We approach the materiality of mental hospitals through the (post)phenomenologically oriented literature, applying this approach to its entanglement with humans and non-humans and the (metaphorical) notion of vital materiality that informs, e.g., the texts of Jane Bennett (2010) and Sara Ahmed (2010). Our primary focus is on interaction and the quality of encounters between human beings and material objects. Here the thoughts of Bruno Latour (2005) on objects as agents come into play.

Furthermore, we discuss the notion of corporeal empathy in the context of human beings and their encounters with materiality in mental hospitals. In this study, corporeal empathy is understood as a method of attunement: the mover attunes to the lived memories that trigger the movement while simultaneously the members of the audience attune to the corporeality of the mover, a process which may lead them to resonate with a particular kind of corporeal experience. Our notions of corporeal empathy draw on the phenomenologically oriented writings of Edith Stein (1989 [1916]). ${ }^{3}$

The experience of others is always encountered through one's own corporeality. One's present corporeal state, past experiences, and imaginative ability are interwoven with the experiences of others. Empathy refers not just to movements of the mind but also to movements of the body, the senses and the ways of interacting with other bodies and material objects (cf. Aaltola/Keto 2017: 60-95). Empathy can be understood as a specific act whereby a person focuses on another's experience and empathises with it, but simultaneously distinguishes between the other's experience and her/his own empathic experience. The person who empathises knows that she/he cannot experience the primordial experience (Stein I989 [19I6]: IO; cf. Parviainen 2003: 328).

Corporeal empathy pierces the different phases of research: reading the written material, selecting excerpts, choosing photographs, reading the excerpts aloud, and fleshing them out through movement. The writers' memories support this reading. Their descriptions involve materialities and immaterialities in a mental hospital and reveal the ways they have attached themselves to material objects. Our aim is to create conditions for the awakening of corporeal empathy for the audience through performative events.

We consider corporeal empathy to be a thus far uncharted possibility in approaching experiences related to mental hospitals. Corporeal empathy can take various directions: listening to others' memories, looking at photographs, and through watching or performing movement. Intersubjectivity, which is an important incor- 
Heimonen/Kuuva

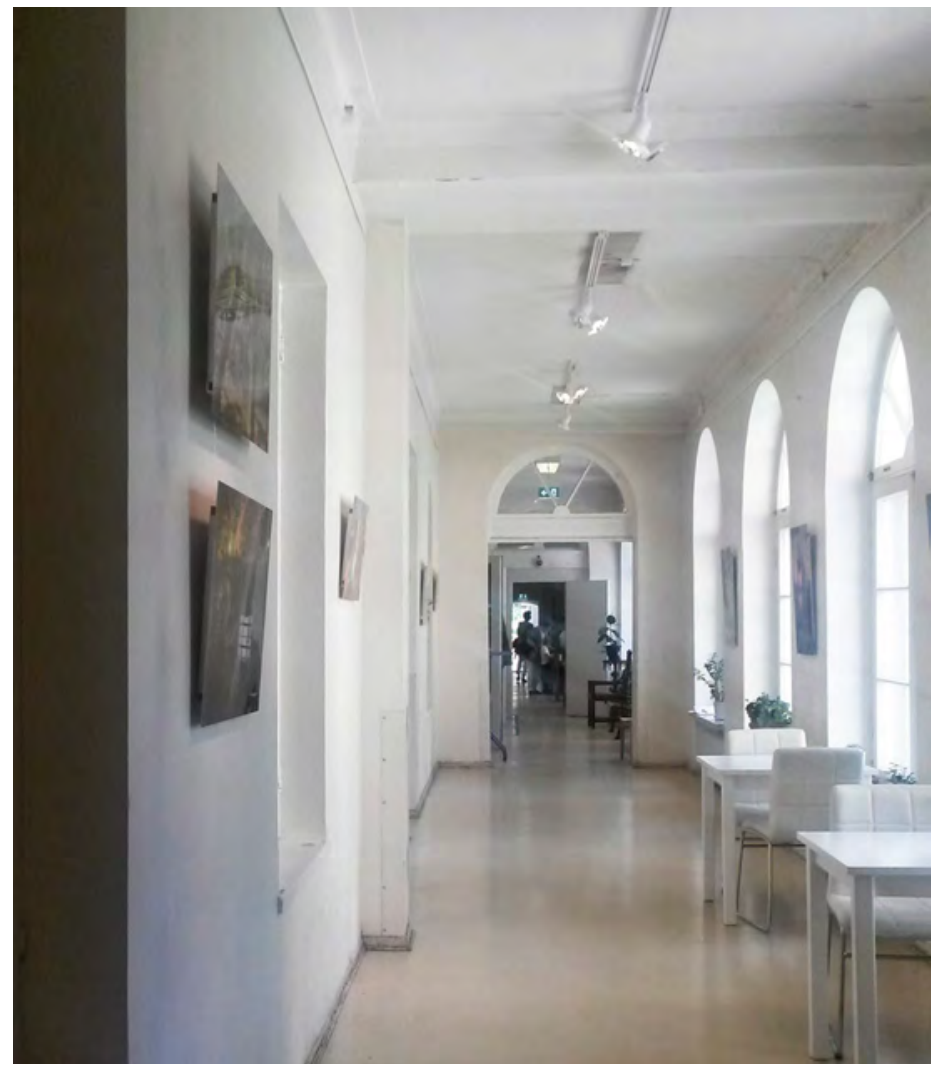

Fig. 1: Corridor in Lapinlahti hospital,

(C) Sari Kuuva, 2017 
poreal interpretation of memories, reaches all the senses and the inter-materiality described in memories as well as the immaterialities present at the site of the performative events. Thus, corporeal empathy is a central notion in our collaborative method designed to awaken imagination and compassion, remind us of our own corporeality, and access corporeal dimensions experienced in the past. In addition to words, pictures, and movement, the material environment activates empathy when the attention is guided to it by the performative event.

\section{Corridor, Room, and Window Sill}

For this article, we approached the materiality of mental hospitals by selecting three extracts from the written memories. In the following we offer two different approaches to each of them, a kind of dialogue of two monologues. Apart from corridors, the research material contains numerous descriptions of patients' rooms and window sills.

Kirsi:

My background is in dance and somatic practices. One specific somatic method, the Skinner Releasing Technique (SRT), has a strong influence on my life: moving, thinking, writing, breathing. The principles of this technique, ${ }^{4}$ e.g. letting go, maintaining a watchful state, effortless effort, and suppleness, are embedded in the corporeality resonating in my encounters with materiality. Furthermore, cultivation of the transparency of the self enhances one's possibilities to perceive the unperceivable in material encounters - here in perceiving memories.

While each excerpt contains an abundance of impulses for me as the performer to follow, the selection process is almost untraceable during the performance. The sound of the words awakens something that resonates in each performative venue. The materiality of the site, the texture of the floor under my feet, the color of the walls, or the posture of a spectator will have some influence on the event. In each venue, encounters with materialities occur through movement and this resonating corporeality. The practice of the Skinner Releasing Technique has brought forth crucial features of the event: attuning and surrendering to each moment, the mover has become merely a vehicle in the happening, in which the temporal absence of the known I and the lessened control over mover's actions emerge. 
The availability of memories and openness to both them and the present situation can thus be described through the resonance that is vital in the creation of a movement and in the happening overall. Jean-Luc Nancy describes how a person "is perhaps no subject at all, except as the place of resonance, of its infinite tension and rebound, the amplitude of sonorous deployment and the slightness of its simultaneous redeployment" (2007: 22). Nancy is referring mainly to the auditory sense; here, however, the core of the resonance lies in listening in and through one's corporeality, a kind of vibration that is lived, and how the whole situation affects it. In the act of moving, listening through one's corporeality refers not only to hearing, since all the senses are acting mutually, but to being attentive to the ingredients of the situation through which movement and speech come into being.

\title{
Corridor
}

\author{
In some wards, I paid attention to the wide corridors that gave rise to \\ a feeling of space when walking through them ... and that brought \\ imagination into play. ${ }^{5}$ (SKS 0395 Patient)
}

Sari:

As a researcher of visual art and culture, I have primarily focused on the relationship between visuality and emotionality in people's memories of mental hospitals. For our performative events I have tried to find photographs that somehow resonate with the selected extracts from written memories. Here, resonance refers to an aspect shared by picture and text, although they are not similar. I suppose that the juxtaposition of texts and photographs can create a tension similar to that induced by the juxtaposition of words and movements. In both cases, the goal is to activate spectators' corporeal memories by creating tensions through the deployment of different media and the stimulation of various modalities. As a background to our performative events we used both historical and contemporary photographs of the exteriors and interiors of Finnish mental hospitals.

In discussing the ability of things to "authorize, allow, afford, encourage, permit, suggest, influence, block, render possible, forbid" human action, Bruno Latour refers 
to the notion of affordance introduced by James Gibson (Latour 2005: 72). According to Gibson, affordance of the environment offers the animal what it provides or furnishes (Gibson 1979: 127). In the hospital environment, material objects or things like corridors and window sills are affordances for walking, running, jumping, sitting, or even dancing - depending on the person who is experiencing the space in a particular situation. As Theodor Lipps, the German philosopher and early theorist of empathy, suggested, we can mentally imitate the rhythm or compositional dynamism of the space and experience this dynamism as emotion (Lipps I960 [1903]:38I-382).

Henri Bergson was interested in the durational dimension of the human experience and drew attention to the mind's capacity to attribute meaning to each present instant through recourse to past corporeal memories (Jones 20I2: I2-13). By means of photographs, both temporal changes and spatial differences between hospitals become visible. The traces of time can be seen in the abrasion of surfaces. For example, traces of the footsteps of previous inmates or staff can sometimes be perceived in the corridors and staircases of old hospital buildings. In her study of the materiality of district psychiatrist centers, Inger Beate Larsen (2008) cites a patient who experiences the old hospital building as soulful. ${ }^{6}$ When buildings are renovated, the traces of the past may disappear.

Kirsi:

Attuning to memories of the site in its materiality and listening to these memories through corporeality extends to photographs as they guide the dancer's way of moving, acknowledging dancing as a thoughtful act (yet one that is not wholly consciously controlled). I discuss the chosen excerpts through the thoughts corporeally aroused in moving, and they are linked with the observations of the photographs.

A corridor as a space to pass through, to run along like a child all the way up to the wall at the other end. Even if the corridor is a narrow space such as that between the rows of chairs at the performance site, or even if it is only a short distance, the words read aloud trigger a change in the rhythm of movement. To feel the air flowing along my ribcage and sides while running, while the speed of movement creates ripples of air that can be felt on the skin by people sitting close by. Perhaps this rush of air brings memories closer, reminding those present of the corporeality beyond them, a token of the aliveness of memories. The image of the airiness of the corridor and its form gives an impression of inter-spatiality hinting at a state of being in-between, between patient's rooms, offices, the kitchen, and treatment rooms, between various historical events, of dwelling in the midst of materialities, and being affected by 

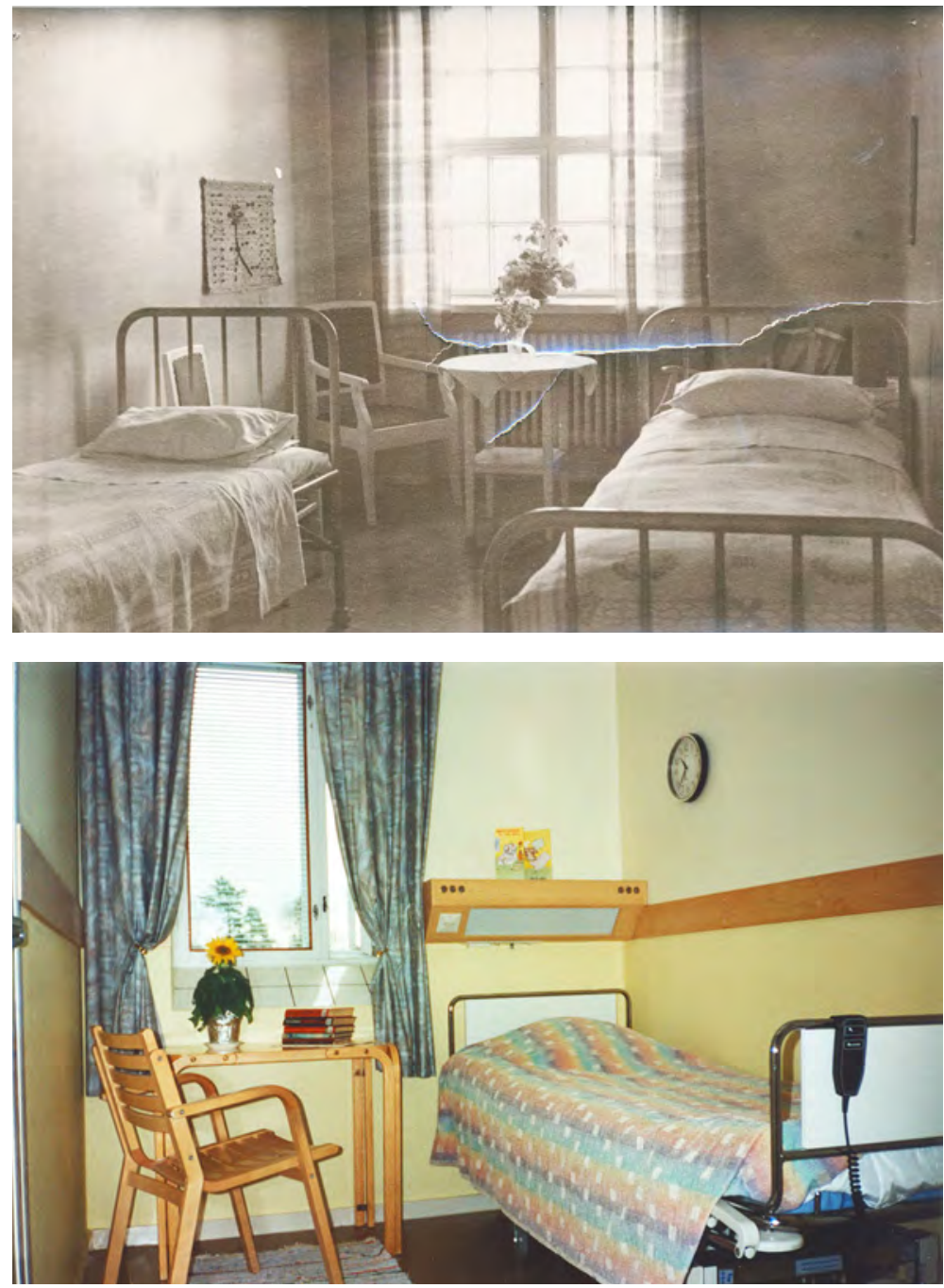

Fig. 2: Halikko hospital, (c) The Hospital District of Southwest Finland/Turku Lazaret Museum

Fig. 3: Juurikkaniemi hospital, (c) Hospital Museum of the Central Finland Health Care District 
them. In the excerpt, the writer refers to a sense of space and to the imagination, and strangely, despite its form, the memory of the corridor brought corporeality in all its dimensions vividly present alongside the frontal orientation of running through the corridor in the happening. All this affirms the corridor as a no man's land or as a state of waiting for something indeterminate, or as a passage from one state to another.

The notion of living one's memories through corporeality parallels the thought by Maurice Merleau-Ponty (2005 [1945]: xviii): “The world is not what I think but what I live through." The phenomenological approach focuses on the lived, experiencing body in the world and the value of the immediacy of experience. As the written memories demonstrate, the intertwining of the human being and the environment and patients' sensitivity to materialities is intense in mental hospitals. When moving to the spoken excerpt above, the process of attuning to the image of the corridor as if it were really there induces thinking-in-action that transcends rational thinking.

\title{
Patients' Rooms
}

\begin{abstract}
My mother's room was tiny, white, and sparsely furnished. There was a narrow bed, a chair and a table, and perhaps a few extra chairs for visitors. ... I was mentally prepared for her to scream and cry and be upset, however she was frighteningly calm, and as expressionless and pale as the hospital building itself. ${ }^{7}$ (SKS 0339, relative)
\end{abstract}

Sari:

While two photographs of patients' rooms feature shared objects like beds, chairs, and tables, they also show interesting differences that remind us of the historicity of buildings and their interiors. The first picture shows Halikko hospital. The hospital was built, along with many other mental hospitals in Finland, around the beginning of the twentieth century. Many of these buildings, which greatly resemble each other, were designed by Axel Mörne (1886-1935). The rooms have high ceilings, high windows, long, wide corridors, and interiors dominated by the color white. The old photograph of Halikko hospital is slightly torn, a feature which incorporates new historical layers into the hospital's environment. 
White was typically used in the interiors of hospitals and in the interiors of other public buildings. For example, as described by Mohsen Mostafavi and David Leatherbarrow (1993), whiteness in the architecture of Le Corbusier (I887-I965) was not only understood to signify honesty, dependability, objectivity, and "truth," but it also aimed to transcend class barriers (Mostafavi/Leatherbarrow 1993: 73-77). It has also been debated whether white should be understood as a color or not (e.g. Kandinsky I9I2; Oettl 2008). Wassily Kandinsky (I866-I944), reflecting on the spiritual influences of colors, describes white as a great silence. That silence is not dead, but pregnant with possibilities like pauses in music that temporarily break the melody (Kandinsky I977 [I9I2]: 39).

The color white was frequently mentioned in the writers' memories of mental hospitals. White was described as present in the clothing of personnel, in corridors, on walls and window sills, in the snow outside, and even in the faces of patients. Mental hospitals can be understood as liminal spaces, where all possibilities are open and movements toward better and worse are equally possible. The white interiors of hospitals emphasize the idea of openness. In our research material, the whiteness of hospital interiors has sometimes aroused wonder and even dislike in patients and visitors, particularly when they have entered hospital buildings after first passing through their beautiful and blooming gardens.

Over the decades, Finnish hospital wards have been furnished in various ways. At the beginning of the twentieth century, patients' bedsteads were usually made of iron. Windows were hung with long curtains in light fabrics and patients' rooms contained small tables and chairs and indoor plants, as can be seen in the photograph of a patient's room in Halikko hospital (fig. 2) (cf. e.g. Neuman-Rahn 1924: 255, 348-349). The number of beds varied across hospitals and wards. Positive experiences of hospital environments in our research data usually relate to the older hospital environments dating from the beginning of the twentieth century. These were usually located outside cities and towns and surrounded by gardens, lakes, and forests (cf. e.g. Ahola 20I5: 30-3I).

Around the middle of the twentieth century a great many new mental hospitals, socalled B-hospitals, were built in Finland. These hospitals were mainly designed for chronic patients, and the buildings were typically low, compact blocks (ibid.: 47-57). They were also furnished in new styles. At the end of the century, darker colors were used in hospital interiors, and natural materials, like wood, were typical design elements. The photograph taken in Juurikkaniemi hospital (fig. 3) shows how patients' rooms were furnished at the end of the twentieth century. 
Thus, mental hospitals exhibit interesting cultural and historical layers. Spaces affect patients, and the personal history of patients is mingled with the history of the buildings they occupy. Memories of other public buildings also intertwine with experiences of mental hospitals. People's images of mental hospitals and other public buildings are combinations of the real and imagined - constructions combining cultural imagery, narratives, and personal memories.

Kirsi:

In various performance sites, I was attracted by the corners, as these emphasized the tininess and gloominess of a room. The furniture described in the excerpt and in the photograph made my movements cautious as if I were too large, as if moving around in a playhouse. The corporeal connection to the paleness or whiteness became obvious and strong. When touching the wall with my hands, arms, legs, sides, back, and cheek, as well as being touched by it, the porousness and transparency of the corporeal experience invited me to disappear into the wall, to become the wall. This led to a slowing of movements, at once vertical and yet still moving. Also, while moving, the surrounding gloominess became like a thin, white material that passes through everything. That something, a transparent web-like whiteness, permeated my skin touching the curves of my bones. It fascinates yet it escapes - a brief lived encounter. The notion of tininess and whiteness also brought a sense of security and simplicity: no need to make big movements, and it supported me in letting go of some features of the known I.

The wall and furniture are seen here as inherently vital; they are moving companions that induce one to act differently, pushing aside one's own will and control. Jane Bennett (20I0: xiii, I22) discusses vital materiality in the same manner, laying the foundation for a materiality that is far from being passive or mechanistic, and she equates affect with materiality. Encounters with vital matter reveal a wider notion of agency in materialities and question the notion of human mastery. Moreover, one's own corporeality is material, although not fully human; instead, it has an "alien" quality (ibid.). Bennett stresses "the very radical character of the fractious kinship between the human and the nonhuman" (ibid.: II2, emphasis original) through the notion of vital materiality. Writing of alien quality in encounters with materiality, Bennett questions the notion that humans have full control over their own corporeality, since it entails something that is strange, unknown, and that strangeness within materiality resembles my lived notions of materiality. 


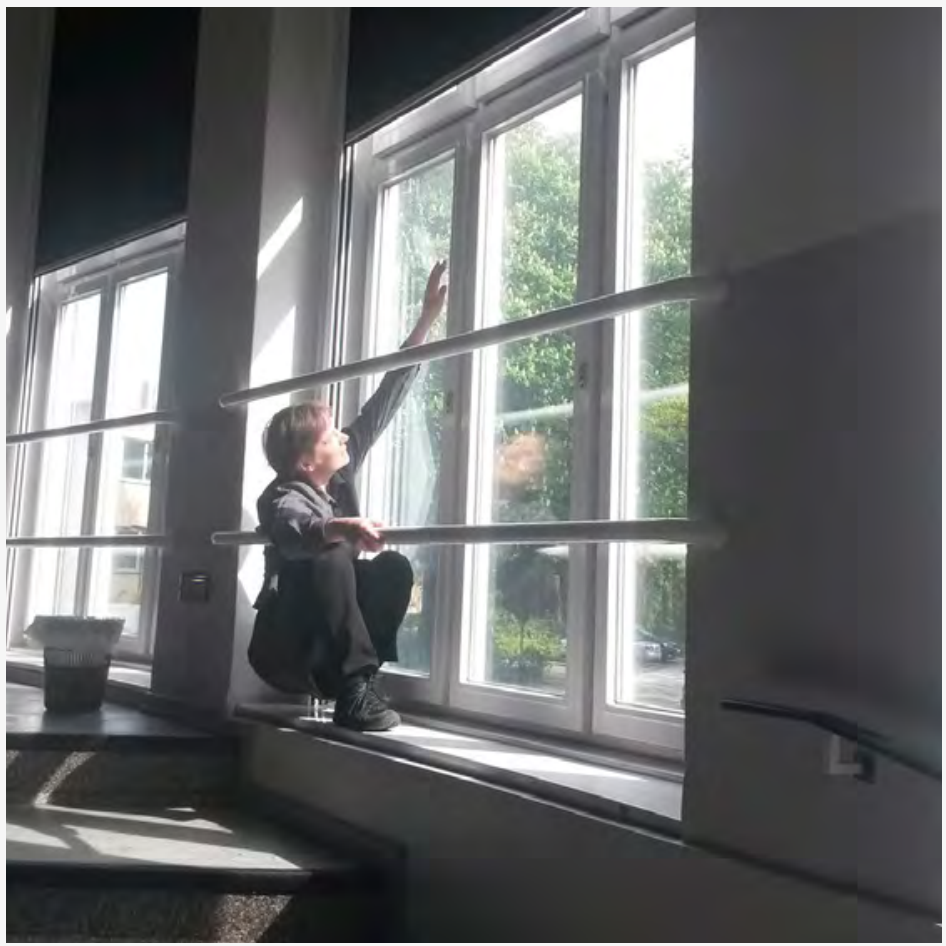

Window Sill

Each night was sleepless during the three-month treatment period. I sat on the window sill in my room. I liked that. It was painted white, a broad concrete shelf. I watched the outside world until the early hours. Watching the falling snow brought a kind of beautiful fulfilment. It calmed down the accumulation of anxiety that was circling around inside me. ${ }^{8}$ (SKS 0483, patient) 
Sari:

As stated by Edith Stein, the phenomena of life, such as growth, development, aging, health, sickness, vigor, and sluggishness, can fill the living body and soul, color every spiritual act and every bodily event. Therefore, through posture and movement we can see how a person feels and make evaluations of her mental and bodily state (Stein I989 [I9I6]: 68-69; see also Parviainen 2003: 337-338).

Sara Ahmed has reflected on how spaces, with their material dimensions, shape bodies. Edmund Husserl and Maurice Merleau-Ponty have described bodily histories as sedimented histories. Phenomenologically, bodies are understood as shaped by histories which are performed in their comportment, postures, and gestures (Ahmed 20I0: 246-250). Traditionally, the patients have lived in mental hospitals for a long time, even decades, and the materiality of hospitals has greatly affected their corporeality. As inmates, patients have spent most of their time in the hospital's rooms or corridors, and the materiality of hospitals has sedimented in their bodies.

Photographs generate rich corporeal knowledge of mental hospitals as lived spaces by opening their unique perspectives on materiality (Kuuva 20I8). How many beds were there in a room, and what possibilities for privacy did patients have? What kinds of pillows, blankets, and curtains were used? What did it feel like to walk through the hospital's corridors and up and down its staircases, and in the yards, gardens, and woods surrounding the hospital, or to be a patient looking through the window at the landscape - day after day, month after month, even year after year?

Because photographs of mental hospitals are linked with specific sites and situations, they may be reminiscent of a person's experiences of other, similar sites like general hospitals, schools, and other public buildings. The corporeal knowledge triggered by photographs resonates with images of other rooms stayed in, corridors walked, beds slept in, and clothing worn when one has been tired, hopeful, sad, anxious, or relieved. In our performative event, the resonance between texts, photographs, and movement may open a pathway for corporeal imagination and empathic experience.

Kirsi:

Corridors and windows have something in common, since they both open up further possibilities and act as bridges between different rooms or indoor and outdoor sites. On the institutional scale, a window sill can offer one a place of safety, security. A window sill is a kind of threshold at which day and night, outside and inside are both present. Snowfall brings softness, silencing sounds and rendering the land- 
scape harmonious, covering all in a white blanket. Night time strengthens the density of spatiality; others are sleeping, tranquility fills the person and environment. Something is being transferred when one pauses to watch the snowfall, something that moves through the person, window and air. Spaces, materialities and immaterialities intertwine with each other and permeate the corporeality of the experiencer, settling into her horizon of experience. Furthermore, sitting on a window sill at that moment or being moved by the excerpt recalls the description given by Sara Ahmed (2006:9): "spaces are like a second skin that unfolds in the folds of the body." And each performing site, the time of day, quality of the light, echoes of sounds, and participants influence and fold in to an ever-changing corporeality.

In performing, the writer's words about nighttime called a halt to the progression of movement, and the rhythm changed: the movement became slow, pondering, and extremely delicate. The image of snowflakes dissolved the tension in my corporeality, even the sound of my voice softened. Perceiving the landscape as dual, as two landscapes transparent and overlapping, was always a powerful experience: to see the view opening from the window at each venue, e.g. seeing tall pine trees in the light of May while at the same time seeing the landscape covered in snow as described in the excerpt. The image of snowfall in the calmness drew my attention. No need to move much, but just to rest in movement. Each change of position was enough. The movements were clearly outlined and, importantly, breathing was autonomous, unconstrained. Something consoling that made it possible for me to be at one with both environments and their atmospheres, a sense of thereness and hereness without any contradiction (Heimonen 2009).

The three examples given above suggest how movement, speech, and photographs can bring forth the responses of patients and visitors to the affective materialities of the mental hospital. Those in the audience attune to these (im)materialities, and their corporeality is in a continuous process of becoming. Corporeality does not pre-exist; instead it is co-produced relationally in specific situations and sites (McCormack 2015). In her discussion of Bruno Latour's notion of the body, Lisa Blackman, referring to the connections that produce and enact bodies, describes the body as an assemblage that is performative, as "an association and concatenation of a range of heterogeneous elements which produce what we take entities to be" (Blackman 2008: I22, emphasis original). The body is thus taken as a mixture of intertwined processes, and these relational connections denote what the body can do or become (Latour 2004; Blackman 2008: I22-123). These descriptions invite one to ponder the possibilities of patients in mental hospitals to corporeally sense 
and attune to the (affective) materialities of their situation and, at each moment, to be in a state of becoming in their various relational connections. Living in and through corporeality, memories enhance sensitivity and make us fully aware of the materialities surrounding us.

\section{Possibilities and Limitations of Corporeal Empathy}

In this article, the entanglement or intertwining of materiality and person in a mental hospital has been investigated as a corporeal attunement to written experiences, photographs, and movement. The present collaboration between two researchers has shown how corporeal empathy towards others and towards material objects can be induced by performative events that foreground the significance of (im)materiality in a mental hospital. The corridors, rooms, windows, and whiteness described in the written memories emphasize the multidimensional aspect of materiality.

The idea underlying our performative events has been to create possibilities for the awakening of corporeal empathy in the audience. We assume that corporeal empathy can be activated through multi-modal performative events. In the present instance, mental hospitals and their environments are understood as carriers of affective meanings, and written memories of environments resonate with people through corporeality. When they imagine life in a mental hospital of the past, spectators use their own corporeal memories of institutions like hospitals and schools. Thus, both performers and spectators are simultaneously present in different spaces, while the past flows through them and assimilates with the present.

The questions of singularity and situationality are important in this research. Each memory is unique, as are our readings of them: environments and one's own corporeality with its traditions and notions leave their imprint. Moreover, each spectator or participant in a performative event has a unique relation to it, which, via one's own corporeality and openness to the specific situation, enhances and guides the possibilities for corporeal empathy.

In the context of a performative event, people find themselves in a situation in which they have diminished control. They may even be exposed to something that is not pleasurable or triggers unpleasant memories. How far should people be protected from this and for what reasons? The most important objective has been to offer audiences the opportunity to engage in others' memories, yet at each per- 
formative event the ethical questions remain of how far one can go while leaving intact the integrity of the writers of the original memories and not insulting them.

The aim of our method is not to indulge in our personal issues; on the contrary, it is to step beyond our subjectivity by taking a different approach to the research material that involves trusting one's own corporeal experience. This does not mean offering an interpretation that all can agree on, or suppressing subjectivity, or neglecting the cultural traditions and historicity of each corporeality. However, the method may reveal something about memories of lived materiality that is uncommunicable by other means.

We suggest that this collaborative method may also be useful to other researchers studying past experiences. The method encourages researchers to listen to the resonance of words, pictures, and movement, and to their own corporeality. We stress the importance of thinking, reading and interpreting one's corporeality, and valuing the knowledge it brings while acknowledging its ever-changing modes and situational aspects. This method offers a space for the unsayable that dwells in photographs and in corporeality, and thus it offers an alternative interpretation for lived memories.

\title{
Epilogue
}

\author{
And the end of all our exploring \\ Will be to arrive where we started \\ And know the place for the first time \\ T.S. Eliot (1943)
}

This study, after starting at and travelling through a corridor, has sought to demonstrate the power and influence of (im)materialites and material objects in encounters with humans. Lived experiences in mental hospitals have been transformed into performative events and then into writing (this article) in order to take the co-existence between humans and materiality into account. The article invites the reader to pay attention to the material environment, and how one is - even if unconsciously - continuously encountering it, and how it affects one's actions and decisions. 


\section{Notes}

\section{1}

This article stems from our conference presentation in Hamburg in 2018, in which we opened up some insights of selected memories through a performative event: Sari was reading memories and showing some photographs while Kirsi was moving them. This event encouraged us to reconsider our different approaches and propose a way in which they could be interwoven while maintaining the integrity of both of them.

2

The research project is funded by Kone Foundation, 2017-2020, https://muistoihinkaivertuneet. wordpress.com/english/.

\section{3}

Kinesthetic empathy and choreographing empathy, which are understood as sub-concepts of corporeal empathy, are also included in our approach. In the context of dance, kinesthetic empathy is closely tied to movement - in particular to the movement between humans. Choreographing empathy, in turn, denotes the construction of a kind of physicality, which guides the kinesthetic experience in the context of dance. It refers to the particular means of creating a dance performance by choreographers focusing on kinesthetic empathy which is reflected to the audience (e.g. Foster 2011; Heimonen 2009; Parviainen 2002; Jones 2012). We assume that the relationship between human beings and their material environment can be discussed more comprehensively through corporeal empathy than through kinesthetic and choreographing empathy.

\section{4}

Cf. "About Skinner Releasing Technique," http://www.skinnerreleasing.com/aboutsrt.html.

\section{5}

"Joillain osastolla kiinnitin huomiota leveisiin käytäviin jotka antoivat tilan tuntua niillä kävellessä ... ja se antoi mielikuvitukselle kyytiä" (SKS 0395). All quotations originally in Finnish were translated by Kirsi Heimonen.

\section{6}

"Jeg tenker at det er en bygding med sjel. Det har vaert mange gode sjeler som har vandret her, som har avsluttet livet sitt. Jeg synes liksom det er fred over hele huset. Det er nog godt med huset. Det er sjel i hvert rom" (Larsen 2008: 4).

\section{7}

"Äitini huone oli pieni, valkoinen ja niukasti kalustettu. Siellä oli kapea sänky, tuoli ja pöytä, ehkä pari ylimääräistä tuolia vieraille. ... Olin henkisesti varautunut siihen, että äitini huutaisi ja itkisi ja olisi pois tolaltaan, mutta äitini olikin pelottavan tyyni, yhtä eleetön ja väritön kuin sairaalarakennus itsessään" (SKS 0339).

\section{8}

"Kolmen kuukauden hoitojakson aikana jokainen yö oli uneton. Istuin huoneessani ikkunalaudalla, pidin siitä; se oli valkoiseksi maalattu, leveä betoninen syvennys ikkunan äärellä. Katselin myöhään aamuyöhön asti ulkomaailmaa. Lumisateen katseleminen toi jotain kaunista tyydytystä, rauhoitti sisimmässäni kiertävää ahdistuksen keskittymää" (SKS 0483). 


\section{Bibliography}

Aaltola, Elisa/Keto, Sami (2017): Empatia. Myötäelämisen tiede [Empathy. Science of compassion], Helsinki: Into.

"About Skinner Releasing Technique," January 3, 2019, http://www.skinnerreleasing.com/aboutsrt. html, accessed February 12, 2020.

Ahmed, Sara (2010): "Orientations matter." In: Coole, Diana/Frost, Samantha (eds.): New Materialisms: Ontology, Agency, and Politics, Durham/ London: Duke University Press, pp. 234-257.

Ahmed, Sara (2006): Queer Phenomenology: Orientations, Objects, Others, Durham/London: Duke University Press.

Ahola, Teija (2015): Terveyttä kaikille: B-mielisairaalat 1950-luvulta 1970-luvulle [Health for all: B mental hospitals from the 1950's to the 1970's], https://www.museovirasto.fi/uploads/Arkisto-jakokoelmapalvelut/Julkaisut/b-mielisairaalat.pdf, accessed February 12, 2020.

Bennett, Jane (2010): Vibrant Matter: A Political Ecology of Things, Durham/London: Duke University Press.

Blackman, Lisa (2008): The Body: The Key Concepts, Oxford/New York: Berg

Coole, Diana/Frost, Samantha (eds.) (2010): New Materialisms: Ontology, Agency, and Politics, Durham/London: Duke University Press.

Eliot, T.S. (1963): Collected Poems 190o-1962, London: Faber and Faber Limited.

Foster, Susan Leigh (2011): Choreographing Empathy: Kinesthesia in Performance, London/ New York: Routledge.

Gibson, James J. (1979): The Ecological Approach to Visual Perception, Boston: Houghton Mifflin.

Heimonen, Kirsi (2009): Sukellus liikkeeseen: Liikeimprovisaatio tanssimisen ja kirjoittamisen lähteenä [Dive into Movement: Movement Improvisation as a Fountain of Dancing and Writing], Acta Scenica 24, Helsinki: Teatterikorkeakoulu. Jones, Amelia (2012): "Kinesthetic empathy in philosophical and art history: Thoughts on now and what art means." In: Reynolds, Dee/Reason, Matthew (eds.): Kinesthetic Empathy in Creative and Cultural Practices, Bristo//Chicago: Intellect, pp. 11-15. Kandinsky, Wassily (1977 [1912]): Concerning the Spiritual in Art, transl. M. T. H. Sadler, New York: Dover.

Kuuva, Sari (2018): "Ruumiillinen tieto sairaalaympäristöissä: Valokuvia suomalaisista mielisairaalahistoriikeista" ["Corporeal Knowledge in the Environments of Hospitals: Photographs from Finnish Histories of Mental Hospitals"]. In: Ennen ja nyt. Historian tietosanomat 4/2018, http://www.ennenjanyt net/2018/12/ruumillinen-tieto-sairaalaymparistoissa -valokuvia-suomalaisista-mielisairaalahistoriikeista, accessed February 12, 2020.

Larsen, Inger Beate (2008): "Det sitter i veggene": Materialitet og mennesker i distriktpsykiatriske sentra ["It's Embedded in the Walls": Materiality and people in district psychiatric centres], dissertation, Bergen: Universitetet i Bergen.

Latour, Bruno (2005): Reassembling the Social: An Introduction to Actor-Network Theory, Oxford: Oxford University Press.

Latour, Bruno (2004): "How to Talk About the Body? The Normative Dimensions of Science Studies." In: Body \& Society 10/2-3, pp. 205-30.

Lipps, Theodor (1960 [1903]): "Empathy, Inner Imitation, and Sense Feelings." In: Rader, Melvin (ed.)

A Modern Book of Esthetics: An Anthology, 3rd edition, New York: Hold, Rinehart and Winston, pp. 374-382.

Maibom, Heidi L. (2017): "Introduction to Philosophy of Empathy." In: Maibom, Heidi L. (ed.): Routledge Handbook of Philosophy of Empathy, London/New York: Routledge, pp. 1-9. Mostafavi, Mohsen/Leatherbarrow, David (1993): On Weathering: The Life of Buildings in Time, Boston, Mass: MIT Press.

McCormack, Derek P. (2015): "Atmospheric Choreographies and Air-Conditioned Bodies." In: Hunter Victoria (ed.): Moving Sites: Investigating Site Specific Dance Performance, London/New York: Routledge, pp. 79-92.

McCormack, Derek P. (2013): Refrains for Moving Bodies, Durham/London: Duke University Press. 
Merleau-Ponty, Maurice (2005 [1945]): Phenom-

enology of Perception, transl. Colin Smith, London/New York: Routledge.

Nancy, Jean-Luc (2007 [2002]): Listening, transl. Charlotte Mandell, New York: Fordham University Press.

Neuman-Rahn, Karin (1924): Sielullisesti sairas ihminen ja hänen hoitonsa [A mentally ill person and his care], Porvoo: WSOY.

Oettl, Barbara (2008): Weiss in der Kunst des 20. Jahrhunderts: Studien zur Kulturgeschichte einer Farbe, Regensburg: Schnell \& Steiner.

Parviainen, Jaana (2002): "Kinesteettinen empatia: Pohdintoja Edith Steinin empatiakäsityksen ulottuvuuksista" ["Kinesthetic Empathy. Reflections on the Dimensions of Edith Stein's Conception of Empathy."] In: Haaparanta, Leila/Oesh, Erna (eds.): Kokemus [Experience], Tampere: Tampereen yliopistopaino, pp. 325-348.

Stein, Edith (1989 [1916]): On the Problem of Empathy, 3rd revised edition, transl. Waltraud Stein, Washington, D. C.: ICS. Publications. 


\section{Psychographics and the \\ Materials of Time Measurement \\ in Modern French Psychiatry}

Maia Isabelle Woolner

During the last decades of the 19th century and the first decades of the 2oth, French psychiatrists and psychologists, like their counterparts elsewhere in Europe and North America, tried to transform and invigorate the study and diagnosis of mental illness through new forms of inscription, measurement, and quantification. As Dr. Jacques Roubinovitch put it in 1900, the French alienist - as French psychiatrists were then called - could not be content with "vague psychology, all in words." Instead he must embrace the "objective examination of his patient, from head to feet" (Roubinovitch 1900: 23). ' The aim was to translate the transience of mental signs into durable material records, which would in turn enable French psychiatrists to subject their patients' symptoms to increased standardization and order. Some of the instruments and techniques French clinicians and researchers used were borrowed from general medicine or imported from experimental physiology and psychology. Indeed, contact between French psychiatry and experimental psychology, as well as the appropriation of instruments and technologies from other more established areas of medical research, was often deliberate and formed part of a strategy meant to bolster the professional legitimacy of the field. ${ }^{2}$ Other methods were "updated" versions of practices already present in psychiatry. Regardless of their origins, these approaches formed an essential part of a broader project initiated during the second half of the igth century to establish the biological and physiological markers of mental illness with the intention of making French mental medicine more "scientific" (Basso/Delbraccio 2017: 268-269). 
This chapter explores several examples of one particular dimension of French attempts at doing scientific psychiatry: the use of time as an "objective" measure in the study and diagnosis of mental illness. Examples include the identification and standardization of prognosis, or the temporal evolution of particular diagnoses; the "real-time" graphical inscription of physiological events concomitant to episodes of mania or depression; and the allotment of diagnostic and prognostic power to reaction time measurements. While the use of chronophotography and the serialized ordering of clinical drawings in psychiatric practice to standardize the temporal trajectory of hysteria has been relatively well documented (cf. Didi-Huberman 1982; de Marneffe 199I; Pichel 2017), the deployment of charting techniques, graphical inscriptions, and timekeeping instruments to similar ends remains under-examined by comparison. Though less visually provocative to 2ist-century eyes than photographic images of interned asylum patients or Paul Richer's synoptic table of a "grand hysterical attack" (Richer I885: Pl V), the visual materials produced by these paper technologies and graphical techniques can, in the end, hardly be called neutral. Though their champions upheld them as objective, these charts, tables, and visualizations were not mirror reflections of the "natural" realities of mental illness. Instead they reveal how the construction of material evidence in support of new theories about the temporal markers of insanity were also forms of reduction, unable to capture information about the patient experience of psychic distress in meaningful ways. They also intimate how the introduction of new data recording and laboratory techniques influenced the temporalities of psychiatric observation.

\section{Charting the Temporal Evolution of Mental IIIness}

Emmanuel Régis (I855-1918) was an eminent professor of mental medicine at the medical faculty in Bordeaux. In the I880s he developed a series of charts for his students that represented the "typical" temporal evolution of what was then called circular or double-form insanity. Circular or double-form insanity were diagnoses introduced into French psychiatry in the mid-Igth century by Régis' teachers, Jean-Pierre Falret (1794-I870) and Jules Baillarger (I809-1890), respectively. Today both psychiatrists are often credited as the first to identify and describe the form of mental illness now classified in the DSM-5 under bipolar disorders (cf. Sedler 1983; 
Pichot 2006). In the I870s and '8os, however, the "natural" reality of these disease categories was still the subject of some debate, and Régis' visuals served as material evidence in support of Falret's and Baillarger's theories about the periodic and cyclical temporal structure of certain forms of intermittent insanity.

Though initially conceptualized for the classroom context to aid his students' understanding of mental illness classification, Régis' charts were also received by the French psychiatric community with early enthusiasm. Discussions at the Paris Medico-Psychological Society in I884 reveal his colleagues' keen interest in the prognostic and clinical possibilities of charting mental illness in this new way (Motet I884: I06-I07). After this successful debut, Régis published these charts in his first textbook Manuel pratique de médecine mentale (I885 and I892). They also appear in modified form in Régis' more famous Précis de psychiatrie, which became a classic text in French psychiatry during the first third of the 2oth century with editions appearing in 1906, I909, I9I4, and I923 (Camus I9I8: 298-299; Morel 1996: 205)33.

This section focuses on a specific example of Régis's charts, a figure entitled "Graphical Representation of States of Mania and Melancholy." It appears in the last two editions of Régis' Précis de psychiatrie (fig. I). As the final version to appear in print, it represents the ultimate expression of Régis' vision for his charts. It also best demonstrates the standardizing impulse of these visuals and the charting method Régis imagined should accompany them. Part of a sizable chapter dedicated to differentiating mental illness by outbreak, the figure's location within the Précis also firmly situates it within the context of distinguishing between chronic and acute forms of mental illness, an opposition increasingly elaborated in French psychiatry during the second half of the I9th century (Lanteri-Laura 1972: 554) and one that had significant and lasting implications for notions of curability.

In the original text, "Graphical Representation of States of Mania and Melancholy" is printed as a full-page color inset composed of eight smaller diagrams. Each of these corresponds to a specific form of mental pathology, ranging from "simple acute mania" to "periodic insanity." Their side-by-side placement encourages comparison. Within each individual diagram, a central, slightly bolded, horizontal line represents the normal state as steady and invariable, suggesting that "normal" is a kind of unchanging and homogenous mode of being with no extreme variations in 


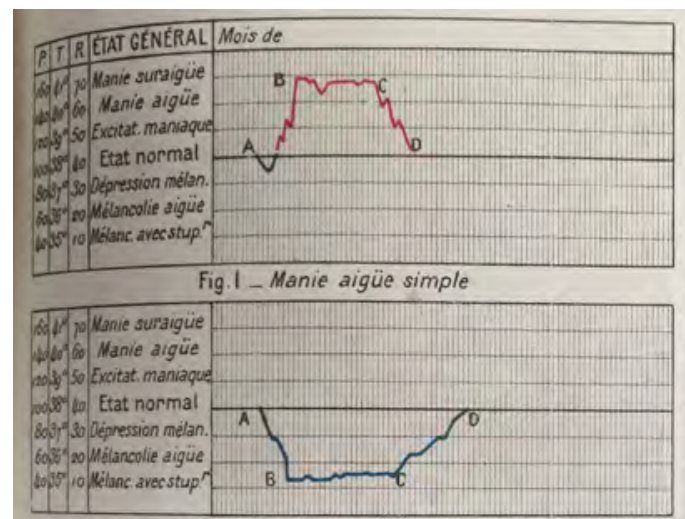

fig. II_Mélancolie aigüe simple

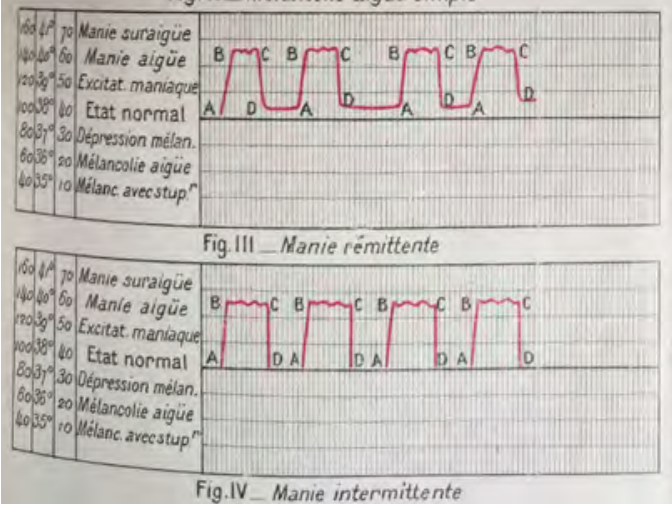

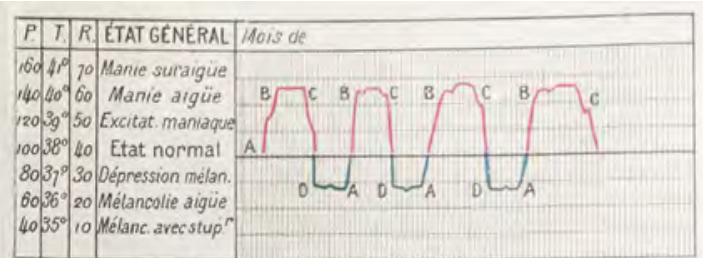

Fig.V_Manie_Mélancolie continue (folle à double forme circulaire)

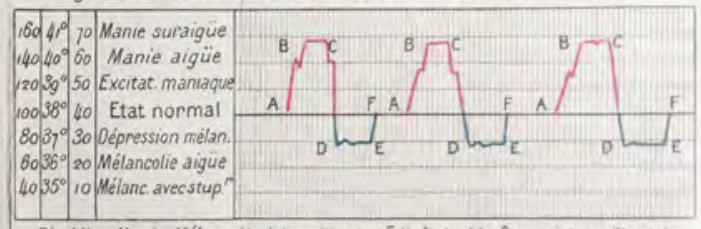

Fig.VI _ Manie_Mélancolie intermittente (folie à double forme intermittente)
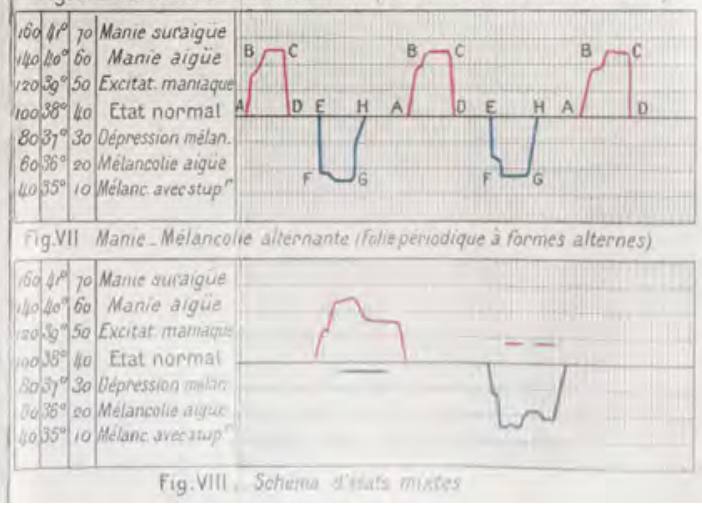

symptom or emotional intensity. In the text accompanying the chart, Régis writes that the vertical lines moving from left to right in each diagram are time markers in this case, days - an indication that symptom distribution is meant to be plotted chronologically at strictly uniform temporal intervals (Régis I9I4: 324). The wellformed curves in undulating lines of red and blue neatly order the temporal oscillations and evolution of symptoms according to each diagnosis. They emphasize - at the expense of qualitative details - what we might call the temporal shape of each pathology, a kind of visual structure that is created by recording changes in symptom intensity over time. As a chart that visualizes the "typical" or "ideal" versions of these forms of periodic insanity, this rendition of Régis' graphic was designed to train the expert eye (cf. Daston/Galison 1992, 2007) of medical students. With its help they would learn to compare, contrast, and quickly recognize the "particularities relative to the constitution and evolution" of these psychoses (ibid.: 327). 
Régis' figure works to standardize the diagnoses of intermittent mania, circular insanity, and other forms of mental illness by illustrating their characteristic fluctuations in symptom intensity over time. It privileges temporal rhythms and patterns - in short illness course or prognosis - rather than a symptomology based, for example, on the content of a patient's delusions. In this way Régis' chart shares some parallels with the use of serial photography in publications that sought to standardize the clinical description of hysteria. As is well known, Jean-Martin Charcot (I825-I893) and his colleagues at the Salpêtrière asylum in Paris used sequentially ordered photographic images, as well as drawings of patients, to "prove" the existence of Charcot's four phases of a grand hysterical attack (cf. Richer I885). Régis' "Graphical Representation of States of Mania and Melancholy" also highlights temporal trajectory, deploying well-ordered lines in near perfect symmetry to depict the "ideal" form of a variety of diagnoses.

While the charts published in his textbooks primarily served a teaching function to illustrate these ideal or archetypical cases, Régis also envisioned from the beginning that the basic technique of systematically charting a patient's symptom changes at regular intervals could have important clinical value (Régis I885: I86). Even in the earliest version of his Manuel pratique he argued that the charts could be used as paper technologies in the daily observation of patients, "just as is done for fever" (ibid.). That Régis announced temperature charting as his inspiration is highly significant. In the wake of Carl Wunderlich's I868 work on clinical thermometry, temperature charts became an important visual tool in general medicine, not only for teaching, but also for clinical care (Porter 1997: 345). Temperature charts soon peppered the pages of French medical textbooks (cf. Jaccoud I870: 75).

Moreover, the method of fever charting had permitted physicians to ascertain that certain illnesses had distinct and identifiable fever patterns (Porter 1997: 678). No doubt Régis understood the power of equating his method with one that relied on numerical measurement and quantification. While eliding the fact that his technique did not use measurement instruments, but actually rested on the psychiatrist's individual subjective judgment to designate the intensity of a patient's symptoms, Régis visually aligned his charting technique to methods used in general medicine and physiology. As is observable on the left-hand side of the individual diagrams in figure $\mathrm{I}$, Régis included columns for the measurement and charting of pulse and respiration, as well as temperature, so that all measures could 
be visualized on one sheet of paper at the same time. ${ }^{4}$ These specifications indicate that Régis wanted to establish the practice of charting the temporal evolution of symptoms as a parallel to other, more established, ways of medically observing, quantifying, and scientifically inscribing changes in patients' symptoms. Moreover, the "scientificity" of Régis' charts was further enhanced by their "physiological aesthetic" (cf. Brain 20I5): not only did they look like temperature charts, but they also resembled the visual traces made by instruments used in the application of graphical recording instruments to clinical medicine and research (cf. Marey I878), as we shall see below.

After their initial publication in his first textbook, Régis' charts and charting method influenced the way in which other practitioners shared and circulated medical case histories. ${ }^{5}$ François-Léon Arnaud (I858-1927), a French psychiatrist who worked for much of his career at the private psychiatric clinic of Vanves (Morel I996: I5), appropriated Régis' technique to create graphics for his chapter on periodic insanity in Gilbert Ballet's co-authored Traité de pathologie mentale (1903: 576-6I7).

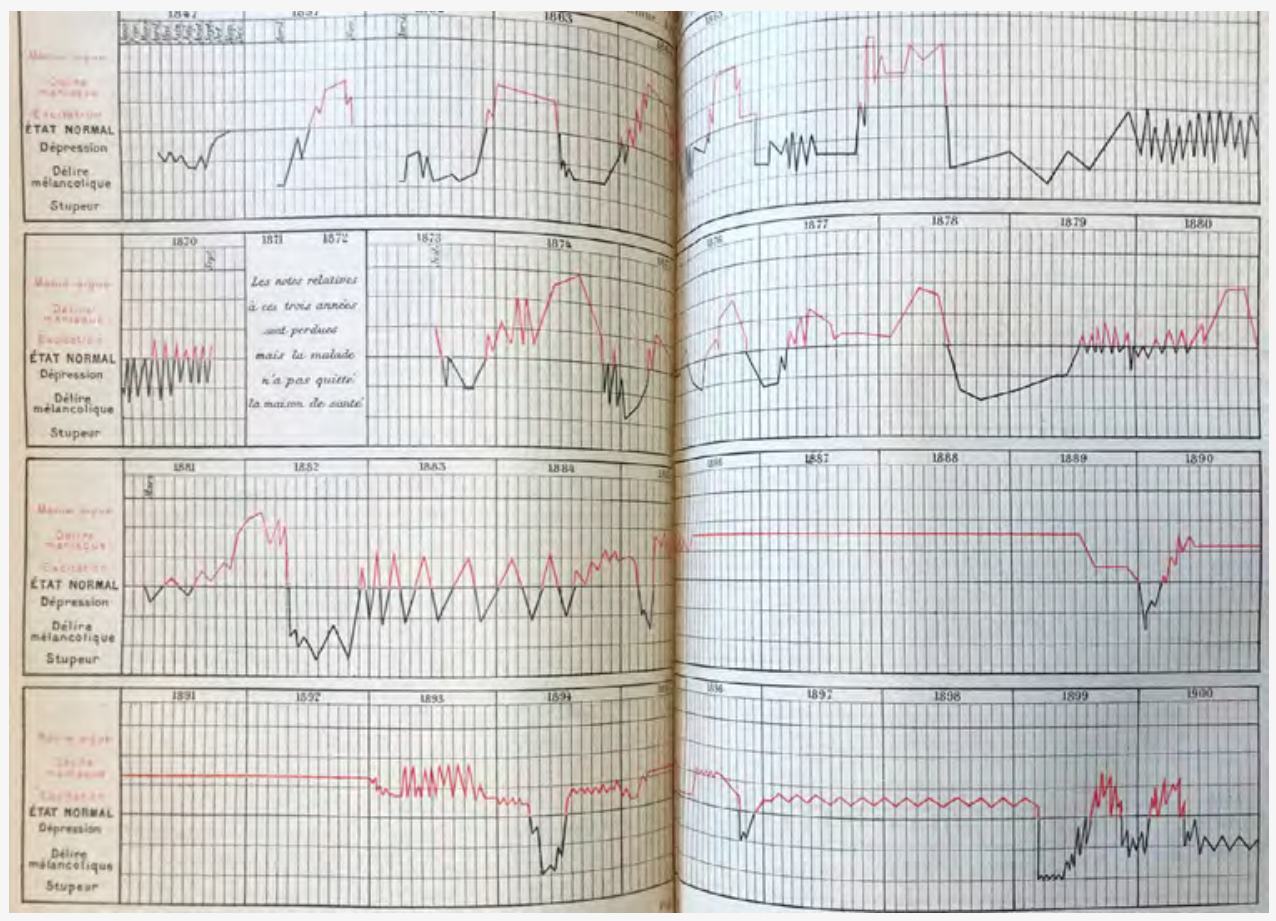


Figure 2, which was published as part of that chapter, ${ }^{6}$ represents the illness course of a female patient identified simply as "M.B." from 1847 until her death in 1900 . The textual information at the heading of the figure reads: "Trace. 6 - M.B. Woman born in 1826. Circular insanity began at twenty-one years, by a melancholic outbreak ..." (ibid.: 606-607).

Contrary to the practice of charting directly from clinical observation as Régis had intended, Arnaud made his graphical inscription of M.B.'s symptoms after the fact, from written case notes. ${ }^{7}$ Thus M.B.'s illness, which appears in figure 2 as a series of irregular spikes and dips in red and black, is actually a "translation" from the verbal to the visual. The chart stands in for the array of symptoms, behaviors, conversations, delusions, etcetera that would have made up a written account of M.B.'s case. Arnaud's linear rendering of M.B.'s medical history is an operation of both synthesis and abstraction. From verbal description to linear transcription, M.B.'s clinical picture is portrayed as a succession of points and sharp lines.

For Arnaud's like-minded colleagues in the early 2oth century, the benefits of moving from words to lines were clear. Étienne-Jules Marey, the French physiologist, wrote extensively about the graphic method in medicine as a way to overcome the slippery, imprecise nature of language (Marey I878: i). In a similar way, Arnaud validated forms of non-verbal charting as a kind of parallel to Marey's method, and thus as a step forward for the scientificity and objectivity of mental medicine. But for historians interested in trying to ascertain information about a patient's personhood or experience of illness, the move from description to transcription is a kind of loss. While revelatory of shifting methods in psychiatric charting and case sharing, these visual materials limit the possibility of obtaining information about who a patient was as a person even further.

But to the trained eyes of psychiatric experts circa 1900, Arnaud's image of M.B.'s illness was instantly legible as material and visual proof of M.B.'s circular insanity diagnosis. The act of reading a lengthy, detailed, textual account of her symptoms was unnecessary because the temporal shape of her illness immediately rendered her diagnosis apparent in the blink of an eye. Even if the chart didn't conform exactly to the idealized version of circular insanity from Régis' "Graphical Image of States of Mania and Melancholy," M.B.'s diagnosis and prognosis were instantaneously recognizable. Indeed, Arnaud provides no additional commentary to accompany the figure because he could assume that for his audience the figure was self-explanatory.

Régis' method and his textbooks' figures help demonstrate how French psychiatrists and pedagogues at the end of the 19th century developed paper technologies 
and produced visual materials to support the idea that prognosis or temporal shape was a defining and objective characteristic of mental illness that could clarify both classification and diagnosis. In these images it was the different temporal patterns more so than the content or variety of symptoms which differentiated one form of mental illness from another. By visually demonstrating that it is only by regular, periodic, and orderly clinical charting in the long term that accurate diagnoses can be made, these figures establish each form of mental illness as a distinct temporal object - as a disease entity that is defined by fixed and recognizable temporal signposts. Thus, while Régis' Précis also included a significant number of photographs and drawings of patients, none offer as forceful a visual argument in favor of longitudinal clinical observation. Though most often associated with the work of the German psychiatrist Emil Kraepelin (I856-I926), diagnostic standards based on the temporal trajectory or "diachronic criterion" of a patient's illness were also essential to French psychiatry's continued "will to science" (Lepoutre 20I2: 358). These charts also suggest certain tensions in the temporalities of psychiatric observation: on the one hand, Régis' charting method implies that accurate diagnosis can only be achieved through consistent clinical observation in the long durée. On the other hand, these charts condense the patient's medical history into something that can be "read" in a single glance, instantaneously.

\section{Psychophysiology in Units of "Microtime"}

For his work La tristesse et la joie (1900), psychologist and doctor Georges Dumas (I866-I946) conducted clinical experiments on interned psychiatric patients at the Sainte-Anne Asylum in Paris. The experimental data he collected by subjecting patients diagnosed with mental illnesses to various kinds of testing formed the basis for claims Dumas would make about the expression of both "normal" and "morbid" emotions (Dumas I900: 5). Not uncommonly for the period (cf. Carroy and Plas 1993), Dumas argued that the "most pathological and abnormal cases are interesting because they present in magnified form, the ordinary laws of the normal state" (Dumas I900: 4). Indeed, Dumas was one among many French researchers in the years around 1900 who made the psychiatric space into a site for doing medical research and clinical experiments (cf. Danziger 1990). In the French asylum in particular, the "hysterical woman" served as the "frog of the laboratory" (Binet and Simon I909: 120). 
One of Dumas' "model" experimental subjects was a woman he identified as "Marie D." She was 39 and interned at Sainte-Anne, where she had been diagnosed with circular insanity. In La tristesse et la joie Dumas recounts certain elements of her medical and personal history in some detail. Born in December I86I, Marie had experienced several bouts of contagious illness as a child. She first menstruated at 13 and was married by 20 . More recently she had suffered a miscarriage, as well as the loss of several of her children in their infancy (Dumas I900: 3I-32). Like Régis, Dumas was in favor (at least in theory) of longitudinal clinical observation for patients. He argued that it was more accurate accounting for the periodization of Marie's episodes of mania and depression that had allowed physicians to finally diagnose her correctly (ibid.: 33). Her first experience of mental illness, he writes, began with a bout of melancholy in the wake of the death of her twins. This melancholic phase was followed shortly thereafter by a period of mania. But because she had frequently been transferred from one institution to another - and because of the early irregularity of her alternating symptoms - Marie initially had been diagnosed with a whole catalog of different disorders: for example, melancholic depression, erotic excitation, and mental debility.

In order to confirm the legitimacy of her most recent diagnosis, Dumas also included a schematic diagram in his work, one that was not entirely dissimilar to those used in the aforementioned works by Régis and Arnaud. Marie, like other patients diagnosed with circular or periodic insanity, was considered especially "useful" as a subject for experimental medical research. As Dumas wrote, "[t]his woman ... presents alternating periods of sadness and gaiety; it is thanks to her that I could undertake a large number of experiments" on these emotional states with the great "advantage of being able to compare between them" (ibid.: 3I).

In Dumas' research lab at Sainte-Anne, Marie was subjected to multiple kinds of physiological testing. To undertake these measurements Dumas used instruments borrowed from experimental physiology and graphical medicine, including Weber's compass, Marey's recording cylinder, the pneumograph, the sphygmograph, and the dynamometer (ibid.: 86, 9I, 2I9, 220, 33I). ${ }^{8}$ While Dumas did use photography and electrical manipulations in his other works on facial expression and emotion (cf. Dumas 1906: 39), in his research for La tristesse et la joie it was physiological instruments in particular that enabled him to penetrate inside the pathological 
body and mind. The purpose of this testing was to ascertain information about a patient's mental or emotional state by measuring physiological processes at moments of extreme emotional or mental distress.

The importance of temporality to physiological measurements and graphical medicine is well known (cf. Braun 1992; Brain 2015). In using various inscription devices, Dumas' aim was to fix ephemeral and unseen bodily and mental phenomena by graphically inscribing them into more stable material forms. These devices produced "objective" visual traces, each of which provided a durable record of normally invisible pathological processes as they unfurled in "continuous, real-time motions" (Porter 1997: 345). The material byproduct of these instruments could then be studied and interpreted by physicians and researchers after the fact. They furnished a kind of material archive of a patient's "morbid" states. Dumas used these traces to try and identify the degree of emotion experienced by an individual based on the intensity of that emotion's measurable physical concomitants during a specified temporal duration. Indeed, the duration of an individual's emotional response, and its relationship to the provoking cause of that emotion, was deemed by Dumas and other researchers as relevant to determining the difference between normal and pathological emotivity (Dumas 1900: 5-6; cf. Féré 1892).

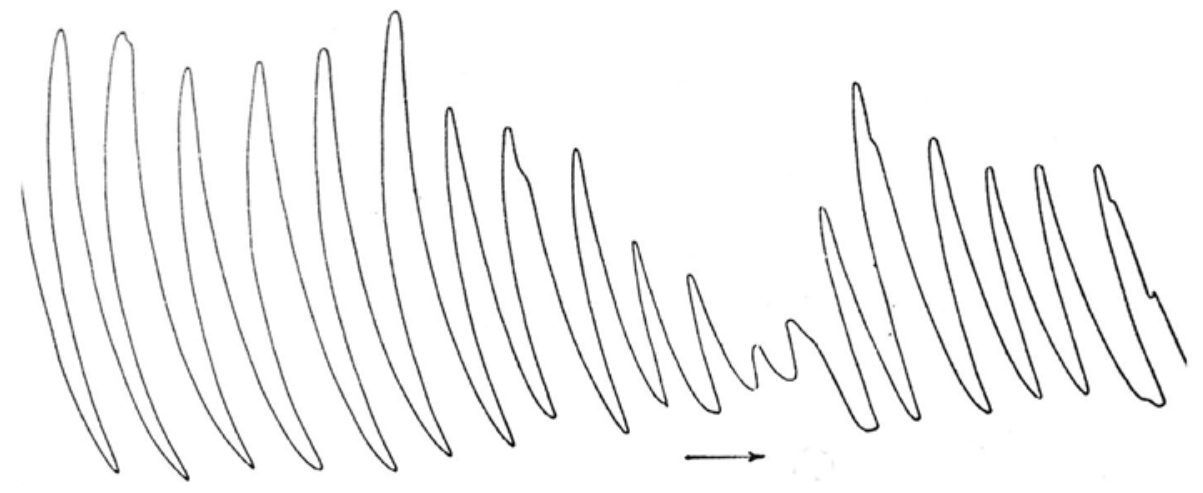


Figure 3 is one example of many that feature in Dumas's La tristesse et la joie. By taking often uniform-duration graphic recordings - in this case the rate of respiration of a patient identified as "L." during a 25 -second "erotic hallucination" - Dumas created discrete temporal objects out of the psycho-physiological responses he recorded. These measurements not only isolated distinct bodily processes from the holistic experience of emotion, but also dissected emotional states into separate psycho-physiological events, subject to quantifiable interpretation, objectification, and experimentation.

We know that Marie found the presence of the graphical recording devices themselves particularly distressing; Dumas recorded that she called them "instruments of torture" (Dumas 1900: 9I). The emotional events Dumas sought to objectify and measure were frequently provoked, as he often introduced patients at Sainte-Anne to particularly challenging or emotionally overwhelming situations, including unexpected and sudden visits from children or other family members (ibid.: 42). Dumas, in his chapter on the nature of sadness and joy, also reports trying to induce emotional responses from Marie by changing her internal physiology (circulation, respiration, pulse, etcetera). To do this he made her tonics of strong coffee, and administered massages, potassium bromide, and hypodermic injections of hyoscine, the latter of which he reported was a drug frequently used in Dr. Valentin Magnan's service at Sainte-Anne to put agitated patients to sleep (ibid.: 377-380).

In addition to psycho-physiological experiments, Dumas also was intrigued by another relatively new research area in French psychiatry that was equally oriented around temporal analysis: the measurement of "psychic time" or "reaction time" (cf. Philippe 1899). Like other French psychopathologists including Charles Féré, Jean Philippe, and Victor Henri - who conducted reaction time experiments at the Salpêtrière asylum - Dumas was interested in the potential of mental chronometry for scientific psychiatry and psychology. For the proponents of mental chronometry, the duration of reaction or response times could reveal important information about "nervous activity and mental functions" (Philippe I899: 42).

Doctor and polymath Jacques-Arsène d'Arsonval (I85I-I940) had designed a special chronometer in the mid-I88os for explicit use in the physiological and neurological clinic (d'Arsonval I886: 236). Unlike the Hipp chronoscope, which was the timekeeping object of choice in German experimental psychology laboratories, 
d'Arsonval's time-measurement device was light, portable, and easy to manipulate (by I9th-century standards). Using an electric current to start and stop the movement of a hand on a dial, it served to measure intervals of extremely short duration at up to I/Iooth of a second. Though it was considered less precise than the Hipp chronoscope, its convenience and flexibility soon made it the time-measurement device of choice for French experimental psychology (cf. Nicolas/Thompson 2015). In particular, its portability enabled practitioners to enlist it within a clinical setting, and soon after its invention French researchers began to debate and discuss the diagnostic and prognostic value of reaction time testing for psychiatry (cf. Henry I894; Canales 2009).

Though Dumas didn't have a specialized chronometer at his disposal when he was conducting research for La tristesse, it turned out that two of his colleagues, Édouard Toulouse (I865-1947) and Nicolas Vaschide (I874-I907), had already conducted reaction time experiments on Marie only a few years earlier in I897. Dumas reported on their experiments at length and also referred readers to their publication.

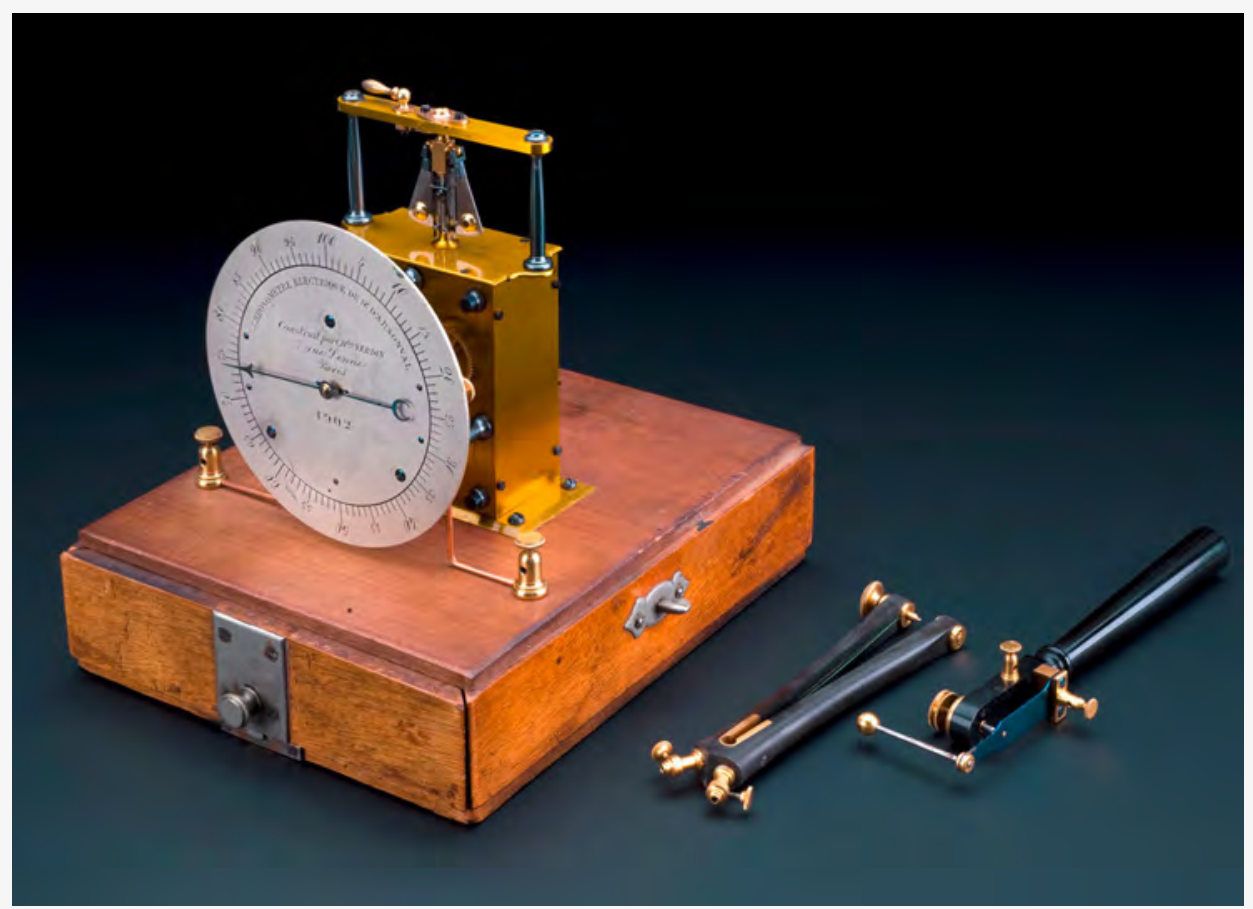


Apparently, the testing was conducted at Io in the morning in the psychology laboratory at Sainte-Anne. Using d'Arsonval's chronometer to measure the duration of her reactions, Toulouse and Vaschide asked Marie to respond to auditory stimuli that were presented at irregular rhythms so that she couldn't anticipate them. To suppress both the conscious and unconscious influence of visual perception, the operators of the experiment were separated from Marie's view with a screen. According to Dumas, Marie had also been trained ahead of the official start of the experiments (Dumas 1900: 46).

Of particular interest to Dumas and other researchers was the question of reaction time measurements and their relationship to attention. With a few exceptions, it was assumed by many psychopathologists during this period that shorter reaction times indicated a higher degree of attention and thus were an indication of "better" mental health. To accompany this discussion, Dumas included a graph that visually illustrated the numerical values of a series of Marie's reaction times. For Dumas, this graph of Marie's results, including the minor irregularities in duration of her reactions, demonstrated that Marie's responses were always "voluntary" rather than automatic or unthinking. Dumas also used the graph to illustrate that during periods of depression, the ability to maintain attention was diminished (ibid.: 46-48).

From the measurement of psycho-physiological responses to the testing of reaction times in hundredths of a second, Dumas's research area investigated the pathological mind-body relationship in units of "microtime" (Canales 2009: x). Unlike in Régis's charting method, Dumas's approach to pathological emotivity was one centered on real-time recording and distinct, relatively short-term events. And yet, while Dumas was clearly committed to the use of instruments and quantitative measurements for the purposes of his study, he was not entirely disinterested in the emotional lives and personal histories of the patients at Sainte-Anne on whom he conducted these tests. At least in the case of Marie, Dumas did pay some attention to Marie's life experiences and how she described her illness. Very interestingly, he was even intrigued by Marie's perception of passing time and her inability to coherently integrate and make sense of her past, present, and future. In recounting one of their conversations, Dumas remarks that she was not able to go back into her memory to the things that might be bothering her; she had no thoughts of the past, nor did she fear the future (Dumas I900: 43-44). "While certainly she can remember other periods of sadness and other joys ... her current sadness is so profound ... that she cannot conceive of its end" (ibid.: 44). Stuck in a kind of eternal present, Marie accepted the "fatal rhythm" of her diagnosis (ibid.). 


\section{The Medical Analysis of Writing}

Originally a line of investigation opened in France by Dr. Louis-Victor Marcé (1828-I864), the medical analysis of writing was increasingly pursued by French alienists during the end of the 19th century (Artières 1998: 6I-64). For example, according to prominent French psychiatrists Alix Joffroy (1844-1908) and Jules Séglas (I856-I939), texts written by patients could have diagnostic and prognostic potential (cf. Séglas I892: 244; Ballet 1903: 926-930). Joffroy divided the medical analysis of pathological writing into two different categories; the first, called calligraphie, dealt with the actual material execution of writing, and included elements such as the dimensions and formatting of the letters, the appearance of trembling or other motor coordination issues, as well as the general appearance of the composition. The second category, psychographie, denoted psychic "stigmata" as revealed in writing: unusual expressions, modifications in style, hyperbolic language, omissions or repetitions of letters, syllables, and words - all of which might reveal the different affective states or delirious ideas of patients, as well as deficits in logic, memory, or attention (Ballet 1903: 926-930).

One of the most complete but little-studied treatises dedicated to both kinds of graphical pathologies, Les écrits et les dessins dans les maladies nerveuses et mentales (1905) was written by Dr. Joseph Rogues de Fursac (1872-1942), a French alienist who had collaborated with Georges Dumas a few years earlier on an article about anxiety (Dumas I900: I0). Following the research done by his predecessors, Rogues de Fursac understood writing as the ideal material byproduct of the pathological mind and body. An interface between somatic and psychic, writing samples - when interpreted by a trained clinician - could become a powerful tool in the "neuro-psychiatric clinic" (Rogues de Fursac 1905: v). Moreover, in the case of some illnesses, namely general paresis, Rogues de Fursac argued that writing samples alone were often sufficient to make a diagnosis (ibid.: vii, 262). While Rogues de Fursac's optimism about the diagnostic power of writing samples was more tempered for other illnesses, he nevertheless believed that all psychic conditions and diseases - from excitation and melancholia to intermittent insanity and epilepsy - modified the material and intellectual nature of one's writing.

Les écrits et les dessins dans les maladies nerveuses et mentales opens with a chapter on methods and then proceeds to investigate writing samples produced by patients grouped according to a wide variety of diagnostic categories including hysteria, 
epilepsy, dementia praecox, neurasthenia, manic depressive insanity, and what Rogues de Fursac called "attention deficit" (ibid.: 303). The primary aim of the book was clinical (Morel 1996: 209), namely to expose readers to as many different examples as possible, to a kind of "museum" of pathological writing (Rogues de Fursac I905: 9-IO). To this end Rogues de Fursac reprinted 232 figures in his text, as well as multiple writing samples from the same patient. Most - including figure 5, a spontaneous writing sample featuring "childish drawings" by a patient identified as Vincent M. - were reprinted in actual size (ibid.). Each of the figures in Rogues de Fursac's monograph appears with a caption. These indicate information including the name and age of the patient, their level of education and/or occupation, their diagnosis, and the type of writing sample. In the caption to figure 5, for example, we learn that Vincent was a 53-year-old man and a journalist.

For Rogues de Fursac, the objectivity and material durability of writing samples made them at least as valuable as photography from a clinical perspective (ibid.: iv-v). Photography in psychiatric practice during the end of the Igth century (like in other sciences) had largely taken on the status of an "objective" measure (cf. Daston/Galison 2007). It was often used to illustrate and prove the existence of certain physical stigmata or physiognomic characteristics associated with particular conditions (cf. Dagonet I876; Londe I893). Thus, while by today's standards the medical analysis of handwriting seems far from objective, the fact that Rogues de Fursac explicitly linked the medical analysis of writing samples to photography was an unambiguous statement in the early 2oth century. It is a testament to his belief in the practice's scientific credibility.

Perhaps cognizant of potential detractors' arguments, however, Rogues de Fursac also spent a significant amount of space in the forward to his book differentiating the medical analysis of writing from what he refers to as graphology. "Graphology," writes de Fursac, "differs from the medical analysis of writing in both its object and its method" (Rogues de Fursac I905: vii). One of the most relevant differences is that where the graphologist limits himself to the study of "spontaneous writing," the doctor also submits his patients to writing tests and to "provoked writing." Dictation exercises provided the basis for testing pathologies of memory, whereas the ability of a patient to copy texts was considered a measure of attention 



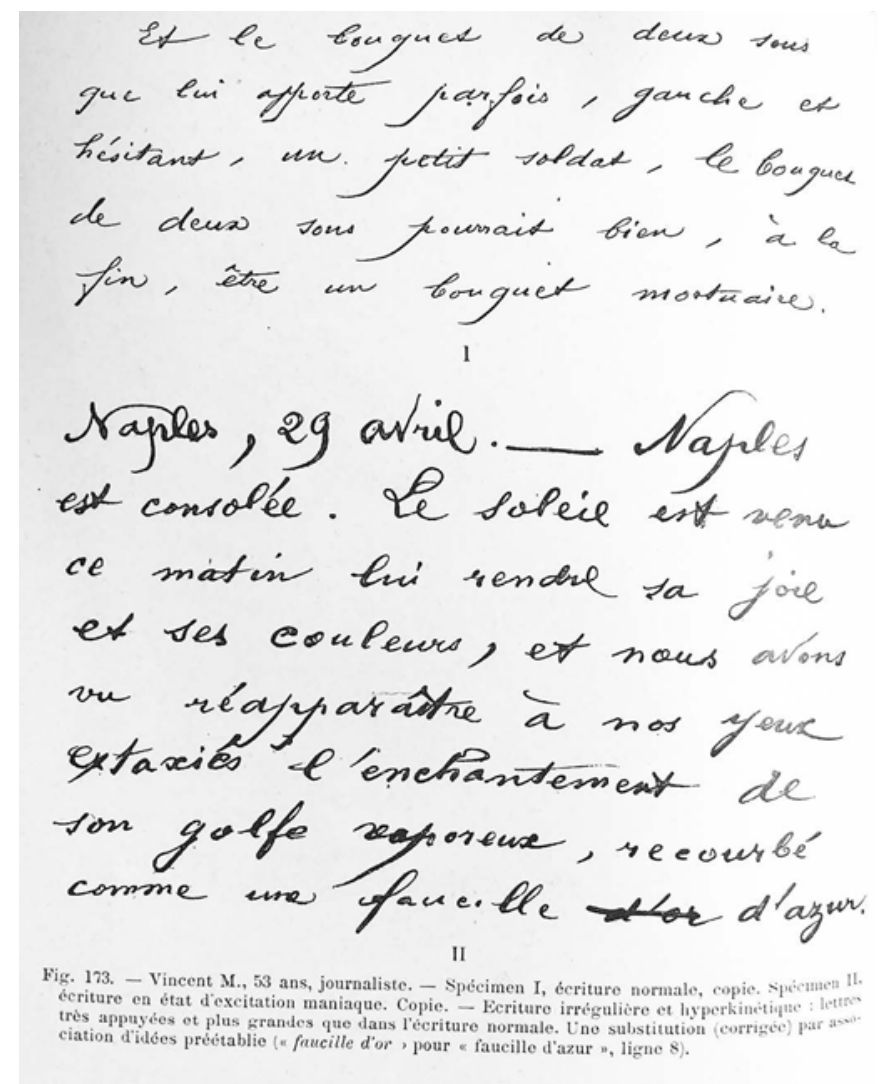

Fig. 6: "Figure 173. - Vincent M ... Specimen I,

normal writing, copy. - Specimen II, Writing during

a state of manic excitation. Copy. - Irregular and

hyperkinetic writing ..." (Rogues de Fursac 1905: 200) 
(ibid.: I-6). Thus, by also aligning his method with experiments and experimentation, Rogues de Fursac situated the medical analysis of writing as potentially more valuable than pure empirical observation, and even hinted at its superiority to the documentary photography of psychiatric patients.

For one, photography - because of its technical requirements - was a more involved process. The collection of writing samples was advantageously low-tech by comparison. No special lighting, chemicals, or expensive equipment were required - just paper, quill, and ink. Photography also often necessitated that patients be moved from one ward of the hospital to another. Writing samples, on the other hand, could be taken in situ without modifying or moving the patient. Most importantly, Rogues de Fursac also stressed that writing was the material byproduct of "neuropsychiatric activity" (ibid.: v), and therefore significantly more dynamic than the static and momentary image captured by a photographed pose. Emanating from inside, rather than from the bodily surface, writing was actually a graphic action of a particular duration that could externalize not only the mind-body connection in real time, but also "the richness or the poverty of [a patient's] ideation" (ibid.: 3). To validate their worth, writing samples where ideas and emotions were of primary interest were not photographically reproduced in the text, but typographically transcribed from the patient's own handwriting into typeface. For Rogues de Fursac these texts helped demonstrate that the subject matter of a patient's writing was also significant and could reveal "carefully dissimulated deliriums" or "the origin of certain behavioral anomalies" (ibid.: 3).

In this particular specimen (fig. 6) Rogues de Fursac offers two side-by-side samples to encourage comparison. The caption states that Vincent composed the top sample prior to a manic episode, and the second one during it. This before and during contrast is especially important. It serves to accentuate that what makes writing samples especially useful is their ability to provide a clinician with a point of entry into current and contemporaneous neuropsychiatric activity, not dissimilar to Dumas' psycho-physiological measurements of patients interned at SainteAnne. Moreover, by collecting multiple as well as different types of specimens from spontaneous writing to dictations and copying exercises - the physician could "follow the evolution of an illness, from the point of view of its severity and the form of its outbreaks" (ibid.: vi).

Rogues de Fursac used this time-stamping method to engage in the periodization and regimentation of psychiatric and neuropsychiatric diagnoses. This is especially visible in his analysis of patients diagnosed with general paresis, epilepsy, and hys- 
teria. In the chapters on these categories, the captions accompanying the writing samples often include additional temporal information. For example, in the case of patients with epilepsy, the general frequency of seizures, the length of time since the most recent seizure, and the duration of time it took the patient to write the sample are often included. Rogues de Fursac even argued that using writing samples taken from patients at varied increments post-seizure (for example, at I5 minutes, $30 \mathrm{~min}$ utes, 45 minutes, etcetera) had enabled him to periodize four successive phases in the time of seizure recovery, all according to "deficiencies" visible in handwriting and execution. Rogues de Fursac named these stages: "complete mental automatism," "relative automatism," "simple mental deficits," and finally, "lucidity" (ibid.: IOO). This kind of temporal periodization is equally at work in Rogues de Fursac's discussions of general paresis. Writing tests such as dictation or copying exercises provide material evidence of the slow decline and de-evolution of the patient's prognosis. Texts written by patients with general paresis become increasingly "infantile" and "clumsy," analogous to "the writing of illiterates" (ibid.: II2).

Rogues de Fursac saw the periodic and frequent collection of writing samples as a way to monitor neuropsychiatric activity not only at discrete moments, but also over the longer term. "To cite but one example," he wrote, "the symptoms of periodical psychosis are reflected in writing with such an exactitude that the study of collected specimens [of writing] during the course of diverse outbreaks [in the same patient] permit one to frequently establish the clinical characteristics of each" (ibid.: vi). Rogues de Fursac also suggested collecting writing samples from the patient's past, which could then function as the basis for a retrospective medical case history. This archive of documents would establish "unalterable material evidence" of an individual's "pathological history," and this objective record could help stave off, according to Rogues de Fursac, the "non-negligible subjective element" in clinical observation which might differ according to the "doctrinal tendencies" of the practitioner (ibid.: v). Though medical dossiers of psychiatric patients from this period do contain letters and other handwritten documents, it is difficult to know how frequently clinicians turned to this kind of analysis. And yet while Rogues de Fursac writes that most of the writing samples from his book came from patients whose care he oversaw, he nevertheless thanks colleagues working at other institutions, including Gilbert Ballet and Alix Joffroy, for sharing their patients' writing samples with him (ibid.: $\mathrm{x}$ ). This reference to the sharing and circulation of patient texts suggests that the medical interpretation of writing was a more common practice than we might initially imagine. 
But the 232 figures in Rogues de Fursac's monograph also provide an opportunity for a different kind of interpretation. Where Rogues de Fursac used patient-authored texts as the unalterable evidentiary proof of pathology - the material data with which to construct a body of medical knowledge - a historian might consider the possibility of understanding these figures in ways that Rogues de Fursac would have disallowed: as time-capsules of subjectivity, patient experience, and even, agency. If Rogues de Fursac was convinced that the content and genre of his patient's spontaneous writing samples often matched their particular condition, perhaps these "pathological histories" can also be read against that prescription. For example, Rogues de Fursac argued that patients with persecutory delirium often wrote letters in the form of juridical or legal documents (ibid.: 264-267). Instead of this, what if we interpreted these documents as examples of patients advocating for themselves and their rights in whatever ways they could. Rogues de Fursac also identified "psychopaths" as having a particular weakness for writing poetry (ibid.: 267). Alternatively, we might see these documents as evidence that some patients still maintained the will to express their creativity, even in the face of internment. And finally, whereas Rogues de Fursac reads one of his patient's lists of assorted medical ailments as a sign of hypochondria (ibid.: 258-259), perhaps we can see a patient taking control of their own medical narrative.

\section{Conclusions}

Régis, Dumas, and Rogues de Fursac sought to analyze the temporal dimensions of mental illness in both increments of "microtime" and across the long durée. In separate ways and using different technologies and techniques, their methods produced temporal objects out of the different elements they sought to isolate and examine - prognosis, psycho-physiological processes, and neuropsychiatric activity. The measurements they performed and the methods they endorsed produced a plethora of papers, charts, curves, and lines - the kinds of documents that fill archival files and published psychiatric treatises. Time manifests itself in many material forms, but we don't always think about paper and ink in their materiality. The examples discussed above help remind us that paper had (and has) material power. Not only does it serve as "evidence" in the construction of medical and psychiatric knowledge, but it also structures and influences clinical spaces and temporalities, including the temporalities of psychiatric observation. 
Thus, to chart and follow the temporal trajectory of mental illness, to isolate psychophysiological events using graphical medicine, and to interpret a patient's past, present, and future through writing samples, all necessitated different kinds of interactions between patient, doctor, the psychiatric space, and the temporalities of the clinic. Régis' charts - though based on the practice of fever monitoring - imply a synthetic gaze, the ability to combine and reduce symptomology to a relationship between intensity and duration. Though in theory an argument in favor of longitudinal clinical observation, Régis' charts also made retrospective diagnosis possible in the blink of an eye. They reduce a patient's medical history to a mere instant. Dumas' graphic traces necessitated the poking and prodding of bodies, physical contact, and the utilization of measurement instruments. His experiments focused on correlating real-time changes in physiological processes to the simultaneous unfurling of emotional events, but they also reveal how patients in asylums were subjected to multiple experiments over long periods of time, sometimes even over the course of years. Rogues de Fursac's collection of writing samples dictated that all areas of the asylum or clinic were places where clinical observation and testing could take place. Nor was a patient's past off limits; with the analysis of old writing samples the physician could travel back in time, to the beginning of one's "pathological history." 


\section{Notes}

1

All translations are my own.

\section{2}

For the classic accounts of French psychiatry's professionalization during the 19th century, see Dowbiggin (1991) and Goldstein (1987)

\section{3}

The enumeration of these editions is slightly convoluted. In spite of the title change, Régis' 1906 version of the Précis de psychiatrie is listed as a 3rd edition, presumably following the 1885 and 1892 editions of his Manuel pratique de médecine mentale.

\section{4}

Régis added these columns for the first time in the second edition of Manuel pratique de médecine mentale (cf. Régis 1892: 220).

\section{5}

Régis' charting method was also the subject of a lively debate between French and German psychiatrists in 1906-7. See chapter l of my PhD dissertation, "Time to Cure: Psychiatry, Psychology, and Speed in Modern France, c. 1880s1930s."

\section{6}

Special thanks to Nicole Topich at the Oskar Diethelm Library, New York, for providing me with this photograph.

\section{7}

Note that part of the chart is missing. In its place, Arnaud signals: "the notes relative to this period (1870-1872) are lost, but the patient did not leave the clinic" (Ballet 1903: 606).

\section{8}

Weber's compass was used to measure tactile sensitivity; Marey's recording cylinder was used in a variety of experimental designs to record graphical inscriptions; the pneumograph was used to measure respiration; the sphygmograph was used to measure pulse; and the dynamometer quantified and measured muscular strength. For more information on these instruments see Nicolas (2017, 2018). 


\section{Bibliography}

Artières, Philippe (1998): Clinique de l'écriture. Une histoire du regard médical sur l'écriture, Paris: La Découverte.

Ballet, Gilbert (ed.) (1903): Traité de pathologie mentale, Paris: Octave Doin.

Basso, Elisabetta/Delbraccio, Mireille (2017): "Introduction: la psychiatrie en ses archives, entre histoire et épistémologie." In: Revue d'histoire des sciences 2, pp. 255-273.

Binet, Alfred/Simon, Théodore (1909): "Hystérie." In: L'Année psychologique 16, pp. 67-112.

Brain, Robert (2015): The Pulse of Modernism: Physiological Aesthetics in Fin-de-Siècle Europe, Seattle/London: University of Washington Press.

Braun, Marta (1992): Picturing Time: The Work of Etienne-Jules Marey (I830-1904), Chicago/ London: University of Chicago Press.

Camus, Paul (1918): "Le professeur E. Régis (18551918)." In: Paris médical 30, pp. 298-299.

Canales, jimena (2009): A Tenth of a Second: A History, Chicago/London: University of Chicago Press. Carroy, Jacqueline/Plas, Régine (1993): "La méthode pathologique et les origines de la psychologie française au XIX siècle." In: Revue internationale de psychopathologie 12, pp. 603-611.

Dagonet, Henri (1876): Nouveau traité élémentaire et pratique des maladies mentales, 2nd edition, Paris: Librairie J.B. Baillière et fils.

D’Arsonval, Jacques-Arsène (1886): "Chronomètre à embrayage magnétique pour la mesure directe des phénomènes de courte durée." In: Comptes rendus des séances de la Société de biologie et de ses filiales 38, pp. 235-236.

Daston, Lorraine/Gallison, Peter (1992): "The Image of Objectivity." In: Representations 40, pp. 81-128.

Daston, Lorraine/Galison, Peter (2007): Objectivity, New York: Zone Books.

De Marneffe, Daphne (1991): "Looking and Listening: The Construction of Clinical Knowledge in Charcot and Freud." In: Signs 17/1, pp. 71-111.
Didi-Huberman, Georges (1982): Invention de l'hystérie: Charcot et l'iconographie photographique de la Salpêtrière, Paris: Éditions Macula. Dowbiggin, lan (1991): Inheriting Madness: Professionalization and Psychiatric Knowledge in Nineteenth-Century France, Berkeley/Los Angeles: University of California Press.

Dumas, Georges (1900): La tristesse et la joie, Paris: Félix Alcan.

Dumas, Georges (1906): Le sourire (psychologie et physiologie), Paris: Félix Alcan.

Féré, Charles (1892): La pathologie des émotions. Études physiologiques et cliniques, Paris: Félix Alcan.

Goldstein, Jan (1987): Console and Classify: The French Psychiatric Profession in the Nineteenth Century, Cambridge: Cambridge University Press. Henry, Charles (1894): "Le rôle du temps dans les phénomènes psycho-physiologiques." In: La Lumière électrique, 20 Janvier, pp. 101-112.

Jaccoud, Sigismond (1870): Traité de pathologie interne, Paris: Adrien Delahaye.

Lantéri-Laura, Georges (1972): "La chronicité dans la psychiatrie française moderne. Note d'histoire théorique et sociale." In: Annales. Economies, Sociétés, Civilisations 27/3, pp. 548-568.

Lepoutre, Thomas (2012): "Introduction and Translation (Part 2) of 'De la non-existence de la monomanie' by Jean-Pierre Falret (1854)." In: History of Psychiatry 23/4, pp. 488-495.

Londe, Albert (1893): La photographie médicale, application aux sciences médicales et physiologiques, Paris: Gauthier-Villars.

Marey, Étienne-Jules (1878): La méthode graphique dans les sciences expérimentales et principalement en physiologie et en médecine, Paris: G. Masson.

Morel, Pierre (1996): Dictionnaire biographique de la psychiatrie, Le Plessis-Robinson: Synthélabo. Motet, Auguste-Alexandre (1884): "Méthode graphique appliquée à l'étude de la folie à double forme." In: Annales médico-psychologiques 12, pp. 104-107.

Nicolas, Serge (2017): "Weber's compass and the measurement of the threshold of tactile sensitivity: 
Alfred Binet's critical approach to esthesiometry." In: L’Année psychologique 117/1, pp. 41-85.

Nicolas, Serge (2018): La mesure de la vie mentale. Les premiers instruments emblématiques de la psychologie de laboratoire, Paris: Université Paris Descartes.

Nicolas, Serge/Thompson, Peter B. (2015): "The Hipp Chronoscope Versus the D'Arsonval Chronometer: Laboratory Instruments Measuring Reaction Times that Distinguish German and French Orientations of Psychology." In: History of Psychology 18/4, pp. 367-384.

Philippe, Jean (1899): Technique du chronomètre d'Arsonval pour la mesure des temps psychiques, Paris: Georges Carré et C. Naud.

Pichel, Beatriz (2017): "The Backstage of Hysteria: Medicine in the Photographic Studio." In: Remedianetwork, January 16, https://remedianetwork. net/2017/01/16/the-backstage-of-hysteria-medicine-in-the-photographic-studio/, accessed October 22, 2019.

Pichot, Pierre (2007): "Tracing the origins of bipolar disorder: From Falret to DSM-IV and ICD-10." In: Journal of Affect Disorders 96/3, pp. 145-148. Porter, Roy (1997): The Greatest Benefit to Mankind: A Medical History of Humanity, New York: W.W. Norton \& Company, Inc.

Régis, Emmanuel (1885): Manuel pratique de médecine mentale, Paris: Octave Doin.

Régis, Emmanuel (1914): Précis de psychiatrie, Paris: Octave Doin.

Richer, Paul (1885): Études cliniques sur la grande hystérie ou hystéro-épilepsie, Paris: Adrien Delahaye et Émile Lecrosnier.

Rogues de Fursac, Joseph (1905): Les écrits et les dessins dans les maladies nerveuses et mentales, Paris: Masson et Cie.

Roubinovitch, Jacques (1900): La pathologie mentale à la fin du XIX siècle, Paris: Jean Gainche.

Sedler, Mark J. (1983): "Falret's Discovery: The Origin of the Concept of Bipolar Affective Illness." In: American Journal of Psychiatry 140/9, pp. 1127-1133.

Séglas, Jules (1892): Des troubles du langage chez les aliénés, Paris: J. Rueff.
Toulouse, Édouard/Vaschide, Nicolas (1897): "Temps de réaction dans un cas de mélancolie circulaire." In: Comptes rendus des séances de la Société de biologie et de ses filiales 49, pp. 616-617.
A number of the ideas and arguments presented here are further developed in my PhD dissertation. 

TEACHING PROJECTS 


\section{Artistic Research on Things in/of Psychiatry: An Interdisciplinary Teaching Project}

Céline Kaiser

In the room next to the Small Anatomical Theatre, there is a bed up against the wall. It looks comfortable. Although it is the same color as its surroundings, its fluffy, crumpled covers and pillows form a noticeable contrast to the sterile washroom with beige tiles, where corpses were once cleaned for autopsies and brought in and out. It stands there, the unmade bed, as if someone had just gotten up, perhaps to drink a coffee or to take a shower. An intimate moment, surrounded by a clinical room in which the horizontal position evokes quite different, frightening connotations.

Indeed, in her work Materiality (see page 226 in this book), Daniela Hoge, a student at the University of Applied Sciences and Arts [Hochschule für Künste im Sozialen, $H K S$ ], Ottersberg, not only claims the familiarity of a bed; she actually exhibits her own, personal bed in order to reflect in a very sensorial way on the loss of intimacy that patients experience in the clinical context.

With her artwork she makes a gesture that to a certain extent takes up a central thesis of the international conference "Material Cultures of Psychiatry." In their exposé for the conference, Monika Ankele and Benoît Majerus emphasized that everyday objects change their meaning in the realm of psychiatry. "[A] bed clearly changes its meaning in a psychiatric hospital" (ibid.), where it could be a place to sleep, a medium of understanding disease, a therapeutic agent, or a patient's personal refuge (see, for example, Ankele 2018). Yet how should we think about such a change of meaning? How can it be researched? And what aspects and dynamics can be considered? 
Socio-scientific, science-historical, or cultural and media-analytic perspectives can direct their attention to the relations that things enter into in psychiatric-historical contexts, for example, as well as to the semiotic processes that are thus generated. If, following the research approaches in the work of Hans-Jörg Rheinberger, Gilles Deleuze, and Bruno Latour, one assumes that material cultures cannot be exhaustively analyzed based on the system in which they are embedded or from any kind of creative drive, then the focus shifts to the things and the possibilities that lie within them. The way in which things in the context of psychiatry, for example, are "chained" and rearranged with each other and with human actors "links" them in a different way than in the domestic space; in this way, things separate from contexts, but "can also be separated off again and introduced into new structures," as Friedrich Balke emphasized in light of a "return of things" in recent academic theories (Balke 20II: I3).

Even the form of things itself could be changed. A literal de- and reconstruction of objects introduced a transformation that affected the objects themselves. This in turn could be accompanied by a symbolic redefinition, a new linking of things and actors. Aesthetic (cf. Kämpf-Jansen 2002) and artistic approaches to research open up interesting connections for exploring such processes of transformation.

While the aforementioned scholarly research perspectives analyze the arrangements of things as quantities that create meaning, artistic research is less interested in the reconstruction of, but rather in playing with structures of meaning. Artistic research opens up the possibility of building on sensory experience, aisthesis, and allows a specific mode of perception (see Klein 2018, among others).

A combination of cultural-science research with aesthetic and artistic strategies thus does not serve as an "evidence machine of an experiential society," as Thomas Thiemeyer critically noted about hybrid forms of scientific and aesthetic strategies in cultural-historical exhibitions (Thiemeyer 2013: 26). It is not the obvious shortening of a movement of thought (cf. Cuntz et al. 2006) that is the concern of artistic research; rather, it creates interferences and an opening of levels of meaning and perception. As Julian Klein emphasizes: "Artistic experience is an active, constructive, and aesthetic process in which mode and substance are inseparably fused" (Klein 20II: 2). Synesthesia and the creation of meaning collide with and also refer to one another.

A turn to the things of psychiatry, which are at the intersection or tipping point between cultural-historical and artistic research, aims at the poietic dimension of the material cultures of psychiatry. To follow these transitions - or, more precisely, 
to open up a specific space for them - was the aim of a teaching project that took place in the summer semester of 2018 at the HKS Ottersberg and was jointly led by Monika Ankele (University Medical Center Hamburg-Eppendorf) and Céline Kaiser (HKS Ottersberg).

The teaching format "Interdisciplinary Project 2 " is aimed at students in the third and fourth semesters from all bachelor's programs at the university (Art in Social Contexts. Art Therapy; Dance and Theatre in Social Contexts. Theatre and Dance Pedagogy; Fine Art; Social Work) and aims at a topic-centered interdisciplinary artistic work. A preparatory seminar introduces content and strategies, which are then taken up in the context of a project week in individual or group work. The resulting artworks are finally presented and reflected on in an artistically designed portfolio.

The framework of this "P2 project" was set by the conference "Material Cultures of Psychiatry," where the presentation of the artworks took place. In terms of content as well, the connection to the other artistic and scholarly contributions to the conference was intended to be as narrow and fruitful as possible. The preparatory seminar, which spanned two and a half days, therefore had the task of building bridges between research on material cultures and the participants' own artistic engagement with the things of psychiatry. Since there was not enough time for detailed research with the group, the aim was to offer an introduction to the topic, to offer conceptual impetuses, and to begin a transfer for the artistic work.

In this sense, the lecturers created a conceptual and experiential space that was intended to foster students' own experimental and creative ideas. The preparatory seminar thus took on the character of a curated space, which was meant to allow for close links between scientific and artistic research movements on material cultures of psychiatry.

Based on example objects, arrangements, and practices, different groups of things were examined. The relationship between abundance and lack of things, the specificity of over-defined objects of psychiatry on the one hand, and the superficial familiarity of everyday objects in the psychiatric space on the other hand were discussed, as were the radical processes of transformation that patients' objects were subjected to. Writing assignments and performative material explorations, which took place between cultural-science and cultural-historical thematic blocks and in relation to them, initiated the first artistic forms of engagement. The aim of these transfer phases was to open up associative spaces, to stimulate mimetic, transformative, and associative engagements with materials and forms, and to test and use bodily practices in connection with concrete things. 
In this way, during the ensuing week of the project, a series of works took shape which artistically explored the aesthetic and poietic dimensions of things based on material cultures of psychiatry.

In a performance in the lecture hall of the Institute for History and Ethics of Medicine in Hamburg (Loss of Identity, see page 298), Anne Wilk explored how a radical loss of personal things could affect patients' identity. Some things are particularly tied to the identity of their owners: shoes bear the traces of their wearers and have their own history that makes them unique, as Kai Schlawin explored in his work Schuh is Who.

Lydia Oertelt was concerned about how the lack of things for patients could become a "breadless art" of its own. In an exercise lasting several days she moistened and kneaded bread - following the example of some patients - in order to plasticize with it. In addition to a bread sculpture, amulets were created which were distributed to the conference participants (see page I85).

In the foyer of the historical event hall, a special exchange of things and words took place: Viviane Stopp offered drawings of things she had made based on historical sources in exchange for personal belongings from her interaction partners (Pat. No. 25682, see page 30). In the Small Anatomical Theatre, Stephanie Lange spun "five threads of duration." Untangling knots, pulling strings, and crocheting, she dealt with the feeling and phases of mourning. The above mentioned work by Daniela Hoge was also shown there.

Raja Goltz presented a special examination of the form and function of everyday objects, their material qualities, and our expectations of them in the lecture hall. In her performance (Have a Seat; see page 138), a chair crocheted out of torn sheets and the artist engage in a dialogue in which they negotiate how we can enter into and deal with transformations of material culture.

Synesthesia and semiosis came together in the students' artworks, opened up complex perspectives, offered aesthetic perceptions and new possibilities of interpreting the things of psychiatry, and thus expanded the perspectives of the scholarly contributions to the conference. 


\section{Bibliography}

Ankele, Monika (2018): "Horizontale Szenographien: Das Krankenbett als Schauplatz psychiatrischer Subjektivation." In: Friedrich, Lars/Harrasser, Karin/Kaiser, Céline (eds.): Szenographien des Subjekts, Wiesbaden: Springer, pp. 49-64.

Balke, Friedrich (2011): "Einleitung." In: Balke, Friedrich/Muhle, Maria/Von Schöning, Antonia (eds.): Die Wiederkehr der Dinge, Berlin: Kulturverlag Kadmos, pp. 7-16.

Cuntz, Michael/Nitsche, Barbara/Otto, Isabell/ Spaniol, Marc (eds.) (2006): Die Listen der Evidenz, Cologne: DuMont.

Kämpf-Jansen, Helga (2002): Ästhetische Forschung: Wege durch Alltag, Kunst und Wissenschaft: Zu einem innovativen Konzept ästhetischer Bildung, 3rd edition, Cologne: Salon.

Klein, Julian (2011): "Was ist künstlerische Forschung?" In: kunsttexte.de/Auditive Perspektiven, no. 2, 5 pages, www.kunsttexte.de, accessed March 20, 2020

Klein, Julian (2018): "The Mode is the Method Or How Research Can Become Artistic." In: Jobertová, Daniela (ed.): Artistic Research: Is There Some Method?, Prague: Academy of Performing Arts, pp. 78-83.

Thiemeyer, Thomas (2013): "Evidenzmaschine der Erlebnisgesellschaft: Die Museumsausstellung als Hort und Ort der Geschichte." In: Jahrbuch für Politik und Geschichte 4, pp. 13-29. 



\section{Cover, Rip Up, Unwrap: \\ Scenes with Material from the Mental Asylum. \\ A Documentary Theater \\ Based on Medical Records}

Anna Urbach

The documentary theater that we developed focuses on scenes representing the use, interpretation, and appropriation of textile materials in daily life in psychiatric hospitals around 1900 as related to medical treatment, nursing, and the actions of patients.

The starting point of the documentary theater was a selection of medical and administrative files from the former Prussian state hospital Uchtspringe. Established in I894, at the beginning of the 20th century, Uchtspringe was a model institution throughout Europe for testing new models of living and working for the mentally ill. The hospital specialized in the treatment of epileptics. In the context of the ideal of "freer treatment of the insane," bed treatment [Bettbehandlung] and work therapy were increasingly used there. Both the concept of the "agricultural colony" applied at Uchtspringe and the related "foster family care" with medical supervision were based on the economic utility of the adult and adolescent patients as workers. ${ }^{\mathrm{I}}$ This allowed the institution located in a rural area of the Prussian province of Saxony to operate to a large extent autonomously. At the same time, keeping patients physically and mentally active for practical purposes represented one of the central forms of treatment and discipline not involving medications (Urbach 2015). 
Against the backdrop of the ambiguous nature of the employment of patients - as therapy and as a means of disciplining patients as well as for meeting the asylum's own needs - examining the importance of textiles in daily life at psychiatric hospitals seems particularly promising: after all, most of the textiles used in Uchtspringe were produced by patients themselves under the guidance of nurses. Not only were durable fabrics for everyday use produced, but also filigree and fashionable unique pieces, which also enjoyed great popularity outside the institution. In addition, textiles, explicitly long linen cloths, were used in the practice of "wet wrapping" to calm down anxious patients. Finally, the fact that many patients had to stay in bed for days or weeks on end for therapeutic purposes leads to the question of what could happen under/over/with the covers in the context of psychiatric hospitals around 1900 .

This publication and the performance shown at the conference in Hamburg were created with medical students in a specialized track in history, ethics, and the theory of medicine at the University of Magdeburg. In the following, our approach to this experimental teaching format will be described, which was conceived based on the medical humanities. The six-day course began with an excursion to the former Uchtspringe asylum, now the Salus-Fachklinikum Uchtspringe. There the course participants visited the exhibition on the history of the institution. Guided by theater educator Kerstin Reichelt, they explored the pavilion-style grounds in a playful and sensorial way. ${ }^{2}$ They talked to a doctor about the development of psychiatric classification systems and the diverse tasks of psychiatry yesterday and today.

This was followed by the study of primary and secondary sources, including Monika Ankeles's study (2010) of the appropriation of space by psychiatric patients around I900. Publications by the physicians working at Uchtspringe at the turn of the 2oth century and the instructions for care used there were read. The students worked on presentations about topics such as the historical development of work and bed therapy, the handling of suicidality in everyday psychiatric care, and the treatment of epileptic patients as well as their perception of themselves and others. This was followed by the study of selected medical and administrative files from Uchtspringe. We had the students read a few medical histories in their entirety. They were impressed by the heterogeneous makeup of the material and the laborious deciphering of the Sütterlin script. The surviving source material was examined for passages that provided a better understanding of the different functions and roles that textiles could serve in the psychiatric context. Did the surviving medical reports and documents from the patients themselves provide information 
on the appropriation and reinterpretation of the materials used in the asylum, both by the patients as well as the staff? How was an epileptic patient shielded from external stimuli in the life-threatening "status epilepticus"? How was "wet wrapping" practiced? How did a cleaning rag make it possible to "grow into" the asylum, and how did a loom help patients integrate into foster family care? What significance did a doily gain when - made in the asylum's workshop - it traveled beyond the institution's boundaries?

Scattered theatrical units complemented the study of sources. They served to make acting experiences possible and to develop a common aesthetic language for the team. The theatrical units were prepared in regard to historical content, including speech training and body work. The challenge in the staging was to weave a narrative plot out of the jointly selected text fragments and to develop striking images for the performance. How much material does it take to represent material on the stage ${ }^{3}$ The result was a collage as a reading of scenes: a kind of patchwork blanket whose individual text patches created a new pattern. The documentary play "Cover, Rip Up, Unwrap" shows: materials delineate and shield. Materials connect individual members of a psychiatric institution with each other as well as with a world beyond the boundaries of the institution. Through appropriation and creative reinterpretation, they provide the actors with moments of calm and privacy, distancing and encounters, play and diversion, punishment and self-confidence. "The spoken sources gain a new plasticity and emotionality. They make the motivations and actions of the historical actors ... tangible. Both personal and institutional links become transparent in the context of the historical structures" (Historikerlabor 20I7). 
Play Template

(by Anna Urbach and Kerstin Reichelt with Franziska Heitmann, Josephine Runge, Jakob Leander Schulte, Jonathan Stahl)

Play for 4 players, set at the former Prussian State Asylum Uchtspringe for male and female psychiatric patients, around 1900.

Legend: A ... Actor, P ... Patient, W ... Warden, D ... Doctor

Empty stage with lectern on right-hand side at front of stage, partition walls flank rear of stage to left and right, props behind them. Players wear neutral gray.

\section{Props:}

3 patient files, 3 pillows, 5 large bedsheets, 3 sets of knitting with balls of wool, I ball of wool, I lace pillow, including bobbin winder, I bucket (half-filled with scraps of wastepaper) and cleaning rags, I pair of woolen socks

$\mathrm{A} 1,2$, and 3 each have an approximately $\mathrm{A} 5$-size sheet of paper with pen in pocket of pants, tucked into which $\mathrm{A} 3$ also has a newspaper.

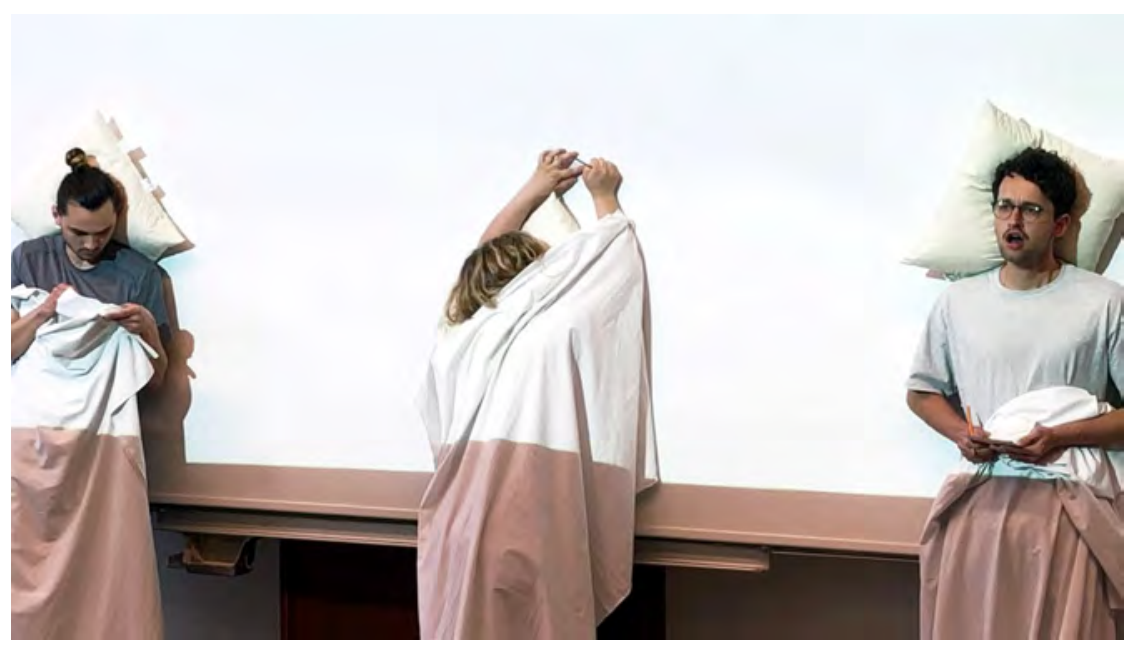


SCENE 1 ARRIVING

\section{Location: Ward}

Music plays (instrumental, neutral theme)

$P 1$ and P 2 enter stage with sheets and pillow - each makes themselves a "bed" stage left and right, respectively: standing leaning against rear wall, pillow held pressed between back of head and rear wall, sheets cover body to chest-height center stage, a "bed" is free

Music stops

D I enters stage carrying patient file, goes to the lectern, reads out loud:

Name: Conrad, Marie Luise 4

P 3 enters carrying pillows and a sheet, makes herself a "bed" center stage

D 1: Rank: Domestic servant

Born: August 30, 1867, in Delitzsch

District: Bitterfeld

Admitted: November 12, 1894

Provisional diagnosis: Epilepsy with insanity

Music plays

Patients continue settling in their "beds"

Music stops

D 1: The patient states that she has suffered since adolescence from cramps, which occur with particularly acute frequency during menstruation; at times, only absence seizures accompanied by clouded consciousness and confused behavior. Has repeated agitated episodes of raving madness and bouts of semi-consciousness lasting days to weeks.

Music playing 
Patients continue settling in their "beds"

Music stops

D 1 gives lecture:

Epilepsy: Even with an affliction that has become notorious as a "disgrace of therapy" ...

P 1, P 2, P 3 look to audience and whisper in chorus:

A disgrace of therapy.

D 1: $\quad$... an experienced neurologist will be able to point to success stories.

Based on our accumulated experiences with thousands of epileptics at Uchtspringe, it is probably fair to say that you can aim to cure ...

P 1, P 2, P 3 look to audience and in chorus:

Cure!

D 1: $\quad . .$. at least ten percent and, with another approximately fifty percent, expect a substantial recovery. ${ }^{5}$

P 1, P 2, P 3 look to audience and in chorus:

Recovery!

D 1 exits left

Music plays 


\section{SCENE 2 COVERING}

\section{Location: Ward}

Patients in bed retrieve pens and paper from their pants pockets and, partially hidden from one another, start writing letters in secret

Music stops

P l, looking to audience:
My dearest and best pal! I'm stuck here now and am at a complete loss. Dare not leave bed, as my feet cannot carry me, my head is empty, and all is silent both within and about me.
Warmest wishes from your old pal ${ }^{6}$

\section{Music plays}

Change poses - continue writing in secret

Music stops

P 2, facing wall ("lying on belly"), despairing

\section{Please come here straightaway, I can't live any longer! Anna ${ }^{7}$}

Music plays

Change poses - continue writing in secret

Music stops

P 3 with sheet over head

To: Dr. Weidenmüller in Uchtspringe, Altmark, building no. 20

I wish to you on this New Year

The smile of fortune and good cheer

And grant to him, dear Lord above

A life both long and full of love

I am but young, no gifts to share

I've had a year... Let's leave it there. 


\section{In the meantime, dear Doctor, \\ let us hope I may one day emerge from this \\ Louise Conrad}

Music plays

Change poses - continue writing in secret

Music stops

P 2 to the wall:

\section{I implore you, come immediately I beg you, help me! \\ Anna $^{8}$}

Music plays

\section{SCENE 3 KNITTING}

\section{Location: Ward}

Music stops

Patients put away letters and pens, boredom sets in

P 3 pulls out her newspaper, leafs through languidly, finds the job advertisements, looks to audience:

\footnotetext{
If only I could get away from here, I wanted to work so much; here am I, like in prison.
}

W 1 enters from left with three sets of knitting, takes newspaper off $P 3$ and hands her the knitting, then distributes remaining balls of wool to the other patients, exits right; the patients knit 


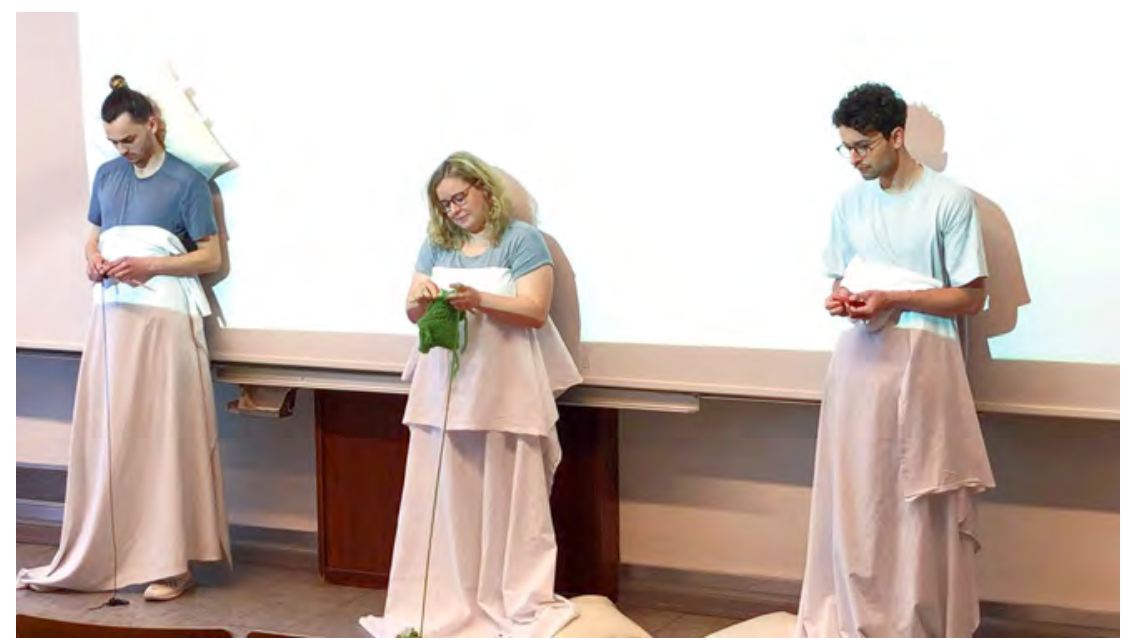

P 2 to audience, stops knitting while he talks, assuming role of a doctor:

This sock-knitting task not only allows us to occupy large numbers of patients unsuited to other kinds of work, the completed socks are also a considerable and welcome comfort for nearly all the asylum's residents. ${ }^{9}$

Pl to audience, stops knitting while he talks, assuming role of a doctor:
A halfway skilled patient can complete a pair of socks in a day over eight working hours, while a proficient man can knit between two and two and a half pairs in the same time. As they work, the patients also develop a certain taste in the socks they knit by selecting specific col- ors for the stripes in the fabric. ${ }^{\text {Io }}$

Music starts

All patients knit 


\title{
Location: Ward
}

\author{
Music stops \\ P3 suddenly drops knitting on floor and "freeze" \\ $\mathrm{P} 1$ and $\mathrm{P} 2$ look to $\mathrm{P} 3$ \\ D 1 comes to lectern, gives lecture:
}

\begin{abstract}
This is known as status epilepticus, a condition experienced intermittently by epileptics, when they suffer a dangerous sequence of fits in uninterrupted succession. In the past, there was nothing that could be done for the majority of epileptics who fell victim to this condition, which was responsible for almost half of deaths."
\end{abstract}

$\mathrm{Pl}$ and $\mathrm{P} 2$ take their bedding and knitting, leave

$\mathrm{D} 1$ switches to role of $\mathrm{W} 1$, leaves lectern, goes downstage left, puts on socks W 2 and $W 3$ enter from right and left respectively, each holding outspread sheet stretched between hands above their heads, run back and forth, attempt to shield P3 from audience's view

W 1 while this happens, tiptoeing to front of stage, speaks softly to audience

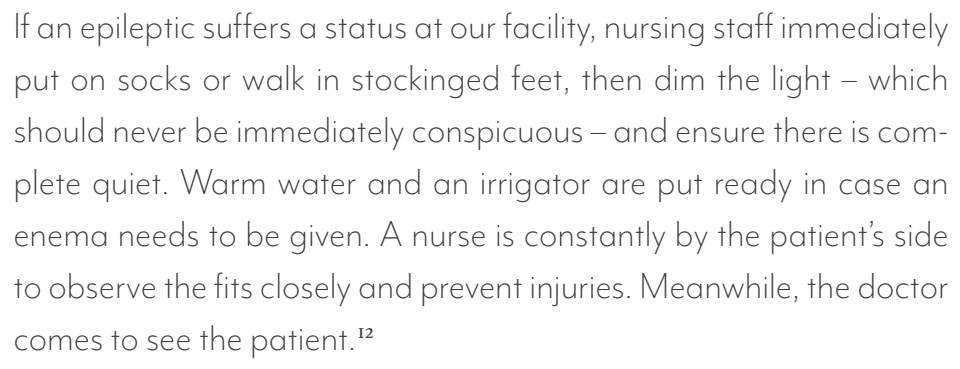

W 2 and W 3 stand at rear wall, create a "triangle" with the sheets to shield P 3 from view $P 3$ and $W 1$ exit, $W 1$ takes off socks behind partition wall $W 2$ and $W 3$ exit 


\section{Location: Corridor}

P 2 enters with bucket and cleaning rags, takes a routine look around room, studies floor closely, goes upstage right and starts mopping floor from kneeling position - almost ritual-like quality to cleaning, seems meditative, almost compulsive, each stage visible and ordered

$W 2$ in parallel to actions of $P 2$, comes downstage left with patient's file, observes $\mathrm{P} 2$ and makes notes in file, talking at same time:

July 18: Patient often felt unwell over last few days, unable to work as hard as usual, complained of stomach pains, dizziness. Had stomach pumped multiple times. Today menstruating. Patient feels somewhat better, will stay in bed.

July 25: Patient thought doctor had said to her that she could no longer finish her work by herself.

P 4 joins scene, takes the second cleaning rag and starts wiping floor as well, although in free rather than ritual manner, uses the bucket

P 2 feels under pressure from P 4, whom she sees as competition, both scramble for the bucket, game of: "That's my cleaning spot!" $\mathrm{W} 2$ in parallel to actions of $\mathrm{P} 2$ and $\mathrm{P} 4$ :

... Now became worried that another patient would do the work. The patient then lay under the bed in her nightshirt; after a while, she got dressed again.

P 2 goes to stage left

$W 2$ in parallel to actions of $P 2$ :

July 28: Patient became agitated because another patient wanted to help mop the wards; she poured the bucket over her own head, threw herself to the floor, started hitting herself in the head with fists. 
P2 pours bucket of "water" over herself ("water" made from scraps of paper), short "freeze" with bucket over head

Music on (new theme: loud, urgent, impulsive)

P2 exits

P 4 and W 2 clear up stage, exit

\section{SCENE 6 WRAPPING UP}

\section{Location: Patients' garden}

P 2 and P 4 enter stage, run back and forth around the room making jerky, fast movements, hopping

W 4 arrives with patient file, takes place downstage center

Music off

$\mathrm{Pl}$ enters from left, places bedsheet over center of the rear wall, joins others in running around the room

W 4 reads from file:

May 26: The patient went for a walk with the other invalids this afternoon; while the warden was inviting the others to accompany her back to the next institution, the patient suddenly bound across country. She attempted to hit and bite the warden, who brought her back to the path, snatched his watch from his pocket, and hurled it to the ground. After passing villa no. 6 , the patient then walked fairly calmly with the warden, although she attempted to throw stones at the wardens following behind. The patient was then given chloroform ...

Patients position themselves in line at rear of stage, from right to left: $\mathrm{P} 1, \mathrm{P} 4, \mathrm{P} 2$; in synchronized movement, put right hand in front of nose and mouth W 4: $\quad$... and wrapped in warm, damp sheets.

Goes stage left to lectern, switches to role of D 2 
In synchronized movement, the patients start turning slowly counterclockwise on their own axis, hands hanging by side of body, their pose stiffening from feet upwards with each rotation

D 2, at same time, gives lecture:

\begin{abstract}
Starting from below, the body is now wrapped in sheets that have previously been dipped in cold water, wrung, then folded and rolled several times according to length. Once the body is wrapped up to the neck, which is left uncovered, the body is also enveloped in a woolen blanket attached at the side by three dry, folded blankets. A cold compress or ice pack is applied to the patient's head for the duration of the wrap. ${ }^{13}$
\end{abstract}

Patients stop rotating, "freeze" in a line, look to audience

\title{
D 2: A doctor's instructions determine how long the wrap lasts. ${ }^{14}$
}

$\mathrm{Pl}$ and P2 switch to the role of wardens, go to P 4 and carry this "wrapped" patient to "bed", tuck patient in ( 4 is carried upstage in a vertical position, leaning against the center of the rear wall, $P 1$ and $P 2$ pull the pre-folded sheet up to $P$ 4's neck, which is tucked into position behind shoulders), exit P 4 "lies" motionless in "bed", staring ahead with fixed gaze $\mathrm{D} 2$ switches to the role of $\mathrm{W} 4$, leaves lectern, goes downstage right with patient file, reads:

In wrap from 6 to 9 o'clock. Patient resisted this with all her strength, kicked at and attempted to bite wardens, spat at them. After being wrapped in the sheets, she banged her head non-stop against the wall and floor, sang popular ditties, and worked herself up into an increasing rage. Initially, a guard was with her the entire time. However, after about one and a half hours, she gradually calmed down, although she remained in the wrap until 9 o'clock and could then be taken back to the ward. 


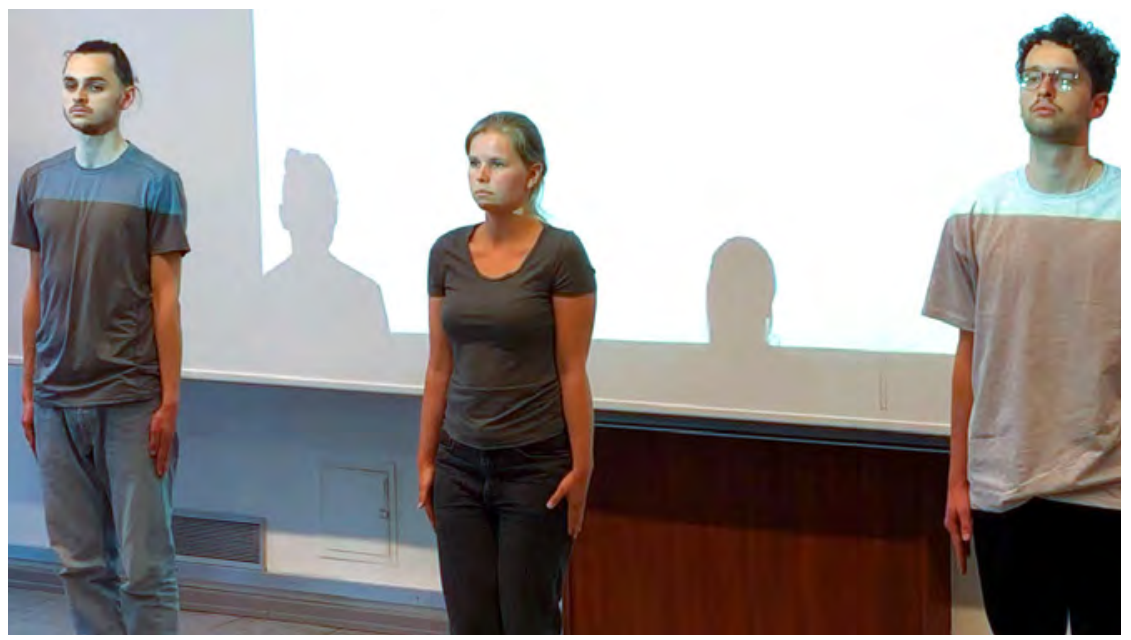

D 3 approaches lectern from right, gives a speech addressed to an imaginary audience of doctors:

Gentlemen!

Known as an "agitated state", the condition is in part due to an excess of blood in the brain and the pathological increase in activity that this triggers in the organ. When dealing with this condition, we are able to harness the property of a damp wrap, which expands skin vessels and so draws blood outwards away from the internal organs, specifically from the brain; as the excess of blood decreases, so too does the unhealthy excess of brain activity, which allows the overactive organ to rest and recover. ${ }^{15}$

\section{3 exits}

P 4 exits right with the bedsheet 


\section{SCENE $7 \quad$ OCCUPYING}

Location: Ward

$\mathrm{P} l$ enters with sheet, starts ripping it up and arranging the resultant strips of material into a pattern on the floor

W 1, W 3, and W 4 enter stage, each carrying a neatly folded sheet over right arm

- position themselves stage right in a diagonal line facing $\mathrm{Pl}$, shake out sheets simultaneously so that the draft destroys the pattern into which the strips of material have been arranged

$\mathrm{P}$ l puzzled, starts making pattern again

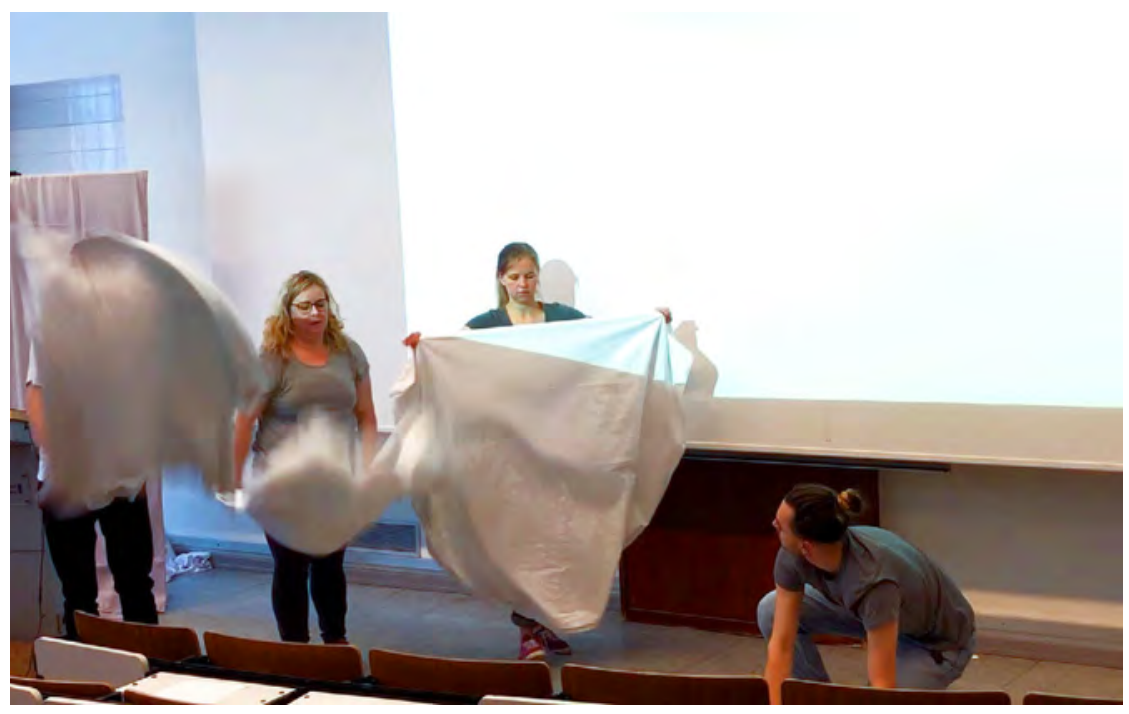


W 4 to audience:

August 16: Today, on discovering a louse while combing her hair, the patient became so agitated that she immediately jumped out of an open window. She ran to the river Uchte to drown herself.

Wardens move stage left, reposition themselves in a diagonal line and shake out sheets simultaneously

$\mathrm{Pl}$ incredulous, starts making pattern again

W 3 to audience:

July 26: She had asked the warden to replace the water that had grown warm in the ward - it was a very hot day - with cold water. Angered by the warden's attitude, she suddenly decided to jump over the railing in order to break her neck.

Wardens move to stage right, reposition themselves in a diagonal line and shake out sheets simultaneously

$\mathrm{Pl}$ annoyed, starts knotting the strips of material into a cord W 1 to audience:

June 27: At noon, the patient suddenly left her bed to go to the toilet, where she attempted to hang herself on the doorframe using her sanitary bandages.

P l exits left with cord

$\mathrm{W} 1$ to audience:

Perhaps the patient's agitated state was in part due to the fact that the director did not shake hands with her when he walked through the department that morning.

All wardens exit 
SCENE 8 WEAVING

Location: Asylum workshop

Set up "loom": A 4, A 2, and A 1 form line from right to left, a red woolen thread is attached to A l's upper body

"Shuttle" (A 3) enters from right, holds other end of thread (the ball of wool) in hand, positions self behind the "loom"

Sound: GONG

"Shuttle" (A 3) sets the "loom" in motion (triggers A 2)

The movement of a "loom" is recreated: A 2 moves in opposite direction to A 4 and $A 1$, thereby forming a triangle - they stamp in same rhythm - with result that $A 3$ loops the woolen thread around A 4, A 2, and A I until a weave emerges.

Text read in parallel to these actions, interspersed rhythmically

A 4: September 1905, report to the provincial governor: weaving school running since March; 12 to 14 women; epileptic, hysterical, and juvenile idiots. ${ }^{16}$

A 1: $\quad$ Most patients very much enjoy working at the loom. In particular, it gives them a sense of satisfaction at being able to accomplish positive work. ${ }^{17}$

A 2: July 1907: Additional looms set up in boys' building no. 8 and in men's building no. 5. ${ }^{18}$

"Loom" comes to a stop

A 3: Items produced here include: material for aprons and dresses, rugs, shirts, window drapes, dusters, carpets. Fabrics made this way are considerably more durable than those made by machines. ${ }^{19}$

"Loom" exits right, A 3 exits left 


\section{Location: Asylum workshop}

$\mathrm{Pl}$ enters from right, goes stage left, examines self from every direction in imaginary mirror, speaks to reflection:

Dear parents, please send me another fifteen marks in the next few days so I can pay for the ankle boots l've already been measured up for; l've previously discussed this with Mom. My new suit is being made free of charge at the asylum's taylor workshop. Dr. Weidenmüller said that l'd already covered the costs through my work here. When my new suit is ready, l'll send you the old one so that you can take it for cleaning. Once cleaned, you can then send it back to me, and that should help slightly reduce wear on the new suit. ${ }^{20}$

W 4 enters stage, interrupts $\mathrm{P} 1$ by tapping him on shoulder

W 3 enters stage, holding a lace pillow in both hands

W 4 shows $\mathrm{P} I$ how to make lace

D 1 enters stage, walks to lectern:

June 1911: Lace-making introduced a year ago; currently twelve to fifteen female patients employed: daily eight-hour working day; actual training period, 6 hours every day for 14 days, then 2 months with constant supervision and instruction.

It has been noted that mildly feeble-minded youths are more adept at learning the requisite hand positions for lace-making and work more finely than even their healthy peers. A number of special products are made here for which there are ample buyers. Here you see the Uchtspringe Lace Collection, which was even highly praised recently by Her Imperial Majesty!21

A photo is projected onto the rear wall: Historical photographs of the "Uchtspringe Lace Collection" ${ }^{22}$

D I leaves the lectern and joins the others 
All actors switch into the role of patients, looking at the audience

P 1: My weaving frame was made by Franz at the asylum's carpentry workshop!

P 2: l'm taking my loom with me into my foster family's care!

P3: My socks are worn by Professor Alt!

P 4: The Kaiser's wife wears my lace! 


\section{Notes}

1

In 1868 and 1869, the reform psychiatrist Wilhelm Griesinger (1817-1868) propagated a separation of psychiatric care into urban and rural asylums. The latter consisted of a central institution, which was reserved for the group of permanent patients incapable of integration, and the connected, freer forms of the "agricultural colony" and "family care." Often these colonies were farms on which the patients did agricultural work under the supervision and guidance of the caretakers. As part of "family care," patients lived and worked with families in the area around the asylum, but remained under the supervision of the asylum's doctors and nurses (cf. Sammet 2000: 257)

\section{2}

For instance, some of the students closed their eyes and let the other students lead them across the grounds. The participants were also invited to use a camera to capture the supposedly typical symbols of psychiatry while independently exploring the grounds.

\section{3}

We would like to thank Monika Ankele, who drew our attention to the documentary "Die Alsterdorfer Passion: Die Alsterdorfer Anstalten 1945-1979" (Rotermund/Simon 2018), in which a former psychiatric patient uses only his own body to illustrate how the "wet wraps" were practiced on him until the 1970s.

\section{4}

Unless otherwise indicated, all descriptions of and statements by patients are direct quotations from the medical file of Marie Luise Conrad, who was admitted as a patient in 1894 at the former Uchtspringe psychiatric hospital [Landes-Heil- und Pflegeanstalt], where she was treated until her suicide in 1900. Medical file of Marie Luise Conrad (1894), State Archives of Saxony-Anhalt (LASA), C 98 Landes-Heil- und Pflegeanstalt Uchtspringe (1894-ca. 1946).

\section{5}

Alt (1905: 585).

6

Patient file of Anna Müller, née Schwiesau (1908), LASA, C 98.

7

lbid.

8

Ibid.

9

Ludwig (1897: 21).

10

Ibid.

11

Alt (1905: 585).

12

Ibid.: 588.

13

Schlöss (1905: 42-43).

14

Ibid.: 43.

15

Weber (1898: 104).

\section{6}

"Report by Konrad Alt on the Governor of the Province of Saxony, 25/09/1905." In: LASA, C 92, no. 2720: Beschäftigung der Kranken der Landes-Heil- und Pflegeanstalt zu Uchtspringe (1896-1923), fol. 29-30.

\section{7}

lbid.

18

"Report by Alt on Governor, 20/07/1907."

In: Ibid., fol. 34-35.

19

"Report by Alt on Governor, 25/09/1905."

In: Ibid., fol. 29-30. 
20

Patient files of Reinhold Eckstein (1897),

LASA, C 98.

21

"Report by Alt on Governor, 28/06/1911."

In: LASA, C 92, no. 2720, fol. 38.

22

Ibid., n. pag.
Urbach, Anna (2015): "'Heilsam, förderlich, wirtschaftlich': Zur Rechtfertigung, Durchführung und Aneignung der Arbeitstherapie in der LandesHeil- und Pflegeanstalt Uchtspringe 1894-1914." In: Ankele, Monika/Brinkschulte, Eva (eds.): Arbeitsrhythmus und Anstaltsalltag: Arbeit in der Psychiatrie vom frühen 19. Jahrhundert bis in die NS-Zeit, Stuttgart: Franz Steiner, pp. 71-102. Weber, Ludwig Wilhelm (1898): "Die feuchte Packung, ihr Nutzen und ihre Gefahren in der Irrenpflege." In: Die Irrenpflege 2, pp. 101-108.

\section{Film}

"Die Alsterdorfer Passion: Die Alsterdorfer Anstalten 1945-1979," Rotermund, Bertram/Simon, Rudolf, DEU 2018, https://www.rotermundfilm.de /?page_id=792, accessed on June 13, 2019.

All quotations originally in German were translated by Anthony DePasquale. 



\section{Notes on Contributors}

\section{Monika Ankele}

is a historian. She is a scientific researcher at the Institute for History and Ethics of Medicine at the University Medical Center Hamburg-Eppendorf and curator at the Medical History Museum. Her research focuses on the history of psychiatry and its institutional cultures. Her last research project was funded by the German Research Foundation (DFG) and addressed the material culture of psychiatry, putting a special emphasis on the hospital bed and the bathtub. Her latest paper titled "Material Configurations of Nursing and Its Ethical Implications: The Prolonged Bath Treatment in Psychiatry" is published in the European Journal for Nursing History and Ethics $\mathrm{I} / 2 \mathrm{O} 2 \mathrm{O}$.

\section{Mascha Deneke}

studied fine arts and has been working as a stage designer at various theaters in Germany, Switzerland, Austria, and Luxembourg.

\section{Michelle Williams Gamaker}

is a moving image and performance artist and academic teaching at Goldsmiths College, University of London. Her key focus is the development of "fictional activism": the restoration of marginalized brown characters as central figures, who return in her works as vocal brown protagonists challenging the fictional injustices to which they have been historically consigned. She recently completed Dissolution, 
a trilogy of films comprising House of Women (2017), The Fruit Is There to Be Eaten (2018), and The Eternal Return (2019) in which characters from Powell and Pressburger's 1947 Black Narcissus unravel as they become aware of their screen and staged realities. Collaboration is also a crucial element of Williams Gamaker's work; since 2009 she has worked with American artist Julia Kouneski, revisiting the work of Brazilian artist Lygia Clark's psychotherapeutic research as inspiration for interventions with the body, architecture, and landscape.

\section{Max Gawlich}

is a postdoc researcher at the Institute for History at the University of Heidelberg. Interested in the history of psychiatry, he earned his doctorate with a dissertation about the implementation of electroconvulsive therapy in Britain, Switzerland, and Germany during the 1940s. His dissertation is published under the title Eine Maschine, die wirkt: Die Elektrokrampftherapie und ihr Apparat, 1938-1950 (Paderborn: Schöningh 2018). Currently he is studying the German history of early childhood in the 1970 in a research project funded by the German Research Foundation (DFG). The research focuses on everyday care and its scientific study by psychologists, pediatricians, and pedagogues.

\section{Novina Göhlsdorf}

is a cultural theorist and historian of science. She works on the emergence of psychiatric and psychological knowledge and on the history of affect and emotions, including pain and empathy. She has also done research on historical and contemporary conceptions of childhood. Göhlsdorf is particularly interested in the intersections between epistemological genealogies and forms of representation. Her current project focuses on figurations of autism from I90o until the present day. Göhlsdorf has also curated thematic exhibitions in various museums.

\section{Raja Goltz}

studies art therapy and art education at the University of Applied Sciences and Arts, Ottersberg, near Bremen. 


\section{Kirsi Heimonen}

is an artist-researcher acting as a visiting researcher at the Performing Arts Research Centre of the Theatre Academy, University of the Arts in Helsinki, Finland. She is a certified teacher of the Skinner Releasing Technique, a somatic practice that has heavily influenced her artistic research. In the research project Engraved in the Body: Ways of Reading Finnish People's Memories from Mental Hospitals, funded by the Kone Foundation (2017-2020), she focuses on the corporeality of patients and affective atmospheres of mental hospitals in her artistic research. Alongside this research project, slowness and silence continue to intrigue her.

\section{Louise Hide}

is a social historian of psychiatry and its institutions. She is a Wellcome Trust Fellow in Medical Humanities and based in the Department of History, Classics and Archaeology at Birkbeck, University of London. Her research project "Cultures of Harm in Residential Institutions for Long-Term Adult Care, Britain 1945-I980s" (ref. 205417/Z/I6/Z) seeks to gain a better understanding of the intersections between personal, professional, and institutional notions of care. She co-edited with Joanna Bourke a special issue of Social History of Medicine (November 2018) titled "Cultures of Harm in Institutions of Care." She has published on the histories of pain, delusions, and institutional cultures. Her first monograph, Gender and Class in English Asylums, I890-I9I4 was published in 2014.

\section{Daniela Hoge}

is a graphic designer and student at the University of Applied Sciences and Arts, Ottersberg.

\section{Céline Kaiser}

is professor of media cultural studies and scenic research at the University of Applied Sciences and Arts, Ottersberg. As a Dilthey Fellow of the Volkswagen Foundation, she has researched the cultural history of scenic forms of therapy since the I8th century. Her current focus of work is on medical humanities and artistic research, history, theory, and aesthetics of applied theater and media 
history of psychiatry. She recently published a monograph titled Szenen des Subjekts: Eine Kulturmediengeschichte szenischer Therapieformen seit dem I8. Jahrhundert (Bielefeld: transcript 20I9). She co-edited with L. Friedrich and K. Harrasser Scenographies of the Subject (Wiesbaden: Springer 2019) and with M. Ankele and S. Ledebur Aufführen, Aufzeichnen, Anordnen: Wissenspraktiken in Psychiatrie und Psychotherapie (Wiesbaden: Springer 2019).

\section{Linnea Kuglitsch}

is a recent graduate of the University of Manchester. Trained as both a historian and an archaeologist, Linnea Kuglitsch's research has focused on examining daily life and practice in hospitals, prisons, asylums, and other historic institutions. With experience conducting archaeological research throughout the United States, the United Kingdom, and Australia, Linnea's previous work has centered around highlighting the experiences, behaviors, and emotional worlds of inmates and exploring their relationship to the outside world. Her recent research project, Materia Medica, Materia Moral uses archaeological materials to understand the nuances of moral treatment practice in lunatic asylums in the United States.

\section{Sari Kuuva}

is a scholar in art history and cognitive science, and her earlier investigations have mainly focused on emotions - particularly on their cultural aspects. Kuuva has also been interested in the relationship between emotions, pictures, and corporeal knowledge. In the research project Engraved in the Body: Ways of reading Finnish people's memories from mental hospitals, funded by the Kone Foundation (2017-2020), Kuuva has investigated corporeal knowledge in photographs of mental hospitals and the emotional experiences of the children of mental hospital personnel. Key emotions in her analysis have been nostalgia, melancholia, fear, feelings of security, topophobia, topophilia, and empathy.

\section{Lisa Landsteiner}

is a psychologist and a research fellow at the Institute for History at the MartinLuther-University Halle-Wittenberg. Her research interests lie in the interface of 
historical and psychological fields and phenomena. Rooted in a psychological practice that is fundamentally interwoven with queer feminist approaches and steadily challenged by the critical analysis of institutionalized spaces, she is currently working on an interdisciplinary research project on the experience of arrival by former wartime children from Bosnia-Hercegovina in Austria and Germany.

\section{Anatole Le Bras}

is a $\mathrm{PhD}$ candidate in contemporary history at the Centre d'histoire de Sciences Po, Paris. His current research aims at studying biographical trajectories of mentally ill persons inside and outside lunatic asylums in France in the second half of the Igth century. He recently published Un enfant à l'asile: Vie de Paul Taesch (I874-19I4) (Paris: CNRS Éditions 2018).

\section{Katrin Luchsinger}

is an art historian and lecturer at the Zurich University of the Arts. At the Institute for Cultural Studies in the Arts she does research on art, psychology, and psychiatry around 1900. She led the project Preserving Special Cultural Treasures, which was funded by the Swiss National Science Foundation. In the course of the project, medical records of 25 psychiatric hospitals from the period between 1850 and 1930 were searched for artworks by inmates. More than 5,000 artworks were found and digitized (see https://blog.zhdk.ch/bewahrenbesondererkulturgueter/). Luchsinger has also edited many books on the subject.

\section{Benoît Majerus}

is Professor of European History at the University of Luxembourg. He has widely published on the history of psychiatry in the I9th and 2oth centuries, most recently La folie à Paris du Moyen-Âge à aujourd'hui (Paris: Parigramme 20I8).

\section{Lydia Oertelt}

studies art therapy at the University of Applied Sciences and Arts, Ottersberg, and works, after more than ten years as a midwife, with people with multiple disabilities. 


\section{Christine Rehders}

is a self-taught artist located in Hamburg. She works on sculptural installations. In her artistic work she focuses on the topic of surface. www.christinerehders.fr

\section{Kai Sammet}

studied medicine at the University Medical Center Hamburg-Eppendorf and the University Medical Centre Göttingen. Since 1998 he has worked at the Institute for History and Ethics of Medicine at the University Medical Center Hamburg-Eppendorf. In his research he focuses on the history of German psychiatry from I80o to I933.

\section{Marianna Scarfone}

is a historian working on the social and cultural history of psychiatry and mental health. She is maitre de conférences at the Departement for the History of Medicine at Strasbourg University. She is co-responsible for the DFG-ANR project Retrieving Alternatives: Pluralism in Practice in European Psychiatry, I950-I980.

\section{Viviane Stopp}

studies art therapy and art education at the University of Applied Sciences and Arts, Ottersberg.

\section{Anna Urbach}

is a physician and research associate at the Department of History, Ethics and Theory of Medicine at the University Medical Center Magdeburg. Her current dissertation project is about the hospital and social history of epilepsy at the turn of the 2oth century through the lens of the former Uchtspringe Prussian State Asylum from I894 to I933. This resulted in publications on the history of medical observation and documentation, education and unionisation of psychiatric nurses, occupational therapy, and the self-perception and perception others had of people who have been described as epileptic at that time. In her work as a lecturer, she enjoys developing teaching concepts with the freelance drama teacher Kerstin Reichelt. 


\section{Maia Isabelle Woolner}

received her $\mathrm{PhD}$ in history at the University of California, Los Angeles in 2020. She holds a B.A. from McGill University and an MPhil in intellectual history from the University of Cambridge. Her research focuses on topics at the nexus of medical, technological, and cultural history. Her work has been supported by the Franco-American Fulbright Commission and the Camargo Foundation.

\section{Anne Wilk}

is a student at the University of Applied Sciences and Arts, Ottersberg.

\section{Stefan Wulf}

is a historian. He is a scientific researcher at the Institute for History and Ethics of Medicine at the University Medical Center Hamburg-Eppendorf. His research focuses on the history of psychiatry, the history of the Hamburg Tropical Institute, and the role of medicine in German foreign cultural policy before 1945 . He has published two books on the Hamburg tropical doctor Peter Mühlens (I874-1943). His current research project discusses psychopathy in clinical and expert practice between I9I8 and 1969. An important focus of his interest lies in the specific structures of the history of psychiatry in the port city of Hamburg, e.g. the topic of insanity and migration in Hamburg Ioo years ago. He has also published a book on time structures in the late Middle Ages as well as biographical articles about opera singers, especially Jewish artists. 

The book was funded by the German Research Foundation (DFG)

and the Luxembourg Centre for Contemporary and Digital History $\left(\mathrm{C}^{2} \mathrm{DH}\right)$

Funded by

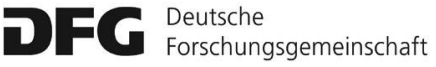 \\ German Research Foundation}

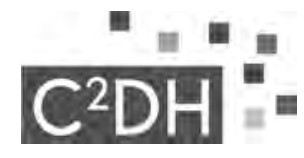

Bibliographic information published by the Deutsche Nationalbibliothek

The Deutsche Nationalbibliothek lists this publication in the Deutsche Nationalbibliografie; detailed bibliographic data are available in the Internet at http://dnb.d-nb.de This work is licensed under the Creative Commons Attribution-Non Commercial 4.0 (BY-NC) license, which means that the text may be may be remixed, build upon and be distributed, provided credit is given to the author, but may not be used for commercial purposes. For details go to: http://creativecommons.org/licenses/by-nc/4.0/

Permission to use the text for commercial purposes can be obtained by contacting rights@transcript-verlag.de

Creative Commons license terms for re-use do not apply to any content (such as graphs, figures, photos, excerpts, etc.) not original to the Open Access publication and further permission may be required from the rights holder. The obligation to research and clear permission lies solely with the party re-using the material.

(c) 2020 transcript Verlag, Bielefeld

All rights reserved. No part of this book may be reprinted or reproduced or utilized in any form or by any electronic, mechanical, or other means, now known or hereafter invented, including photocopying and recording, or in any information storage or retrieval system, without permission in writing from the publisher.

Cover layout: Juma Hauser

Cover image: (c) Daniela Hoge

Book layout: Juma Hauser

Design, Picture editing: Juma Hauser, Johanna Roither

Proofread by Anthony DePasquale

Translated by Anthony DePasquale (German texts by Max Gawlich, Céline Kaiser, Katrin Luchsinger, Kai Sammet, Anna Urbach, Stefan Wulf), Ulrike Nichols (German text by Monika Ankele)

Printed by gugler*

Printed on Munken Lynx $100 \mathrm{~g} / \mathrm{m}^{2}$

Print-ISBN 978-3-8376-4788-4

PDF-ISBN 978-3-8394-4788-8

https://doi.org/10.14361/9783839447888 